
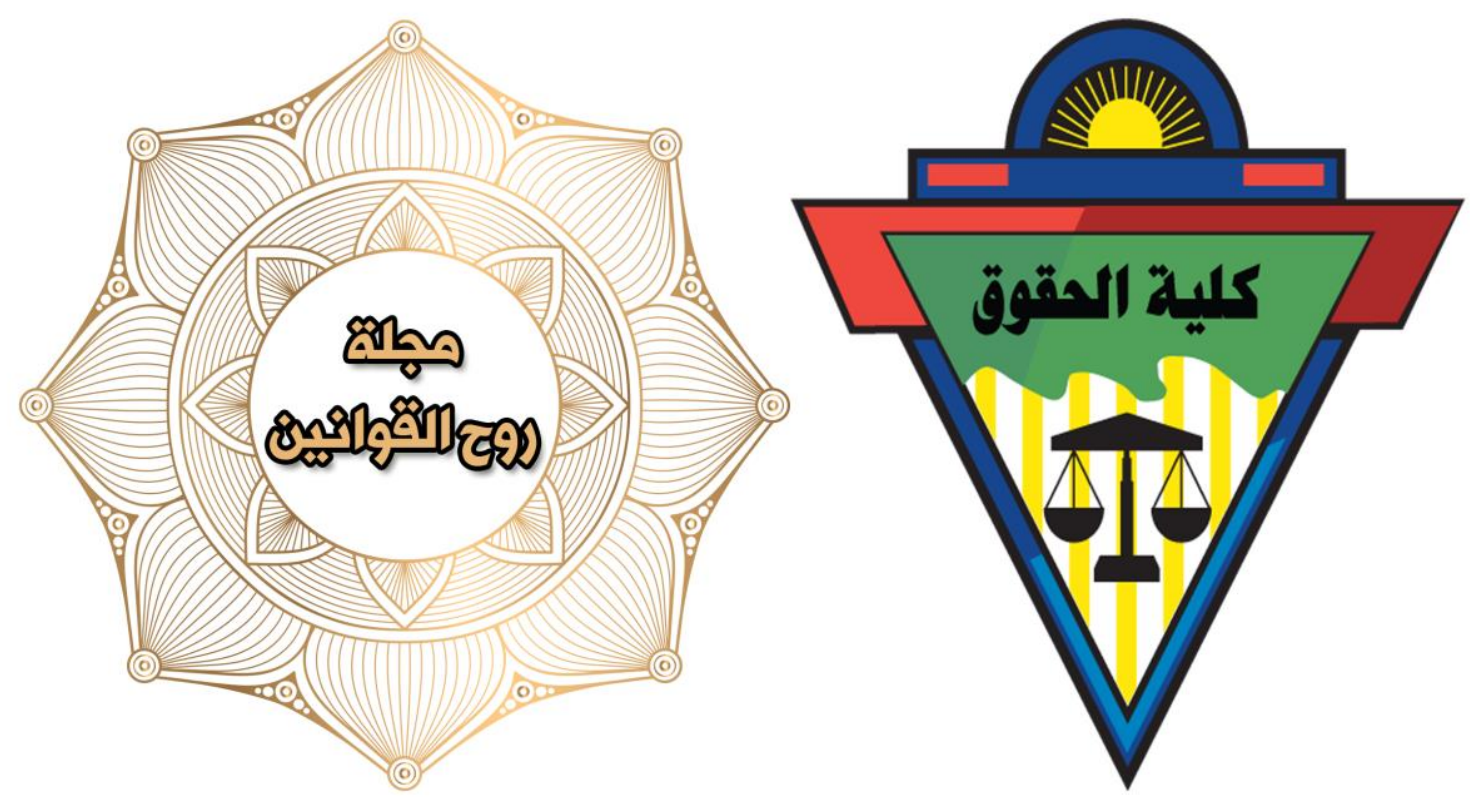

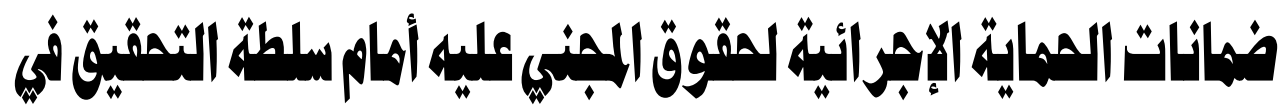

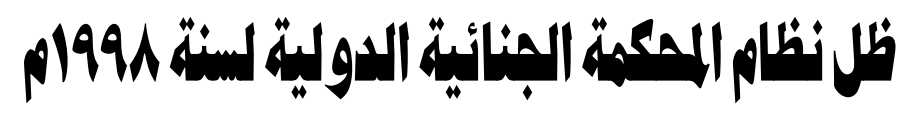

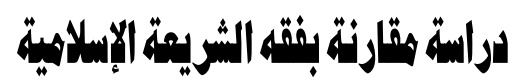

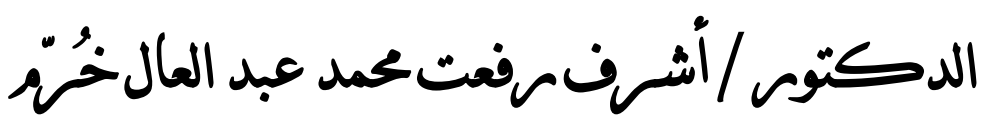

أستاذ القّانون الجكنائي المشامك

$$
\begin{aligned}
& \text { معهد الإدامةالعامة - الراض المملحة العريةالسعودية } \\
& \text { وعضوالجمعية المصرة للاقتّعاد السياسي والإحصاء والتشه ع } \\
& \text { وعضوابكمعة المصرة للقّانون الدولي }
\end{aligned}
$$


يعد موضوع القضائي الدولي الجنائي من الموضوعات التي طالما استحوذت على اهتمام الفقهاء والكتاب في ميدان القانون الدولي والقانون الدولي الجنائي والقانون الجنائي. ويأتي إنشـاء المحكمة الجنائية الدولية نتيجة جرائم ومجازر دولية شهدتها البشرية على مدار قرون راح ضحيتها ملايين الأبرياء، نتيجة حربين عالميتين مدمرتين

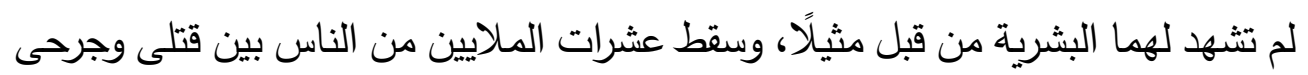
وأسرى ولم يقتصر الضحايا على الجنود وحدهم، بل شمل كذلك المدنيين، فهدمت مساكنهم ودمرت مصانعهم ومتاجرهم وخربت كثيرًا من مدنهم (') فضحايا الجريمة كانوا سبيا في تتبيه المجتمع الدولي إلى ضرورة وجود قضاء دولي جنائي يختص بمحاكمة مجرمي الحرب ومرتكبي الجرائم ضد الإنسانية دون وجه حق، لكن كان الهدف الايدلوجي وازدواجية معايير العدالة وتطبيق قانون المنتصر خطراً يجعل نجم العدالة يأفل و يخيم اليأس على المجني عليهم في كل دول العالم وخصوصاً في الدول التي لا تحترم حقوق الإنسان، إذ إن تحقيق العدالة وتطبيق العقوبـة على مرتكب الجريمـة يُعد من متطلبات الحياة الاجتماعية الآمنة لسير الدول والمجتمعات واحترام للقواعد الدنيا في حماية المجني عليه. ويجب على المجتمع الدولي تطوير آليات معاقبة الجناة لكي تعيد العدالة الجنائية حقوق المجني عليه التي انتهكت باستهتار الأفراد بقواعد القانون الدولي الإنساني في زمن الحرب وانتهاك القانون الدولي لحقوق الإنسان في زمن السلم. وتعد المرحلة المعاصرة الأكثر إسهاما في تطور القانون الدولي الجنائي خصوصاً بشأن تطوير المركز القانوني لضحايا الجرائم الدولية بصفة خاصة قياساً على العصور السابقة. إذ يجزم بعض الباحثين بعدم وجود أية وثيقة أو سابقة قضائية في القانون الدولي الجنائي سابقة على الحرب العالمية الثانية تتطرق إلى دور ضحايا 


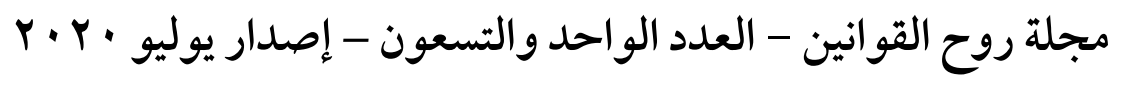

الجرائم الدولية في المحاكمات الدولية(') ـ وافتقاد التوازن في الميزان العلي بين الضحية

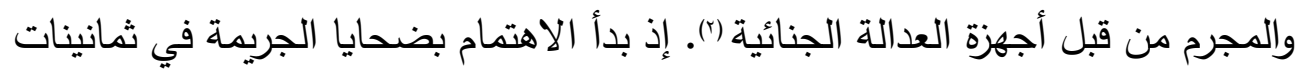

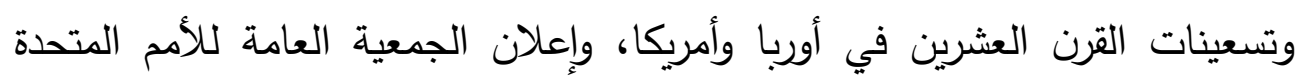
للمبادئ الأساسية للعدالة لضحايا الإجرام وسوي استخدام السلطة.

ا-هشكلة البمث:

يهرف القانون الجنائي بفرعيه إلى إحداث التوازن بين حماية المصـــلـحة العامة التي

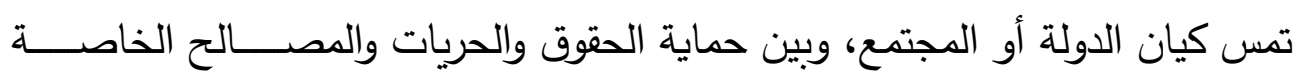

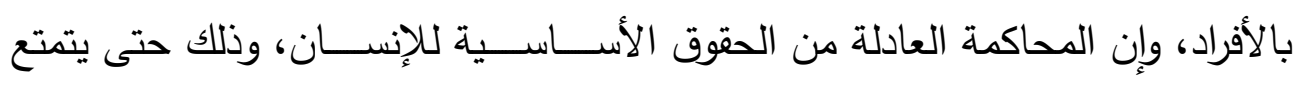

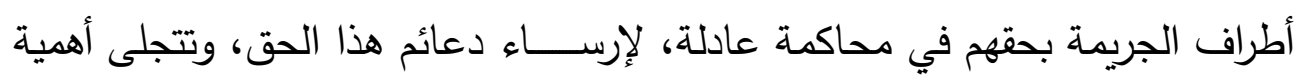

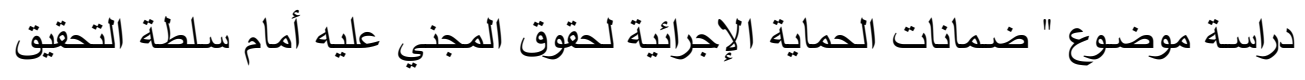

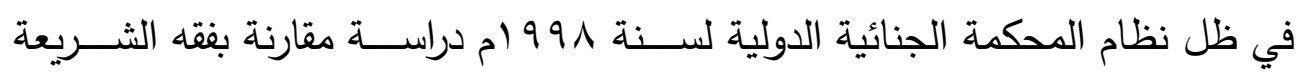

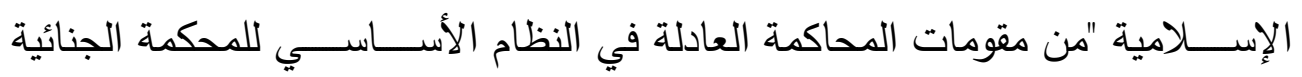

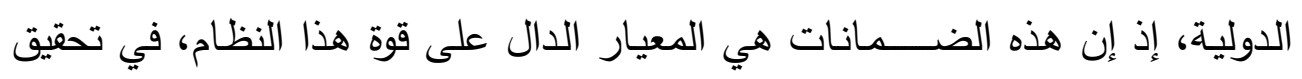

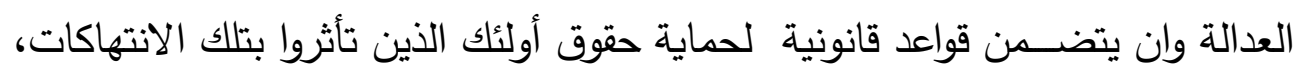

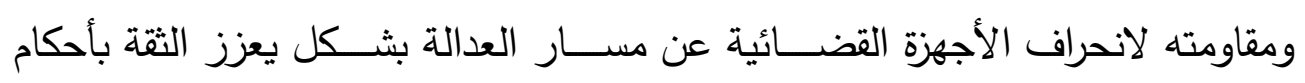

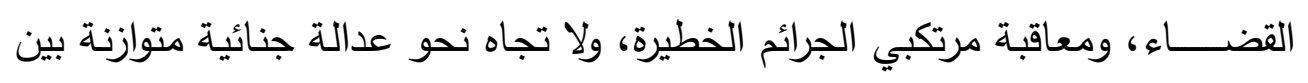

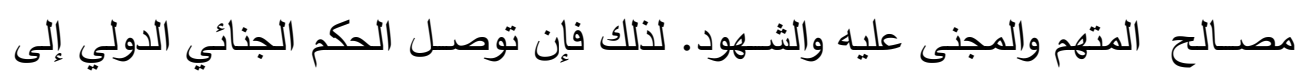
احترام ضـــانات حقوق المجني عليه في مراحل الدعوى الجنائية كان عنوانا للحقيقة.

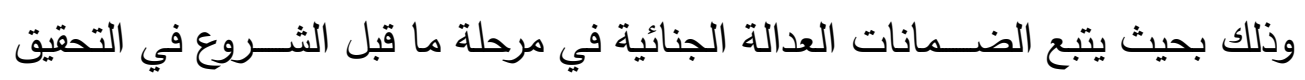

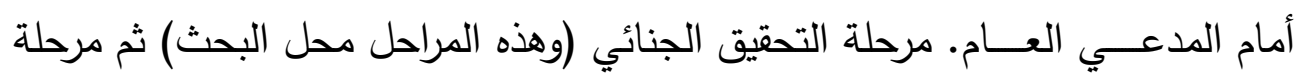

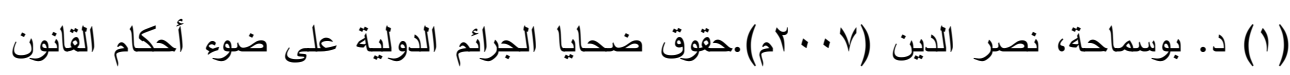

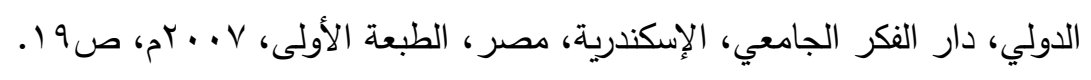

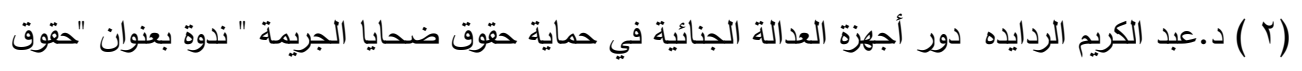

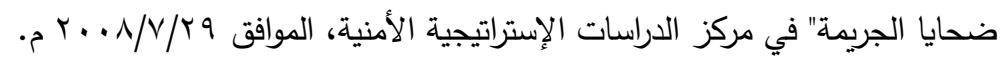
(ro.) 
المحاكمة وهي مرحلة مناقشة الأدلة وإعطاء الحكم ('). بصـدور حكم نهائي يتضمن

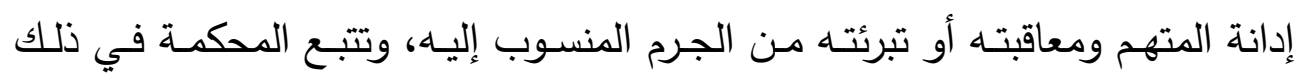

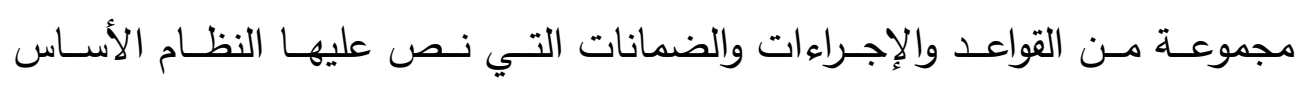
للمحكمة الجنائية الدولية (†) وتقتصر الدراسة على مرحلة التحقيق في النظام الأساسي دون المحاكمة. وما هذه الدراسة إلا محاولة لبيان القواعد القانونية الخاصة بضمانات الحماية الإجرائية لحقوق المجني عليه أمام سلطة التحقيق في ظل نظام المحكمة الجنائية الدولية لسنة 199 ام. وذلك بالكثف عن الحقوق الإجرائية للمجني عليه التي مكنه منها النظام الأساسي للمحمة الجنائية الدولية للجوء إلى العدالة نتيجة أن كثيراً من الضحايا يواجهون حواجز إجرائية ومالية عند الاستفادة من سبل الانتصاف (־).وبيان هل إنل يحصل على معاملة جنائية منصفة ومتساوية مع المتهم والادعاء؟ وذلك باعتبار أنه من تقع عليه الجريمة وهو المظلوم الأول والصاحب الأول للحق في القصاص العادل وجبر الضرر وإعادة التأهيل وتوفير ضمانات لكل ما سبق. وفقد قال تعالى: روَهَنْ

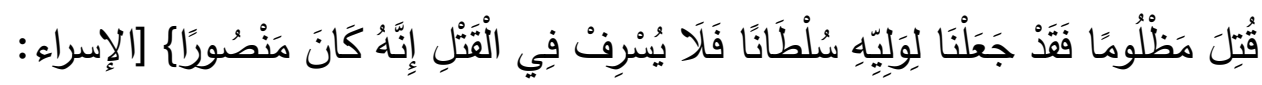
سب] ودلالة الآية ذكر الله-تعالى - أنه جعل لولى القتيل سلطانًا، ولم يذكر أي ولي؛ فيشبه أن يكون المراد من الولي الذي يخلف الميت في التركة، وهم الورثة إذ هو حق

(1 ) د · حوة، سالم حوة (10 ب م). سير المحاكمات الجنائية في القانون الدولي الجنائي على ضوء

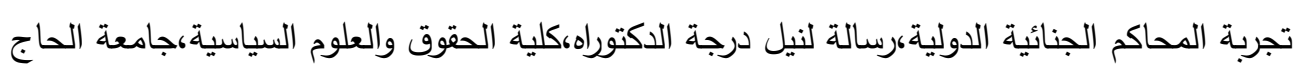

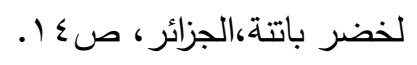

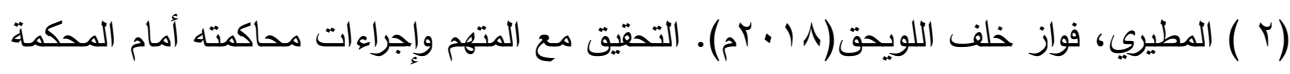

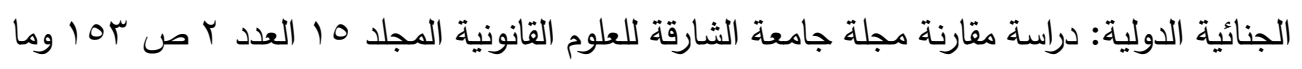

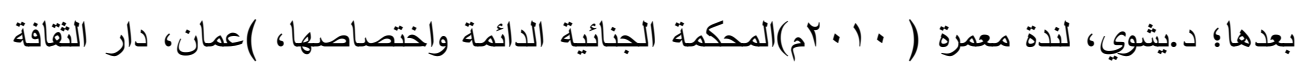

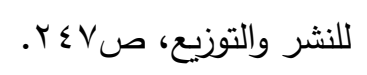

(ץ ) د.عبد اللطيف، براء منذر كمال(^ . . rم). النظام القضائي للمحكمة الجنائية الدولية دار الحامد

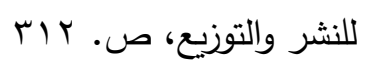




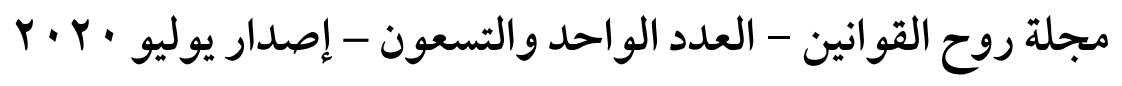

كغيره من الحقوق؛ فذلك إلى الورثة، فحرم اللَّه قتل النفس بغير حق؛ إذ في إباحته

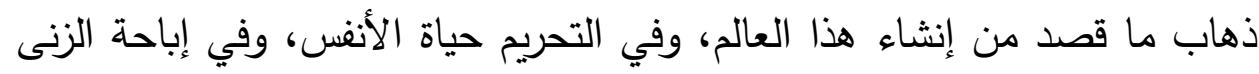

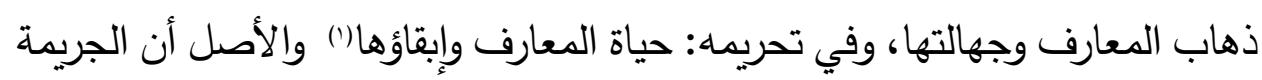

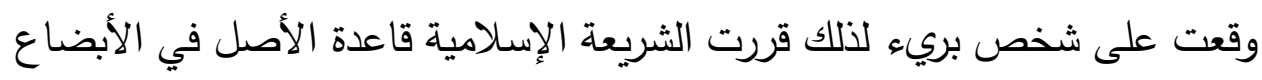

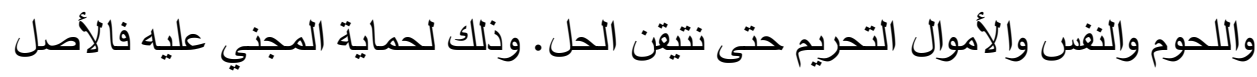
في تحريم العدوان على الأبضاع للمجني عليه زنا واغتصاب وتطهير عرقي ويعني:

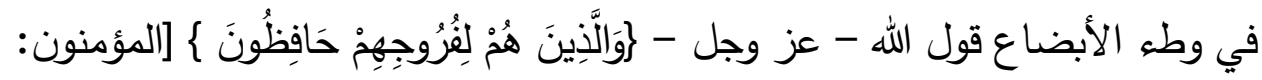
0]، [المائدة: ؟]. والأصل في تحريم اللحوم يعني: في أكلها لقوله تعالى: قول الله الله -

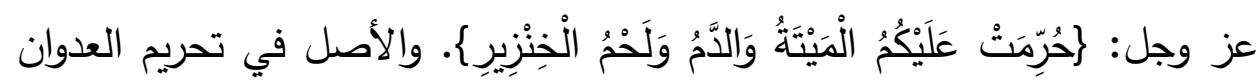
على الأنفس وما دونها والذي يشمل كل الجرائم الدولية يعني: في سفكها قول الله -

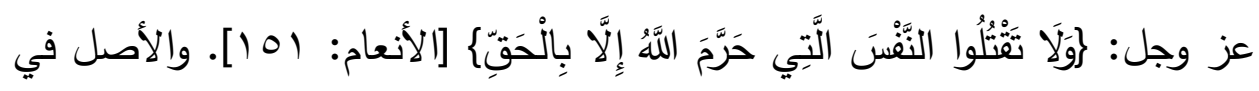

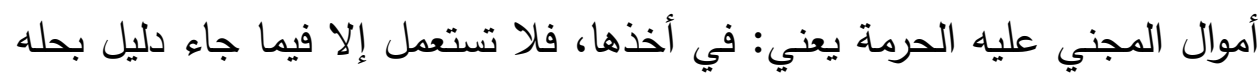

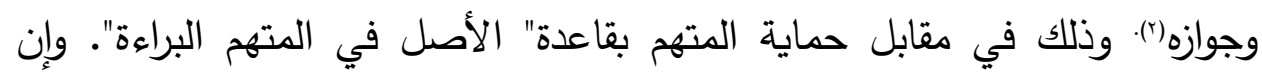

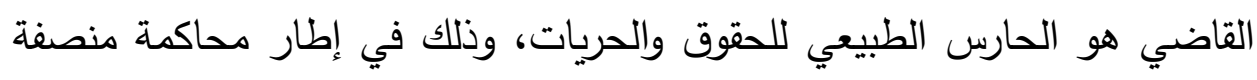

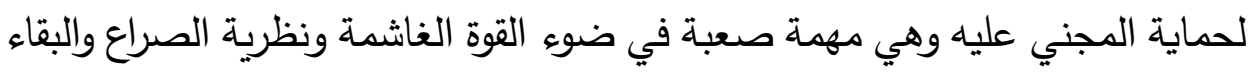
للأقوى وذلك لرفع العدوان الذي لحقه من الجريمة، أو لرفع العدوان من الإجراءات

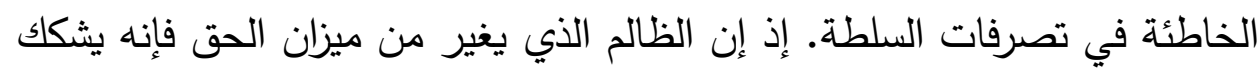

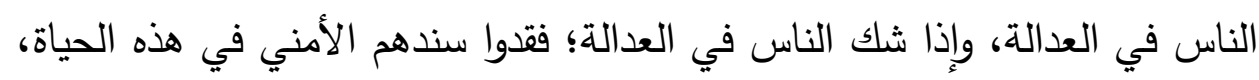

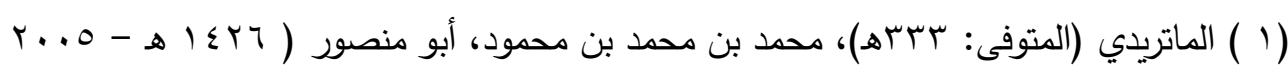

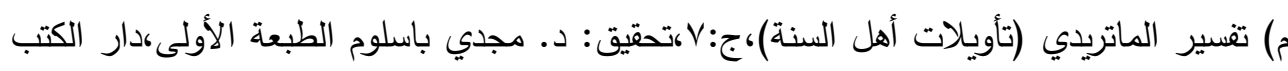

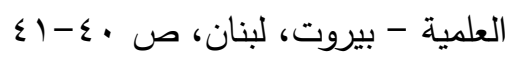

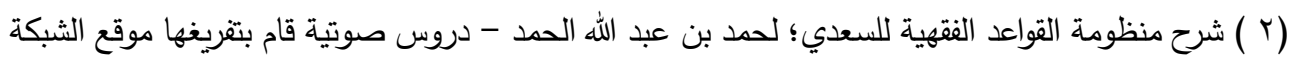

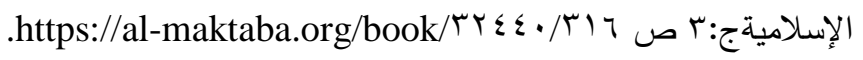


فيفسد المجتمع كله وتفسد معايير الحق مما يؤثر في العاقبة في الدارين الدنيا

والآخرة(')

وهنا يطرح التساؤل حول ما الحقوق الإجرائية للمجني عليه لدى سلطة التحقيق لدي المحكمة الجنائية الدولية؟ و حول قدرة هذه المؤسسة القضائية الجديدة، والمتمثلة في سلطة التحقيق للى المحكمة الجنائية الدولية وغيرها في توفير الضمانات لضحايا الجرائم الدولية لاستيفاء حقوقهم، سواء ما تعلق منها بالضمانات في مجال الاختصاص القضائي أو الضمانات في مجال الإجراءات الجنائية وبيان المركز القانوني للمجني عليه في النظام الأساسي والنظم الإجرائية المعاصرة. ومعرفة حماية حقوق المجني عليه في مرحلة ما قبل الثروع في التحقيق لدي المحكمة الدولية،وحق المجني عليه في تحريك الدعوى الجنائية أمام أجهزة المحكمة الجنائية الدولية،والوقوف على حقوق ضحايا الجريمة أثناء التحقيق الابتدائي والكثف عن حق المجني عليه في الدفاع أمام سلطة التحقيق ،وإبراز حق ضحايا الجرائم الدولية بجبر الأضرار بالحصول على التعويض الملائم، ومن حقوقهم الحصول على تعويض من الدولة في حال عدم معرفة الفاعل وحق المجني عليه في طلب الحماية إذا استشعرت أن حياته معرضة للخطر والتهديد وحقه في الاستعانة بمحام، وحق المجني عليه في الوصول إلى العدالة بأقصر وقت ودون تباطؤ.

تبدو أهمية البحث العلمية والعملية في دراسة حقوق المجني عليه وحمايتها في الرعاية والتعويض، سواء من منطق العدالة الجنائية أو من منطق النفعية الاجتماعية في آن واحد. ولذلك يجب أن تبذل في تفعيل آليات قانونية قائمة أو مستحدثة لسد ذلك الفراغ. وكذلك تذليل هذه العقبات وسد النقائص والثغرات التشريعية التي تقف حائلا دون تمكن ضحايا الجرائم الدولية من استيفاء حقوقهم. فيهدف البحث إلى ما يأتي:

( ( ) د. أحمد عبد اللاه ، هلالي (r . . Y). تجريم فكره التعسف كوسيلة حماية المجني عليه في مجال استعمال

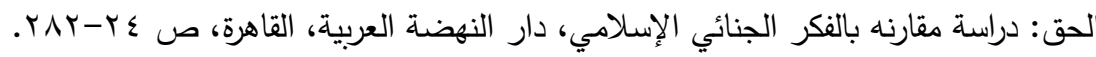
(rot) 
r. r. • مجلة روح القوانين - العدد الواحد والتسعون - إصدار يوليو

أولا: إبراز المركز القانوني للمجني عليه في النظام الأساسي والنظم الإجرائية

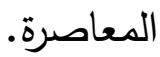

ثانيا: تحديد حماية حقوق المجني عليه في مرحلة ما قبل الشروع في التحقيق لدي

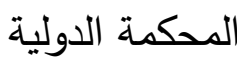

ثالثا: تحديد حماية حق المجني عليه في تحريك الدعوى الجنائية أمام أجزة المحكمة

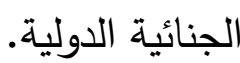

رابعا: الوقوف على حقوق ضحايا الجريمة أثناء التحقيق الابتدائي.

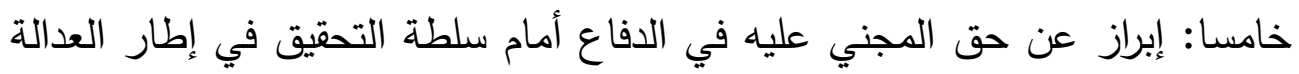

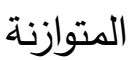

سادسا: إبراز حماية حق ضحايا الجرائم الدولية بجبر الأضرار .

$$
\text { أهداف البمث: تركز أهداف البحث فيما يأتي: }
$$

أولا: التعرف على المركز القانوني للمجني عليه في النظام الأساسي والنظم الإجرائية

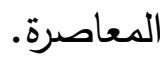

ثانيا: إدراك حماية حقوق المجني عليه في مرحلة ما قبل الشروع في التحقيق لاي

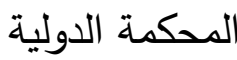

ثالثا: إيضاح حماية حق المجني عليه في تحريك الدعوى الجنائية أمام أجهزة المحكمة

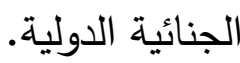

رابعا: بيان حقوق ضحايا الجريمة أثناء التحقيق الابتدائي.

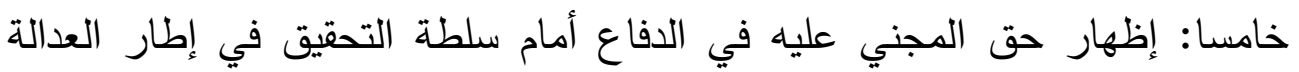

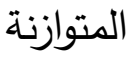

سادسا: التعرف على حماية حق ضحايا الجرائم الدولية بجبر الأضرار.

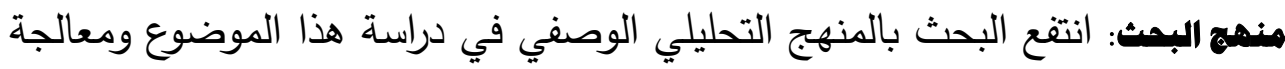

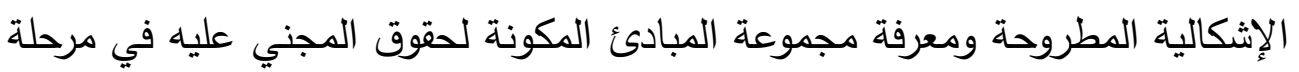
التحقيق في الدعوى الجنائية لاى سلطات المحكمة الجنائية الدولية. وذلك من خلائل 


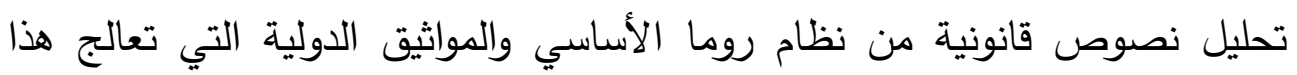

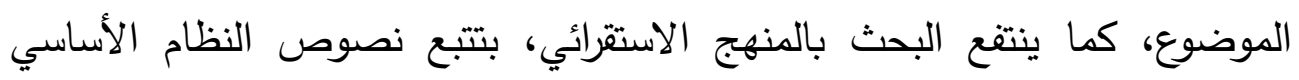

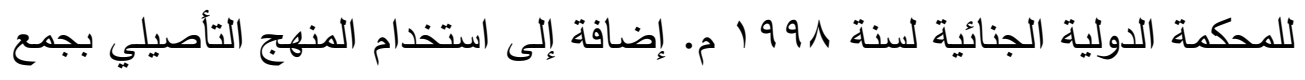

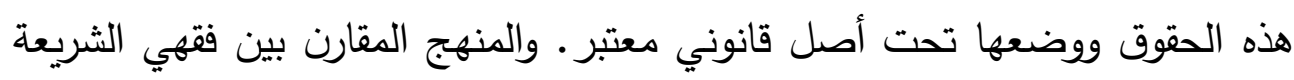

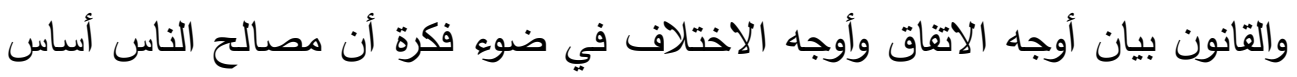

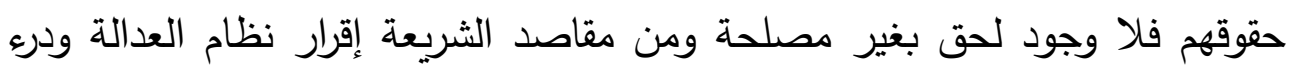

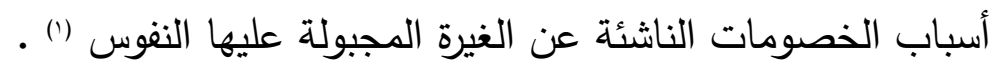
الدراسات السابقة: اهتمت الدراسات السابقة بالدحكمة الجنائية الدولية. وكذلك بالجرائم

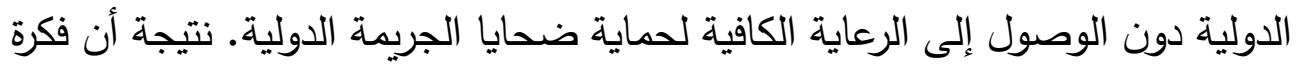

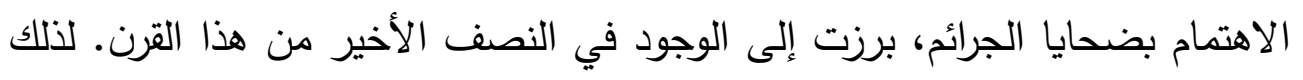

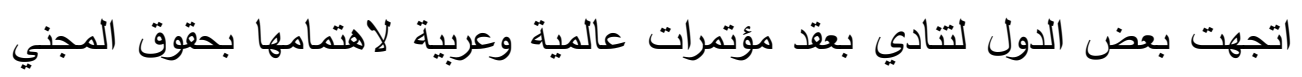

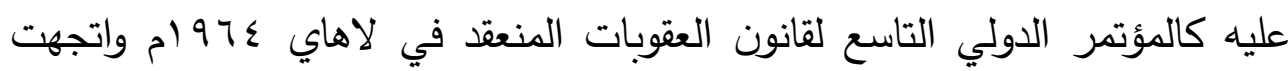

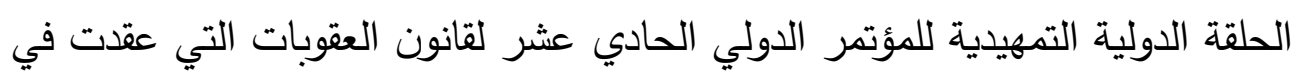

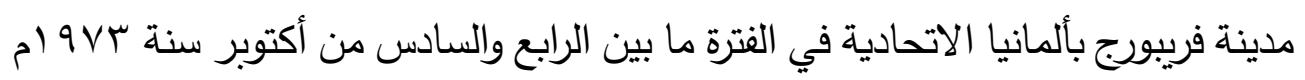

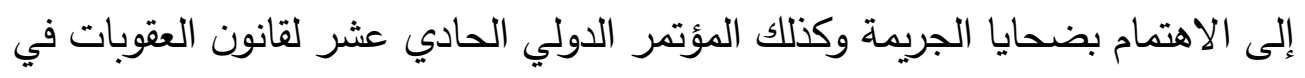
بودابست في عام ع و ام كنلك عقدت الندوة الدولية لحماية حقوق ضحايا الجريمة

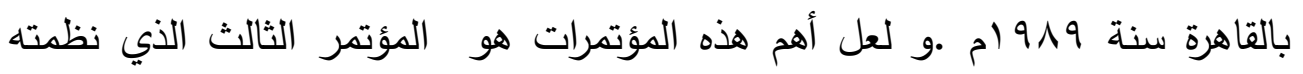

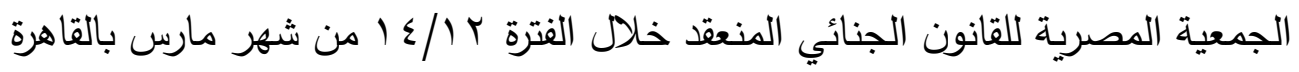

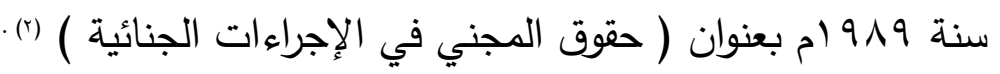

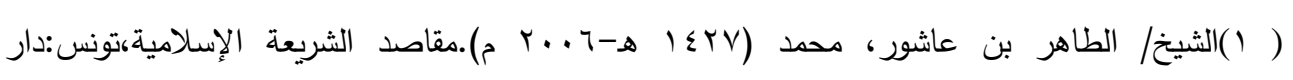

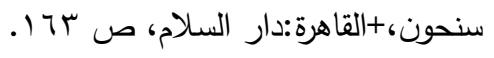

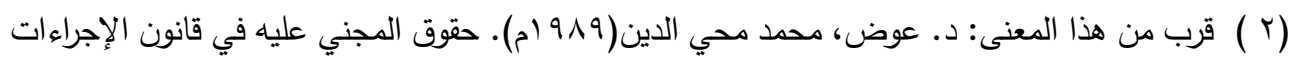

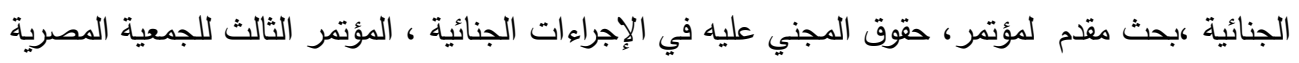

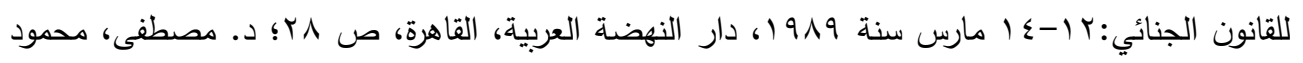

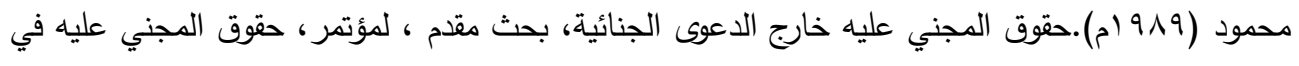


r.r. · مجلة روح القوانين - العدد الواحد والتسعون - إصدار يوليو

\section{المبمث الأول}

المركز القانوني المجني عليه

\section{في النظام الأساسي والنظم الإجرانية المعاصرة}

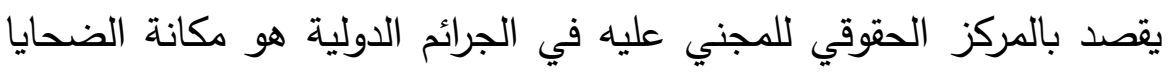

ودورهم في الإجراءات القضائية الخاصة بمحاكمة المسئولين عن ارتكاب الجرائم الدولية

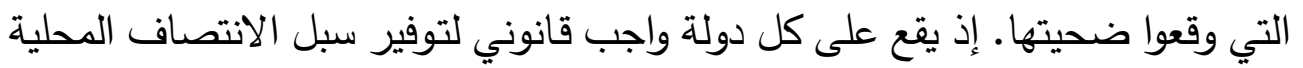
للضحايا باعتباره واجبا ملازما للواجب العام في حماية حقوق الإنسان، كما يقع الالتزام

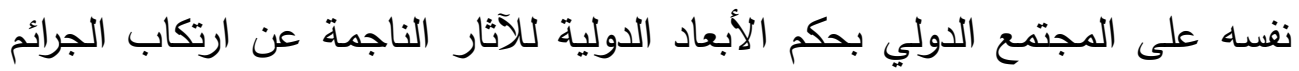

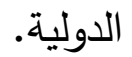

\section{المطاب الأول \\ اتجاهات السياسة الجنائية بشأن بحماية حقوق المجني عليه}

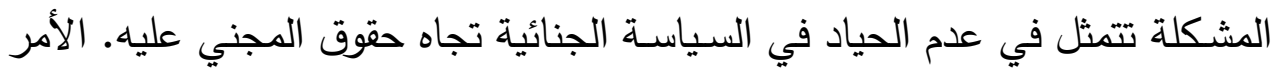

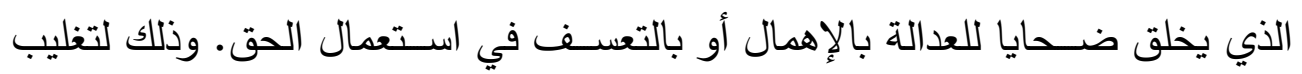

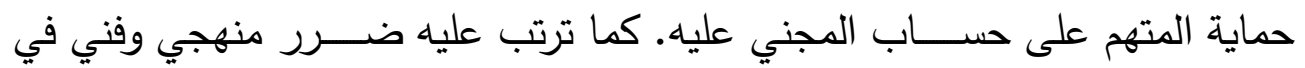

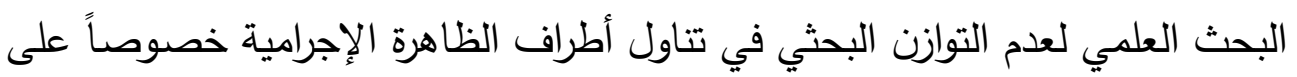
المستوى الدولي. وذلك على الوجه الآتي:

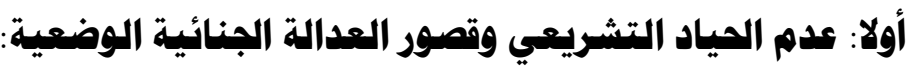

اتجهت التشـريعات الوضـعية إلى النظر الأحادية في توزيع الحقوق بما يخل بالتوازن

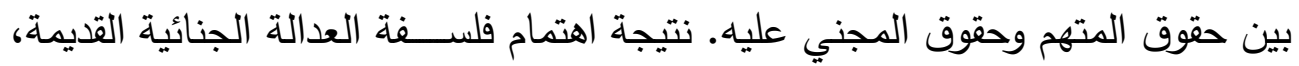

الإجراءات الجنائية ، المؤتمر الثالث للجمعية المصرية للقانون الجنائي، ب ا-ــ المارس سنة 919 1، دار

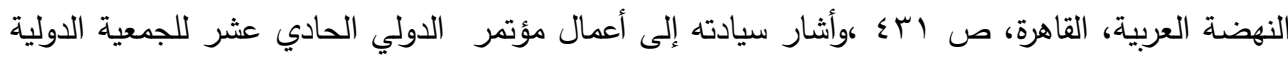

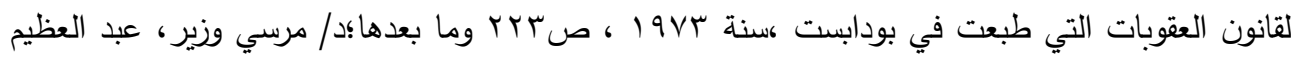

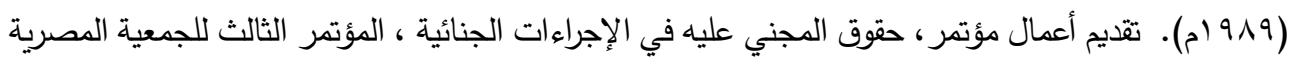

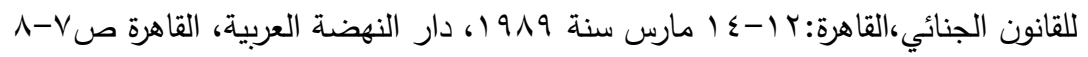
(roT) 
بمركز الجاني وتعقبه وإنزال أشـــــ العذاب به لتطهيره من الذنب. لذلك أخذت العقوبة طابع الانتقام. وفي هذه المرحلة أدمجت العقوبة في التعويض الذي يؤول إلى المجني عليه أو أسرته. وأصبح الملك والإقطاعيون يشاركون المجني عليه في التعويض. ومن ئن ثم لم تلق حقوق المجني عليه الاهتمام الكافي، ولا تحقيق التوازن بين حقوق المجني عليه وحقوق الجاني كأطراف في الظاهرة الإجرامية. وهذا يجعل العدالة منقوصــة. أما في ظل فلســفة العدالة الجنائية الحديثة فقد بدأ الاهتمام ببيان دور المجني عليه في الظاهرة الإجرامية، وإيجاد سبل الدفاع عن حقوق المجني عليه وتعويضـه عما لحق به من أضرار ناجمة عن الجريمة سواء كان من الفرد أو من الدولة. لذلك بدأت السياسة الجنائية منذ منتصف القرن الماضي تبحث عن وسائل تحقق أقصى فاعلية ممكنة في مكافحة الإجرام ومواجهة أزمة العدالة الجنائية (') فبعثت فكرة حماية المجني عليه من

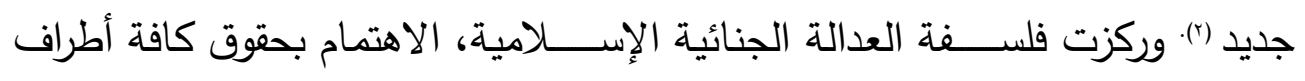
الظاهرة الإجرامية على قدم المســاواة (حقوق "المجتمع، الضـــية، الجاني)". فركزت على مضــون الحق وموضـوعه وغايته ووسـيلته حتى أصـبح لكل حق دعوى تحميه ولكل حق غاية يبتغيها صــــاحب الحق (r). ومن ثم يجب توفر آليات لتحقيق العدالة

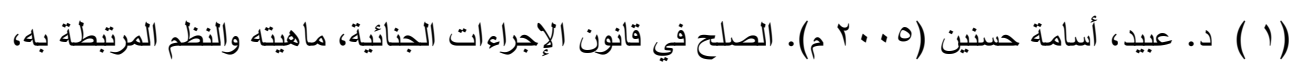

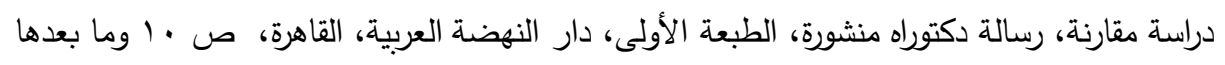

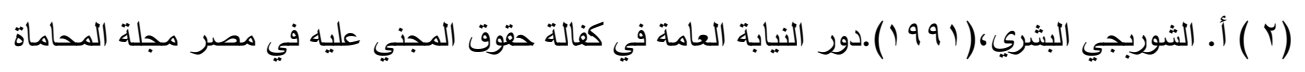

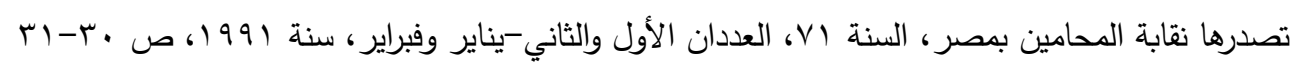

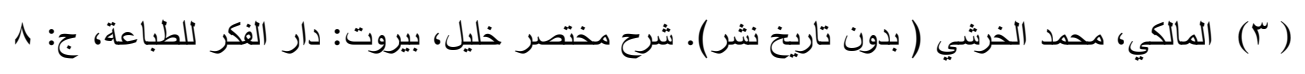

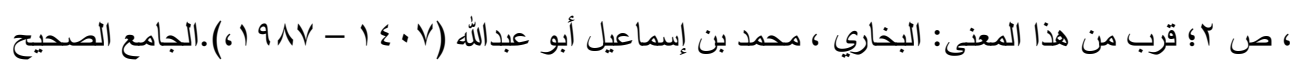

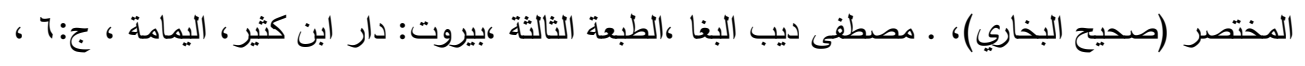

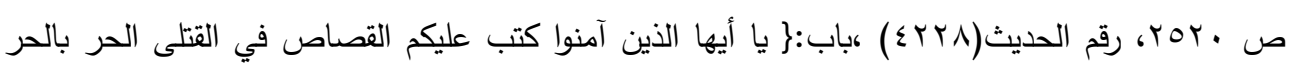

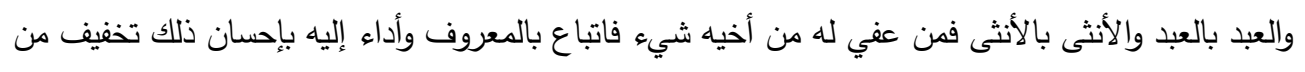

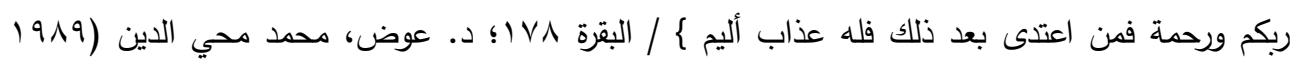

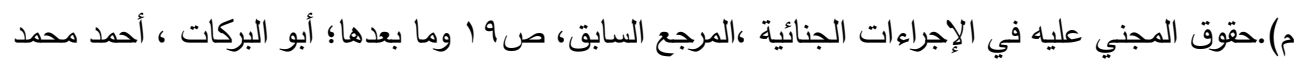

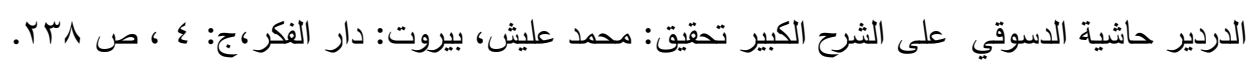




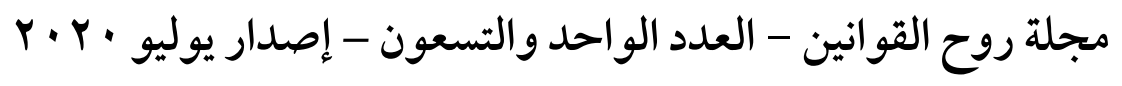

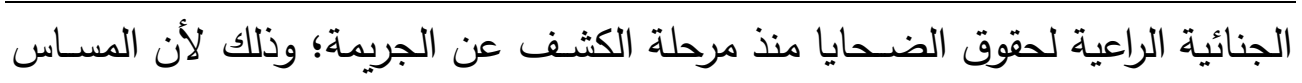

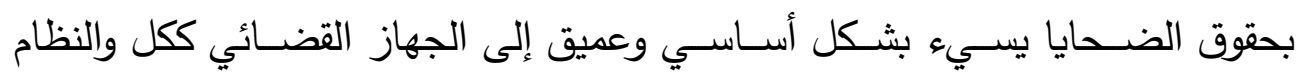

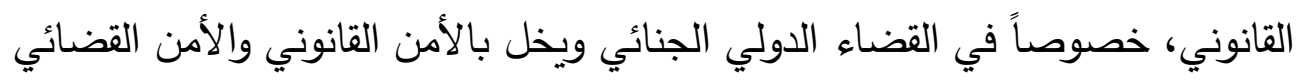

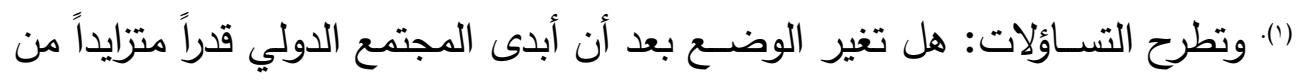

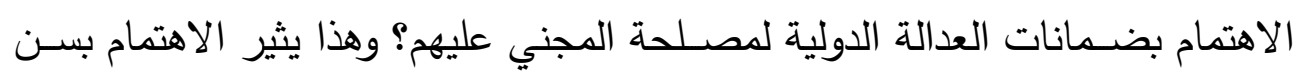

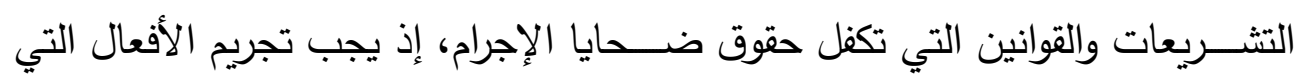

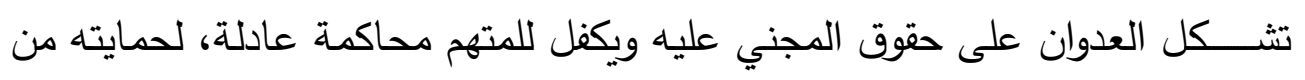

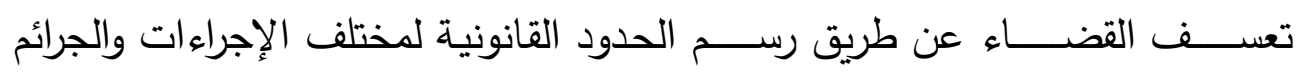

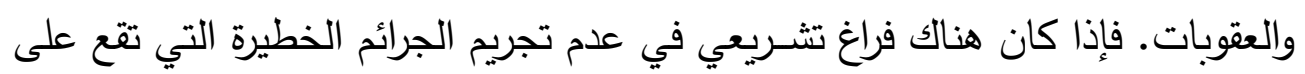

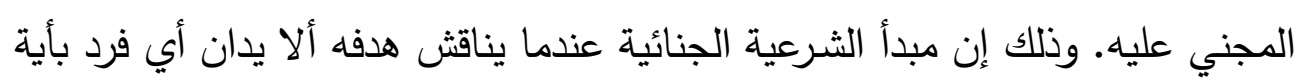

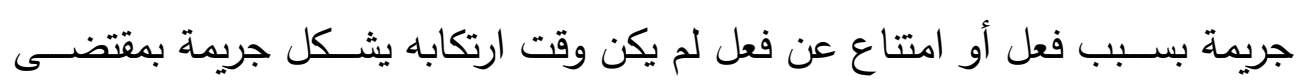

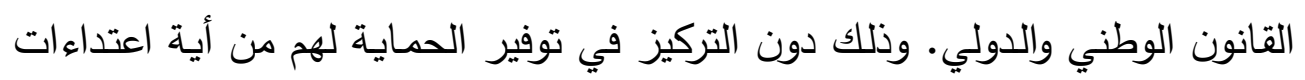

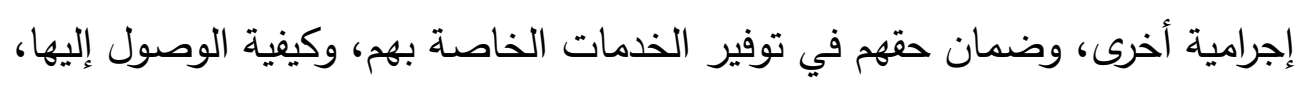

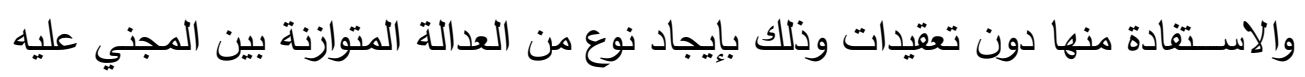

(1 ) د. حسني، محمود نجيب (1909 م م- ـ 197 م م).دروس في القانون الجنائي الدولي القاهرة: دار

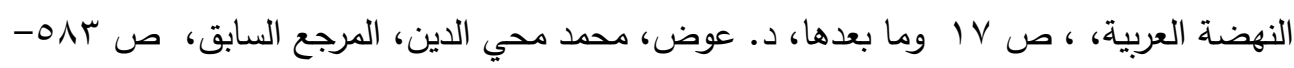

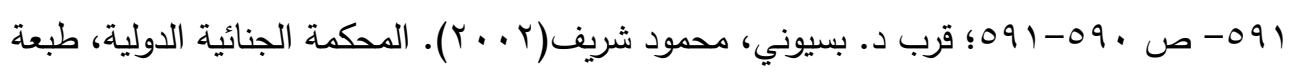

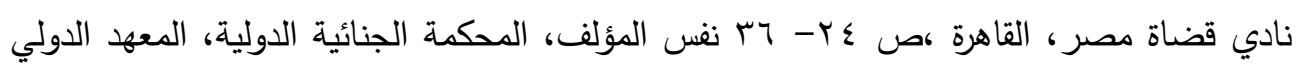

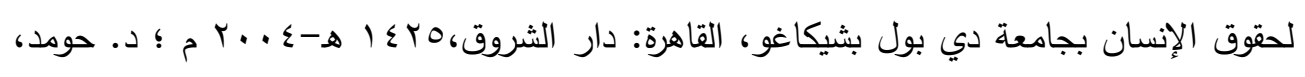

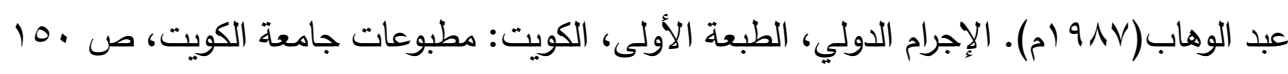

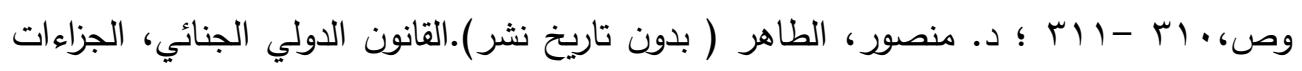

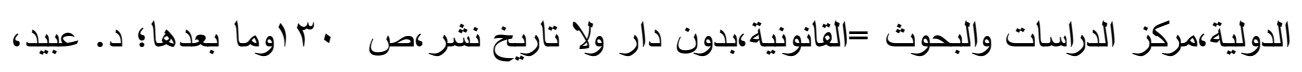

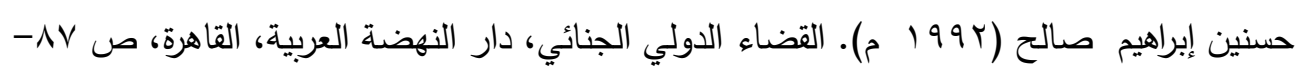

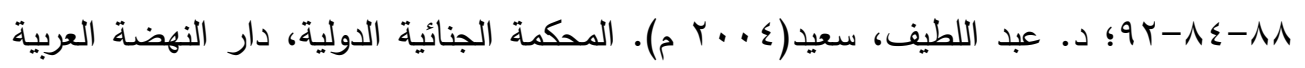

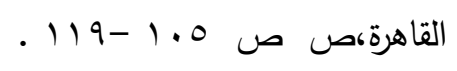
$($ r०N $)$ 
والمتهم والمجتمع وتقعيل حق ضــــحايا الجرائم الدولية في تحقيق العدالة المتوازنة في

مواجهة السلطة العامة الدولية والمحلية (1).

\section{ثانيا: عدم الهياد العلمي وتطور علم المجني عليه:}

سارت غالبية البحوث العلمية على خطي فلسفة العدالة الجنائية في التركيز في حقوق الجاني دون حقوق المجني عليه، أو دراسة العدالة المتوازنة بينهما كما سبق. ومن ثم يصبح البحث عن حقوق المجني عليه مطلبا إنسانياً بعد الإهمال الذي تعرضت له حقوق المجني عليه. الأمر يقتضي نظرة بين الفكر القانوني العربي وبين فقه الثريعة الإسلامية في تحديد العدالة المتوازنة والمتكاملة بين أطراف الجريمة على قدم المساواة ومنها: حق المجتمع في الأمن والسلامة والطمأنينة، وحق المتهم في حماية حقوقه كإنسان خلال مجريات سير القضية، وحق المجني عليه والمضرور من الجريمة من رفع العدوان الذي لحقه من الجريمة (ז). ولم يكن اهتمام اتجاه القانون المقارن بالمجني عليه، إلا فيما يتعلق بعلاقته بالجاني وكانت أكثر الكتابات والدراسات (في علم الإجرام) ومازالت-تتصب على ذلك (†). إن دراسة الظاهرة الإجرامية لا تكتمل إلا بدراسة الطرف الثاني في الجريمة وهو المجني عليه الذي قد يؤدي دوراً مهماً في حدوثها. ويعد علم الضحية من العلوم الجزائية الحديثة التي بدأ الاهتمام بها ابتداءً من عام 9 ـ (م، ويعدّ

(1) د. محمود، مصطفي محمود (1919 م).حقوق المجني عليه في الإجراءات الجنائية ،أعمال

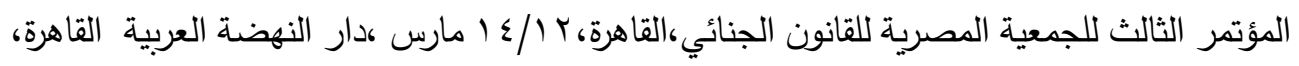

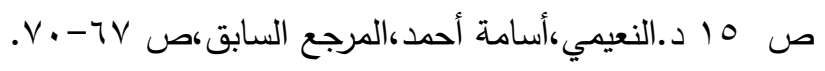

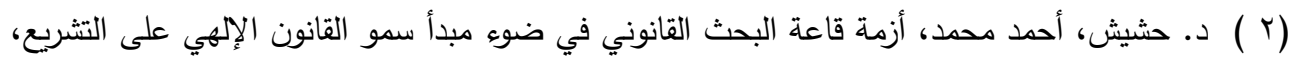

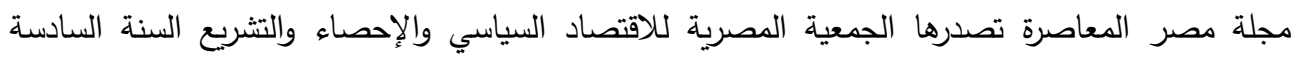

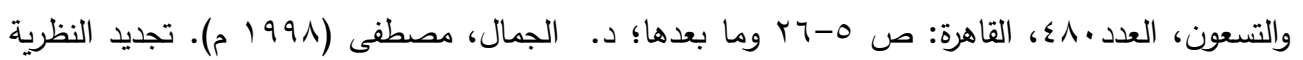

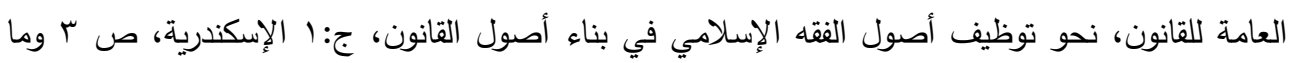




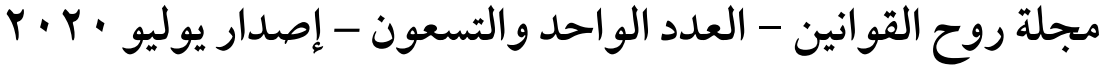

علم الضحية أحد فروع علم الإجرام عند غالبية الفقهاء (')كما قيل يرجع ظهور هذا

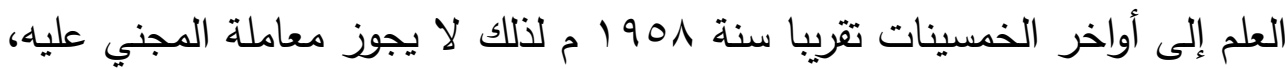

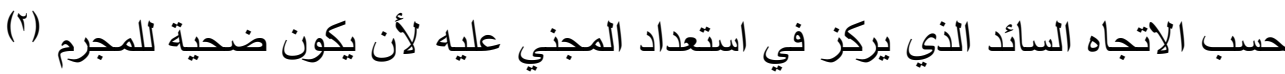

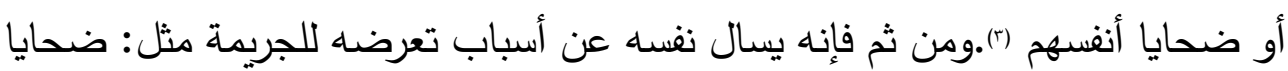

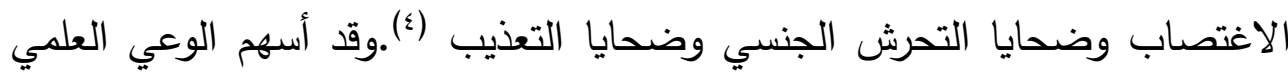
لبعض الأكاديميين، واهتمام وسائل الإعلام الدختلف والحملات الانتخابية وحركات

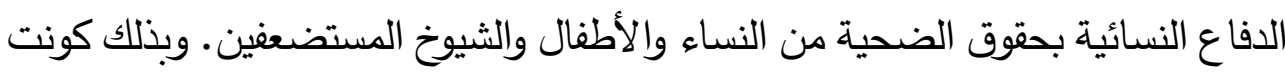
وعيا وضغطا على حكومات بعض الدول-في استدرالك ما هو مفقود في دراسات في

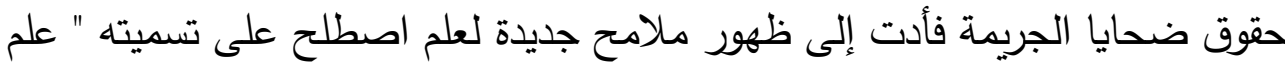

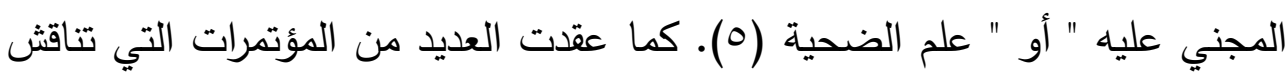

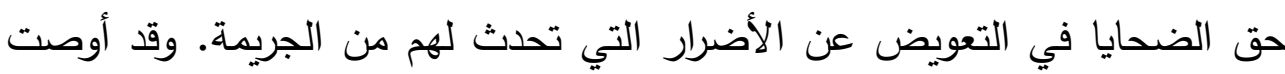
الكثير من الدراسات بضرورة إنشاء هيئات مختصة بمساعدة ضحايا الجريمة وضرورة النارة

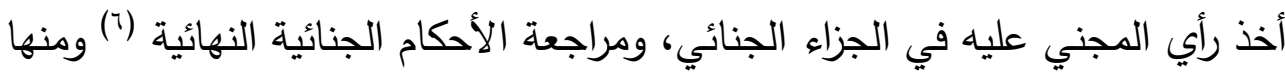

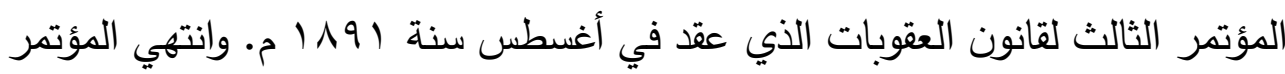
( () د. محمد الأمين البشري، علم ضحايا الجريمة وتطبيقاته في الدول العربية،دار النشر بمركز الدراسات

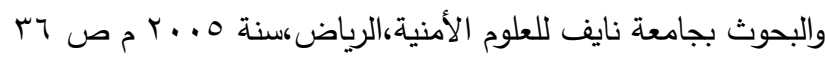

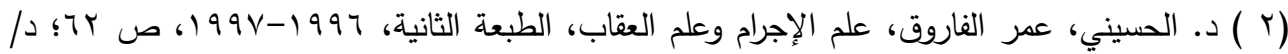

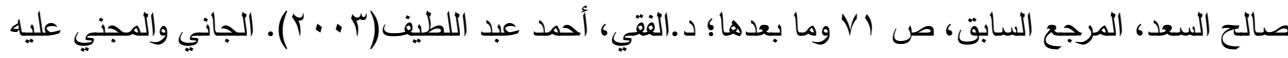

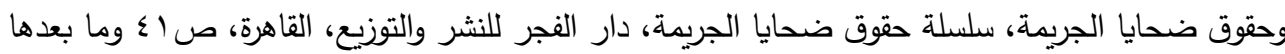

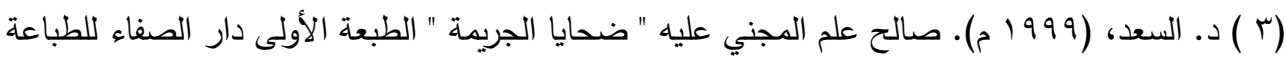

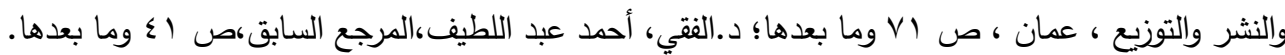

Bonnie.s.Fisher.Steven P.lab; Encyclopedia victimology and crime preventation.volume .1, sage $(\varepsilon)$ publications, California, $r \cdot l \cdot p \leqslant \wedge$

(0 ) د. السعد، صالح المرجع السابق، ص اله به وما بعدها، وجرى تعريفه بأنه فرع من العلم الجنائي يهتم

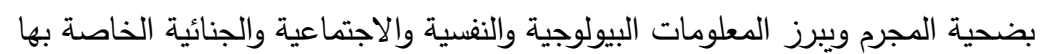
Cf. Rapport au Premier ministre, Pour une nouvelle politique publique d'aide aux victimes, préparé par Groupe ( \) interministériel d'aide aux victimes, M.-N. LIENEMANN (présidence), H. MAGLINO et J. CALMETTES 
ه - ضمانات الحماية الإجرائية لحقوق المجني عليه أمام سلطة التحقيق في ظل نظام المحكمة الجنائية الدولية لسنة 991 ام

إلى ضرورة توفير ضمانات حصول ضحايا الجريمة على تعويضات (') ثم توالت المؤتمرات منها في الأمم المتحدة المؤتمر السابع لمنع الجريمة ومعاملة المذنبين والذي

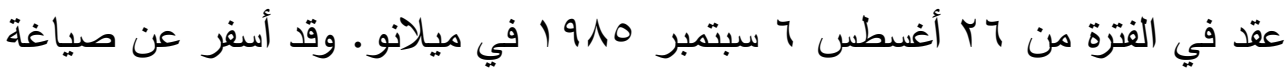

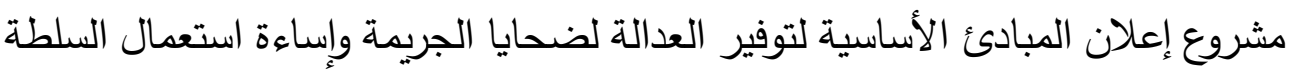

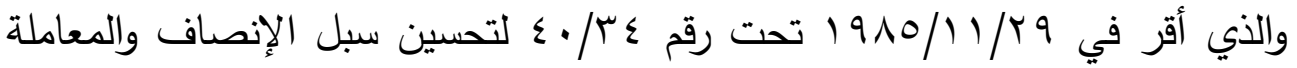
العدالة للمجني عليه لهنع وقوع ضحايا بسبب سوء استعمال السلطة (() وقد قررت التشريعات المقارنة حقهم في التعويض عن الأضرار التي تحدث لهم من جراء الجرائم

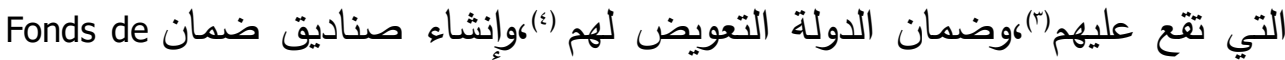
garantie لتعويض ضحايا الجريمة(م)...الخ. وقد وصل الأمر إلى المطالبة بتطبيق عقوبة الإعدام في جميع الولايات المتحدة الأمريكية من أجل ردع الجناة من الاعتداء على الضحايا (i). وأصدرت المنظمات الدولية ومنها منظمة العفو الدولية (Amnesty) ومنظمة مراقبة حقوق الإنسان (human Rights watch) ومركز العدالة الانتقالية العديد

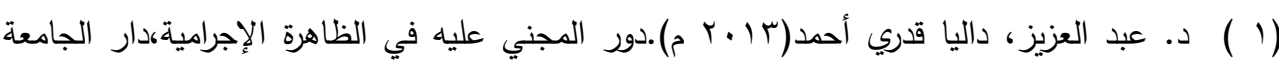

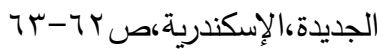

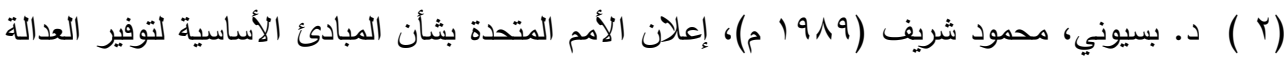

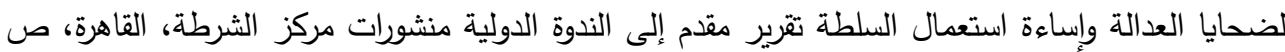
وما بعدها. F. LOMBART, ( $19 \wedge$ r) - Les systèmes d'indemnisation des victimes d'actes de violence, Centre de recherches ( $r$ ) sociologiques sur le droit et les institutions pénales, Paris, Y. CLAPOT, (1990) Indemnisation des victimes: les infractions pénales, dommage, préjudice, réparation, Paris, Editions ESKA, 1990 ( ) د د. عقيدة، محمد أبو العلا (911 (1)). تعويض الدولة للمضرورين من الجريمة، دار الفكر العربي. A. MBARGA, ( $(\cdots)$ L'indemnisation publique des victimes d'infractions, L'indemnisation par le Fonds de garantie, Paris, ÉditeurL'Harmattan ففي فرنسا علي سبيل المثال، تم إنشاء المجلس الوطني لمساعدة ضحايا الجريمة Conseil national d'aide aux victimes بمقتضي مرسوم رقم

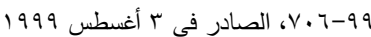
Julien, $(Y \cdot \Upsilon •)$ L'influence perturbatrice du dommage corporel en droit des obligations, th. Tours, Paris : LGDJ, coll.

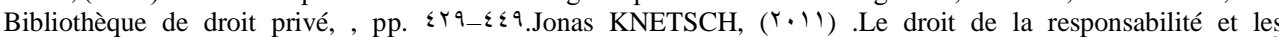
fonds,d'indemnisation Thèse en vue de l'obtention du grade de Docteur en droit privé présentée UNIVERSITÉ PANTHEONASSAS le $\vee$ octobre $r \cdot 11$

(1 (0 ) د. عقيدة، محمد أبو العلا (19/1). تعويض الدولة للمضرورين من الجريمة، دار النكر العربي..

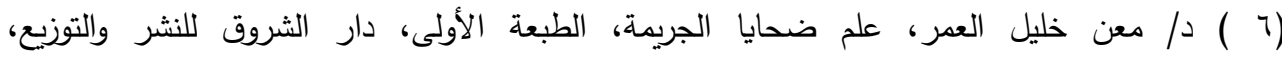

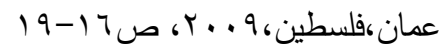


r.r. · مجلة روح القوانين - العدد الواحد والتسعون - إصدار يوليو

من تقارير سنوية متعلقة ببعض الجوانب الخاصة بحماية حقوق الضحايا. فاستجابت

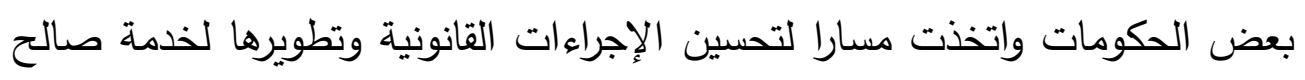
ضحايا الجريمة. كما حدث في بريطانيا عام 191V وفي الولايات المتحدة الأمريكية.

\section{مفهوم الجنبي عليه الثاني}

أولا: تعريف المبني عليه: إن الجريمة هي الذنب الذي يفعله الإنسان مما يوجب العقاب العبه

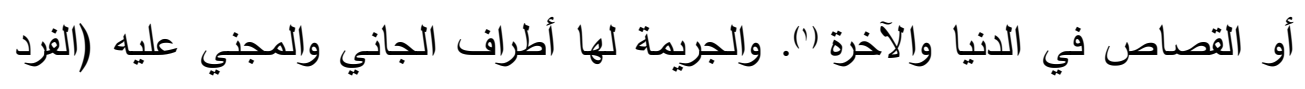

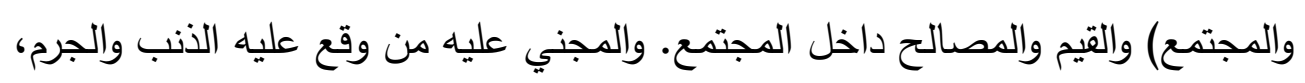

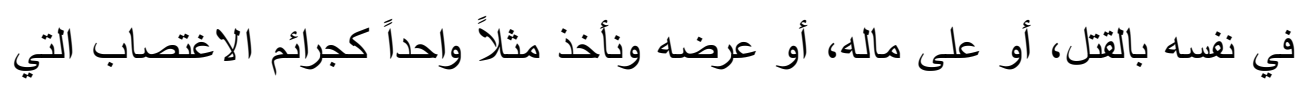

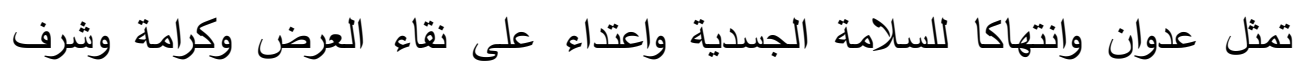

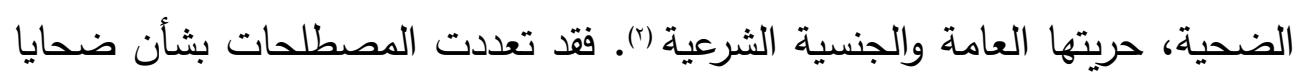

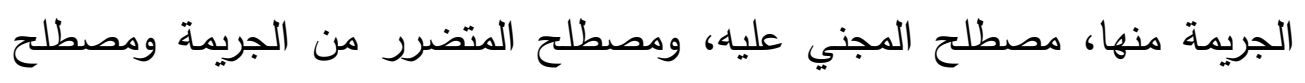

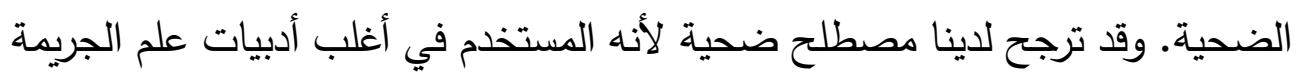

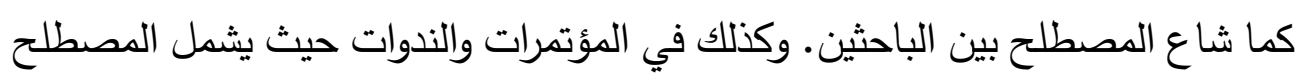

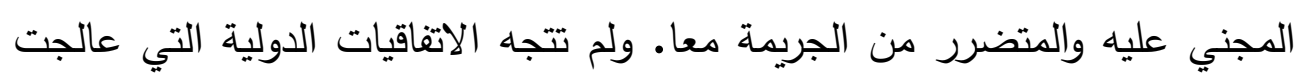

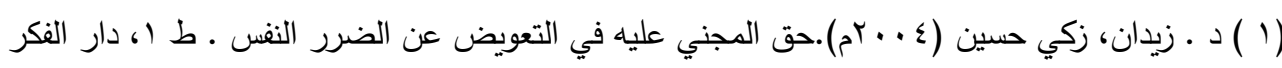

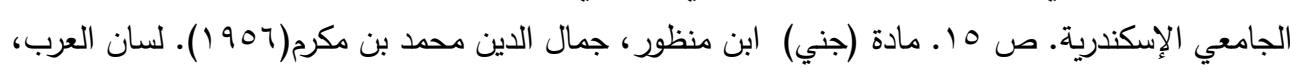

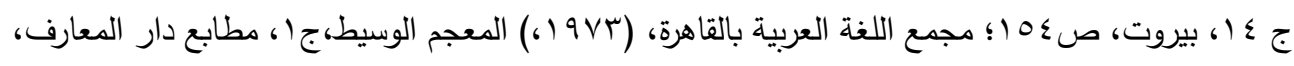

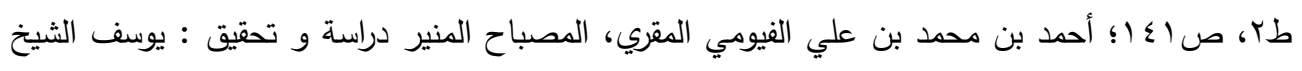

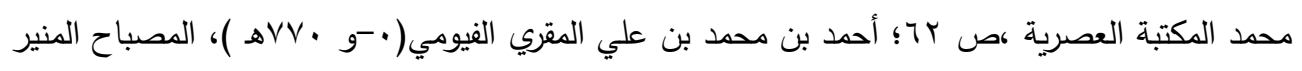

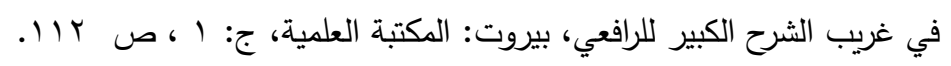

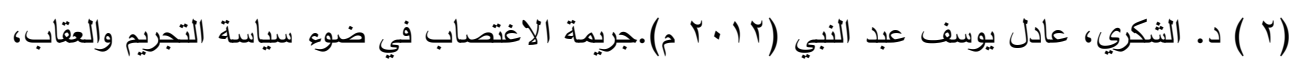

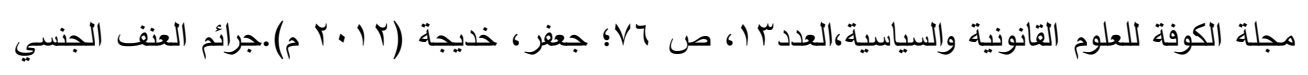

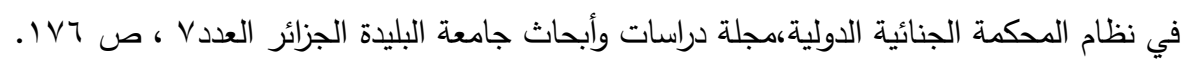


بعض الجرائم الدولية الضحية إلى تعريف المجني عليه، إنما فقط تثير إلى معاناة الضحايا من جراء الجرائم التي ارتكبت في حقهم وتأكيد ضرورة الحد منها ((). وهذا هو إلى النهج الذي انتهجته اللجنة المكلفة بإعداد مشروع قانون العقوبات الفرنسي عندما رأت استبعاد كل تعريف يكون محلاً للخلاف الفقهي (r). كذلك قلما تعني التشريعات بالنص لباعل على تعريف لفكرة ما، إذ ليس من وظيفة المنظم القيام بالتعريف إلا في حالتين: أولاهما: أن يكون غرض التعريف حسم خلاف فقهي قائم. ثانيهما: أن يكون معنى بالن التعريف مغايرا لمعنى مستقر (r). ومن ثم فقد تصدى الفقه والقضاء لتعريف المجني عليه وتعددت تعريفاتهم (ع). لذلك تباينت الاتجاهات في تعريف المجني عليه حسب منها المعيار الأول: معيار ضرر الجريمة الذي يلحق بالمضرور والمعيار الثاني: معيار العدوان على المصلحة محل الحماية الجنائية. كما يأتي:

الاتجاه الأول المفهوم الواسع الصطلح الجني عليه: يعتمد هذا الاتجاه معيار الضرر المتولد عن الجريمة. ويُعرف المجني عليه هو كل من أصابه الضرر من جراء الجريمة سواء أكان ضرراً مباشرا أم غير مباشر (0). أو هو من وقعت عليه الجريمة مباشرة وأصابه

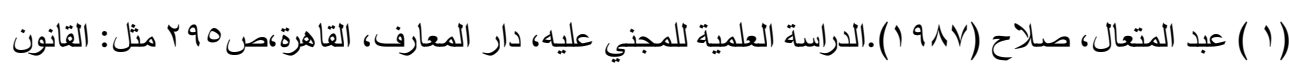

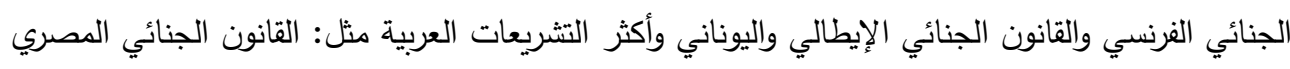
والقانون الجنائي الجزائري والقانون الجنائي الأردني. إلخ الخيائ الإني

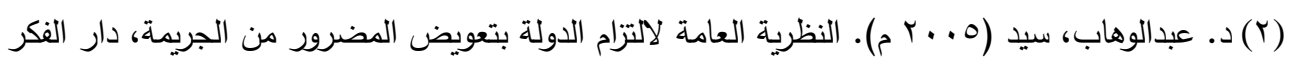

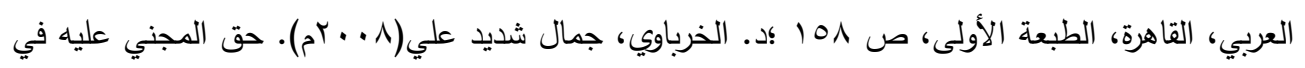

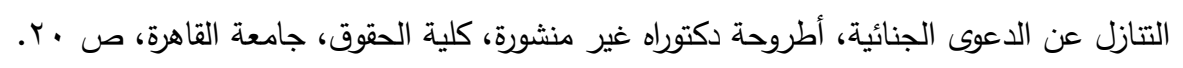

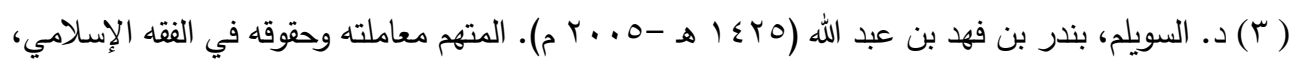

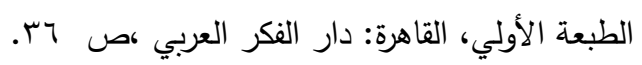

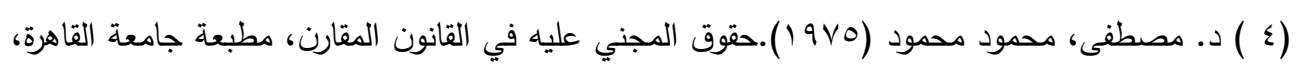

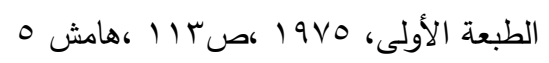

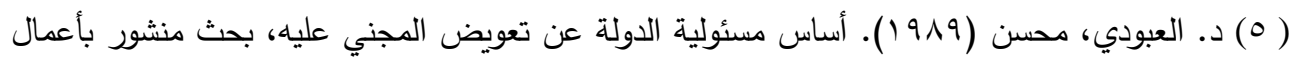

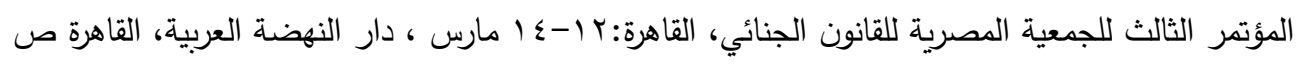




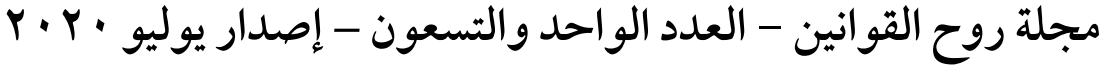

ضرر ('). ويلتزم الجاني قبله بتعويض الضرر الناشئ عنها (r). بشرط أن يكون

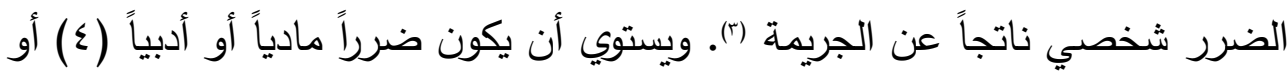

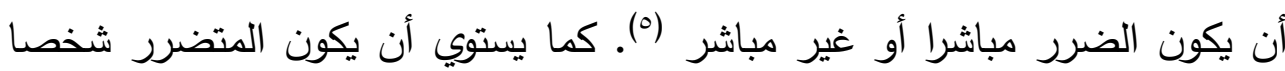

( (1) د. الغريب، محمد عيد (919 (1).الدعوى الجنائية أمام القضاء الجنائي، بحث مقدم في المؤتمر الثالث

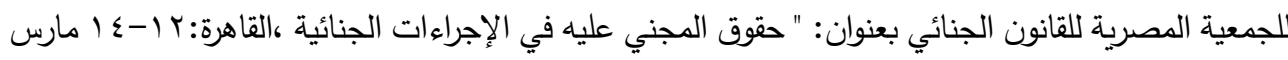

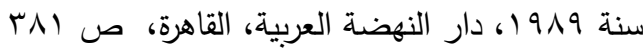

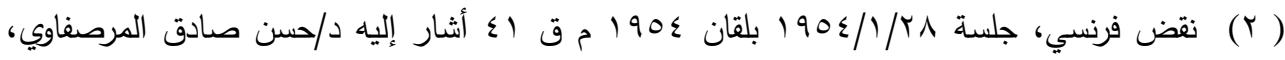

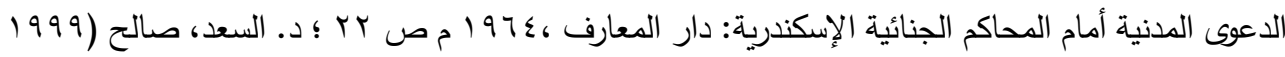

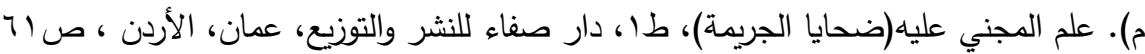

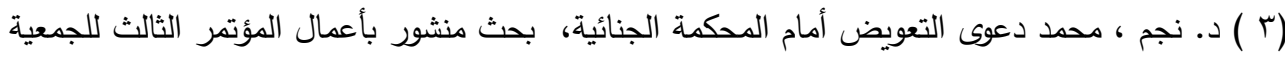

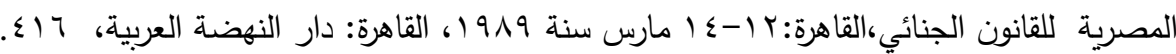
Report Of International Commission of Surists For; Vectims of Crime of Violence;

$19 \wedge r ; p r q$ نقض 17 مايو سنة 191019، مجموعة أحكام النقض، مجموعة المكتب الفني لأحكام النقض، سهـا، رقم

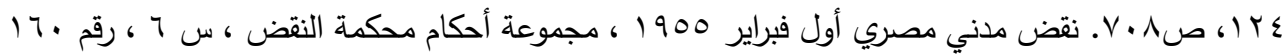

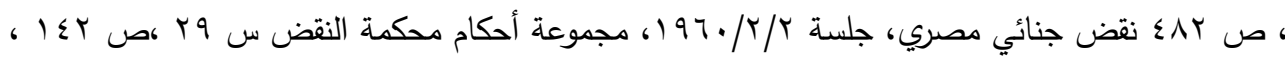

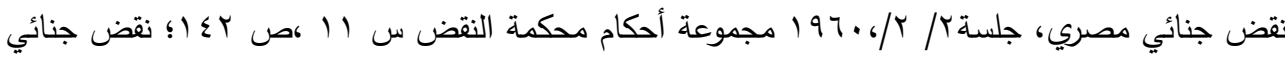

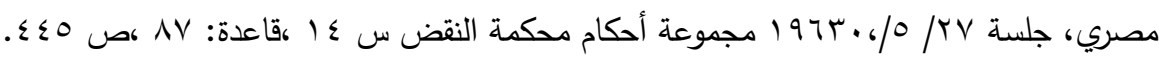
(ع ) د.سليم إبراهيم حربة والأستاذ عبد الأمير العكيلي،(919 ام). شرح قانون أصول الححاكمات الجزائية،

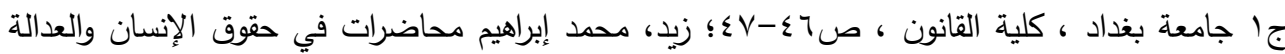

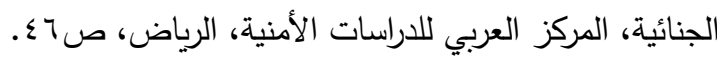

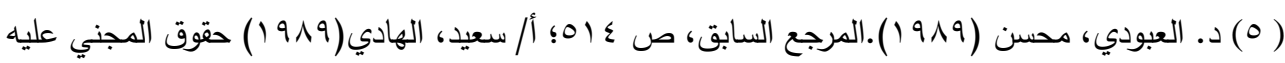

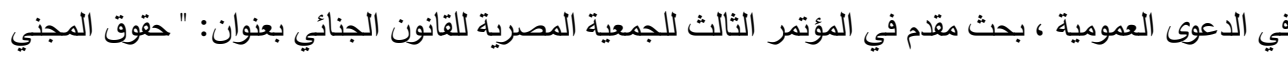

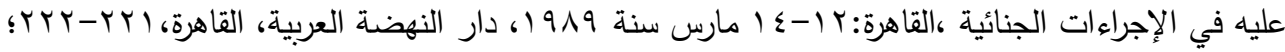

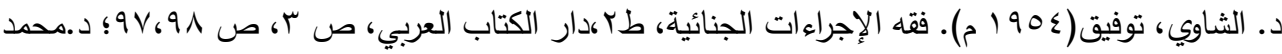

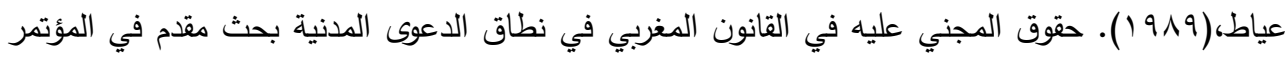

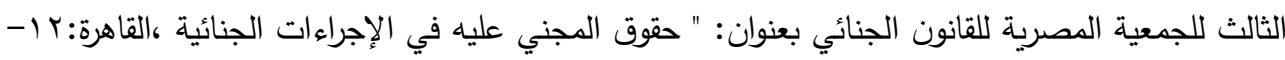

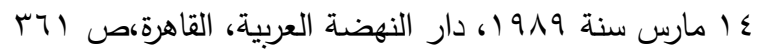




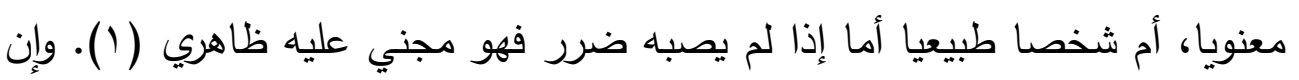

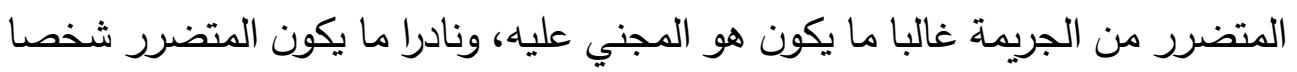

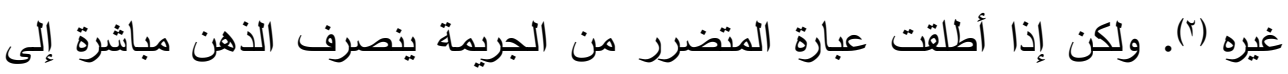

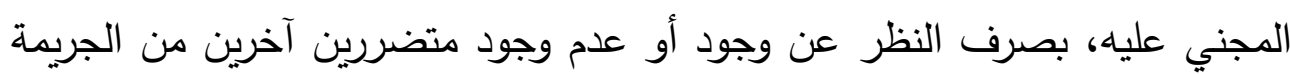

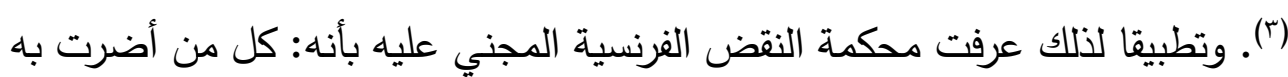

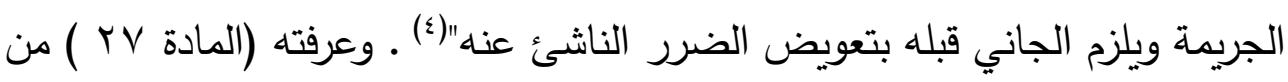

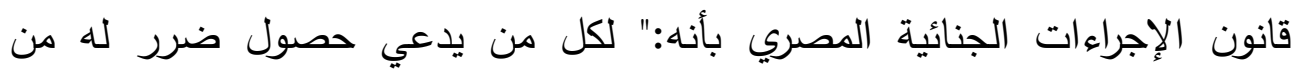

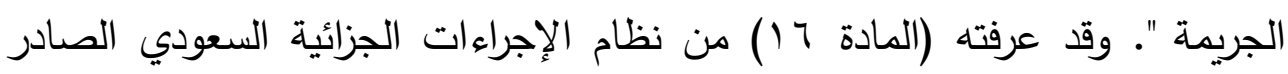

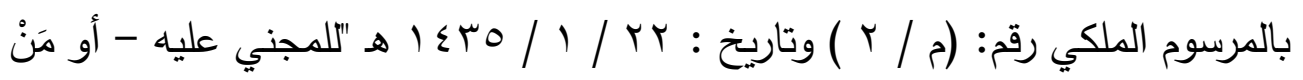

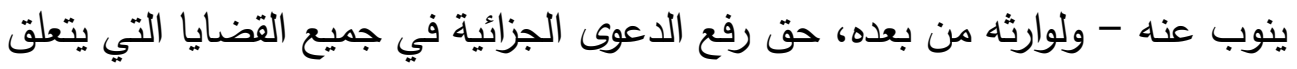
بها حق خاص..."فيفهم من النص التركيز على مصطلح المدعي بالحقوق المدنية بأنه

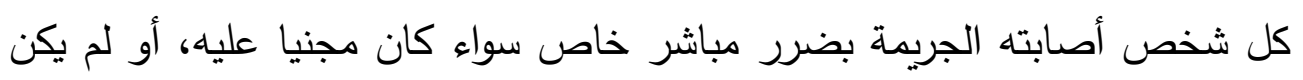

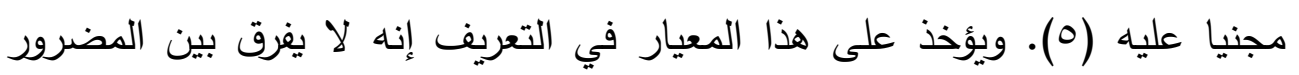

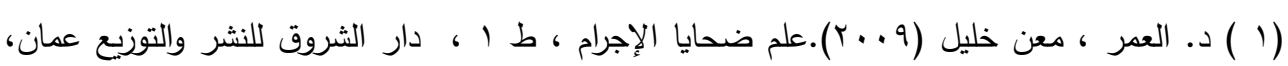

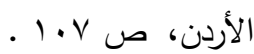

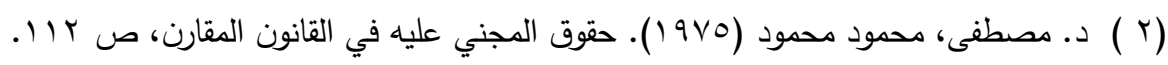

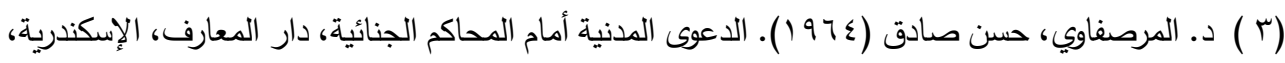

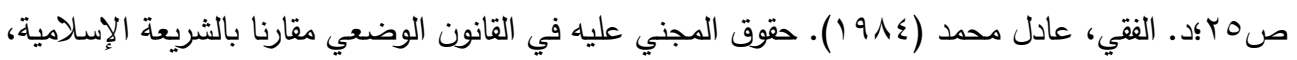

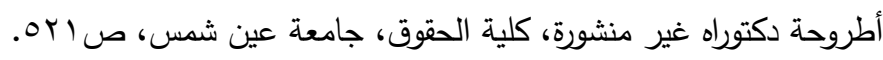

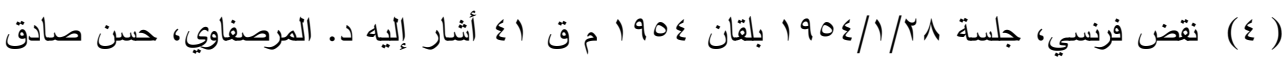
(199V)

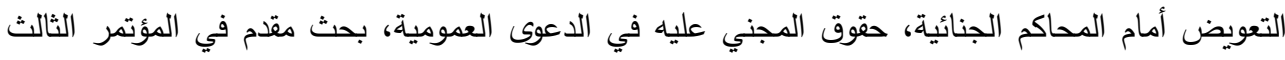

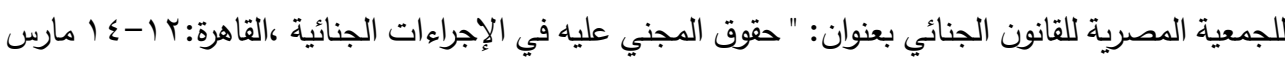

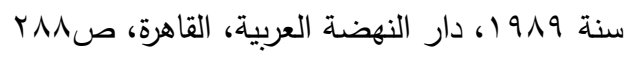

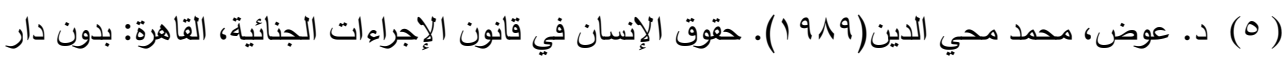
نشر، ص r r ب ؛ أ/ الثيخ ، عادل بن محمد بن حسن الادعاء الخاص في الشريعة الإسلامية ونظام 


\section{مجلة روح القوانين - العدد الواحد والتسعون - إصدار يوليو · ·.}

المدعي بالتعويض في الدعوى الجنائية وبين المجني عليه ( ()، فقد يكون المجني عليه هو المضرور من الجريمة وقد يكون المضرور من الجريمة ولي المجني عليه (ب).

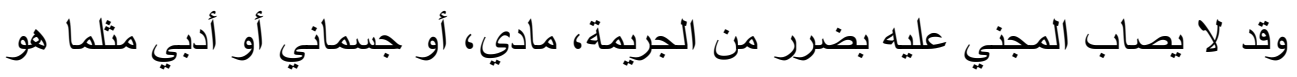

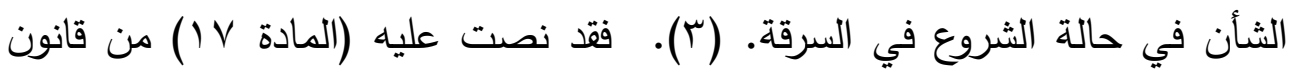
الإجراءات المصري حيث نصت على أن:" الثكوى التي لا يدعي فيها مقدمها بحقوق لهن

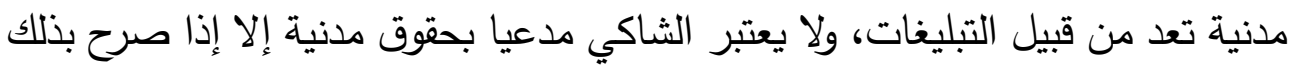

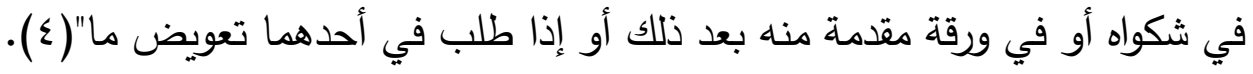

\section{الاتجاه الثاني الضــيق: الجني عليه هو هن وقعت عليه الجريمة: المعيار المتبع في هذا}

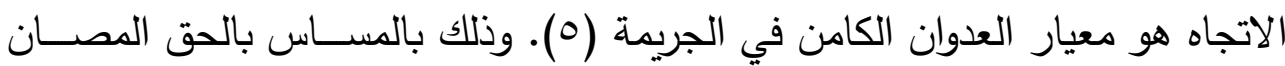

الإجراءات الجزائية السعودي رسالة ماجستير ، جامعة نايف العربية للعلوم الأمنية ،كلية الدراسات العليا ،البحث

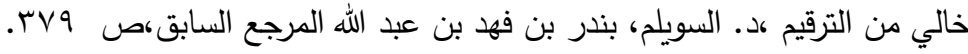

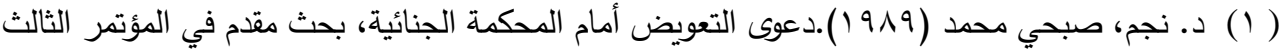

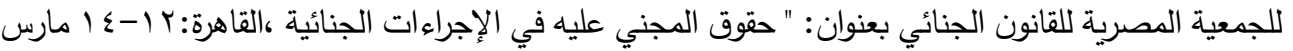

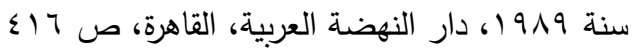

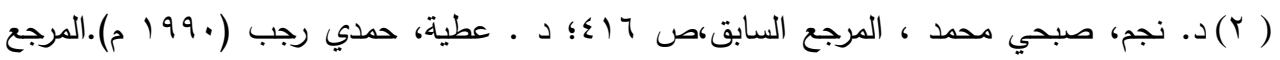

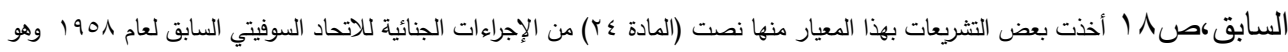

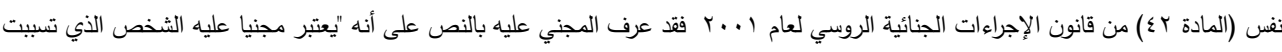

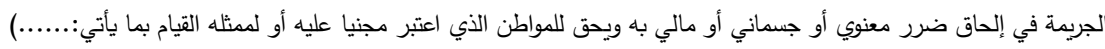

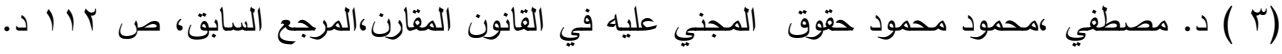

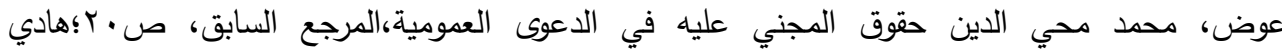

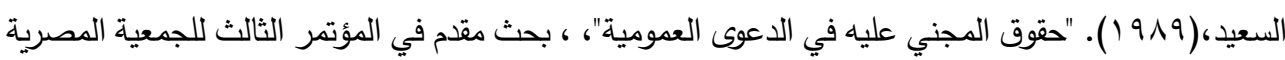

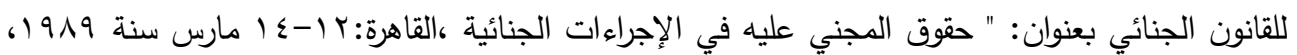

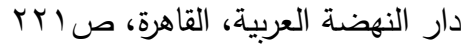

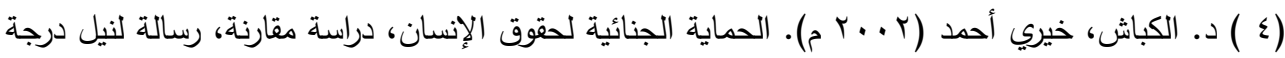

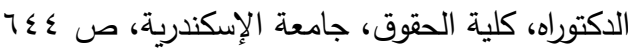

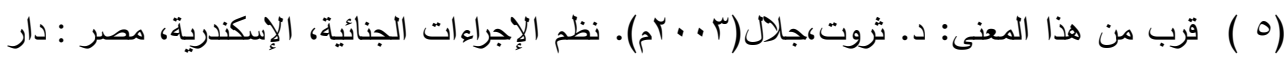

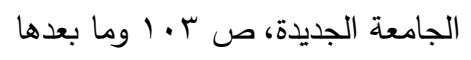




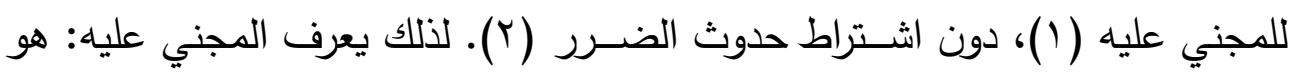
الثخص الذي أعتدي على حقه الذي يحميه القانون (r). أي هو صـاحب الحق الذي

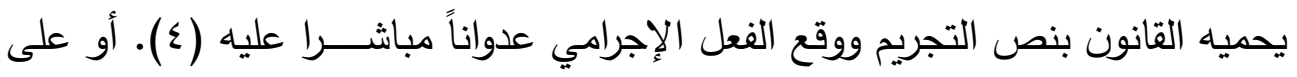
حق من حقوقه الشــــــية، أو من حقوقه المالية بحســب نوع الجريمة (0). أو أن المجني عليه كل من تحقتت فيه النتيجة الإجرامية التي يعاقب عليها القانون (T). وقد يتعدد المجني عليهم كما في حالة الانحراف في التصــــــبـ بينمـا يرى البعض أن المجني عليه: هو من قصــــه المتهم بالاعتداء (V). ومن اســتقراء تعاريف العلماء

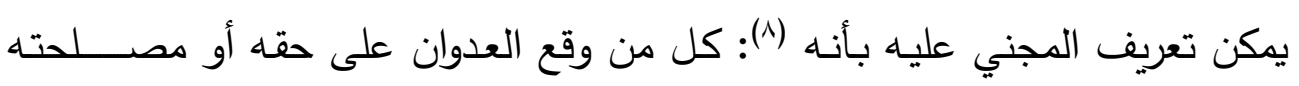

(1 ) د. عودة، عبد القادر (1971 ). التشريع الجنائي الإسلامي مقارنا بالقانون الوضعي، طه، بيروت، دار

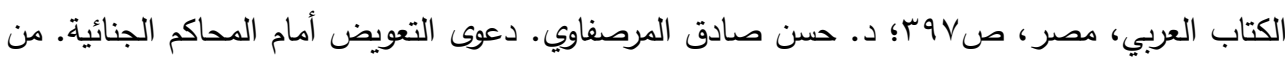

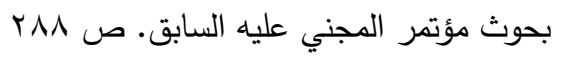

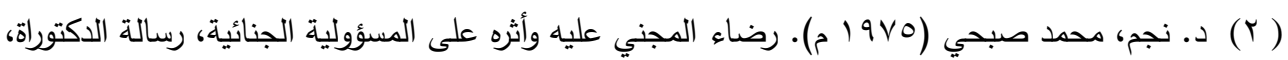

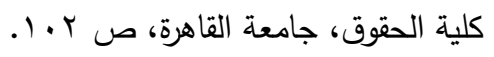

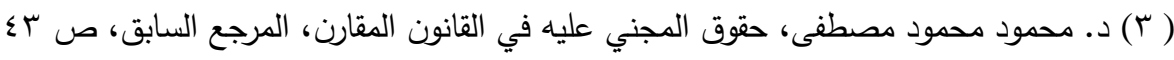

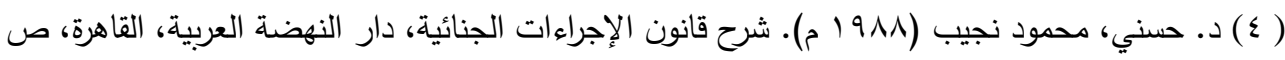

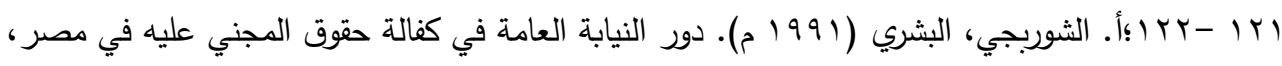

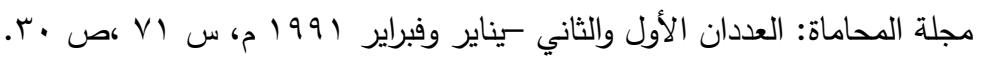

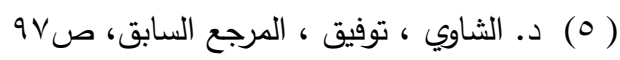

(7) ( د. المرصفاوي، حسن صادق (1997 م) م). الدعوى المدنية أمام المحاكم الجنائية، الإسكندرية: منشأة

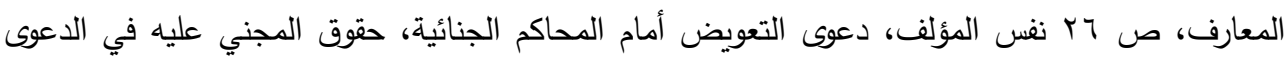

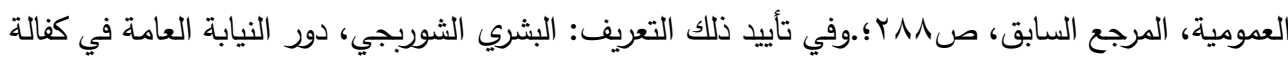

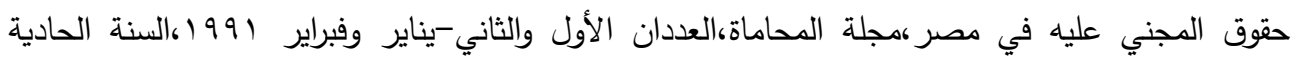

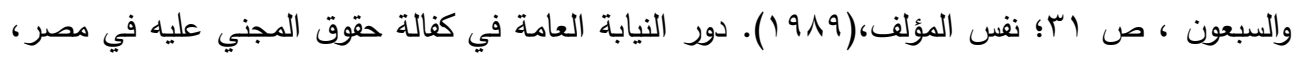

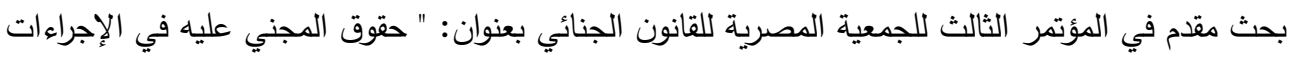

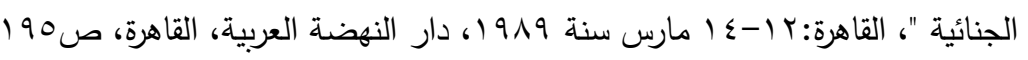

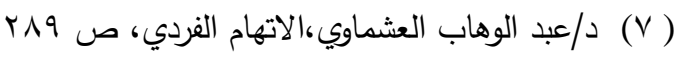

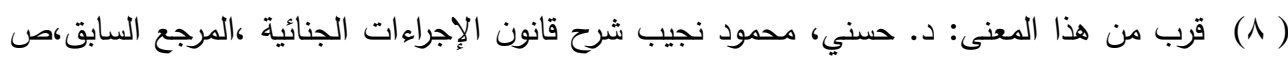

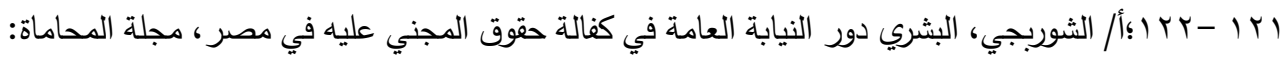




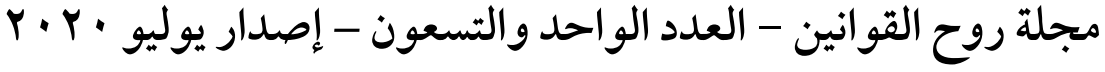

المرجع السابق،ص • ז؛ سعد العجرمي ، حقوق المجني عليه ، رسالة ماجستير كلية الحقوق الجامعة الأردنية

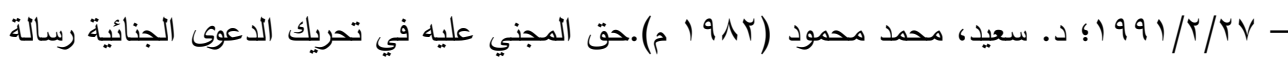

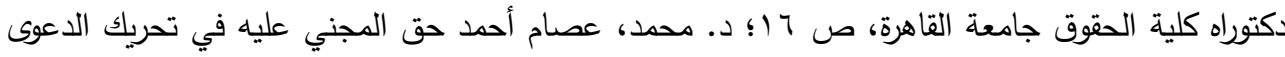
الجنائية الناشئة عن الجرائم الماسة بسلامة جسده،بحث مقدم في المؤتمر الثالث للجمعية المصرية للقانون

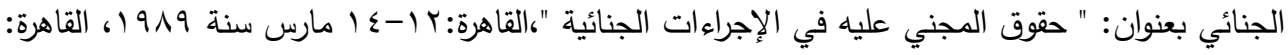

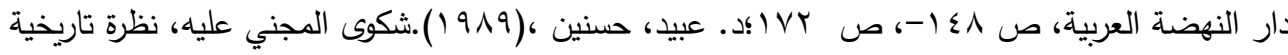

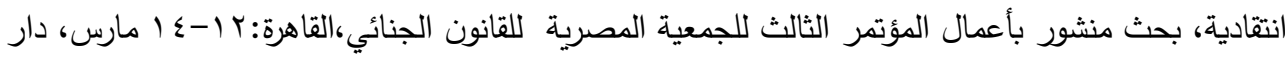

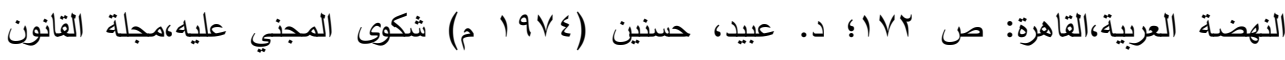
والاقتصاد،تصدرها كلية الحقوق جامعة القاهرة،العدد الثالث، القاهرة ص بـ +1؛ د. عبيد، حسنين إبراهيم

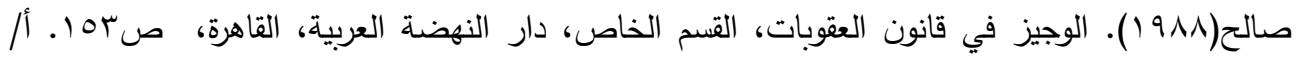

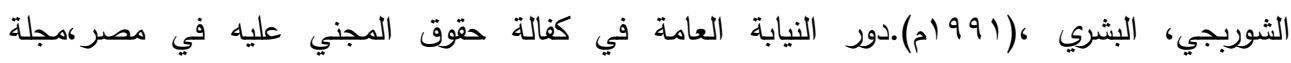

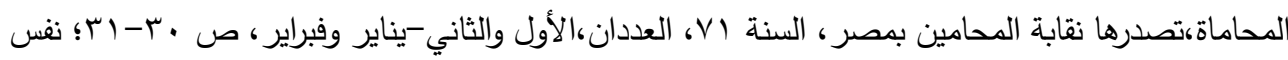

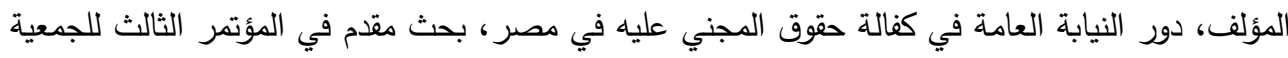

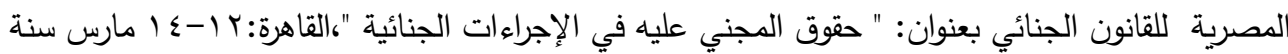

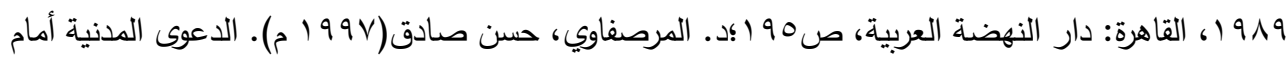

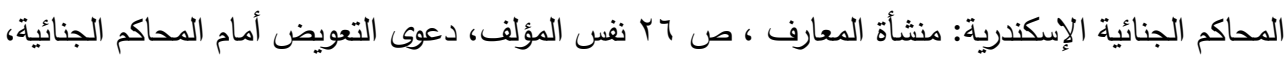

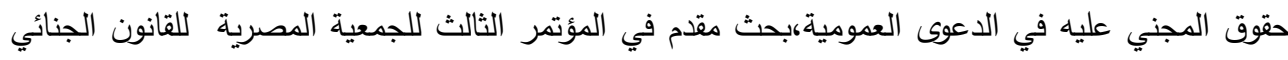

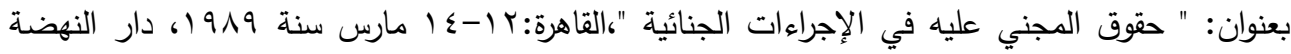

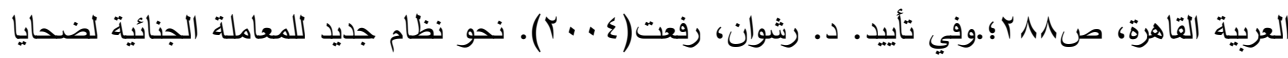

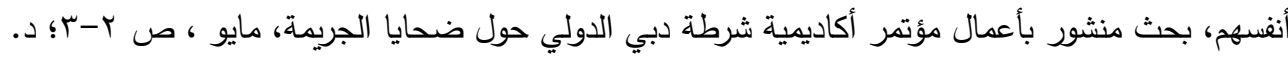

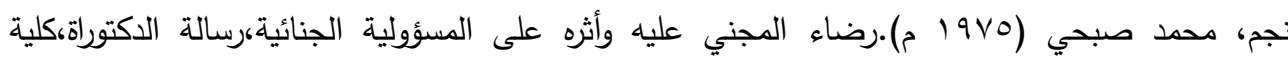




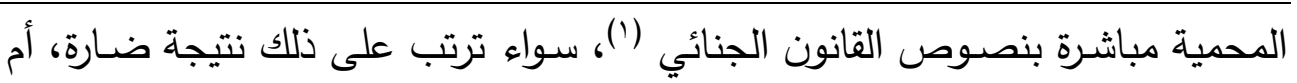

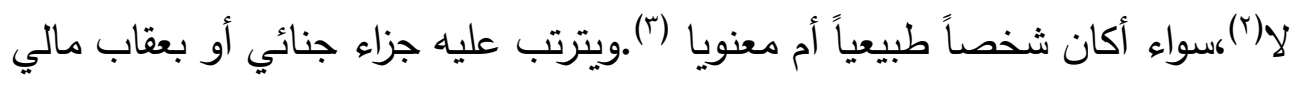

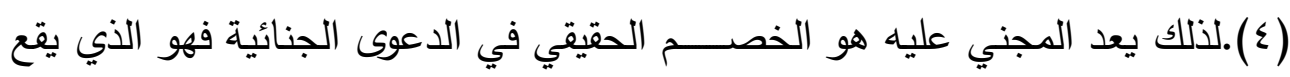

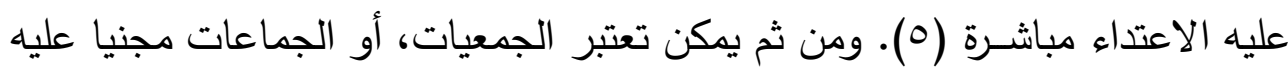

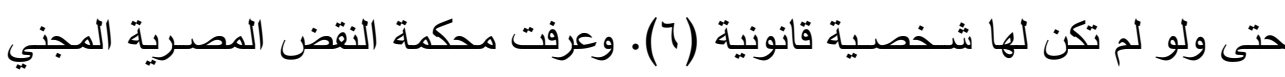

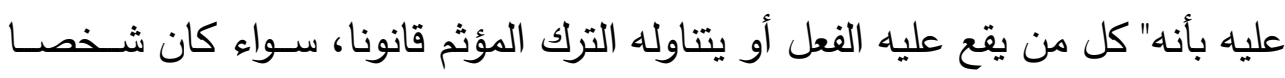

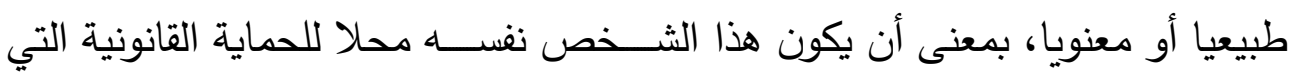

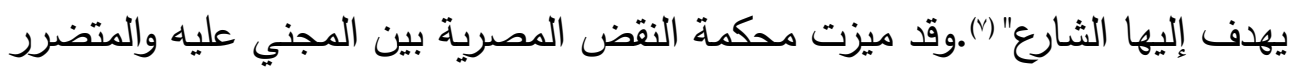

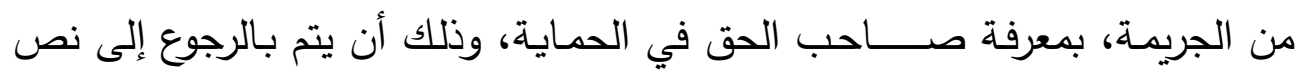

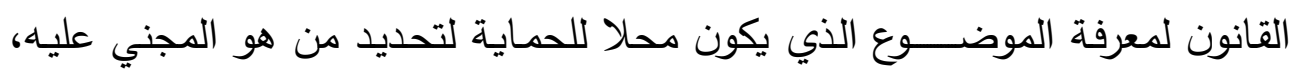

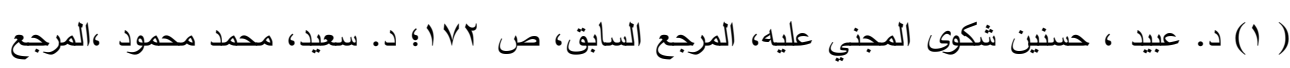

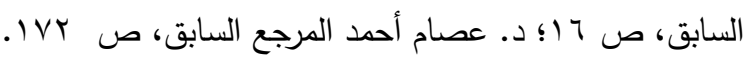

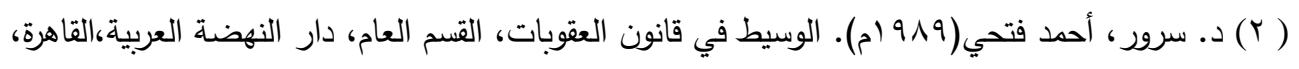
ص س r

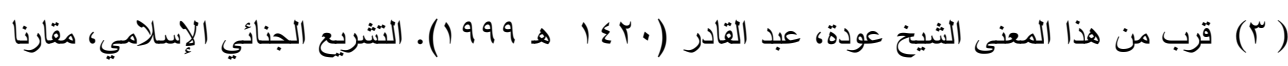

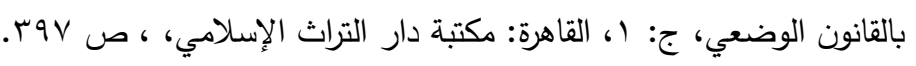

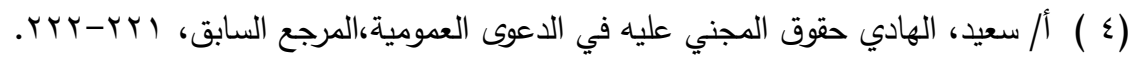

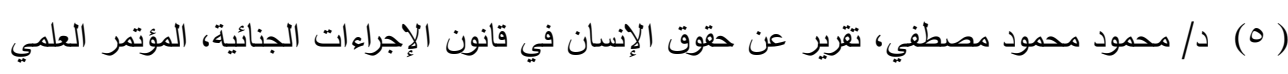

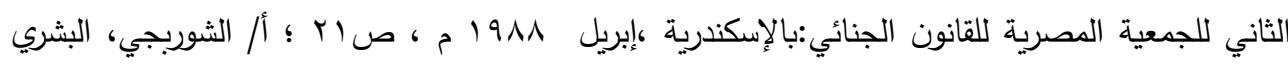

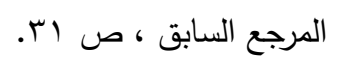

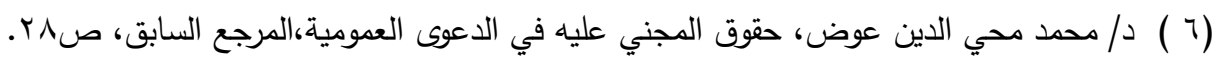

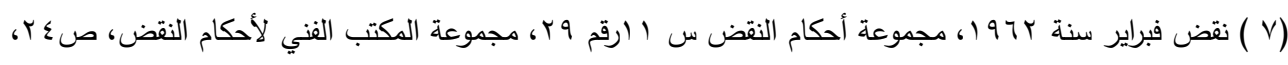

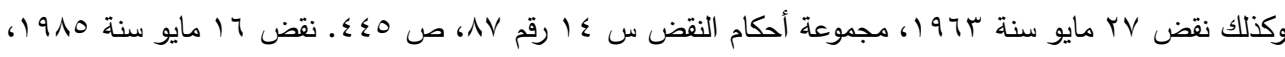

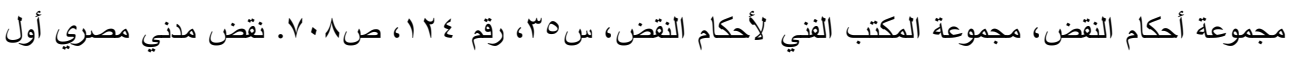

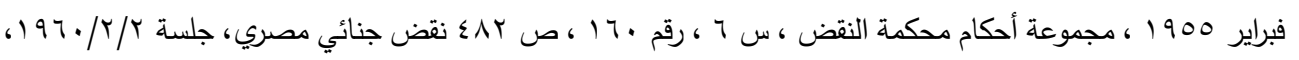

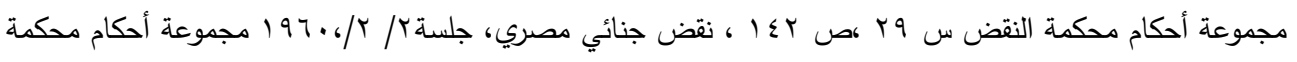

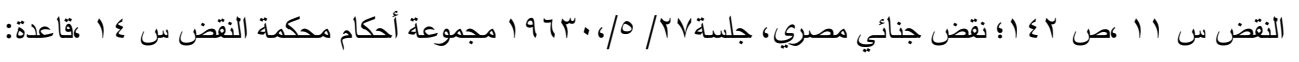




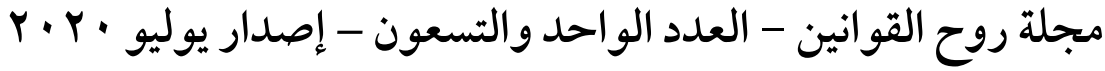

مثال: جريمة القتل فإن موضـوع الحماية فيها هو حق الحياة، وصـاحبها المجني عليه المقتول، وفي السرقة فإن المجني عليه صاحب المال المسروق (") والمقذوف في حقده أو شرفه أو اعتباره مجنبا عليه في جرائم السب. وليس شرطا أن يصاب المجني المني عليه

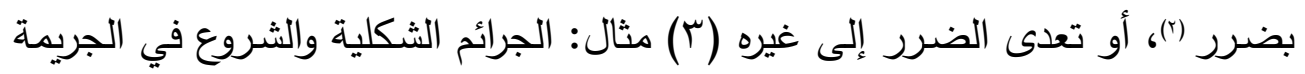

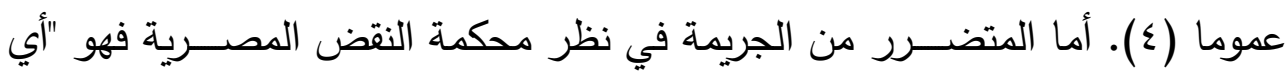

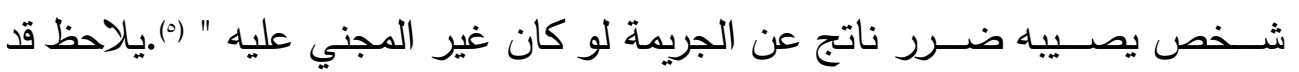

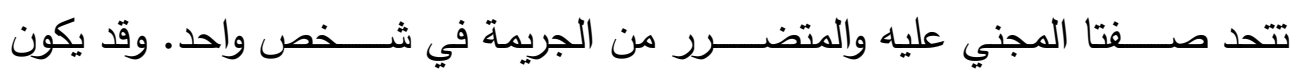

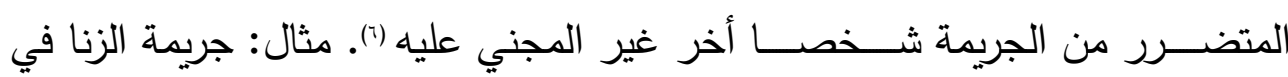

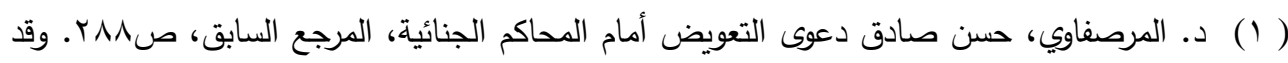
عرفه قانون الإجراءات الجنائية لجمهورية بولندا الشعبية سنة 979 أم في (المادة ، ؛) بأن المجني عليه هو صاحب المال القانوني أو الحقوق التي انتهكتها الجريمة مباشرة أو هددتها بالانتهاك سواء كان شخصا طبيعيا أو قانونيا.مشار لدى: د. محمد محي الدين عوض، حقوق المجني عليه في الدعوى العمومية، المرجع السابق، صט

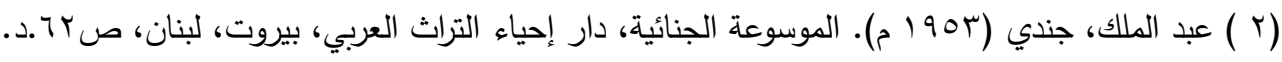

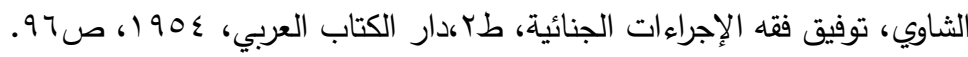
(T ) د. العشماوي،عبد الوهاب(به (190 م).الاتهام الفردي،حق الفرد في الخصومة الجنائية،رسالة دكتوراه،كلية

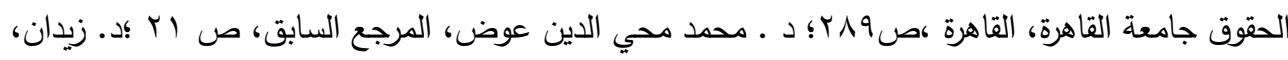
زكي حسين، المرجع السابق، ص 7 (؛؛ د. عبد الفتاح الصيفي ، الإجراءات الجنائية ، المرجع السابق ص صل

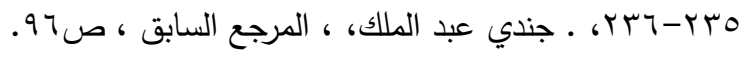
(ع ) د. غنام، محمد غنام(ع · •rم). حقوق المجني عليه في الإجراءات الجنائية، بحث مقدم إلى مؤتمر

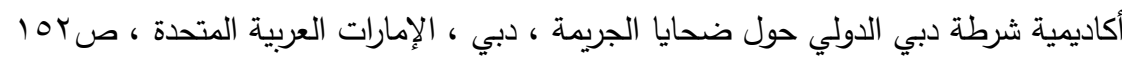
(0 ) نقض 17 مايو سنة 9101، مجموعة أحكام النقض، مجموعة المكتب الفني لأحكام النضض، سهب، رقم צ ا ا، صی • V. نقض مدني مصري أول فبراير 1900 ، مجموعة أحكام محكمة النقض ، س 7 ، رقم

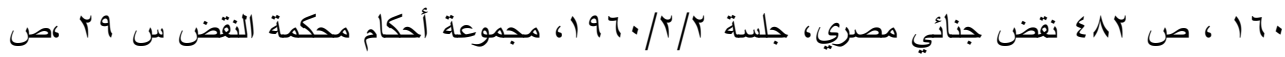

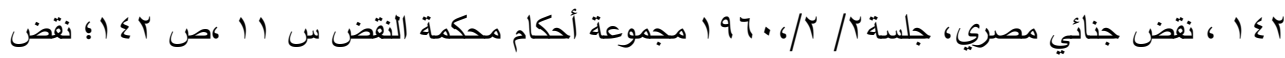

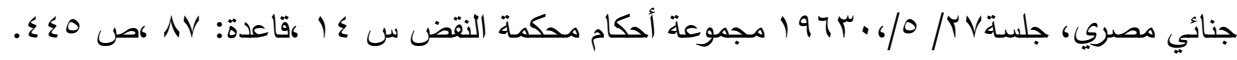

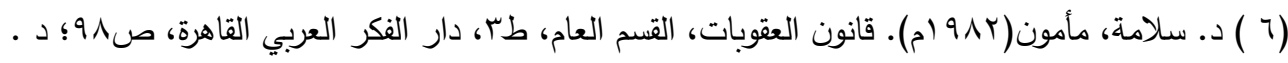
حسن صادق المرصفاوي، الدعوى المدنية أمام المحاكم الجنائية ، المرجع السابق، ص وب ـ ـ 
القـانون يكون المجني عليـه فيها هو الزوج بـاعتبـار جريمـة الزني تقع على علاقـة الزوجية أما الأبناء فقد أصـابهم ضــررا في سـمعتهم وشـرفهم ورغم ذلك ليسـوا مجني

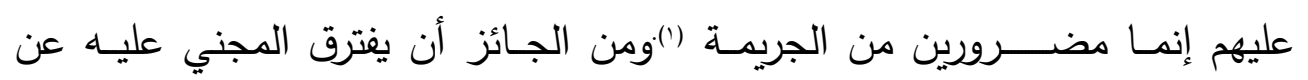

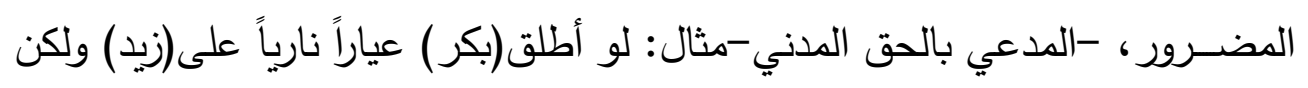
العيار الناري لم يصـبه بل أصـاب دابة مملوكة ل (حسـين) فإن (زيدا) يعتبر مجني عليه في جريمة الثـروع في قتل بينما يعد (حسـين) متضــرر من الجريمة (ب).ويرى بعض الفقهاء أن المجني عليه دائما مضـرور حتى لو وقفت الجريمة عند حد الثـروع منها؛ لأن كل جريمة ولو لم تتحقق نتيجتها تسـبب إزعاجًا واضـطرابًا معنوياً وعصـبياً ورعبا ومسـاس بالصـحة وهذا كاف لتوفر عنصـر الضـرر ولا مبرر لحرمان المجني عليه المضرور أو وليه من تعويضه عما لحقه من ضرر في هذه الصورة (ب). وتأييدا لذلك ذهبت محكمة النقض المصـــرية إلى إجازة التعويض المدني عن حادث إطلاق عيار ناري لم يصـيب المجني عليه وذلك لما أحدثته الجريمة من إزعاج وترويع (ع). ورغم أن القانون الجنائي ميّز بين المجني عليه والمتضــــرر من الجريمـة، فأعطى

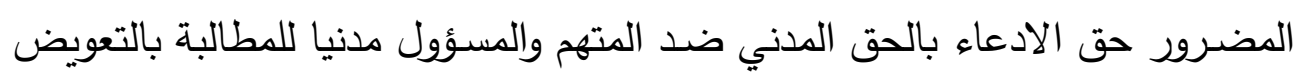
عن الضـرر الخاص الذي تسـببت فيه الجريمة. أما صـفة المجني عليه في الدعوى بـى الجنائية فإن القانون لا يعتد بإرادة المجني عليه إلا في نطاق ما اصطلح على تسميته بجرائم الشكوى، وهي الجرائم التي لا يجوز تحريك الدعوى الجزائية فيها إلا بناء شكوى

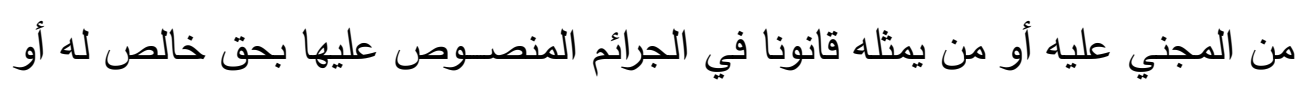

(1 ) د ـ عطية، حمدي رجب (•199 م) مدور المجنى عليه في إنهاء الدعوى الجنائية،رسالة دكتوراهكلية

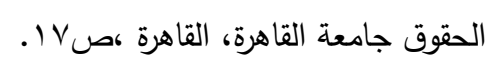

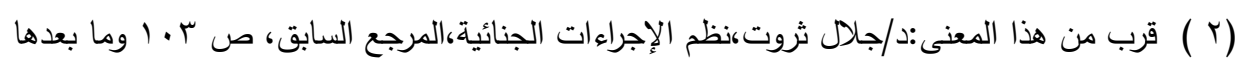

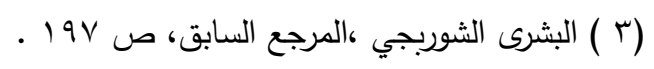

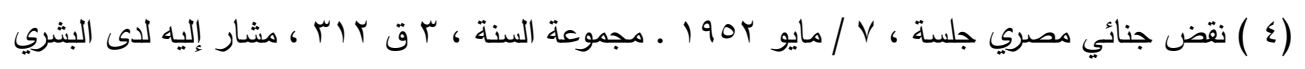

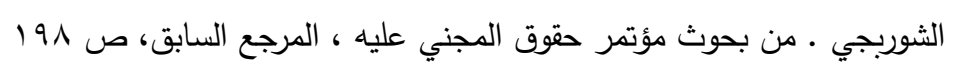
$(r V)$ 
F. r. · مجلة روح القوانين - العدد الواحد والتسعون - إصدار يوليو

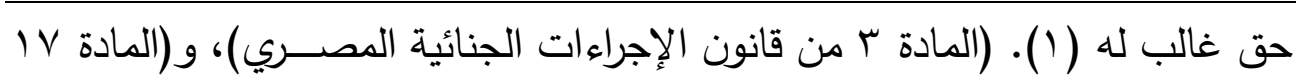

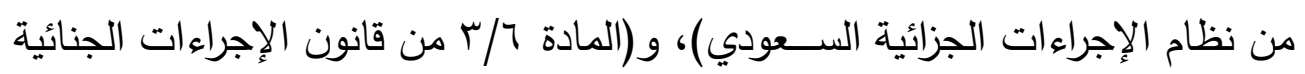

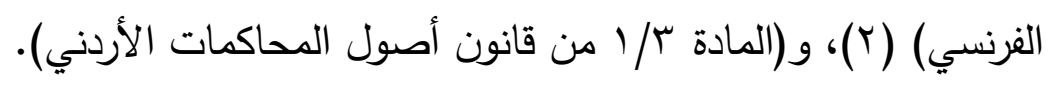

الاتجاه الثالث المنتلط (الضحية): معيار العدوان الكامن في الجريمة على حقوق الثخص

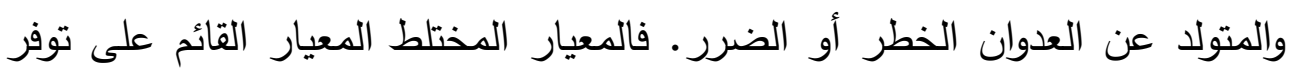

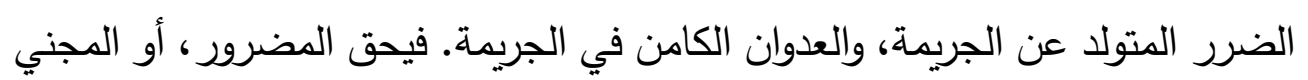

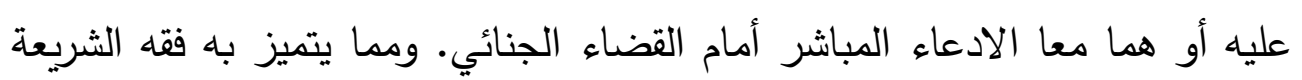

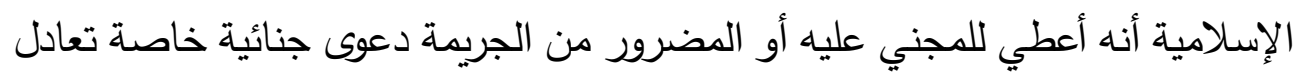

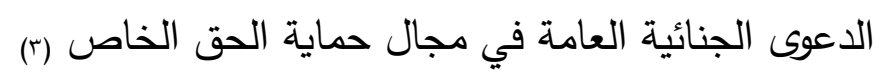

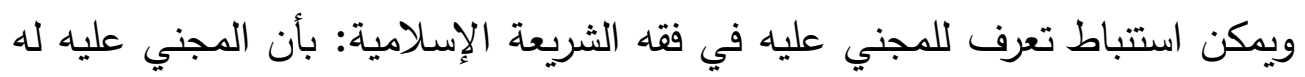

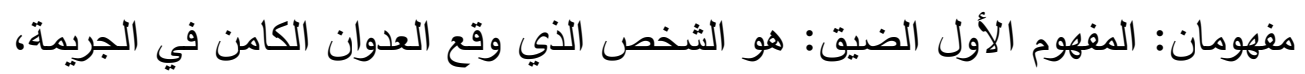

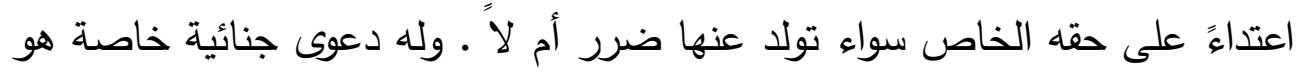
أحد أطرافها كما سيأتي بيانه إن شاء الله تعالى.

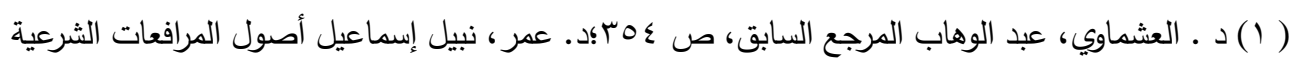

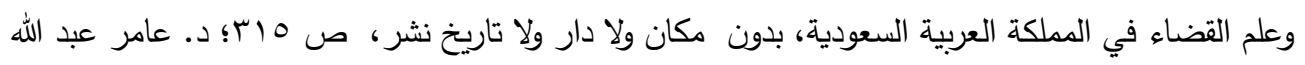

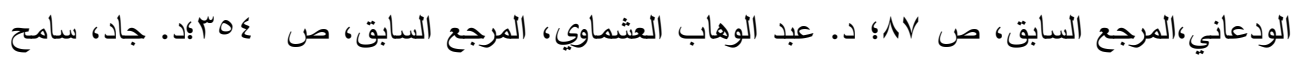

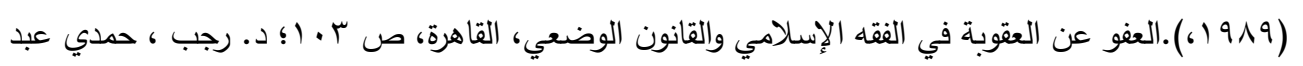

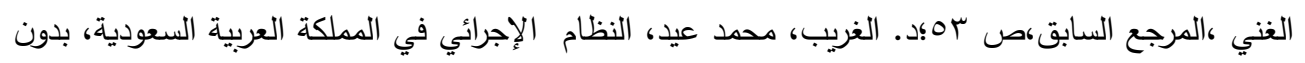

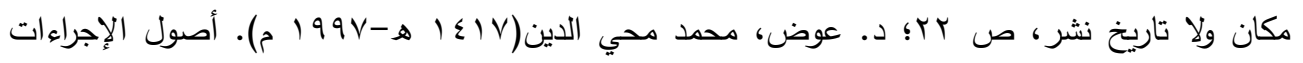

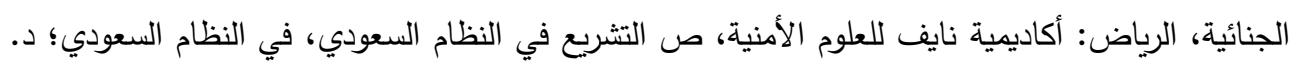

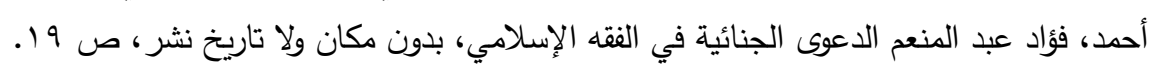

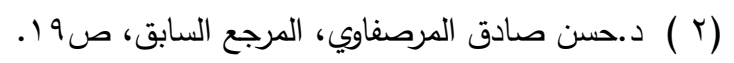

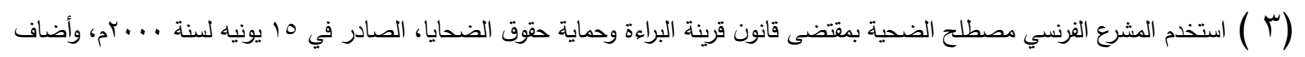

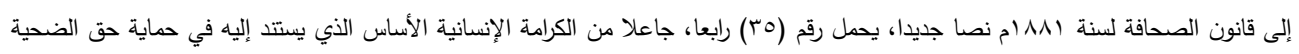
ومنها تجريم نشر صور ضحايا الجريمة سواء على قيد الحياة، أو ميتاً. 
أما المفهوم الثاني الواسع: فهو من وقع العدوان الكامن في الجريمة اعتداءً على حقه العام، سواء تولد عنها ضرر أم لا، سواء أكان شخصاً طبيعياً أم معنويا وله دعوى ولهي جنائية عامة تحمي حق المجتمع هذا، تسمى "دعوى الحسبة" وهي اسم من الاحتساب أي طلبا للثواب وأخذا بالعزيمة رعاية لحق الله المجتمع وعدم تفويته من أي شخص هـ دئه إنكارا للمنكر (1). ودلت الكتب على أن أركان الجناية ثلاثة: الجاني والمجني عليه والجناية (r). فالمجني عليه الذي وقع عليه العدوان الكامن في الجريمة سواء تولد منها ضرر أم لا. وهو الركن الثاني من أركان الجناية (r).ويستوي أن يتعلق بحق خالص لله

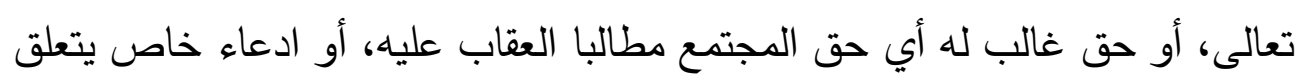
بحق العبد الخالص أو حقه الغالب أي حق الفرد للطالبة باسترداد الحق أو المعاقبة

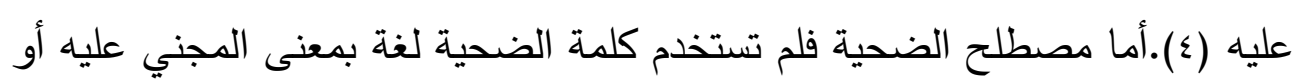
المضرور ، إنما استخدمت لفظ أُضحية، على وزن فعيلة، والجمع ضحايا (ه) وهي اسم

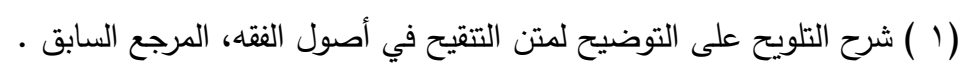

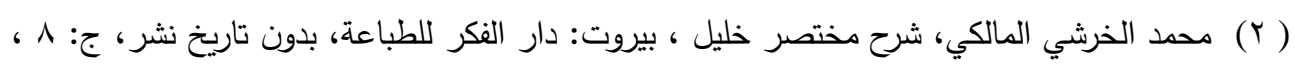

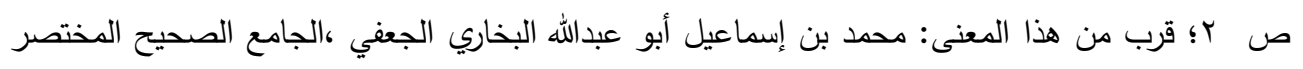

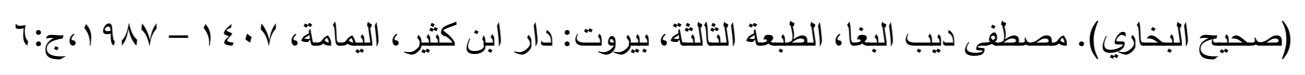

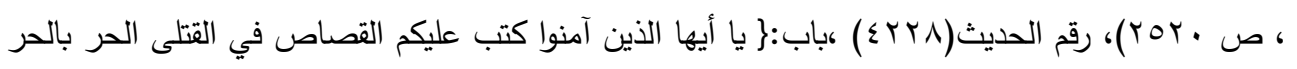

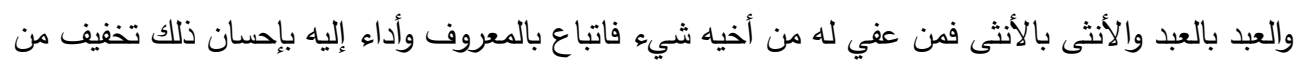

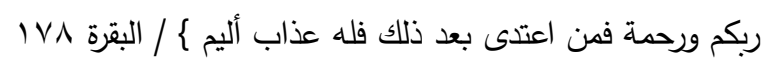

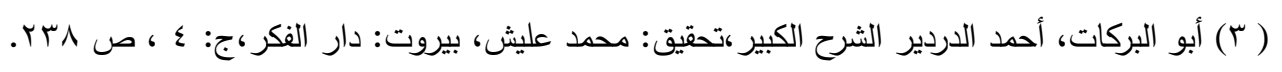

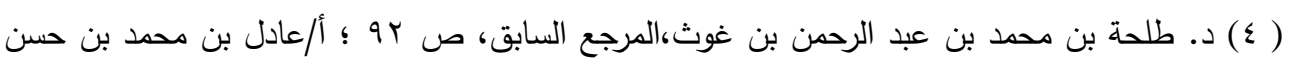

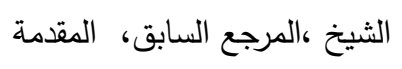
(0) محمد بن مكرم بن على، أبو الفضل، جمال الدين ابن منظور الأنصاري الرويفعى الإفريقى (المتوفى:

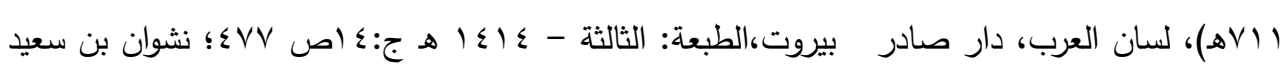

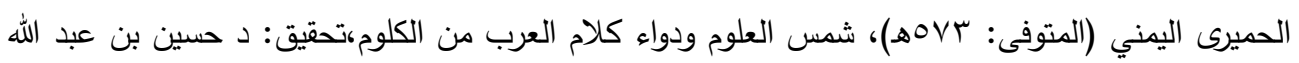

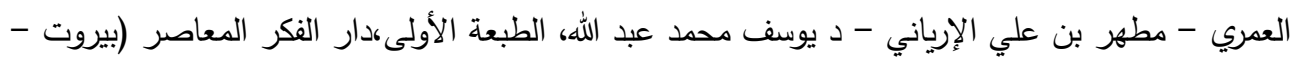

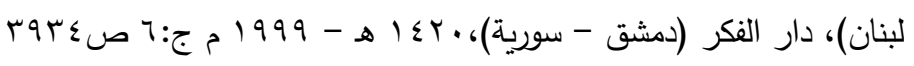
(rVT) 


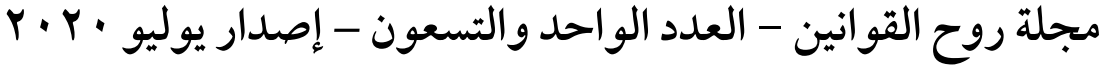

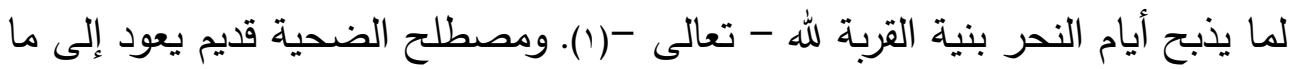

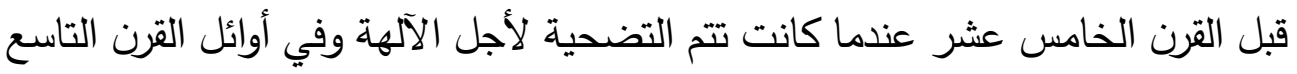

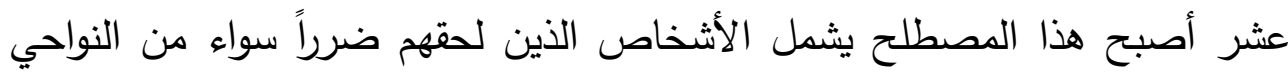

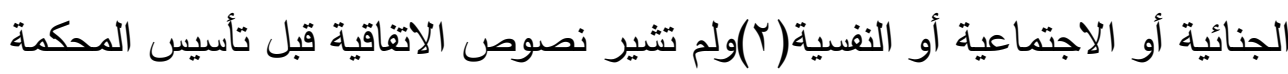
الجنائية الدولية إشارة صريحة إلى مركز ضحايا الجرائم الدولية كما ورد في نص المادة

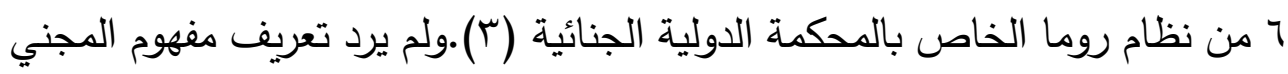

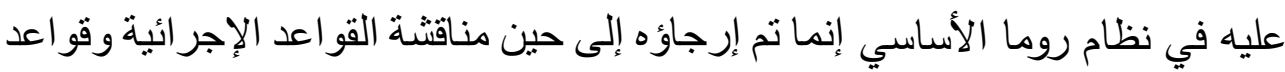

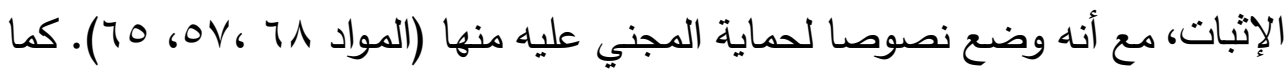

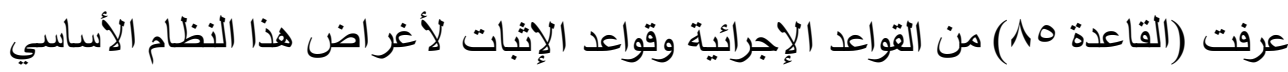
كما يلي: أ -يدل لفظ الضحايا على الأشخاص الطبيعيين المتضررين بفعل ارتكاب أي جريمة تدخل في اختصاص المحكمة. ب-يجوز أن يشمل لفظ” الضحايا" الكيانات القانونية -المنظمات أو المؤسسات-التي

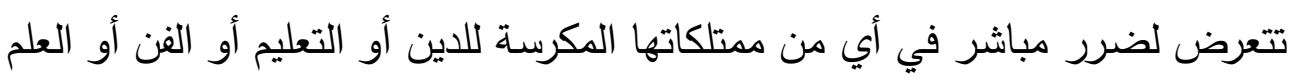

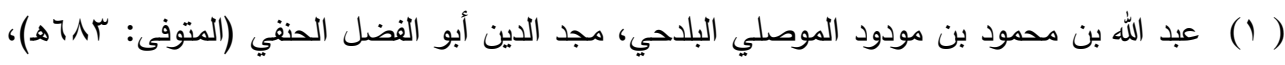

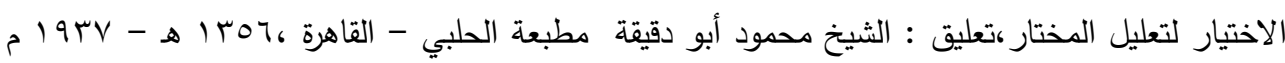

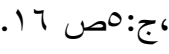
(r) د. حامد، خالد مصطفى (10 بام) الثرعية الإجرائية بين حقوق الضحية والمتهمهمجلة الثرعية والقانون،كلية القانون،جامعة الإمارات العربية المتحدة.

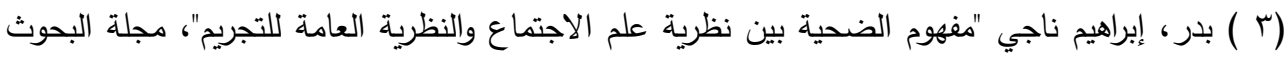

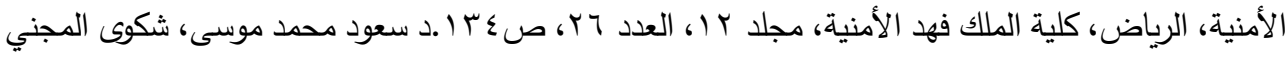

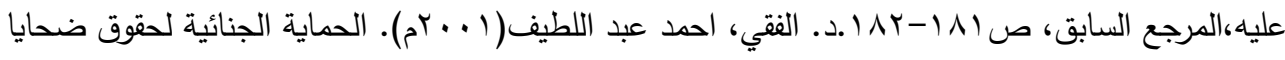

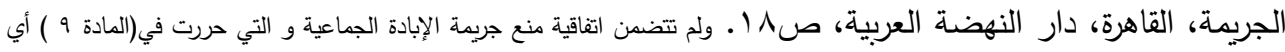

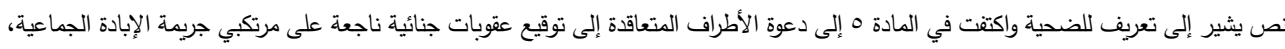

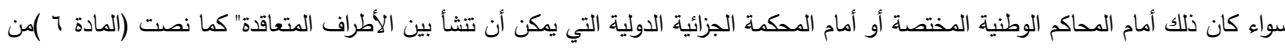

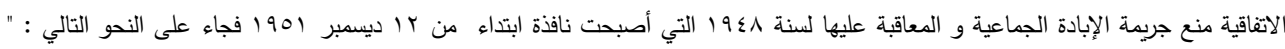

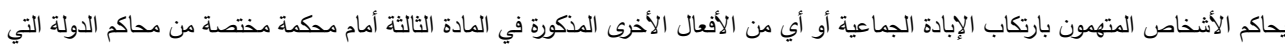

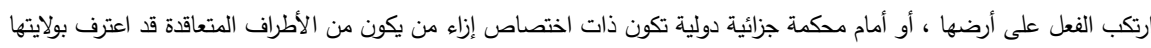


أو الأغراض الخيرية، والمعالم الأثرية والمســتشـفيات وغيرها من الأماكن والأثــياء

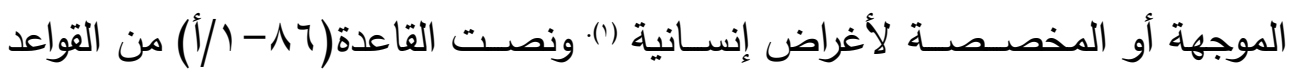
الإجرائيـة وقواعد الإثبات لدي المحكمة الجنائية الدوليـة على أن" تراعي الدائرة، عند إصــــدار أي توجيـه أو أمر، كما تراعي أجهزة المحكمة الأخرى، عند أداء وظائفها بموجب النظام الأسـاســي أو القواعد، احتياجات جميع المجني عليهم والثــهود وفقا للمادة ^7، وعلى وجه الخصـوص احتياجات الأطفال والمسـنين والمعوقين وضـحايا العنف الجنسي أو العنف القائم على نوع الجنس." واصطلاحا: يقصد به الشخص الذي يقاسي من سوء المعاملة في بدنه أو ماله، أو يعاني من قهر جماعات ظالمة أو يقاسي من بعض الأذى أو الحرمان أو الخسارة (r)، مما يقتضي رد فعل المجتمع تجاههم (r). ومن استقراء التعاريف حدد الفئات التي تتدرج

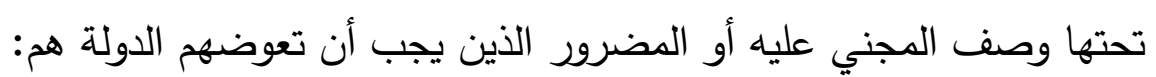
أ-المجني عليهم الذين أصييوا بإصابات جسمانية جسيمة، أو باعتلال الصحة البدنية أو العقلية أو في ممتلكاتهم أو الحرمان بدرجة كبيرة من التمتع بحقوقهم الأساسية على لئ أثر جرائم خطيرة ناتج عن خرق القوانين الداخلية، أو القانون الدولي أو خرق لحقوق لـان

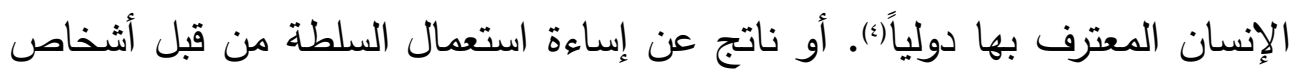

( ) تقرير الفريق العامل،الفصل التاسع المجلة الدولية للصليب الأحمر ، السنة التاسعة، العدد V乏، كانون

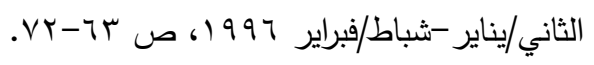

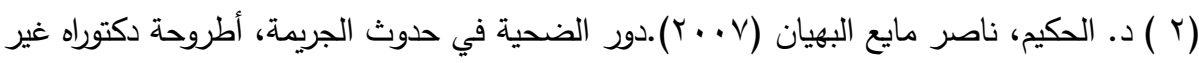

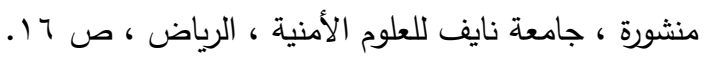
Andrew Karmen, crime victims; An Introduction to victimology, Eighth Edition, Belmont, U S A.p. ${ }^{\Upsilon}$ Bonnie.s.Fisher.Steven P.lab; $r \cdot 1$. Encyclopedia victimology and crime preventation.volume . ', sage ( $r$ ) publications, California,.p. $1 \%$.

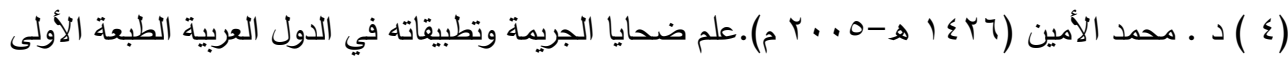

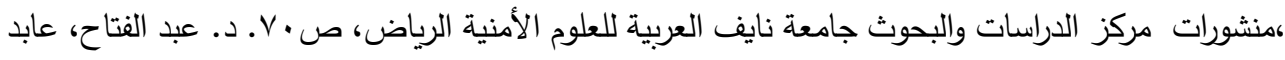

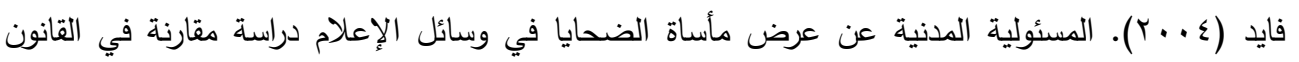

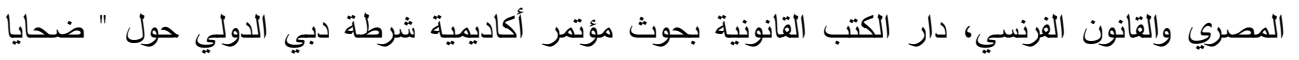

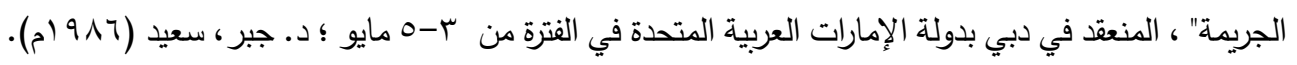

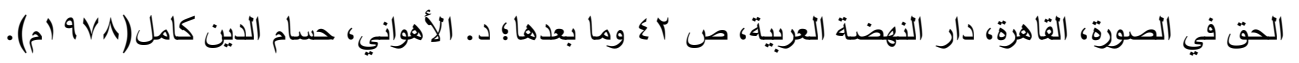


r.r. · مجلة روح القوانين - العدد الواحد والتسعون - إصدار يوليو

ذوي سلطة سياسية أو اقتصادية ('). مثال: ضحايا الحرب وضحايا الإرهاب وضحايا الحوادث وضحايا الفيضانات والزلازل (†) أو كان الفعل بسبب القول القوة القاهرة والأزمات والكوارث الطبيعية.....الخ (r)، وذلك بصرف النظر عن العلاقة الأسرية التي قد تربط الضحية بمرتكب الجريمة (i) ب-أسر الأشخاص الذين قتلوا أو أصبحوا عاجزين بدنيا أو عقلياً نتيجة الإيذاء وبصفة خاصة من كانوا يعتمدون على إعالتهم على هؤلاء الأشخاص (॰). وتشمل الأشخاص الاصن

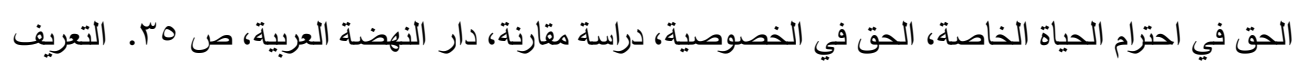

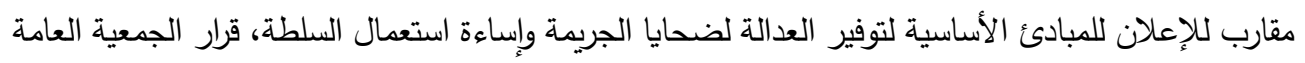

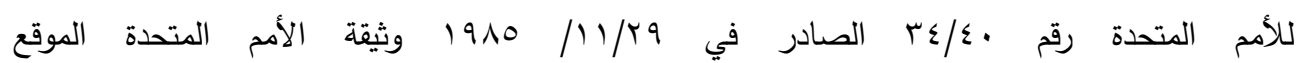
https://www.ohchr.org

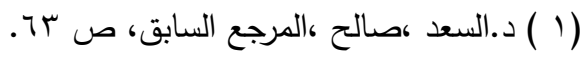

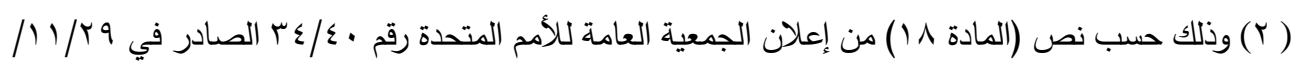

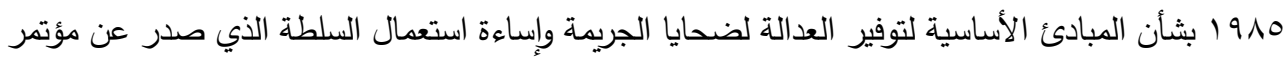

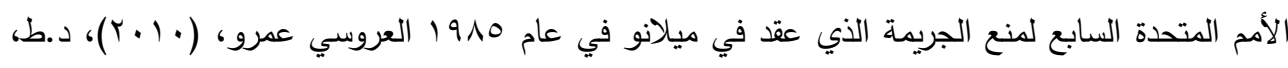

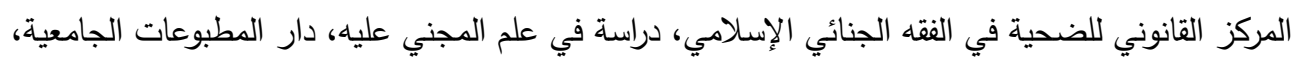
ص آr.

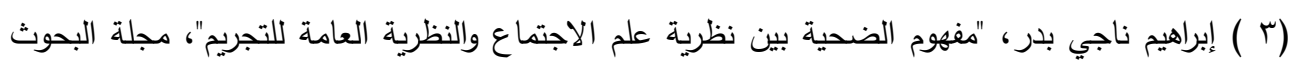

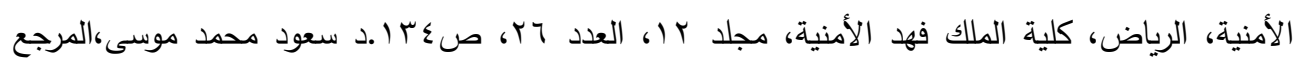

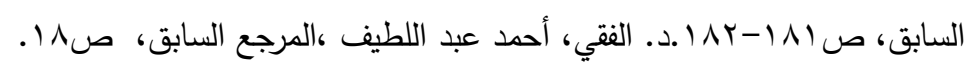

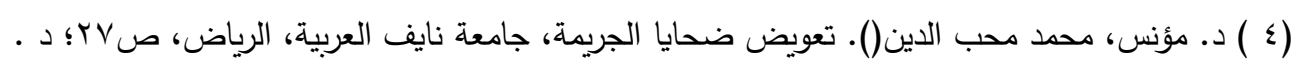

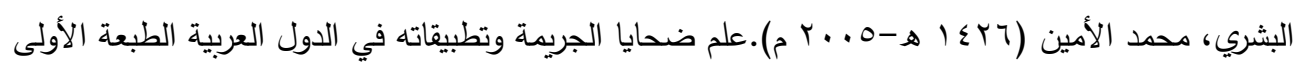

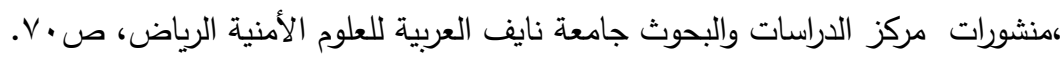

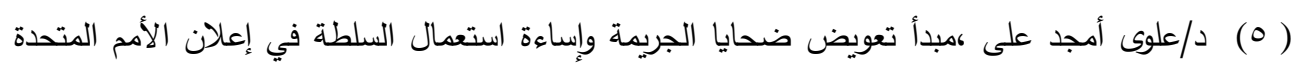

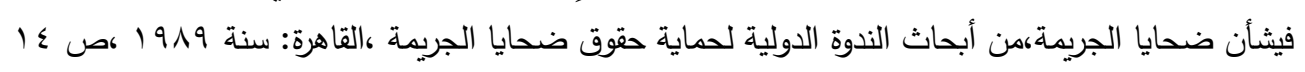

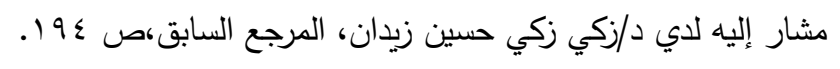

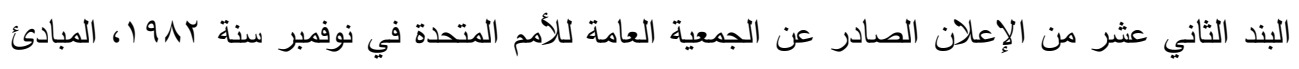

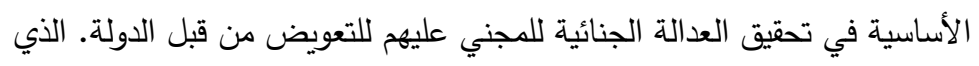


الذين أصيبوا بضرر فرديا أو جماعيا، سواء كان الضرر البدني أو العقلي أو المعاناة النفسية أو الخسارة الاقتصادية. وبتحليل ما سبق يتضح مما سبق ما يلي: ا-تمييز قانون الإجراءات بين المضرور والمجني عليه في المعاملة الإجرائية. إذ ركزت الدراسات لزمن طويل في القانون المقارن على قطبي هذه الظاهرة هم المجرم والجريمة وتم إغفال دور المجني عليه وحقوقه إلا فيما ورد فيه نص على سبيل الاستثناء (1).

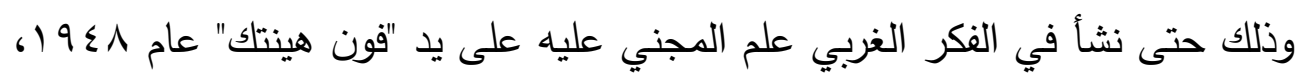
الذي يهتم بضحية المجرم ويبرز المعلومات البيولوجية والنفسية والاجتماعية والجنائية الخاصة بالضحية (r). وإن تعريف المجني عليه تتنازعه ثلاثة معايير في تحديد المجني عليه هم: المعيار الأول-معيار الضرر المتولد عن الجريمة. ونتيجة الأخذ بهذا المعيار تم الأخذ بالمفهوم الواسع لمصطلح المجني عليه: يشمل كل من تضرر من الجريمة، ولو لم يكونوا هم الضحايا المباشرين لها في المصاف الأول. مثال: الضرر الذي يصيب الورثة (r). وركز في صفة المضرور والمدعي بالحق المدني أكثر من تركيزه في صفة المجني عليه. وهو المعيار الراجح في ظل التشريعات الجنائية، فالمضرور : كل شخص أصابته الجريمة بضرر مباشر سواء، كان مجنيا عليه، أو لم يكن مجنيا عليه (\&).

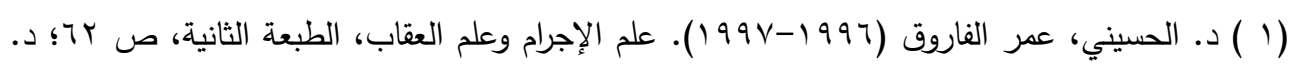

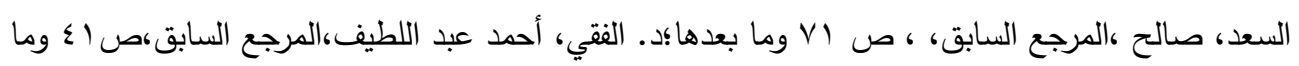

Cf. Rapport au Premier ministre, Pour une nouvelle politique publique d'aide aux victimes, préparé par Groupe interministériel d'aide aux victimes, M.-N. LIENEMANN (présidence), H. MAGLINO et J. CALMETTES (rapporteurs), Paris, 1999.

$$
\text { ) د. السعد، صالح ،المرجع السابق،ص إص وما بعدها . }
$$

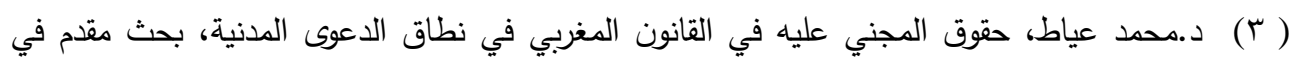

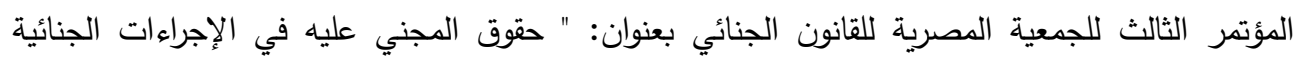

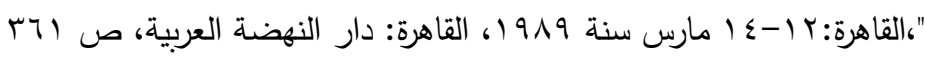

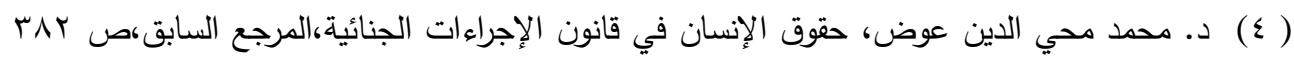

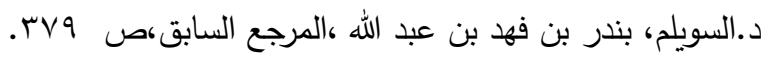


F. r. · مجلة روح القوانين - العدد الواحد والتسعون - إصدار يوليو

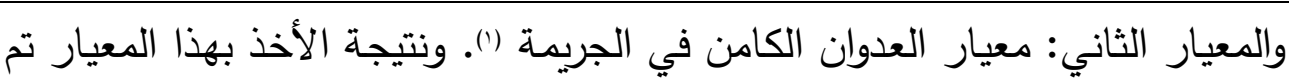

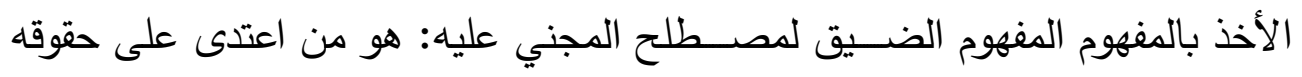

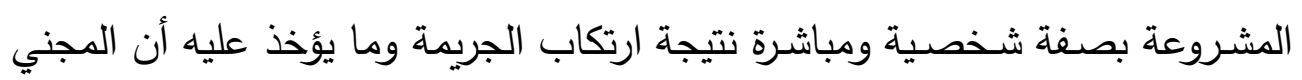

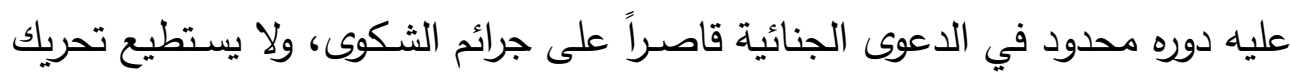

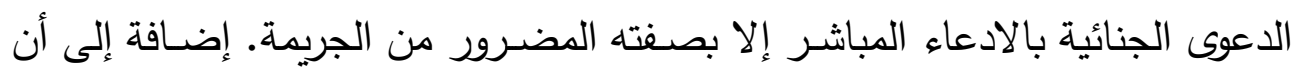

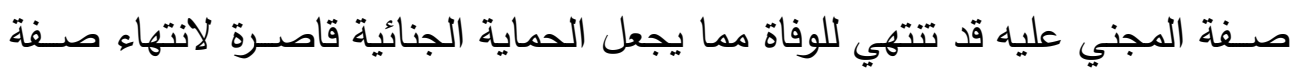

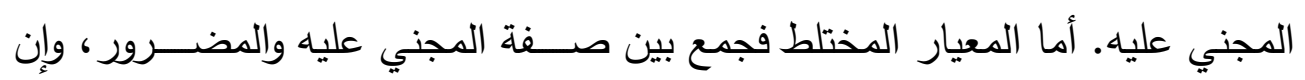

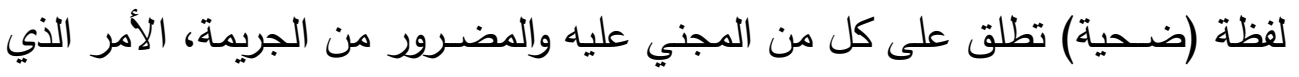

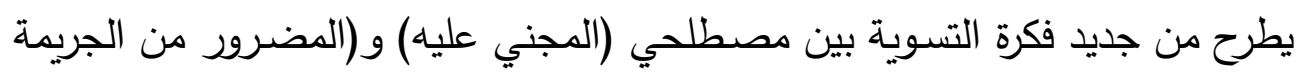
مجنيا عليه) بمعنى أن يكون كل مضــرور من الجريمة مجنيا عليه، وكل مجني عليه

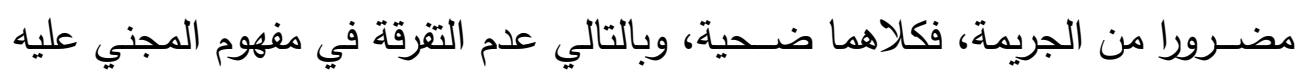

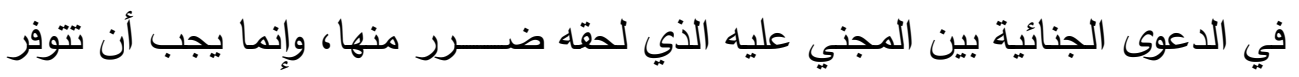
لكل واحد منهما حماية وإجراءات خالصة وخاصة حتى يصدر حكم ويطعن فيله.

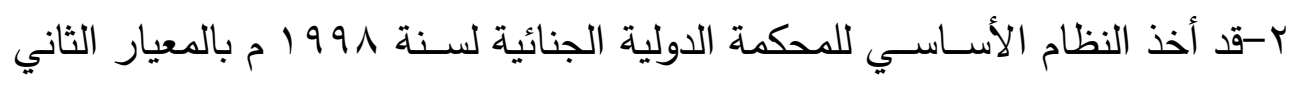
الضـــرر المتولد عن الجريمة بمعيار الضـــرر المتولد عن الجريمة. وليس بمعيار

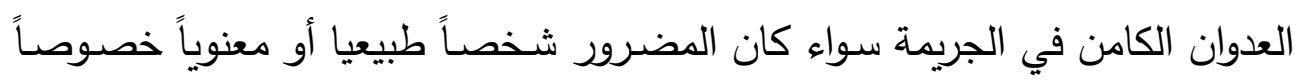

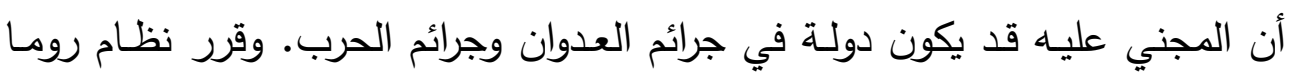

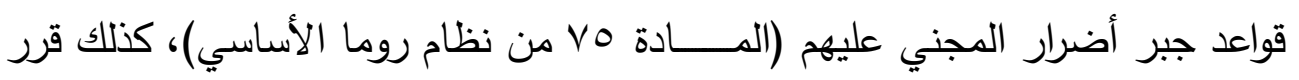

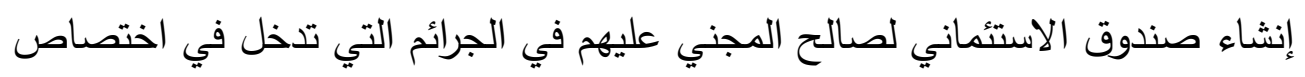
المكمة لصالح أسر المجني عليهم (المادة و ن نظام روما الأساسي) . 
rايشمل مفهوم المضرور الشخص الطبيعي والشخص المعنوي، وإنما قصرت المسؤولية الجنائية على الجرائم الدولية المنصوص عليها في نظام روما الأساسي على الأفراد الطبيعيين فحسب، و هذه الجرائم ترتكب لمصلحة أشخاص معنوية في الغالب أو بتحريض منها مثال: جريمة العدوان (')حسب نص الفقرة الرابعة من ( المـادة هب) من نظام روما الأساسي على أن "لا يؤثر أي حكم في هذا النظام الأساسي يتعلق بالمسئولية الجنائية الفردية في مسئولية الدول بموجب القانون الدولي "،فبرغم أن هذا لأن النيا النص جاء مطلقاً دون تحديد لنوع مسئولية الدولة غير أنه ينصرف للمسئولية المدنية للدولة دون المسئولية الجنائية القائمة على أساس نظرية الخطأ، أو نظرية المخاطر و تحمل التبعة (r) بإلزام -الشخص الدولي -الدولة بتعويض الأضرار الناشئة عن الفعل المجرم متى ثبتت مسئوليتها (). فالمسؤولية أمام المحكمة مسؤولية فردية وشخصية، -بمحاكمة الأفراد الطبيعيين فقط-الذين يرتكبون جرائم بعد بلوغ ^ ا سنة، وقت ارتكاب

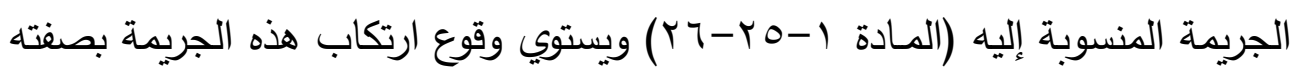
الفردية أو بالاشتراك مع آخر أو عن طريق شخص آخر باعتباره فاعلا أصليا بارتكاب هذه الجريمة أو الثروع في ارتكابها دون تمييز بسبب الصفة الرسمية (ء)، وليست مسئولية للدولة. وهذا يعد تقنينا للمبدأ السابع من محاكمة نورمبرج: مسئولية الشريك في الجريمة الدولية، ويعد الآمر شريكا عن الأفعال التي ارتكبها من نفذ أمره سواء كان

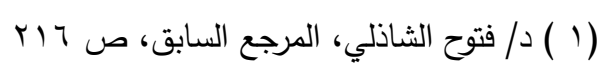

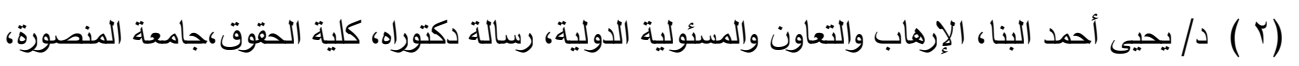
11991 119

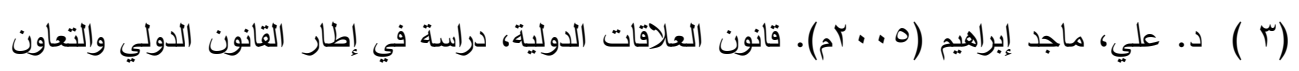

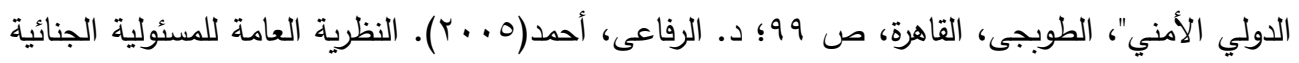

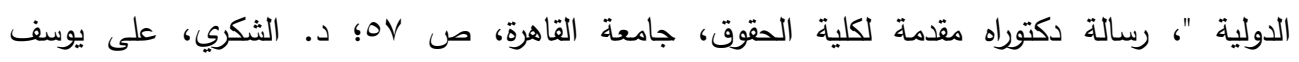

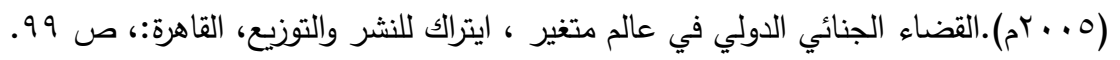

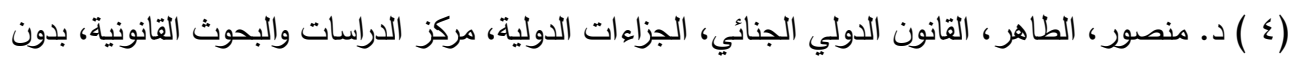

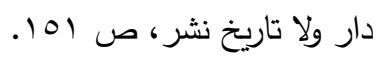




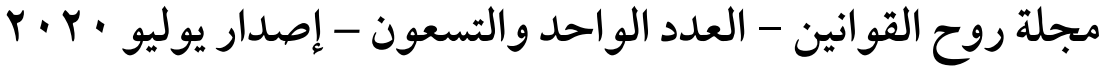

محرضاً أو مساعدا أو مساهماً بأية طريقة (1). والحصانات لا تحول دون ممارسة

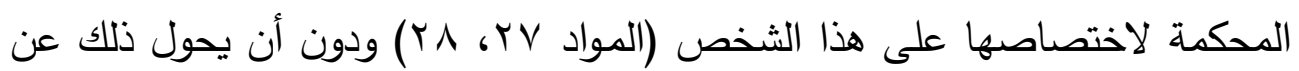

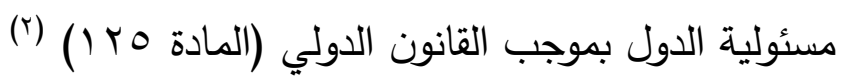
ع -أضاف نظام روما نوعا من المجني عليهج، هم ضحايا العدالة أو القبض والاحتجاز غير المشروع وحقهم في الحصول على تعويض (المادة 10 من نظام روما الأساسي). ه-يرى بعض الفقهاء أن مفهوم الضحية من المنظور القانوني مفهوم مرن يستعصي

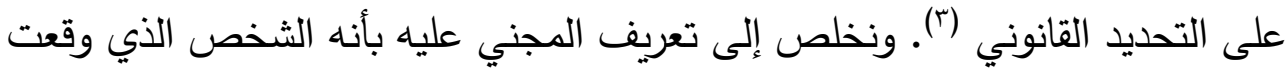

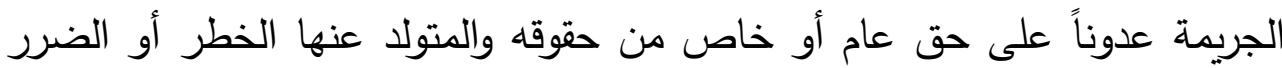

(1 ) انظر إن شئت د. حسني، محمود نجيب (1909 م - ـ 197 م). دروس في القانون الجنائي الدولي،القاهرة:

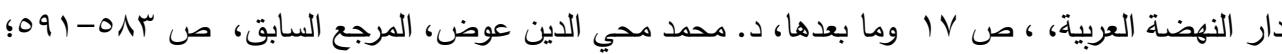

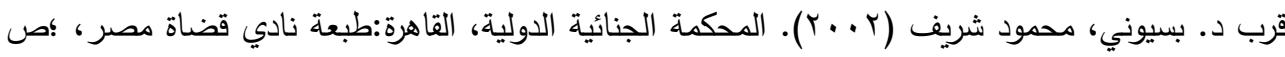
ع r- بr نفس المؤلف، المحكمة الجنائية الدولية، المعهد الدولي لحقوق الإنسان بجامعة دي بول بشيكاغو،

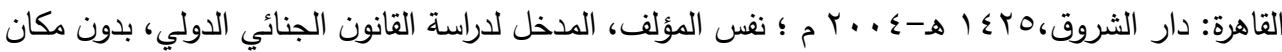

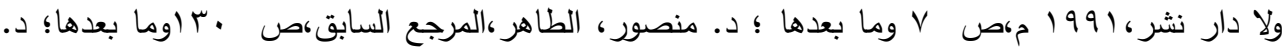

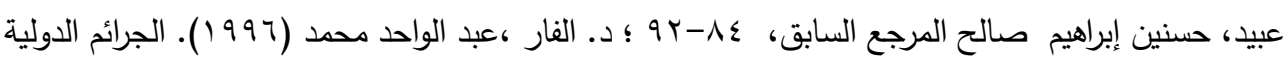

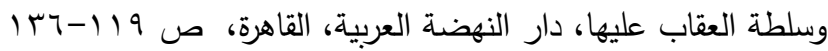

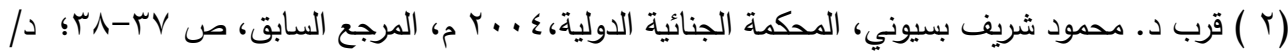

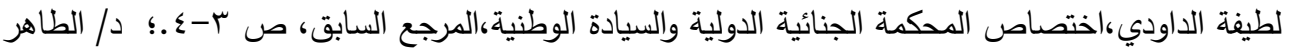

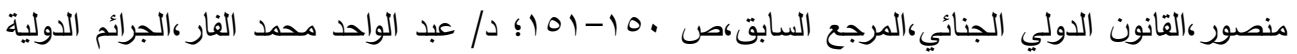

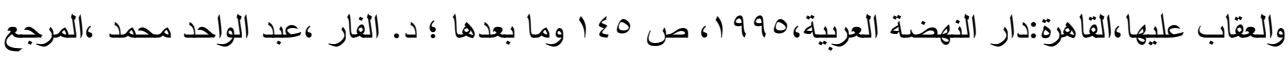
السابق،ص lVY - IVY الأستاذ "عبد الحميد الزناتي" المحامي بمحكة النقض المصرية.الموقع على شبكة الدعلومات الدولية: http://www.aladel.gov.ly/main/modules/sections/item.php?itemid=rฯ .

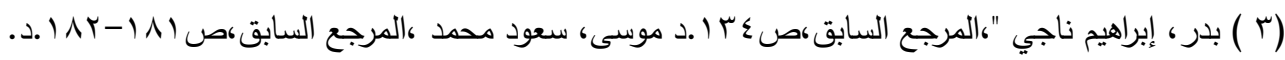

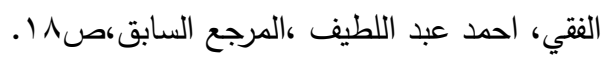
(r^. 

سواء كان شخصا طبيعيا أو شخصا معنويا عاما أو خاصا (') وإنه يشترط لكي يتمتع الشخص بحقوق المجني عليه أن تتوفر فيه الشروط الآتية: أ-أن يكون المجني عليه شخصا طبيعيا أو معنويا بشرط الاعتراف القانوني بالشخصية القانونية للشخص المعنوي. ب-أن يكون هو صاحب الحق، أو المصلحة الغالبة التي مسها العدوان بذلك يشمل جميع أنواع الحقوق التي تمس صاحب الحق ويحميها القانون أو الثرع. ج-أن يكون هناك خطر أو ضرر مادي أو أدبي يصيب الشخص من الجريمة حسب القواعد العامة.

د-أن يكون الضرر مباشراً ناشئ عن جريمة تدخل في اختصاص المحكمة الجنائية(الدولية-الوطنية). هـ-وجود العلاقة السببية بين الفعل والضرر • و -أن يكون إتيان الأفعال المكونة للجريمة اعتداءً على حق شرعي.

\section{الرطبا الثالث}

\section{هوقف النظام الأساسي هن النظم الإجرائية}

\section{وأثره على حقوق المنبي عليه}

إن من حق الضحية الحق في اتخذ الإجراءات في كافة مراحل الدعوى الجنائية لأنه صاحب حق مهدر وقع عليه عدوان لم يستطع المجتمع وقايته من العدوان ومنع الإجرام المحظور • لذلك يسهم في معرفة المركز القانوني للمجني عليه في الرابطة الإجرائية في تحديد حقوق المجني عليه. فإن كان نظام روما الأساسي للمحكمة الجنائية الدولي قد أخذ بالنظام الاتهامي فستقتصر الدعوى على مرحلة واحدة هي مرحلة المحاكمة أما إذ أخذ بالنظام التتقيبي أو النظام المختلط فإن الدعوى الجنائية تمر بالمرحلة التمهيدية قبل

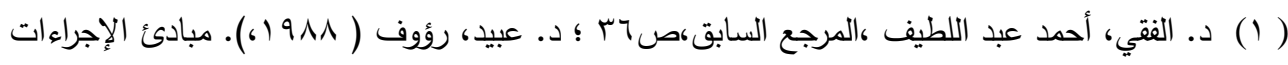

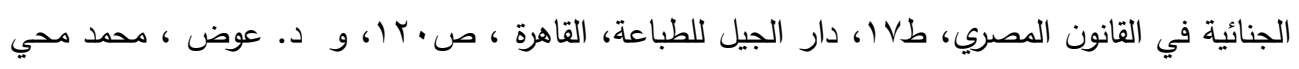

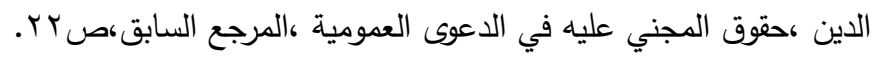
$(r \wedge)$ 


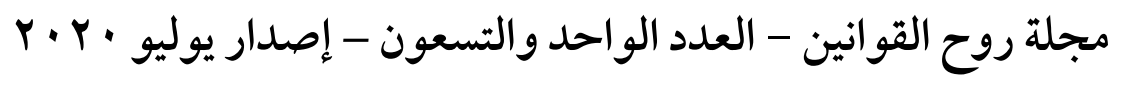

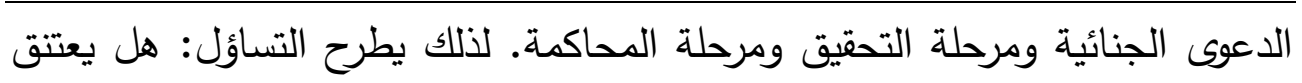

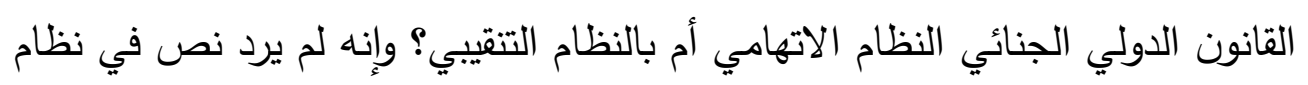

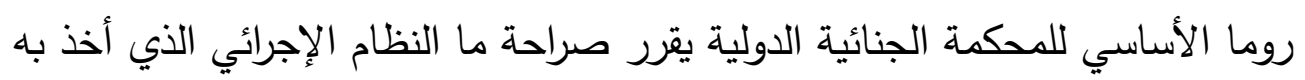

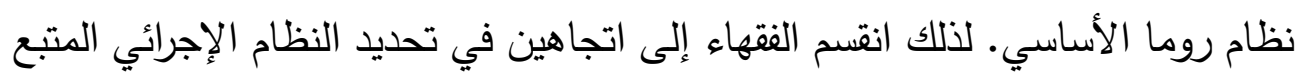

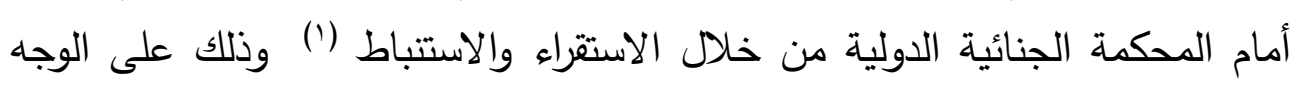

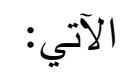

أولا: النظام الآهاهي وموقف نظام القضاء الدولي الجنائي منه: هو أقدم نظم الاتهام في مباشرة

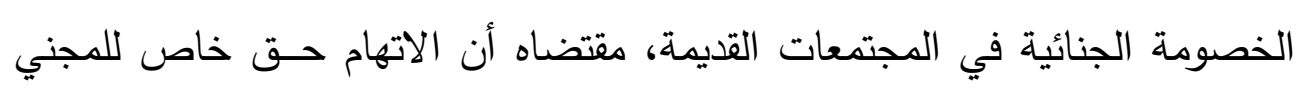

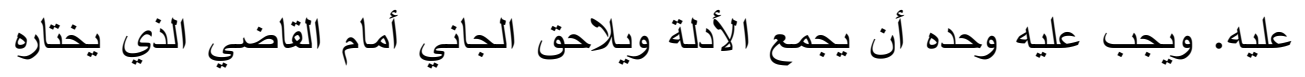

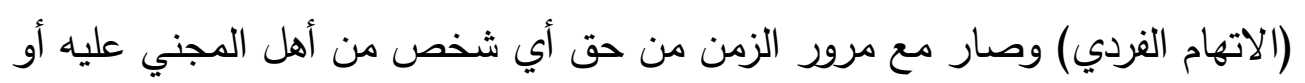

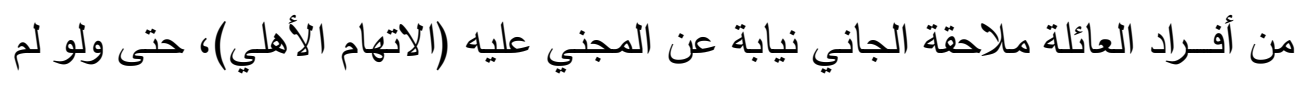

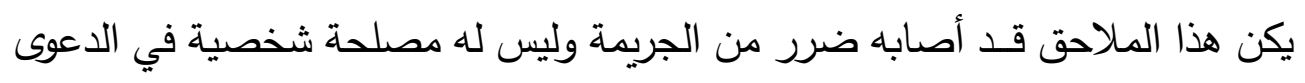

وقد ذهب بعض الفقهاء إلى ترجيح الأخذ بالنظام الاتهامي في نظام روما الأساسي

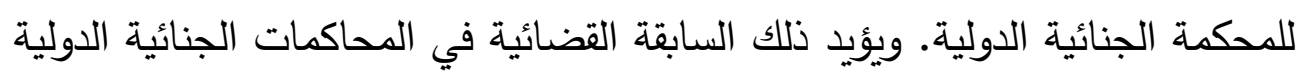

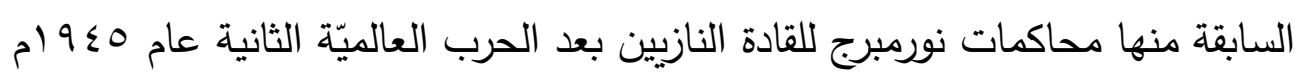
كانت مشكلة وفقا للنظام الاتهامي الأنجلوسكسوني دون النظام التتقيبي اللاتيني (r).

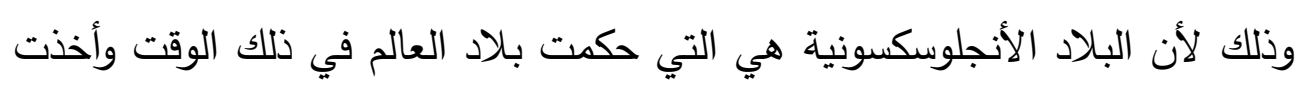

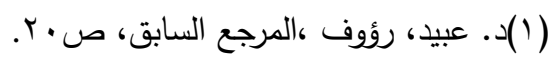

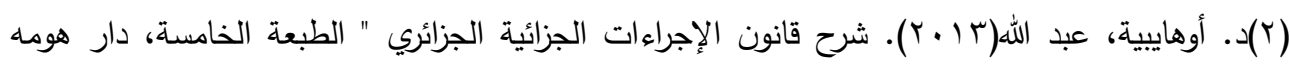

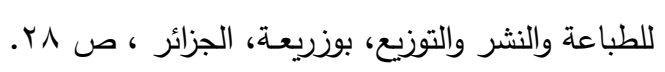

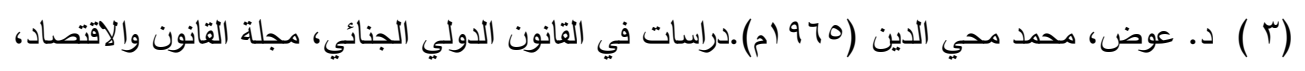

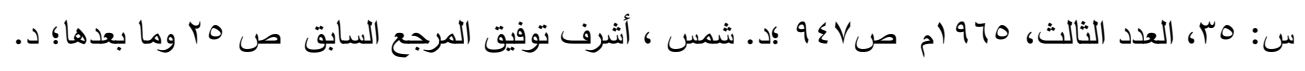

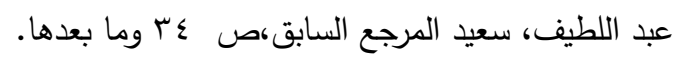
$(r \wedge r)$ 


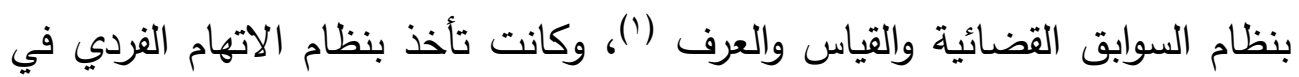
نظمها الداخلية. واستمر هذا الوضع أمام المحكمتين الجنائيتين الدوليتين اللتان أنشئتا

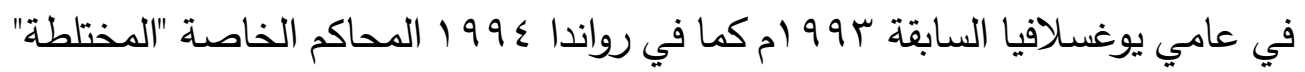
أو "المهجّنة" التي أنشئت في تيمور الثرقية، وسيراليون وكمبوديا. وإن أول النظم ظهوراً

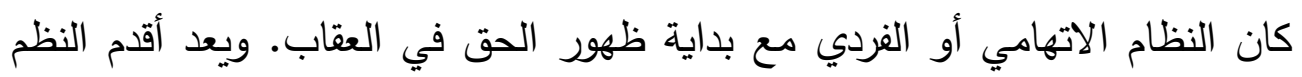

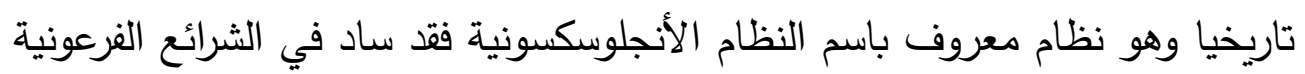

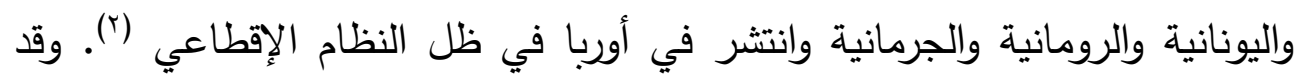

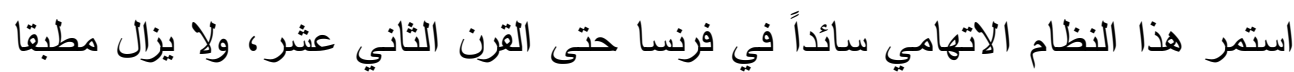

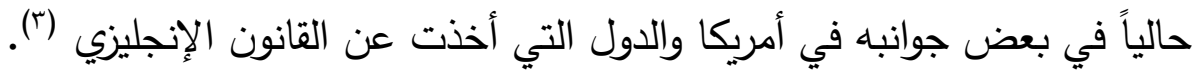

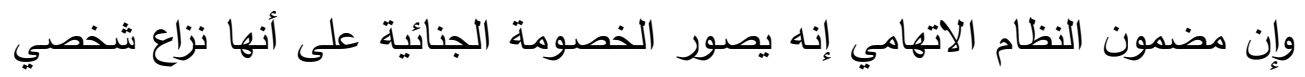

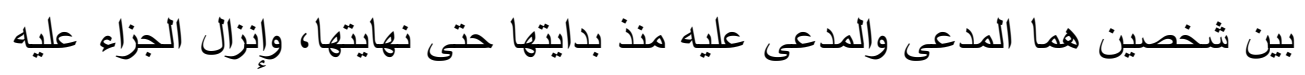

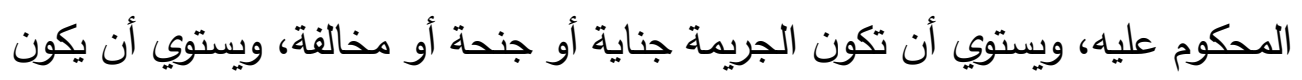

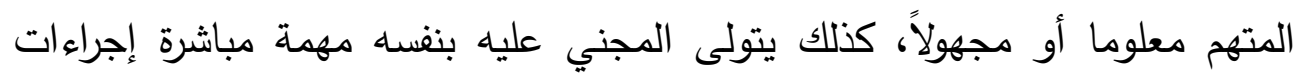
الدعوى() ( . ويركز في الحقوق الآتية:

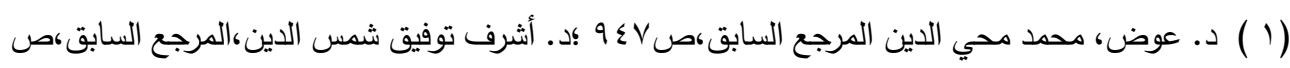

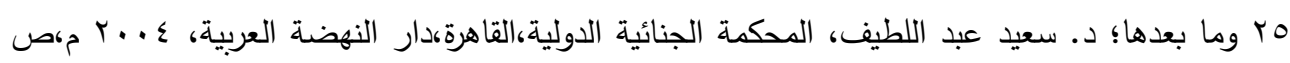
عب وما بعدها.

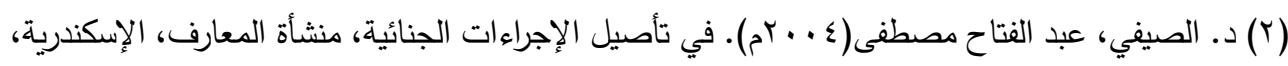

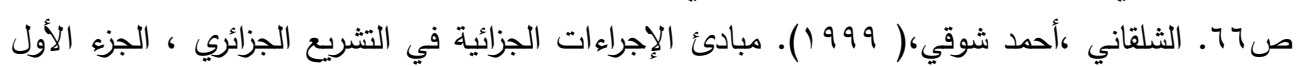

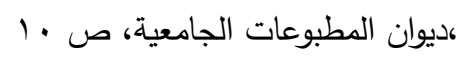

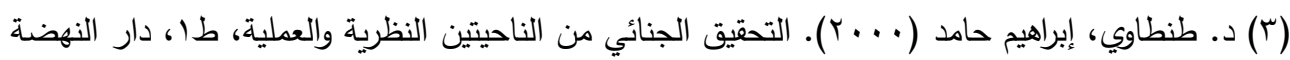

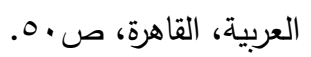

(ع) د ـ المرصفاوي، حسن صادق التحقيق الجنائي، موسوعة الفقه والقضاء للدول العربية، بدون سنة

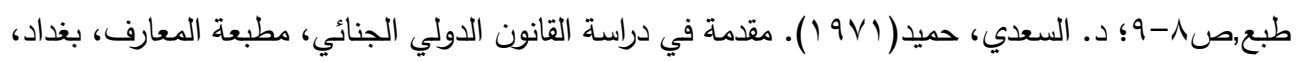

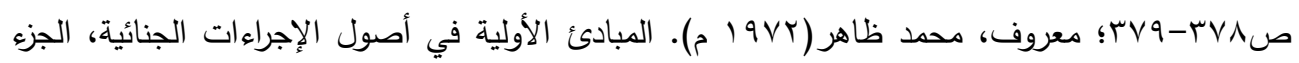

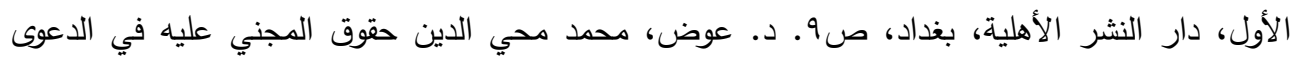

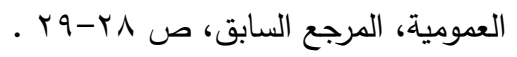
$(r \wedge)$ 


$$
\text { r.r. مجلة روح القوانين - العدد الواحد والتسعون - إصدار يوليو }
$$

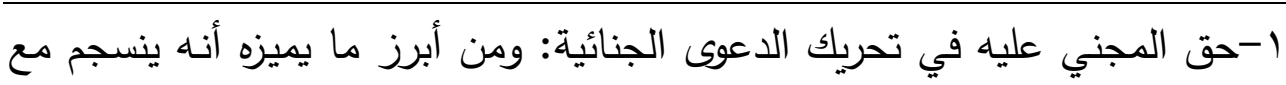

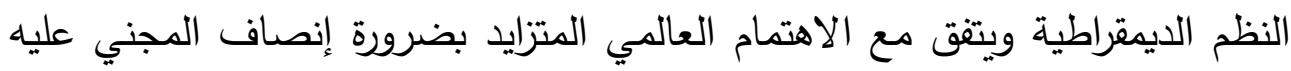

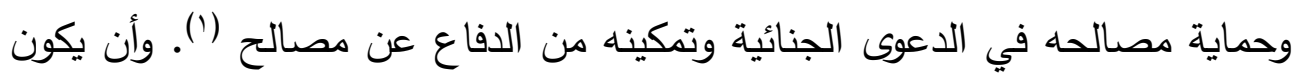
للمجني عليه صلاحية تحريك الدعوى الجنائية أمام المحكمة. وذلك بأن يتقدم بشكواه

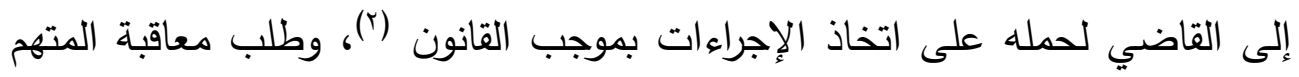

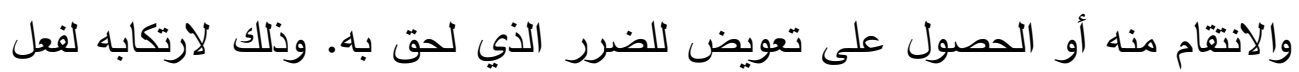

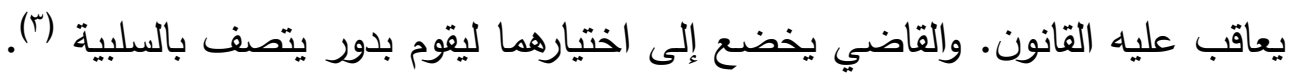

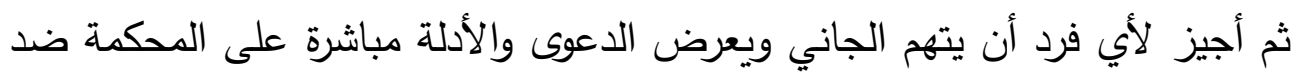
المتهم (๕) آلايز r-حق المتهم في الحضور : يحق للمتهم حضور جميع إجراءات الدعوى وله حق الرد

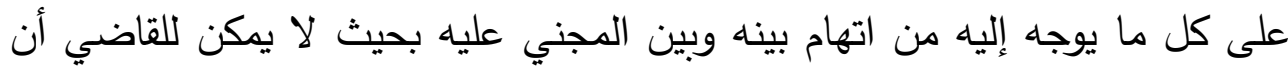

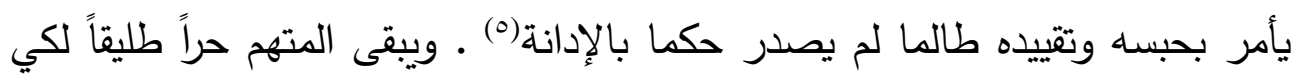

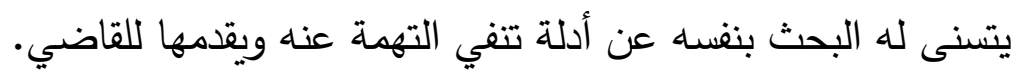

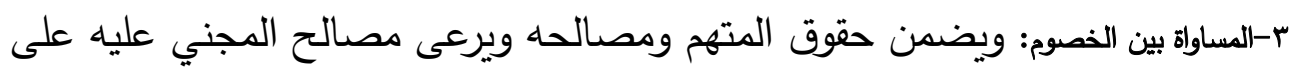

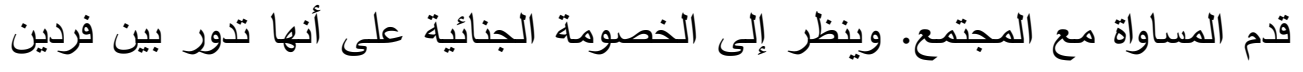

( (1) د. عبد الستار ، فوزية (9v0) (1). شرح قانون أصول المحاكمات الجزائية اللبناني، دار النهضة العبية،

$$
\text { بيروت ، ص107. }
$$

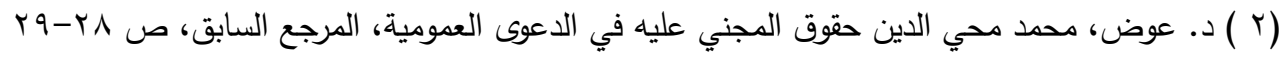

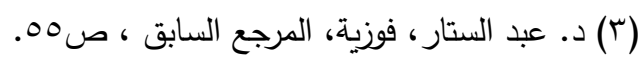

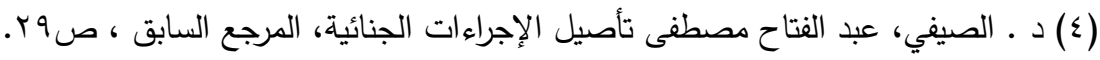

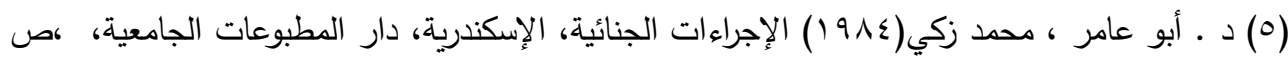


مدعي ومدعى عليه وتقييد الدعوى الجنائية بنطاقها الشخصي والعيني ((). ويؤذ عليه ما يأتي: ا-هذا النظام الاتهامي تمر فيه الدعوى الجنائية بمرحلة واحدة وهي مرحلة المحاكمة. وإن القاضي يجمع بين يديه سلطة التحقيق والادعاء والمحاكمة. لذلك يصبح كل قاضي هو مدعي عام. يتصدى لكل جريمة وصلت لعلمه الشخصي ويحرك الدعوى الجنائية بشأنها (r).

r-واختفاء مرحلة التحقيق وتغييب الادعاء العام وحصره في الادعاء الفردي في شخص المجني عليه (「). وقد تعدل هذا النظام بأن سمحت الحكومة البريطانية لمسؤولي التحقيق بالقيام بإجراءات التحقيق وجمع الأدلة بسرية تامة وعند ثبوت الأدلة تعرض للمناقشة

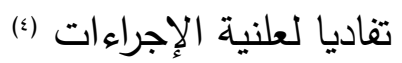

ب-انتفاء إيجابية القاضي الجنائي: فدور القاضي سلبي باعتباره يمثل مطلق الحياد التام في النزاع بين الخصوم (o). ولا يتمتع بحرية الاقتناع وإنما يتقيد بما يقدمه الخصوم من بن أدلة قد تكون معيبة أو قاصرة فلا يصل إلى الحقيقة في كثير من الأحيان كالقاضي المدني مما قد يؤدي إلى ضياع الحقيقة (־). ويترك عبء الإثبات على المجني عليه كلياً. ونظام الإثبات في هذا النظام يخضع لقواعد شكلية، ويأخذ بأدلة معينة تقترب من الحصر • كما أنه يتجاهل التفاوت الصارخ بين إمكانيات النيابة العامة الممولة بما يزيد

(1) د. عوض، محمد محي الدين، المرجع السابق، ص-باسبr وما بعدها؛ د. الصيفي، عبد الفتاح

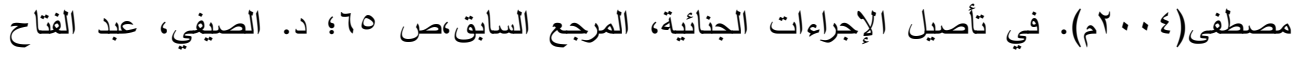

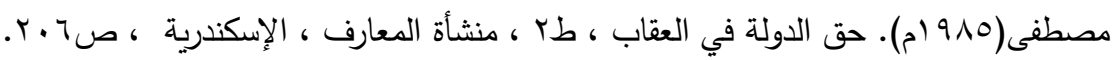

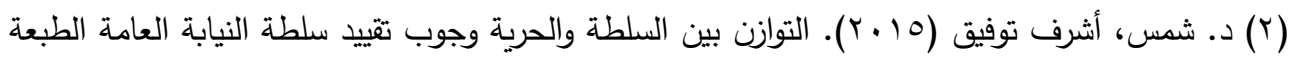

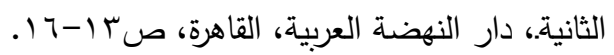

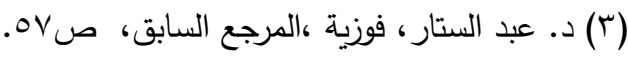

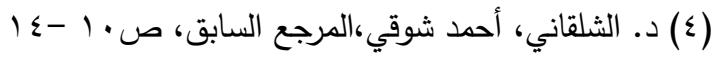

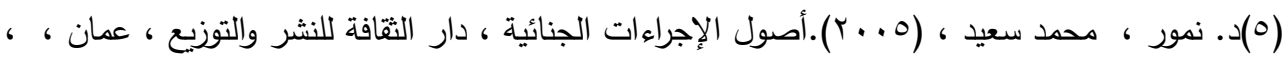


r.r. · مجلة روح القوانين - العدد الواحد والتسعون - إصدار يوليو من الكفاءة والكفاية لها في جمع الأدلة خصوصاً على المستوى الدولي، وبين الإمكانيات

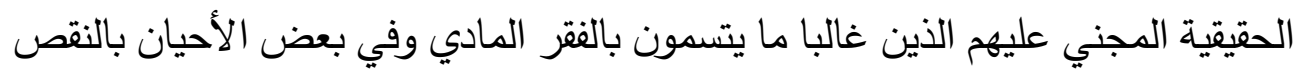
الثقافي والقانوني (1). إضافة إلى أنه يطبق قاعدة تقييد المحكمة بنطاق الدعوى الجنائية

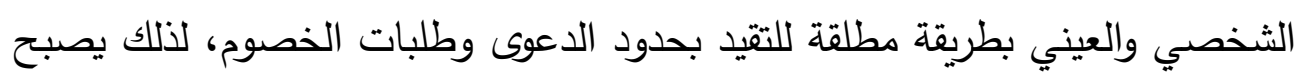
دور القاضي في ذلك سلبيا(). ع -صورية المساواة بين المتهم والمجني عليه في سبيل احترام الحقوق الثخصية: قامت المساواة على تصور خاطئ للنزاع بين الخصمين بافتراض أنها متساويان في القوة.

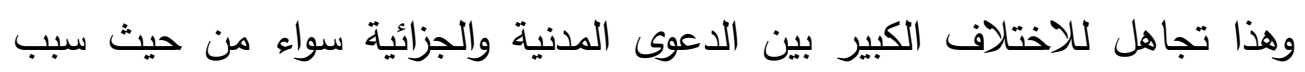
الخصومة ومحلها أو من حيث طبيعتها ...إلخات). ويترتب على اعتناق النظام الأساسي للمحكمة الجنائية للنظام الاتهامي أكثر من النظام

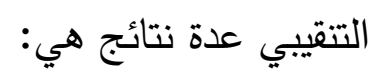
1-أن تكون المحاكمة الجنائية الدولية يكون طرفيها هما الادعاء العام من جهة والمتهح

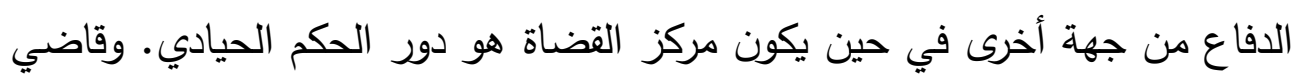

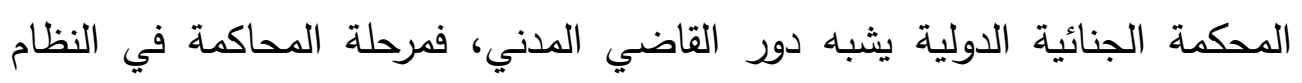

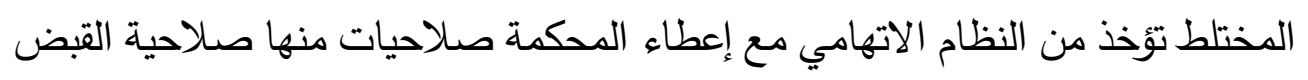
على المتهم حسب المادة (ب9) من نظام روما الأساسي، كذلك مراعاة أشكال التعاون

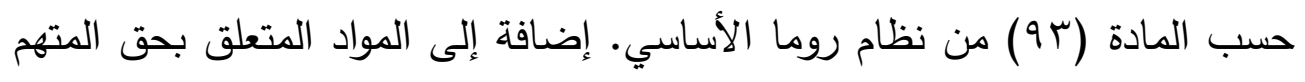

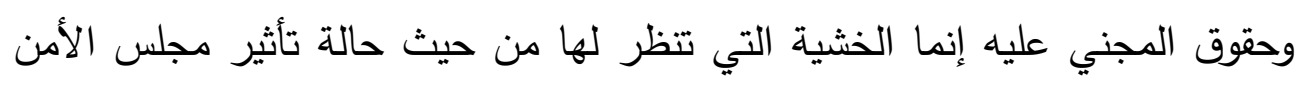

(1) د. مصطفى، محمود محمود( • ( I ). شرح قانون الإجراءات الجنائية، الطبعة العاشرة، القاهرة، دار BESSIOUNI (CH),$\uparrow \cdots$, Note explicative sur le statut de la cour pénale internationale, La cour pénale internationale ratification et mise en œuvre dans les législations nationales R.I.D.P Vol ${ }^{r}$, Pro.

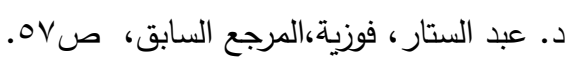

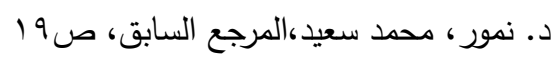


ه - ضمانات الحماية الإجر ائية لحقوق المجني عليه أمام سلطة التحقيق في ظل نظام المحكمة الجنائية الدولية لسنة 1991م

على المحكمة الجنائية الدولية أو عجز المحكمة عن ممارسة دورها نتيجة النزاعات

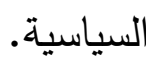

r-اختفاء مرحلة التحقيق أي أن الدعوى الجنائية تمر بمرحلة واحدة وهي مرحلة المحاكمة، فالأدلة ترفع مباشرة أمام المحاكمة ولا تمر بمرحلة التحقيق ولذا فإن مرحلة المحاكمة هي المرحلة الأساسية في ظل النظام الاتهامي وليس من الصحيح القول بعدم وجود مرحلة التحقيق حسب ما ذهب إليه البعض من الفقهاء حول تبني المحاكم الدولية الجنائية للنظام الاتهامي وزوال مرحلة التحقيق. إنما الواقع من النصوص يفيد أن النظام الأساسي للمحكمة الجنائية الدولية أخذ من النظام التنقيبي بإسناد مهمة الاتهام في الجرائم الخطيرة إلى المدعي العام نيابة عن المجتمع فأخذ بذلك بمرحلة التحقيق الابتدائي في القضاء الدولي الجنائي. وإن كانت هذه المرحلة هي مرحلة قصيرة وموجزة، وتباشر فيها جمع وإعداد الأدلة لمباشرة إجراءات المحاكمة واستجواب الثهود والمتهمين والمجني عليهم. وقد خصص النظام الأساسي للمحكمة الباب الخامس للتحقيق والمحاكمة، تحت عنوان "التحقيق والمقاضاة "وهذا يدل على الاستقلال والانفصال بين مرحلتي التحقيق والمحاكمة في ظل النظام الأساسي للمكمة. فالمادة (OY) من النظام الأساسي للمحكمة أشارت صراحة إلى واجبات المدعي العام في مرحلة التحقيق، تحت عنوان " الشروع في التحقيق"، كما جاءت المادة (عام) تحت عنوان " حقوق الأشخاص أثناء التحقيق وكانت مركزة في حقوق المتهم دون ذكر لحقوق المجني عليه. كذلك أن المادة (7ه) من النظام الأساسي للمحكمة بينت دور الدائرة التمهيدية في مرحلة التحقيق فجاءت تحت عنوان" دور الدائرة التمهيدية فيما يتعلق بوجود فرصة فريدة للتحقيق" r-أن تمتلك سلطة التحقيق في النظام الأساسي صلاحيات وسلطات واسعة تتمثل في الجمع بين سلطتي التحقيق والاتهامي. وتمر الدعوى بمراحل متعددة أمام المدعى العام والدائرة التمهيدية أثناء مباشرة إجراءات التحقيق، ويقوم المدعى العام والدائرة التمهيدية في إطار هذه الإجراءات بإصدار أوامر مختلفة، تختلف بحسب طبيعتها وأهميتها ووقت إصدارها والقواعد التي تحكمها والآثار الناتجة عنها، وتعد الدائرة المدخل الوحيد للبدء 


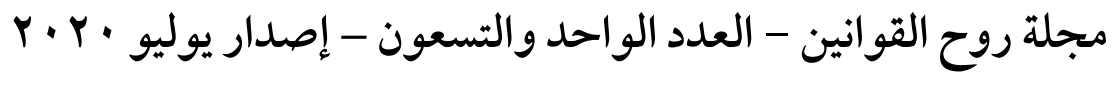

في المقاضاة أمام المحكمة الجنائية الدولية في حالة ترجيح أدلة الاتهام على أدلة

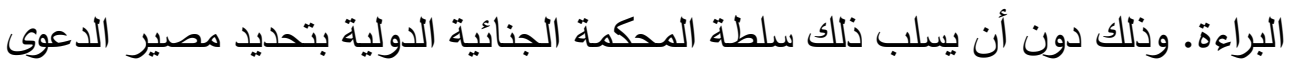

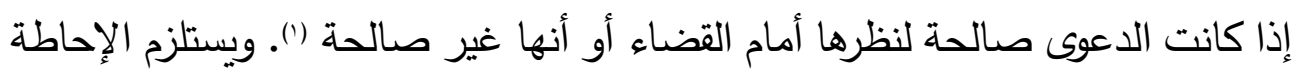
بمرحلة التحقيق في القضاء الدولي الجنائي مع توفير لضمانات حقوق المجني عليه والمتهم (). (4) ثانيا: النظام التنقيبي وهوقف نظام القضاء الدولي الجنائي هنه: ظهر نظام التنقيب والتحري لاحقا للنظام الاتهامي في عهد الرومان وذلك بتطور الجماعات السياسية أصبحت وظيفة

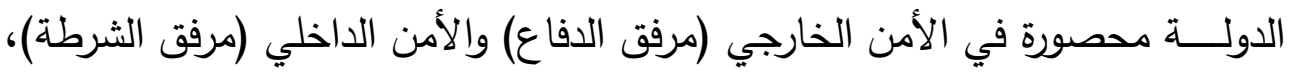

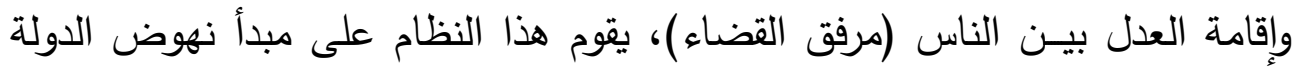

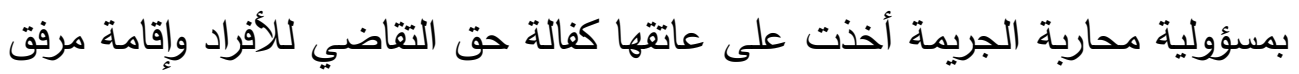

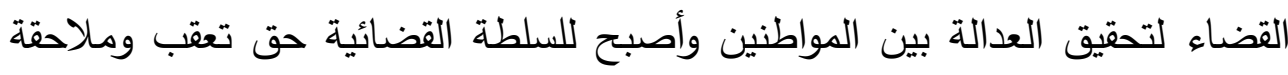
الجاني بمجرد وقوع الجريمة ولو لم يبلغ عنها المجنى عليها(").

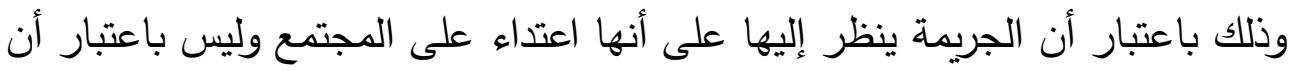

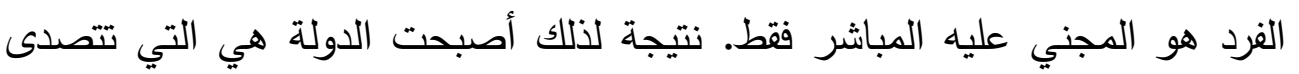

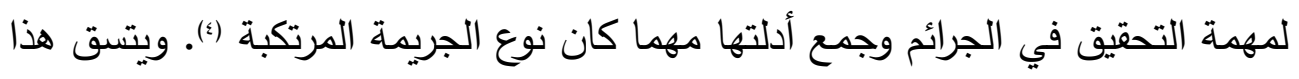

(1) د. سرور ، أحمد فتحي (ب991 م). الثرعية الدستورية وحقوق الإنسان في الإجراءات الجنائية ، دار النهضة العربية ، ص برا. Kai Ambos, international procedure: adversarial, inquisitorial or mixed?, international criminal law review , ( $($ ) Kluer law international Netherlands, issue $r$, $\mathrm{pp}^{\prime}-\mathrm{rr}$ Caianiello. Michele, $(r .11)$ Law of evidence at the international criminal court: Blending accusatorial and inquisitorial models, North Carolina Journal of International Law and Commercial Regulation, Vol rฯ, , p rAv

(r)د. حزيط ، محمد (T ( • r،).مذكرات في قانون الإجراءات الجزائية الجزائري " دار هومه للطباعة والنشر

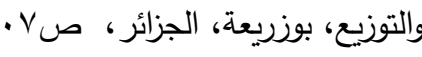

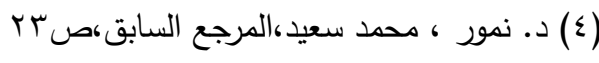
r^ᄉ) 


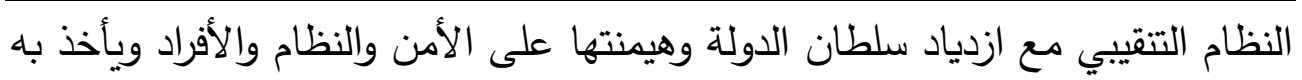
القانون الفرنسي (1). ويركز في الحقوق الآتية: ا-الاعوى ملكا للدولة والجماعة الدولية: ويقوم هذا النظام على التمييز بين التئ الضرى

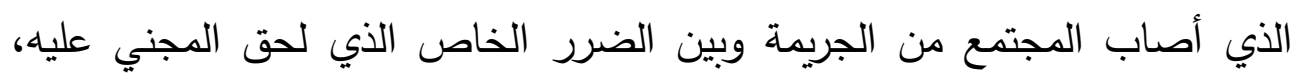

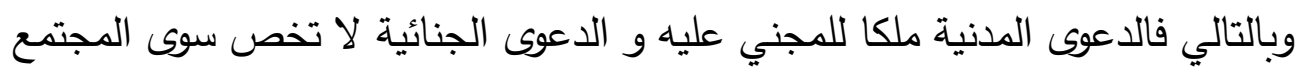

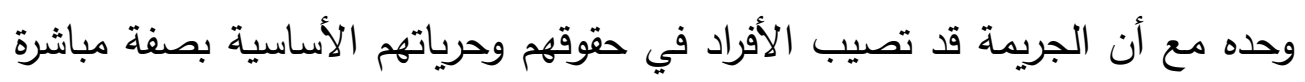

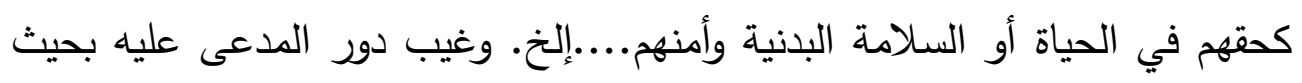
تقوم النيابة العامة مقام المجني عليه في تحريك الدعوى الجنائية ومباشرتها باعتبار الدعوى ملكاً للجماعة لا تملك حق إسقاط الدعوى أو التنازل عنها إلا وفقا للقانون،

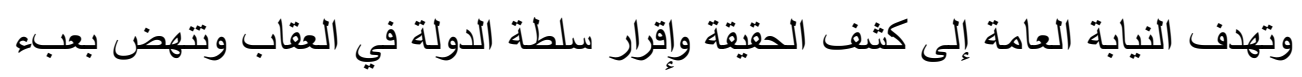

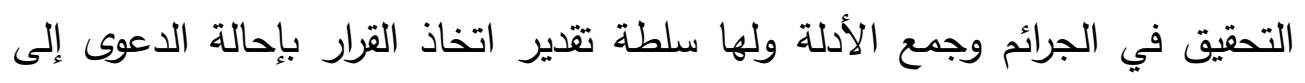

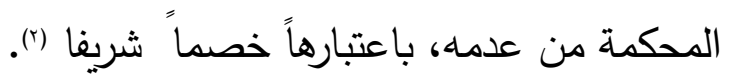

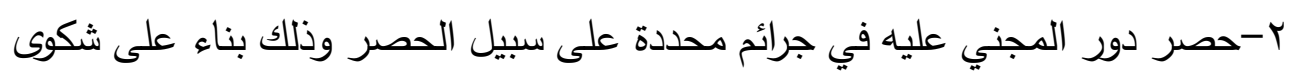
تقدم من المجني عليه والمطالبة بالتعويض عن الأضرار التي أصابته من جراء وقوع لئل الجريمة. ويتسق النظام التنقيبي مع ازدياد سلطان الدولة وهيمنتها على الأمن والنظام

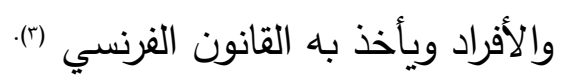

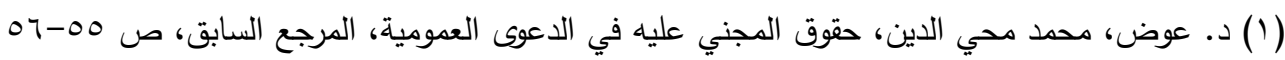

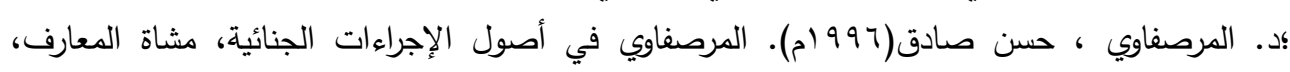

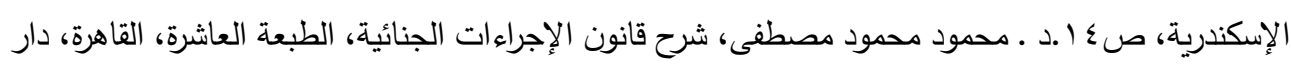

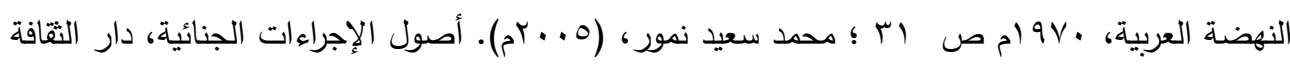

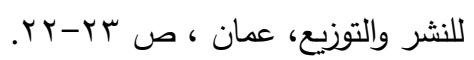
(Y)

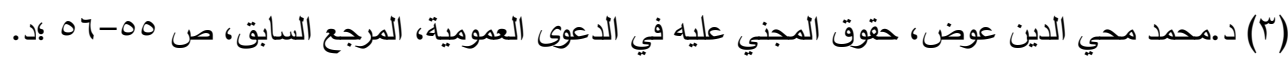

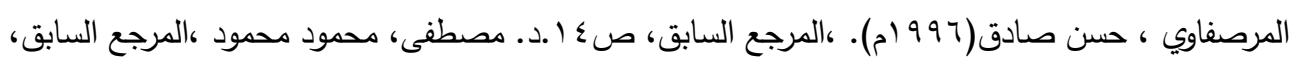

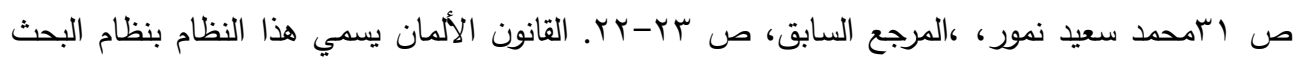
والتحري وأخذ به القانون الإيطالي والهولندي والروماني واليوناني. $(r \wedge q)$ 
r.r. · مجلة روح القوانين - العدد الواحد والتسعون - إصدار يوليو

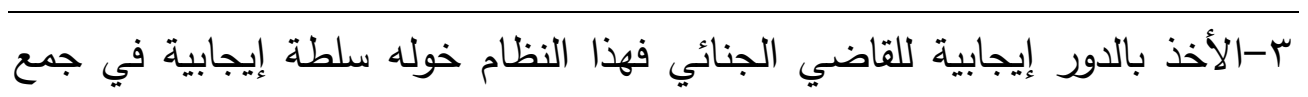
الأدلة قد أبيح الطعن في الأحكام لتدارك ما قد يوجد بها من أخطاء (1).

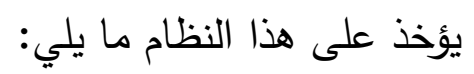
1-إهدار الحرية دون التقيد بطلبات المجني عليه: أباح هذا النظام فيه فكرة الحصول

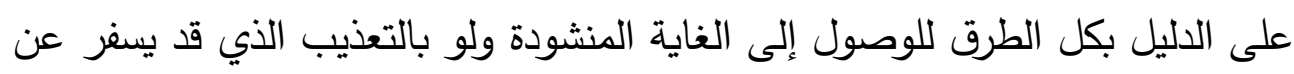

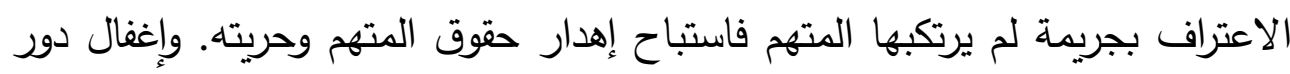

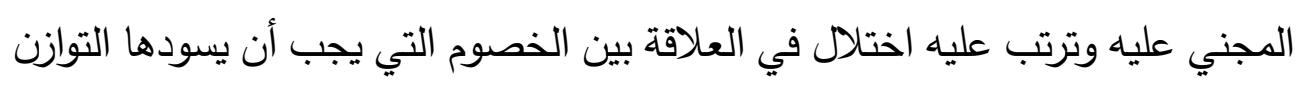

r-سرية الإجراءات بشكل كامل: يهدر هذا النظام بعض الضمانات التي يتمتع بها المتهم في ظل النظام التهامي فقد أصبح التحقيق سريا لجميع الخصوم ومنهم المجني عليه. وبالتالي عدم مناقشة الإجراءات مما يترتب عليه صدور الأحكام المعيبة لغياب

$$
\text { حق الدفاع والرقابة (r). }
$$

r-الأخذ بمبدأ الأدلة القانونية: تقييد القاضي وقناعاته الوجدانية بمبدأ الأدلة القانونية

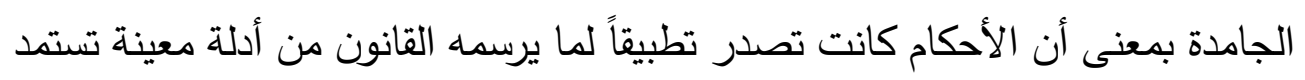

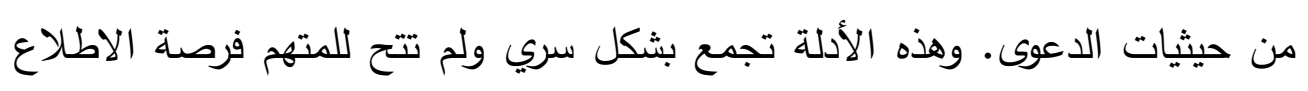

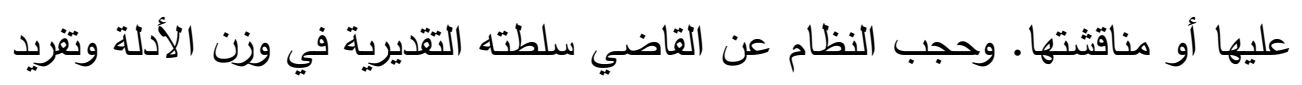
العقاب، مما يؤثر في عدالة أحكامه (8).

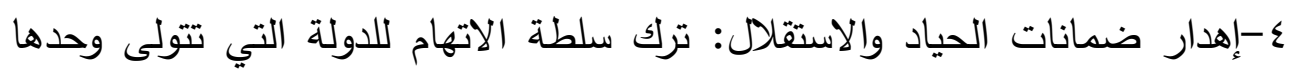
عملية تعقب الأدلة وإثبات الجريمة لفرد من الأفراد وترتب على السلطات الإن المدنوحة

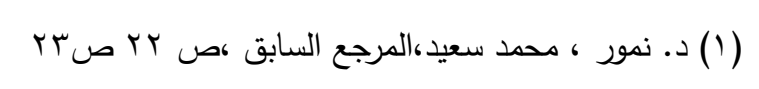

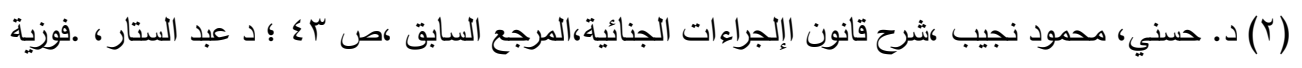

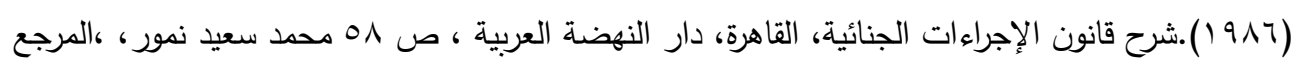

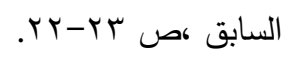

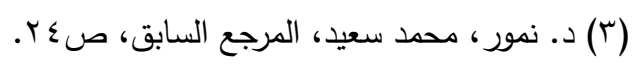

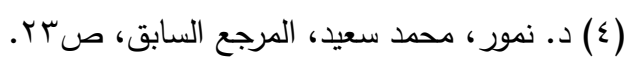




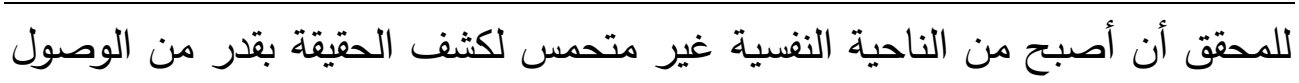

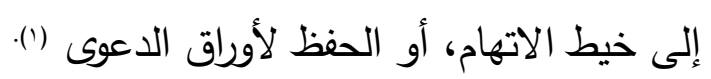

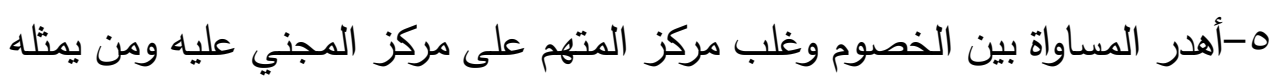

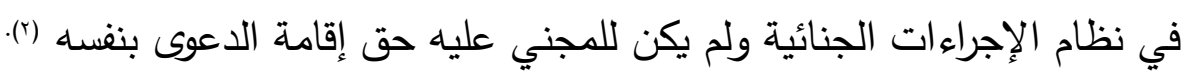
ولم يرجح أحد الأخذ بهذا النظام في نظام روما الأساسي للمحكمة الجنائية الدولية.

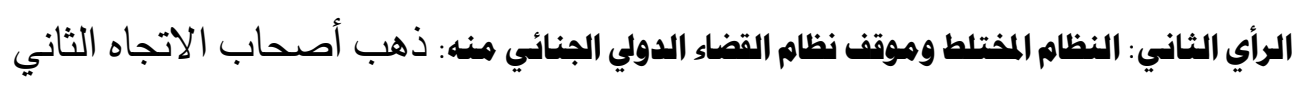

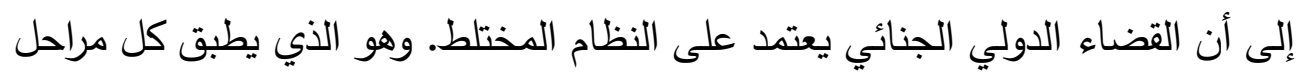

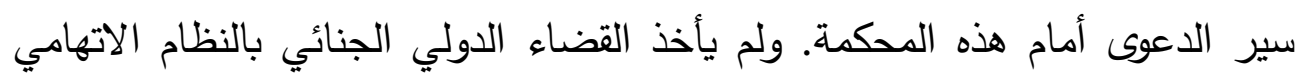

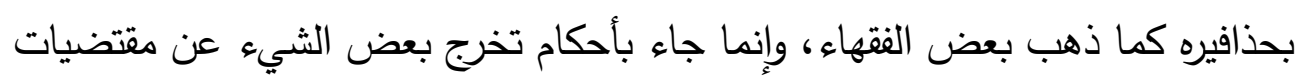

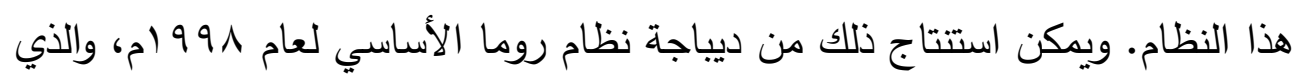

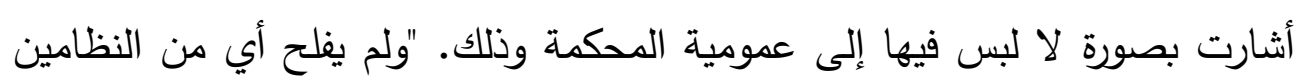

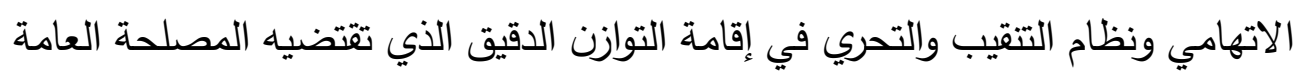

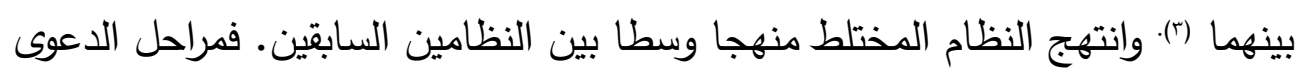

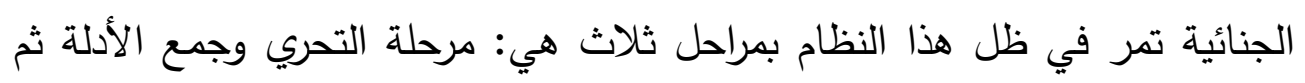

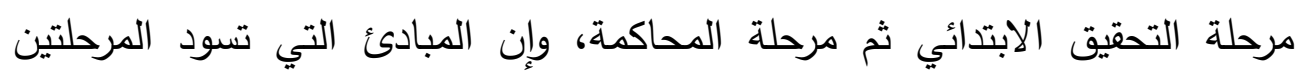
الأخيرتين تكون مختلفة فيما بينهما(). وقد قسم النظام المختلط الإجراءات الجنائية إلى مرحلتين هما: مرحلة التحقيق ومرحلة المحاكمة:

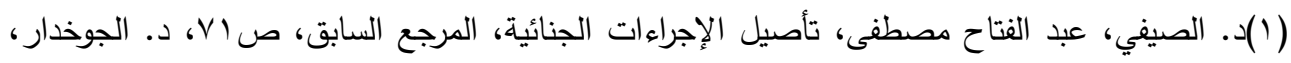

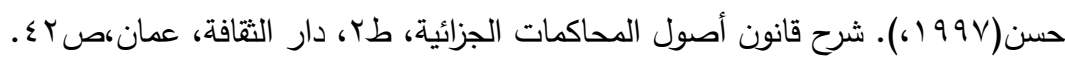

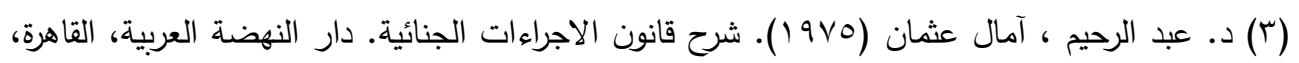




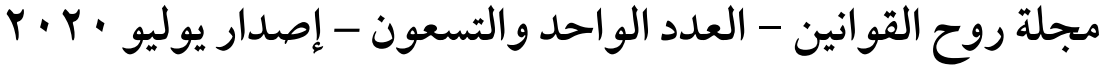

أما مرحلة التحقيق يسود فيهما قيم ومبادئ النظام التنقيبي وذلك لحماية حقوق المجتمع. ويستند التحقيق الابتدائي إلى مبدأ التدوين والسرية اللذين قد تقتضيهما مصلحة التحقيق التهيق (1).وتتولاه النيابة العامة نيابة عن المجتمع والمجني عليه فيكون للاعوى الجنائية طرفان

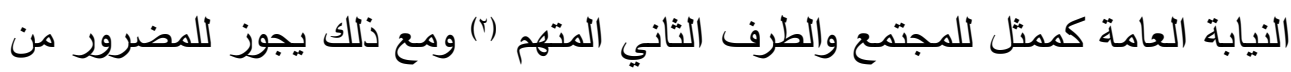

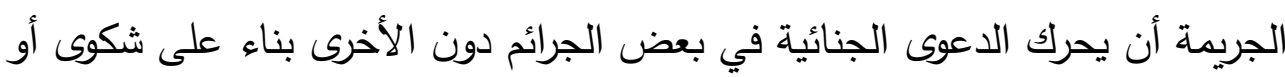

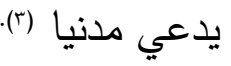
أما المرحلة الثانية: فهي مرحلة المحاكمة ويغلب عليها طابع النظام الإجرائي الاتهامي

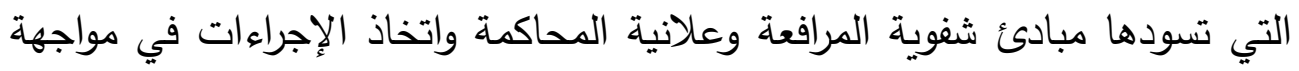

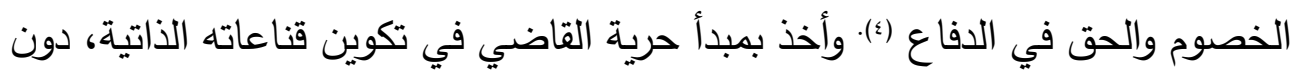

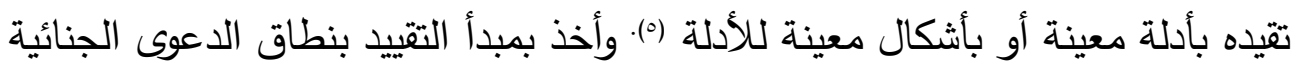
الثخصي والعيني وإن لم يكن بالصورة المطلقة التي تظهر في النظم الأنجلوسكسونية.

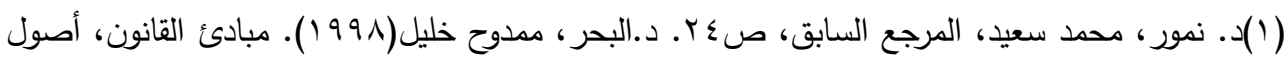

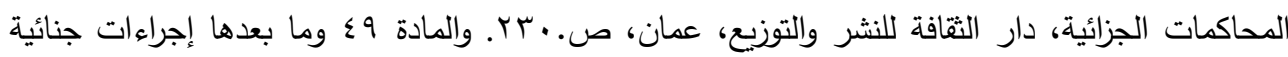

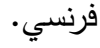

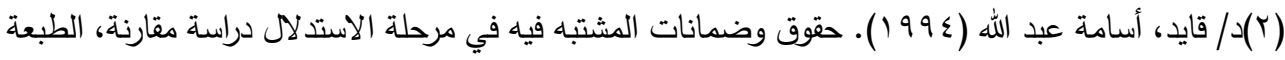

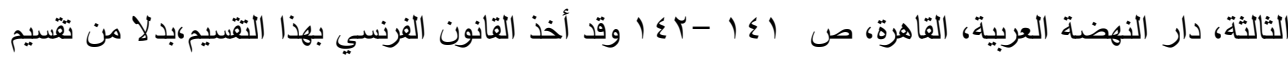
كان ظنين أو مشتكى عليه أو متهم التهر

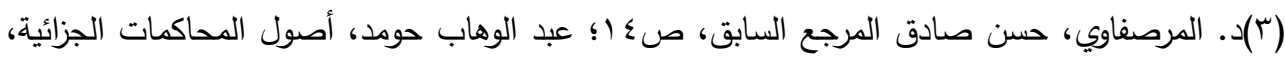

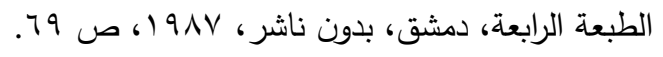

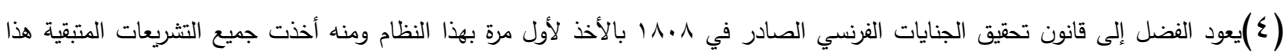

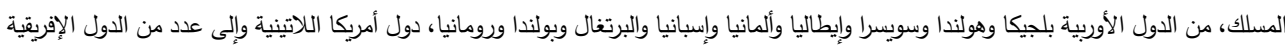

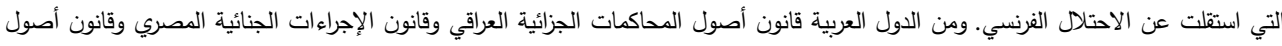

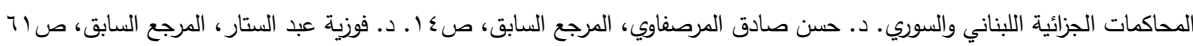
La procédure pénale doit être équitable et contradictoire et préserver l'équilibre des droits des parties...Les personnes se trouvant dans des conditions semblable et poursuivies pour les même infraction doivent être jugées selon les mêmes règles. L'autorité judiciaire veille à l'information et à la garantie des droits des victimes au cours de toute procédure pénale... »

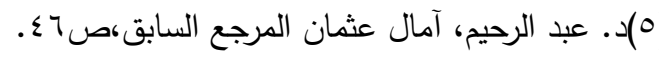


وأخذ بمبدأ الفصل بين سلطة الاتهام وسلطة الحكم (1) وقد أخذت أكثر الأنظمة الإجرائية الجزائية، المطبقة حالياً بالنظام المختلط مثال: يعد القانون الفرنسي في مقدمة تلكانك

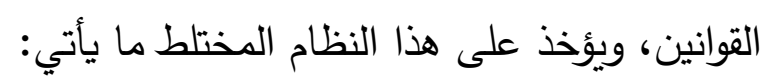

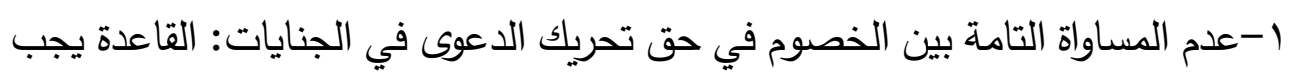

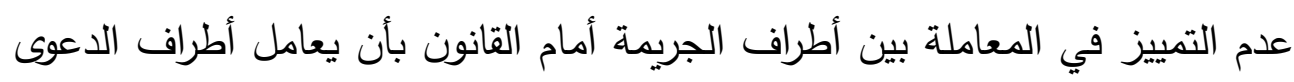

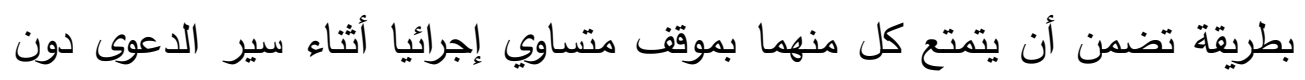

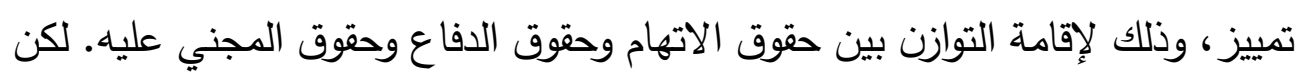

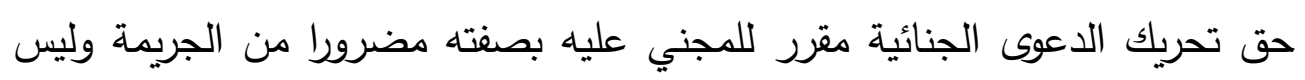

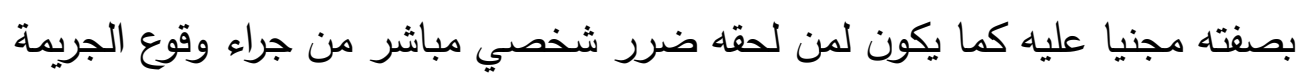

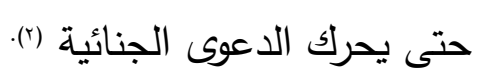

r-هذا النظام المختلط يفتقد إلى أساس فكري يعكس حدود هذا التوفيق بين النظامين

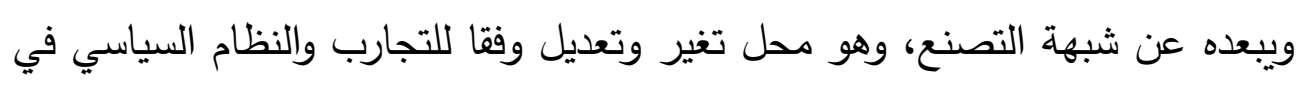
الدول المتخلفة.

\section{الرأي الثالث النظام الإجرائي الإسلاهي وهوقف نظام القضاء الدولي الجنائي هنه: إن}

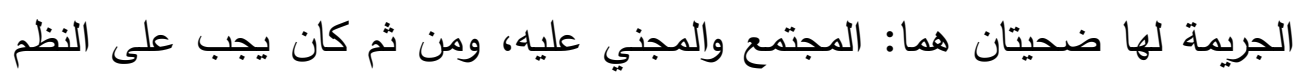

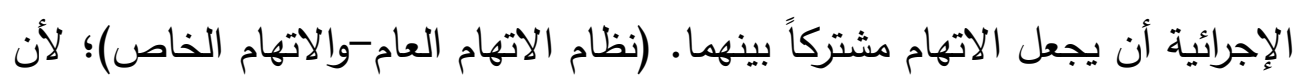

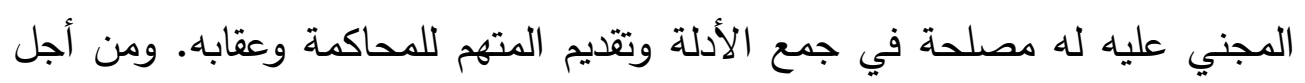
تحقيق التوازن بين حقوق المجتمع كمجني عليه عام والفرد كمجني عليه خاص دون الهن الهن مساس بحقوق المتهم (r). وكانت الشريعة الإسلامية أكمل في تقسيم في العام (الحدود

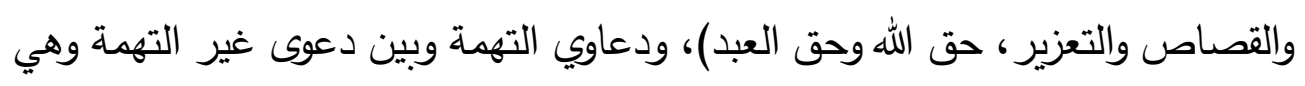

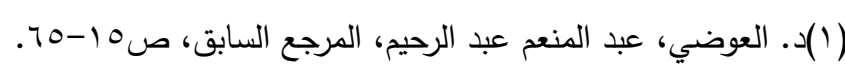

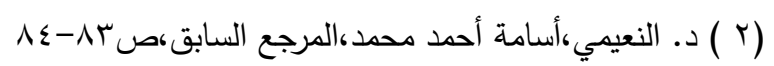

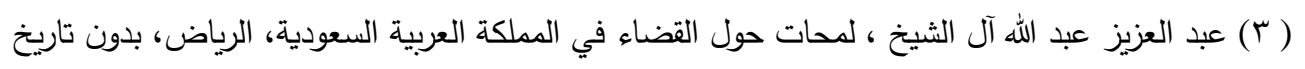

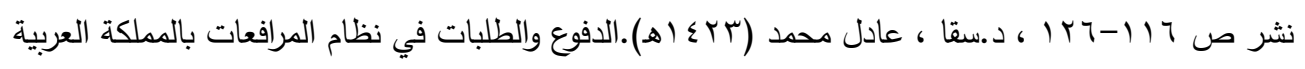

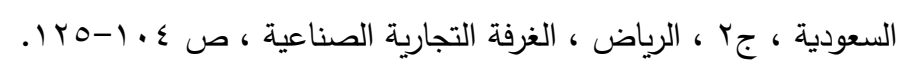




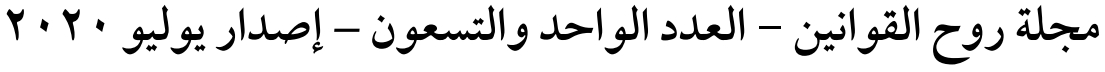

الدعوى المدنية التبعية للدعوى الجنائية التي تقوم على لجوء المضرور من الجريمة

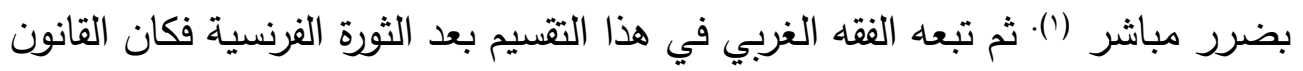

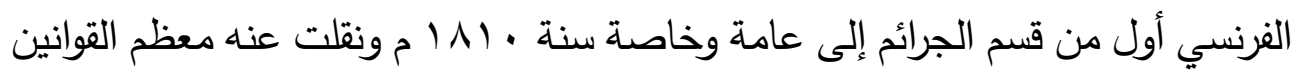

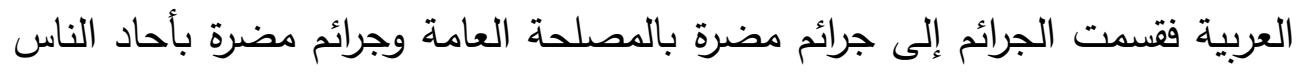

وتندرج تحتها جرائم القصاص والدية (ץ).

النظام الأول: نظام الاتهام الفردي في فقه الشريعة (دعاوي التهمة): يعتمد هذا النظام

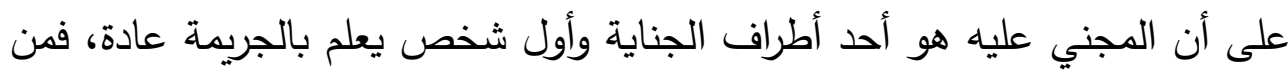
الطبيعي أن يمارس المجني عليه بنفسه مهمة الملاحقة والادعاء بحق الجاني في جرائم

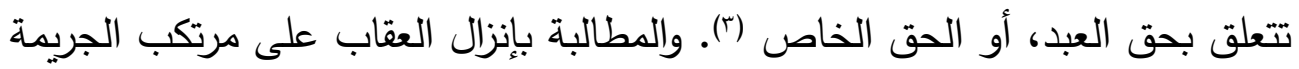

( (1) د. حسني، محمود نجيب المرجع السابق، ص 01؛ د/ سرور ، أحمد فتحي (99 (199).الوسيط في قانون

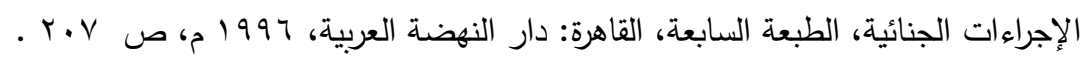

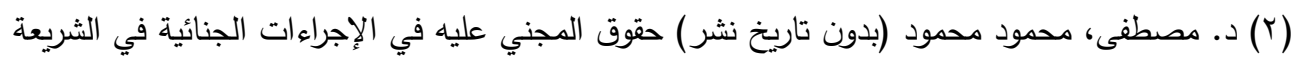

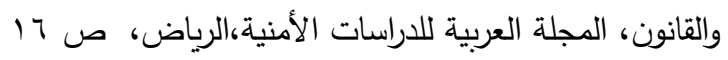

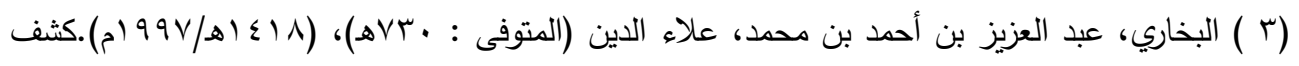

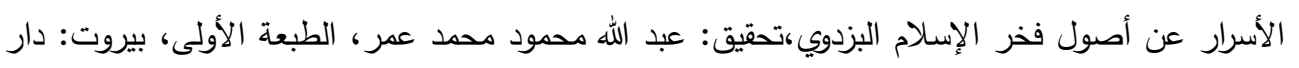

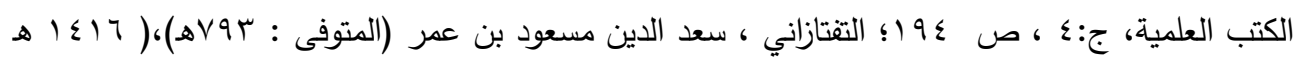

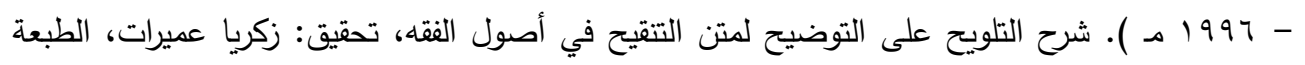

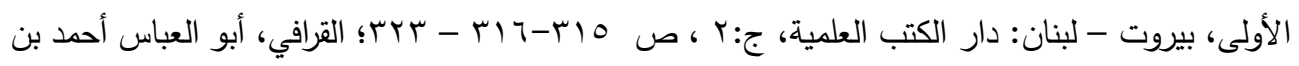

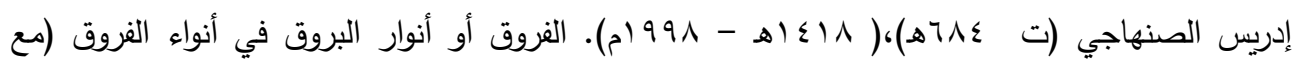

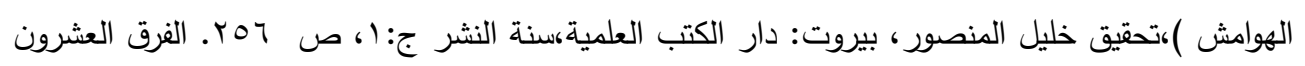

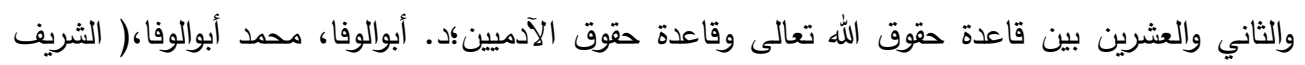

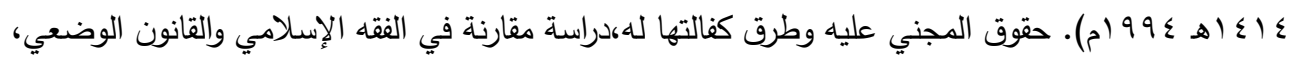

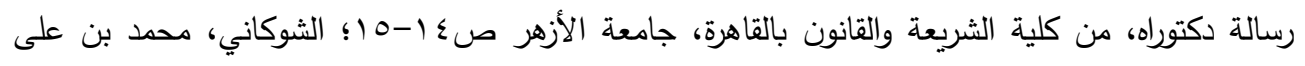

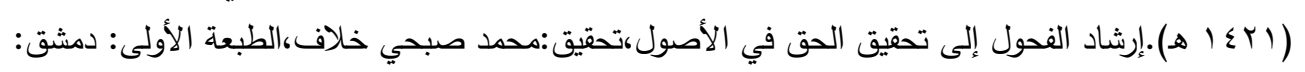

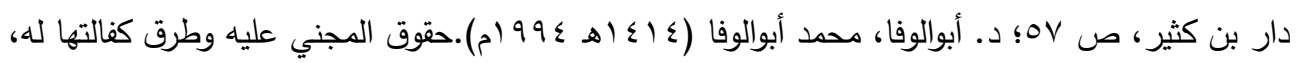

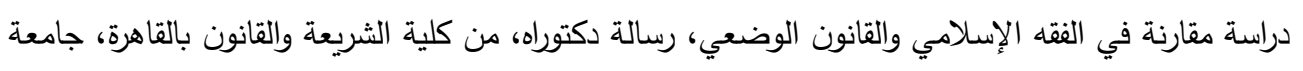
الأزهر الثريفصء (-10 الأحكام السلطانية للماوردي؛ أبو يعلى الفراء الأحكام السلطانية والولايات الدينية 
وتعويضه المجني عليه باعتباره خصماً حقيقيا في الدعوى الجنائية (')، مثل: جرائم القصاص والديات والجرائم التعزيرية التي يكون موضوعها الحق الخاص (؟) والطرف الثاني في الدعوى هو المتهم، سواء كان المتهم معروفا بالصلاح أو المتهم معروفا

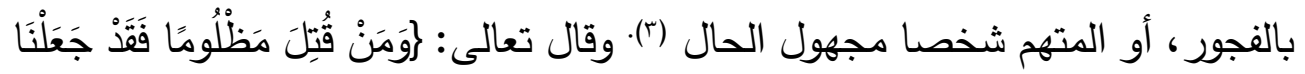

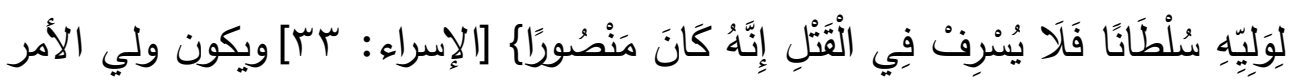

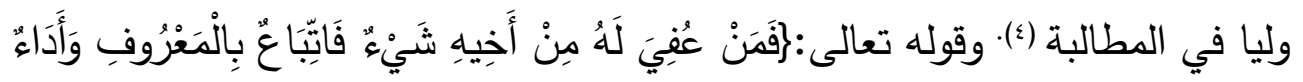

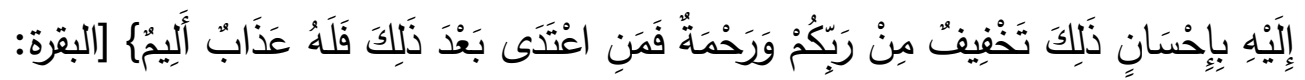

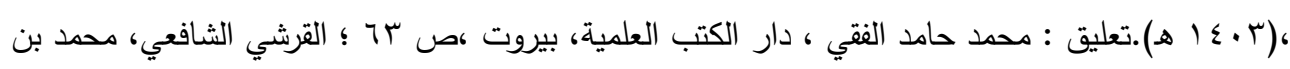

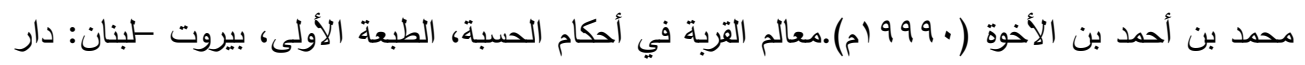

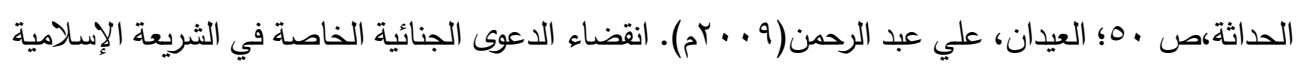

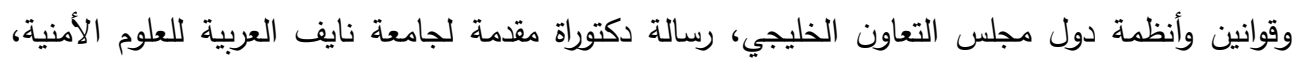

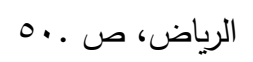

(1 (1) د. عمر ، نبيل إسماعيل ،أصول المرافعات الثرعية وعلم القضاء في المملكة العربية السعودية، بدون

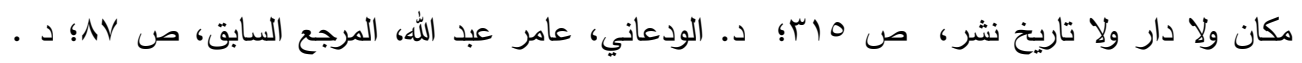

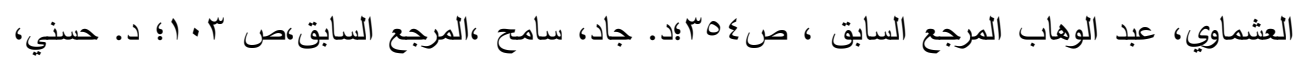

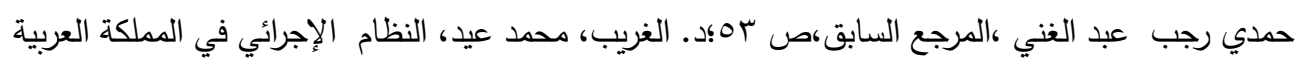

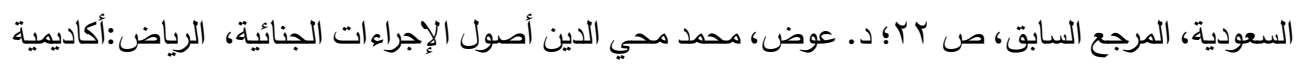

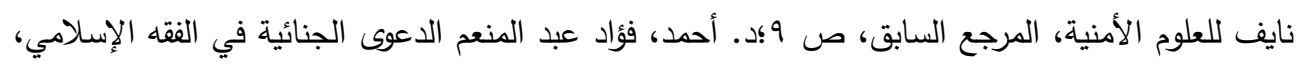

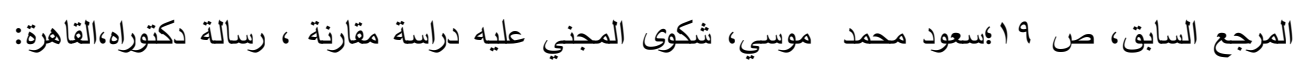

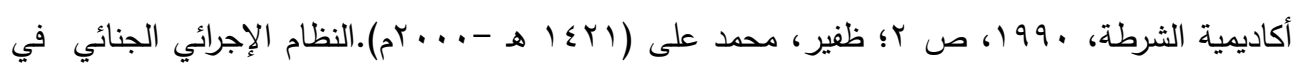

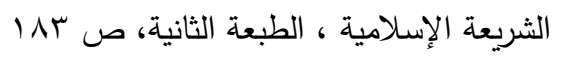

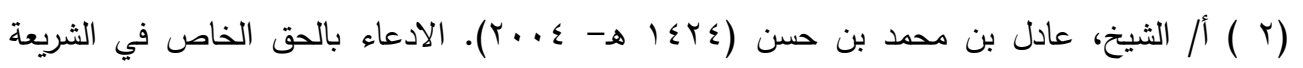

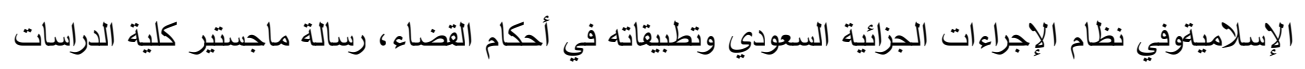

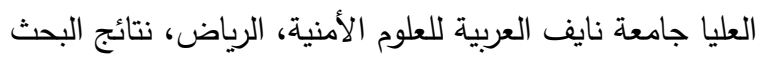

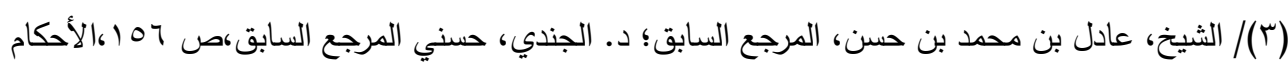

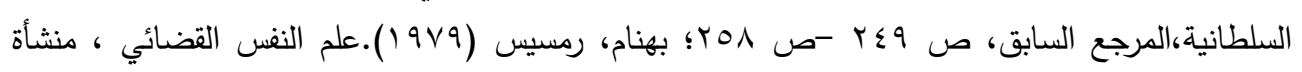

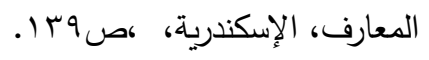

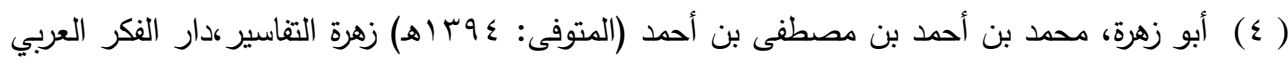

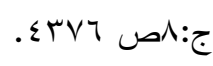




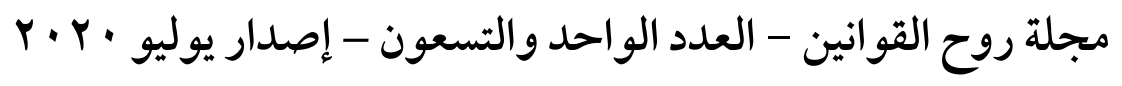

1 VA شيء من العفو والعفو في باب الجنايات عبارة متداولة مشهورة في الكتاب والسنة

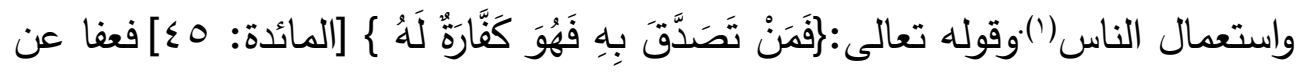
حقه في ذلك فإن ذلك العفو كفارة له عن ذنوبه ويعظم الله أجره بذلك ويكفر عنده (َ).رئا

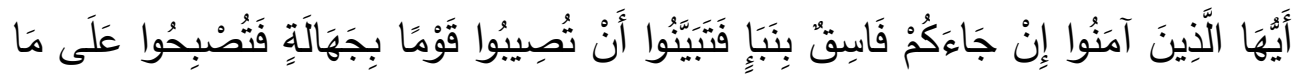

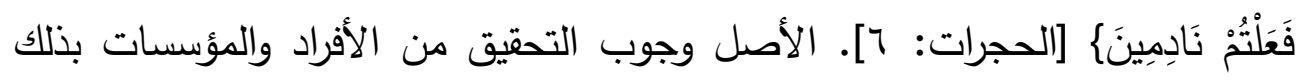
يتجنب هذا النظام الانتقادات الموجهة لادي نظام الاتهام الفردي يقصر حق الإن الادعاء

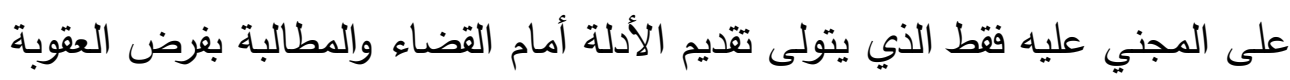
على المجرم. باعتبار حق العبد فيه حق لله فالقصاص الثابت لولي المقتول ففيه حقان حق اللهاء

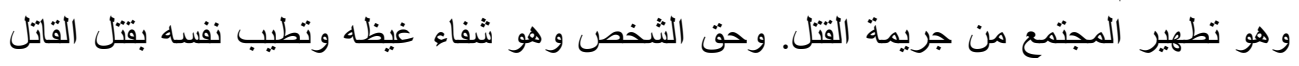
بالمماثلة وحد القذف فيه حقان: حق للمقذوف بدفع العار عنه، وخلاء العالم من الفساد

النظام الثاني: نظام الاتهام العام (دعوى العسبة): الدعوى الجنائية العامة هي كل

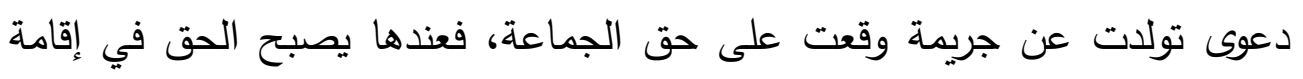

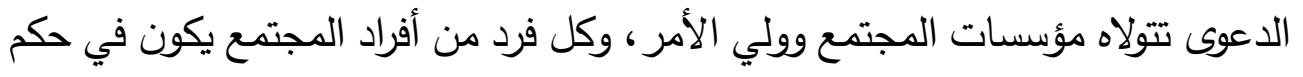

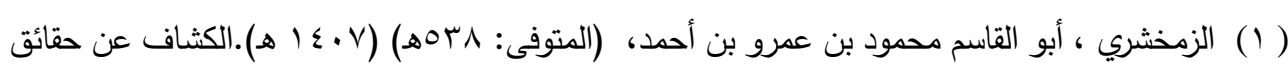

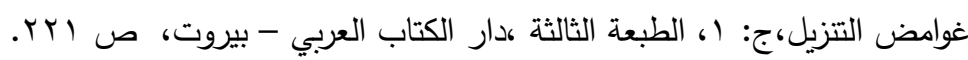

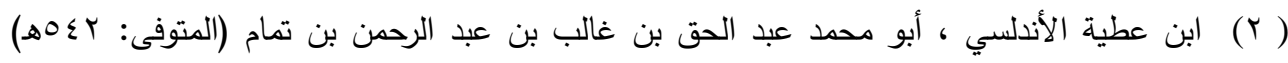

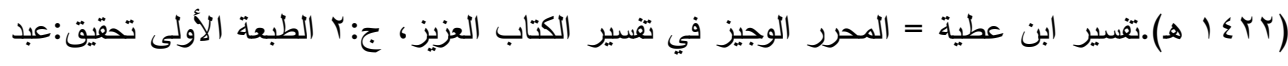

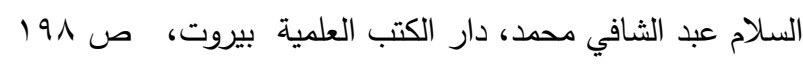

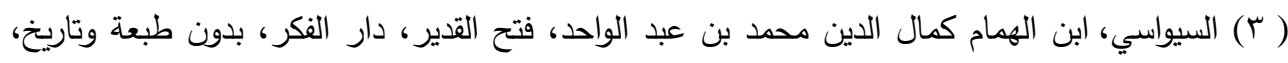

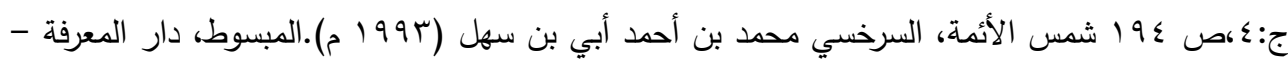

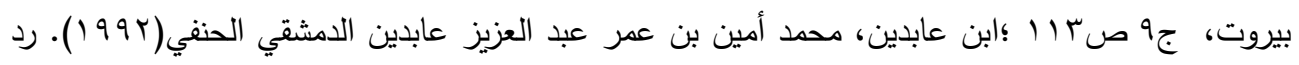

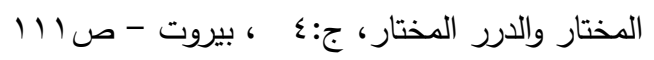


المجني عليه(')، وذلك أن طلب تطبيق عقوبة أو بتدبير احترازي على فاعلها، (r) وذلك بعد إثبات الإسناد المادي والمعنوي للمتهم بحم بات (َ). أما في الاصطلاح فهي دعوى الحسبة تمتد لمطلق الثرعية الدستورية والدولية ومحاسبة مرتكبي الجرائم الدولية في العالم، ويمكن للأفراد تقديمها دون حاجة لنص تشريعي يخولهم ذلك وتكون مقبولة من الناحية الشكلية، وذلك إن توافرت شروطها العامة للقبول تحقيقا للعدل والفضيلة

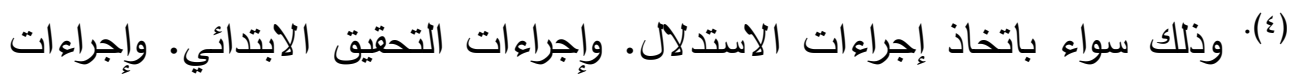

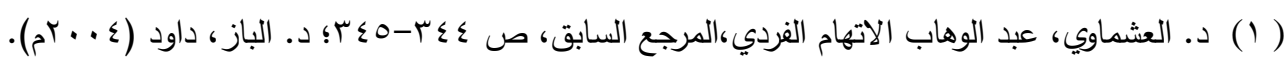

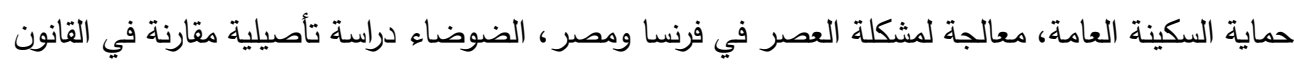

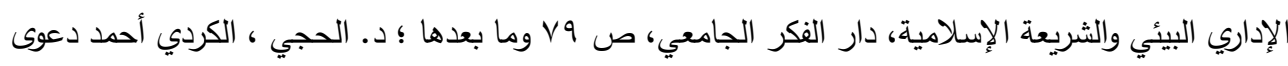

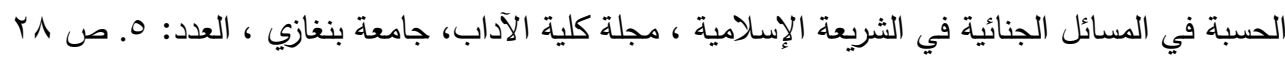

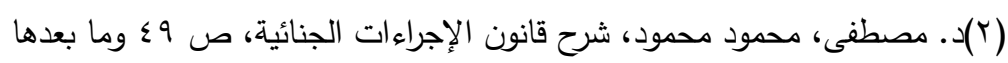

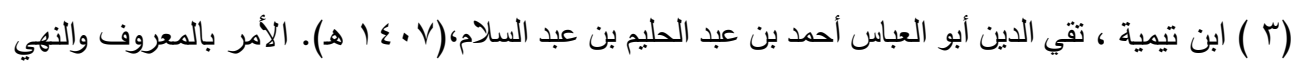

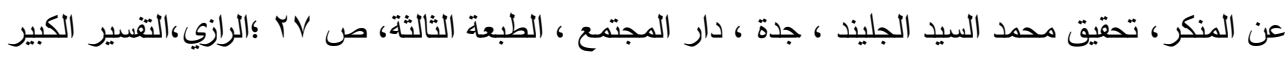

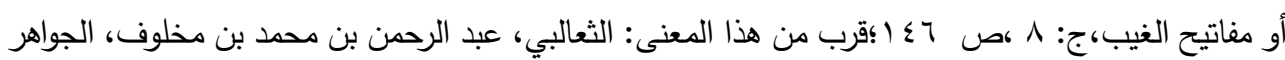

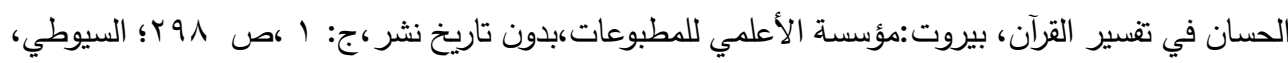

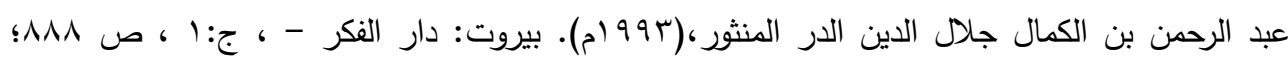

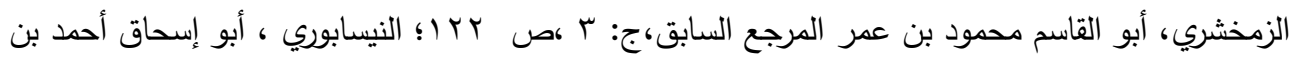

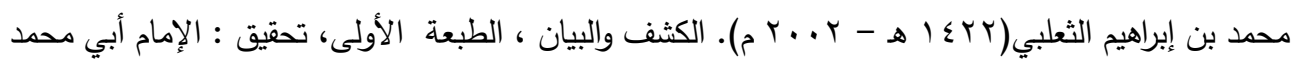

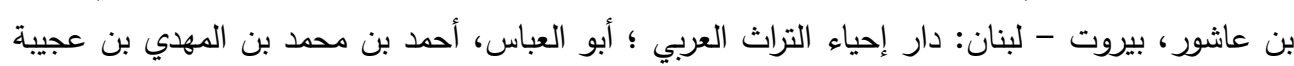

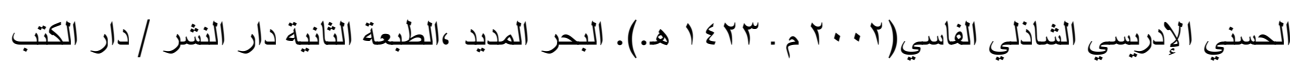
العلمية . بيروت.

(ع) د. الثطناوي، علي خطار (10 (1) ــ - 1990 (1). القضاء الإداري الأردني الطبعة الأولى مطبعة كنعان

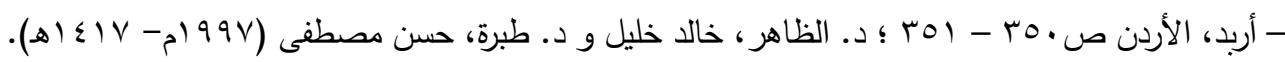

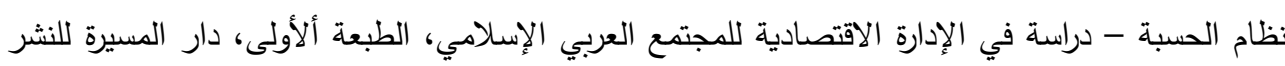

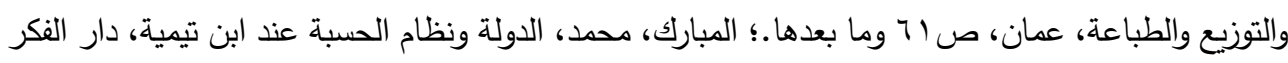

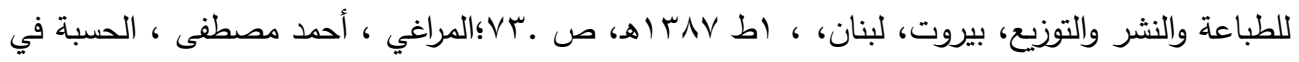

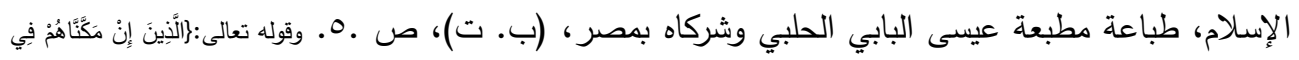

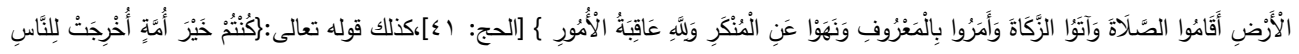

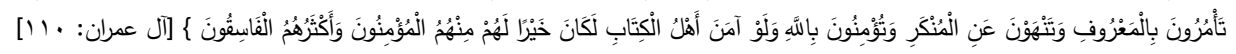


r.r. · مجلة روح القوانين - العدد الواحد والتسعون - إصدار يوليو

المحاكمة وإجراءات التنفيذ ((). وذلك في الدولة القانونية (†) وهذا ما يقترب في القانون

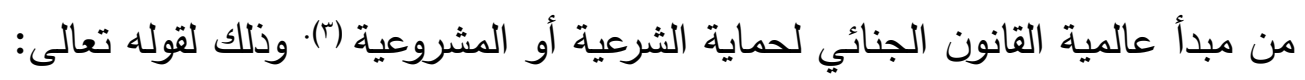

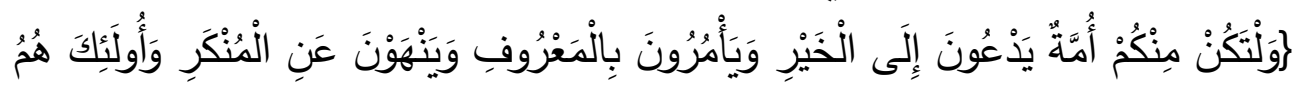

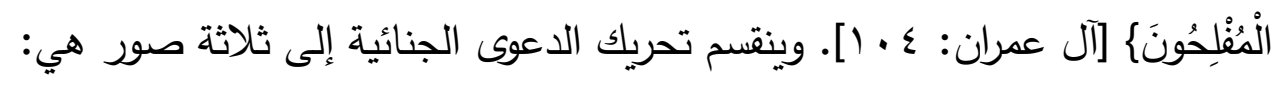
الصورة الأولي: نظام الاتهام العام المسند للنيابة العاهة (دعوى الصسبة): يعهد نظام الاتهام القضائي بمهمة ملاحقة المجرمين وإقامة الدعاوى عليهم أمام القضاء الجنائية إلى هيئة مستقلة عن قضاء الحكم تتوب مناب المجتمع في تحريك الدعوى العامة،

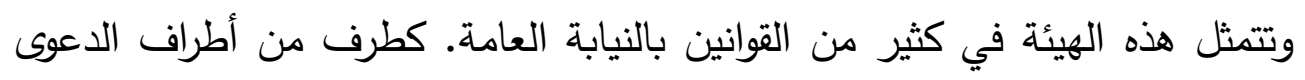
الجنائية وأنها خصم شريف في الدعوى الجنائية (؛). وقد يكون تحريك الدعوى الجنائية

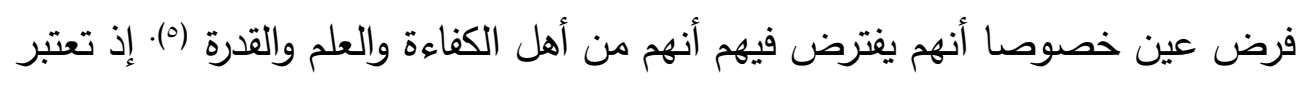

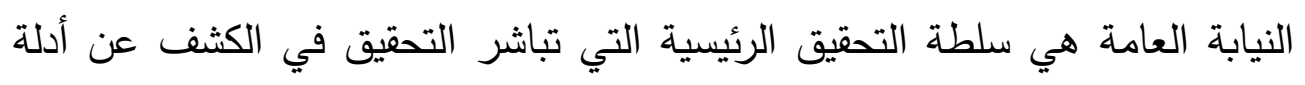

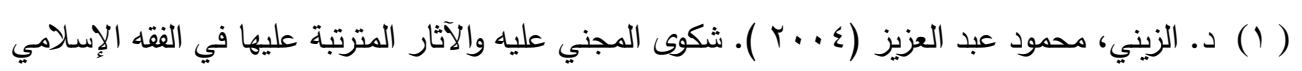

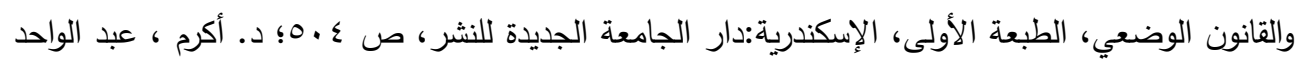

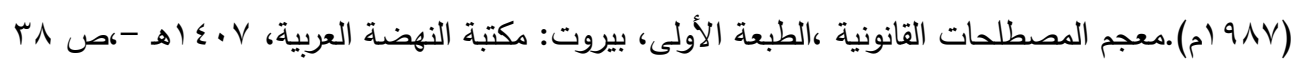

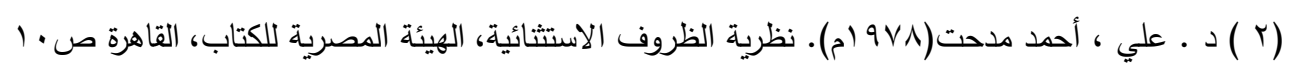

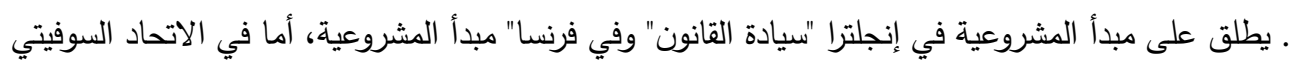

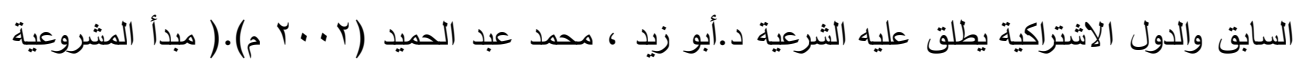

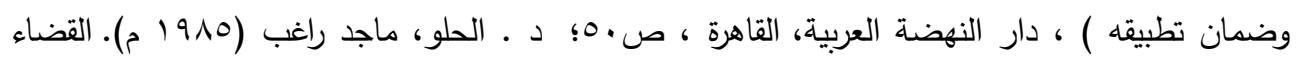

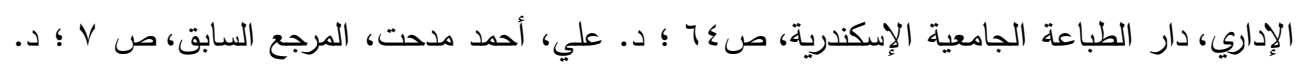

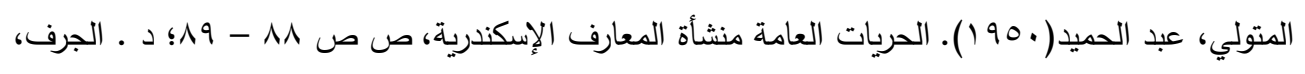

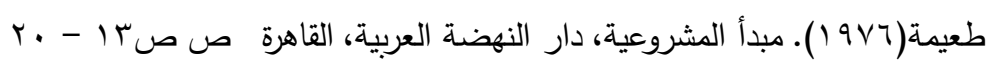

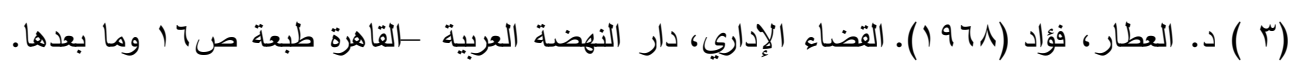

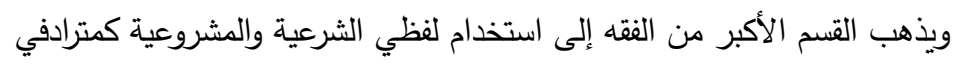

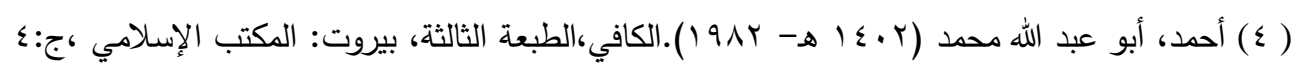
. IVT

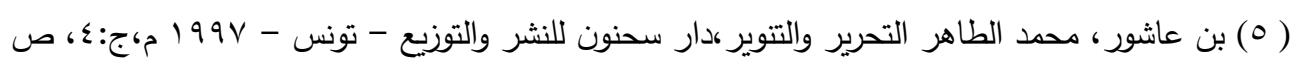

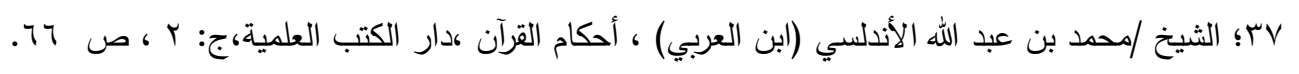


الجريمة ('). ولا يجوز لها الصلح ولا الرأفة بينما الصلح يجوز في الدعوى الجنائية الخاصة بين المتهم المدعى عليه (؟). وقيل إن نظام الحسبة في الإسلام يعادل

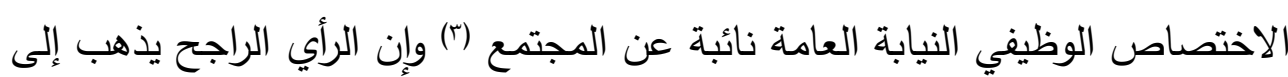
أن اختصاص النيابة العامة في النظم المعاصرة يمثل جزء يسير من وظيفة المحتسب في النظام الإسلامي (؛). فهي وظيفة دينية من باب الأمر بالمعروف والنهي عن المنكر

إذا ظهر فعله (o). الصورة الثانية: نظام الاتهام الشعبي: يستطيع كل فرد من أفراد المجتمع الادعاء على مرتكبي الجرائم أمام القضاء وإن لم يكن مجنياً عليه(؟) كواجب كفائي باتفاق جمهور

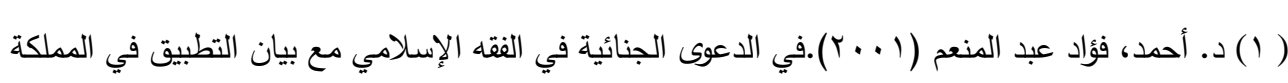

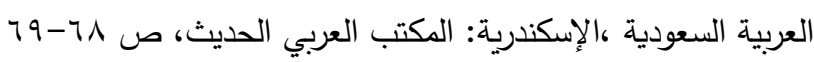

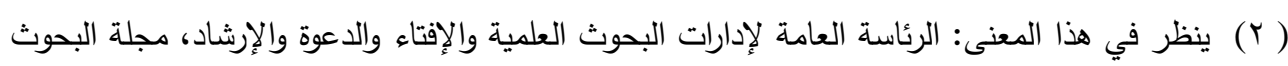

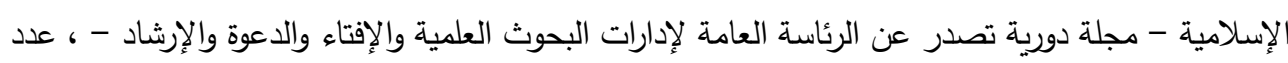

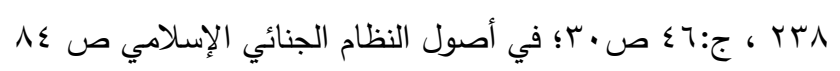

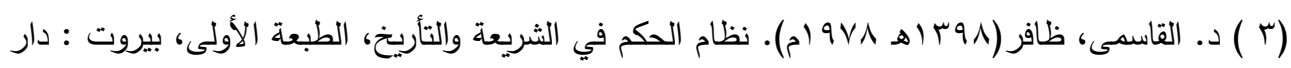

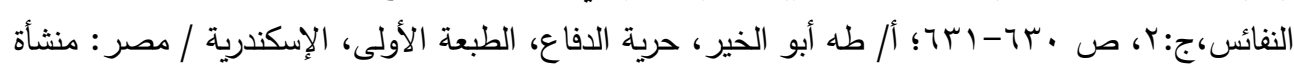

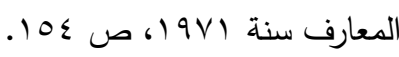

(ع)داد عبد الوهاب عبد العزيز الشيشتاني،حقوق المجني عليه في الخصومة والحكم في الشريعة الإسلامية

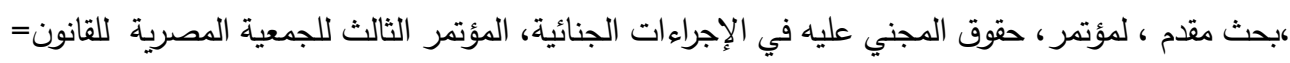

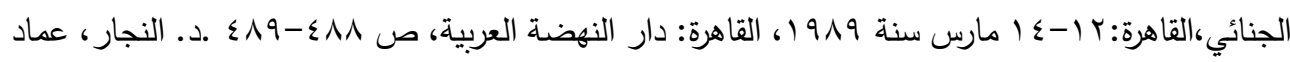

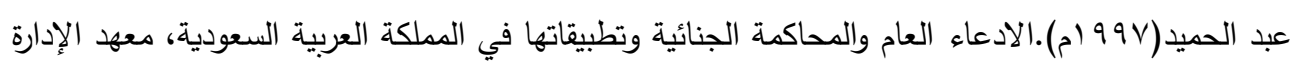

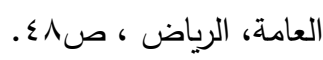

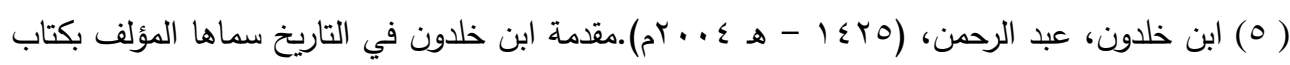

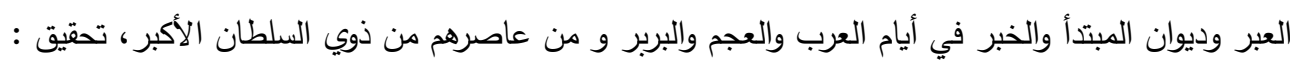

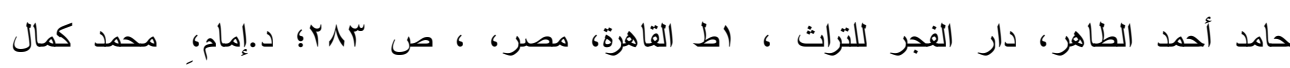

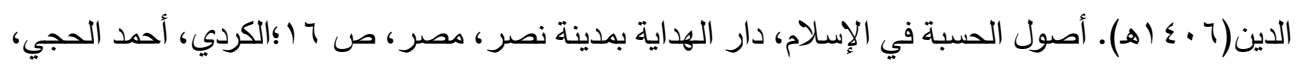

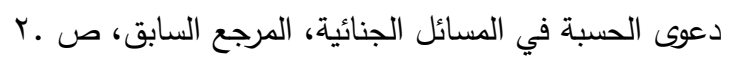

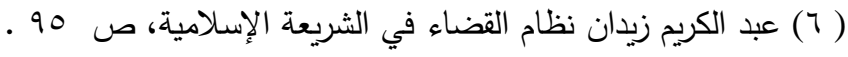


r.r. · مجلة روح القوانين - العدد الواحد والتسعون - إصدار يوليو

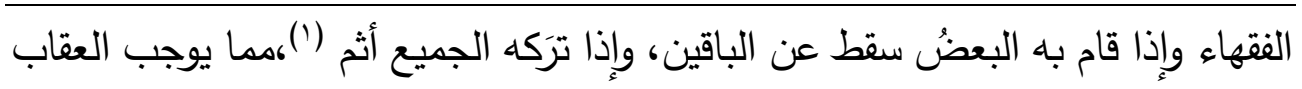

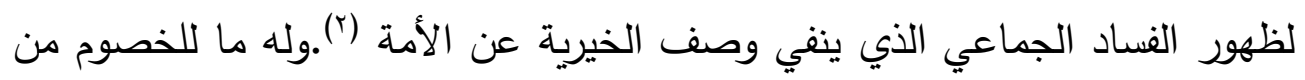

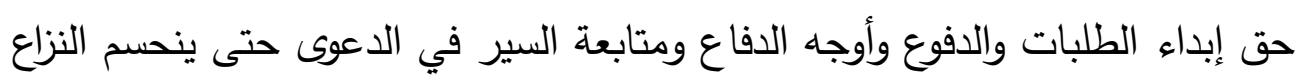

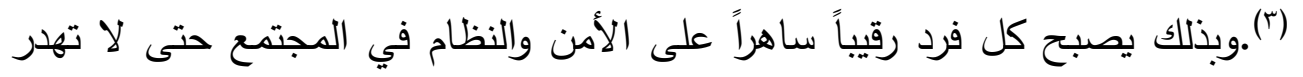

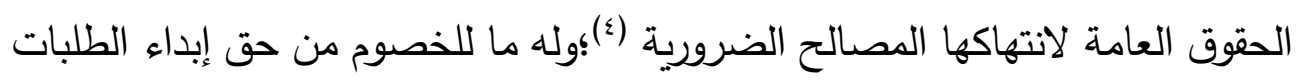

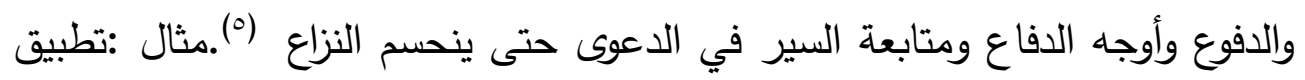

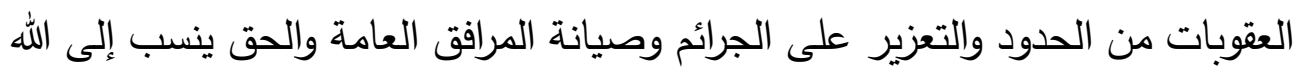

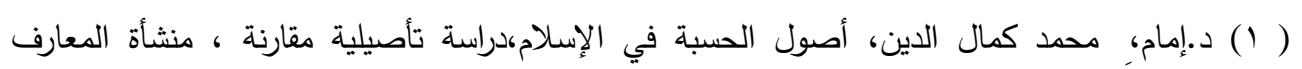

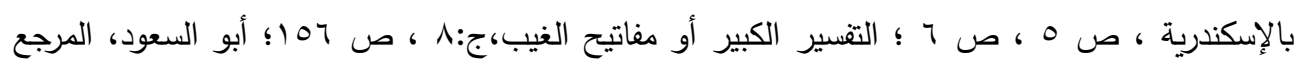

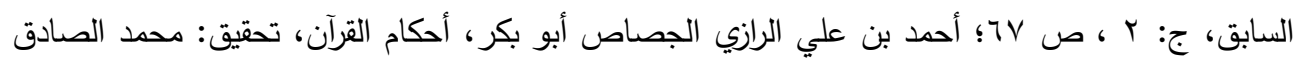

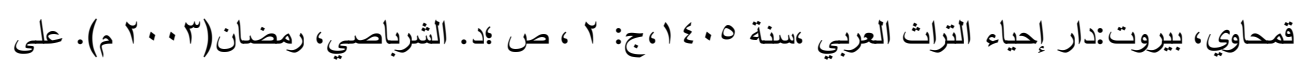

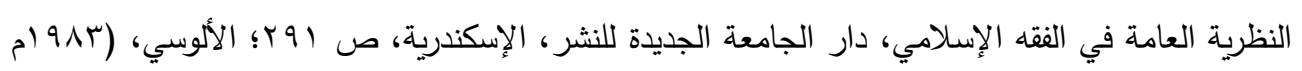

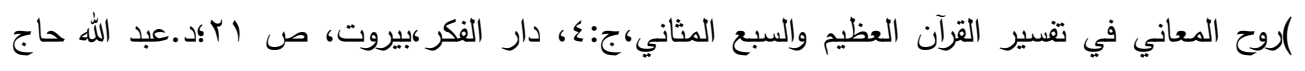

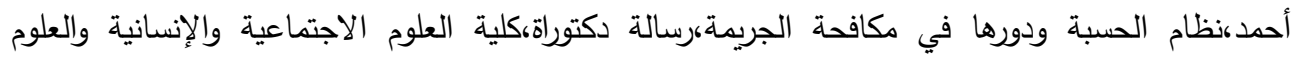

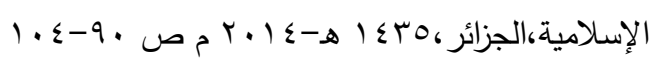

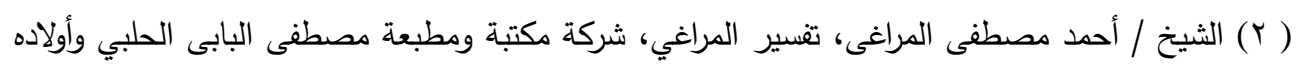

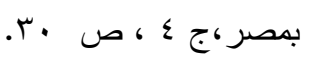

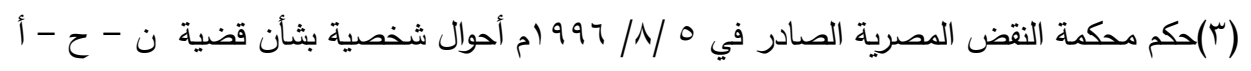

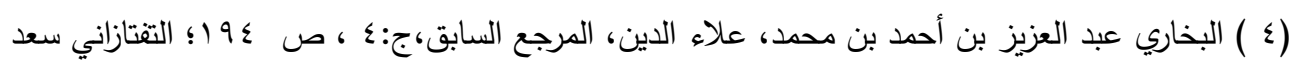

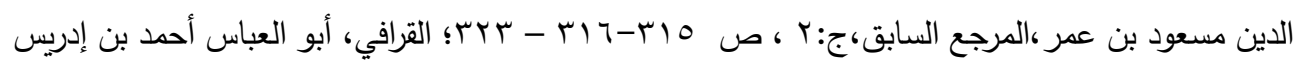

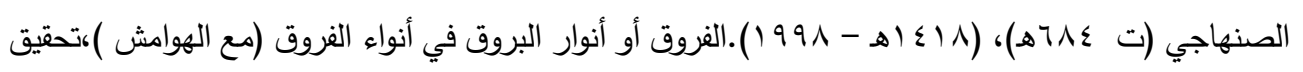

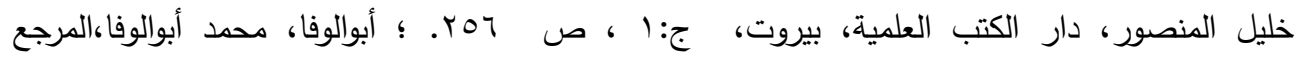

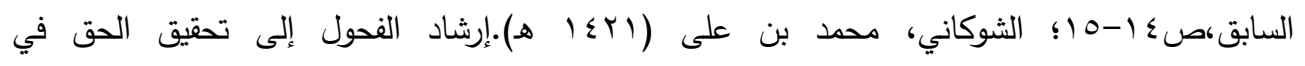

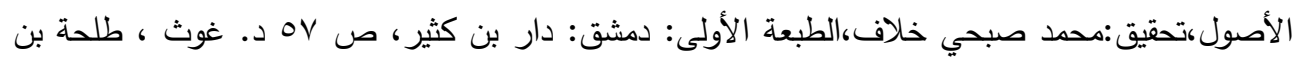

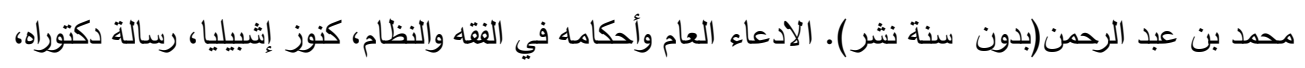

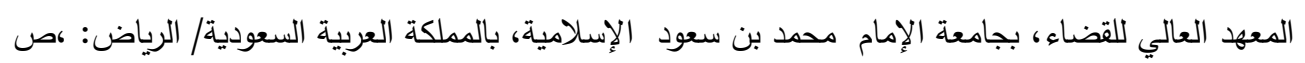
(0)

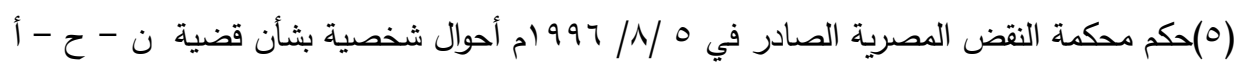
$(r \cdot$. 
سبحانه وتعالي وذلك على سبيل التعظيم (1).وأخذ بقريب من ذلك النظام القانوني البولندي (المواد ^§-r؟)فاعترف بالمجني عليه كمدعي عام مساعد يعلن عن رغبته في أن يقيم نفسه مدعيا مساعدا بعد تحرير ورقة الاتهام العام. وهذا الحق يتوارث. فقد قرر القانون البولندي جزاء إجرائي بحرمان المجني عليه (المدعي المساعد) من حقوقه إذا كان غير ذي صفة، أو كان قد قرر رغبته في أن يكون مدعياً مساعداً بعد الميعاد أو أوراب أن اشتراكه في الإجراءات سوف يعوق بشكل جوهري (المادة 0؛ ) من القانون البولندي (†). وهذا يسمح للعامة تحريك الدعوى الجنائية ضد الجرائم الدولية. وذلك لم يعد لنظام الاتهام الشعبي اليوم أي وجود سوى من خلال ما تقضي به القوانين المعاصرة من

$$
\text { واجب الإخبار عن الجرائم (r). }
$$

الصورة الثالثة: نظام الاتهام القضائي: يوكل نظام الاتهام القضائي مهمة ملاحقة

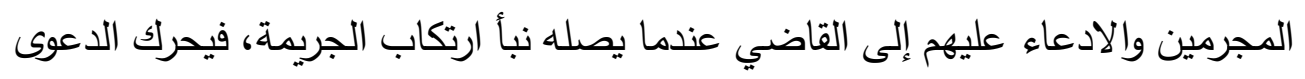
ضد الجاني، ثم يفصل فيها. لما روي عنْ عَمْرِو بْنِ شُعَيٍْ، عَنْ أَبِيهِه، عَنْ جَدِّه، أَنَّْ

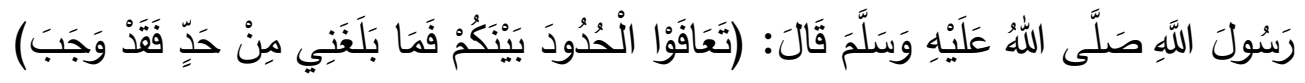

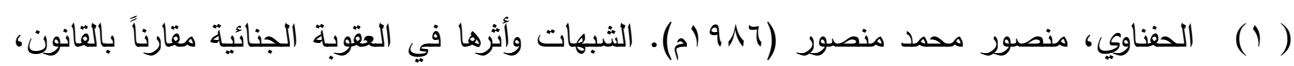

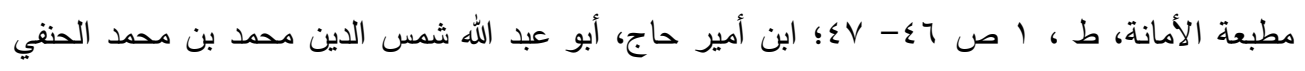

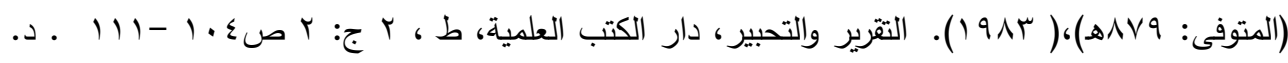

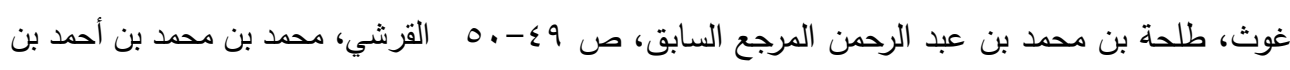

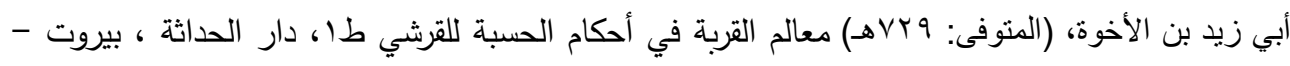

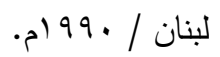

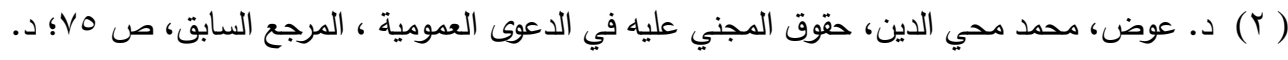

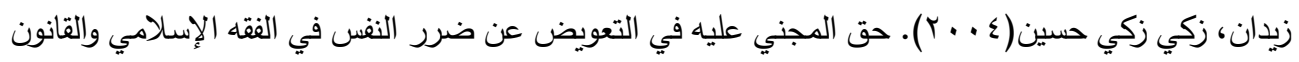

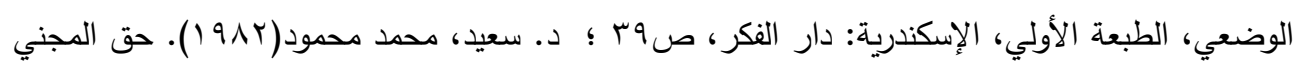

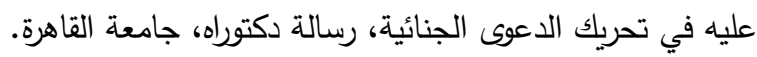

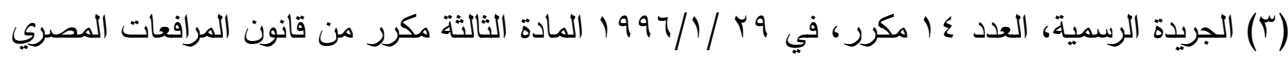

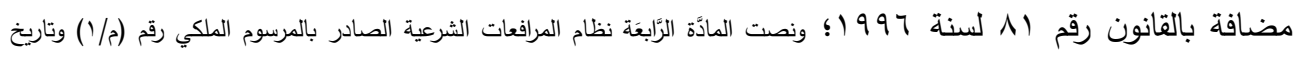

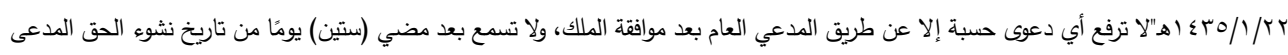

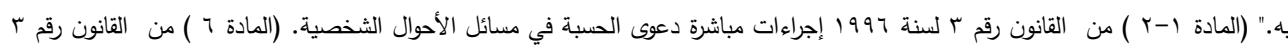




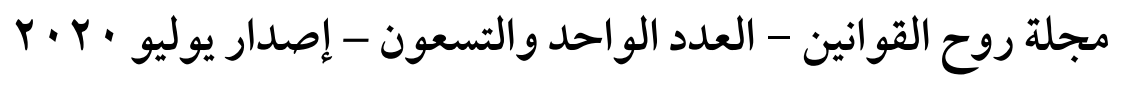

(1). ومن آثار نظام الاتهام القضائي التي مازالت باقية في القوانين الدعاصرة تخويل

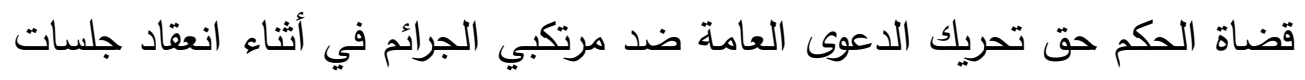

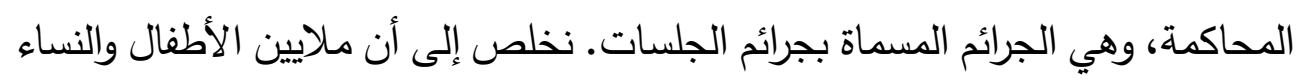

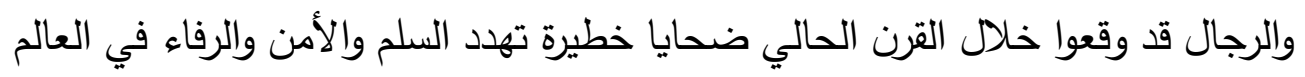

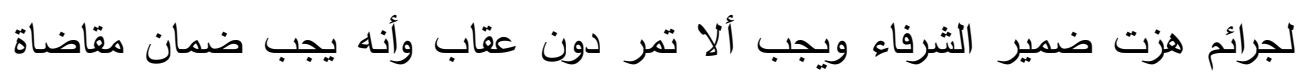
مرتكبيها على نحو فعال من خلال تدابير تتخذ على الصعيد الوطني وفي نظام روما

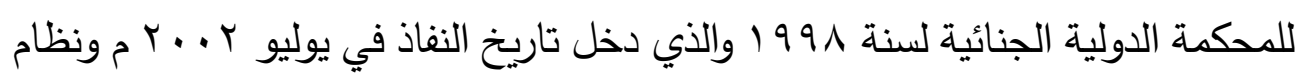
روما للمحكمة الدولية الجنائية حديث النشأة فهو تابع من الناحية الفنية للقانون الجنائي بقسميه الموضوعي (القسم العام والقسم الخاص) والثكلي(قانون الإجراءات الجنائية)

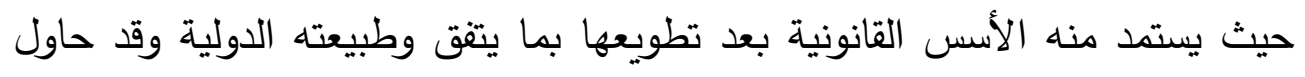
واضعو نظام روما الأساسي للمحكمة الدولية الجنائية، التوفيق بين النظامين القانونيين

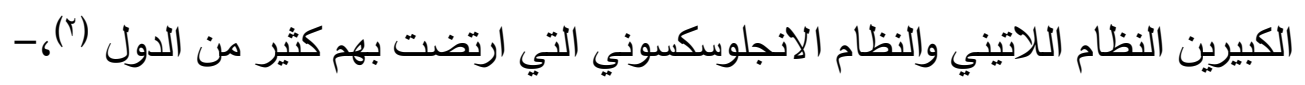

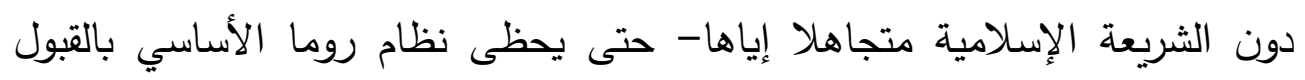

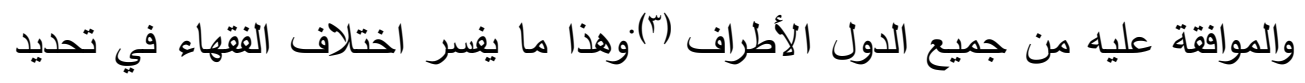
النظام الإجرائي المتبع أمام المحكمة الدولية الجنائية.

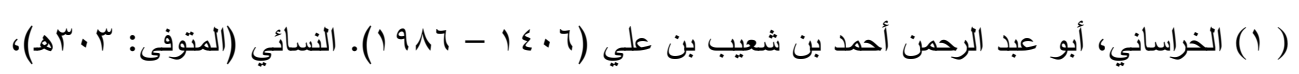

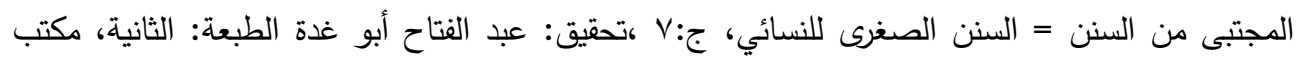

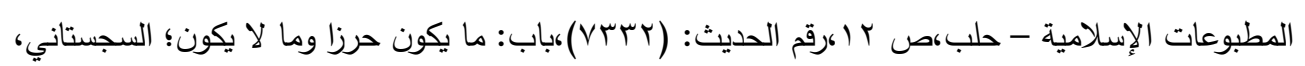

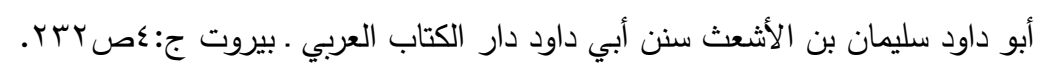

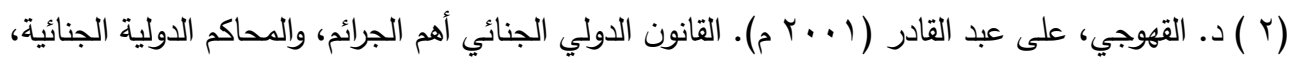

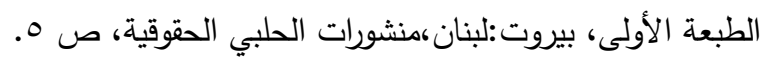

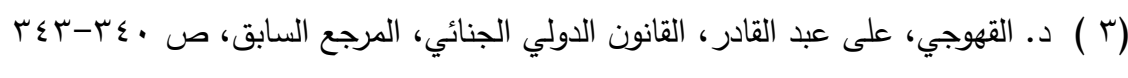
$(r \cdot r)$ 


\section{المبحث الثاني \\ حقوق المجني عليه في هرحلة ها قبل الشروع في التحقيق \\ (التمقيق الأولي )}

إن الفصل في أي محاكمة جنائية وطنية كانت أو محاكمة جنائية دولية يقتضي التحقيق واتخاذ إجراءات الوصول إلى الحقيقة وجمع الأدلة على وقوع الجريمة وثبوتها، وإسنادها للمتهم لكي تقدم إلى المحاكمة التي تتتهي بتقرير الإدانة أو البراءة، ثم تنفيذ الحكم. وهذا يطرح تساؤلات: وكيف يتم جمع المعلومات في المرحلة الأولية السابقة على الشروع في التحقيق من المدعي العام؟ ما حقوق المجني عليه في مرحلة ما قبل الشروع في

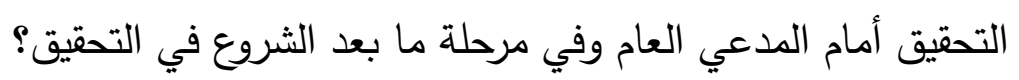

\section{الإطبا الأول \\ التحقيق الأولي وأثره على حقوق المجني عليه}

تبدأ إجراءات التحقيق الأولي بعد وقوع الجريمة من المدعي العام. وذلك باعتباره الجهاز المسؤول عن تلقي الإحالات أو أي معلومات موثقة عن جرائم تدخل في اختصاص بلاص المحكمة. وذلك لاراستها بقصد الاضطلاع بمهام التحقيق على سبيل الاستقلال(1). يمكن تعريف التحقيق الأولي هو جمع المعلومات والأدلة وفحصها وتحليلها بعد وقوع الجريمة وبيان أركانها ومدى إمكانية إسناد الفعل إلى فاعل ما قبل الشروع في التحقيق. والقيام بالفحص الأولي وتقييم المعلومات المتاحة للادعاء ثم إعداد تقارير تتضمن اقتراحات وذلك لتحديد ما إذا كان هناك أساس معقول للشروع في التحقيق وتقديم وتوفير تحاليل وآراء قانونية لذلك فهو أقرب إلى تقصي الحقائق منه إلى التحقيق الفعلي. ولا شك أن المرحلة السابقة على تحريك الدعوى الجنائية في النظم الداخلية، تسمى بمرحلة إلى إلى إلى

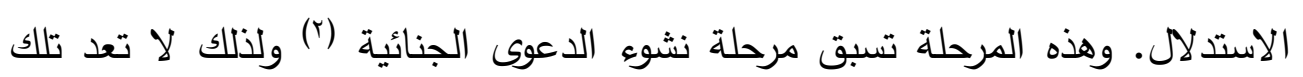

$$
\text { (1) المادة (Y (1) (1) من النظام الأساسي للدحكمة. }
$$

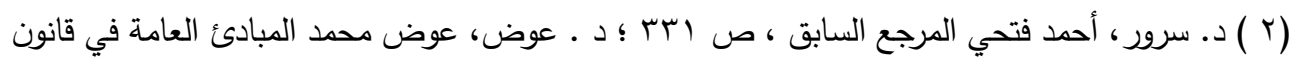

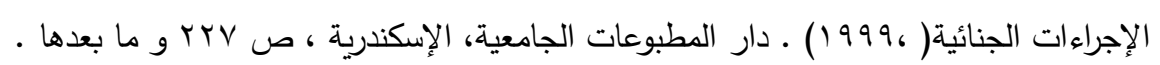
$(r \cdot r)$ 


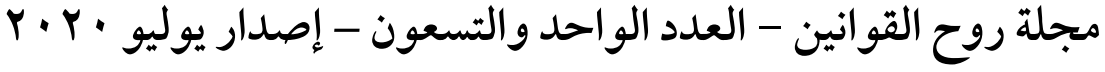

المرحلة حسب الفن القانون في النظم الإجرائية الداخلية من إجراءات الدعوى الجنائية

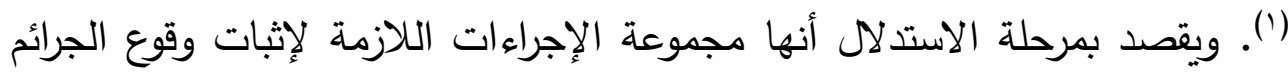

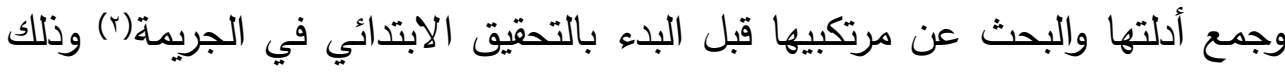

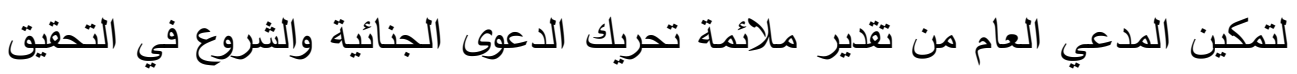

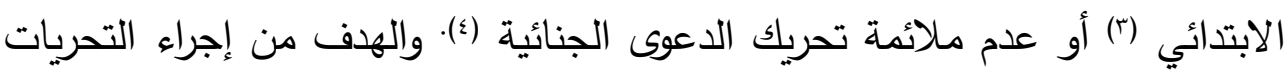

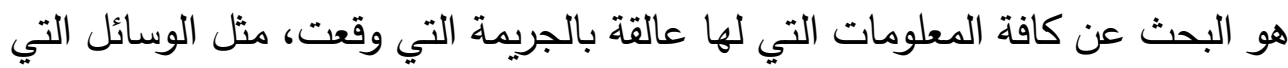

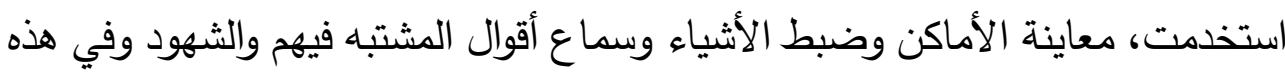
المرحلة أي سؤال يطرحه المدعي العام على المشتبه فيه يعد من أعمال الاستدلال

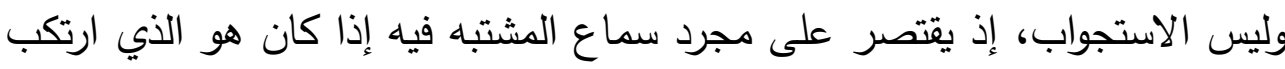

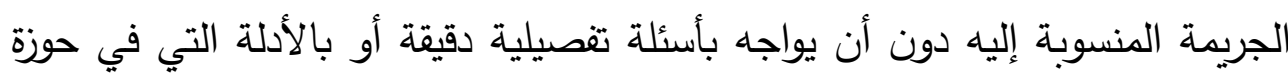
المدعي العام مع تمكين المشتبه فيه من كامل حرياته في إبداء الملاحظات (o).

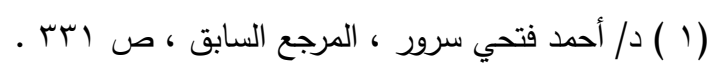

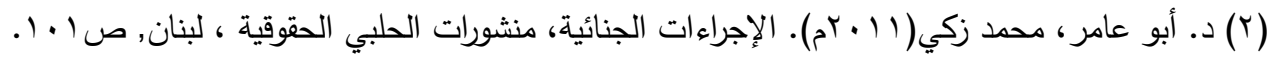

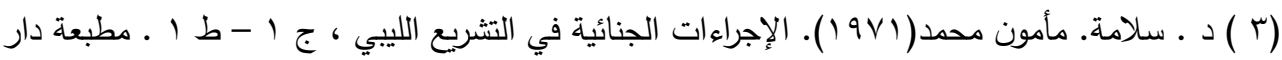

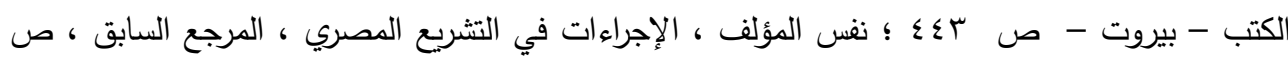

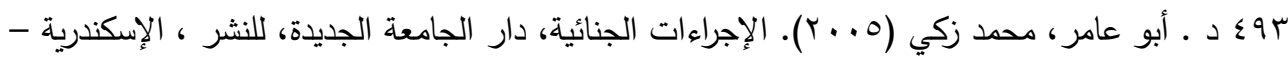

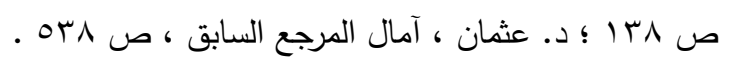

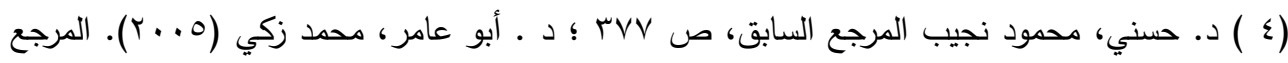

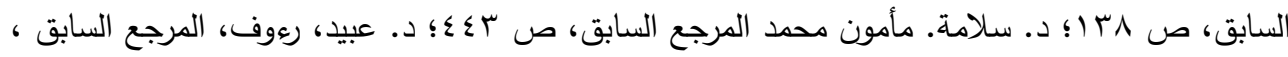

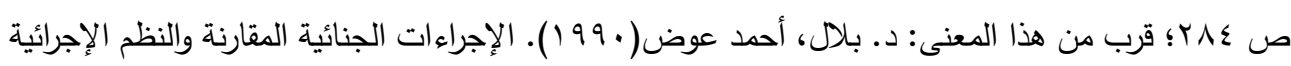

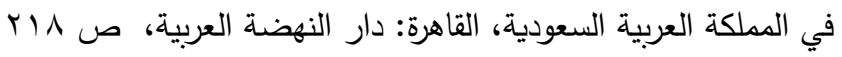

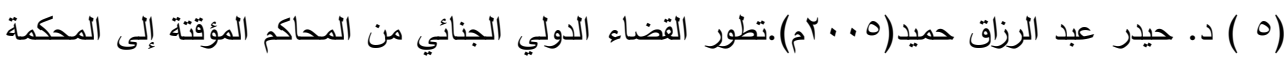

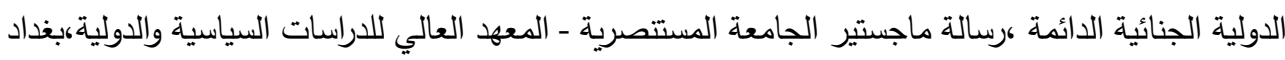




\section{المطلب الأول}

\section{إجراءات التحقيق الأولي لدي المدعى العام لدي المكمة الجنائية الدولية}

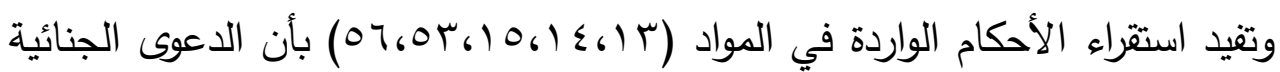
تحال بناء على معلومات أولية يقوم بها المدعي العام القيام بالفحص الأولي وتقبييم

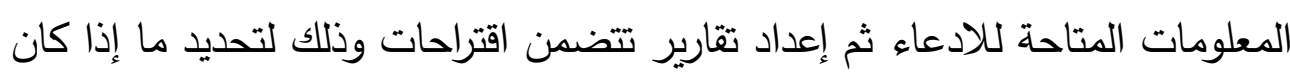
هناك أساس معقول للشروع في التحقيق وتقديم وتوفير تحليل وآراء قانونية للجنة التنفيذية فيما يتعلق بقضايا الاختصاص والمقبولية. وذلك خلال كل مراحل التحقيق والمتابعة.

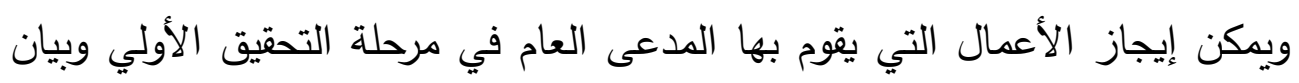

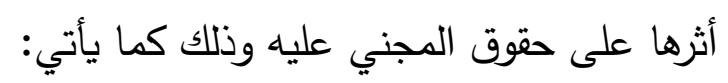

\section{أولا: حق الجني عليه في تقديم البلاغات والشكاوى في هرحلة التحقيه وديق التحيق الأولي:}

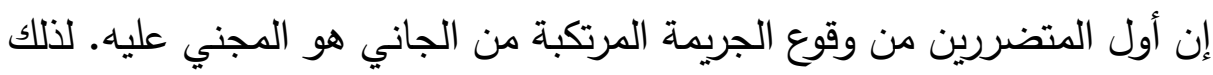

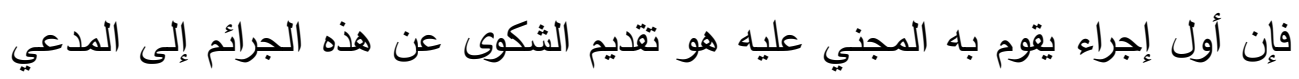

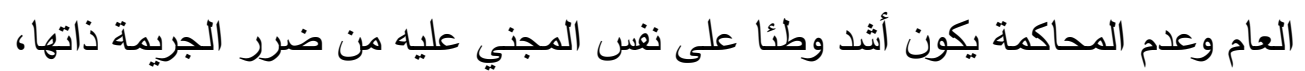

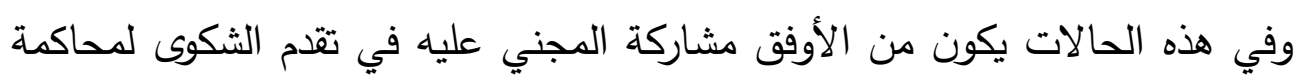

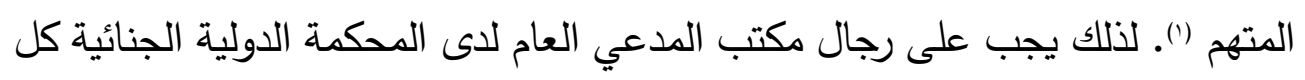
بحسب اختصاصه قبول التبليغات والثكاوى التي ترد إليهم بثأن الجرائم من المجني

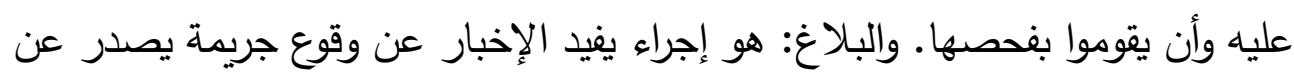

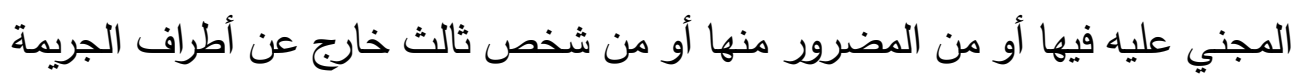

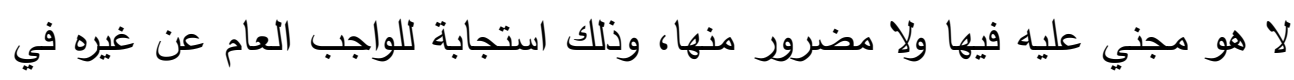

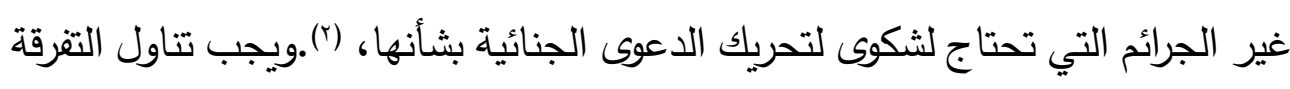

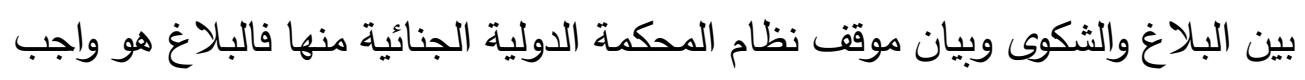

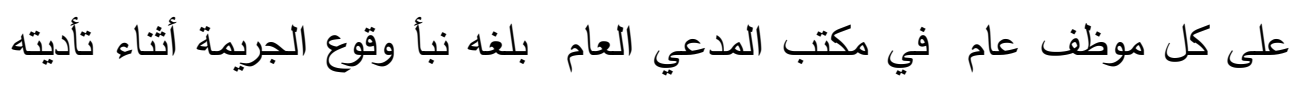

(1) (1وض، عوض محمد المرجع السابق،صر^.

(r) د. الملاح، رضا حمدي(9 .. (r).الموجز في الضبطية القضائية والتحقيق الابتدائي، مكتبة القانون

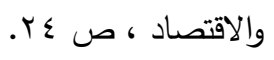
$(r \cdot 0)$ 


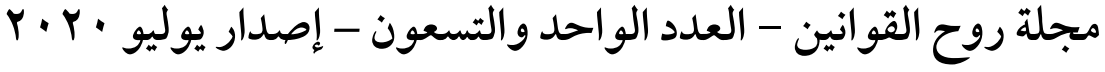

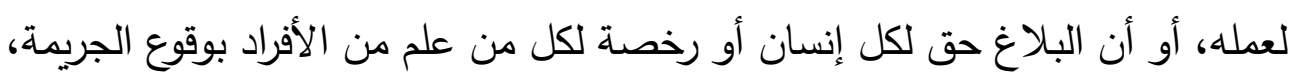

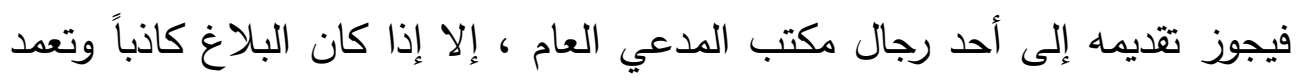

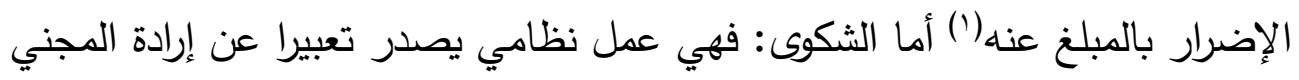

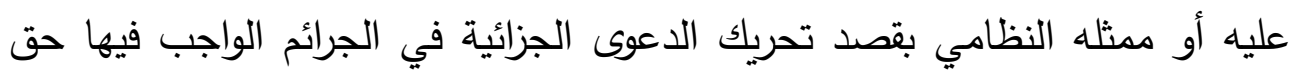

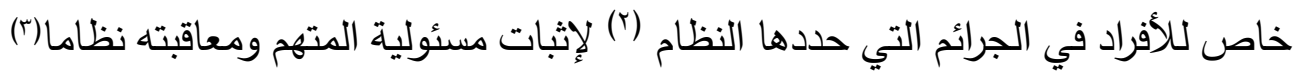

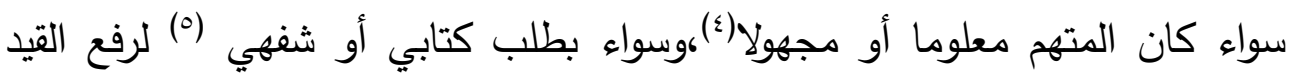

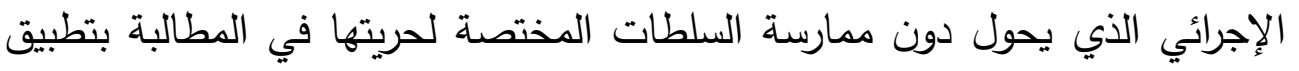

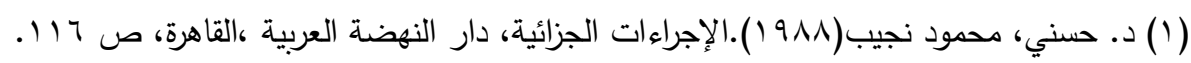

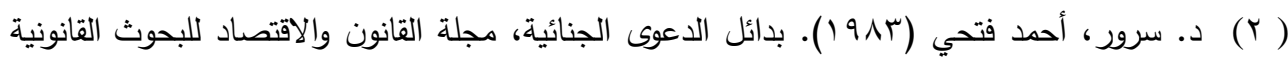

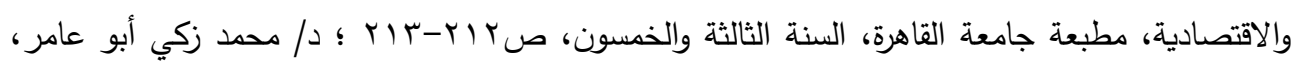

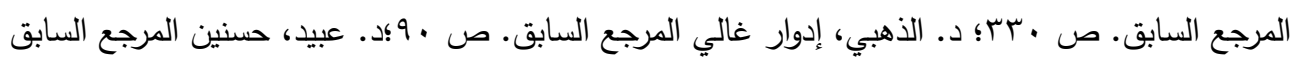

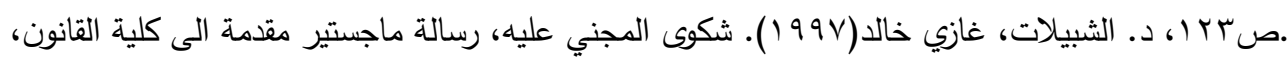

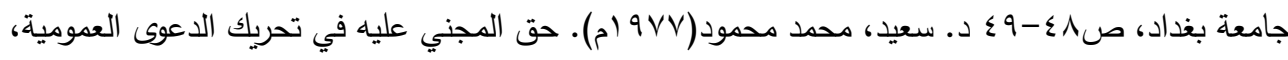

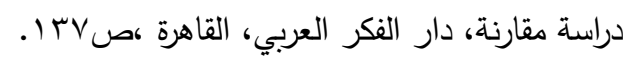

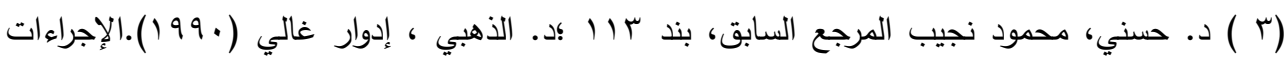

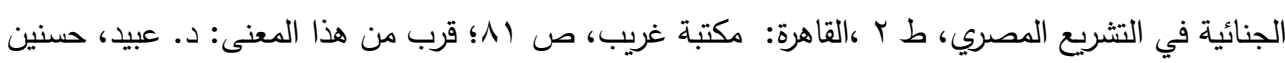

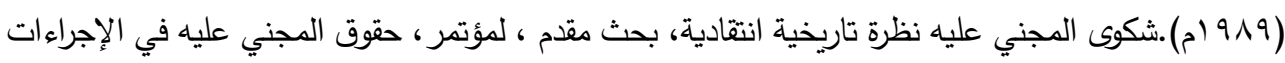

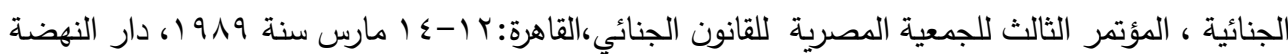

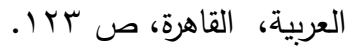
( ) ) قرب من هذا المعنى: د. عوض، محمد محي الدين حقوق المجني عليه في قانون الإجراءات الجنائية

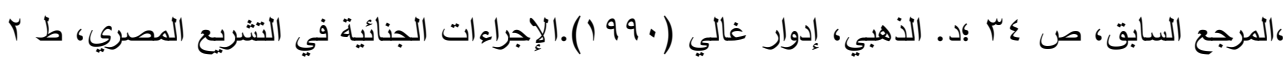

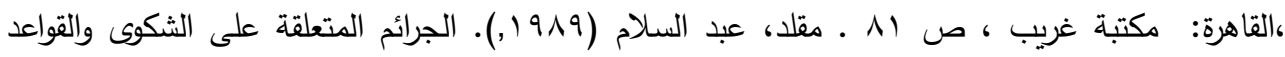

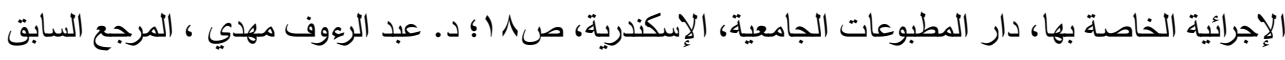

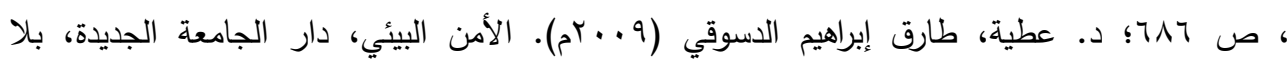

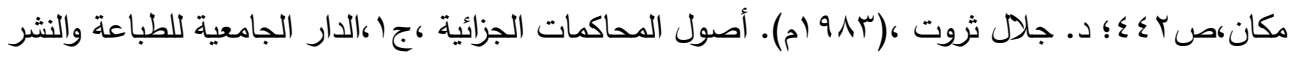


العقاب وفقا للأنظمة القانونية الداخلية(').وليست الثكوى حق شخصي يتعلق بشخص

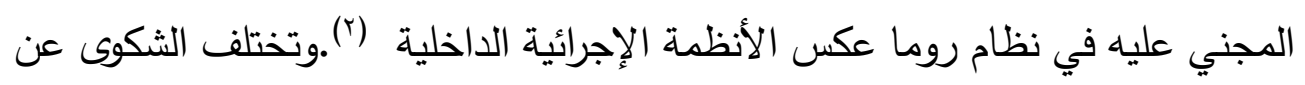
البلاغ الذي يقوم على نقل نبأ وقوع الجرائم إلى السلطات العامة وهو مقرر للأفراد كافة عن الجرائم التي علموا بوقوعها سواء كان البلاغ جوازي من أي فرد أو وجوبي على ولى فئة معينة بناء على القانون (r). كما تختلف الشكوى عن البلاغ في أن النظام القانوني

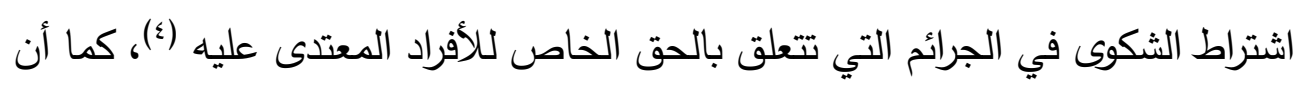

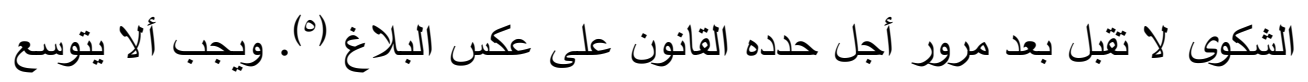
في هذا القيد الذي جعل المشرع مضي المدة القانونية، قرينة على التنازل، حيث إن مضي المدة يعد بمثابة نزول عن الحق في الشكوى، حتى لا يكون استمرار هذه الشكوى، وسيلة للتهديد والابتزاز • وبتطبيق ذلك على التحقيق الأولي يتبين عدم نص نظام روما على حق المجني عليه في الثكوى ولا النص على وسائل تقديمه سواء بطريق ورقي،

( ) ) د. سرور، أحمد فتحي المرجع السابق ، ص 1 ـــ ؛ د. الدسوقي، عزت مصطفى قيود الدعوى الجنائية

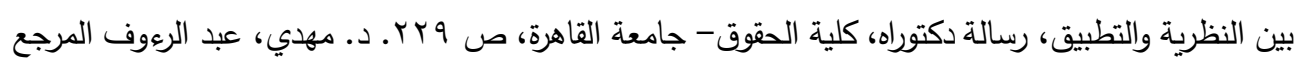

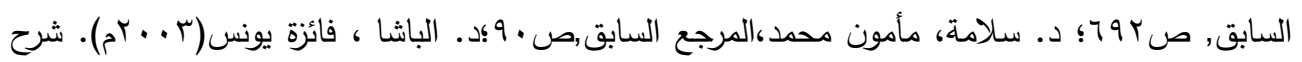

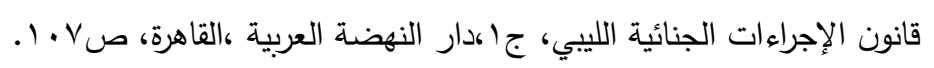

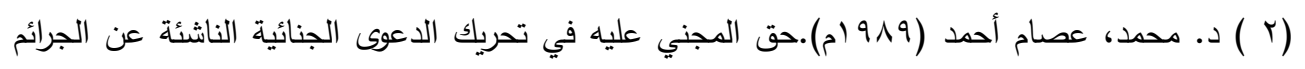

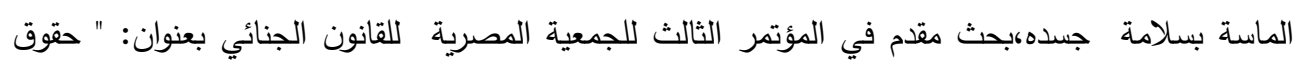

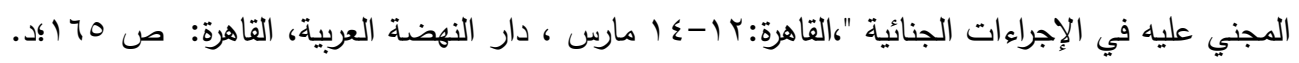

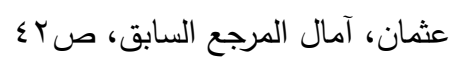

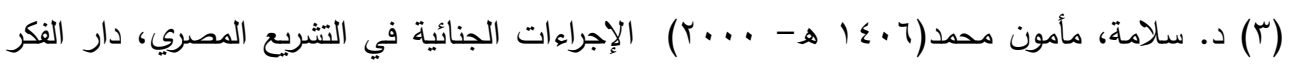

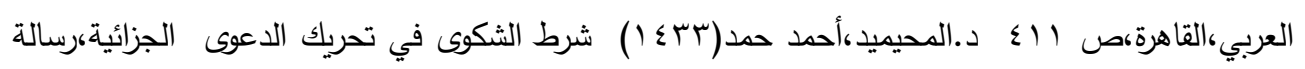

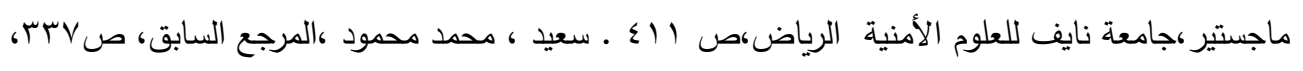

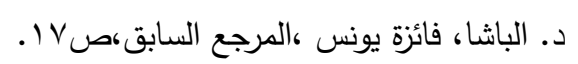

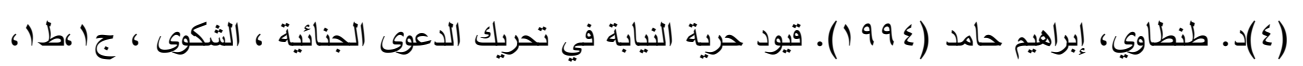

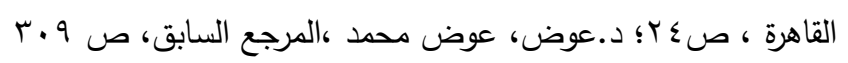

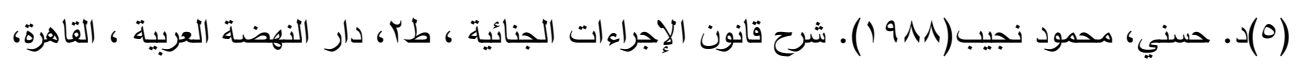

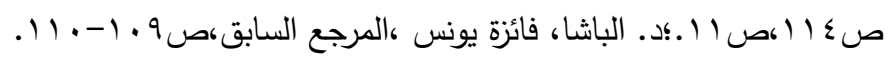
$(r \cdot v)$ 
r.r. · مجلة روح القوانين - العدد الواحد والتسعون - إصدار يوليو

أو الإلكتروني. إنما يوجد نص عام في ضوابط الثكوى بشأن عزل يُعزل القاضي الئي

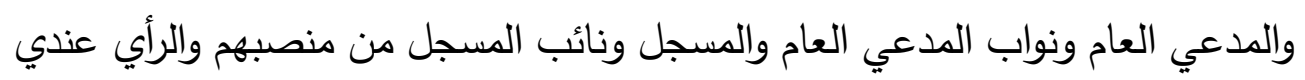

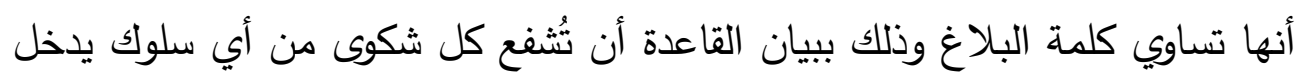

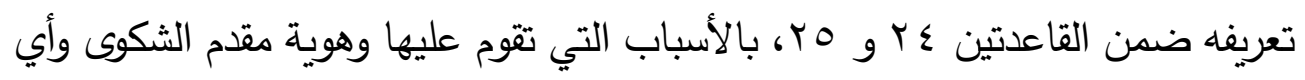

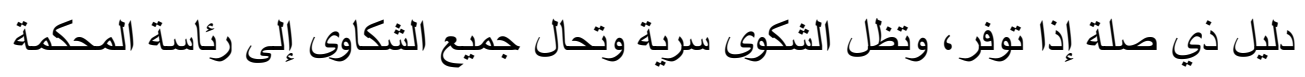

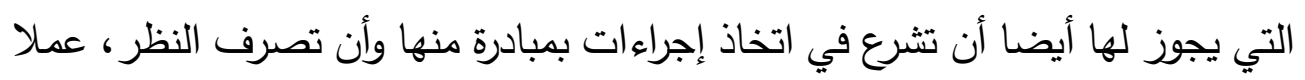

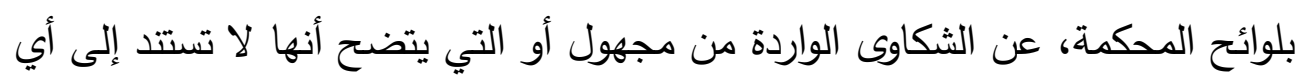

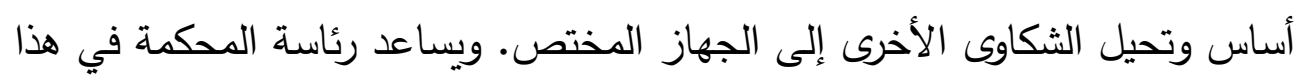
العمل قاض أو أكثر من قاض واحد يعينون على أساس التتاوب التلقائي، وفقا للائحة

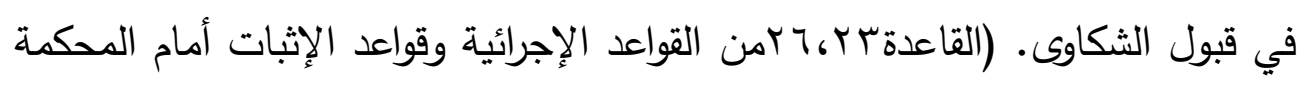

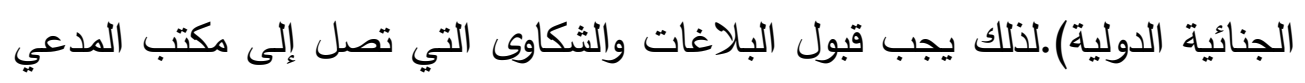

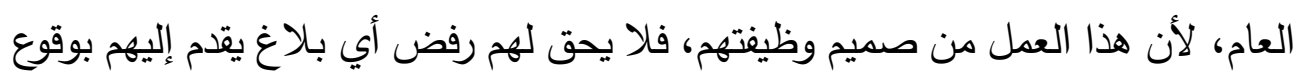

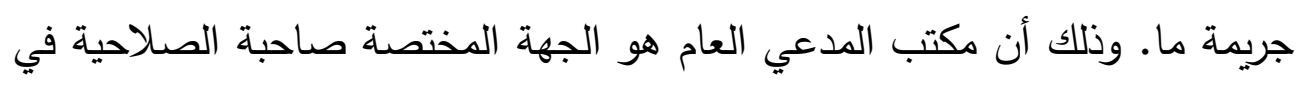

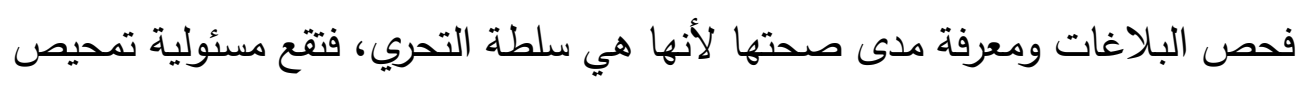

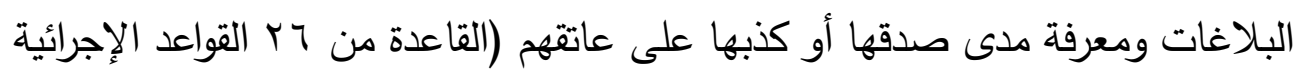

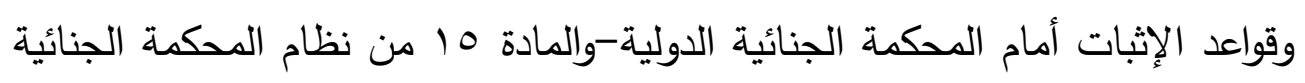

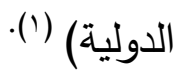

\section{ثانيا: حق الجني عليه في هرحلة إجراء التحريات بكثف الحقيقة: التحريات الجدية}

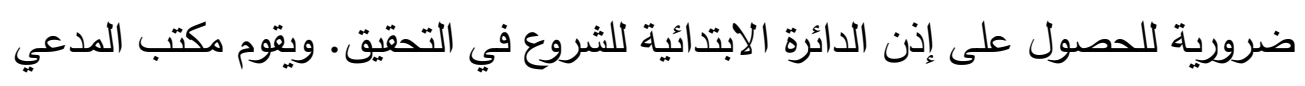

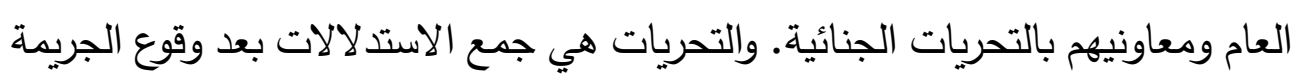

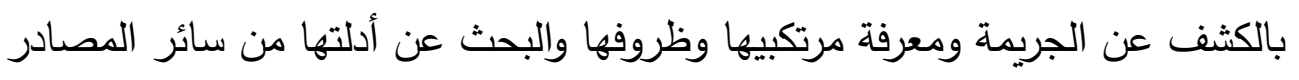

( (1)الحلبي، محمد علي سالم (raA1 (1). اختصاص رجل الضبط القضائي في التحري والاستلال والتحقيق، ذات السلانل، الكويت، ص 119 $(r \cdot \Lambda)$ 


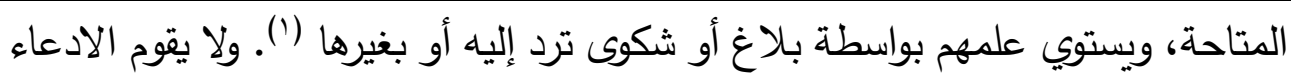

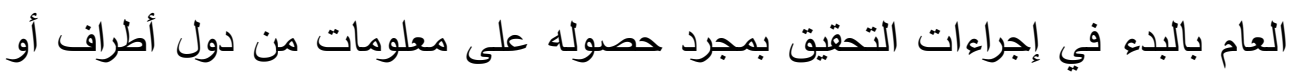

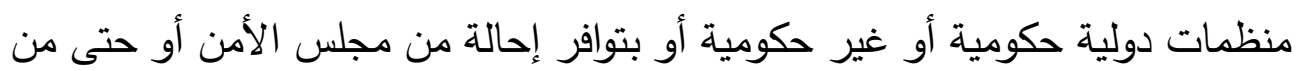

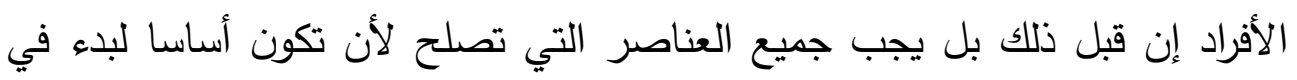
التحقيق نظر الدعوى الجنائية (؟). ويجب عليه:

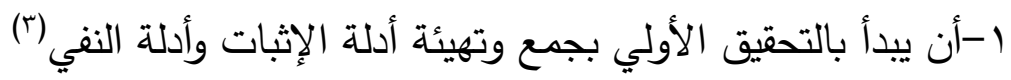
r-أن تتصف التحريات بالجدية ولمكتب المدعي العام في سبيل جعل التحريات معاينة موضوع الجريمة ومكانها وأن يتخذ جميع الوسائل اللازمة للمحافظة على ألى أدلة الجريمة، ويجوز له أن يستعين بأهل الخبرة كالأطباء وغيرهم لإبداء رأيهم فيما يجري الاستعانة

r-أن تباشر ضمن الوقائع التي تدخل ضمن نطاق الاختصاص النوعي والمكاني مكتب المدعي العام (حسب مبدأ التكامل). ع-كما يجب أن يستخدم فيها الوسائل المشروعة (؛)، لكي تكون التحريات صديات صحيحة

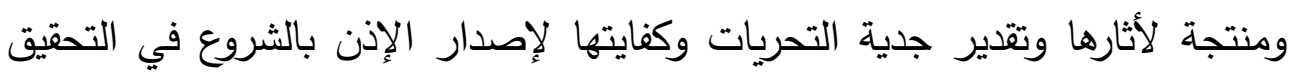

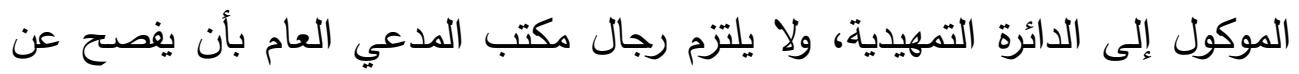
مصدر تحرياته (0). لذلك يجب على المدائهي العام التأكد من توفر تحريات كافية وجدية وذلك بجمع المستندات أو القرائن التي يستعين بها الددعي العام لأنها لازمة

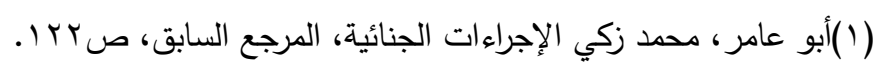

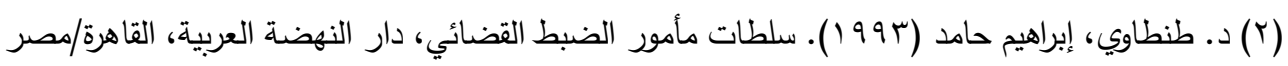

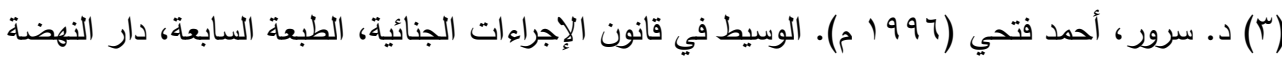

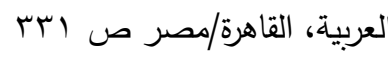

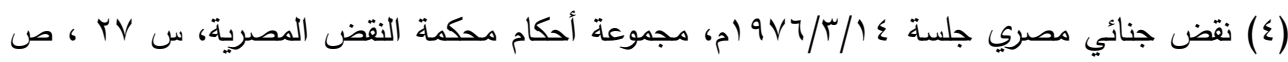

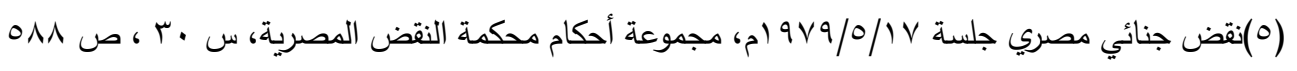


r.r. · مجلة روح القوانين - العدد الواحد والتسعون - إصدار يوليو

للبدء في التحقيق التمهيدي إذ يستعين بها القاضي وتخضع لتقديره كبقية الأدلة بحيث

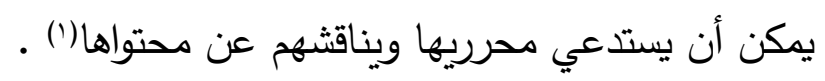

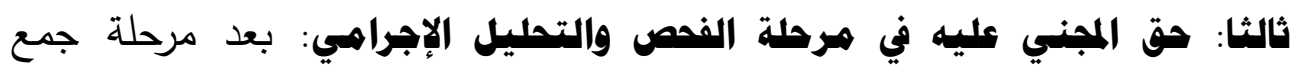
المعلومات بعد حصول المدعي العام على معلومات من الدول والمنظمات الدئ الدولية

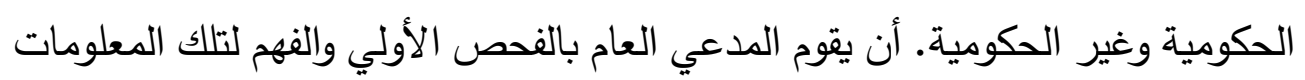

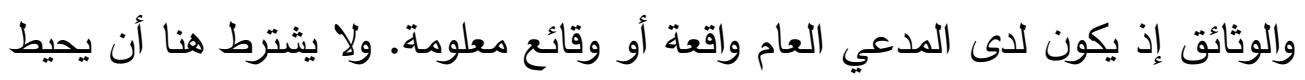

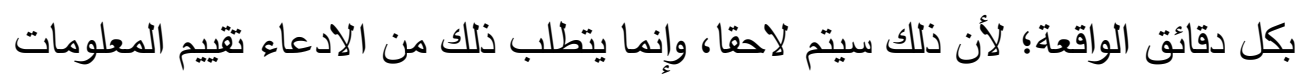

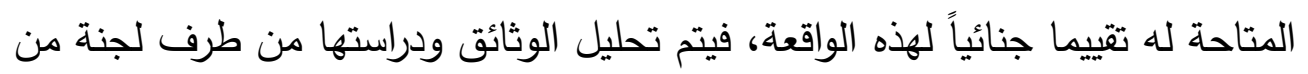

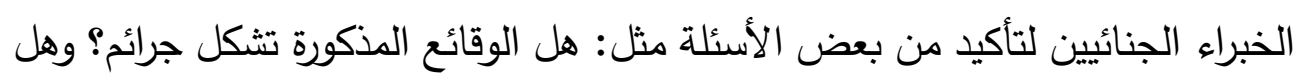

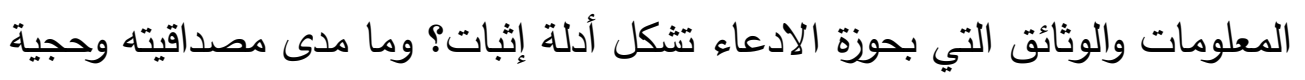
هذه الأدلة؟، وهذا يقتضي ما يأتي:

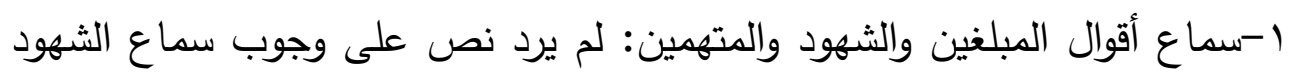

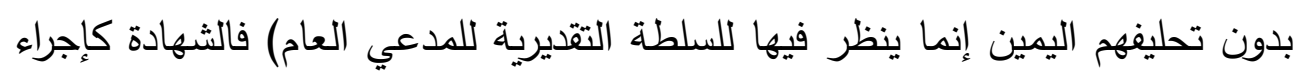

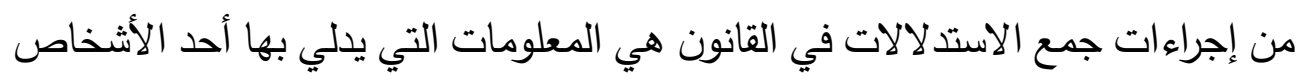

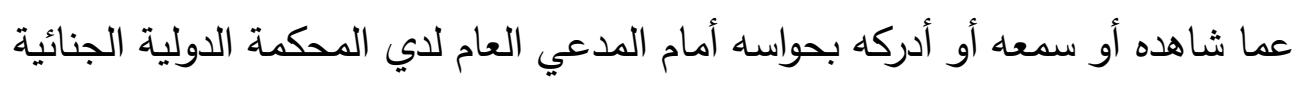

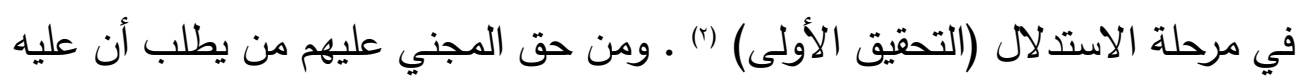

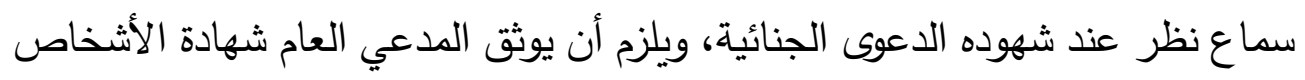

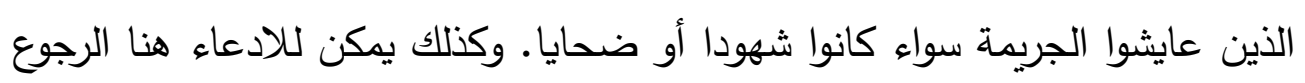

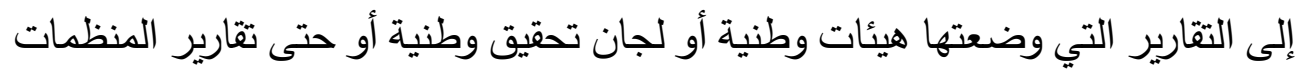

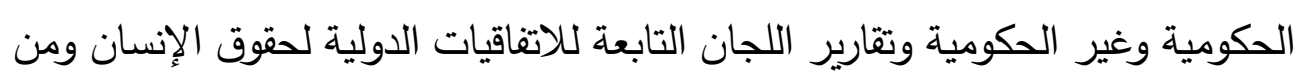

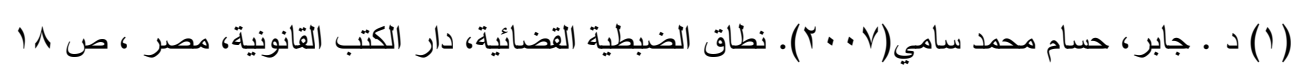

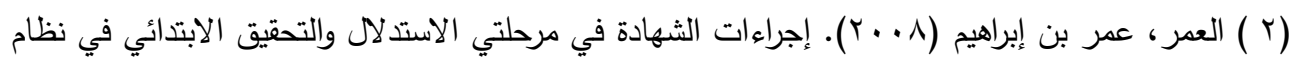

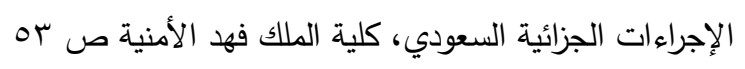

$(r)$ 
الجائز للادعاء حتى الاعتماد على التقارير الإعلامية ('). كذلك الوثائق الرسمية للهيئات الوطنية والدولية وتقارير وسائل الإعلام الوطنية والدولية. وهذه المرحلة تشبه مرحلة الإعاية

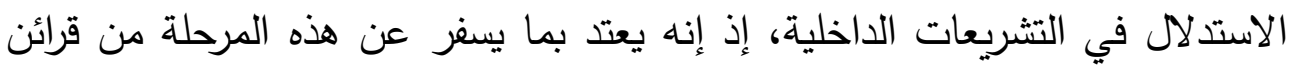

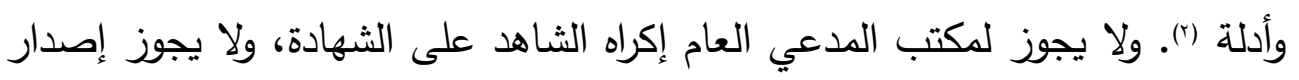

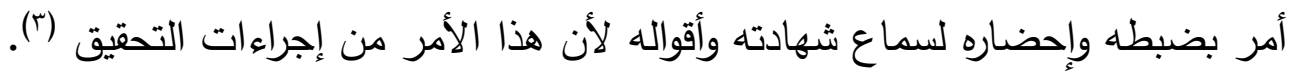

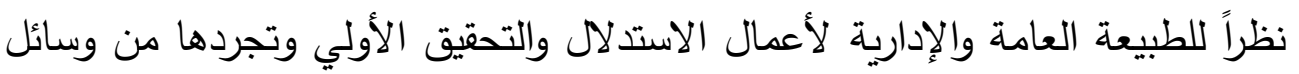
القهر والإجبار لكي تقع في إطار المشروعية. r- سؤال المتهم بدون استجوابهم، أي مجرد استيضاح ما ينسب إليه ولئه وليس استجوابه

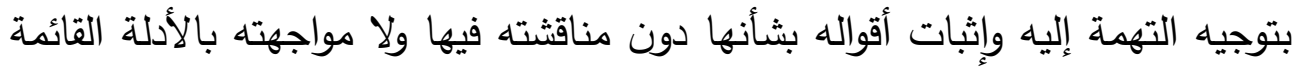
ضده (\{) .ولا يجوز الاستجواب وذلك لأن لاستجواب إجراء من إجراءات التحقيق بمقتضاه

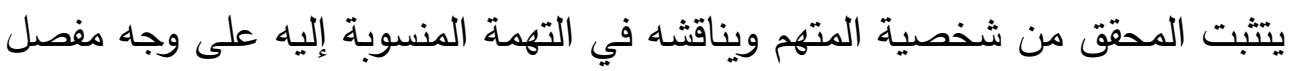

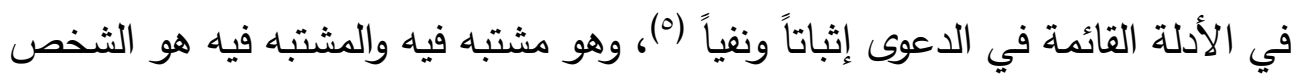
الذي قد توافرت دلائل كافية على اتهامه بارتكاب جريمة من الجرائم، أثناء إجراءات الاتئه

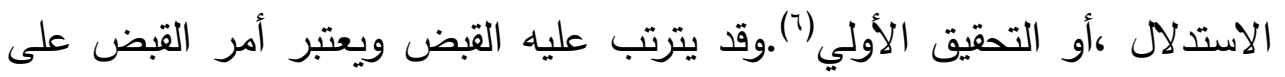

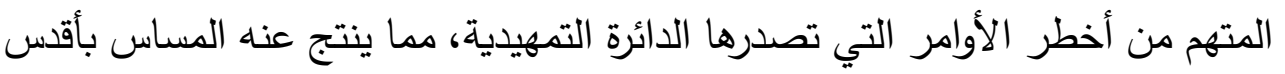

( ( ) د. عبد اللطيف، منذر كمال(1 . . ץ). النظام القضائي للمحكمة الجنائية الدولية، عمان ، دار الحامد ،

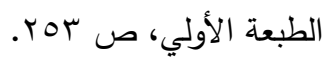

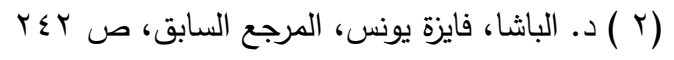

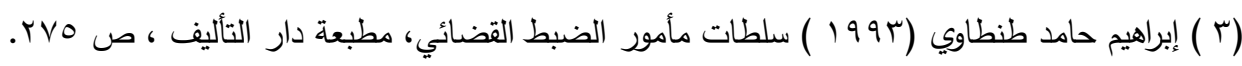

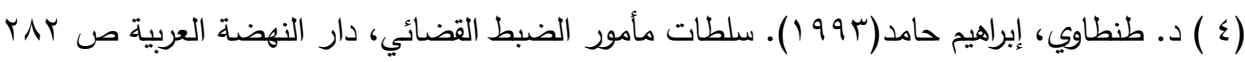

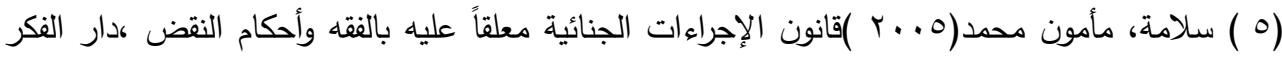




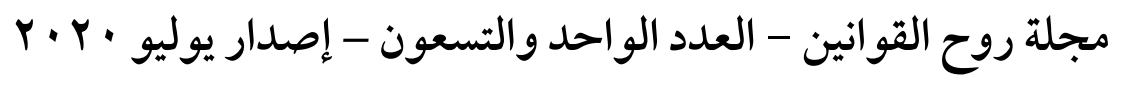
الحقوق الذي هو الحق في الحرية(')وعليه فإن القيود التي ترد على هذا الحق تعتبر كاستثاء لا يجوز التوسع فيه(r).

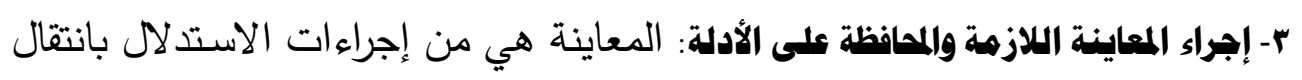

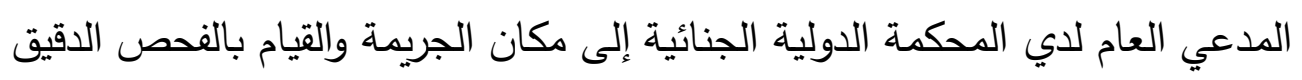

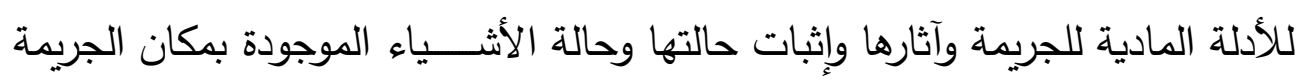

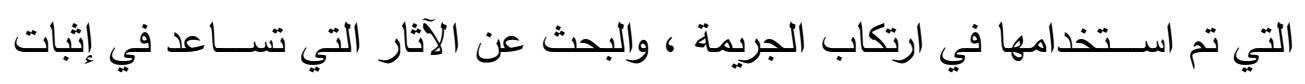

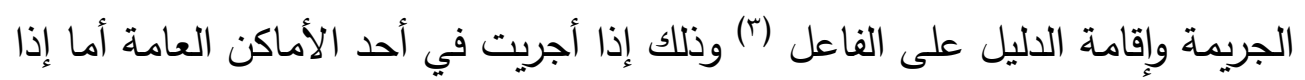

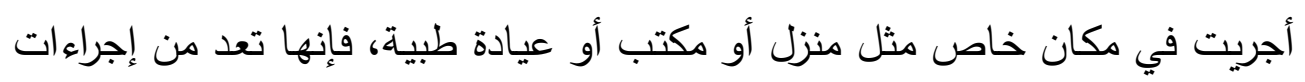

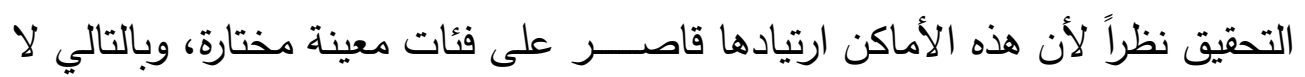
يجوز في التحقيق الأولي دخولها إلا في حالة التحقيق وتحت رلادئ رقابة الدائرة الابتدائية

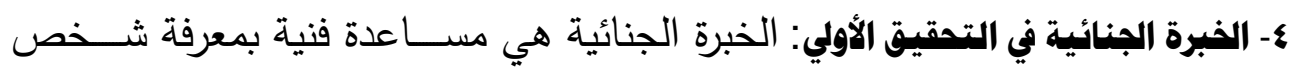

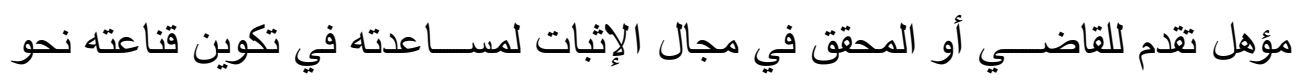

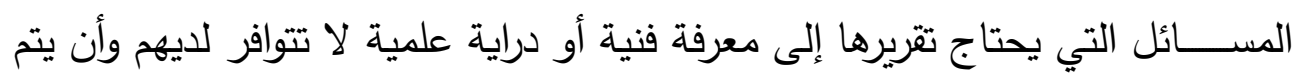

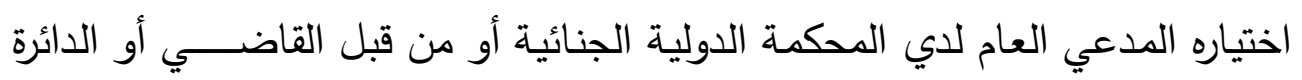

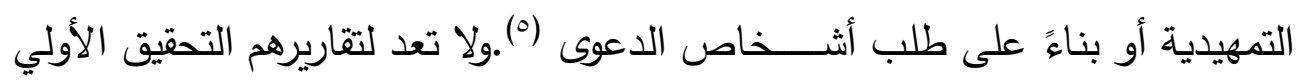

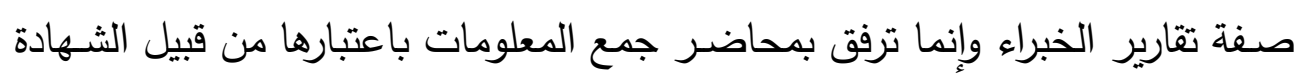

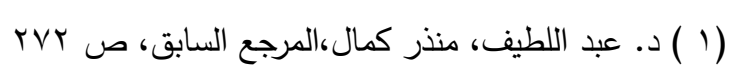

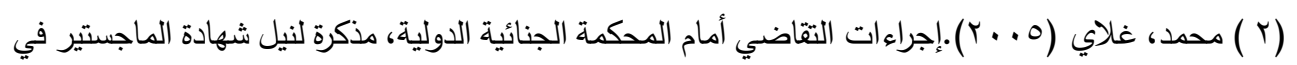

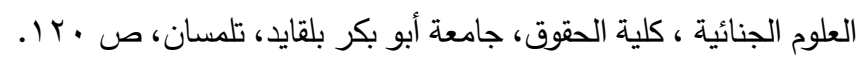

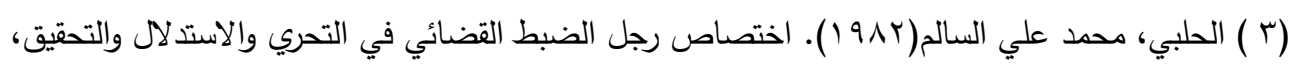

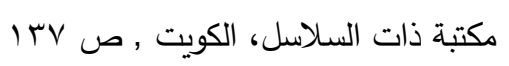

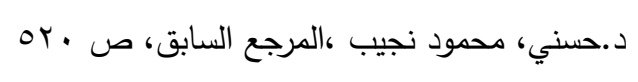

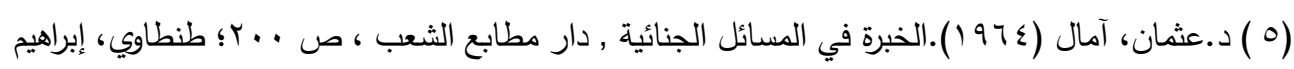

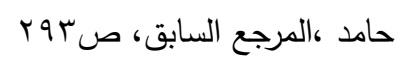


المكتوبة، لذلك لا يجوز أن يؤسس الحكم الصـادر من القضـاء بالإدانة على ما جاء في هذه التقارير فقط (').

رابعا: هرحلة الفهص والتهليل الإجراهي: بعد مرحلة جمع المعلومات بعد حصول

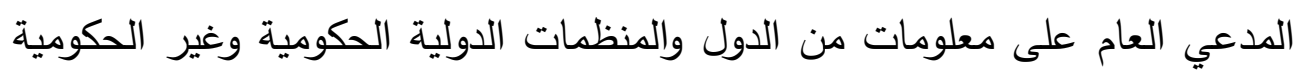

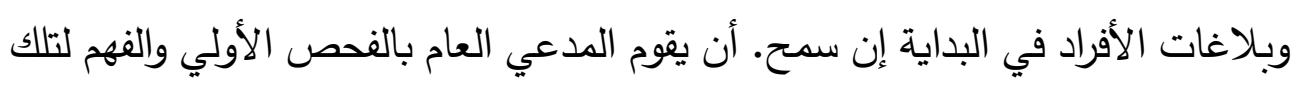
المعلومات والوثائق إذ يكون لدى المدعي واقعة أو وقائع معلومة. ولا يشترط هنا أن أن يحيط بكل دقائق الواقعة؛ لأن ذلك سيتم لاحقا، يتطلب ذلك من الادعاء تقييم المعلومات

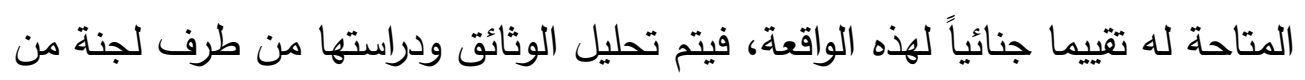
الخبراء الجنائيين لتأكيد هل الوقائع المذكورة تشكل جرائم؟ وهل المعلومات والوثائق التي

بحوزة الادعاء تشكل أدلة إثبات؟ وما مدى مصداقيته وحجية هذه الأدلة؟ خاهسا: إن حق المجني عليه في الاستعانة بمترجم: حق المجني عليه في أن يطلب يفهم لغته في كافة مراحل الدعوى الجزائية والحصول على الترجمة الضرورية اللازمة للإجراءات التي تم اتخاذها والرد على أسئلة المدعي العام حول الواقعة وأسئلة المتهم وهذا الحق يعد من ضمانات حقوق المجني عليه في الدفاع عن مصالحه وعرض شكواه على قدم المساواة مع المتهم، ويكون له الحق في مساعدة مترجم دون مقابل ويعتبر حق أساسي للمتهم لتمكينه من عرض دعواه (r). سادسا: الحق في السرعة في اتخاذ إجراءات الاستدلال: إن من حق الضحية اتخاذ إجراءات الاستدلال السريعة التي تكشف أدلة الجريمة، وتسهم في ضبط مرتكب الجريمة، وأن تتسم إجراءات الاستدلال بالعدل والحياد والثفافية. وأن يكون شريكا في الدعوى الجنائية خصوصاً أن السياسة الجنائية لم تفلح في منع الجريمة عليه. وذلك في ظل الجرائم

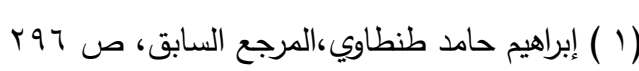

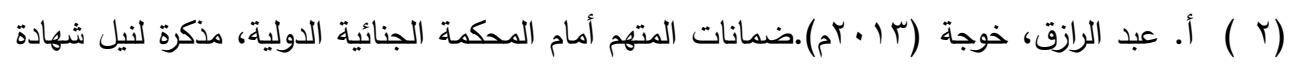

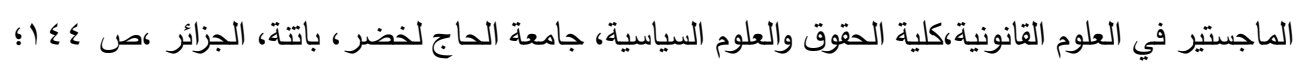

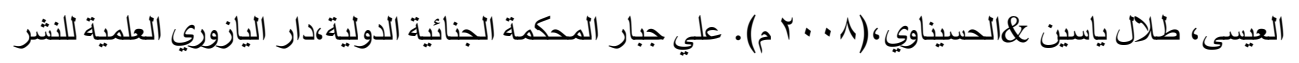

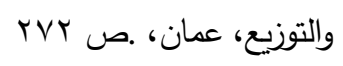




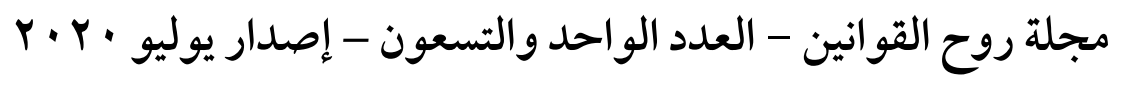

الدولية التي تمثل خطورة إجرامية والتي ظهرت في ظل حروب عالمية ووقوع إرهاب ليس دولة بل أحلاف دولية عسكرية لا تقدر دولة واحدة على مواجهته.

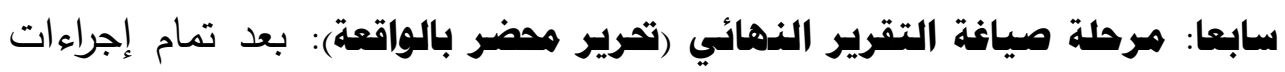
التحقيق الأولى بإعداد المدعي العام تقارير تتضمن اقتراحات دراسة وتحليل الأدلة

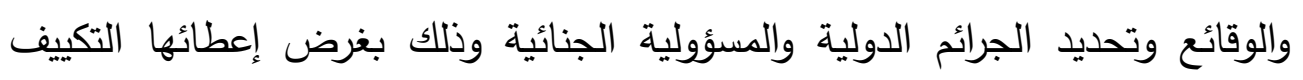

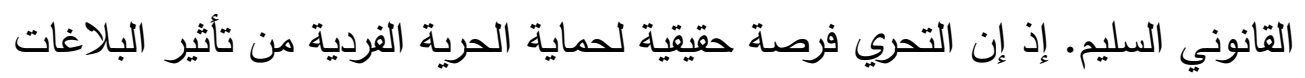

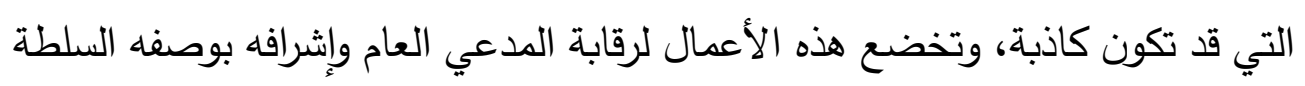

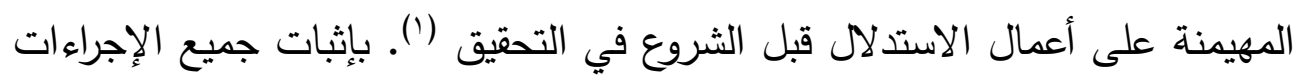

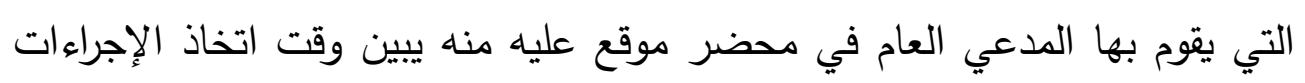

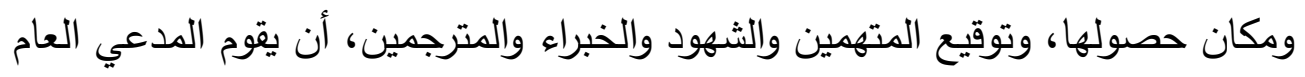

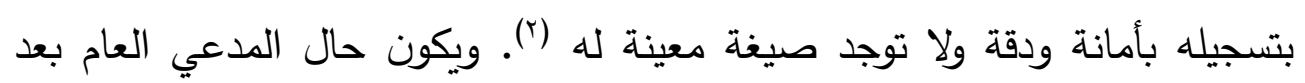
المراحل السابقة قد درس وحلل الواقعة بما يمكنه من صياغة التقرير النهائي المكون من شقين:

الشق الأول: تقرير تحليل استراتيجي: يقوم المدعى العام بالإجابة عن بعض الأسئلة

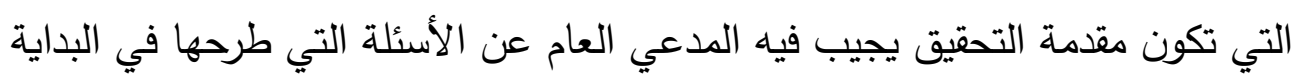

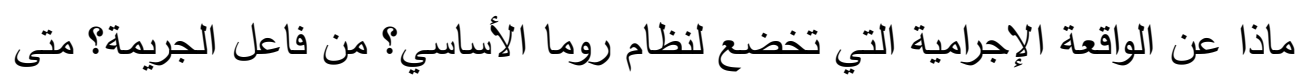

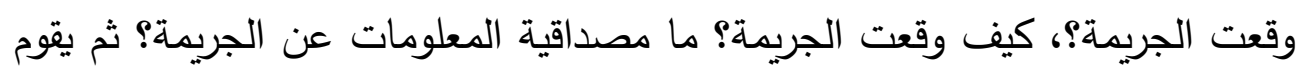
الددعي العام برسم صورة عامة لما حدث وبيان السياق التاريخي والسياسي والاجتماعي الذي تمت فيه الأحداث. الثق الثاني: تقرير تحليل عملياتي: يحدد فيه الوقائع وتحديد الجناة وبيان دور كل لكاتل

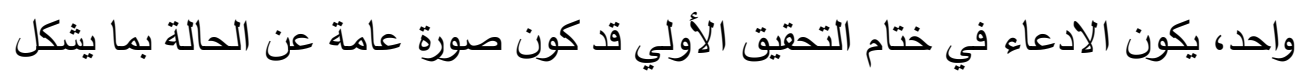

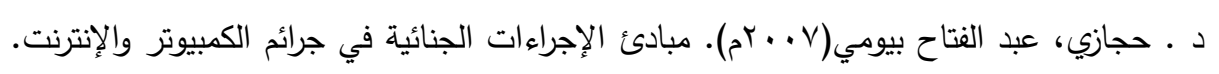

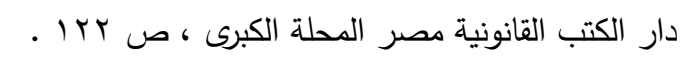

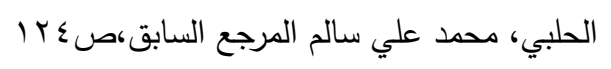


لديه قناعة بوجود أساس معقول لمباشرة التحقيقات سواء بمبادرته عبر السلطة الذاتية التي يملكها أو عبر تفعيل الإحالة الواردة من مجلس الأمن (').ثم يقوم بإرسال هذه المحاضر لجهة لتحقيق الدائرة التمهيدية. مخالفة ذلك لا تؤدي إلى البطلان لأن الغرض من ذلك هو تتظيم العمل وحسن سيره يجب تسجيله بأمانة ودقة ولا توجد صيغة معينة له، لأنه بعد أن يتم تسجيله في السجلات الرسمية المعدة لذلك، لا يجوز إتلافه أو

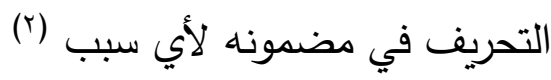
ثاهنا: إخطار الدائرة التمهيدية: يجب على المدعي العام إخطار الدائرة التمهيدية بكل ما قاموا به من إجراءات من خلال إرسال الأوراق والمحاضر والأشياء المضبوطة إليها. فإذا انتهى المدعي العام من تحقيقاته الأولية واستتتج منها وجود أساس معقول في إجراء تحقيق يقدم إلى الدائرة التمهيدية طلبا للإذن لله بإجراء تحقيق ابتدائي أدلة تؤيد طلبه. وهذا ما يتفق مع ما اتجهت إليه التشريعات الإجرائية. إذ لا تبدأ النيابة العامة إجراءات التحقيق الابتدائي إلا في ضوء الاستدلالات التي توصل إليها مأموري الضبط القضائي إزاء الجريمة التي تحققت، حتى يتسنى للنيابة العامة الإذن بالقبض والتفتيش إذا توفرت لديها تحريات كافية وجدية (ץ). ويكون المدعي العام مسئولا عن الاحتفاظ بالمعلومات والأدلة المادية التي يتم الحصول عليها أثناء التحقيقات التي يجريها مكتبه، وعند تخزينها

$$
\text { وتأمينها (القاعدة · ـ من قواعد الإجراءات وقواعد الإثبات) }
$$

تاسعا: حق المجني عليه في هضور التحقيق الأولي: إذا استتتج المدعي العام بعد التحقيق

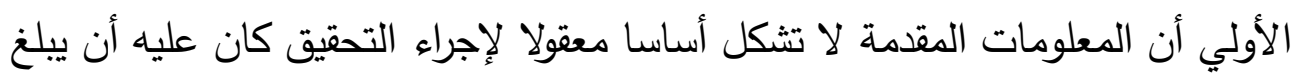
مقدمي المعلومات وبالتالي يملك كل من المدعي العام (المادة 0 //7 من نظام روما

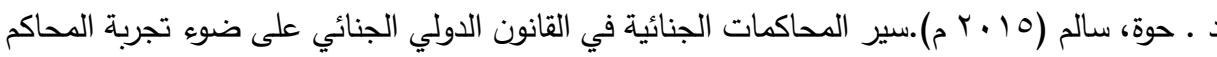

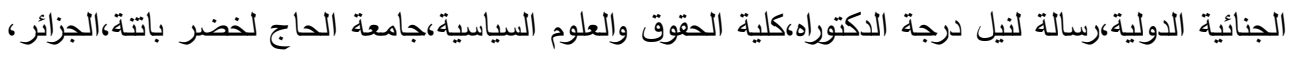
ص

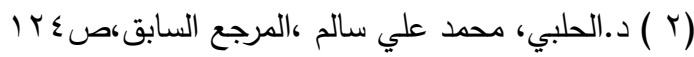

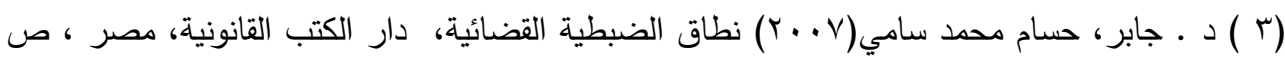




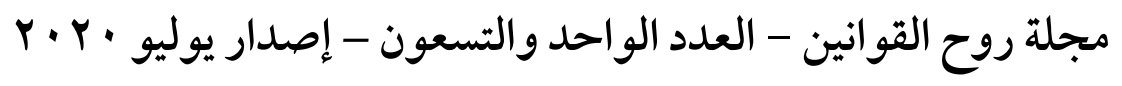

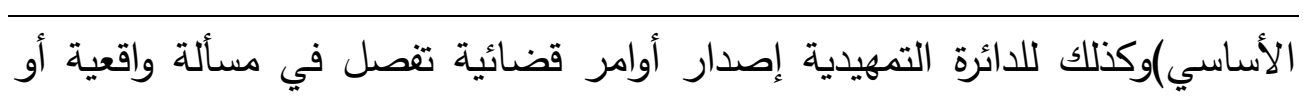

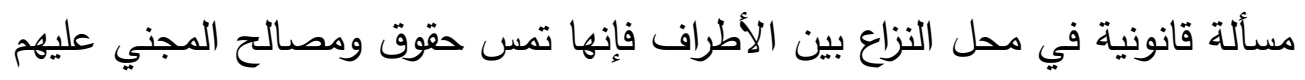

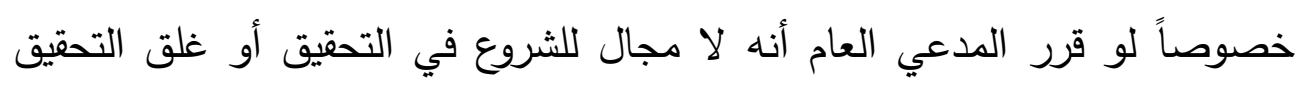

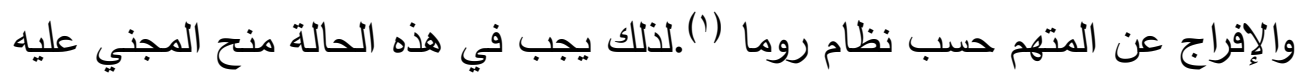

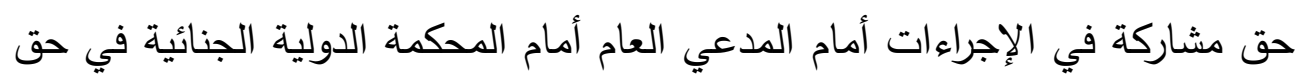

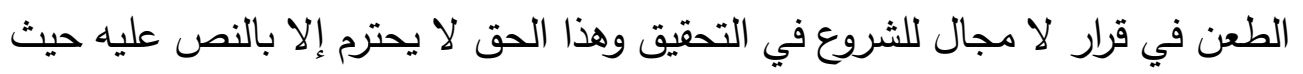
تستمد أعمال التحقيق الأولي شرعيتها من القانون الذي نظم أحكامها بما يكفل للإجراء

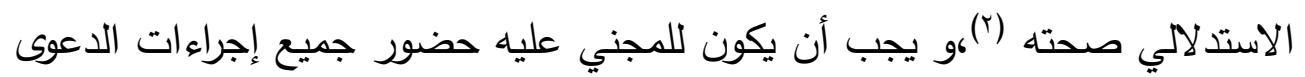

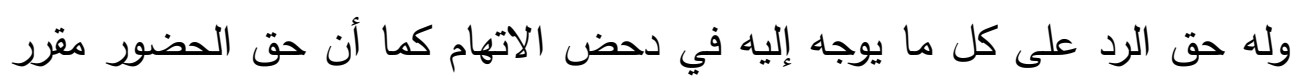
للمتهم (r).ويرجع ذلك إلى مقتضيات تطبيق مبدأ المساواة بين المتهم وبين المجني عليه(؛) . ومن ثم فلا يوجد نص يوجب إعلام المجني عليه ببدء الإجراءات التحقيقات الأولية مما يقلل من حقه في اللجوء إلى القضاء للمطالبة بالحق والمطالبة بالعدالة.

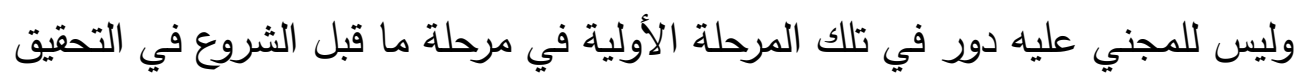

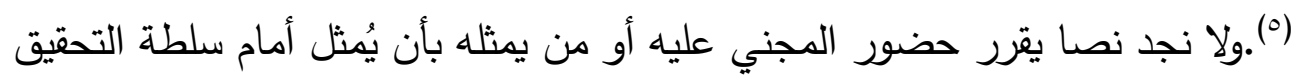

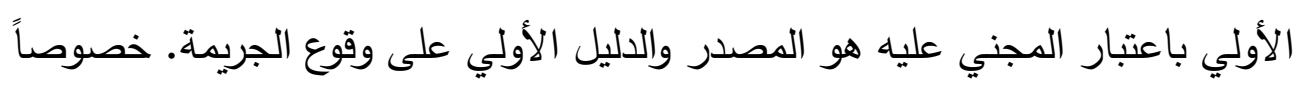

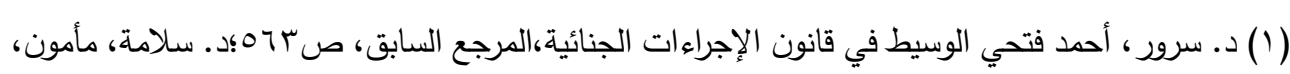

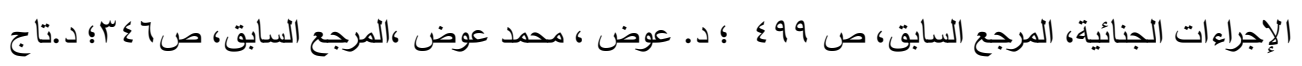

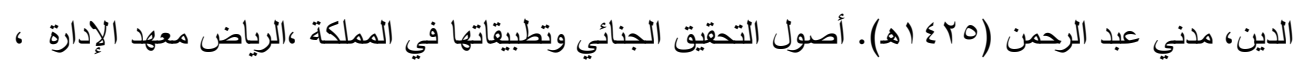

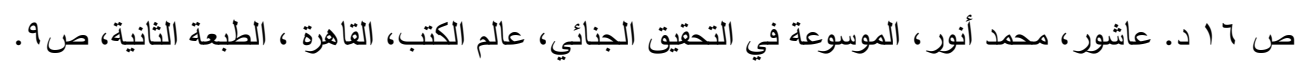

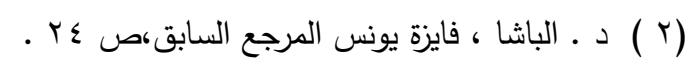

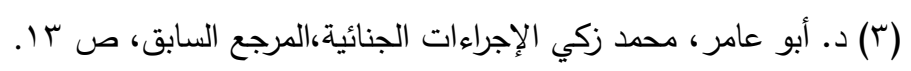

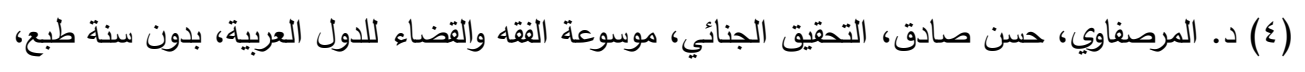

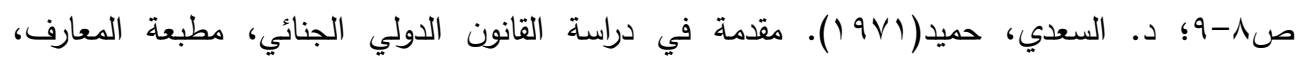

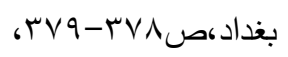
(0 ) د ـ طنطاوي، مددوح( ( . ب). الأدلة التأديبية، الطبعة الثانية ،الدكتب الجامعي الحديث،الإسكندرية ،ص 


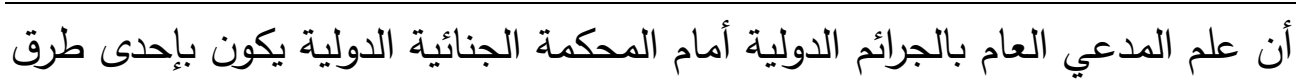

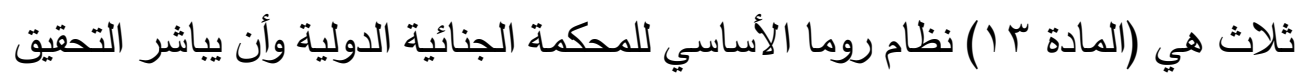

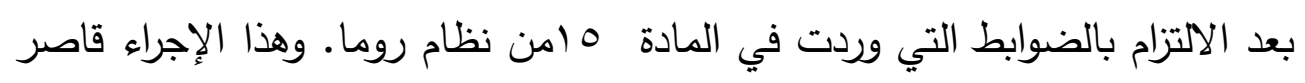

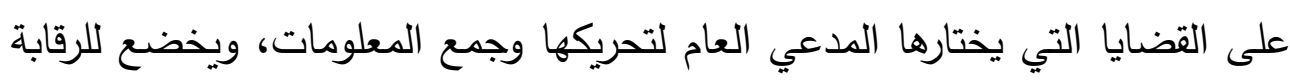

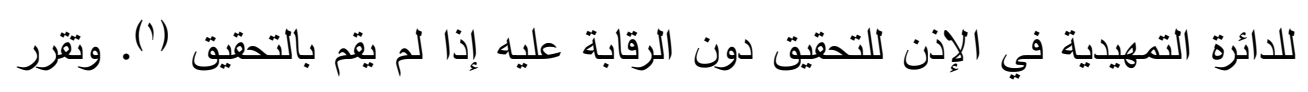

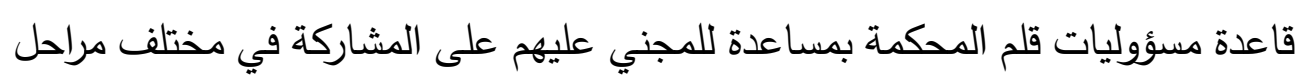

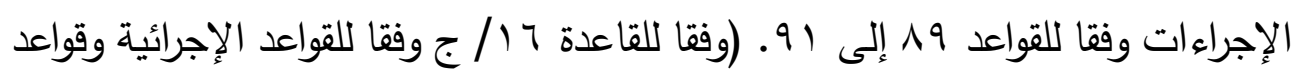

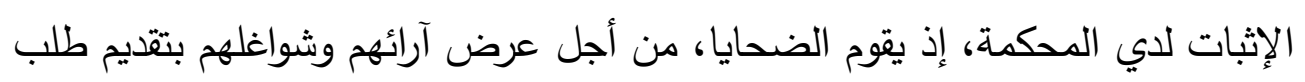

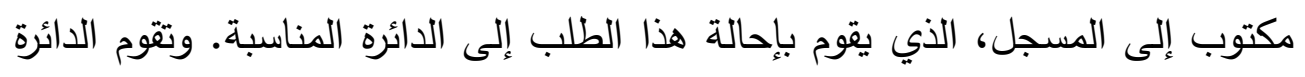

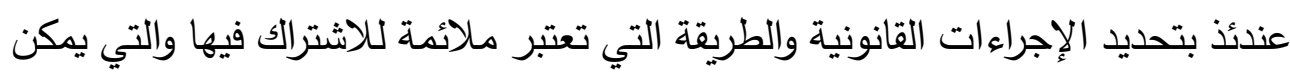

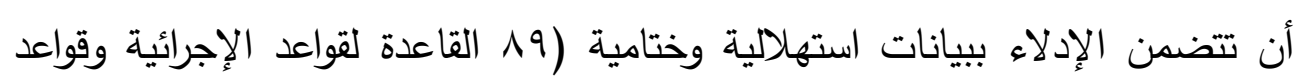

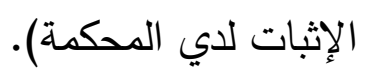

\section{المطاب الثاني \\ الجهة القائمة بالتحقيق الأولي وخصائصها}

يعد مكتب المدعي العام لدى المحكمة الجنائية الدولية من بين أهم أجهزة المحكمة

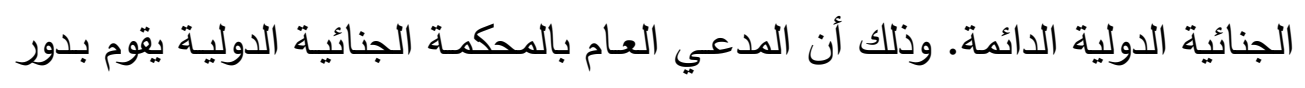

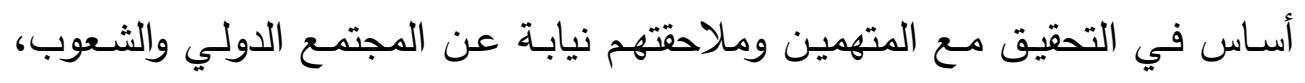

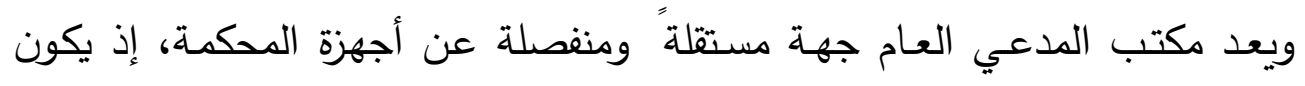

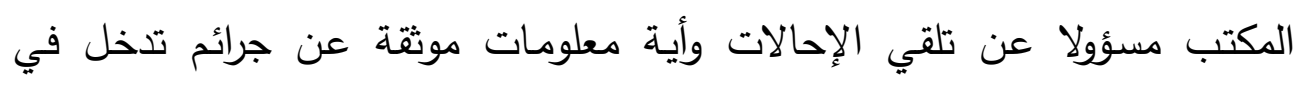

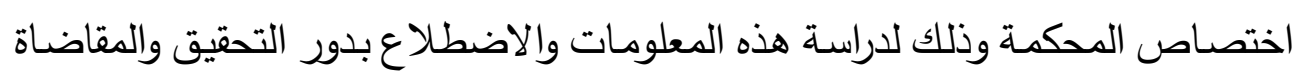

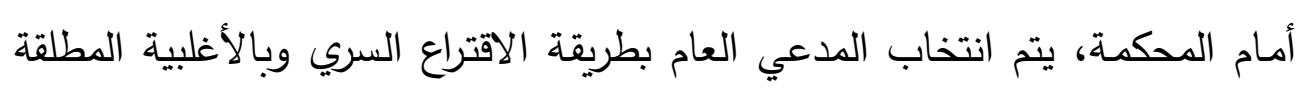

(1 ) د. حسن، سعيد عبد اللطيف(ع +. بام). الدحكمة الجنائية الدولية،القاهة:دار النهضة العربية،مهص 


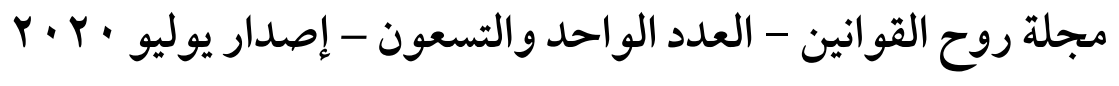

لأعضاء جمعية الدول الأطراف ، وبنفس الطريقة يتم انتخاب نوابه من ضمن قائمة

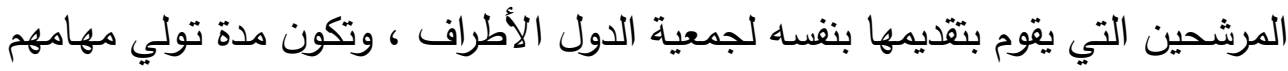

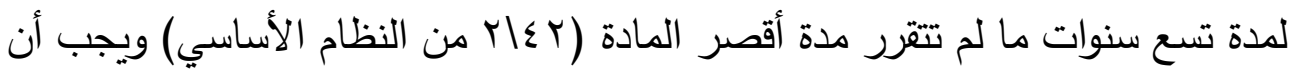

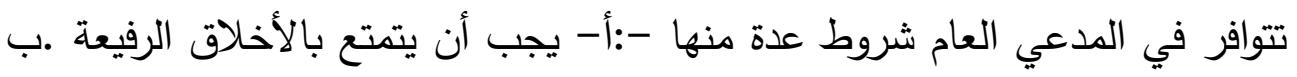
- يجب أن يكون ذا كفاءة عالية، مع توافر الخبرة الواسعة في مجال التحقيقات الجنائية .

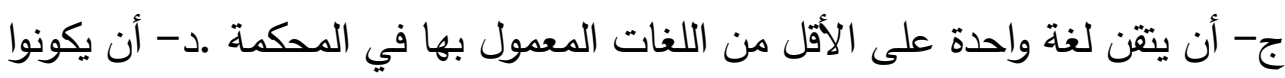

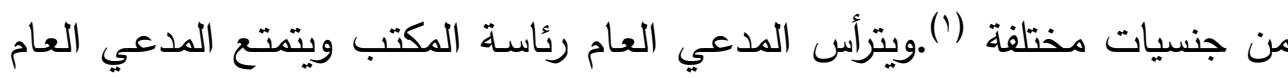

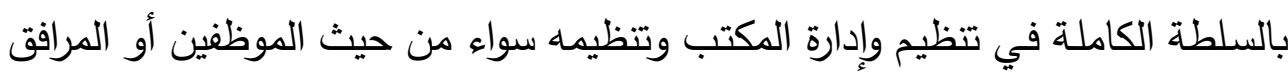
أو موارد الدكتب الادعاء. ومن المفروض أن جهاز مكتب المدعي العام مستقل عن

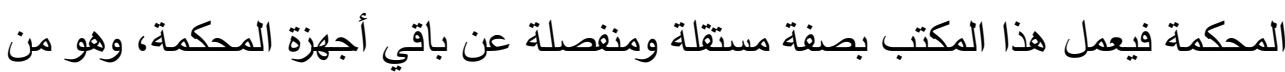

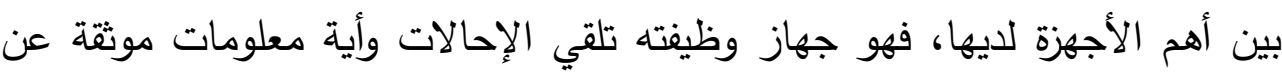
الجرائم التي تدخل ضمن اختصاص المحكمة، ليقوم بدراستها، والبدء بعدها بالتحقيق الإليق والمقاضاة وإن الادعاء هو أحد أطراف الدعوى الذي يكون في مواجهة الدفاع. ويتكون الككتب من ثلاثة أقسام: قسم الاختصاص وقسم التحقيقات وقسم المتابعة الجنائية كما يأتي: القسم الأول: شعبة الاختصاص والتكامل والتعاون: تتولى شعبة الاختصاص والتكامل

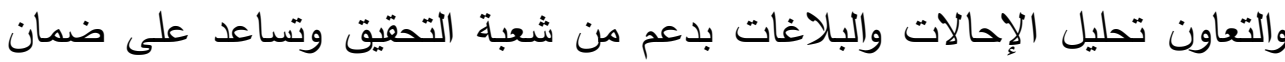

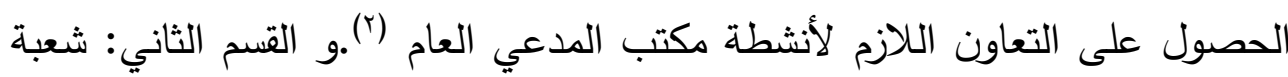

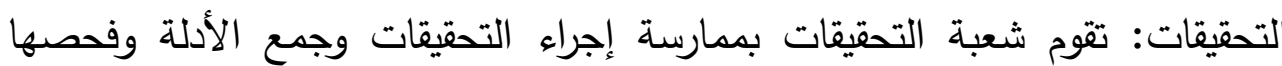
واستجواب الأشخاص. هذا القسم يباشر التحقيقات وتتسيق عملية انتشار المحققين في

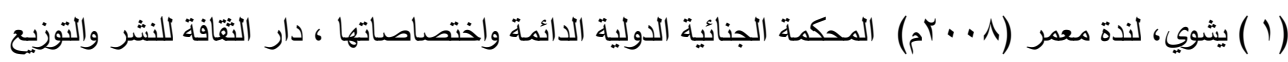

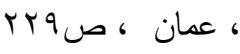

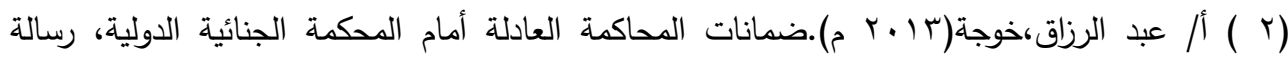
ماجستير ،كلية الحقوق والعلوم السياسية،جامعة الحاج خضر ،باتنة،الجزائر،ص وج وما بعدها. (r) 
الميدان وضمان أمنهم وسلامتهم الجسدية. كذلك مباشرة التحليل الأولي للمعلومات

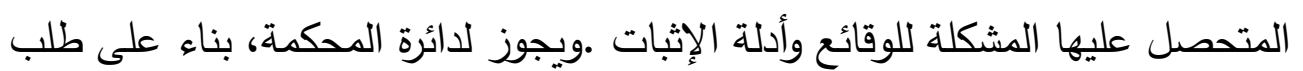

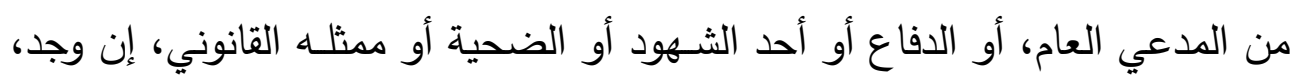

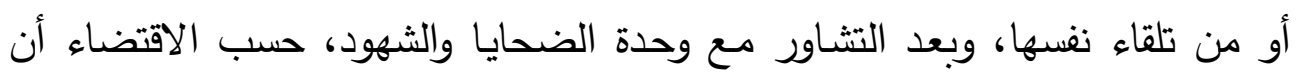
تأمر باتخاذ تدابير لحماية الضحية أو الثاهد أو أي شخص وهده آخر معرض للخطر

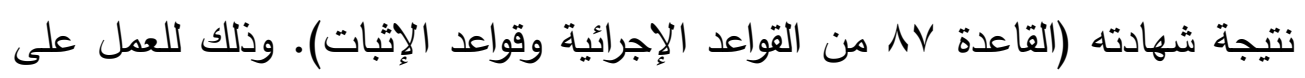

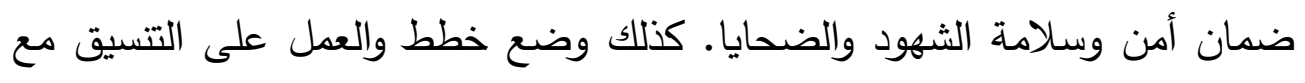
المسجل للاستفادة من خدمات وحدة الشهود التابعة للمحكمة الجنائية الدولية. القسم الثالث: شعبة المقاضاة والمتابعة الجنائية: مهمتها الأساسية متابعة القضايا أمام مختلف وهن الدوائر ومباشرة المتابعة الجنائية أمام غرف المحاكمة للمحكمة الجنائية الدولية وتوفير آراء قانونية لمسائل يمكن أن تثار أثناء عملية التحقيق وتحضير خطة العمل حول تسيير القضية وتقديمها للجنة التنفيذية كي تعتمدها، وأن تحقق التسيق مع مسجل المحكمة الجنائية الدولية. ويتميز مكتب المدعي العام بخصائص منها الآتي:

\section{أولا: عدم التجرئة لمكتب المدعي العام كالنيابة العاهة:}

ويتمتع مكتب المدعي العام بعدم القابلية للتجزئة مثل النيابة العامة في النظم الإجرائية الداخلية. وأنه يقوم بوظائف إدارية ووظائف قضائية كما تنقسم رئاسة المدعي العام إلى بلى رئاسة إدارية ورئاسة قضائية لأعضاء مكتب الادعاء العام. عدم التجزئة يعني أن

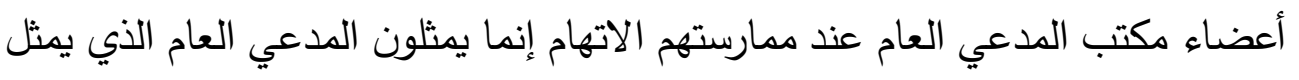
المجتمع الدولي في الجرائم الداخلة في اختصاص المحكمة وهذه الميزة تقتضيها حاجة المجتمع في مواجهة الجريمة، وفرض الاستقرار بانتهاج سياسة جنائية موحدة(').وللمدعي العام ندب أي عضو ممن يعملون معه لغرض إجراء تحقيق، أو أي إجراء آخر يدخل في ولايته ولو كان خلافاً لقواعد الاختصاص للعضو (r)، إلا أن قيام عضو الادعاء

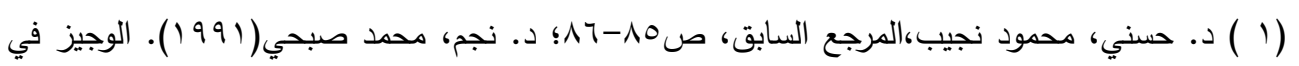

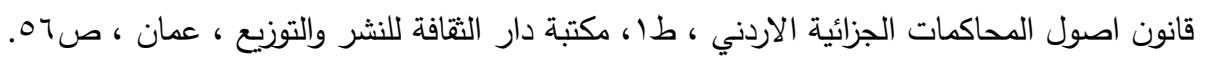

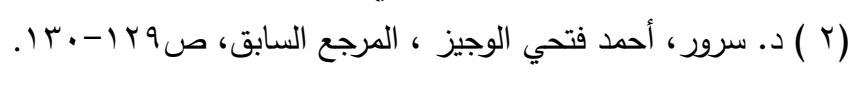




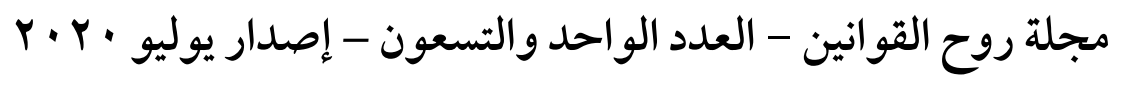

العام، بالتصرف المخالف، لأوامر الادعاء العام، قد يترتب عليه البطلان، ذلك أن صفة البه

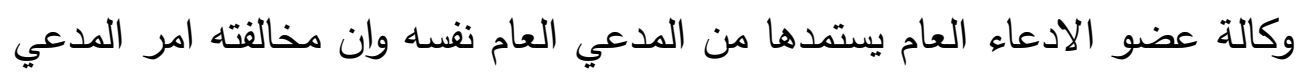

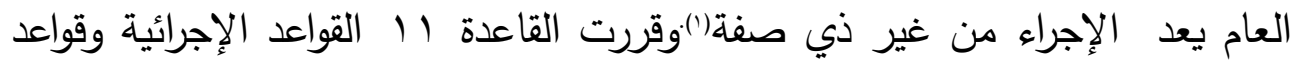

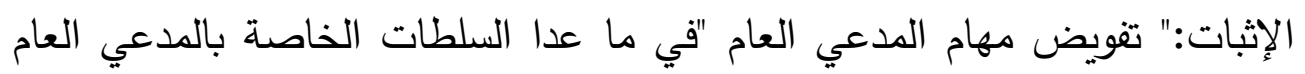

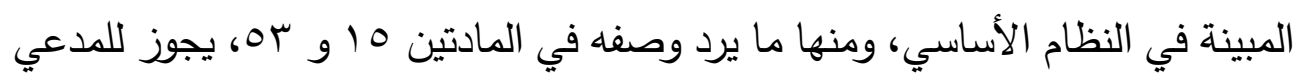

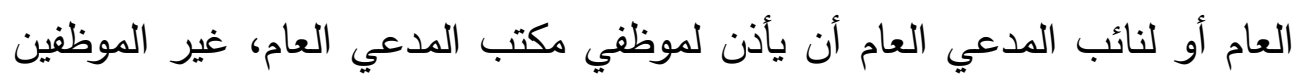

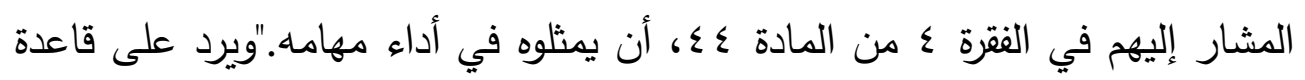
عدم التجزئة قيدان: القيد الأول: التقيد بقواعد الاختصاص النوعي والثخصي والمكاني (() لذلك يجب التقيد

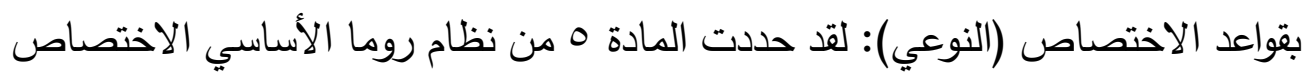

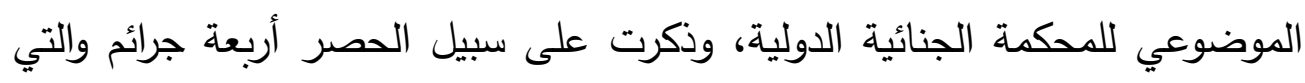

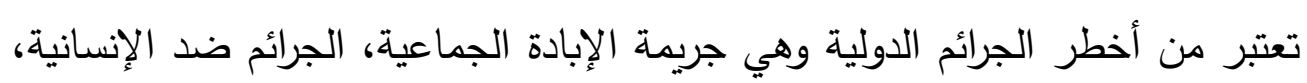

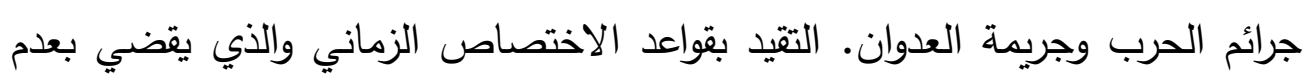

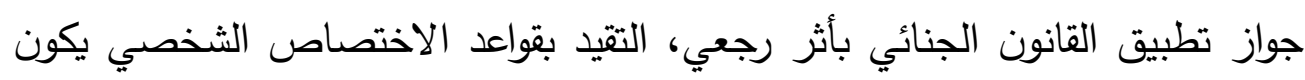

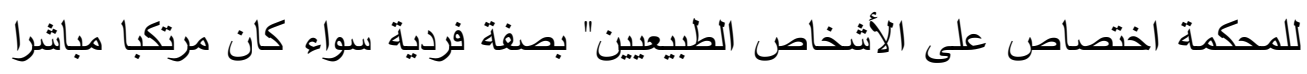

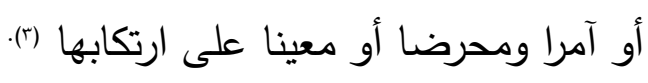

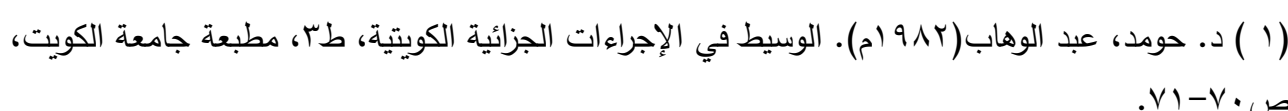

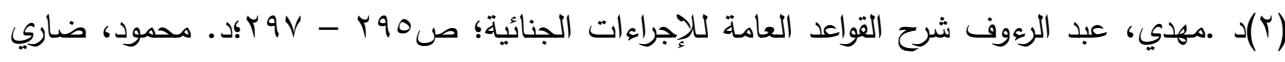

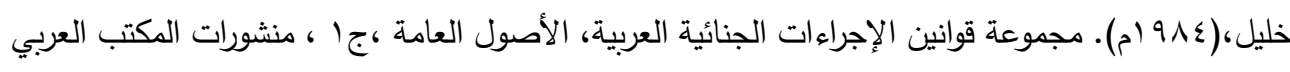

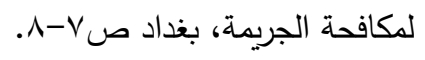

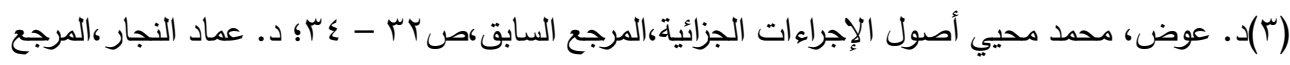

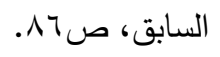


القيد الثاني: شرط الالتزام بحدود القانون (().

ثانيا: عدم المسوفلية: القاعدة لا يسأل أعضاء المدعى العام لدي المحكمة الدولية الجنائية

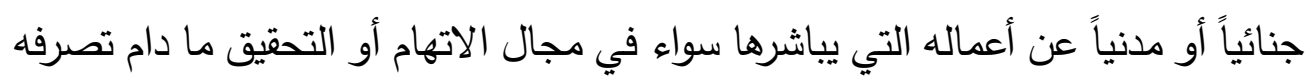
بحسن نية وفي حدود القانون (ז).ولا يسأل عن النتائج التي تترتب على ممارسته لعملهم، بإقامة الدعوى الجنائية ومباشرتها أمام المحاكم المختصة حتي لو حكم ببراءة المتهم. وذلك لأنهم يستعملون الحق في السلطة التقديرية بمقتضى النظام، فلا مسئولية عليهم حتى لو ظهر أنهم أخطأوا في التقدير فصدر حكم ببراءة المتهم لخطأ يسير طالما كانوا لديهم حسن النية (r).وانطلاقاً من مبدأ المساواة أمام القانون ولما يتمتع به الادعاء العام من حرية في العمل وعدم المسؤولية فما يقوم به من أعمال في حدود صلاحيته (9v).ذلك أن الأصل هو أن يتمتع مكتب المدعي العام بخاصية عدم مسؤولية المدعي العام عن الأثار المترتبة على التحقيق الأولي والتحقيق الابتدائي أو التمهيدي يرجع لكون المدعي العام خصماً شكلياً وليس خصما موضوعيا وهدفه سيادة القانون ويعمل بوحي ضميره بهدف تحقيق مصلحة القانون حتى لو ترتب ضرر عليها للأفراد أثناء ممارسة عمله ().إالا أن المسؤولية تقوم على الادعاء العام إذا كان الخطأ فاحشًا فلا يعفى من المسؤولية

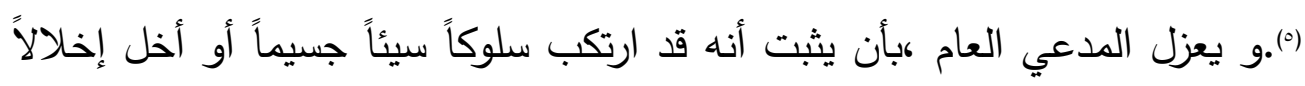

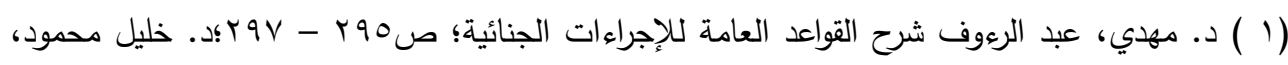

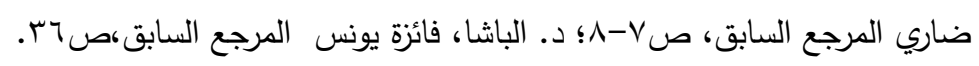

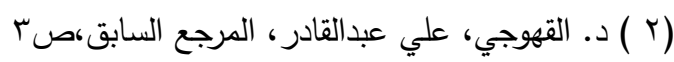

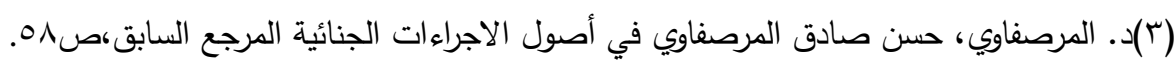

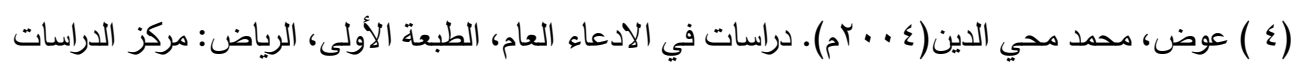
والبحوث، ص 91.

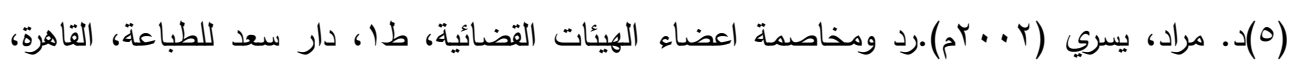

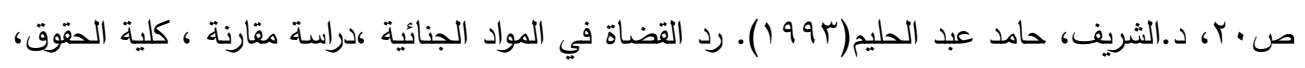

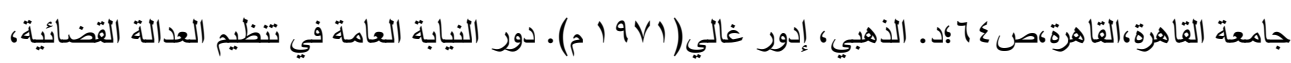

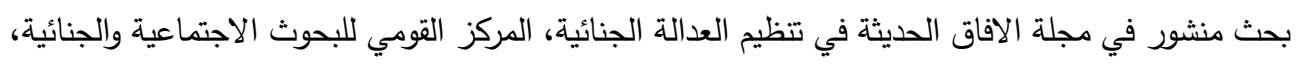

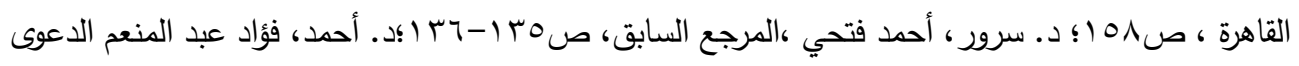




$$
\text { r.r. · مجلة روح القوانين - العدد الواحد والتسعون - إصدار يوليو }
$$

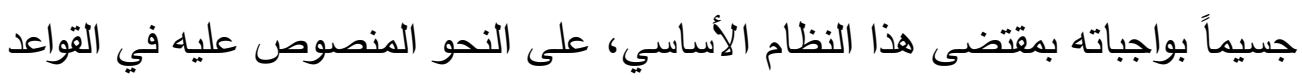

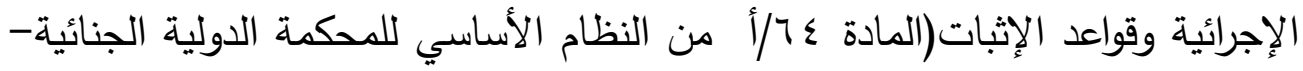

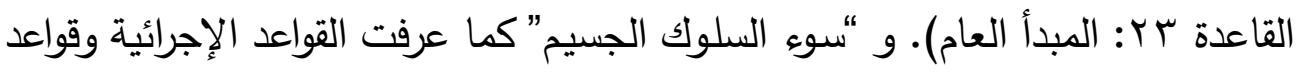

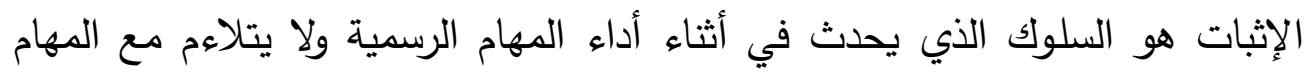

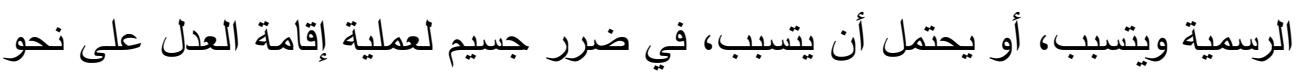

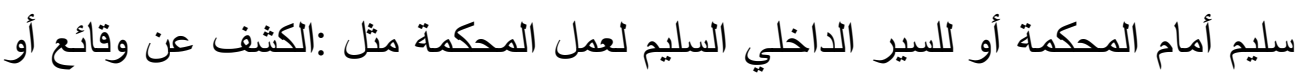

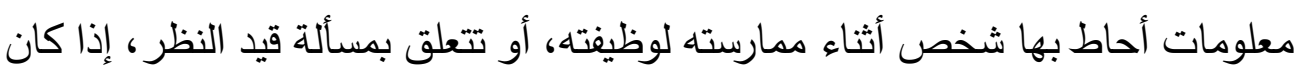
من شأن ذلك الكثف أن يضر بسير المحاكمة أو بأي شخص من الأشخاص وإخفاء

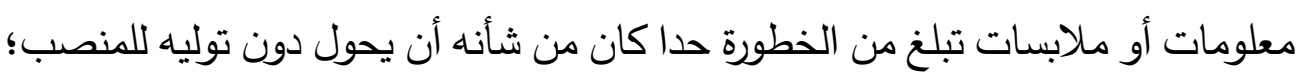

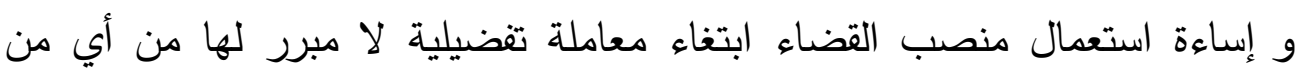

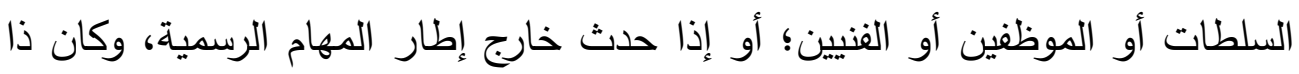

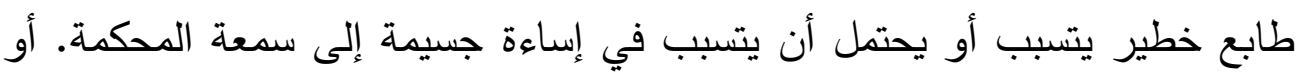

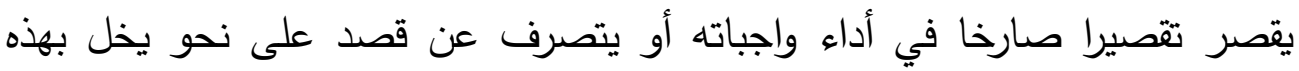

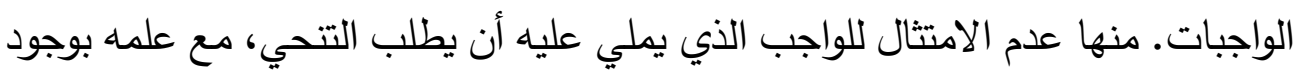

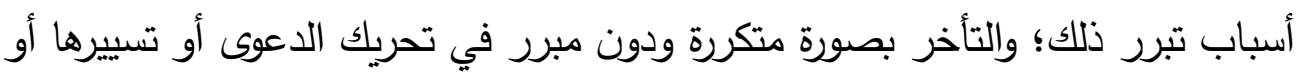

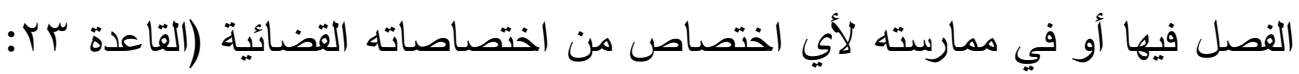
من القواعد الإجرائية وقواعد الإثبات).

ثالثا: سرية الإجراءات وتدويذها في تلك المرحلة: إجراء التحقيق الأولي يتم بواسطة جهات

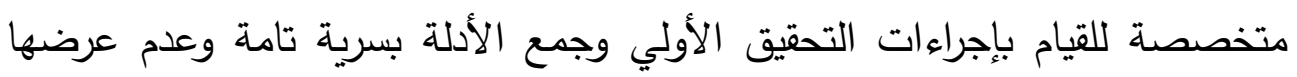

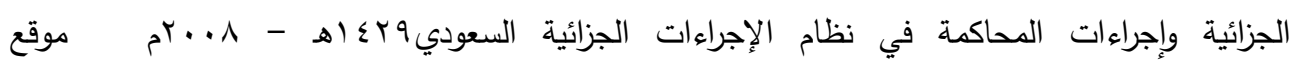
الألوكة www.alukah.net 
للمناقشة تفاديا لعلنية الإجراءات ('). إذ في السرية صيانة لإجراءات التحقيق خشية طمس الأدلة وضياع فرصة المفاجأة للجاني. لذلك لا تعد علنية الإجراءات في مصلحة التحقيق. وهذه الخاصية نتيجة الأخذ بالنظام الاتهامي الذي نادي بسرية إجراءات التحقيق بشكل كامل، وبالتالي ظهر مبدأ تدوين التحقيق الذي يحل محل مبدأ شفوية الإجراءات لمواجهة المتهح بالأدلة القائمة، ولكي تقدم فيما بعد إلى القضاء. مما يهدر بعض الضمانات التي يتمتع بها أطراف الجريمة في ظل النظام التهامي. وبالتالي عدم مناقشة الإجراءات من قبل المجني عليه والمتهم مما يترتب عليه صدور الأحكام المعيبة لغياب حق الدفاع والرقابة (r). نتوصل مما سبق ما يأتي: ا-يمكن تقويم دور المدعي العام بأنه يغلب على عمل المدعي العام طابع الاستدلال في مرحلة ما قبل الثروع في التحقيق التي يقوم بها المدعي العام أي مرحلة التحقيق

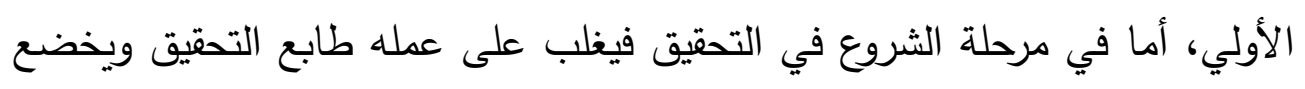
لإشراف قضائي للدائرة التمهيدية على الإجراءات منها إجراءات الحصول على الإذن بالتحقيق والإذن بالتوقيف. ويقرر المدعي العام اتخاذ قرار بالثروع في التحقيق بناء على تلك المعلومات. وذلك في حالة إذا ما وافقت الدائرة التمهيدية ليقوم المدعي العام بالبدء بالتحقيق وطلب حضور أطراف الدعوى والثهود لجمع كافة ما يلزم من أدلة (). وهذا التقدير يستند إلى نص (المادة به/1/) من النظام الأساسي للمحكمة الجنائية الدولية التي تجيز للمدعي العام والدائرة التمهيدية لهما الثروع في التحقيق ولمجلس الأمن أن يطلب من الدائرة التمهيدية مراجعة قرار المدعي العام برفض المعلومات

( () د. الثلقاني، أحمد شوقي(r . r). مبادئ الإجراءات الجزائية في التشريعات الجزائري، الجزء الأول الطبعة

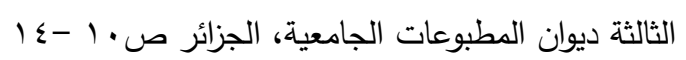
(r)

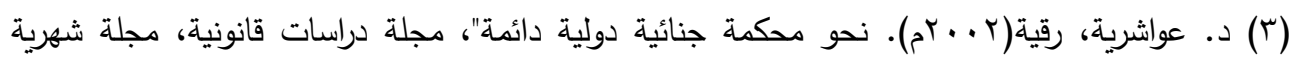

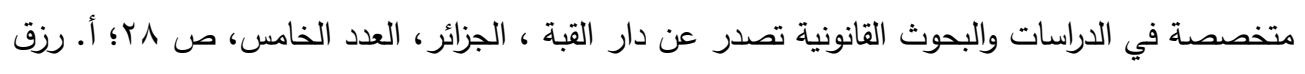

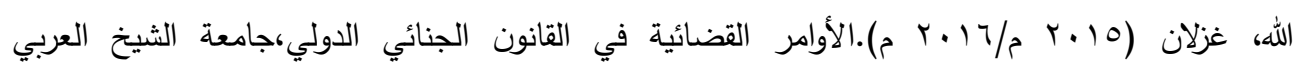

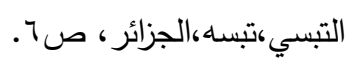


r.r. · مجلة روح القوانين - العدد الواحد والتسعون - إصدار يوليو

الاستدلالية المقدمة وعدم تحريك الدعوى الجنائية بناء عليها وفي ذلك نوع من الاستقلال

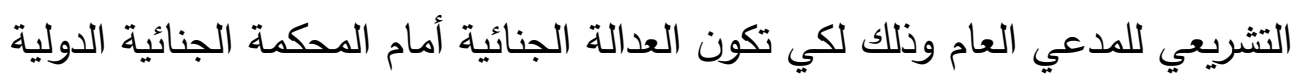
مستقلة.

r-عدم نص على حق المجني عليه في الثـــكوى وعدم النص على وســـائل تقديمه

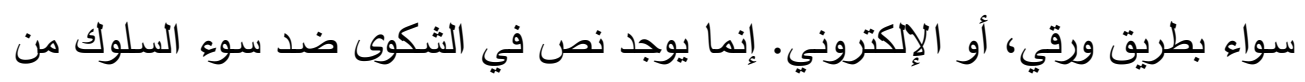

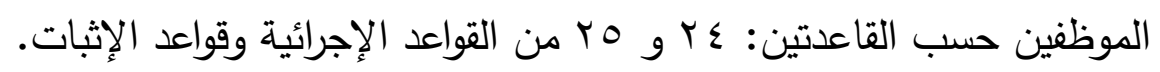

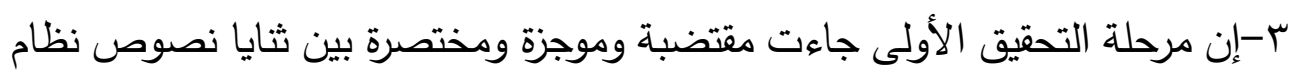
روما. والقاعدة يجب أن يتبع الددعي العام في إجراءات التحقيق الأولي الشرعية

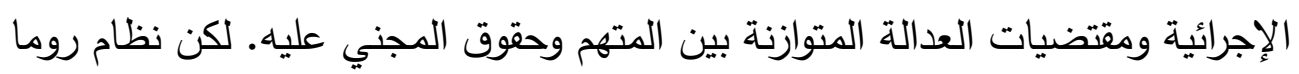

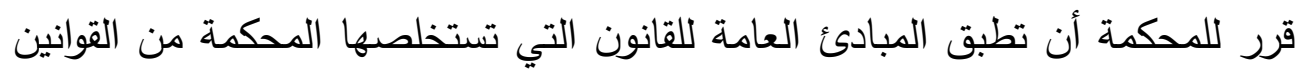

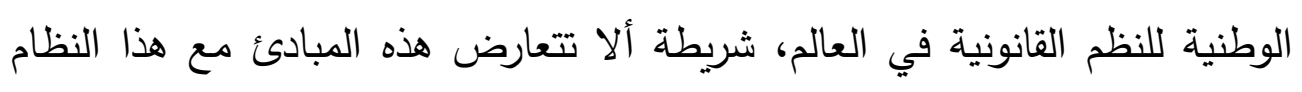

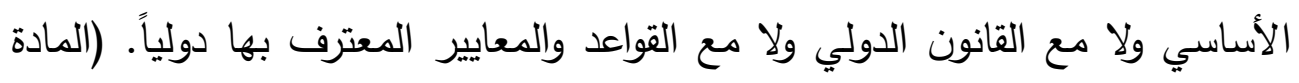

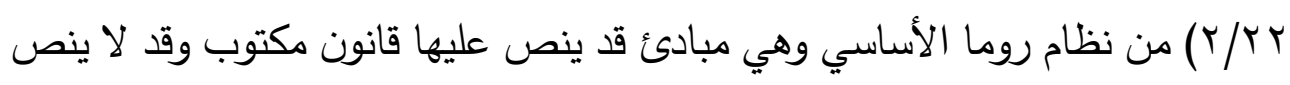

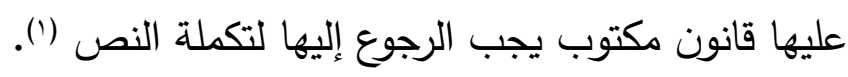
ع-يختص مكتب المدعى العام بجمع التحريات عن الجرائم الواردة في النظام الأساسي.

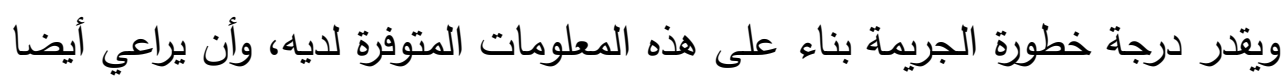

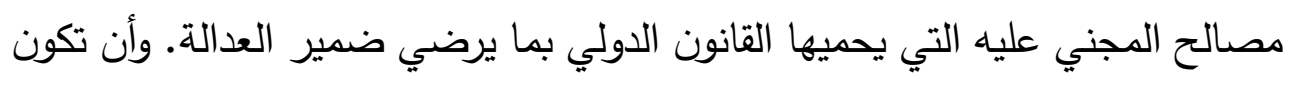

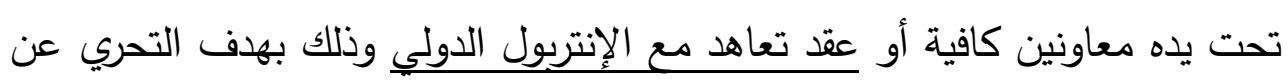

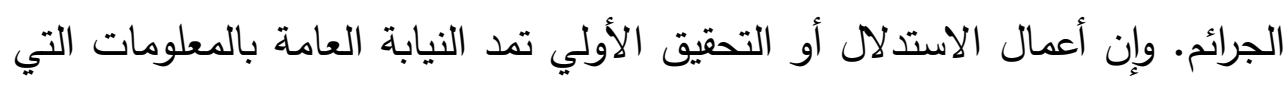

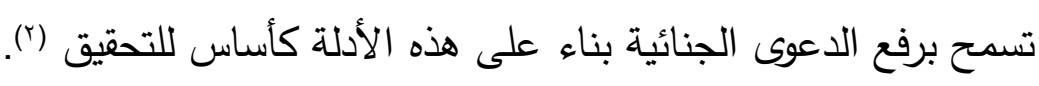

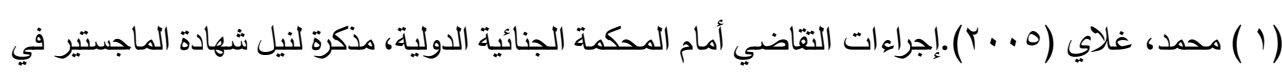

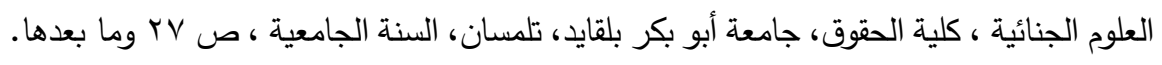

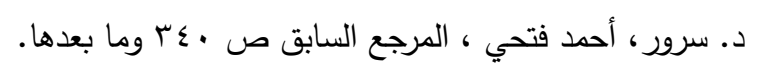


ه-يجب قبول البلاغات والثكاوى التي تصل إلى مكتب المدعي العام، لأن هذا العمل

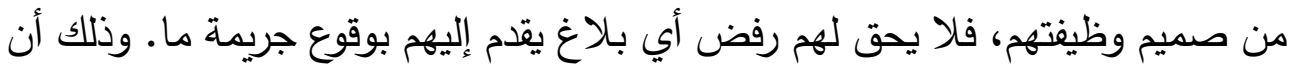
مكتب المدعي العام هو الجهة المختصة صاحبة الصلاحية في فحص البلاغات ومعرفة

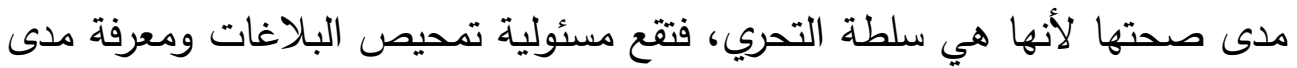
صدقها أو كذبها على عاتقهم. 1-يجب توظيف شبكة الإنترنت في جمع المعلومات في التحقيق الأولي من المدعي

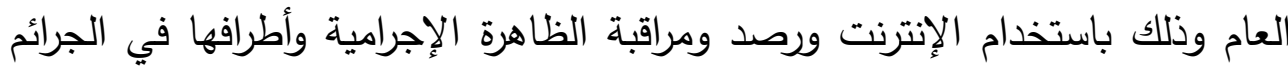

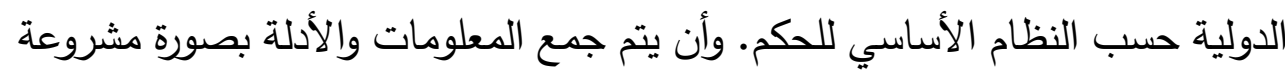

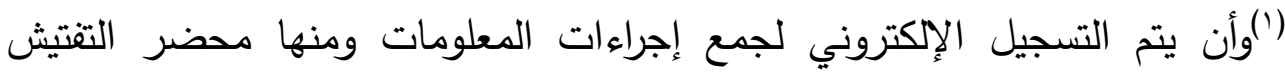
والمعاينة ومحضر الضبط وموجز البلاغ والمرافقات والرسم التوضيحي لمسرح الحادث حتى يجري كل منها بشكل مستقل (†). وذلك بإنشاء مواقع يتم من خلالها التقديم

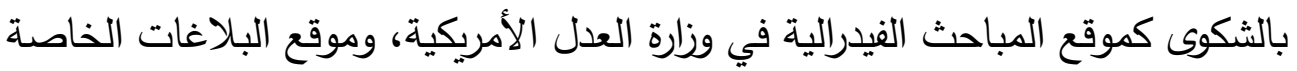
بالمخابرات المركزية الأمريكية خصوصاً الضعفاء من الحماية الضرر عدم به النفسي في كافة مراحل جمع الاستدلال والتحقيق والمحاكمة.

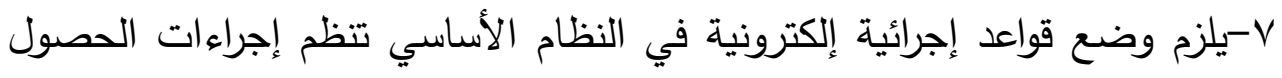

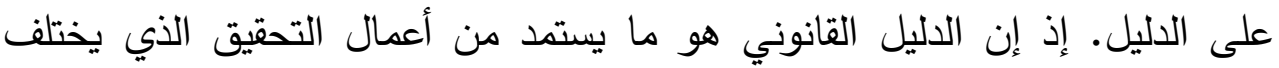

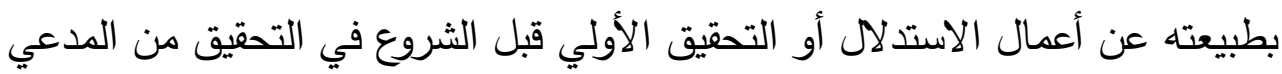

( (1) القحطاني، سعيد ظافر ناجي(ع · . بم). الضوابط المهارية في محاضر جمع الاستدلالات وآثرها في توجيه

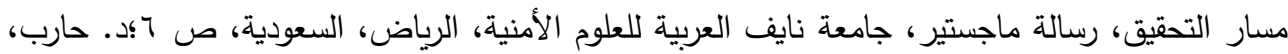

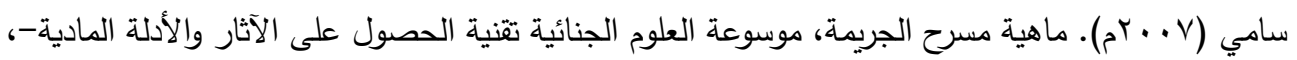

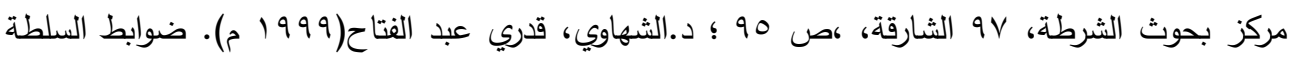

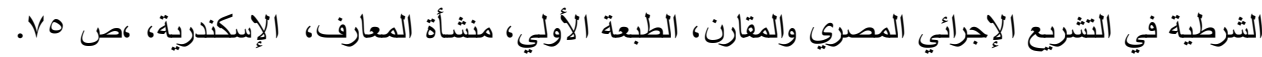
Roberta Julian, Sally Kelty and James Robertson,- r. Ir - "Get it right the first time " : Critical Issues at the Crime Scene, CURRENT ISSUES IN CRIMINAL JUSTICE VOLUME $r \leq$ NUMBER ।, JULY,p $Y$.

Janet Reno,- , 1999- Crime Scene Investigation, A Guide for Law Enforcement, US Department of Justice, ( $Y$ ) Office of Justice Programs, National Institute of Justice, copyright PhotoDisc, In, p r r 
F. r. · مجلة روح القوانين - العدد الواحد والتسعون - إصدار يوليو

العام التي لا يتولد عنها أدلة بالمعنى القانوني، ولا يجوز أن يكون محضر الاستدلال سنداً للقاضي في الحكم، إلا في الحالات التي حددها القانون.

\section{المبحث الثالث}

\section{حق الجنبي عليه في تحريك الدعوى الجنائية أهام أجهزة المكمة الجنائية}

\section{الدولية}

أولا: تعريف التحقيق: التحقيق في اللغة: حقيقة الثيء ومنتهاه يقينا (').وفي اصطلاح

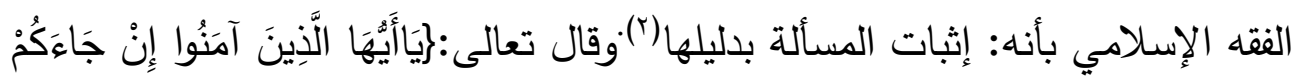

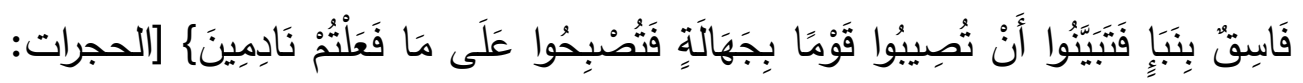

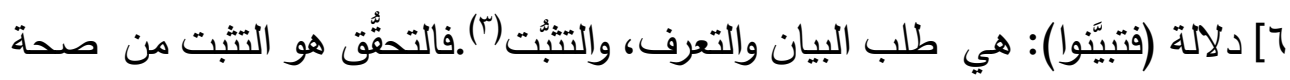

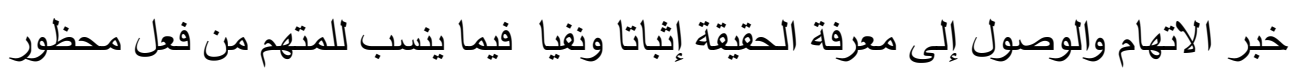
شرعا مما يترتب عليه حد،أو قصاص،أو عقوبة تعزيرية بما يؤكد التهمة أو ينفيها (؛). والأصل وجوب التحقيق على كل مسلم ووجوب بناء أحكام الإدانة على الجزم واليقين لا على الظن والتخمين حتى يكون الإنسان على بصيرة من أمره وهذا أمر شرعيا لنا

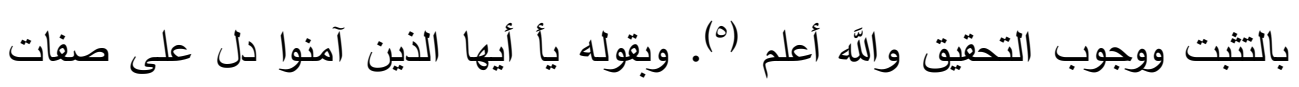

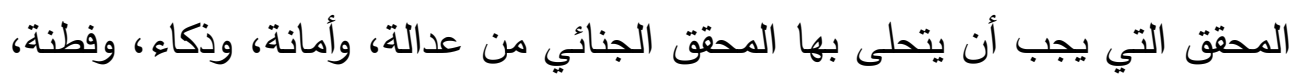

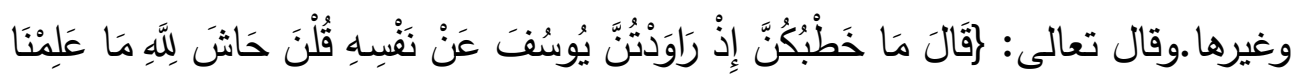

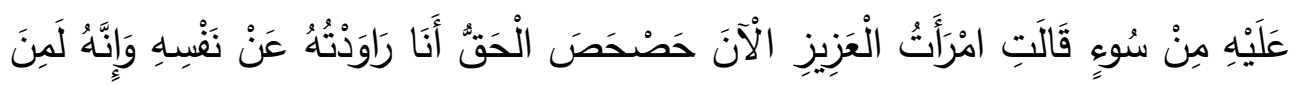

$$
\text { (1) أحمد محمد الفيومي، قاموس اللغة "كتاب المصباح المنير"، نوبليس، الجزء الثاني، ص1919 ا. }
$$

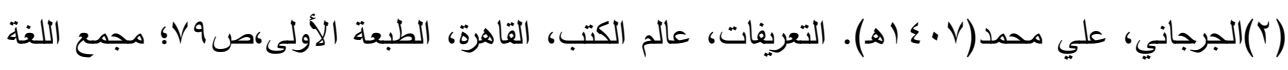

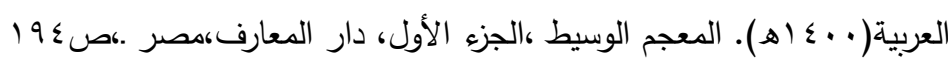

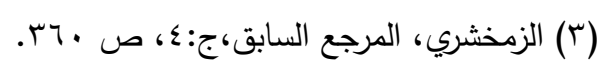

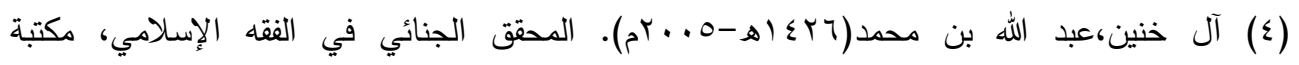

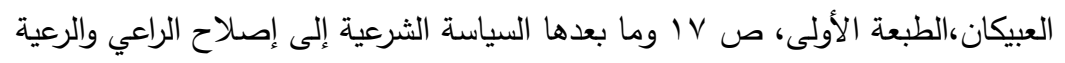

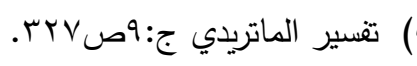


الصَّادِقِينَ \{ [يوسف: 10] دلاة الآية وجوب التحقيق واستجواب الخصوم لبلوغ الحقيقة وشرع من قبلنا شرع لنا وقد قام بالتحقيق الملك وبدأ بهن حتى أقررن أنه كان برييًا ما

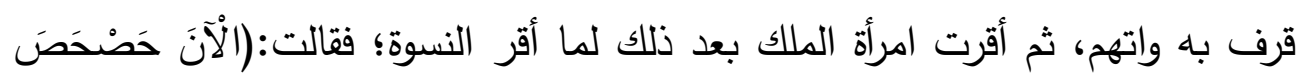

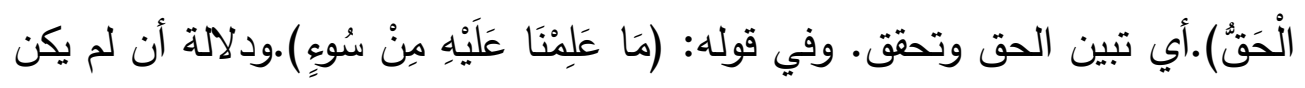
منه ما قاله أهل التأويل من حلّ السراويل وغيره؛ لأنه لو كان منه ذلك لَكَنَّ قد علمن منه السوء (').أما في الاصطلاح القانوني فهو مجموعة الإجراءات والأعمال التي يقوم بها المحقق، لجمـع الأدلـة والبيانـات اللزمـة لكثف الجرائم، والتعرف على مرتكبها والقبض عليه تمهيدا لمحاكمته(r).و مجموعة الإجراءات والأعمال التي يقوم بها المحقق في ضوء ظروف القضية والمقدرة والخبرة الشخصية لـه لكثف الجريمـة وإثبات نسبتها وفق أحكام القانون(r) فقد تعددت التعريفات الفقهية للتحقيق الابتدائي إلا أنها لا تخرج عن تعريفه بأنه: هو مجموعة الإجراءات القضائية التي تقوم بها سلطة التحقيق(المدعي العام) من أجل جمع الأدلة لجريمة معينة وإثبات نسبتها لفاعل معين بالثكل المحدد قانونا ليتم بعدها إجراءات المحاكمة لعرضها أمام القضاء للفصل فيها ().لذلك فإن التحقيق لازم ولا غنى عنه في القضايا الجنائية، إذ لا يجوز بأي حال

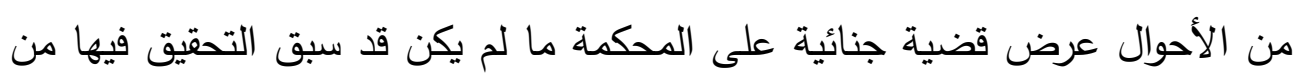

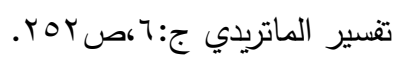

(Y) سراج الدين، كمال(T00 (1) هـ) لقواعد العامة للتحقيق الجنائي وتطبيقاتها في المملكة العربية السعودية،

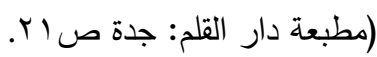

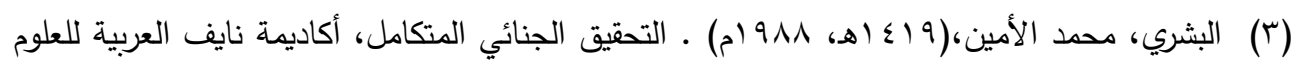

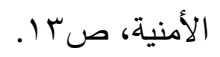

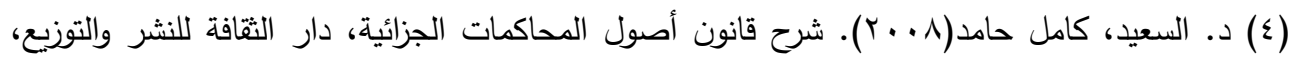

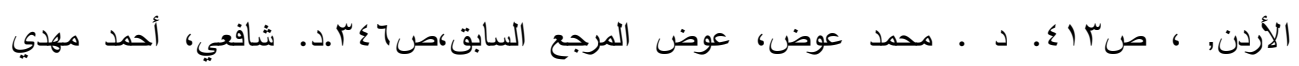

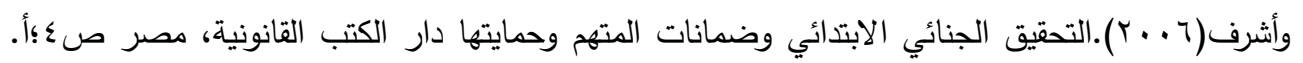
رزق الله، غزلان ،المرجع السابق،صآ؟. د.صبحي،نجم محمد،الوجيز في قانون أصول المحاكمة الجزائية،دار

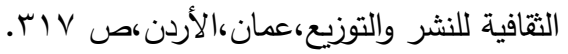


r. r · مجلة روح القوانين - العدد الواحد والتسعون - إصدار يوليو

قبل قضاء التحقيق، خصوصاً أن الجرائم الدولية من الجنايات الكبرى، وقد ورد في

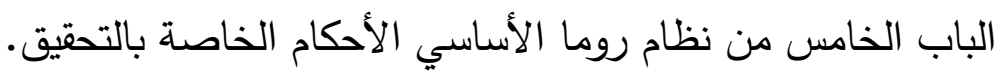

\section{ثانيا: تمييز هرحلة ها تبل الشروع في التحقيق عن التحقيق الابتدائي: توجد ثلاثة}

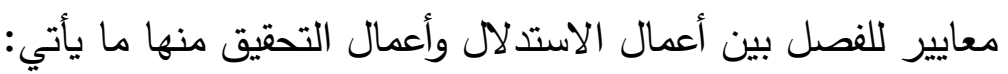
*-معيار النظر إلى غاية الإجراءات: يستهدف التحقيق الكثف عن الحقيقة وتقديم

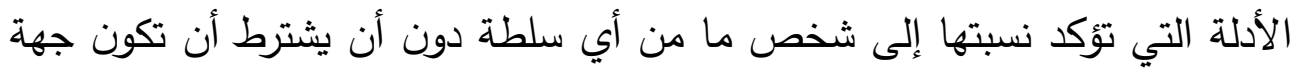

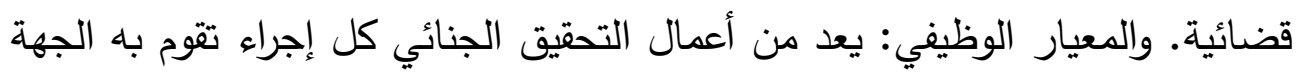

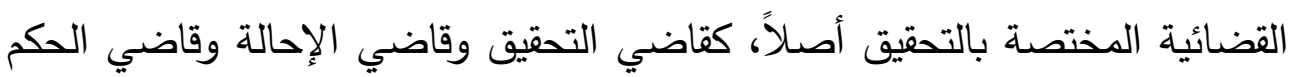

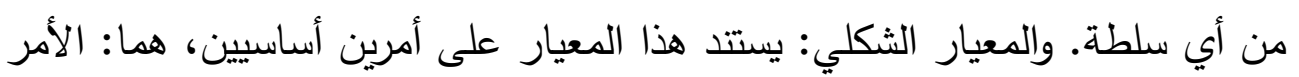

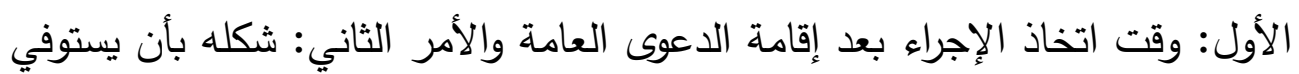

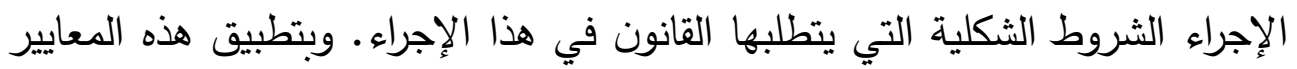
على مرحلة ما قبل الشروع في التحقيق يتبين ما يأتي: 1-إن التحقيق الأولى يأتي قبل أن تتحرك الدعوى الجنائية الدولية فعليا لذا يعد التحقيق لئين

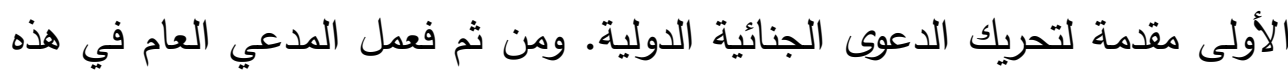

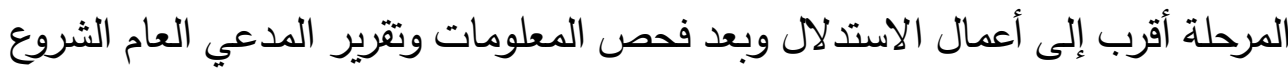

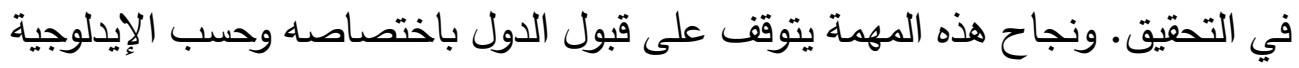

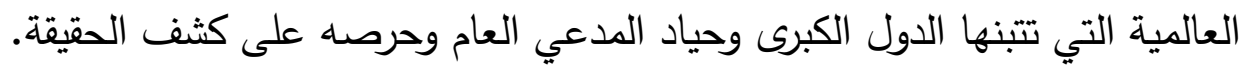
r-يظهر أن اتصال المدعي العام بالجريمة موضوع التحقيق الأولي قد يكون تلقائية

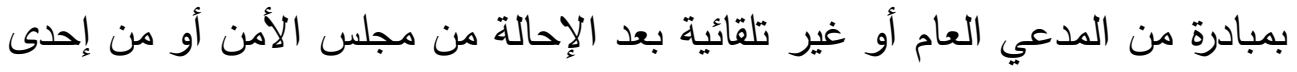

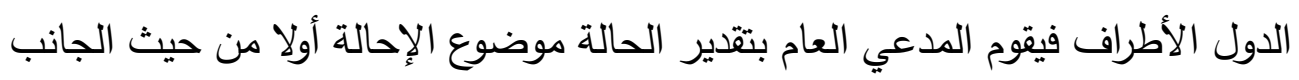

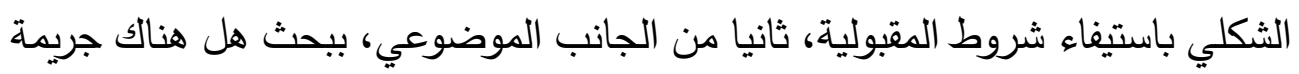
وقعت تدخل في اختصاص المحكمة ومدى توافر أركانها وإسنادها لفاعلها وأدلة ثبوتها. r-تحري المدعي العام، يقوم الددعي العام بتحقيق يوصف بأن تحقيق أولي ويتميز

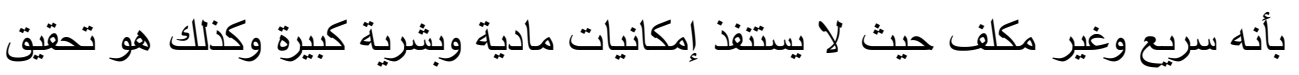




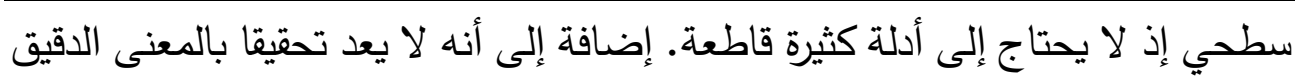

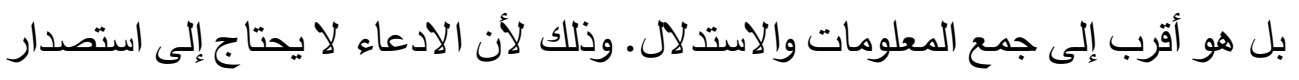

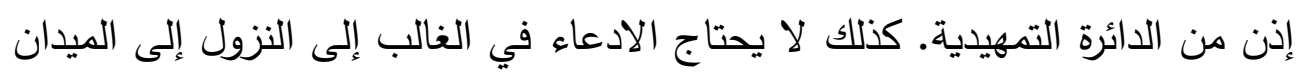

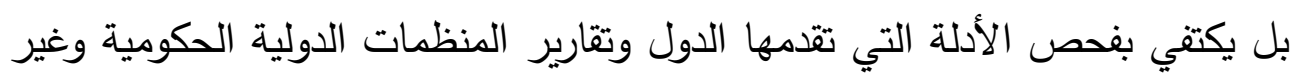
الحكومية وحتى بلاغات الأفراد وذلك للتأكد من جديتها ووجود أساس كاف للمقاضاة.

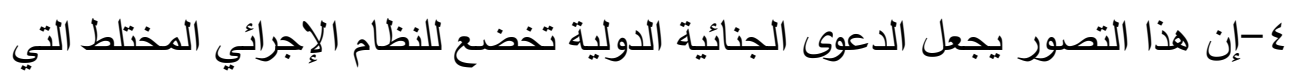

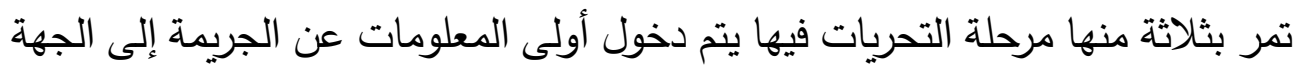

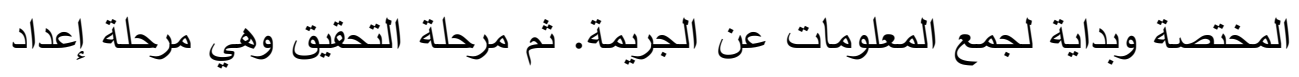

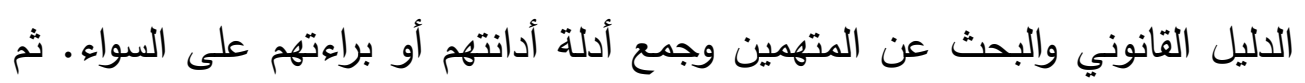

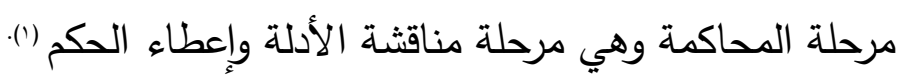

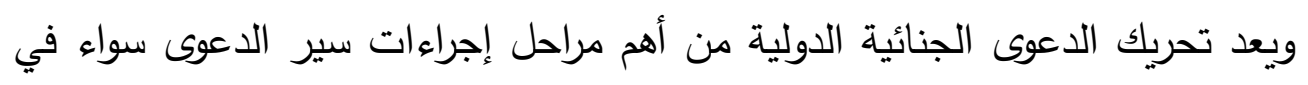

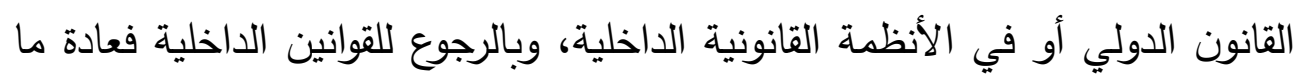

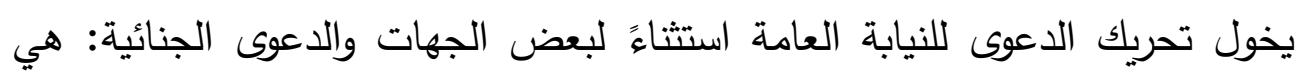

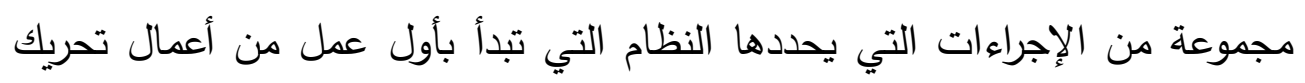

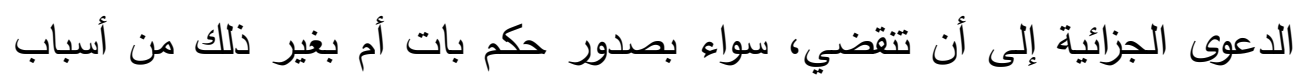

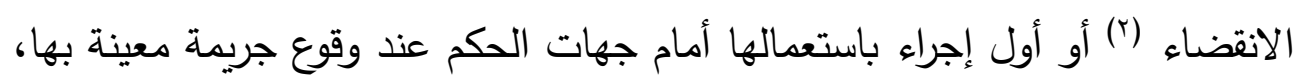
حتى صدور حكم نهائي فاصل في موضوع الدعوى سواء بالإدانة أو بالبراءة ("). لإقرار مدى ما للمجتمع من حق في معاقبة المتهم بارتكاب الجريمة وتوقيع الجزاء الجنائي

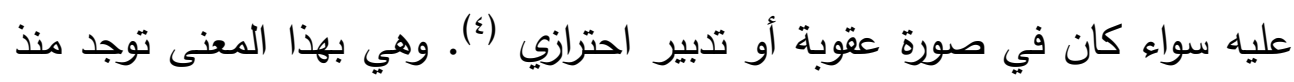
اللحظة التي تقع فيها الجريمة، ولا يتوقف وجودها على مباشرة أي إجراء فيها، ويستند

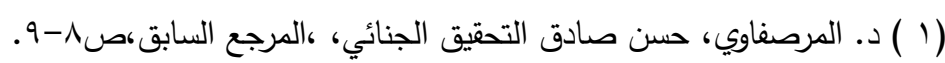

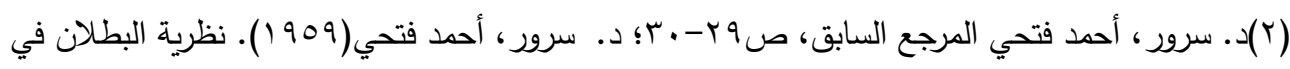

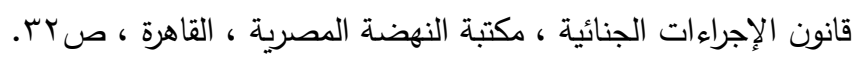

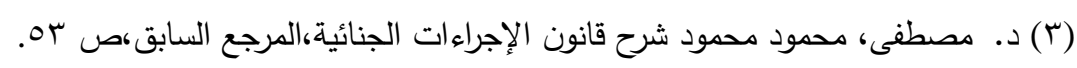

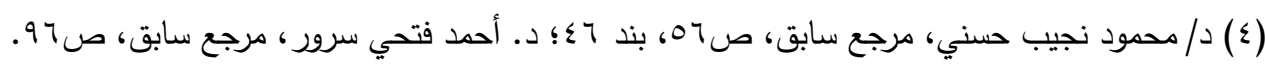
Garaud,V.R, Traité théorique et pratique d'instruction criminelle et de procédure pénale .Tome $1, n^{\circ} \vee V, p^{\prime 71}$. 


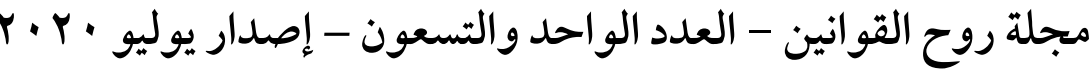

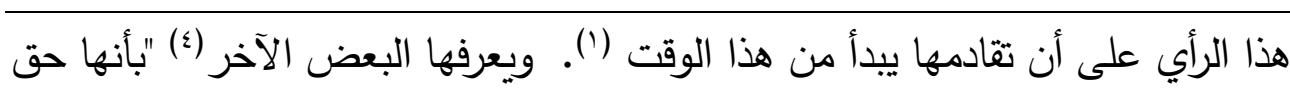

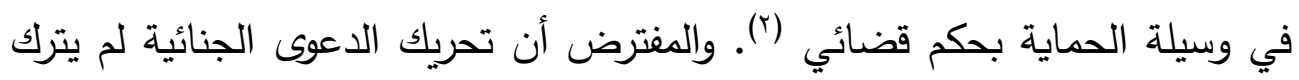

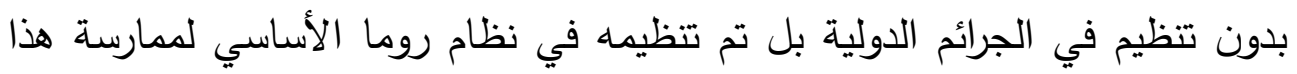

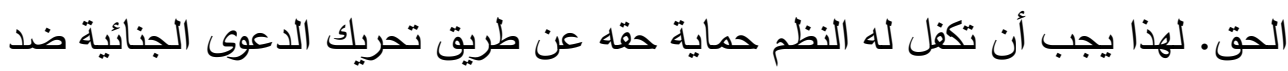

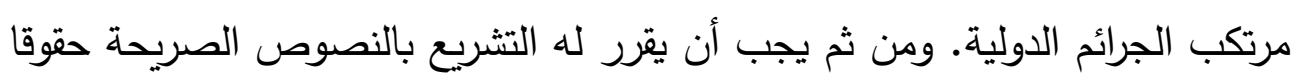

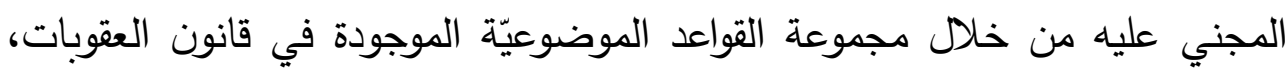

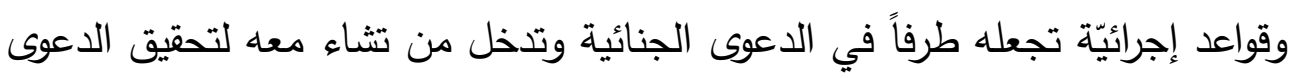

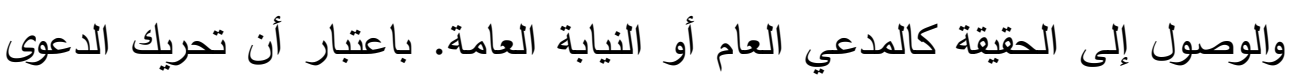

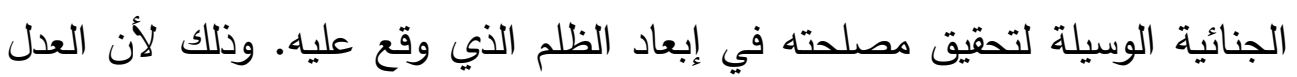

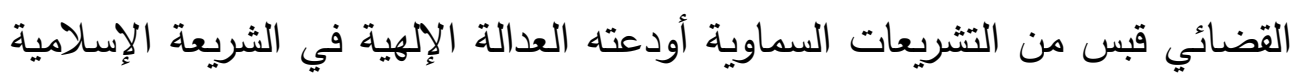

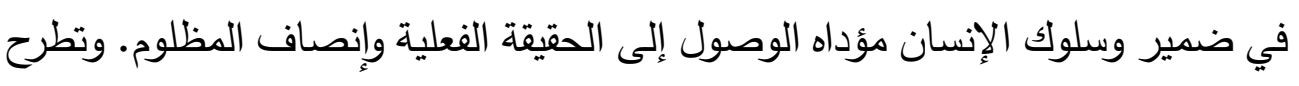

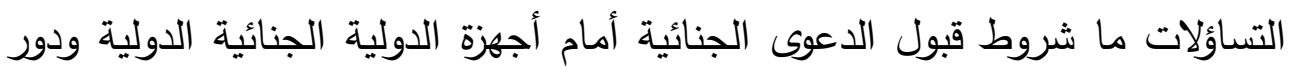

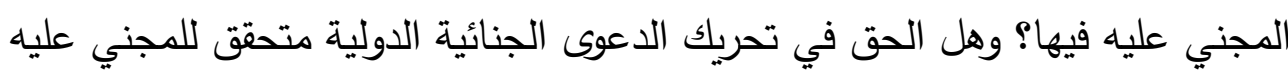

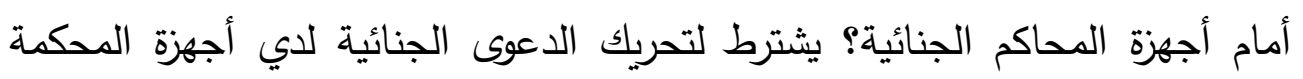

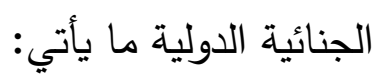

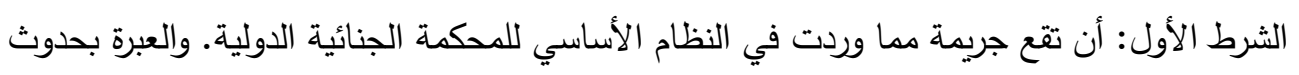

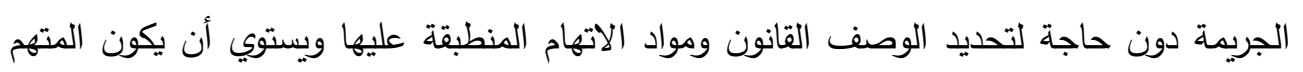

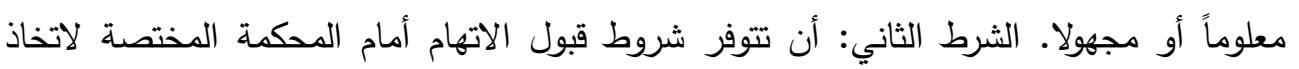
الإجراءات القانونية. من له الحق في تحريك الدعوى أمام المحكمة الجنائية الدولية الدائمة؟ وما آليات الدات الدان

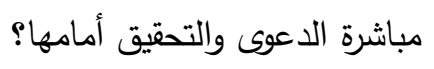

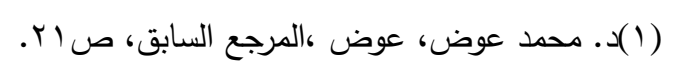

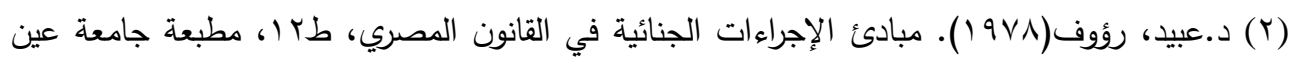
شمس، القاهرة ، صهץ. (r). 


\section{الإطب الأول \\ وقوع جريمة دولية تدخل في اختصاص المكمة الجنائية الدولية وأثرها على حقوق \\ الجنبي عليه}

يعد من الثروط التي يتوقف فيها تحريك الدعوى الجنائية لدى أجهزة المحكمة الجنائية الدولية، هو وقوع جريمة دولية تدخل في اختصاص المحكمة الجنائية الدولية. إذ يقتصر اختصاص المحكمة على أشد الجرائم خطورة موضع اهتمام المجتمع الدولي بأسره، وللمحكمة بموجب هذا النظام الأساسي اختصاص النظر في الجرائم التالية: جريمة الإبادة الجماعية والجرائم ضد الإنسانية، جرائم الحرب، جريمة العدوان (المادة 0 من نظام روما الأساسي). وهذا يقتي تحديد مفهوم الجريمة الدولية وتحديد خصائصها وتحديد وصفها وصفا دقيقاً من جهة الإحالة وجهة التحقيق. وذلك كما يأتي: أولا: تعريف الجريمة الدولية: الجريمة الدولية هي كل مخالفة للقانون الدولي، سواء كان يحظرها القانون الوطني أو يقرها تقع بفعل أو ترك من فرد محتفظ بحريته في الاختيار ومسئول أخلاقيا إضرارً بالفرد أو بالمجتمع الدولي، بناء على طلب الدولة أو تشجيعها أو رضائها في الغالب ويكون من الممكن مجازته وفقا للقانون (ז).كما قيل إن الجريمة الدولية هي: الأفعال

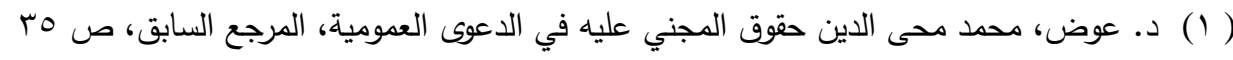

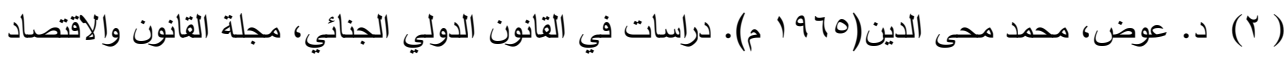

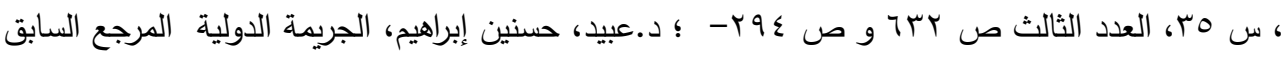

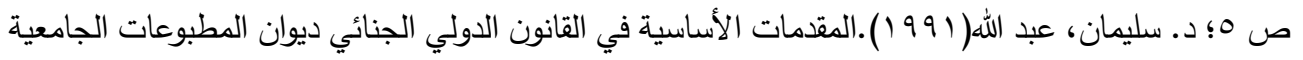

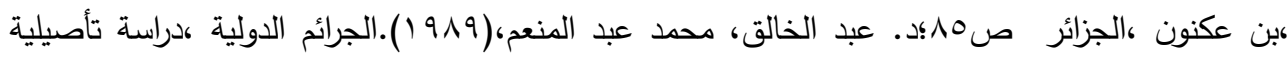

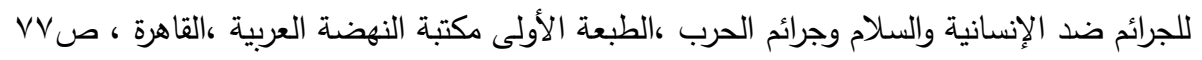




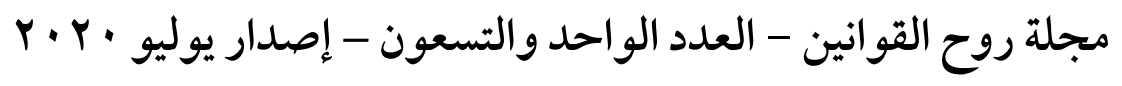

التي ترتكبها الدولة أو تسمح بارتكابها مخالفة بذلك القانون الدولي (1).الجريمة الدولية هي: كل فعل أو ترك تقابله عقوبة وتتفذ باسم الجماعة الدولية (؟).

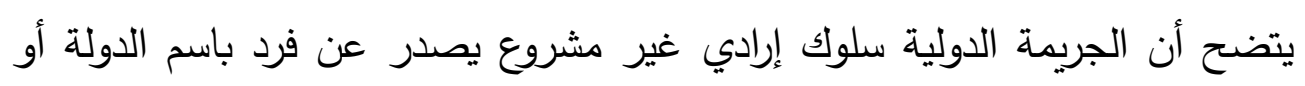

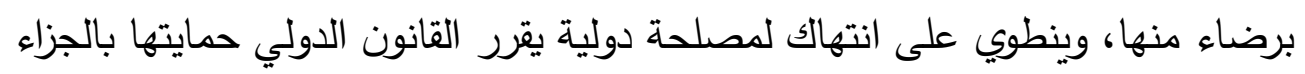

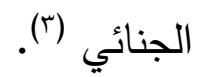

\section{ثانيا: خصائص الجرائم الدولية وحقوق الجني عليه:}

تتميز الجريمة الدولية بخصائص منها:

ا-الجسامة والخطورة: هذه الجرائم بحد ذاتها تشكل الخطر الجسيم على النظام العام

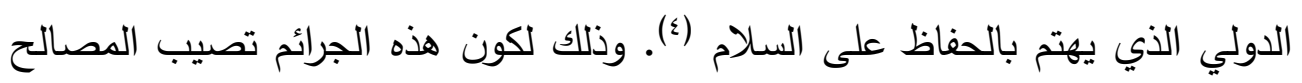
الدولية أو الأساسية الكبرى بضرر يمنعه كل من العرف الدولي والقانون الدولي الجنائي.

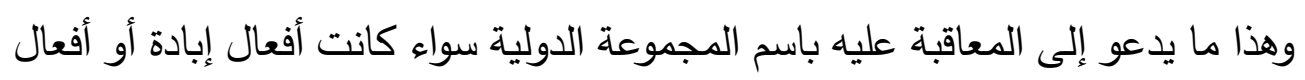

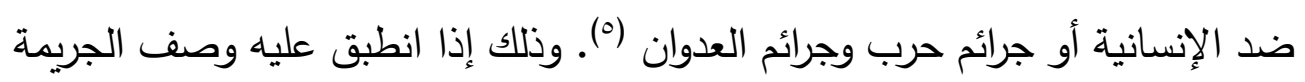

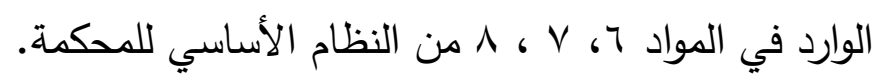

( (1) مطر، عصام عبد الفتاح(· ( (Y). الدكمة الجنائية الدولية، دار الجامعة الجديدة للنشر ، الإسكندرية،

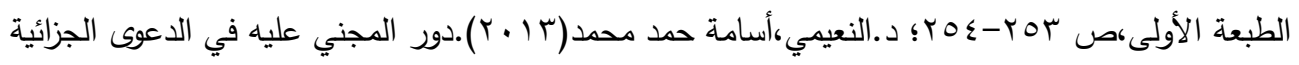

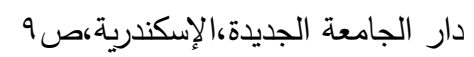
.Glasser L'infraction internationale Ses éléments constitutifs, et ses aspects juridiques . Paris . L.G.D.J. P । Vespasien pella: la Criminalité Collective des états et le droit pénal de l'avenir. reme éditions, ( $r$ ) Bucarest $\left.\left.19 Y^{4} \mathrm{n}\right) \cdot 9, \mathrm{p}\right) \mathrm{V}$ ( ( ) د. الشاذلي، فتوح(r . . r). القانون الدولي الجنائي، أولويات القانون الدولي الجنائي، النظرية العامة

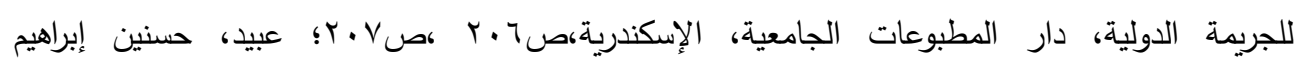

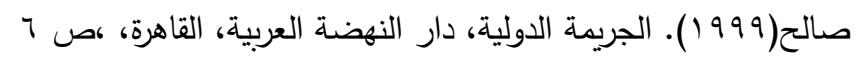
( ع ) د. عثمان، أحمد عبد الحكيم(9 . ؟). الجرائم الدولية في ضوء القانون الدولي الجنائي والثربعة الإسلامية،

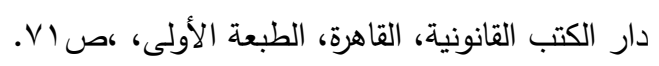

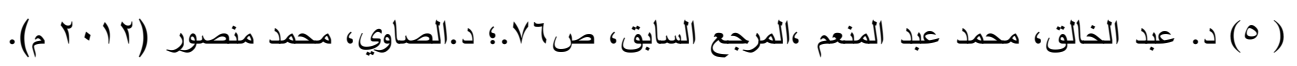
أحكام القانون الدولي المتعلقة بمكافحة الجرائم ذات الطبيعة الدولية، دراسة في القانون الدولي الاجتماعي في مجال مكافحة الجرائم الدولية للمخدرات وإبادة الأجناس واختطاف الطائرات وجرائم أخرى دار المطبوعات 


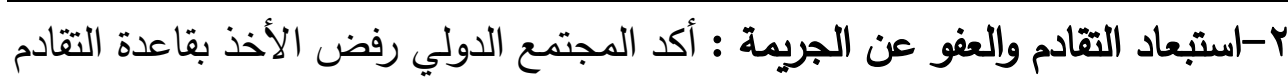

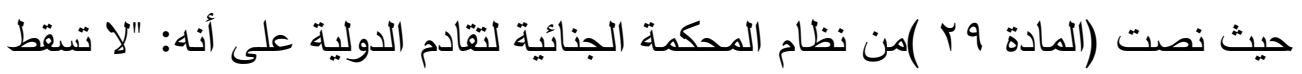

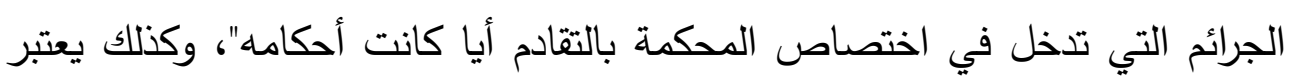

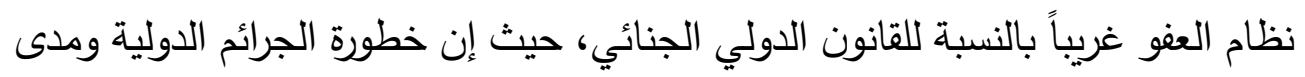

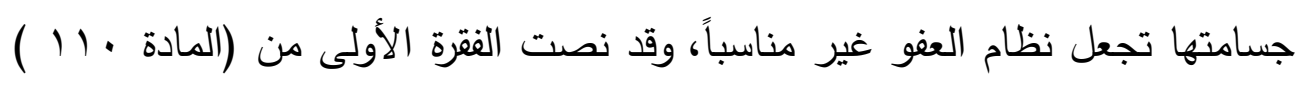

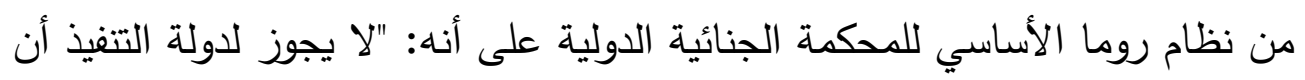

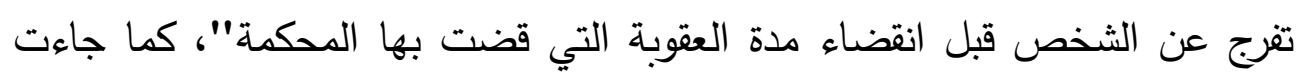

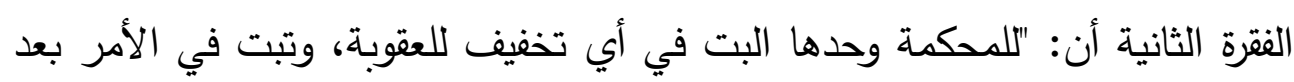

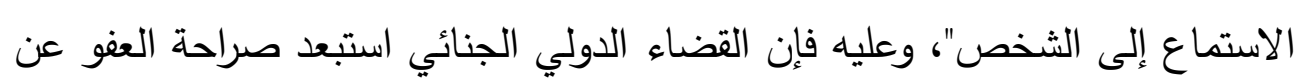

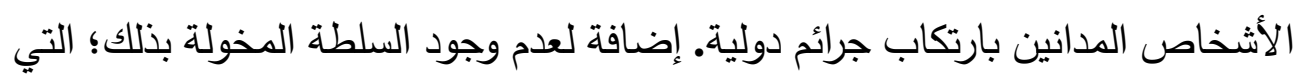
يكون لها الحق في إصدار قرارات العفو، كالعفو الخاص الذي هو من اختصاص الداص رئيس

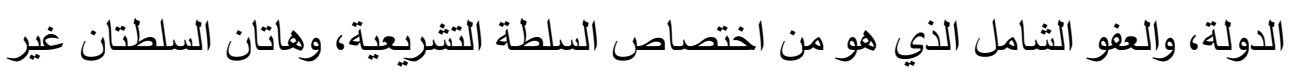
موجدتين في التنظيم الدولي (1).

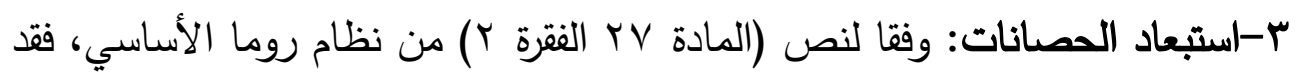

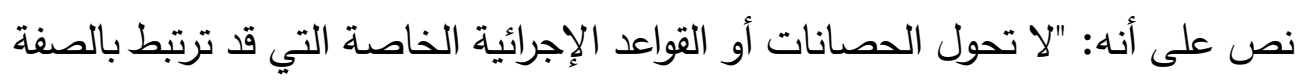

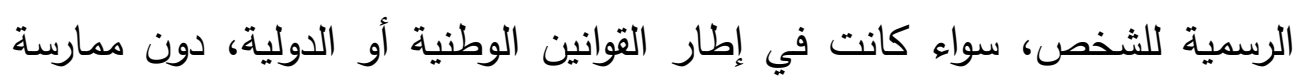

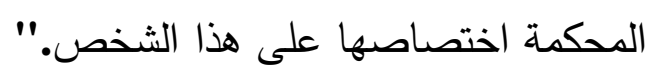

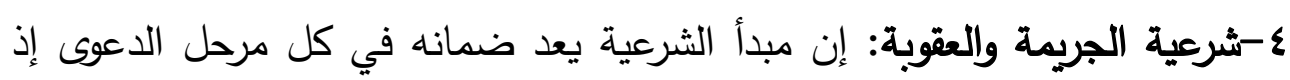
يجب تجريم الأفعال التي تثكل العدوان على حقوق المجني عليه ويكفل للمتهم محاكمة

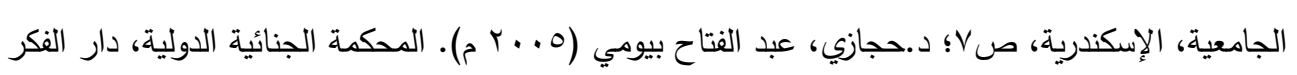

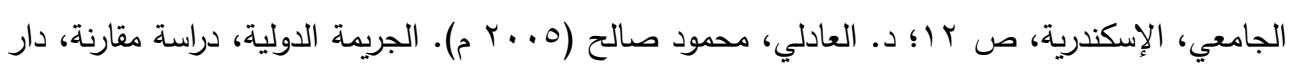

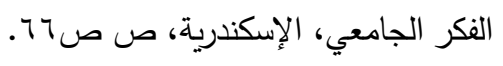

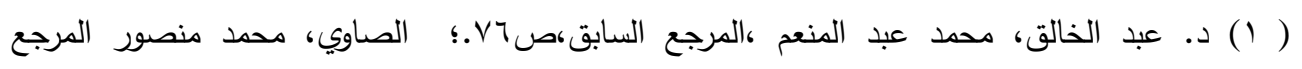

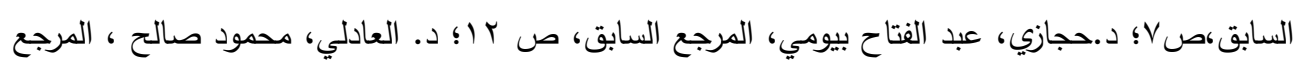


F. r. · مجلة روح القوانين - العدد الواحد والتسعون - إصدار يوليو

عادلة، لحمايته من تعسف القضاء عن طريق رسم الحدود القانونية لمختلف الإجراءات والجرائم والعقوبات. فإذا كان هناك فراغ تشريعي في عدم تجريم الجرائم الخطيرة التي

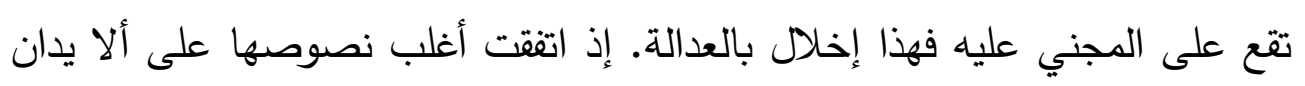

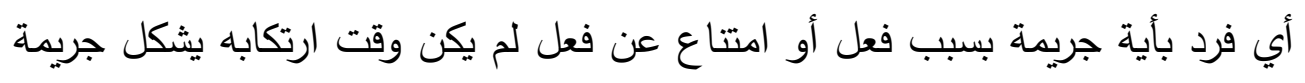
بمقتضى القانون الوطني والدولي وقد خضعت الجرائم الدولية أمام المحكمة الجنائية

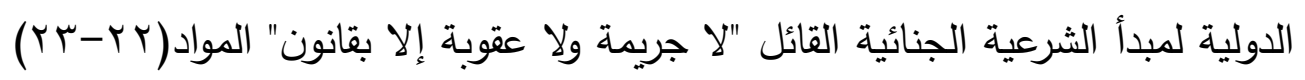

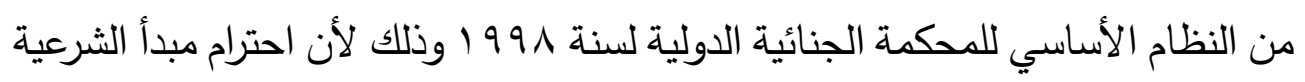

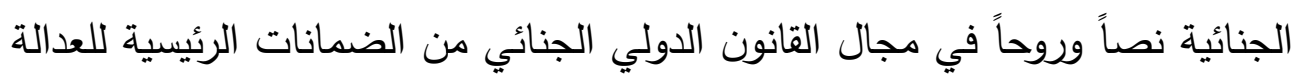
الجنائية للجاني فقد اجتمعت الآراء على وجوب تدوين نصوص النظام (").ويعاني مبدأ

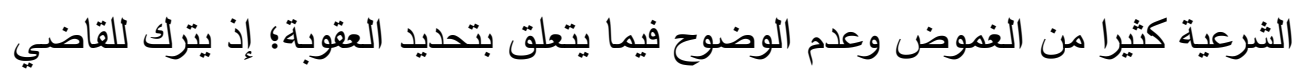
حرية كبيرة في اختيار العقوبة المناسبة على نحو لا يتماشى ومبدأ الثرعية الجنائية

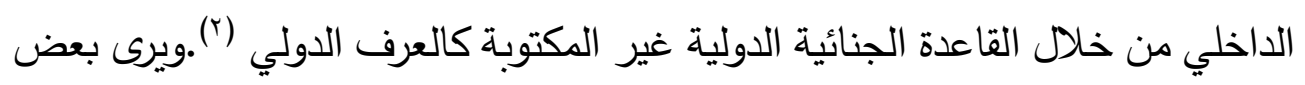

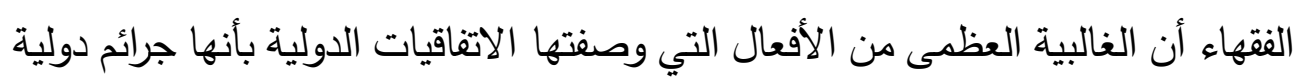

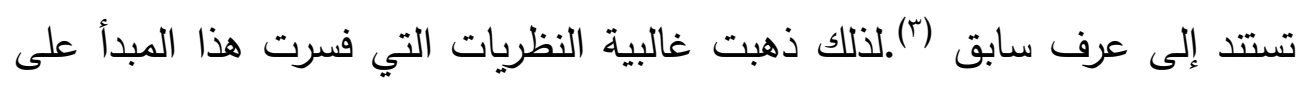

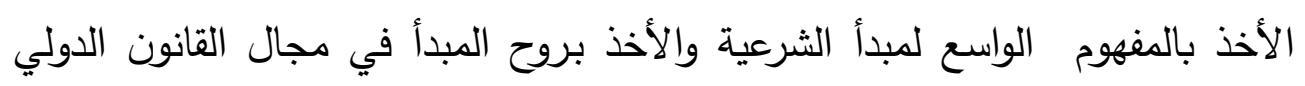

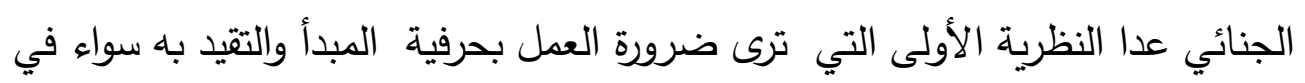

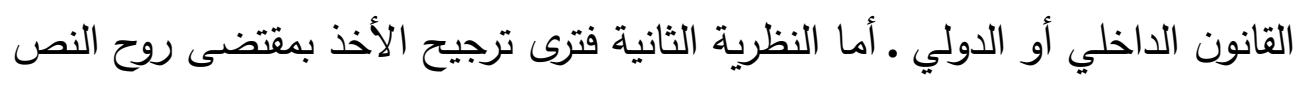

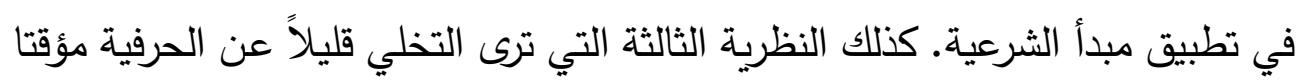

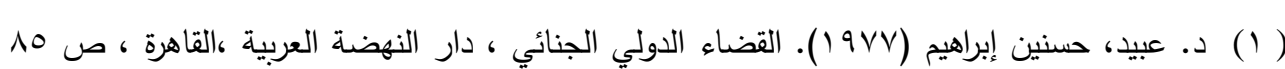

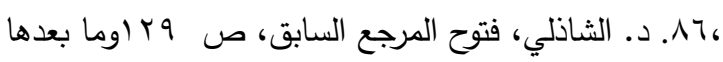

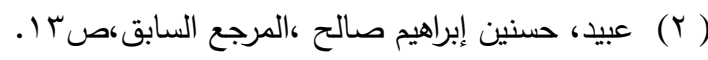

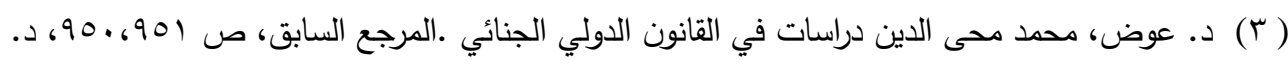

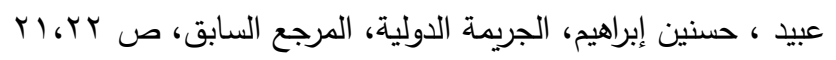


وذلك نظرا لحداثة القانون الدولي الجنائي وطبيعته العرفية المتطورة، وذلك حتى يتم

تتكامل نصوص هذا القانون حسب الفن القانوني (').

ه- الطابع الدولي: يظهر الركن الدولي للجريمة الدولية وذلك بوقوع الجريمة الدولية بناء على تخطيط مدبر من دولة أو من مجموعة الدول، وتتفذ الدولة الجريمة الدولية

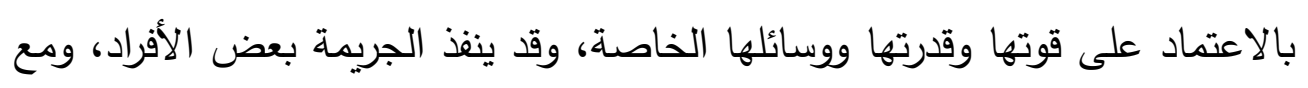
ذلك يتوافر للجريمة ركنها الدولي متى تصرف هؤلاء الأفراد باسم الدولة أو كانوا وكلاء عنها، سواء منحته منصباً عاماً أو فوضته عنها في عمل معين (r).ولا يشترط أن تكون تلك الأفعال من تحريض دولة أو تدبيرها حتى توصف بأنها جرائم دولية، إذ يكفي أن ترتكب ضد دولة ما، أو ضد هيئة محمية دولياً، أو ضد أشخاص محميين دوليين(ّ). وهناك اتجاه حديث نحو الاعتراف بالفرد العادي كشخصية دولية، وجعل هذه الجرائم تعد دولية حتى لو لم تقع بناء على خطة مرسومة من الدولة مثل: الجرائم المرتكبة في

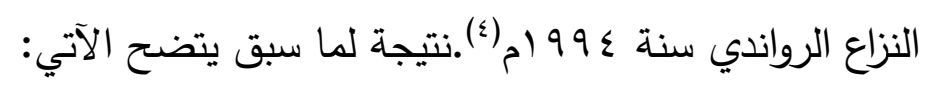
ا-عدم تغطية الجرائم الدولية لكافة سبل العدوان: فقد تم تضيق مفهوم الجريمة الدولية

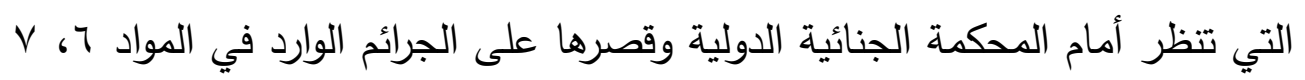
، من النظام الأساسي للمحكمة مما أدي إلى تضييق مفهوم المجني عليه وحماية حقوقه ومصالحه. وعدم التناسب بين قوة الدولة وآليات حماية المجني عليه. ץ-ركزت التعاريف في تقرر المسئولية الجنائية المزدوجة للفرد والدولة عن الجريمة الدولية. ولكن لم يقرر النظام الأساسي المسؤولية الجنائية عن الجريمة الدولية للأشخاص المعنوية. وإنما جعل المسؤولية الجنائية للشخص الطبيعي. وإن دور الدول لا يتعدى الإيل

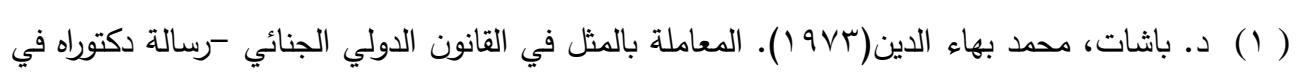

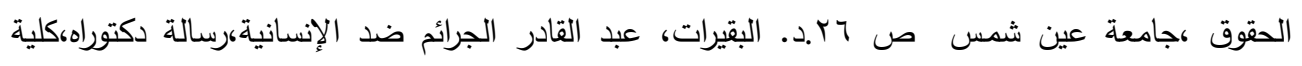

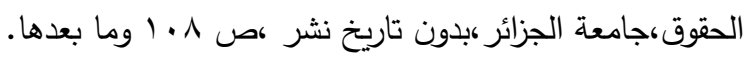

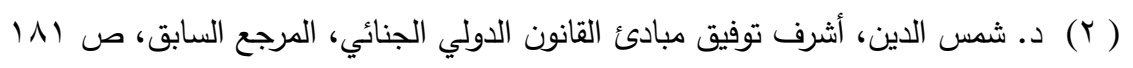

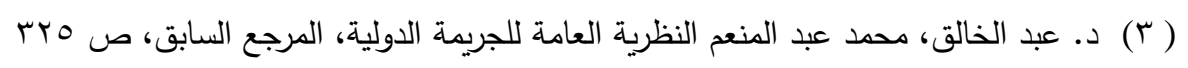

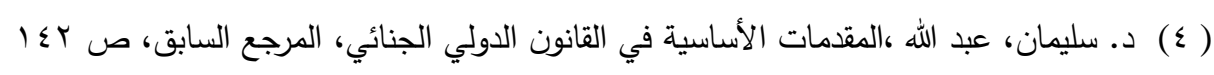




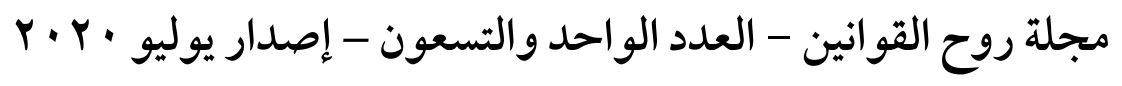

فيها دور الشريك- باعتبارها شخصا معنويا - وليست كفاعل أصلي يمكن محاسبته

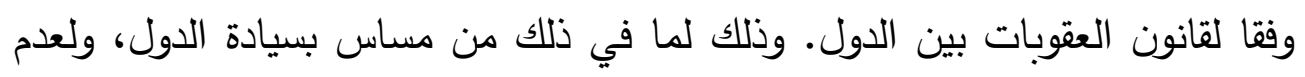

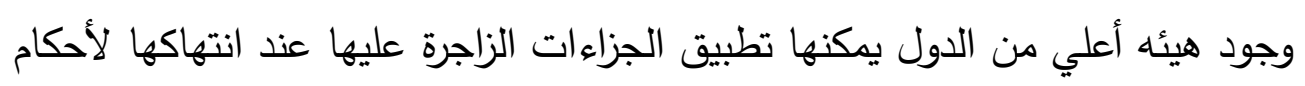

القانون الدولية.

r-نص النظام روما الأساسي للمحكمة الجنائية الدولية في المادة (YY) على إنه "..

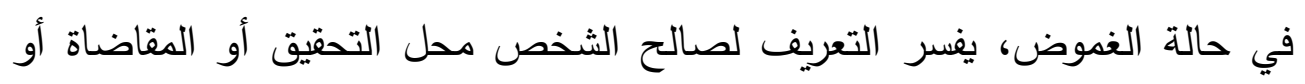
الإدانة.."

ثالثا: وقوع جريمة هن الجرائم الواردة في المادة الخاهسة الداخلة في اختصاص الماكيم

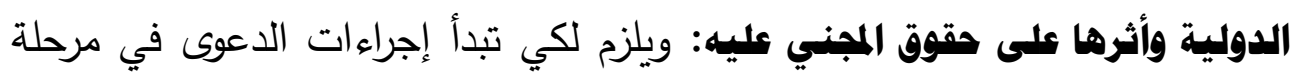

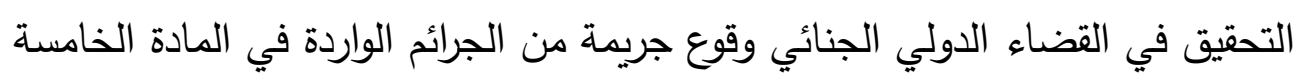

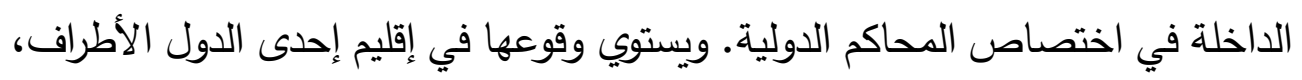
سواء كان المعتدي تابعا للدولة الطرف في النظام الأساسي أو كان تابعا لدولة أخرى.

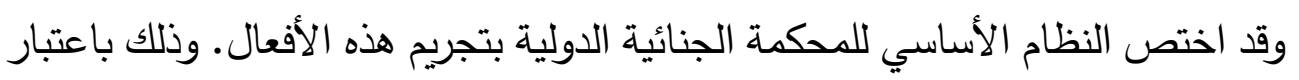

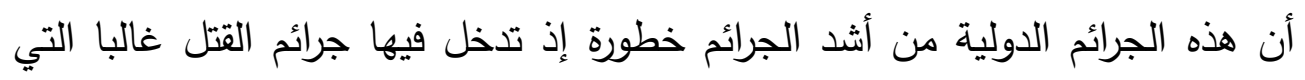
تنقض الحق في الحياة منها: جرائم الإبادة الجماعية، والجرائم ضد الإنسانية، وجرائم الحرب وجرائم العدوان.

ا-جريــة الإبـادة الجماعيسة: جريمـة الإبـادة، هي ارتكاب أعمال معينـة تمثلت

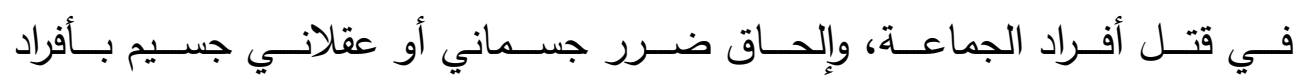

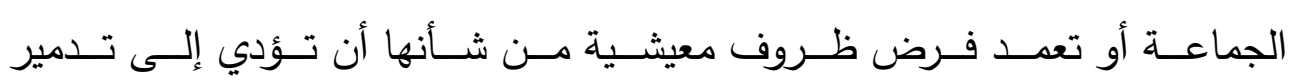

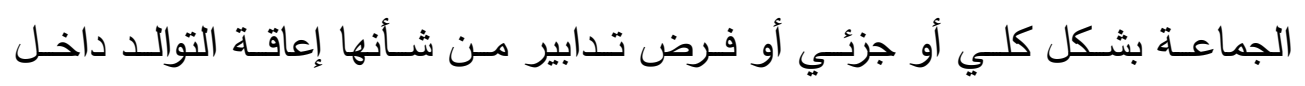

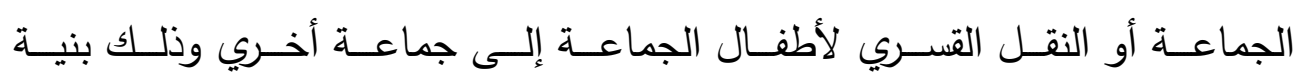

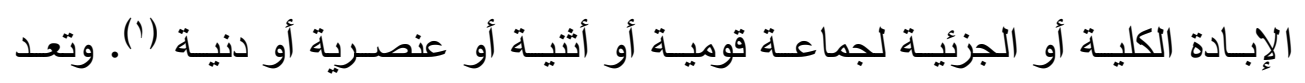

( (1). شبل، لندة معمرالمرجع السابق،صعی1)؛ شبل، بدر الدين محمد (1) (Y).القانون الدولي الجنائي

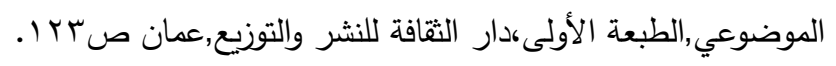




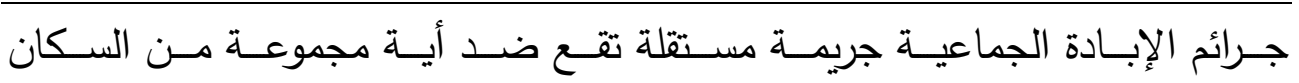

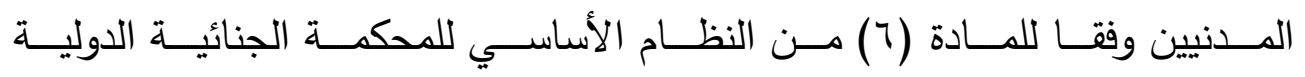

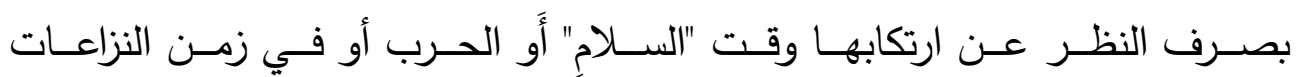
المسلحة ('). وتقوم الجريمة على ركنين هما:

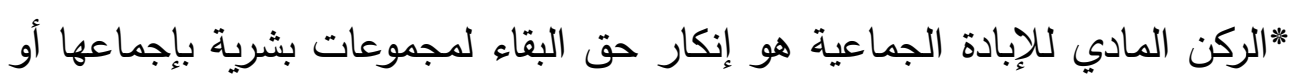
إخضاع الجماعة عمداً لأحوال معيشية صعبة. وذلك بقصد إهلاكها الفعلي كلياً أو جزئياً.

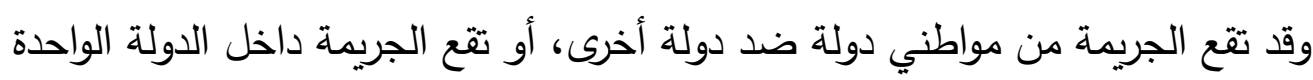

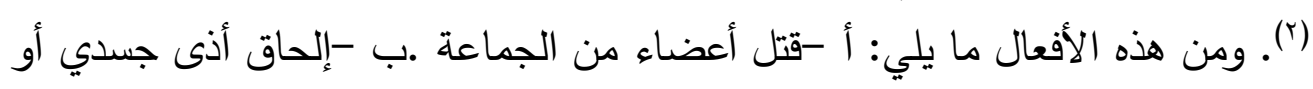

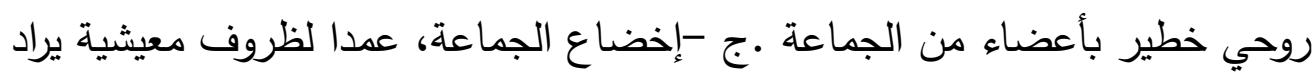
بها تدميرها المادي كلياً أو جزئياً .د -فرض تداعياء تهابير تستهدف الحؤول دون إنجاب أطفال داخل الجماعة .هـ -نقل أطفال من الجماعة عنوة إلى جماعة أخرى. وهذا الأفعال

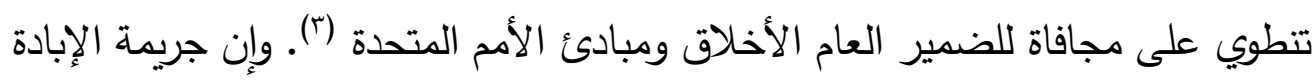

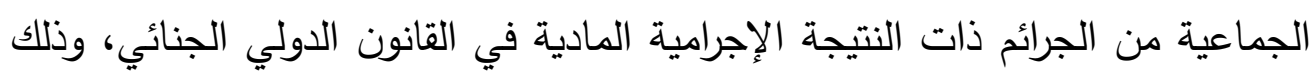

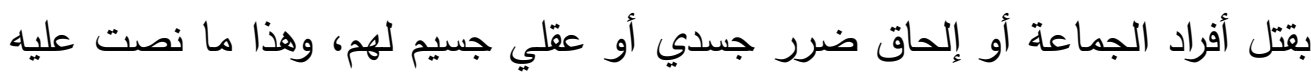

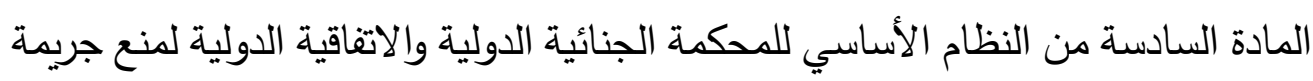

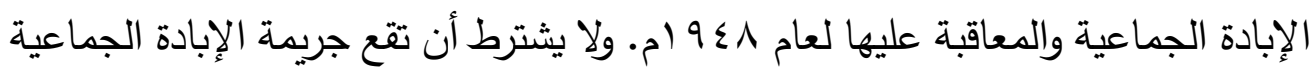

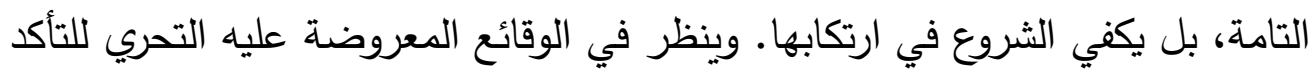

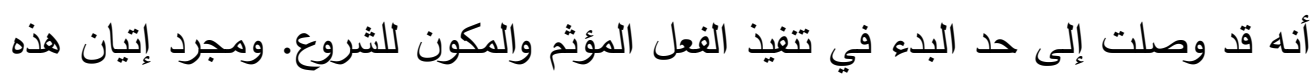

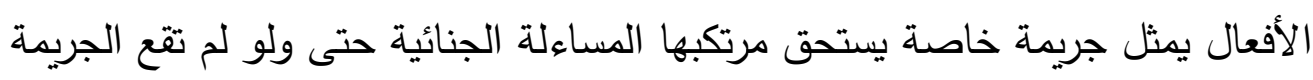

( (1)د. الوريكان، خليل عبد الفتاح 9 ـ ـ م م ().جرائم القتل أمام المحكمة الجنائية الدولية،دار الخليج للنشر

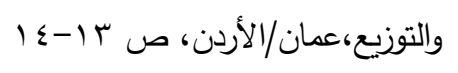

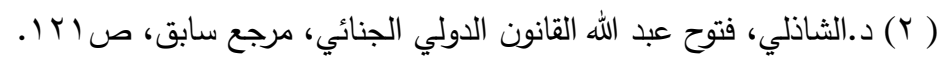

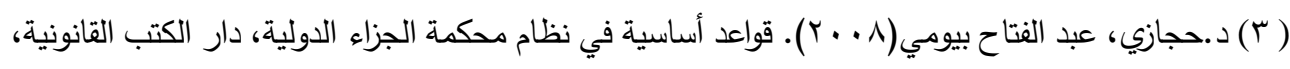

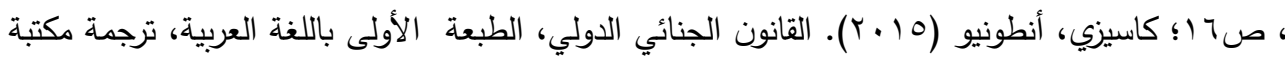

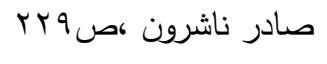




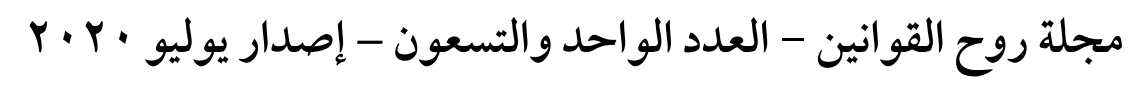

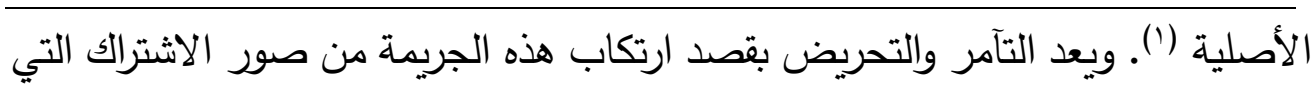
تقابل المساهمة الجنائية يستحق مرتكبها المساءلة الجنائية.

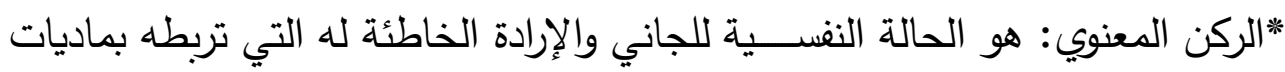

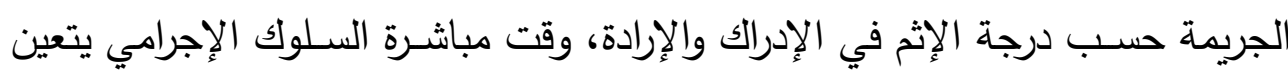

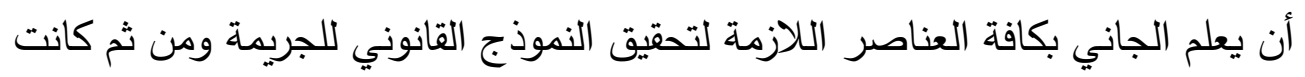

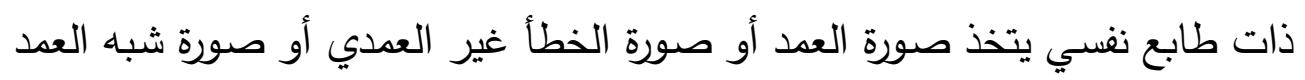

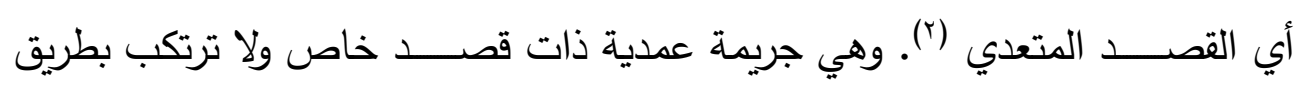

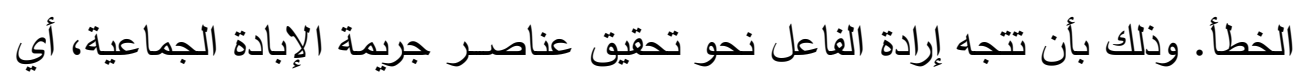

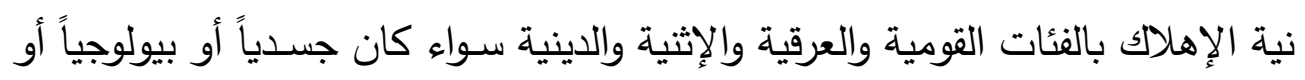

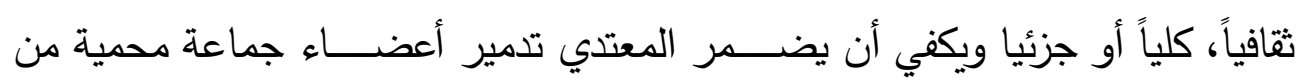

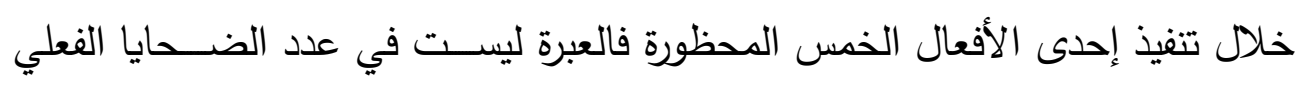

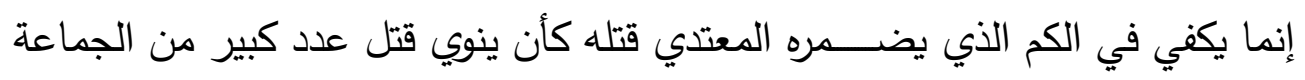

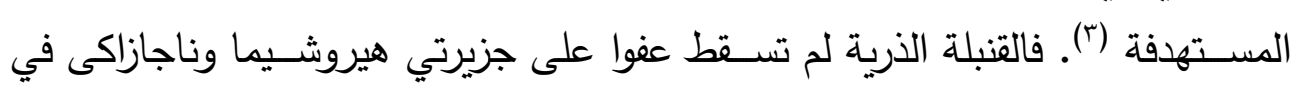

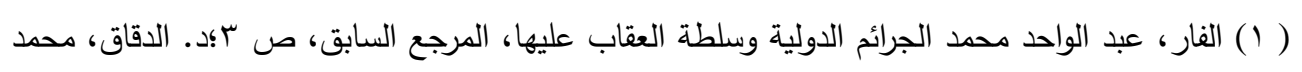

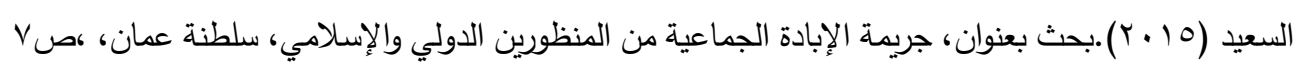

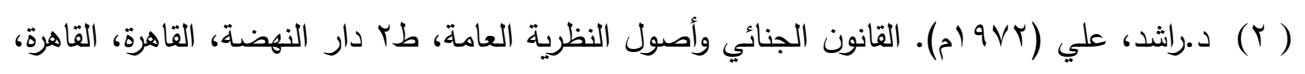

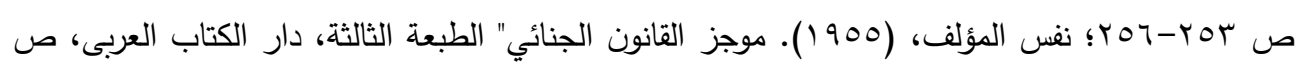

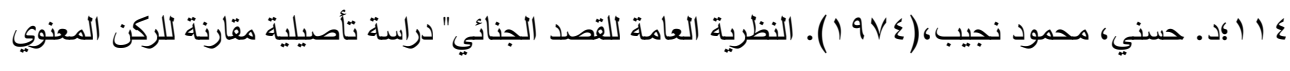

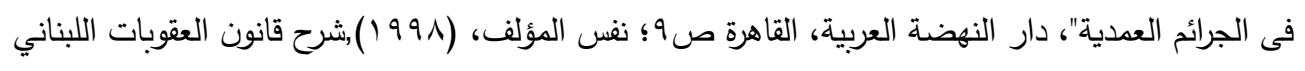

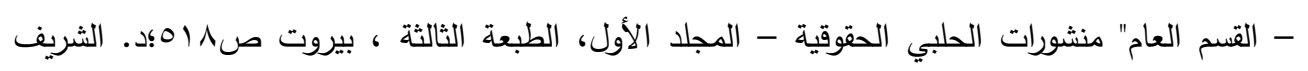

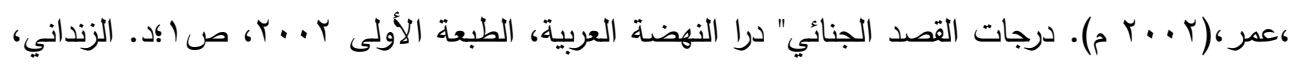

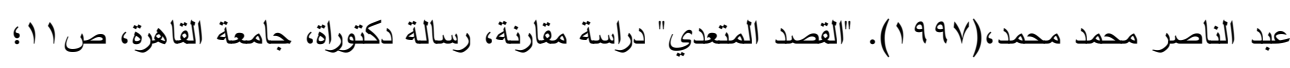

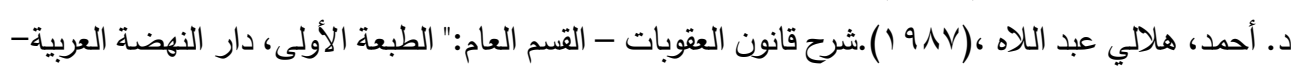

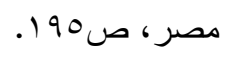

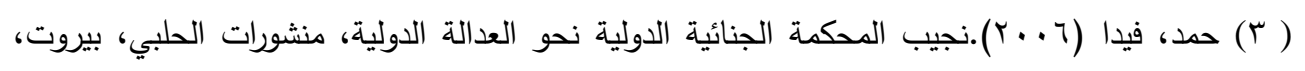

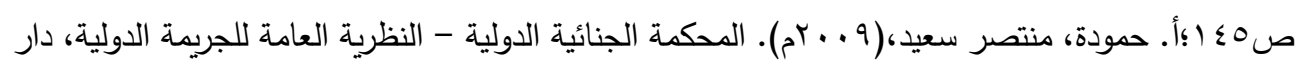


سـنة 9 \1 وقد أدت إلى إبادة سـكان هذه المناطق بصـرف النظر عن انتمائهم ومن نجى منهم أنجب أجيالا من المشوهين وبالتالي لم تنته الجريمة في وقتها وإنما أضحت جريمة مستمرة. ويمكن إثبات الركن المعنوي الخاص بنية الإبادة على نحو مباشر من التصـريحات والأوامر ، كما يمكن اسـتنتاجه من السـياق الذي تم فيه التدمير الموجه للجماعات ('). إنما قد يثبت من التقارير الدولية من جهات محايدة ونزيهة مثل: تقرير

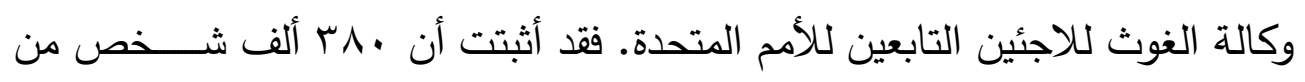
مسلمي البوسنة تعرضوا لخطر المجاعة والأمراض المسرطنة في مدينة سراييفو (†). كما أثبتت وقوع جريمة الإبادة في مخيمي صـبرا وشـاتيلا للاجئين الفلسـينيين في بيروت وقد أنكر الإســـرائيليون حق الفلســـينيين في الوجود (r). ولم تتوفر أدلة كافية على ارتكاب جرائم حرب وجرائم ضـد الإنسـانية حتى يقدم الجاني للقضـاء (ء). يلاحظ من

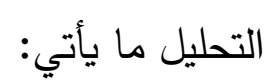
ا-إن جريمة الإبادة الجماعية هي عمليات قتل مركبة يعاقب عليها في جميع البلاد دون استثناء وفى الثرائع السماوية. ץ-إن جريمة الإبادة الجماعية هي جريمة دولية بطبيعتها، فهذا يعني أن المسؤولية المترتبة عليها هي مسؤولية مزدوجة تقع تبعتها على الدولة من جهة وعلى الأشخاص

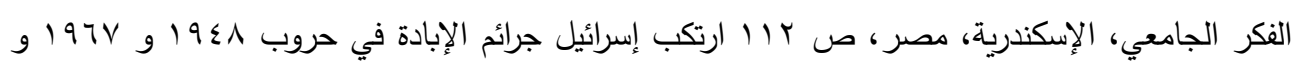

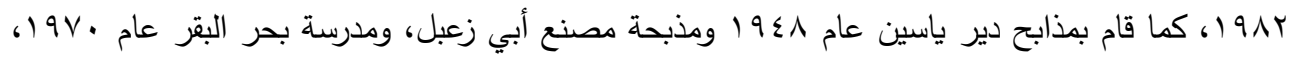

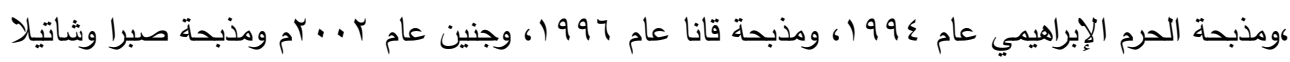

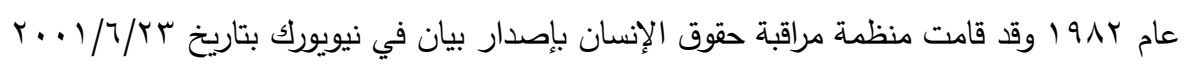

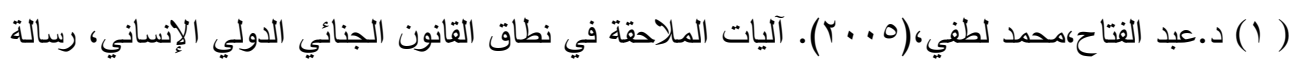

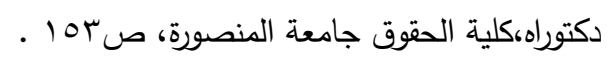

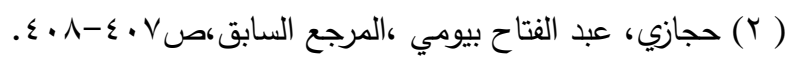

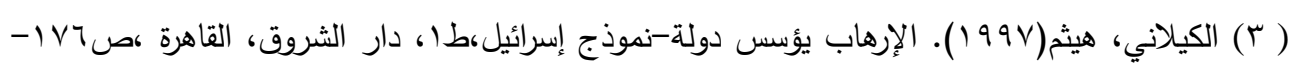

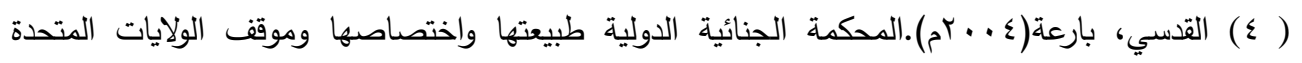

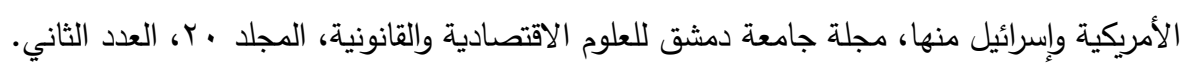




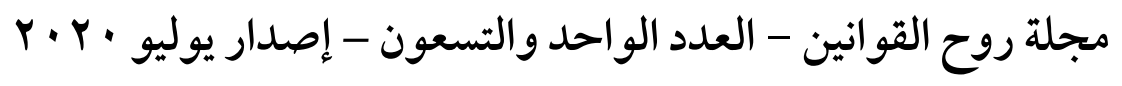

الطبيعيين مرتكبي الجريمة من جهة أخرى (").وجريمة الإبادة الجماعية وصفت بالدولية بصرف النظر عن مرتكبيها ودوافعهم. إنما تكتسب صفتها الدولية من أمرين: أولهما:

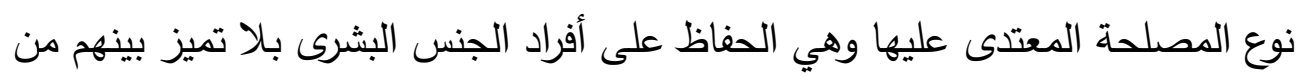

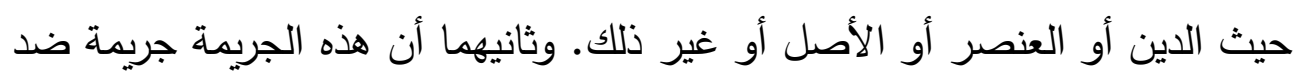

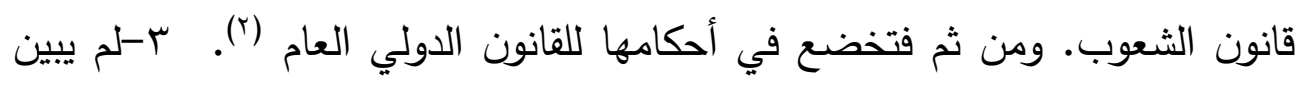

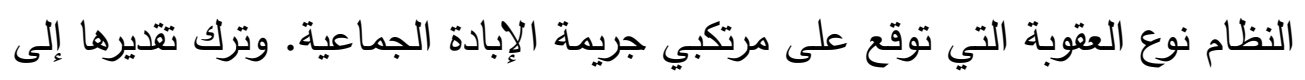

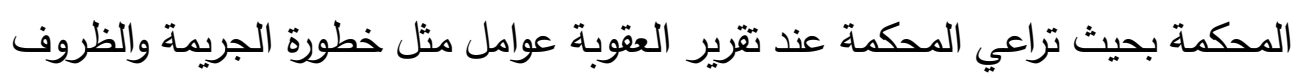

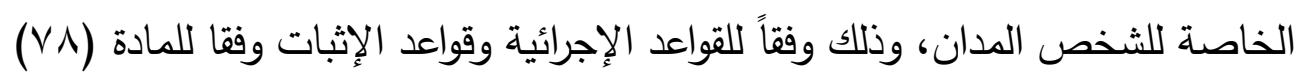

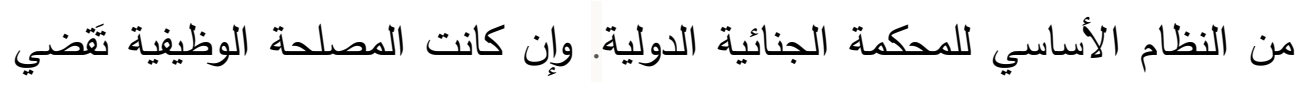

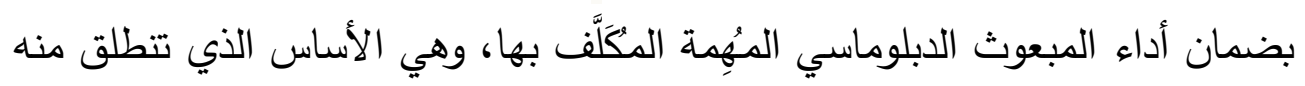

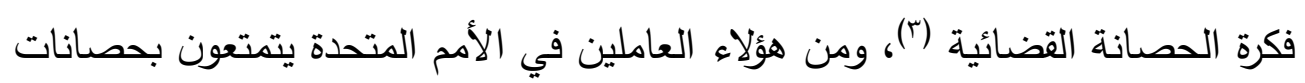

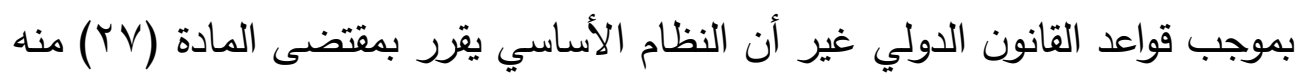

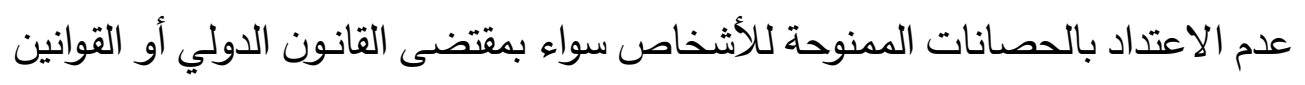

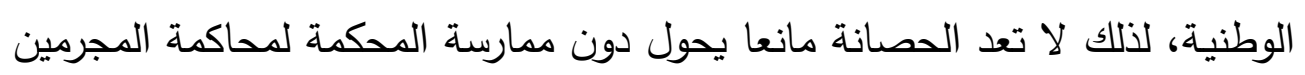

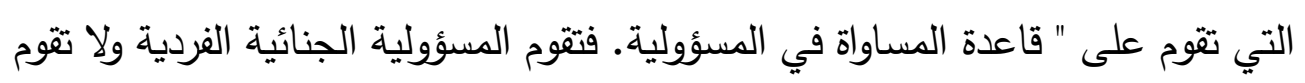

مسؤولية الدولة الجنائية (ई).

( (1) د.الفار، عبد الواحد محدد (910 (). المصلحة الدولية المشتركة كأساس لتطوير النظام الاقتصادي

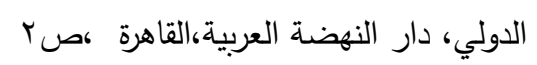

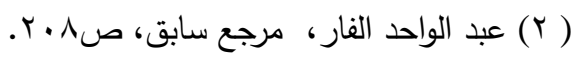

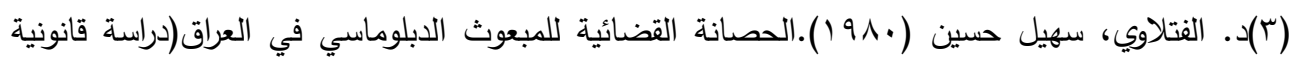
مقارنة) ،مطبعة أسعد ،بغداد ،ص ع ب ا.

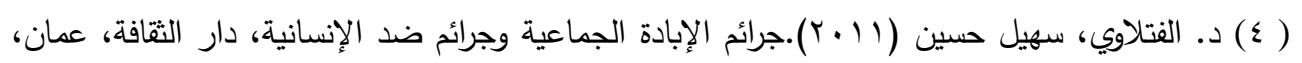

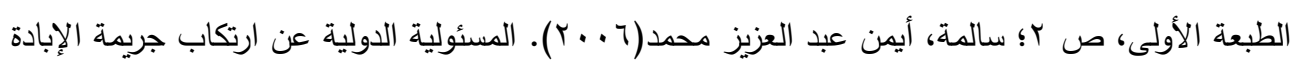

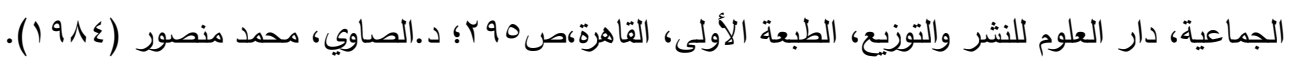


r-الجرائم ضد الإنسانية: الجرائم ضد الإنسانية هي من جرائم القانون العام التي

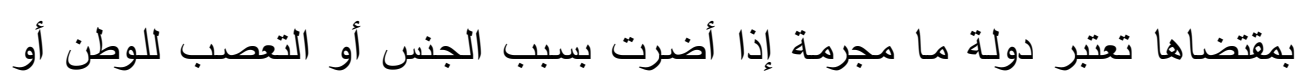
لأسباب سياسية أو دينية أو بحياة شخص أو مجموعة من أشخاص أبرياء من أي

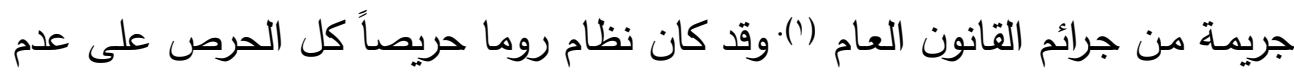
إفلات مرتكبي الجرائم سواء ارتكبت هذه الجرائم قبل الحرب أو أثناء الحرب أو بعدها، أي سواء وقعت في زمن الحرب أم في زمن السلم، وسواء ارتبطت بغيرها من الجرائم

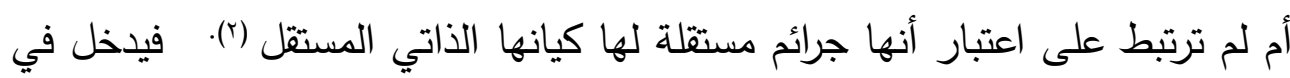
الجرائم ضد الإنسانية التي تدخل في اختصاص المحكمة وهي: القتل العمد، الإبادة، الاسترقاق، وإبعاد السكان أو النقل القسري للسكان، السجن أو الحرمان الثديد على أي نحو آخر من الحرية البدنية بما يخالف القواعد الأساسية للقانون الدولي، كالتعذيب والاغتصاب أو الاستعباد الجنسي، أو الإكراه على البغاء أو الحمل القسري أو التعقيم

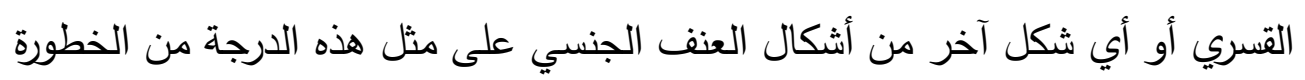
أو اضطهاد أية جماعة محددة أو مجموع محدد من السكان لأسباب سياسية أو عرفية أو قومية أو إثنية أو ثقافية أو دينية, أو متعلقة بنوع الجنس على النحو المعرف في الفقرة r أو لأسباب أخرى حسب المادة (V) من النظام الأساسي. وإن القانون الدولي لوني لا يجيز الاختفاء القسري للأشخاص ولا جريمة الفصل العنصري أو الأفعال اللاإنسانية الأخرى ذات الطابع المماثل التي تتسبب عمداً في معاناة شديدة أو في أذى خطير يلحق بالجسم أو بالصحة العقلية أو البدنية...إلخ وقد تم لأول مرة في التاريخ تعريف

أحكام القانون الدولي الدتعلقة بكافحة الجرائم ذات الطبيعة الدولية، دار المطبوعات الجامعية، الإسكندرية، ص إ)

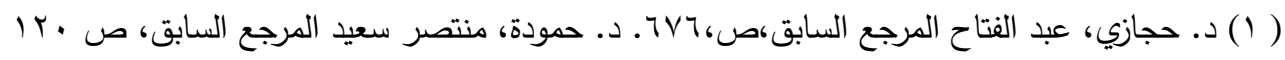

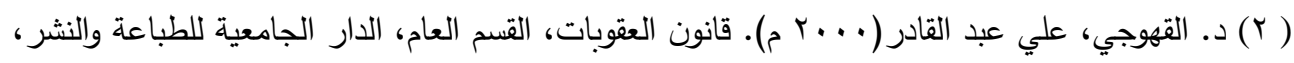


r.r. · مجلة روح القوانين - العدد الواحد والتسعون - إصدار يوليو

الجرائم ضد الإنسانية في معاهدة دولية اعتمدت من قبل غالبية الدول ('). ويجب توافر الإن الأركان التالية لكي يمكن اعتبارها جرائم ضد الإنسانية:

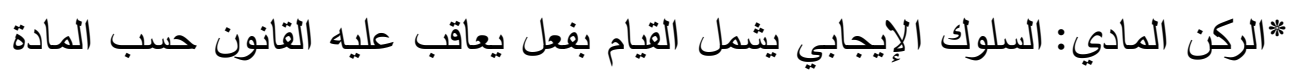

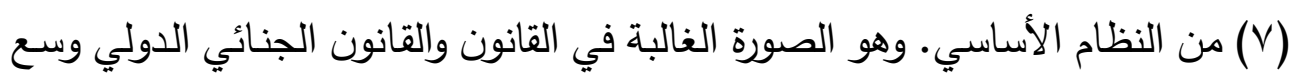

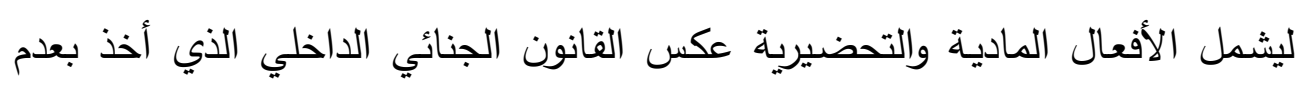

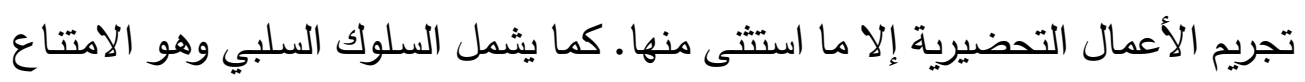

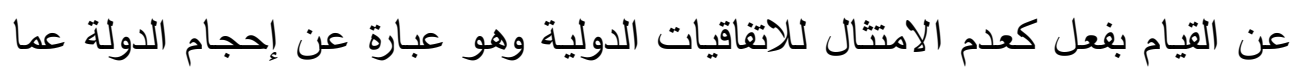

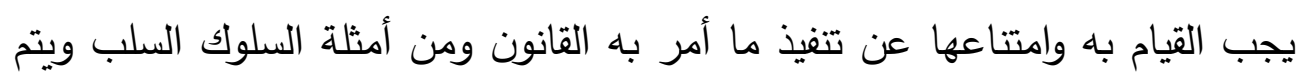

$$
\text { ذلك على الوجه الآتي: - التبام }
$$

أ-أن تكون هناك سياسة دولة أو سياسة من قبل منظمة غير حكومية تسعى لارتكاب جرائم ضد الإنسانية حسب (المادة T/V) من النظام الأساسي للمحكمة الجنائية الدولية.

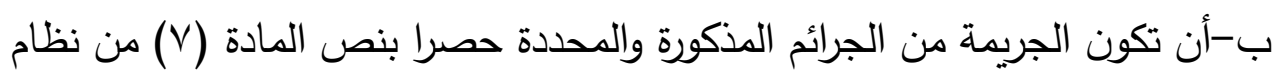

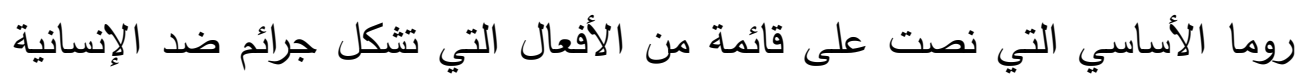
احتراما لمبدأ الشرعية الجنائية. ج-أن ترتكب هذه الجرائم على نطاق واسع أو بسياسية منهجية. ويكون الركن السياسي لجئي هو المحرك في الاختصاص الذي يعمل على تحويل الجرائم من جرائم وطنية إلى جرائم

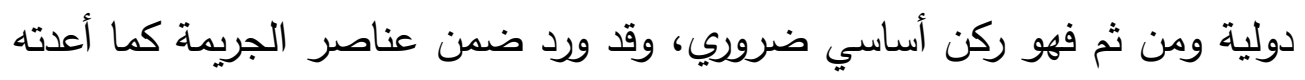

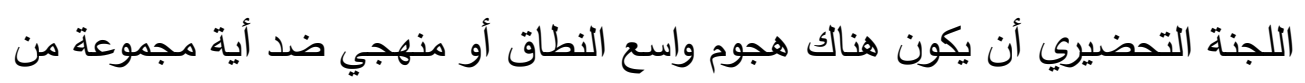

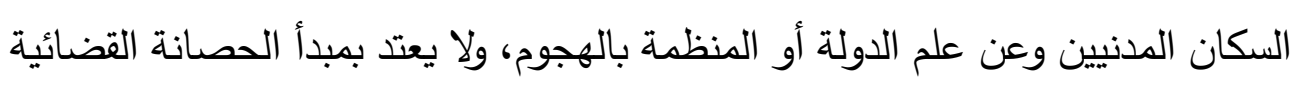

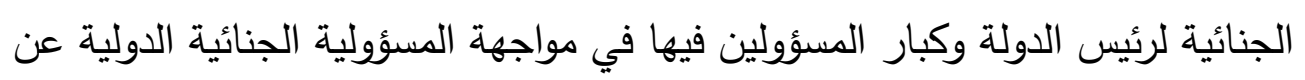

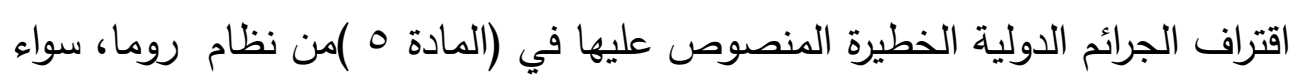

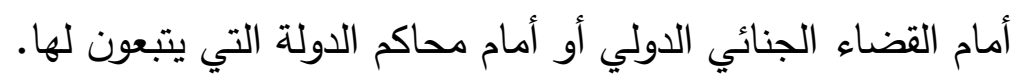

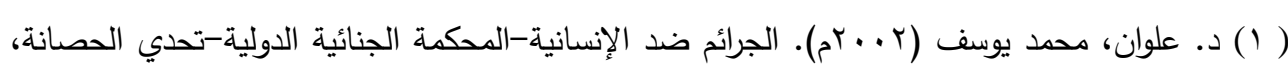

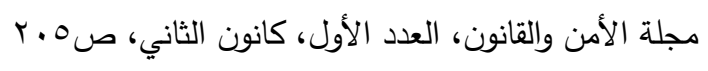
$(r \leq r)$ 


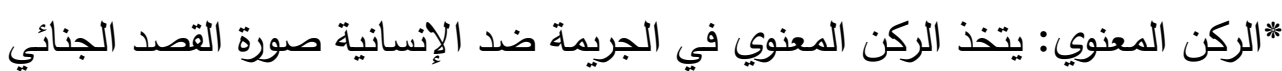

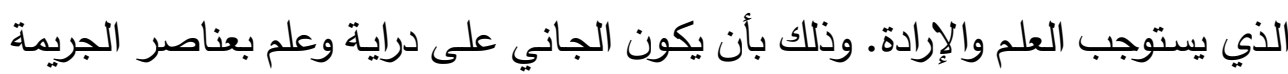

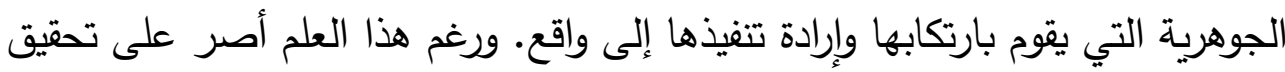
النتيجة الإجرامية (1)

ويتطلب ركن المعنوي للجريمة ضد الإنسانية توافر القصد الجنائي بنوعيه العام

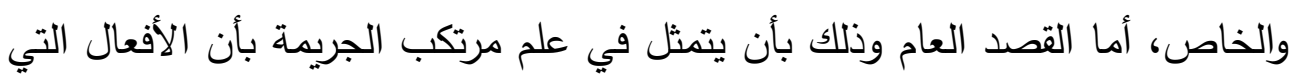

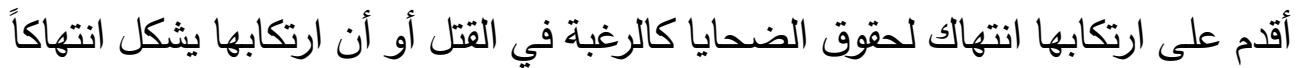

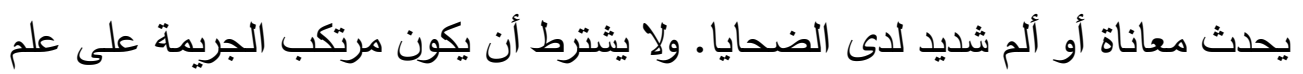

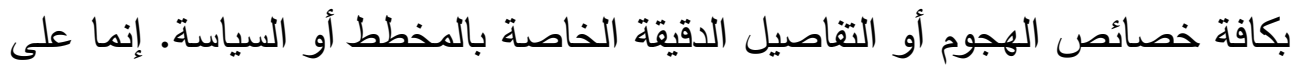

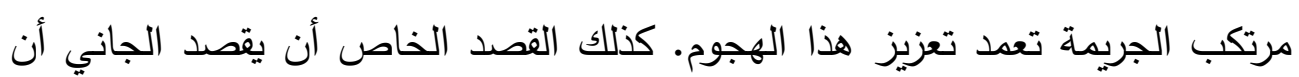

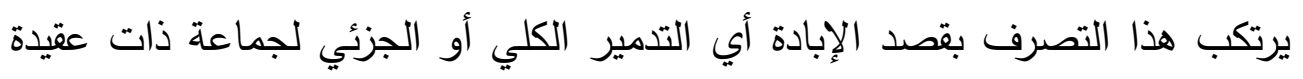

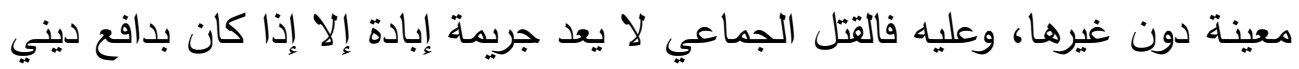

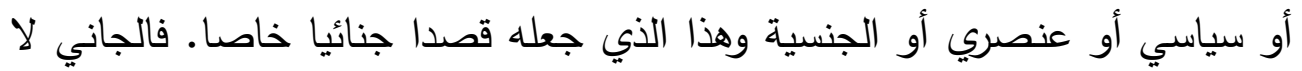
يرتكب الجريمة لحسابه الخاص وإنما بتوجيه من سلطات الدولة كجزء من الهجوم منهجي أو واسع النطاق على سكان مدنيين ().

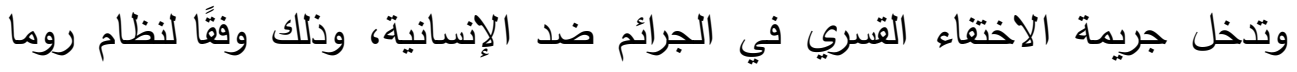

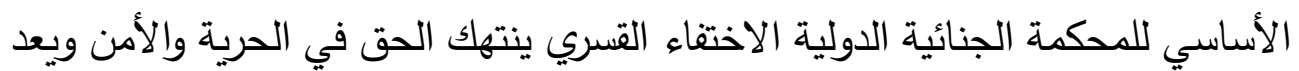
الاختفاء القسري في حد ذاته نوعا من التعذيب النفسي أو المعاملات اللاإنسانية حتى لألى لألى

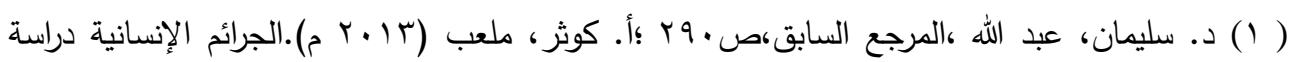

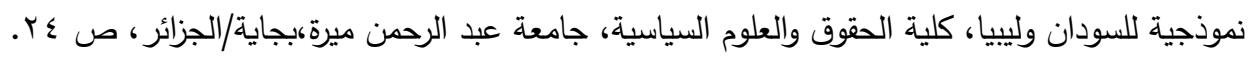

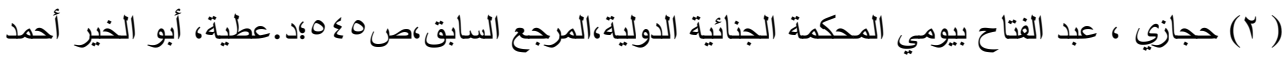

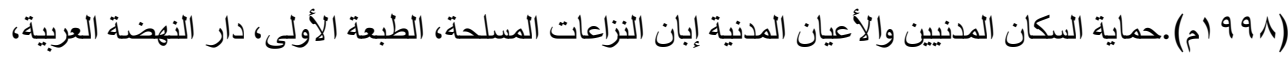

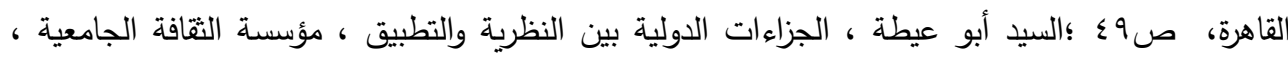

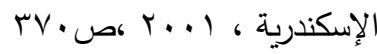
M. Cherif Bassiouni, Crimes Against Humanity, Crimes Against Humanity, Kluwer International .Law, The Hague Second Revised, Edition, 1999. P. Tr) 
F. r. · مجلة روح القوانين - العدد الواحد والتسعون - إصدار يوليو

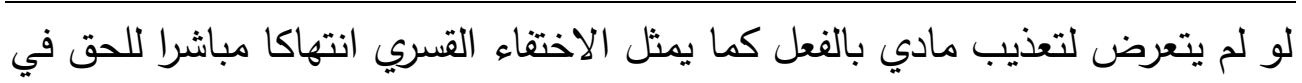
الاعتراف للإنسان بالثخصية القانونية وانتهاك حقه في الحياة أو التهديد الخطير لله لأن غالب من يتعرضون للاختفاء القسري يقتلون أو يموتون في محبسهم والاختفاء

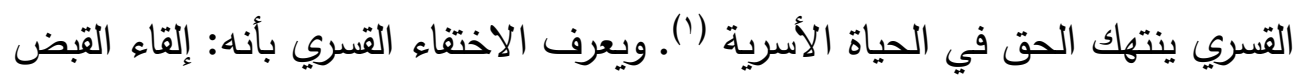

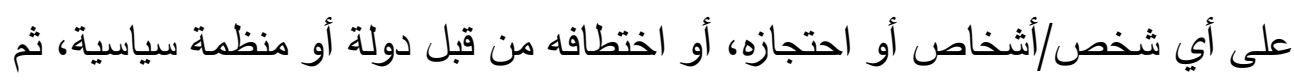

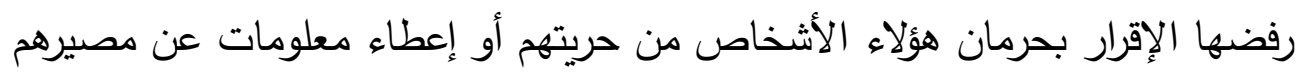

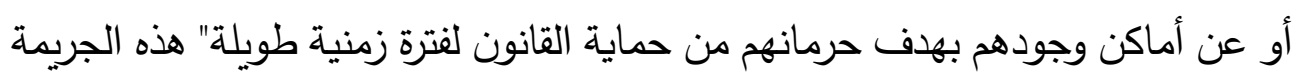

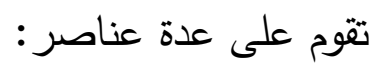
1-الحرمان من الحرية بالإكراه والجبر ب- إنكار أو إخفاء المعلومات الخاصة بالمجني

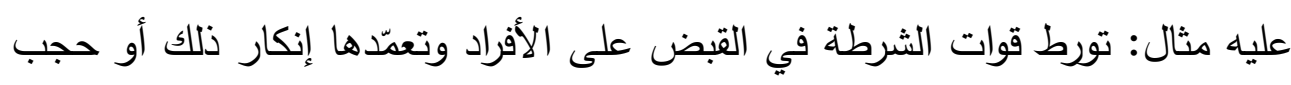
حقيقة ما حدث للمقبوض عليهم عند سؤال ذويهم. بـانعدام الحماية التي يكفلها القانون ممَّا يترتب عليه وضع هؤلاء خارج حماية القانون. وهذا الأمر الذي يرقى إلى الاختفاء

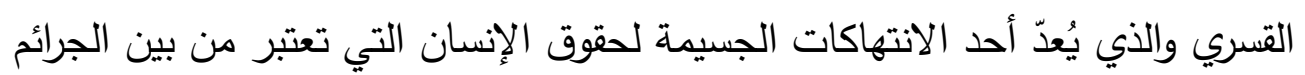

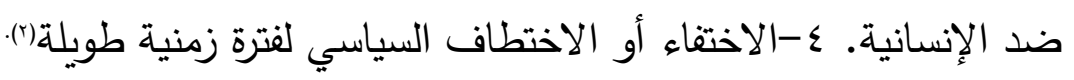
ب-جرائم الهرب: الحرب ظاهرة اجتماعية لزمت الإنسانية على مر العصور ، ولم يخل فئل عصر من حروب حتى صارت سمة تطبع تاريخ البشرية، ودليل على الصراع الدائم

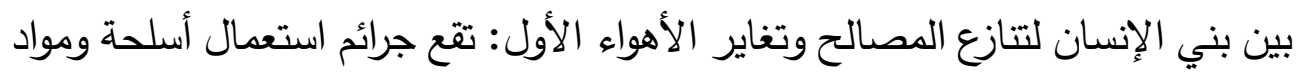

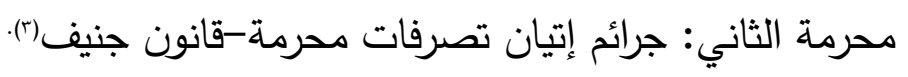

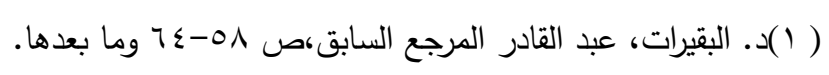

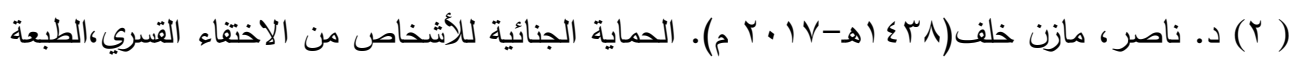

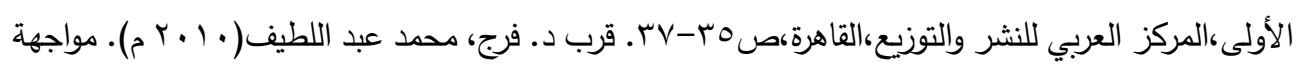

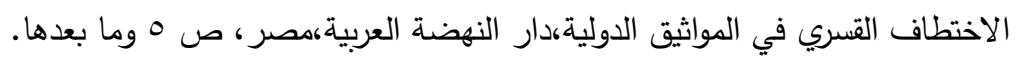

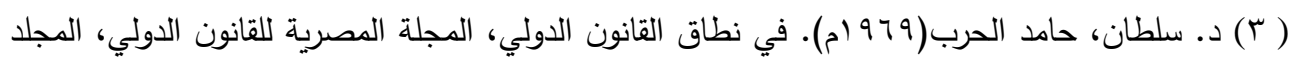

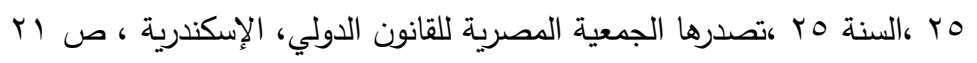




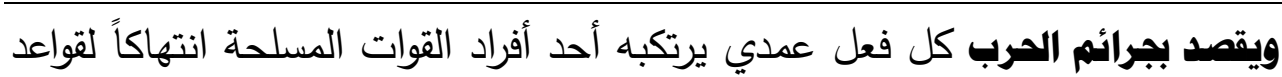

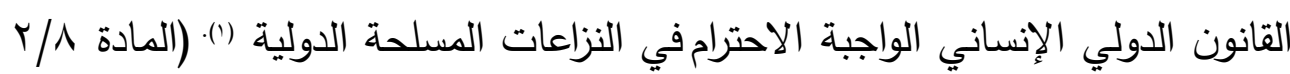
من نظام روما الأساسي للمحكمة الجنائية الدولية) . ويجب توافر الأبرات الأركان الآتية:

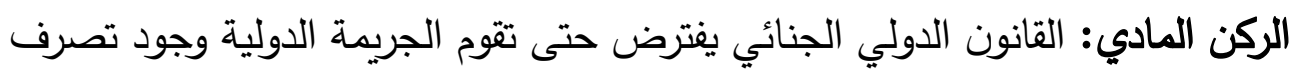

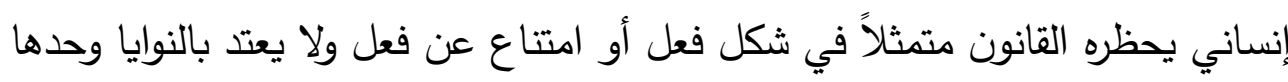

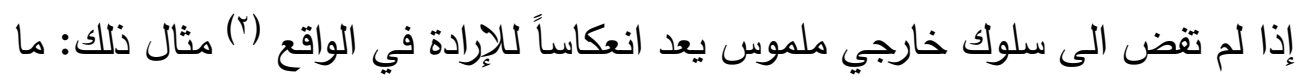

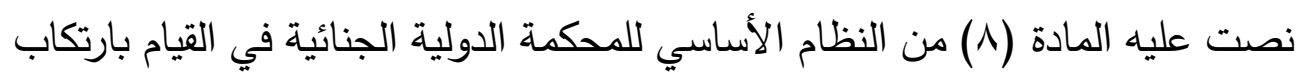

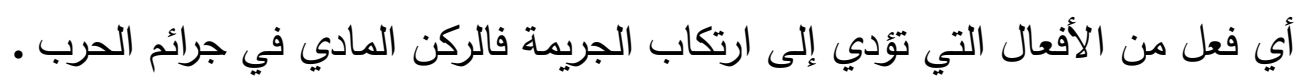
يتكون من شرطين أساسيين: هما: الشرط الأول: توافر حالة الحرب، والثرط الثاني: هو ارتكاب أحد الأفعال المحظورة دوليا. الشرط الأول: توافر حالة الحرب: إن طبيعة هذه الجرائم تقع خلال زمن الحرب أي تقع

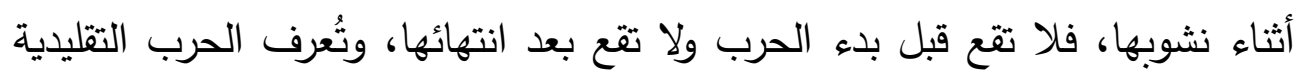

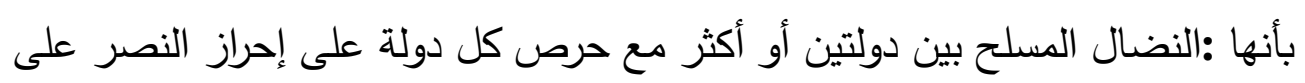

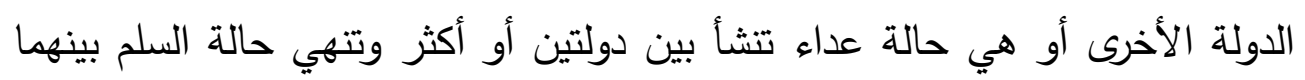
وتستخدم فيها القوات المسلحة في نضال مسلح تحاول فيه كل دولة إحراز النصر وإملاء

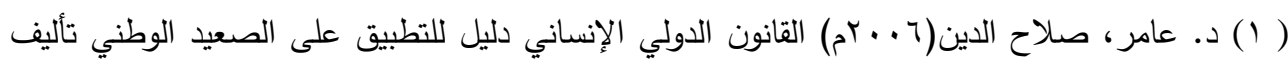

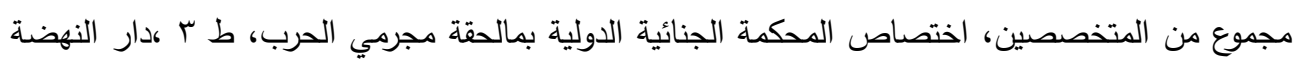

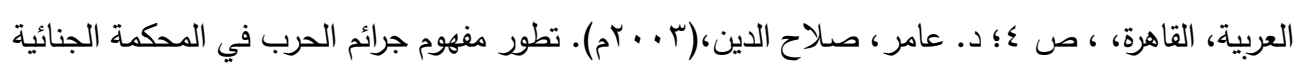

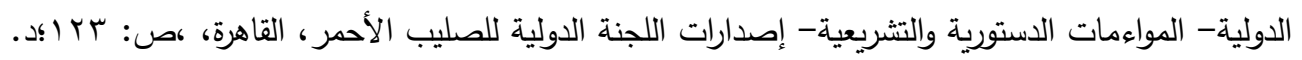

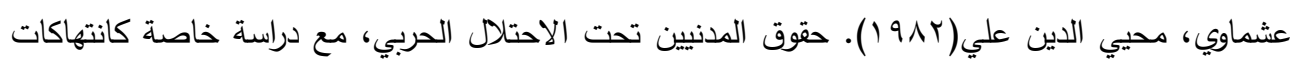

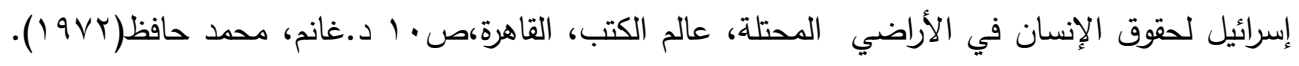

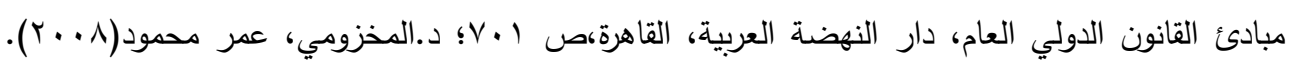

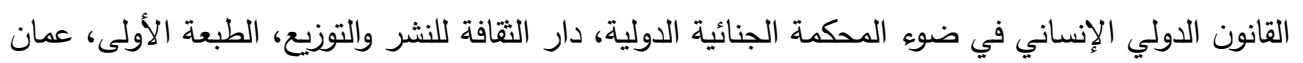
،الهامش ع ،ص: r.

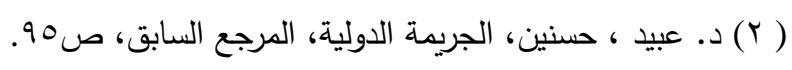




$$
\text { مجلة روح القوانين - العدد الواحد والتسعون - إصدار يوليو ·. F. }
$$

شروطها المختلفة من أجل السلم على أعدائها ومن ثم فرض إرادتها عليهم. ويجب توافر

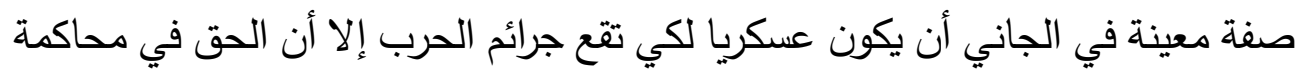

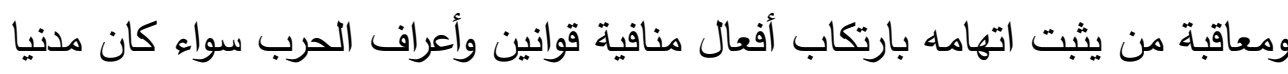

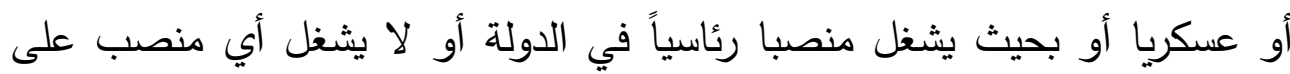
الإطلاق.

الشرط الثاني: ارتكاب أحد الأنعال المظظورة دوليا: تعرف جرائم الحرب باعتبارها

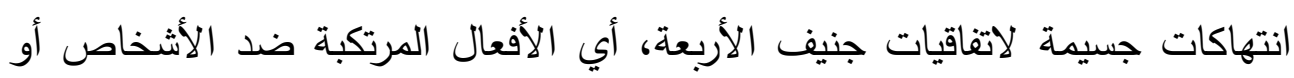

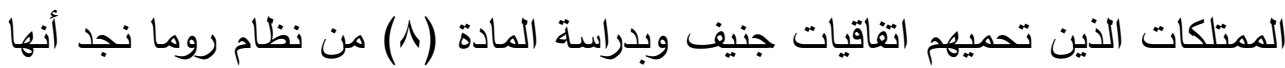
حصرت جرائم الحرب في عدة فئات منها الآتي:

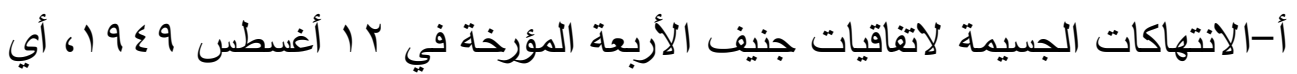

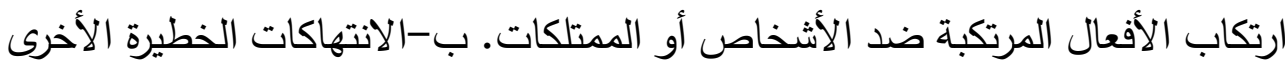
للقوانين والأعرف السارية على المنازعات الدولية المسلحة في النطاق الثابت للقانون الدولي مثل: تعدد توجيه هجمات ضد السكان المدنيين أو مواقع مدنية، كذلك تعمد فئه توجيه هجمات ضد موظفين مستخدمين أو منشئات أو وحدات أو مركبات في مهام للمساعدة الإنسانية.

ج-الانتهاكات الجسيمة للمادة الثالثة المشتركة بين اتفاقيات جنيف الربع المؤرخة عام

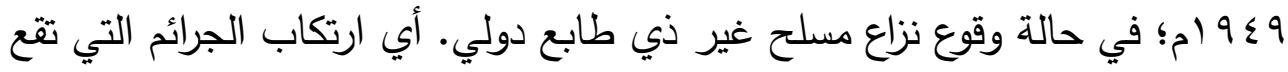

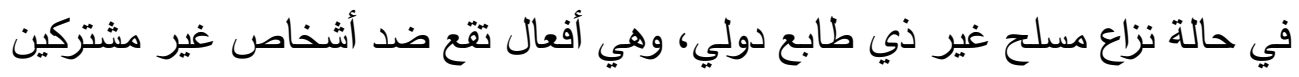

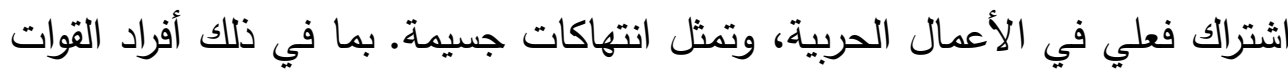

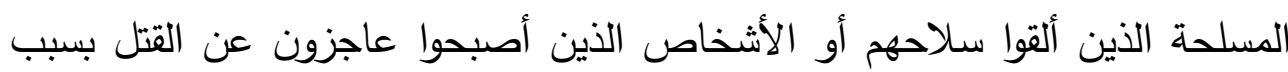

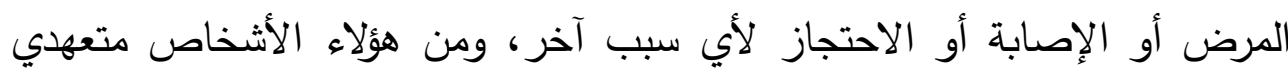


التوريد للمؤن ومواد التموين، ومقاولي البناء والممرضين والأطباء والمراسلين الحربين

(') (1) (1)

د-الانتهاكات الخطيرة الأخرى للقوانين والأعرف التي تتطبق في المنازعات المسلحة غير ذات الطابع الدولي في النطاق الثابت للقانون الدولي تشمل: الجرائُ التي تقع في نزاع مسلح غير ذي طابع دولي على فئات مثل الفئات المنصوص عليها في الفئة الثالثة مثل: الذين ألقوا سلاحهم أو الأشخاص الذين أصبحوا عاجزون عن القتل بسبب المرض أو الإصابة أو الاحتجاز • وذلك في حالات الاضطرابات والتوترات الداخلية

*الركن المعنوي في جرائم الحرب .هو جريمة عمدية كما في باقي الجرائم؛ لذلك يتطلب ضرورة توافر القصد الجنائي العام فقط الذي يتكون من العلم والإرادة، فيجب أن يعلم الجاني أن الأفعال التي يأتيها تؤدي إلى انتهاك حقوق الضحية بالمخالفة للقوانين

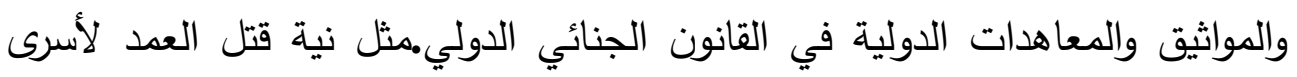
الحرب، والتعذيب أو المعاملة اللاإنسانية بما في ذلك إجراء التجارب البيولوجية. ويجب إعطاء الأولوية لأكثر الجرائم انتهاكاً للمادة (^) من النظام الأساسي للمحكمة (؟). ومثل عرقلة الإمدادات الغوثية للسكان المدنيين، على النحو المنصوص عليه في اتفاقيات

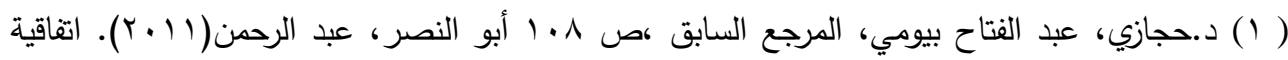

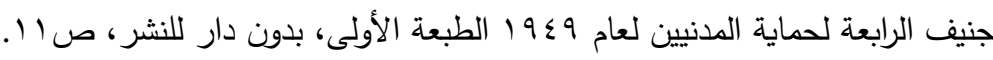

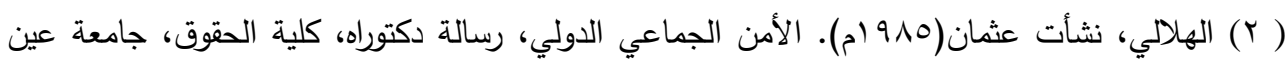

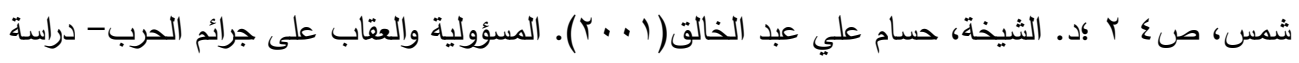

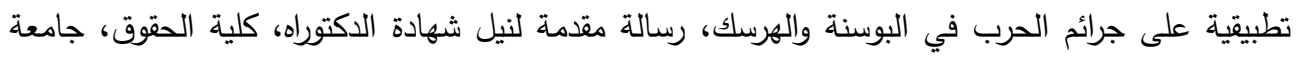

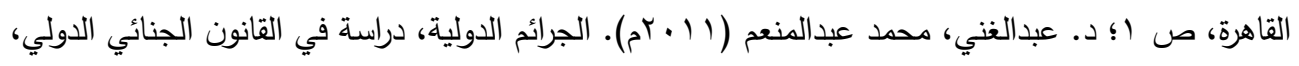

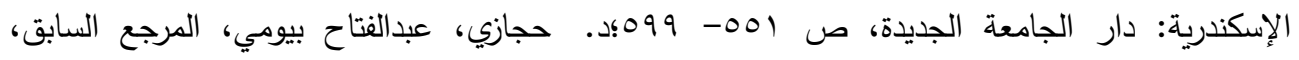
ص: VO - VOT

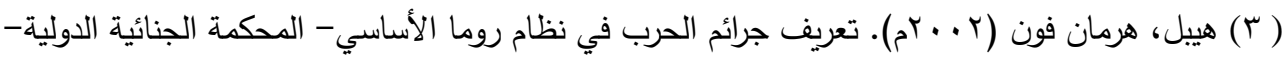

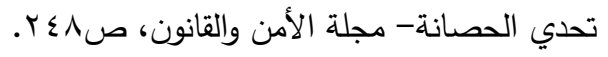


r.r. · مجلة روح القوانين - العدد الواحد والتسعون - إصدار يوليو

جنيف كجريمة حرب وجريمة الاعتقال التعسفي، والإبعاد القسري للمدنيين ('). وكذلك

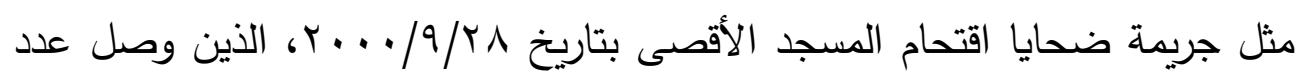

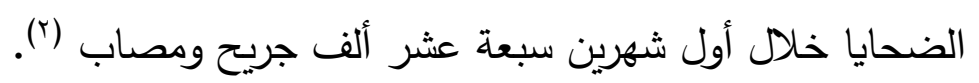

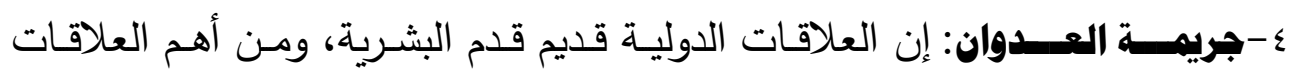

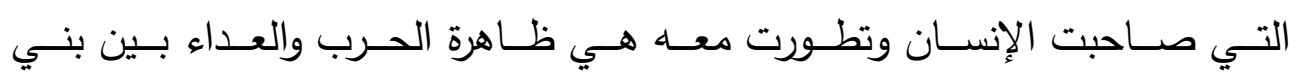

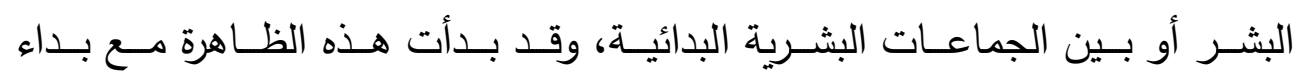

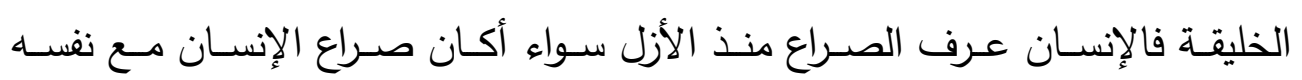

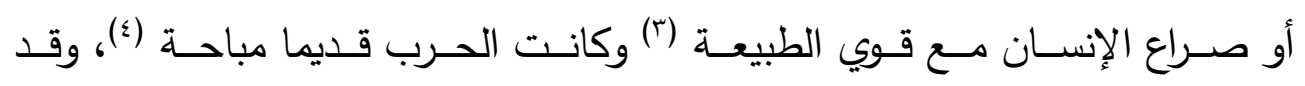

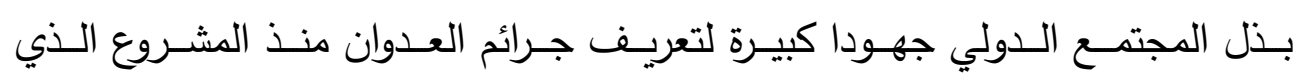

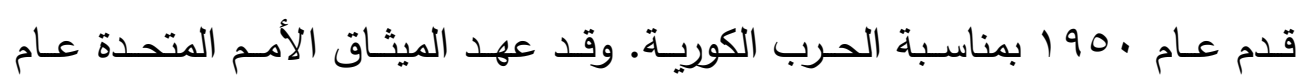

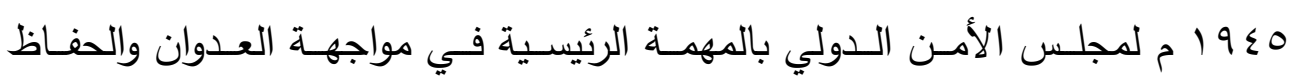

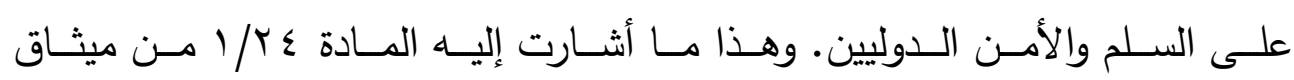

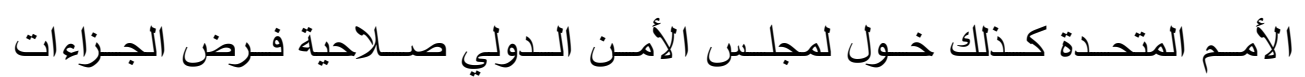

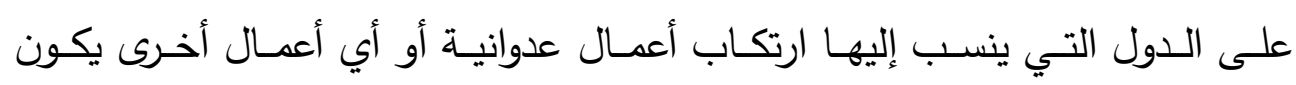

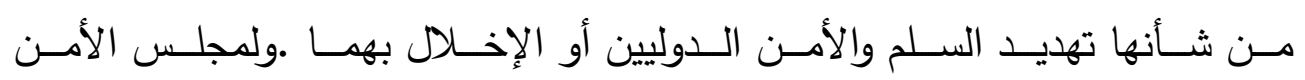

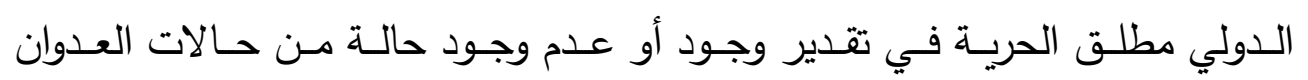

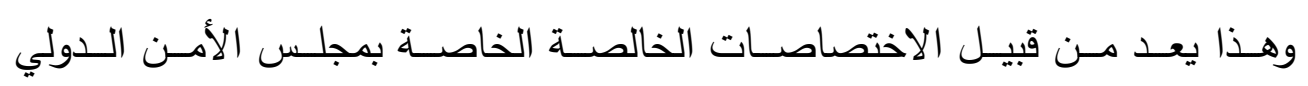

(1) شيخة، حسام علي(r (.rم). جرائم الحرب في فلسطين والبوسنة والهرسك، مركز الدراسات السياسية

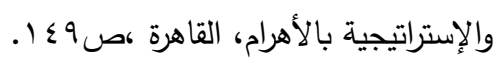

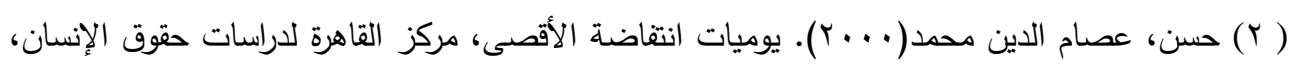
ص rov

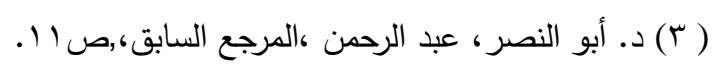

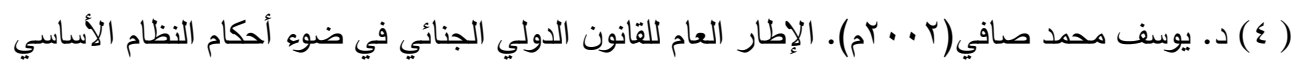

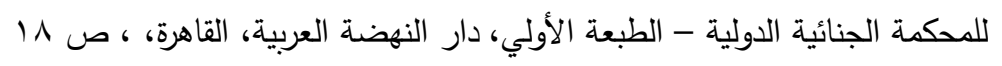
$(r \leq \Lambda)$ 


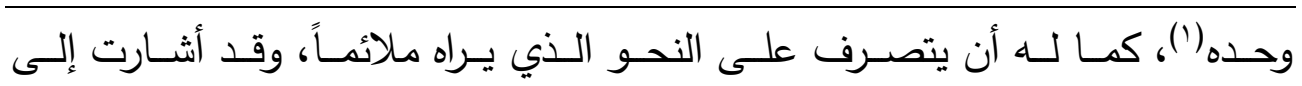

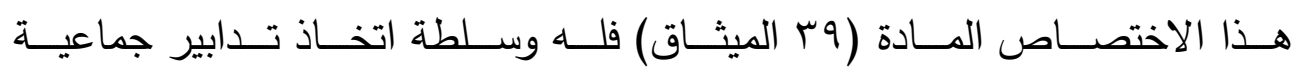

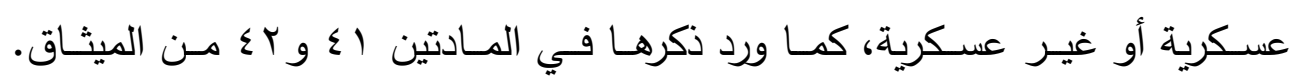

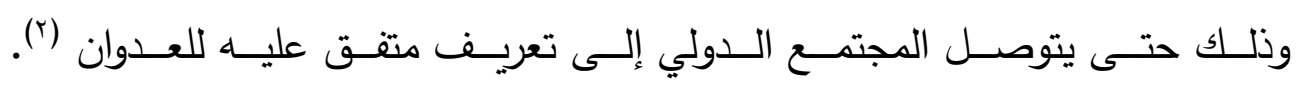

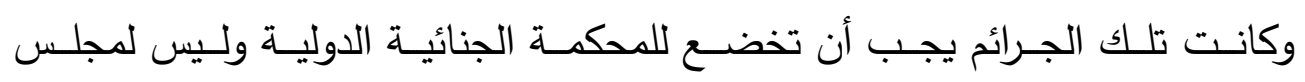

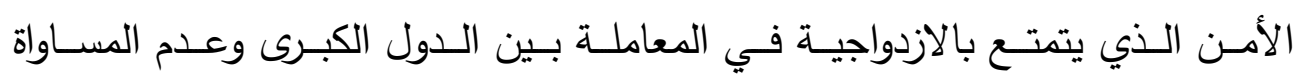
في التصويت للمجلس. وبعد إنشاء الدحكمة الجنائية الدولية في مؤتمر روما تم النص على اختصاص المحكمة

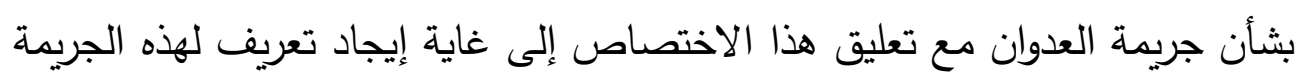

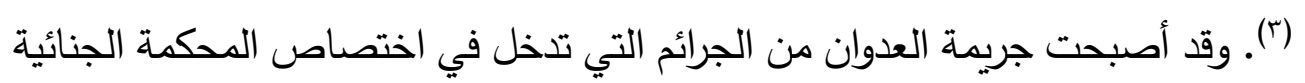

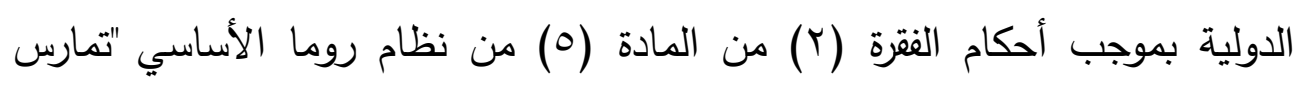

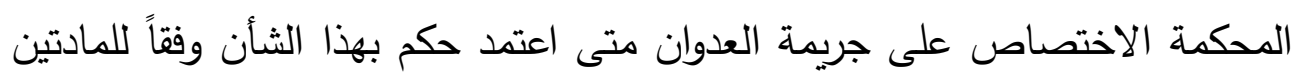

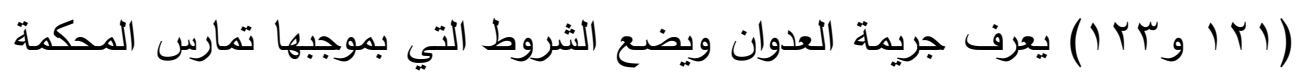

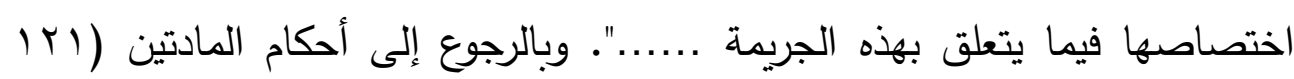

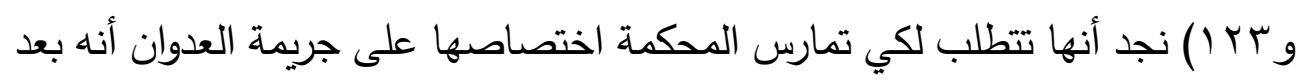

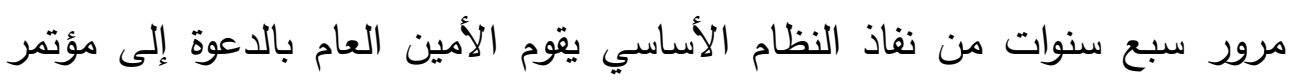

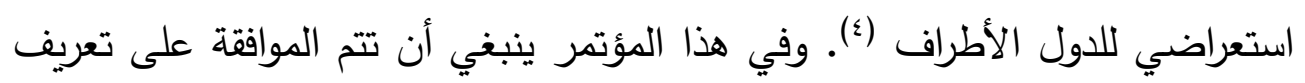

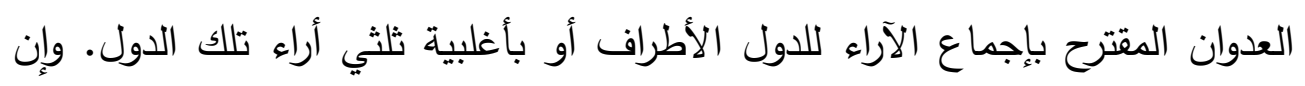

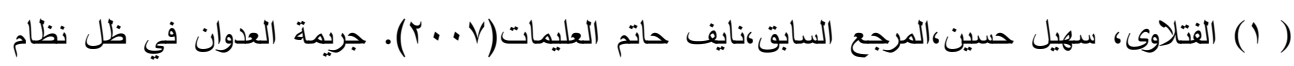

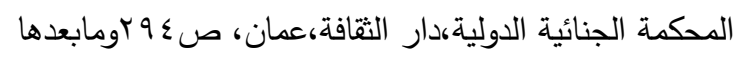

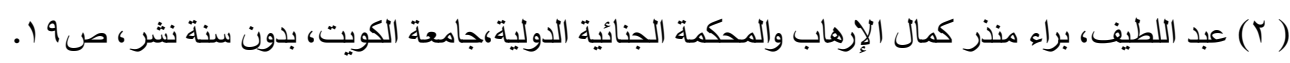

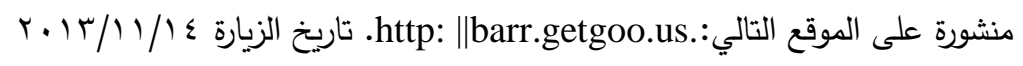

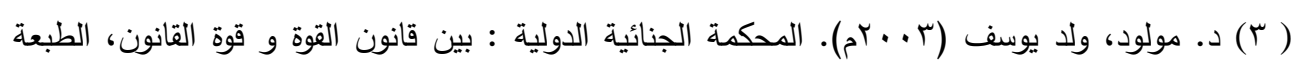

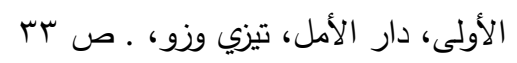

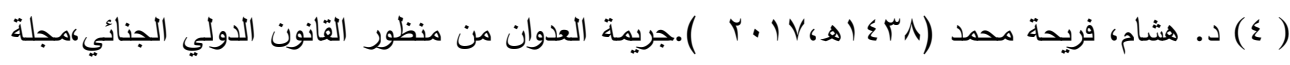

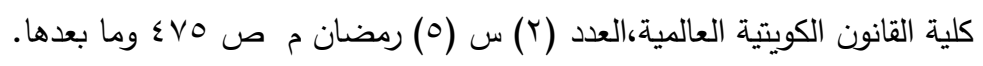




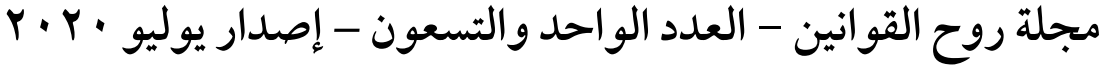

المحكمة تمارس اختصاصها بخصوص جريمة العدوان بعد مرور سنة واحدة من تاريخ

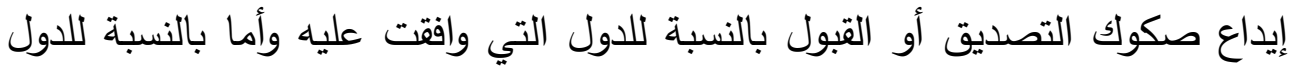

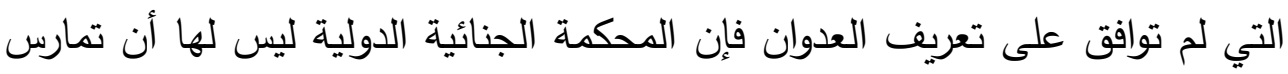

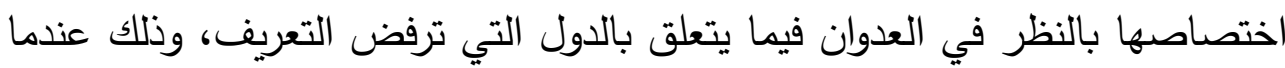

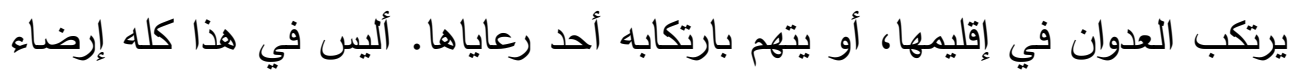

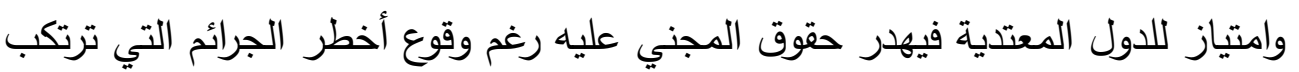

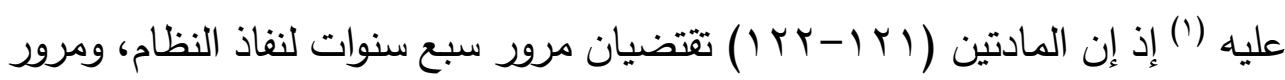

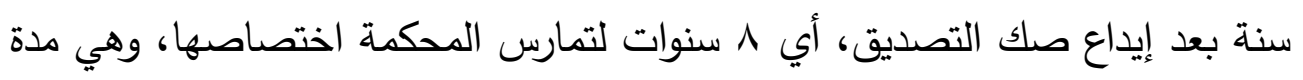

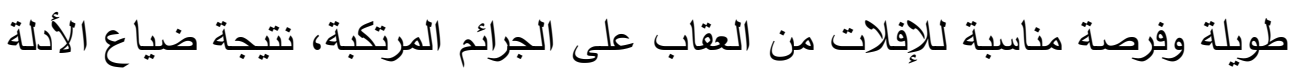

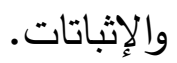

لذلك أرسى المؤتمر الاستعراضي للدول الأطراف بتعديل النظام الأساسي للمحكمة

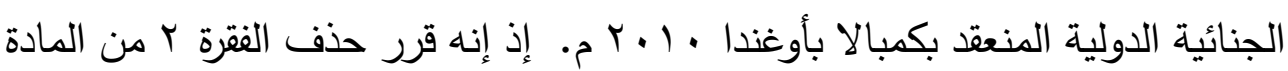

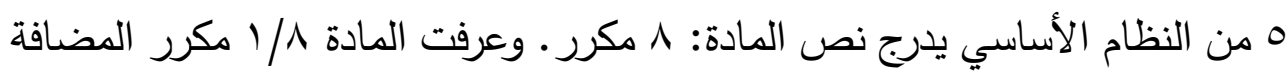

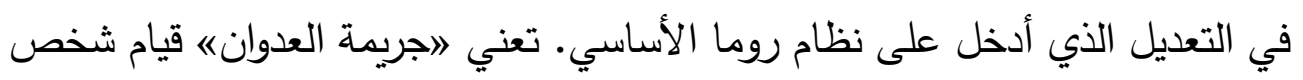

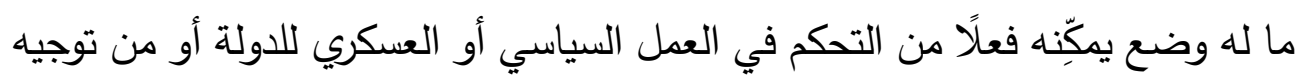

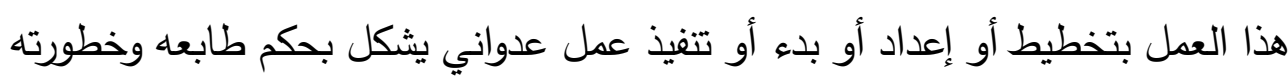

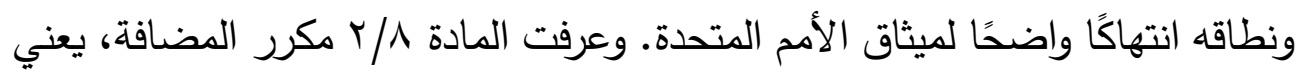

( (1) د.محمود، ضاري خليل(1 . . rم). الهحكمة الجنائية الدولية هيمنة القانون أم قانون الهيمنة، منشأة

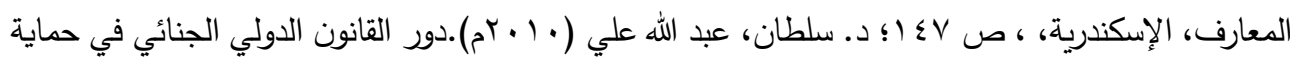

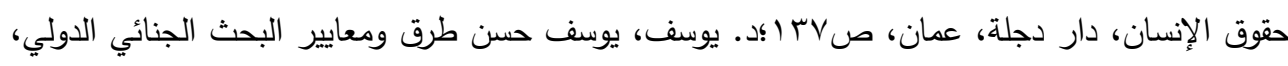

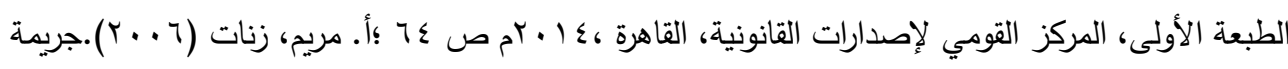

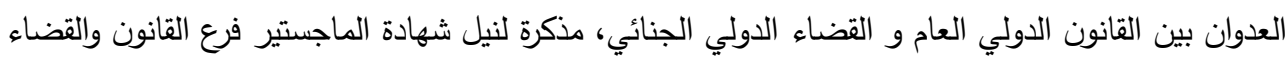

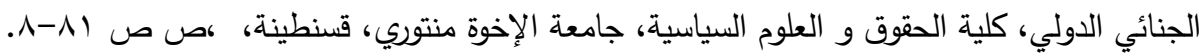
Véronique Michelle METANGMO, Le crime d'agression : Recherche sur l'originalité d'un crime à la croisé du Droit International Pénal et du Droit International du maintien de la paix, thèse pour obtenir le grade de docteur en Droit, faculté de Droit, Université de Liler, $r \cdot 1 r$, pp. $r$ - $r$ r. 


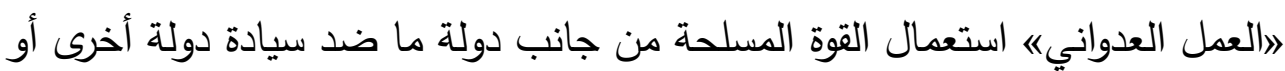

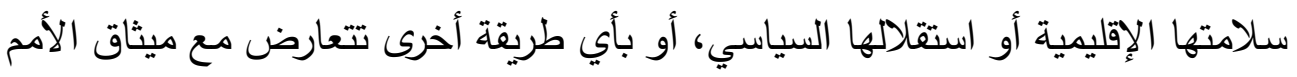

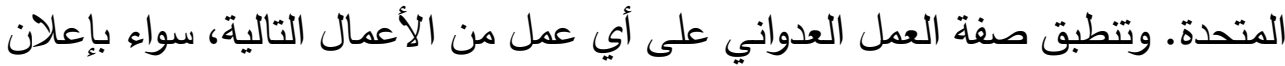

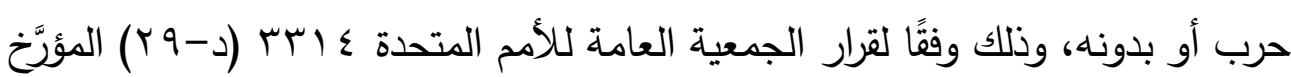

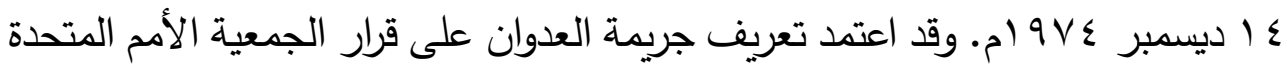

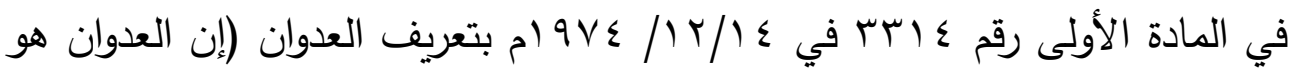
استخدام القوة المسلحة من قبل دولة ما ضد دولة أخرى أو سلامتها الإقليمية أو استقلالها

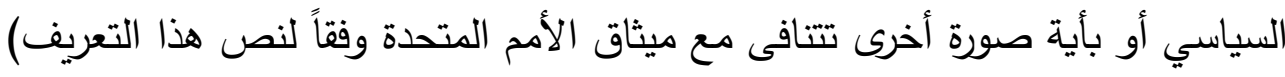

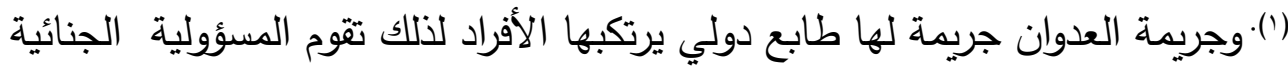
الفردية للقادة والرؤساء عن جريمة العدوان التي تدخل في اختصاص المحكمة الجنائية

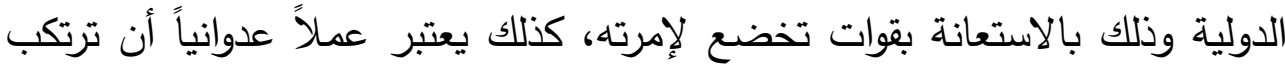

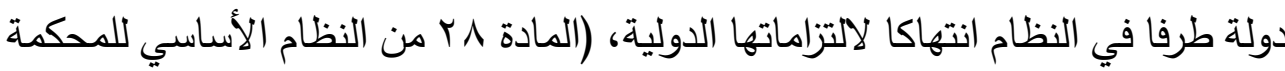

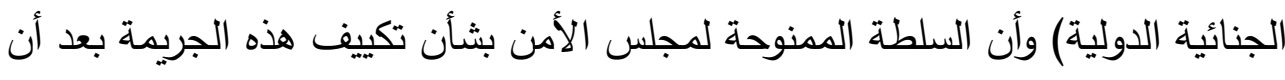

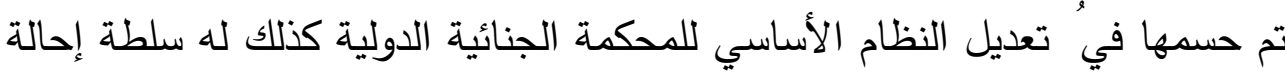

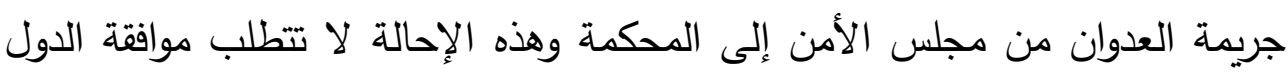

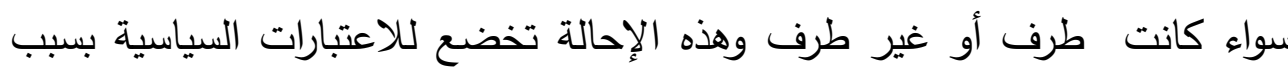
ضغوطات من طرف الدول الدائمة العضوية في المجلس مما يؤدي إلى صعوبة ممارسة الإسة

( (1) د. الدراجي، إبراهيم زهير (r . . Y). جريمة العدوان ومدى المسئولية القانونية الدولية عنها،رسالة دكتوراة

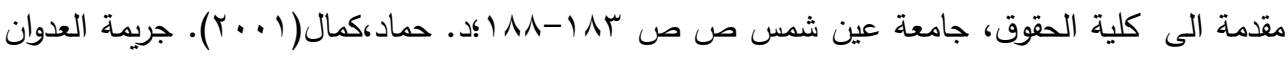
احدى الجرائم الخطيرة في اختصاص الدحكمة الجنائية الدولية، ضمن النية الندوة العلمية (الدحكمة الجنائية الدولية،

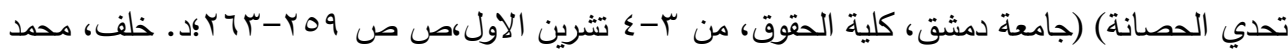

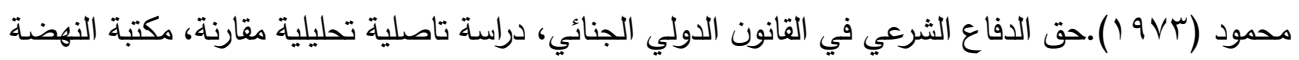

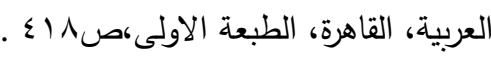
International Review ،Juste War and War of Aggression and International Humanitarian Law ،Francois Bughion

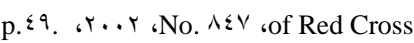

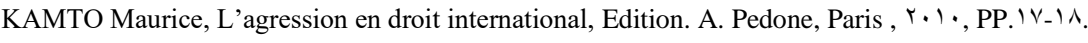

$($ rol $)$ 
F. r. · مجلة روح القوانين - العدد الواحد والتسعون - إصدار يوليو

المحكمة اختصاصها. وقد أحال مجلس الأمن قضية دارفور بالسودان إلى المحكمة

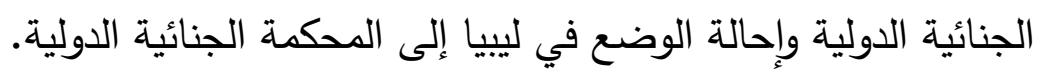
أركان الجريمة: وتقوم الجريمة على الأركان الآتية:

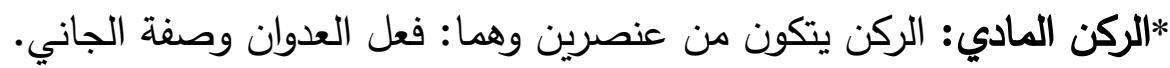

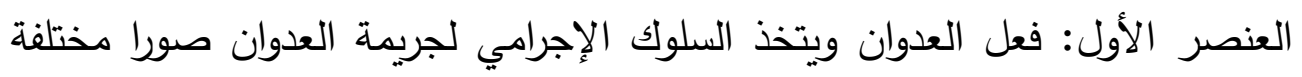

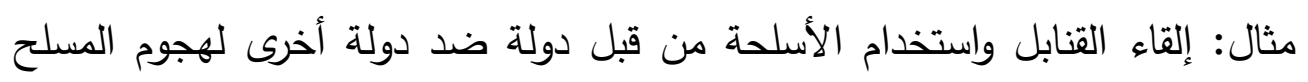
والغزو والاحتلال...إلخ. ويكون ذلك كما يلي:

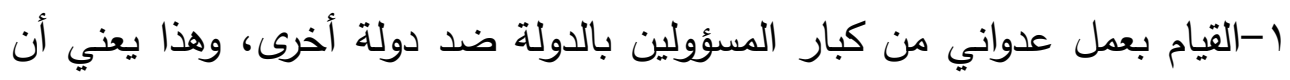

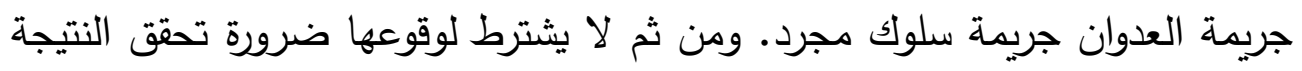

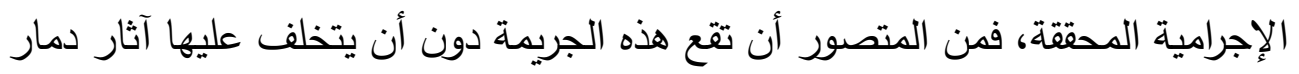

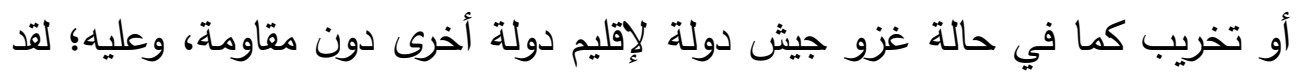

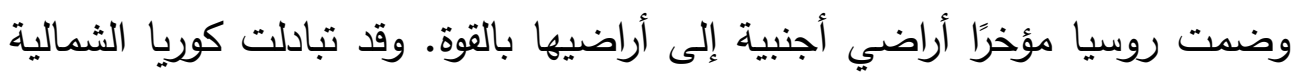

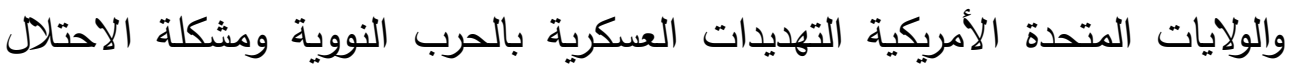
الإسرائيلي. ז-يجب أن ينطوي اللجوء إلى القوات المسلحة على درجة كافية من الخطورة والجسامة:

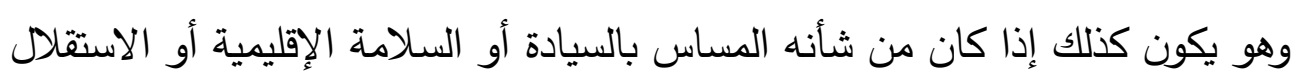

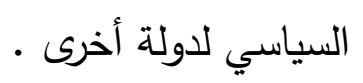

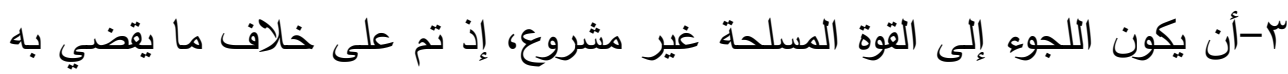

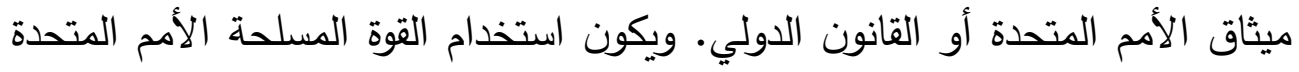

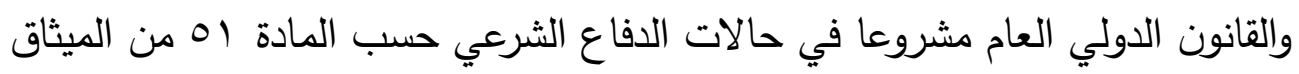

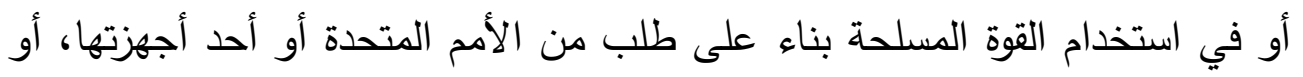
حالة الكفاح المسلح من أجل حق الشعوب في تقرير مصيرها وفي الحرية والاستقلال حق مسلم به في القانون الدولي العام (1). 
العنصر الثاني: صفة الجاني: جريمة العدوان بطبيعتها تتطلب صفة خاصة في الجاني ممن يملكون صفة صانعي القرار في الدولة هو الشخص المتحكم فعلياً في السلطة السياسية أو العسكرية ،أما عدم مسؤولية الجنود العسكريين البسطاء عن هذه الجريمة لأنه يكونون مكرهين على إتيانها، ومجبرين على القيام بها بصفتهم أفراد عسكرين مجندين وضعوا في ميدان القتال، ولا يمنع ذلك من قيام مسئوليتهم بسبب الجرائم التي قد يرتكبونها ضد قوانين وعادات الحرب وضد الإنسانية، كما لو أجهز على أسير أو ونئ جريح خلافاً فضلا عن مسؤوليته عن بقية الجرائم الدولية (كجرائم الإبادة والحرب...) إضافة إلى أن العدوان هو جريمة ترتكب باسم الدولة، لذلك فإنها تثير مساءلة مزدوجة -للدولة وللمسؤول الثخص الطبيعي عن إثارة حرب العدوان معاً لعمل العدواني، وأن تتحمل الدولة المسؤولية المدنية على هذا الفعل، ويتحمل الشخص الطبيعي جريمة العدوان فهو سلوك الفرد الذي على أساسه يتحمل هذا الأخير مسؤوليته الجنائية الفردية (1).كذلك يدخل ارتكاب العمل العدواني المتمثل في استعمال القوة من جانب دولة ضد سيادة دولة أخرى أو سلامتها الإقليمية أو استقلالها السياسي أو بأي صورة أخرى تتعارض مع ميثاق الأمم المتحدة العمل العدواني يشكل بحكم طابعه وخطورته ونطاقه انتهاكا واضحا لميثاق الأمم المتحدة، - كون مرتكب الجريمة مدركا للظروف الواقعية التي أثبت انتهاكا واضحا لميثاق الأمم المتحدة. وأن تكون جريمة العدوان تتطوي على مرنى الخطورة أو الجسامة بمقارنتها أو مساومتها بحرب معلنة أو غير معلنة ((). والنتيجة في جريمة العدوان تتحقق عندما يتم الاعتداء على أي من حقوق الأساسية للدولة، ولاسيما حقها في الحفاظ على سيادتها وحماية سلامتها الإقليمية أو استقلالها السياسي، وهو ما هاء

.Hugo Grotius, The Rights of War and Peace: Book II, Chapter 1 (New York: M Walter Dunne, 19.1 ) p v^ Brian Egan, Legal Adviser, US Department of State, 'International Law, Legal Diplomacy, and the Counter-ISIL Campaign: Some Observations' (Y. (17) International Law Studies, Vol 9 Y , r To

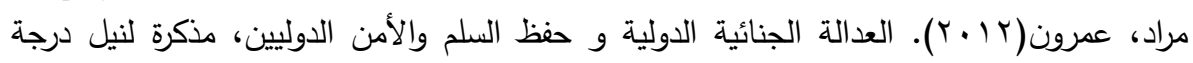

الماجستير في القانون، كلية الحقوق و العلوم السياسية، جامعة مولود معمري، تيزي وزو ،صدء 1

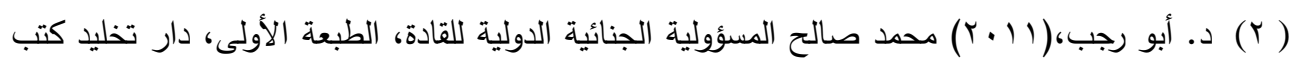

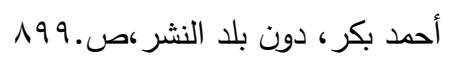


r.r. · مجلة روح القوانين - العدد الواحد والتسعون - إصدار يوليو

أشار إليه المادة الأولى من قرار تعريف العدوان بأن (العدوان هو استعمال القوة المسلحة من قبل دولة ما ضد سيادة دولة أخرى أو سلامتها الإقليمية أو استقلالها السياسي).

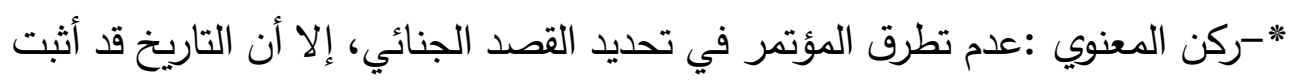

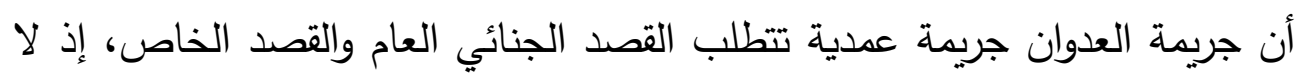

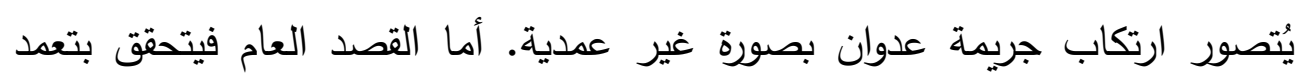

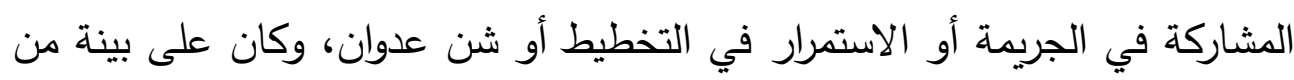

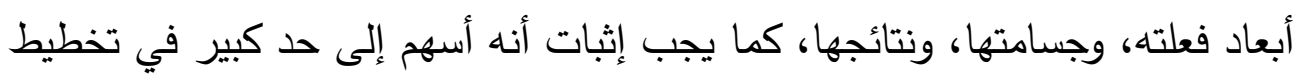

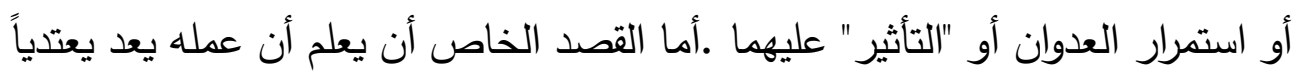

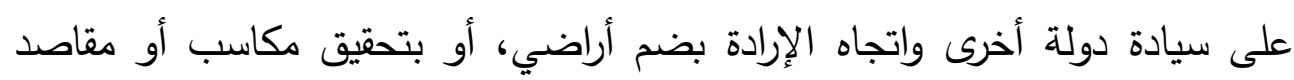

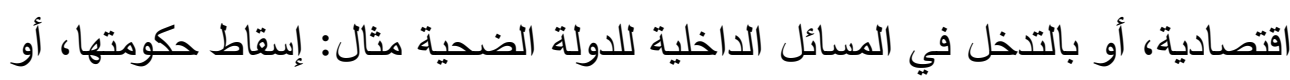

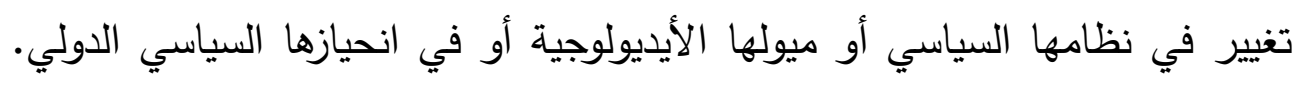

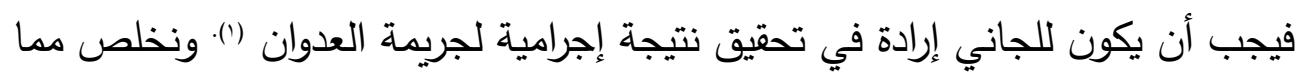

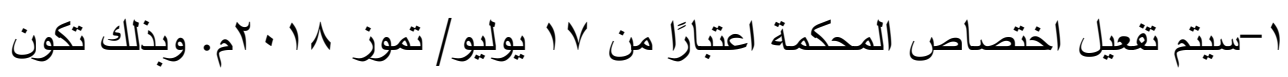
الدول الأطراف مكنت الدائرة التمهيدية في المحكمة الجنائية الدولية بالقيام بدورها

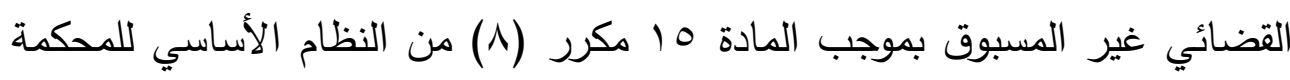

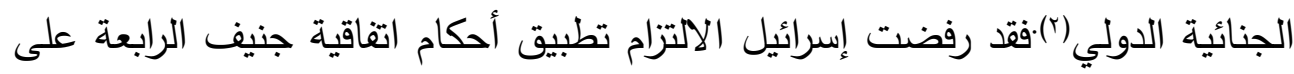

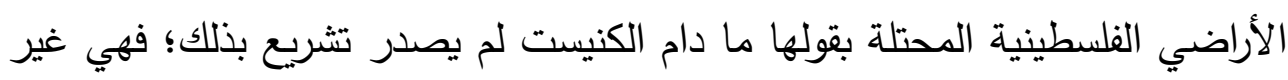

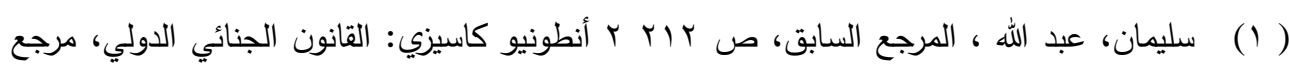
سابق، صه r

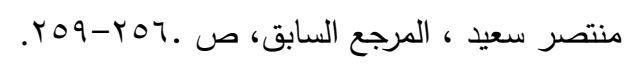

Barriga (eds), The Crime of Aggression: A Commentary ( $r$ vols, Cambridge University Press, $\uparrow \cdot \mid \vee) \downarrow-\wedge$. ( $\uparrow$ ) Francois Bughion Juste War and War of Aggression and International Humanitarian Law, International Review of Red Cross, No. $\wedge \leqslant \vee, \nvdash \ldots r$ p $\{9$ KAMTO Maurice, L'agression en droit international, Edition. A. Pedone, Paris , 
ملزمة بها ('إضافة لعدم إمكانية تحريك الدعوى الجنائية ضدها بسب أساليب التعذيب التي تستخدمها أثناء التحقيق مع المعتقلين الفلسطينيين(r). r-تعد جريمة العدوان من المسائل الموضوعية التي يستلزم اتخاذ قرار بشأنها موافقة جميع الأعضاء الدائمة العضوية في مجلس الأمن التي تتمتع بحق الفيتو مما يجعلها متحكمة في هذا القرار، فعددت هذه الدول إلى استغلال مركزها الذي تحتله في المجلس للحيلولة بينه وبين استصدار القرارات التي تعارض مصالحها دون مراعاة أهمية القرار على السلم والأمن الدوليين لذلك يجب على المدعي العام التأكد من صدور قرار من طرف مجلس الأمن بشأن وقوع عمل عدواني، غير أنه إذا لم يتم الاتفاق داخل المجلس على قرار وجود عدوان في غضون 7 أشهر من تاريخ إبلاغ المحكمة للمجلس فيمكن للمدعي العام المضي في التحقيق. كما في حالتين هما الأولي: تخص قضية كينيا

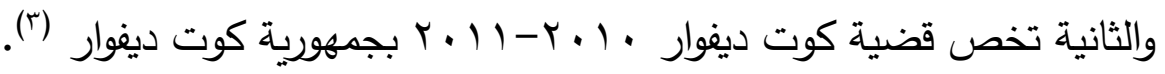
r-إن التعريف الجوهري لجريمة العدوان لا يغطي سوى استخدام القوة الجسيمة من قبل الدولة التي تصل إلى مستوى كبير بحيث يُعد غير قانوني بشكل لا لبس فيه. وعند إصدار مجلس الأمن قرار بشأن تكييفه لجريمة العدوان فلن تستطيع المحكمة الجنائية الدولية وصف الوضع على وجه مخالف، لذا يجب أن تكيف هذه الجريمة كمسألة من المسائل الإجرائية التي تستوجب موافقة تسعة أعضاء دون اشتراط موافقة الدول الخمس الدائمة العضوية. أما في حالة عدم وجود قرار من مجلس الأمن فسيكون للمحكمة مطلق الحرية لوصف هذا السلوك بأنه عدوان (؛)

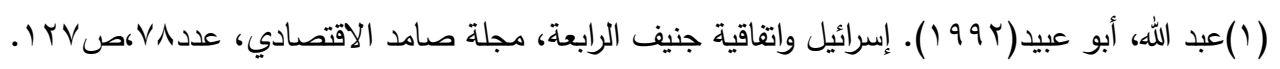

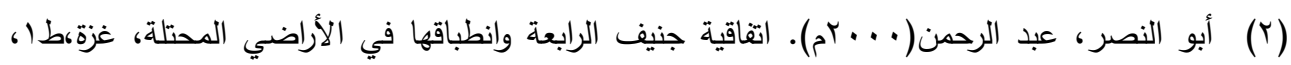

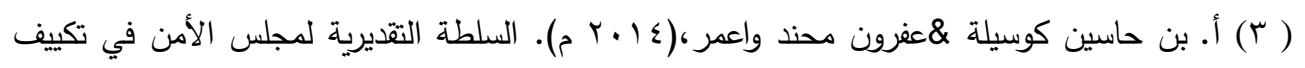
جريمة العدوان مذكرة لنيل شهادة الماستر في الحقوق تخصص القانون الدولي الإنساني وحقوق الإنسان كلية

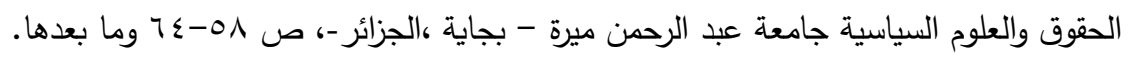

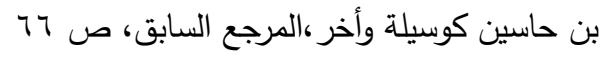


r.r. · مجلة روح القوانين - العدد الواحد والتسعون - إصدار يوليو

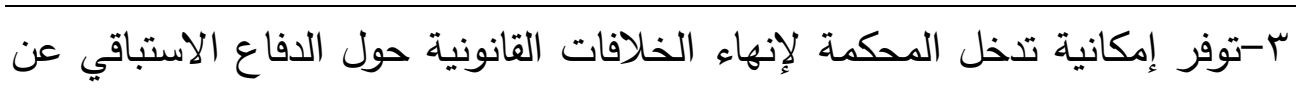
النفس والدفاع عن النفس ضد أي هجوم مسلح من غير الدول.

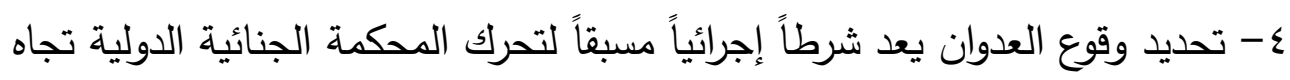

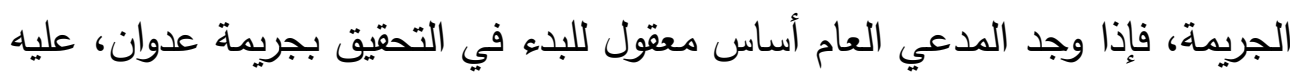

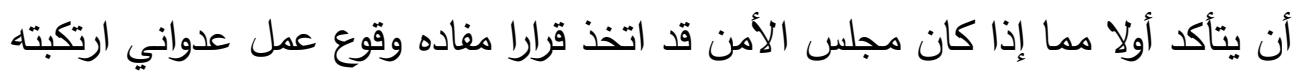

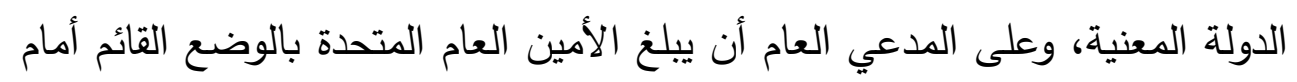

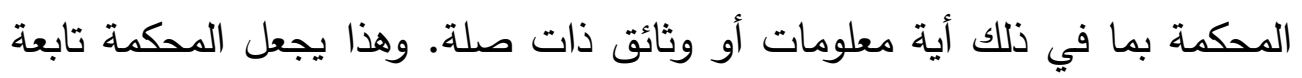
لمجلس الأمن، ومن جهة أخرى إمكانية مجلس الأمن تأجيل إجراءات المحكمة الجنائية

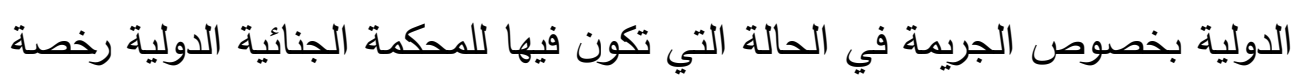
مباشرة إجراءاتها تجاه عملا بالمادة (7 (1) من نظام روما الأساسي للمحكمة الجنائية

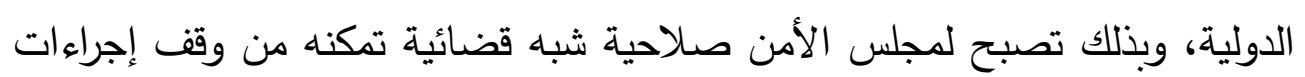
التحقيق والمقاضاة أمام المحكمة. ه-إن الخلاف بشأن هذه الجريمة لا يتعلق بتعريفها حسب بل ينصرف الحفاف إلى مسألة

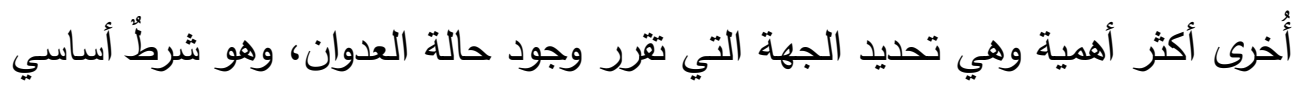

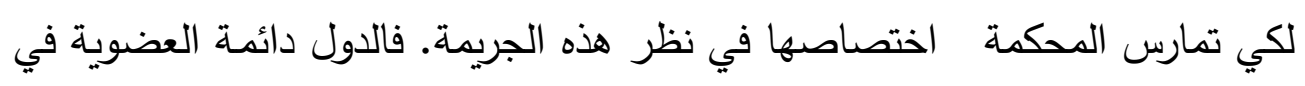

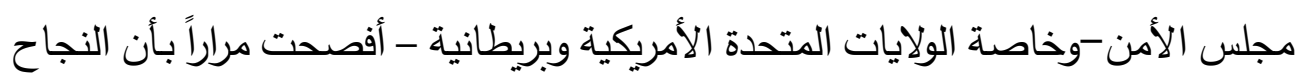

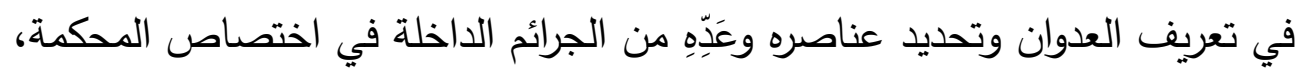

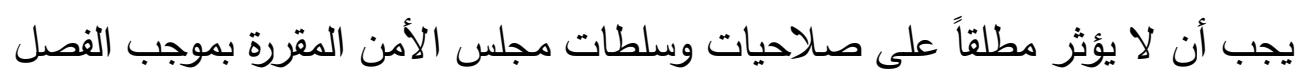

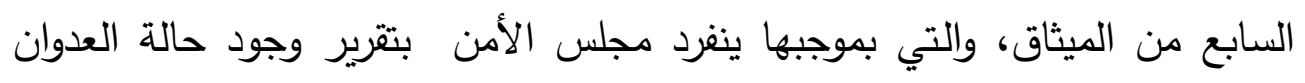

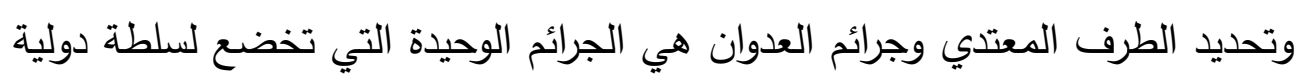

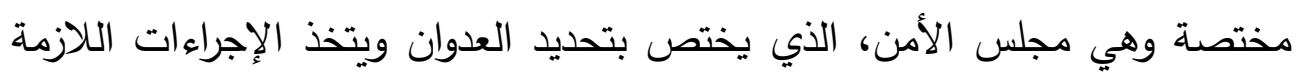

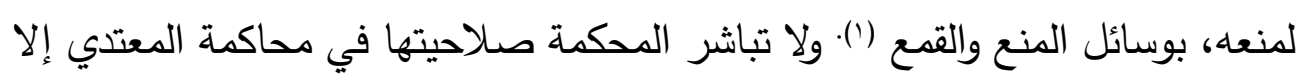

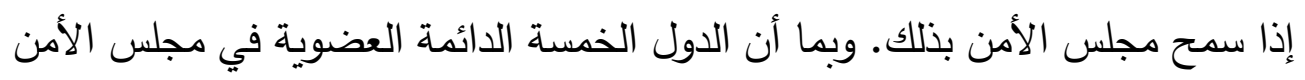




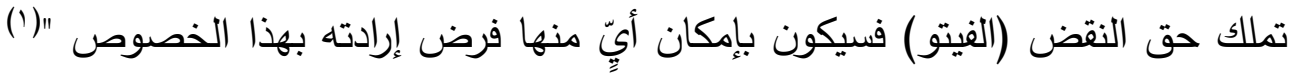
فإن استخدام حق النقض (الفيتو يعني الحيلولة دون إمكانية المحكمة من استخدام

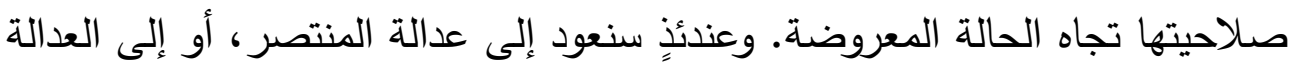

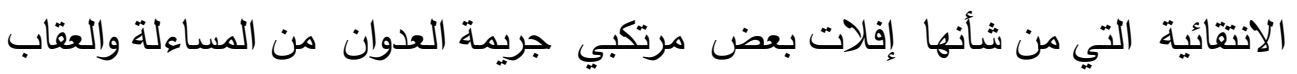

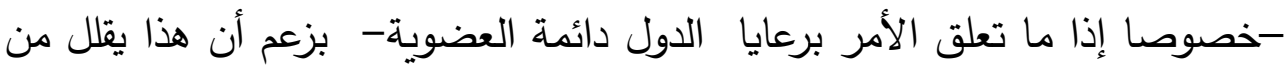

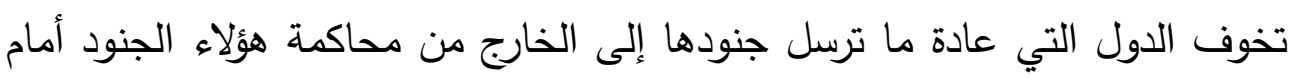

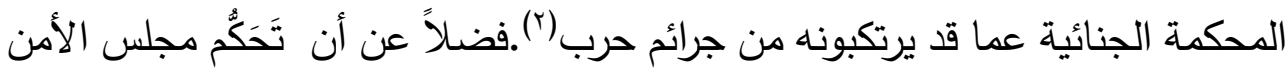

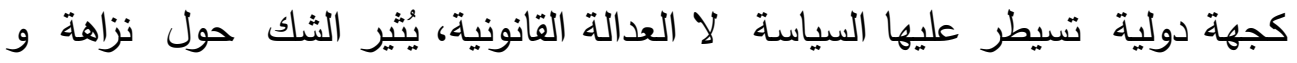

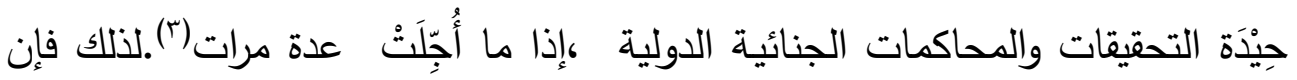

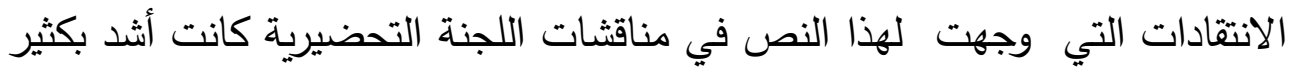

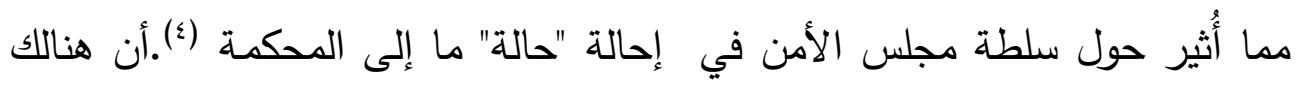

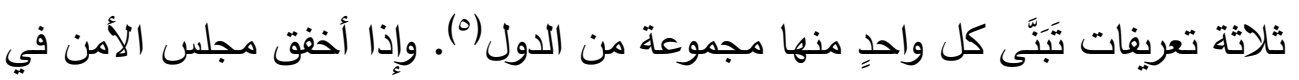

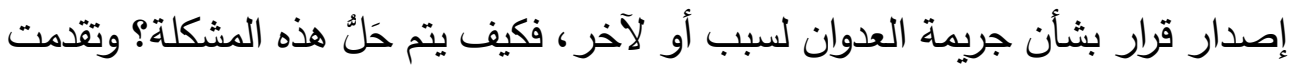

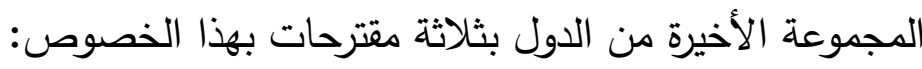

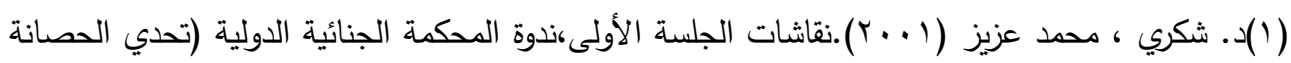

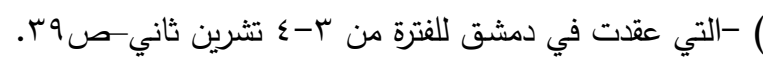

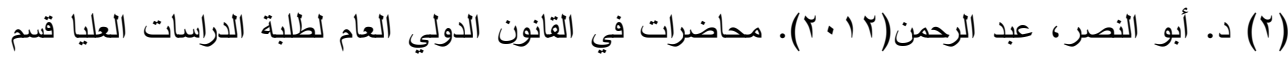
القانون العام ,جامعة الأزهر ,غزة.

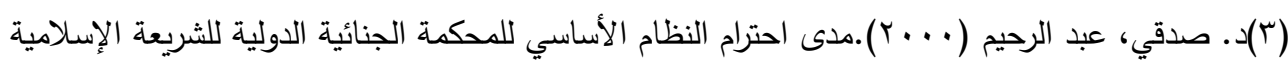

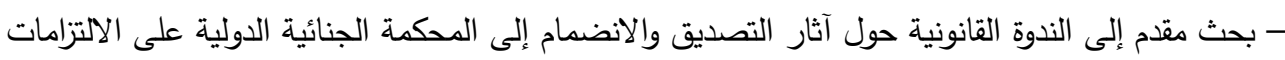

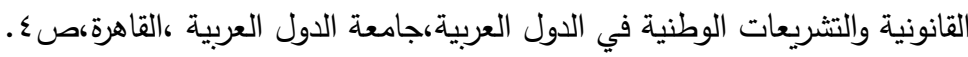

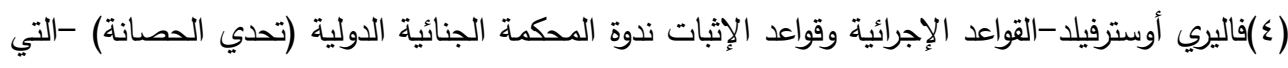

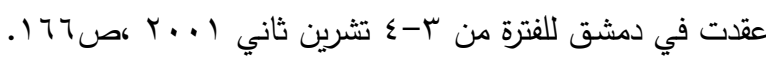

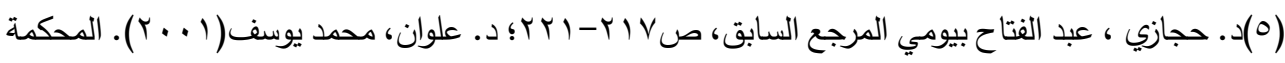

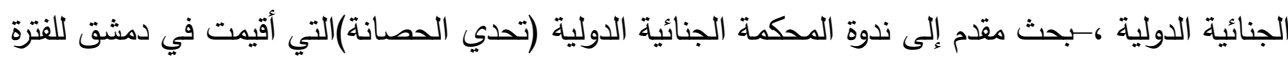

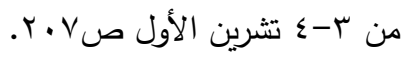




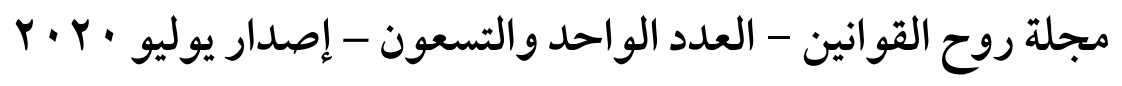

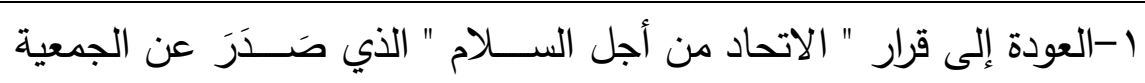

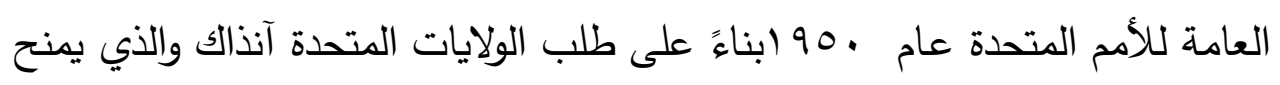

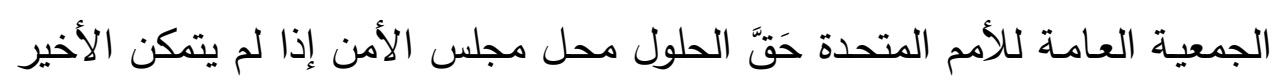

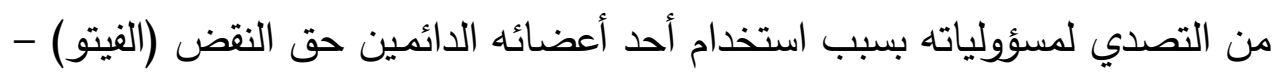

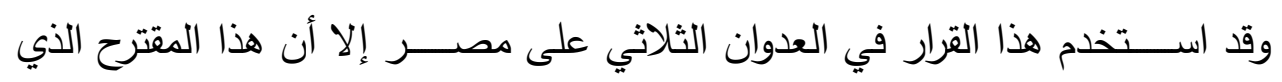

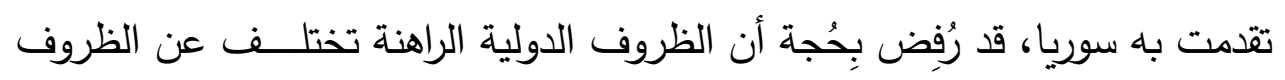

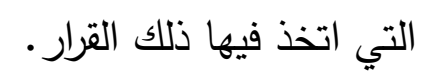

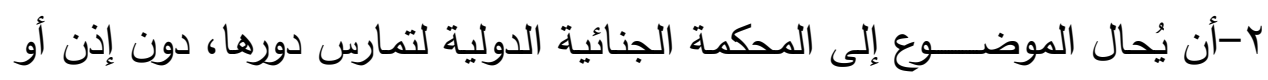

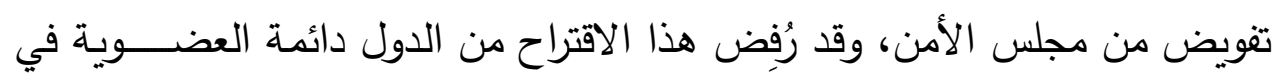

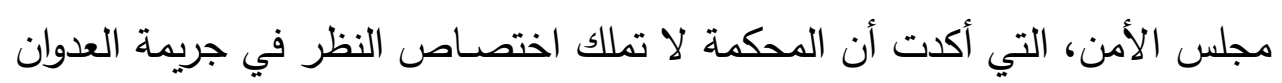

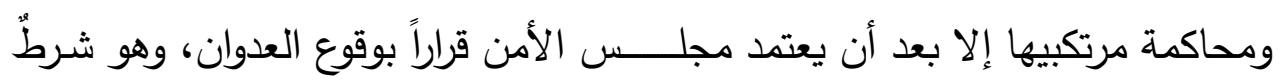

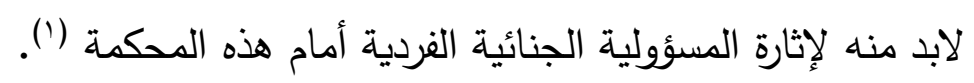

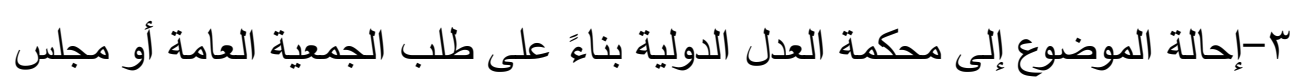

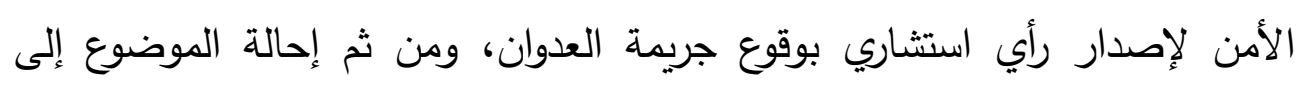

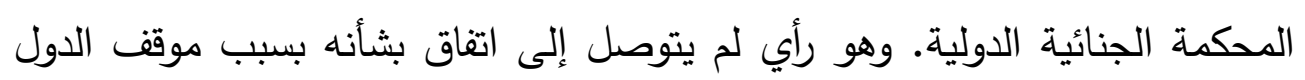

دائمة العضوية الراغب في حَصر تلك الصلاحية بمجلس الأمن الدولي وحده (؟).

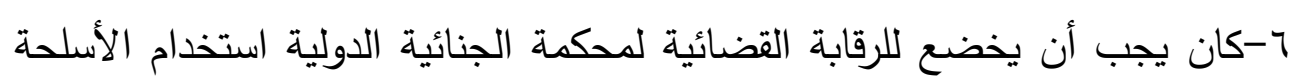

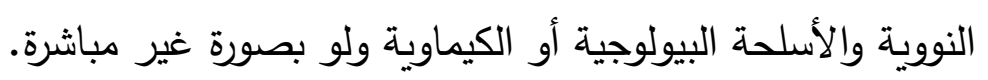

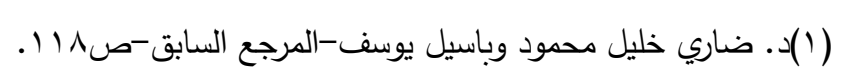

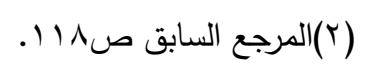
(ron) 


\section{الامطاب الثانبي}

\section{عدم الستفدام مبدأ التكاهلية المهطل لاختصاص المكمة الجنائية الدولية}

إن المسؤولية الأساسية في التحقيق والمعاقبة على هذه الجرائم تقع على عاتق الدول

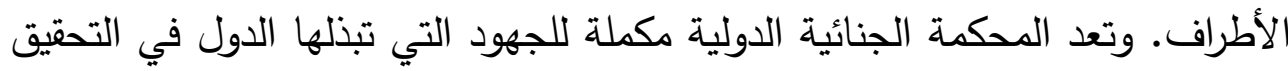

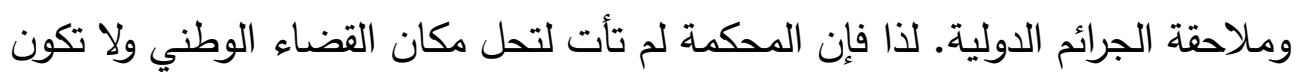

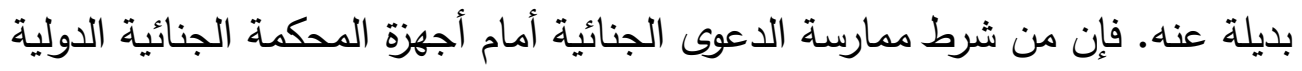

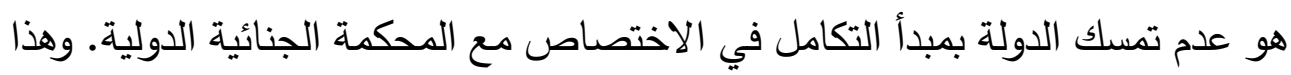
يقتضي البحث عن معيار توزيع الاختصاص بين المحكمتين ومسنده ومبرراته، أي

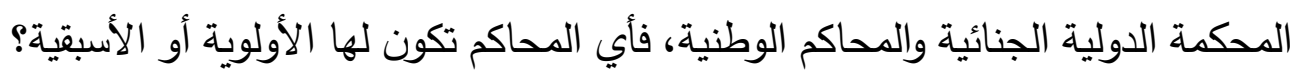
ويستفاد من هذه النصوص أن الاختصاص الأصيل للدحاكم الوطنية في الجرائم

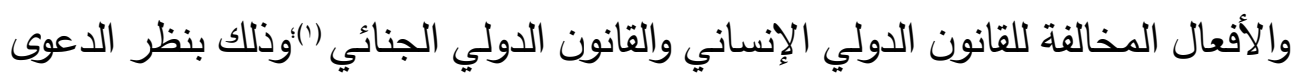

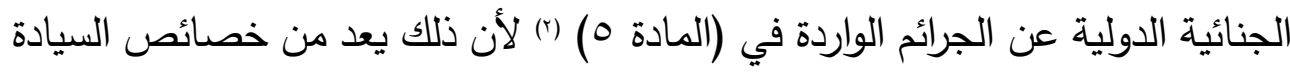

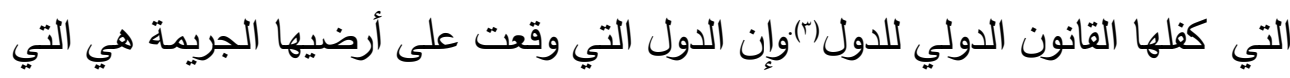

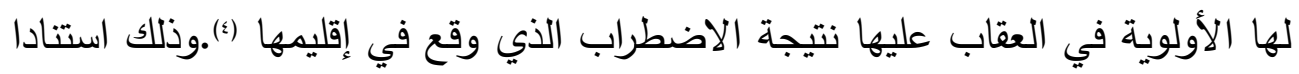
إلى الفقرة العاشرة من ديباجة النظام الأساسي للمحكمة الجنائية الدولية وكذللك المادة الدادية

( (1) د. الطيف، عبد السلام (0. …أزمة دارفور بين التحديات الدولية والقانون الدولي الإنساني مجلة

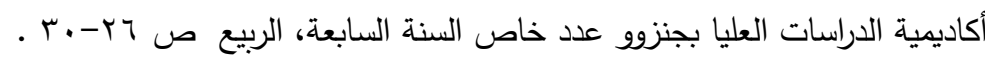

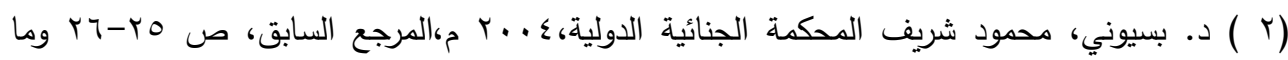

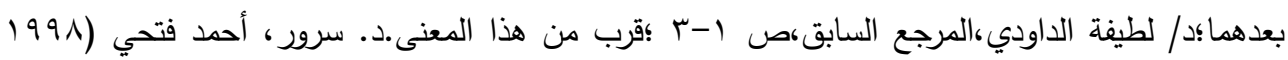

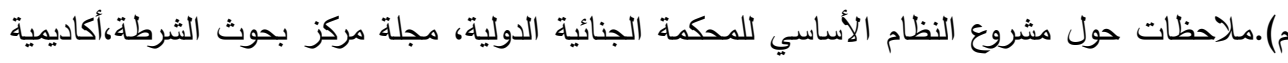

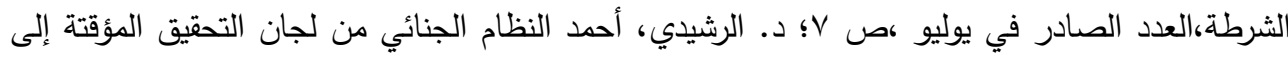

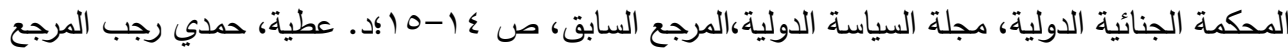

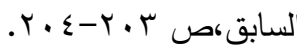

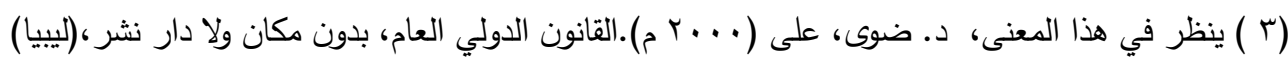

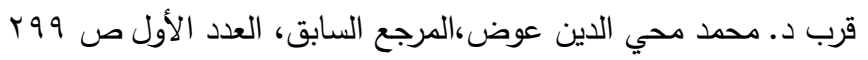




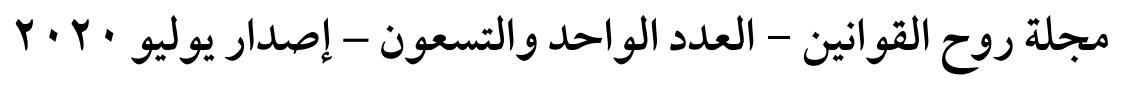

الأولى منه التي جعلت اختصاص المحكمة الجنائية الدولية مكمل للولايات القضائية

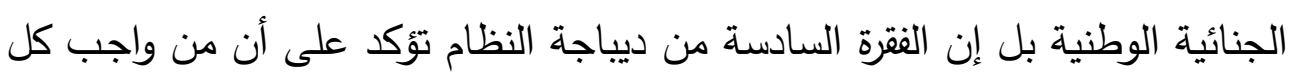

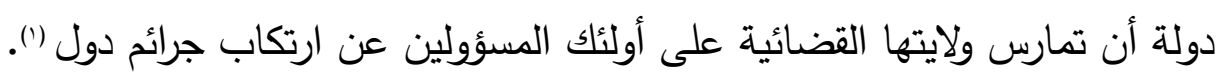

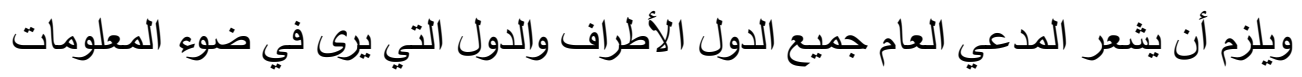

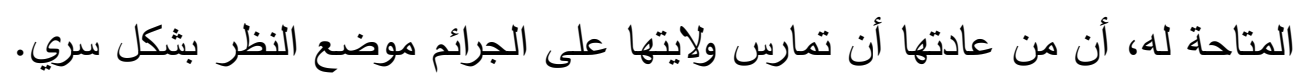

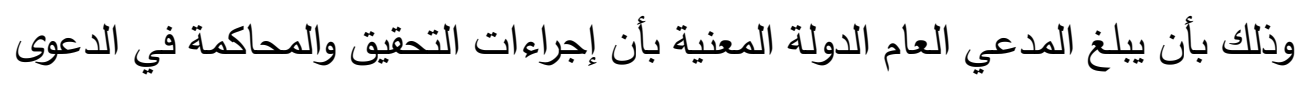

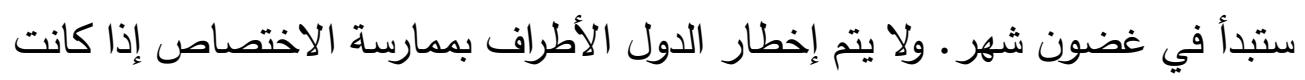

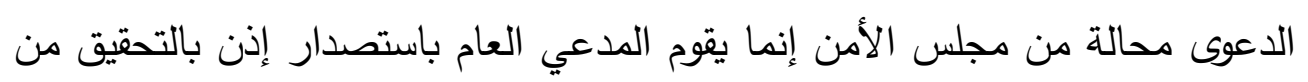

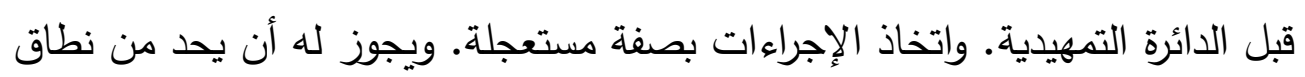

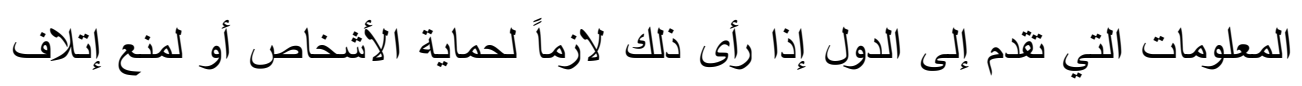

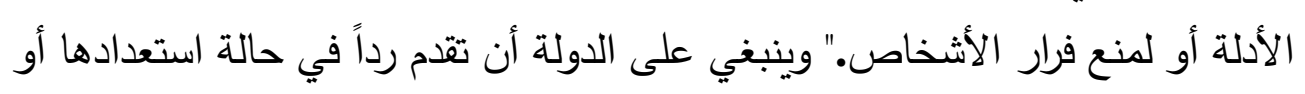

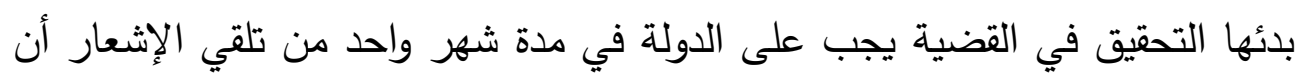

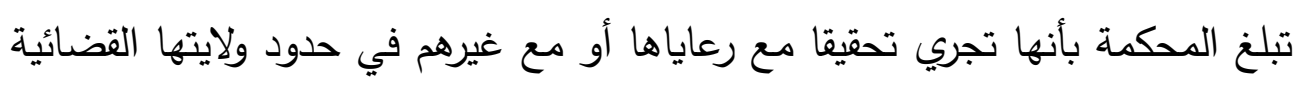

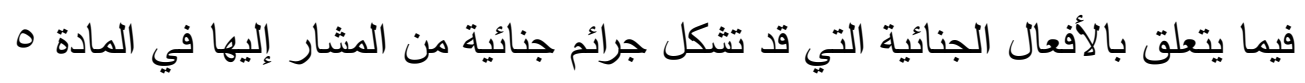

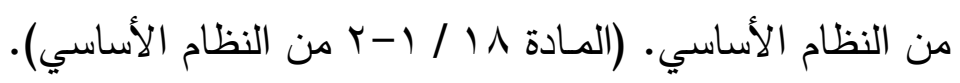

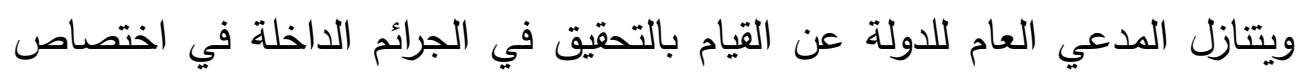

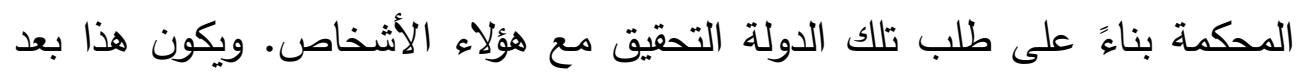
فحص الأوراق والمعلومات للوصول إلى الإجراء الذي يجب إتباء لتاعه، وللدائرة التمهيدية

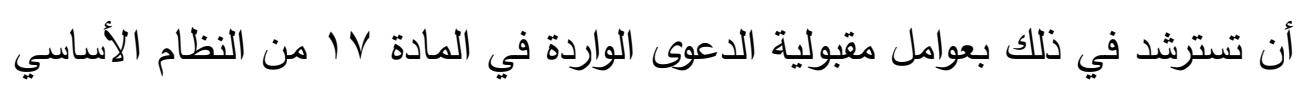

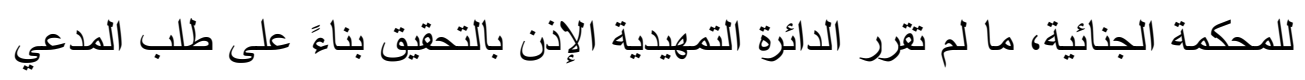

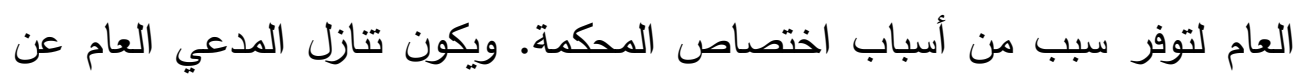

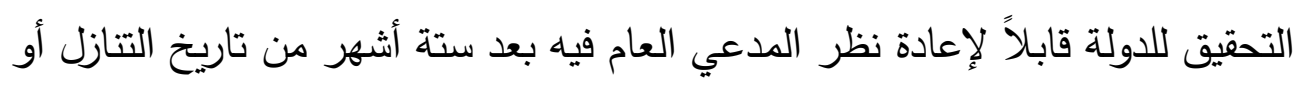

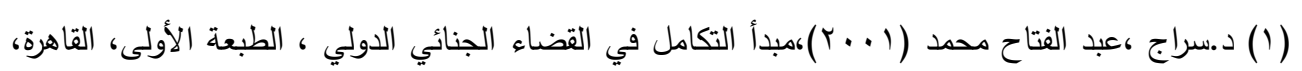
دار النهضة العربية ، ص الص. (1) 


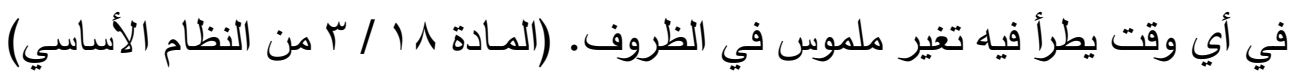

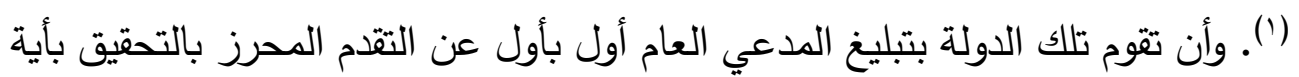

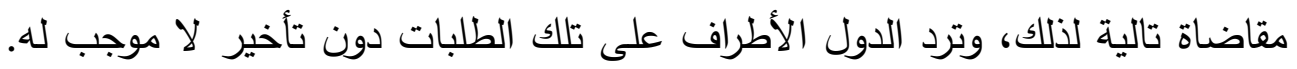

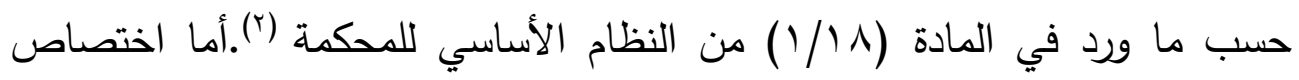

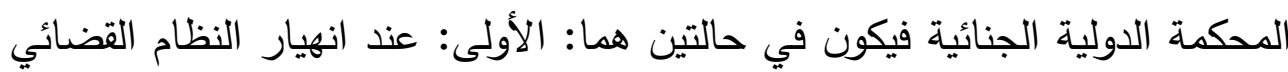

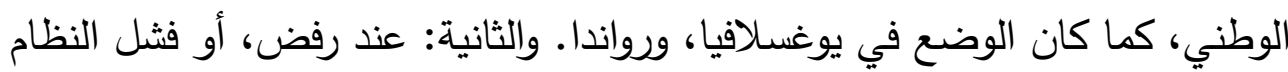

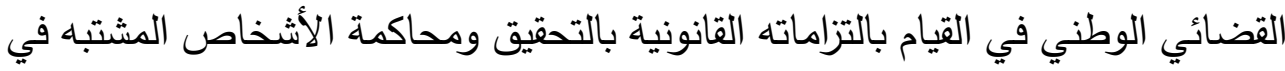
ارتكابهم الجرائم الثلاثة الداخلة في اختصاصات المحكمة، أو معاقبة أولئك الذين أدينوا

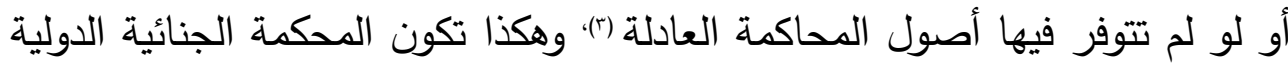
مختصة بنظر الجرائم الدولية في حالة ما إذا وجد فراغ في المحاكمة عن الجرائم الدولية.

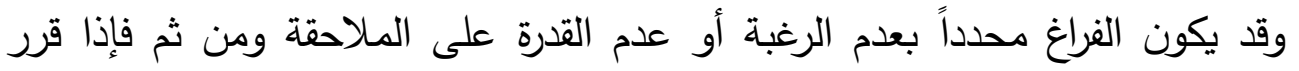

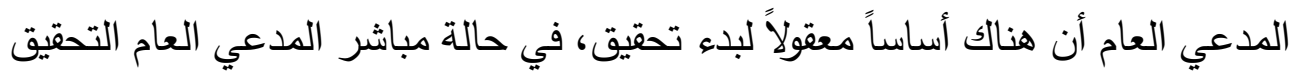

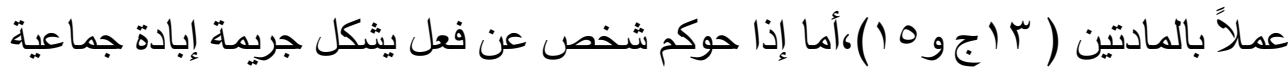
أو جريمة ضد الإنسانية أو جريمة حرب" كما وردت في نظام روما الأساسي. فإنان المحكمة الدولية لن تحاكم الثخص مرة أخرى فيما يتعلق بنفس الفعل الذي حوكم عليه

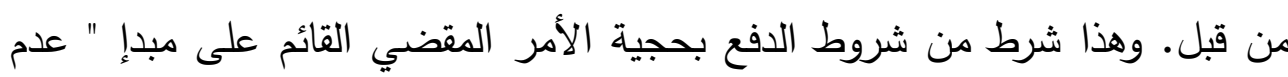

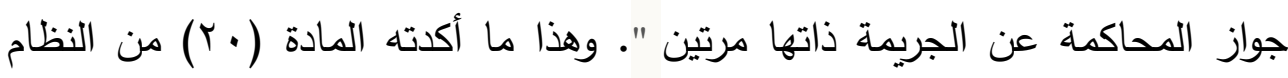

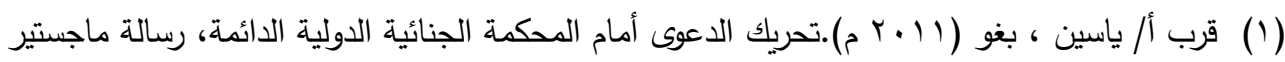

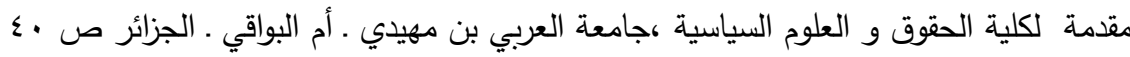

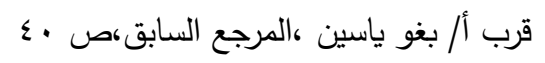

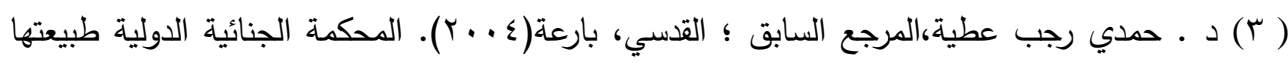

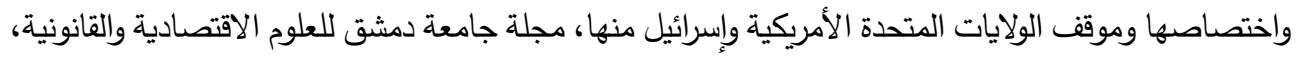

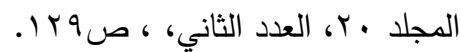
CRETIN ( T ), La Justice pénale internationale son évolution, Son avenir de Nuremberg a ‘BAZELAIRE ( J.P )

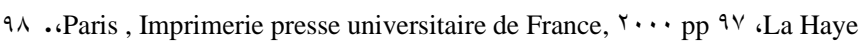




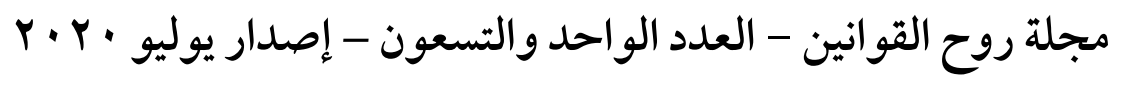

الأساسي للمحكمة الجنائية الدولية والفقرات السابعة، والتاسعة، والحادية عشر من ديباجة

\section{المطاب الثالث - الث}

\section{توفر الاختصاص الزهني والككاني والشخصي للمكيمة الجنائية الدولية}

أولا: توفر الاختصاص الزهني اللهكيمة:

القاعدة العامة في القانون الجنائي التي أخذ بها النظام الأساسي للمحكمة الجنائية الدولية هو الأخذ بمبدأ الأثر الفوري المباشر للقاعدة الجنائية. وعدم جواز تطبيق القانون الفاني

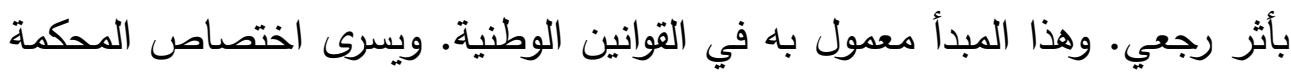

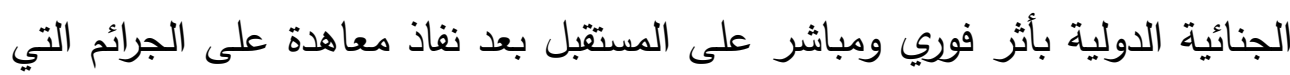

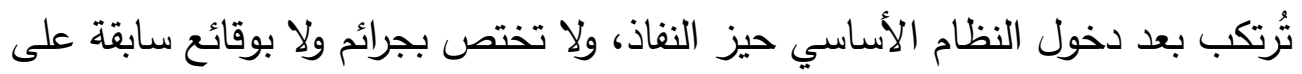
وجود المحكمة (المادة (1) من النظام الأساسي. وذلك تطبيقاً لمبدأ الشرعية الجنائية،

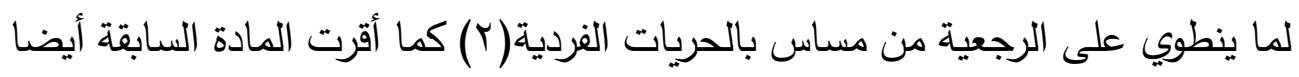

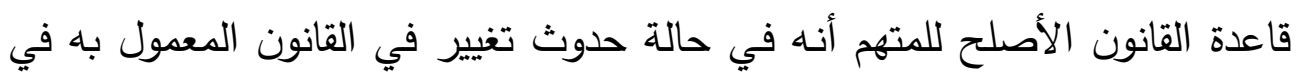

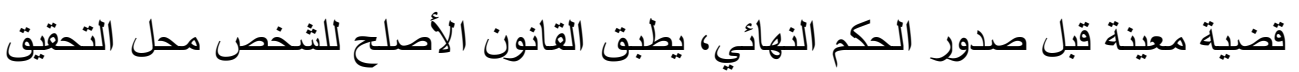

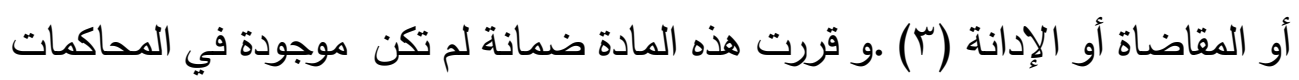

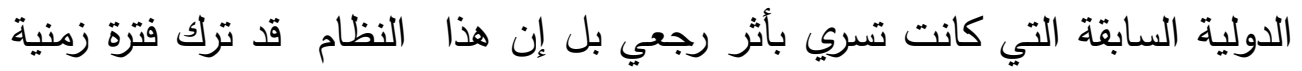

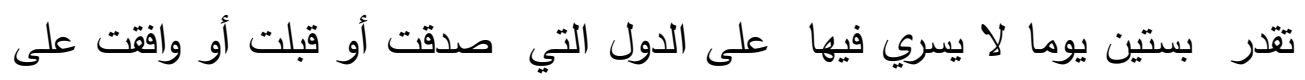

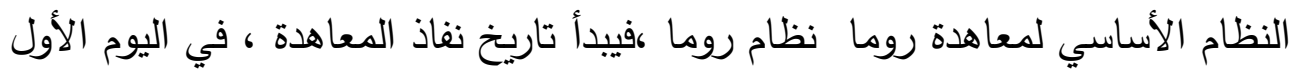

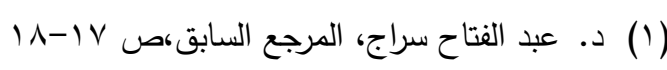

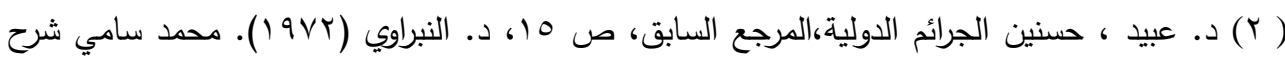

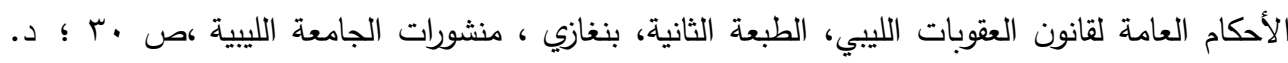

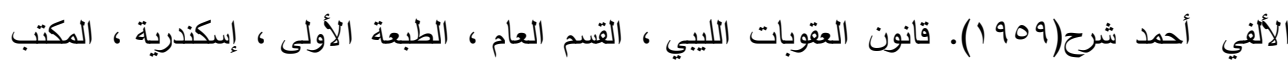

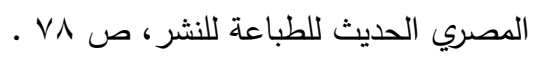

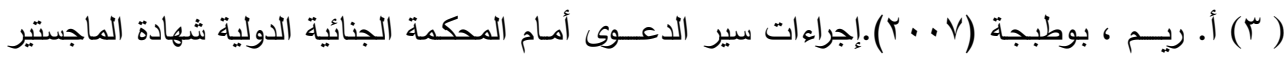

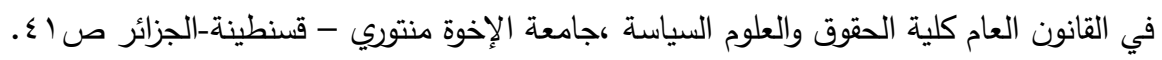




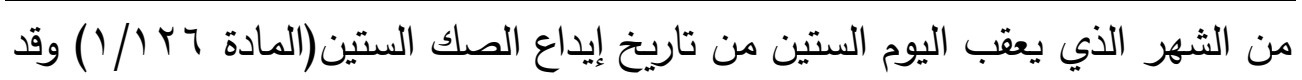

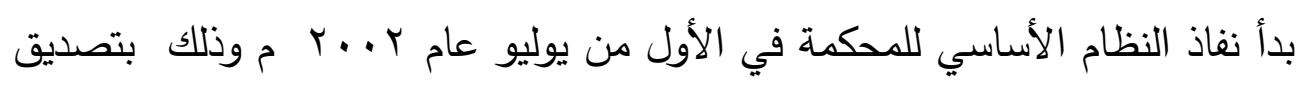

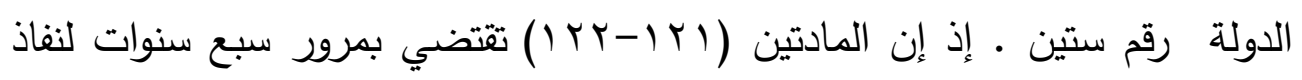

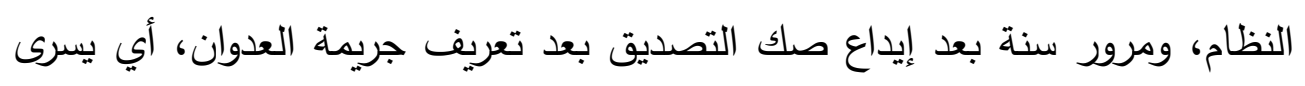

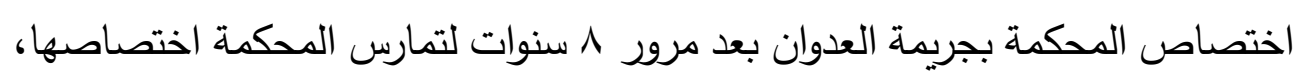

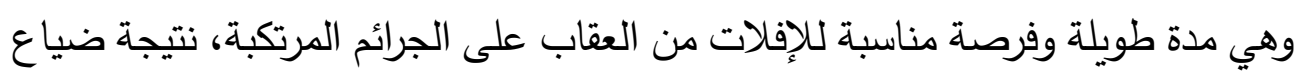

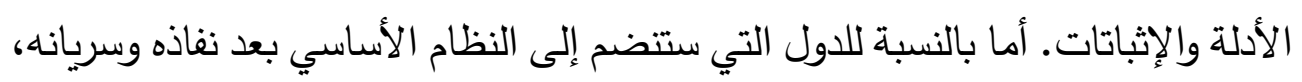

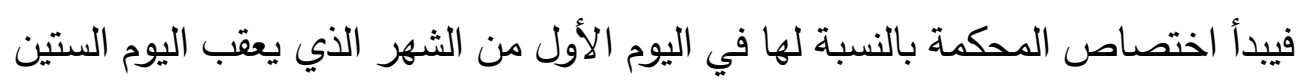

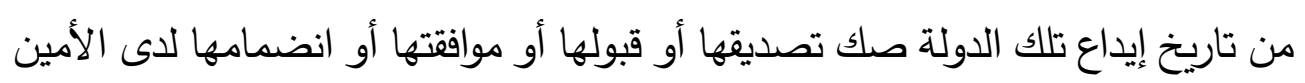

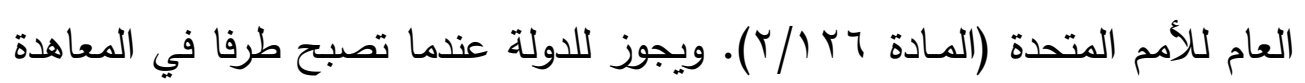

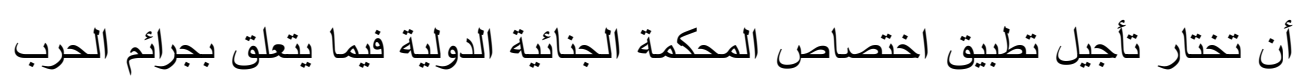

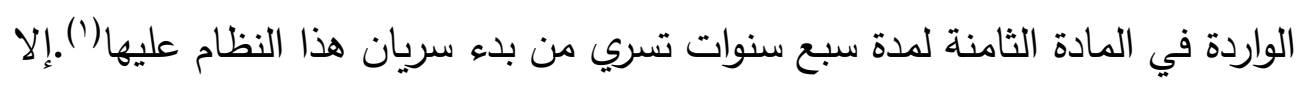

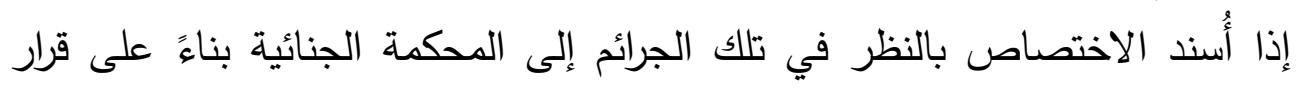

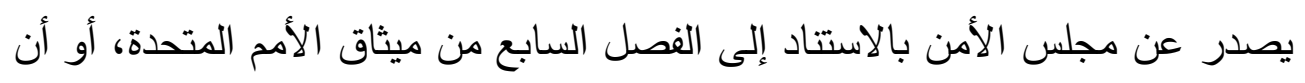

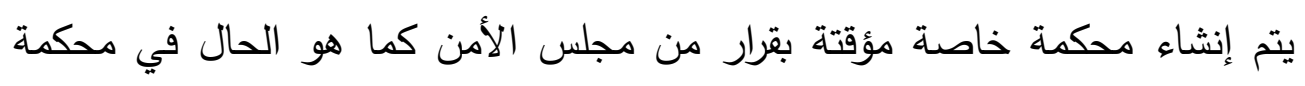

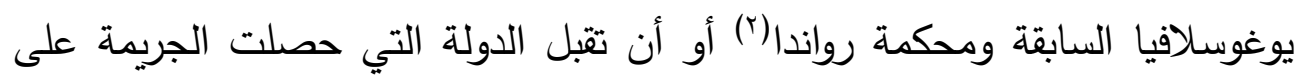

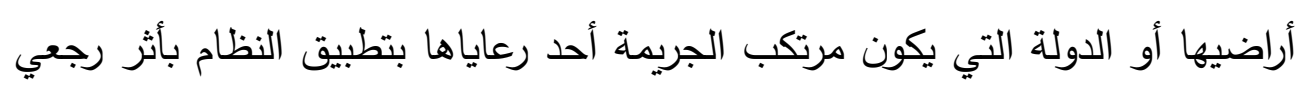

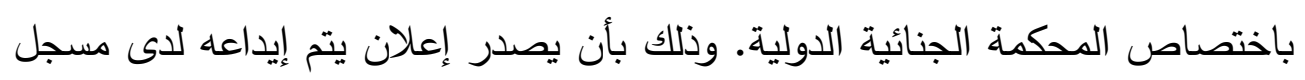

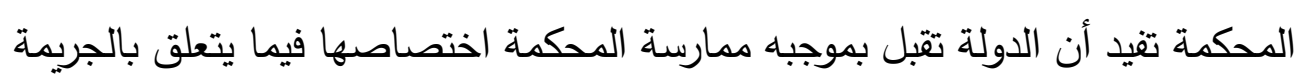

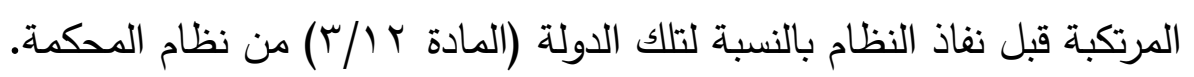

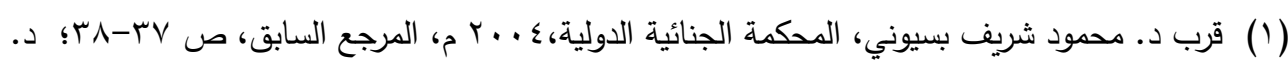

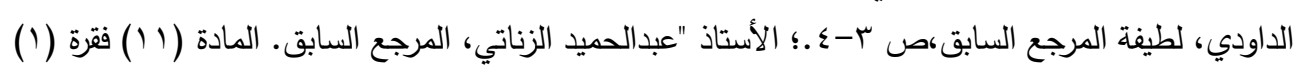
من النظام الأساسي للمحكمة الجنائية الدولية.

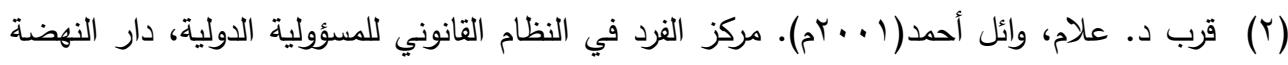




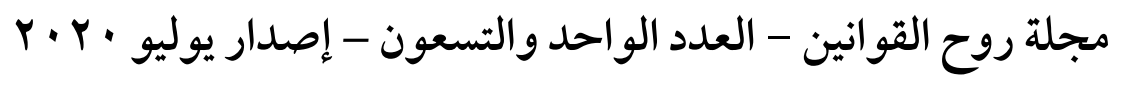

أما الجرائم التي تدخل في الاختصاص الزمني للمحكمة الجنائية الدولية فإنها لا تسقط

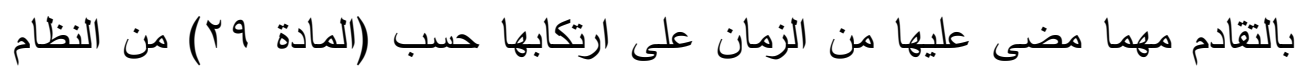

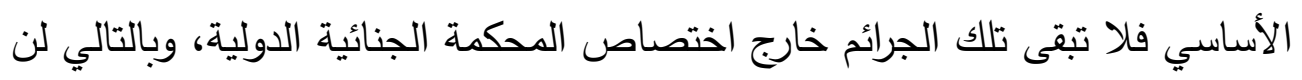

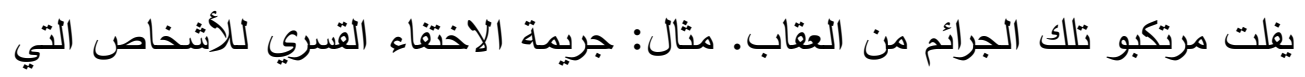
تدخل تحت الجرائم ضد الإنسانية، ذلك أن تلك الجرائم الانتهاكات، باعتبارها جرائم

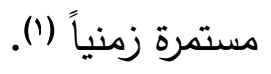

\section{ثالثا: توفر الاختصاص الشخصي}

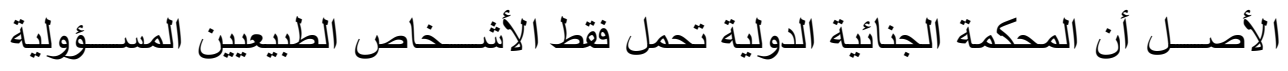

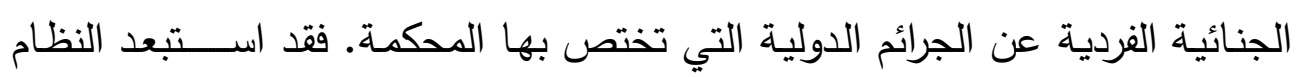

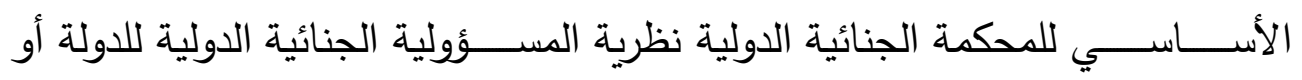

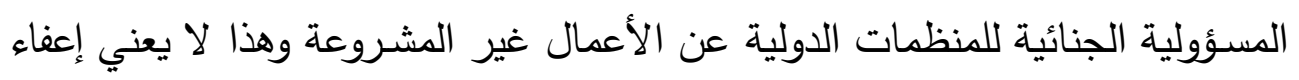

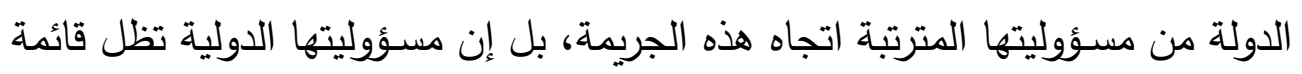

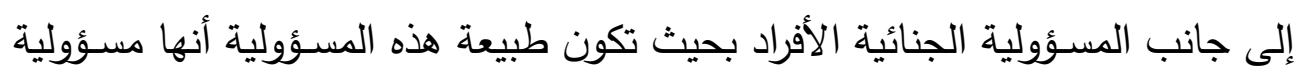

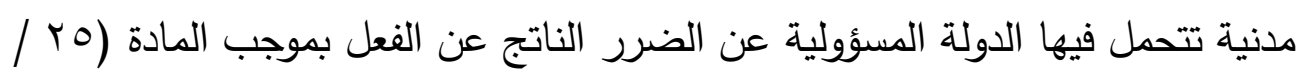

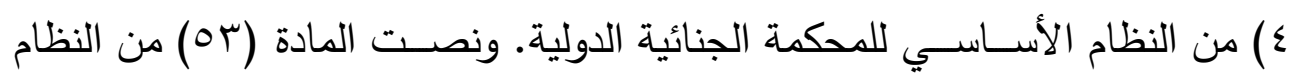

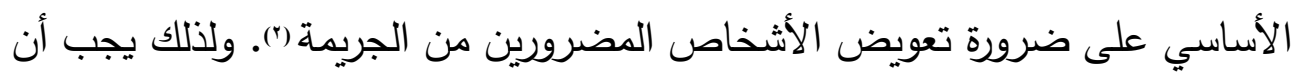

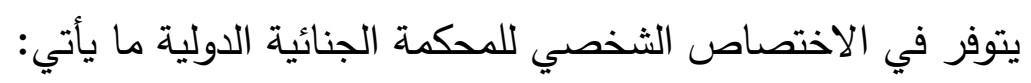

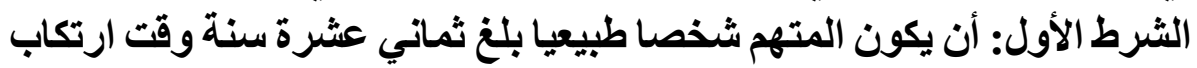

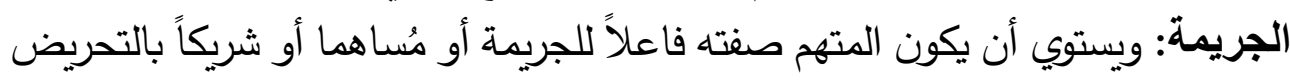
أو المساعدة. كذلك يُسأل الثخص في حالة الثرنه الثروع في ارتكاب الجريمة عملاً (المادة

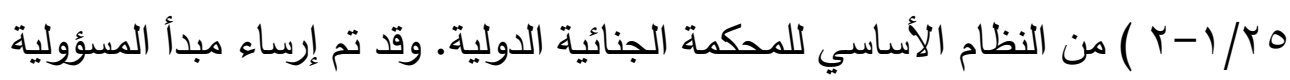

قرب المحكمة الجنائية الدولية:تحدي الحصانة، منشورات اللجنة الدولية للصليب الأحمر،طا، 
الفردية في محكتي نورمبرج وطوكيو، وتم تطبيقه عملياً بحق مجرمي الحرب الألمان

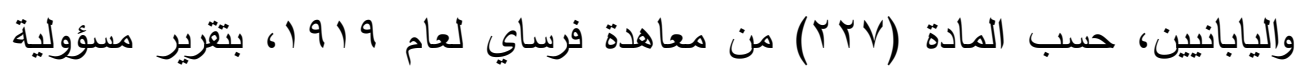

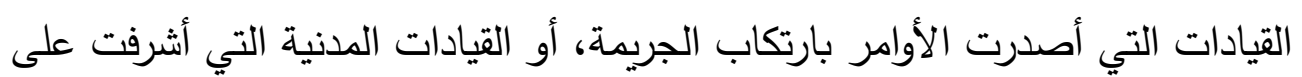

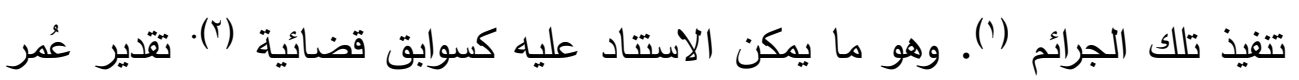

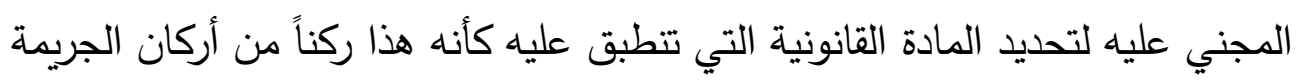
وذلك لغرض تحديد الجهة التي تتولى التحقيق معه وكذلك تحديد المحكمة التي سيتم

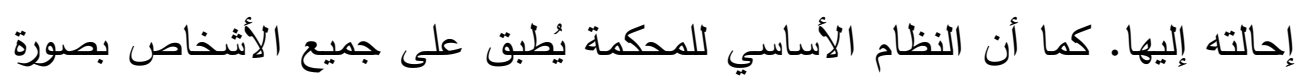

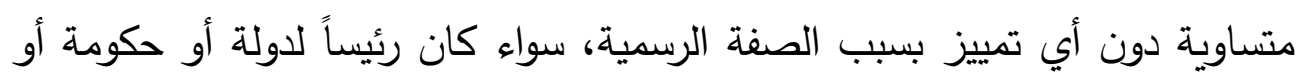

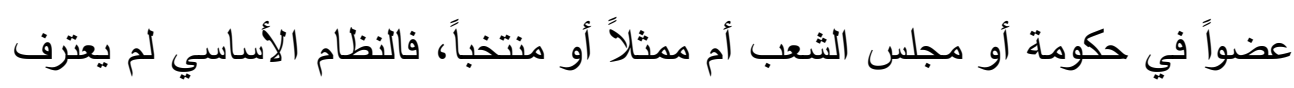

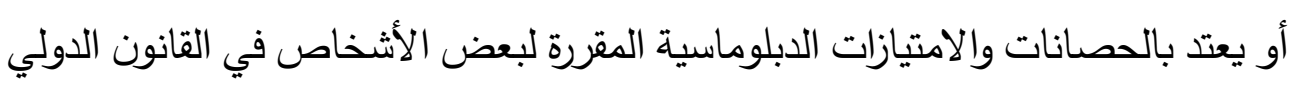

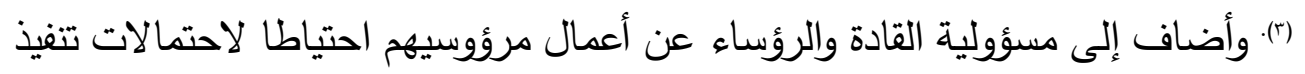

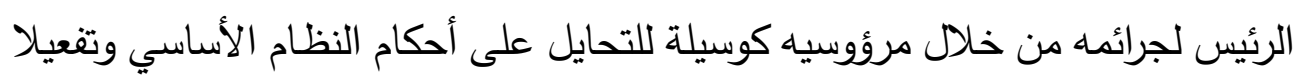

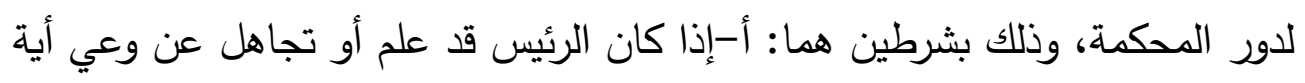

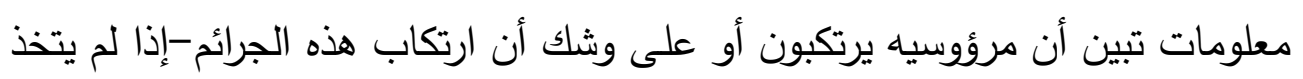

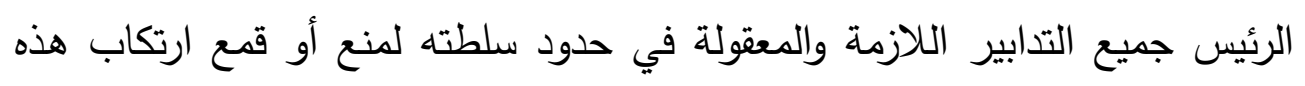

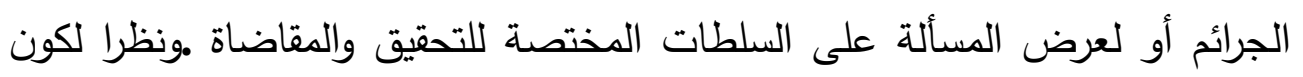

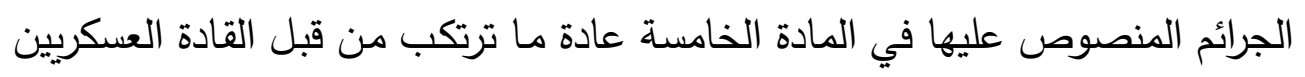

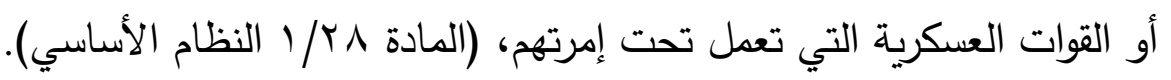

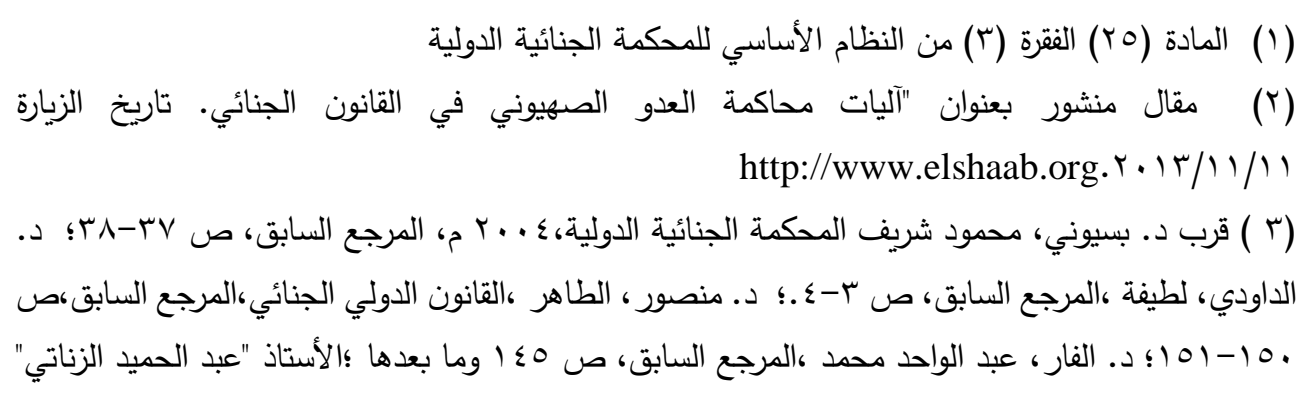

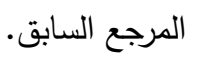


r. r. • مجلة روح القوانين - العدد الواحد والتسعون - إصدار يوليو

الثــرط الثاني: علدم توفر مانع من موانع المســؤولية الجنائية: موانع المســـؤولية

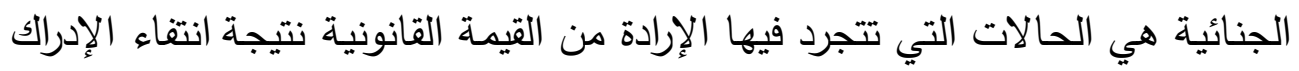

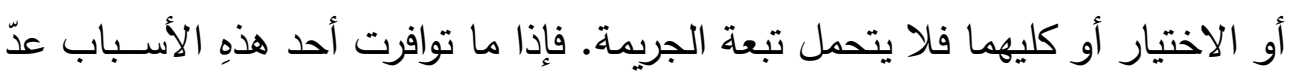
مرتكب الفعل غير مسؤول ('). وذلك كما يأتي:

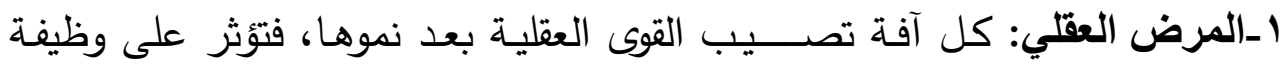

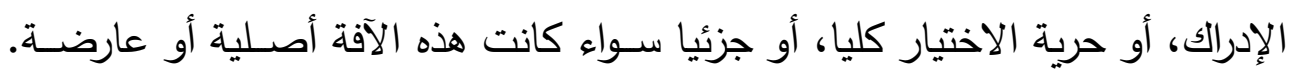

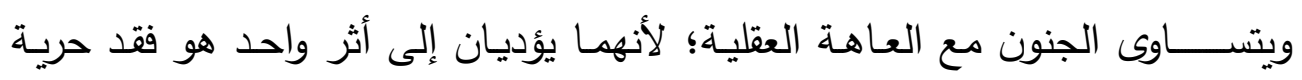

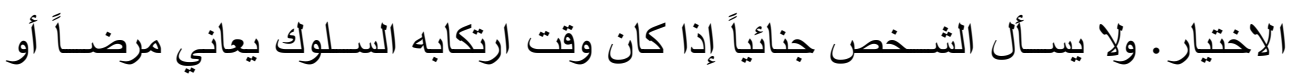

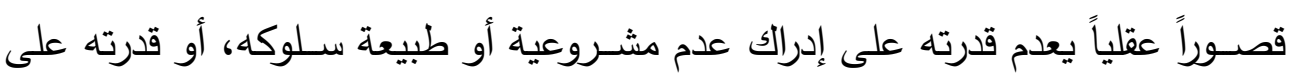

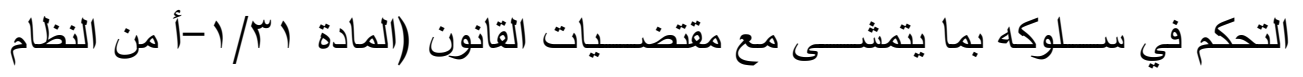
الأساسي للمحكمة الجنائية الدولية).

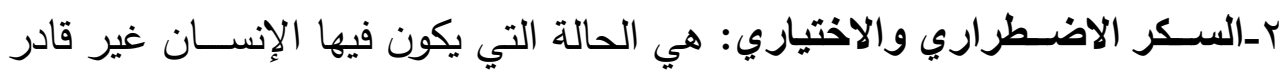

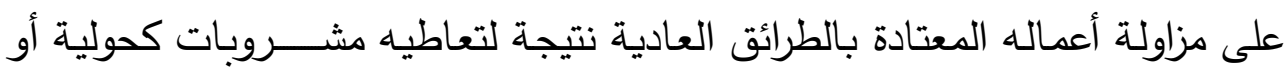

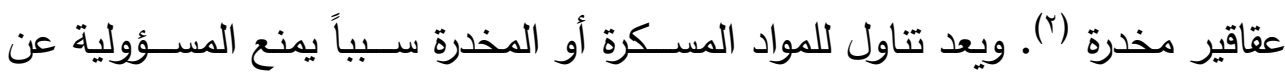

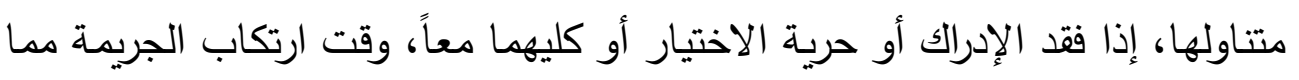

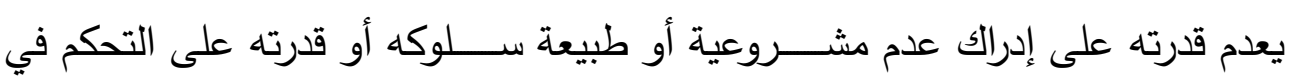

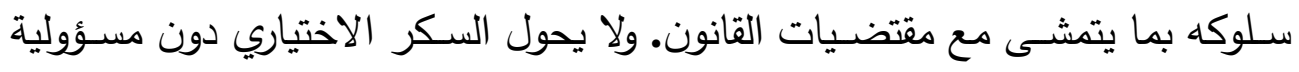

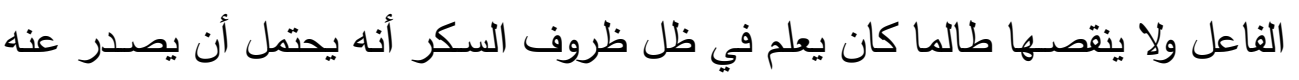

( ()قرب من هذا المعنى: د. شمس الدين، أشرف توفيق (1991 ().مبادئ القانون الجنائي الدولي،دار النهضة

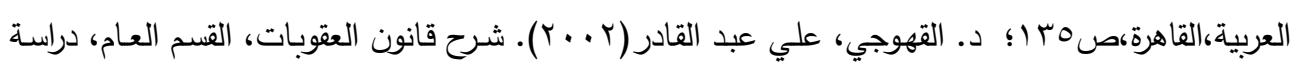

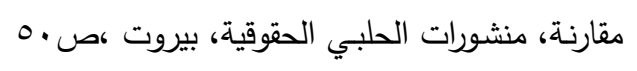
(Y) د. الحسني، عباس(YVY (19). شرح قانون العقوبات العراقي الجديد، المجلد الاول، القسم العام ، مطبعة

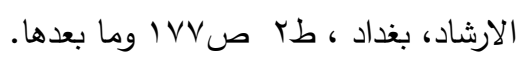




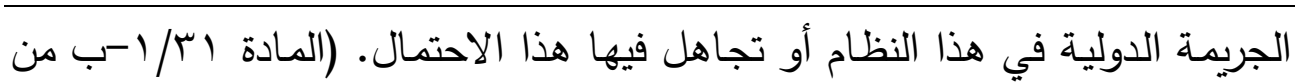

النظام الأساسي للمحكمة الجنائية الدولية).

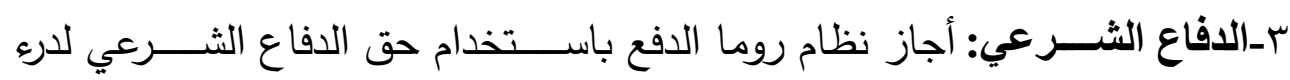
المسـؤولية الجنائية عن مرتكبي أي من الجرائم الدولية، أمام المحكمة الجنائية الدولية وذلك في حالة ارتكاب جريمة عدوان أو إحدى الجرائم الداخلة في اختصاص المحكمة

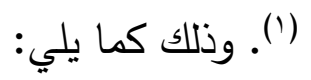
أ-أن يكون العدوان مسـلحا وغير مشـروع وكانت الدولة ضـــية العدوان مسـلح غير مشروع. ب-أن يكون العدوان جسيما وخطيراً ويمس الحقوق الأساسية أن يرد العدوان على أحد الحقوق الجوهرية للدولة وأمالكها والتي تتمثل في الســــامة الإقليمية والحق في السـيادة الوطنية والحق في الاسـتقلال الوطني ج-أن يكون العدوان المســلح حالا ومباشرا أي يجب أن يكون قد وقع بالفعل وليس وشيك الوقوع (ז).

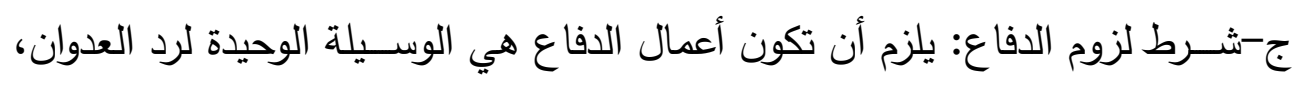

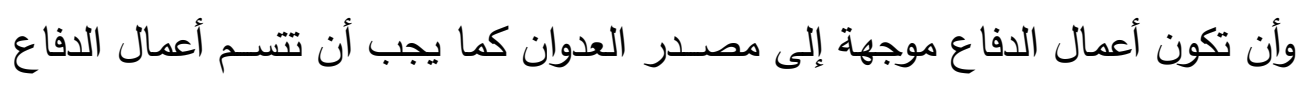
بصـفة التأقيت وذلك لحين اتخاذ مجلس الأمن للإجراءات اللازمة لحفظ السـلم والأمن الدولي. د-شـرط التتاســب، يجب أن تكون أعمال الدفاع التي تقوم بها الدولة المعتدى عليها متناسبة مع حجم العدوان وألا تتجاوزه، وإلا اعتبر ذلك تجاوزًا في حق الدفاع الشرعي، والمعيار المستخدم في هذه الحالة هو المعيار الموضوعي والذي يعني سلوك الشخص المعتاد إذا وضع في نفس الظروف، وإن الشخص وقت ارتكابه السلوك "يتصرف على لي في نحو معقول للدفاع عن نفسه أو عن شخص آخر أو يدافع في حالة جرائم الحرب عن

(1 ) فريزة، بن سعدي (r ( †). المسؤولية الجنائية الدولية عن جرائم الحرب في نظام المحكمة الجنائية

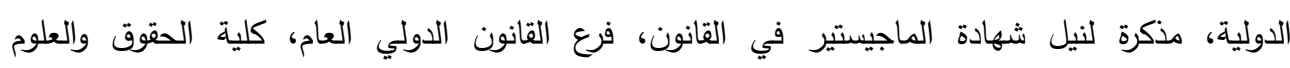

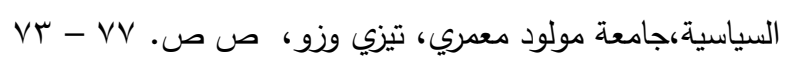

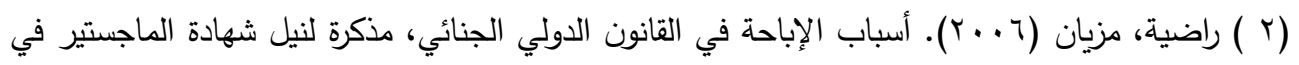

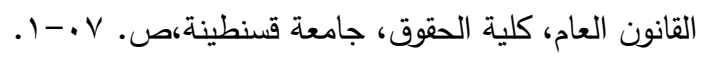


r.r. · مجلة روح القوانين - العدد الواحد والتسعون - إصدار يوليو

ممتلكات لا غنى عنها لبقاء الثخصص أو شـخص آخر أو عن ممتلكات لا غنى عنها

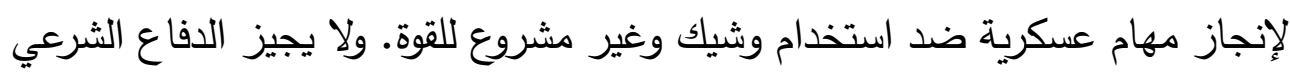

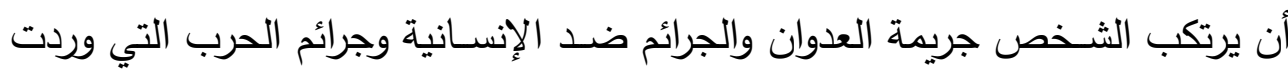

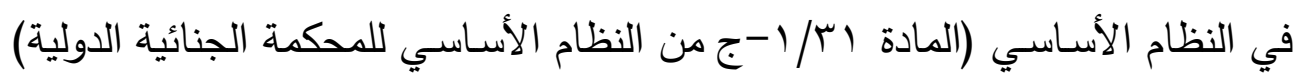

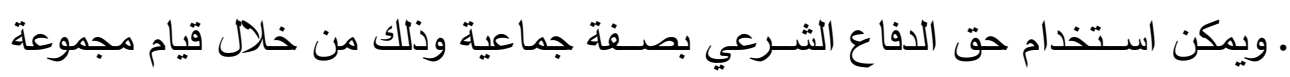

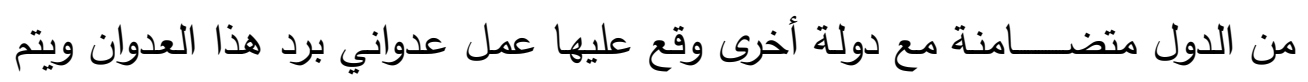

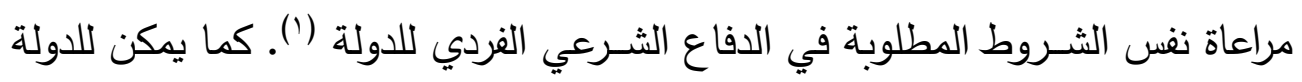

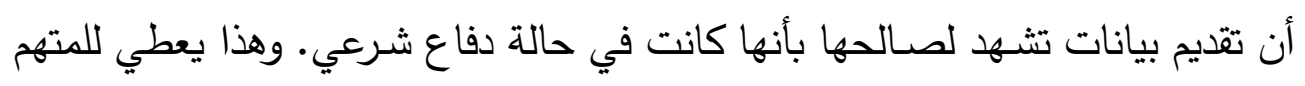

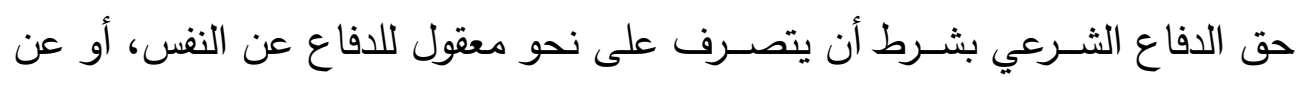
شخص آخر ، أو عن ممتلكات في حالات أخرى (r).

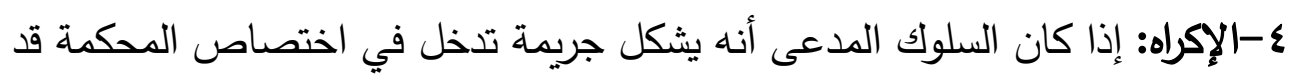

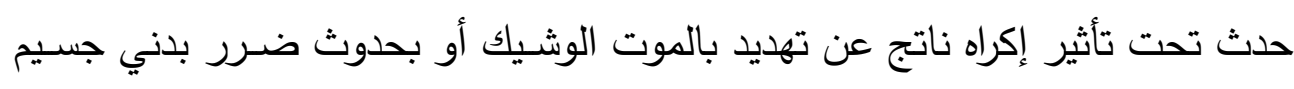
مستمر أو وشيك ضد ذلك الشخص أو شخص آخر ، وتصرف الشخص تصرئ آترفاً لازماً

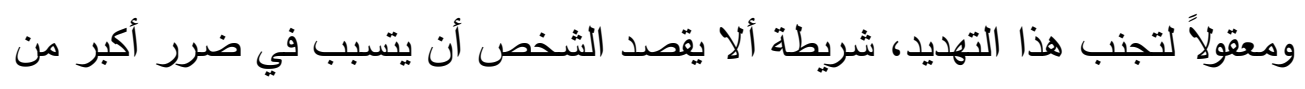
الضرر المراد تجنبه (المادة اس// إسد من النظام الأساسي للمحكمة الجنائية الدولية).

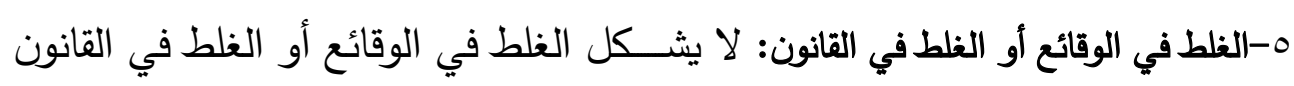

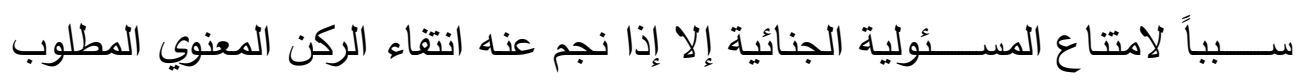

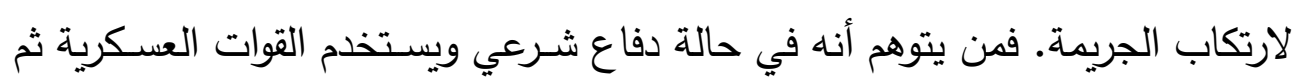

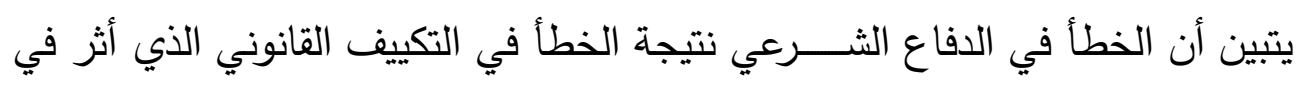

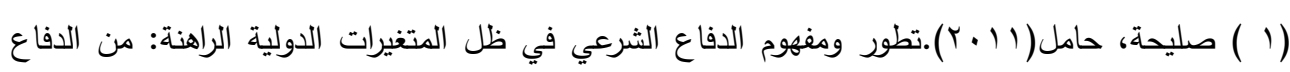

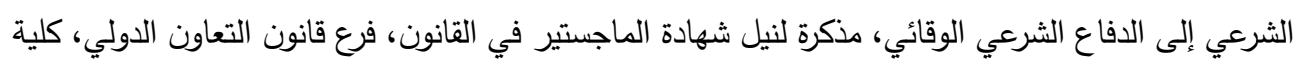

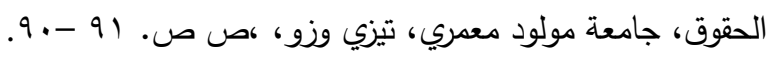

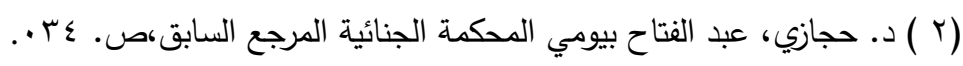




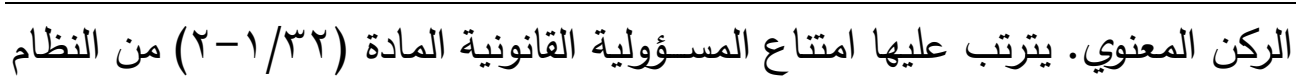

الأساسي للمحكمة الجنائية الدولية (').

7-صغر السن كمانع المسؤولة: لا تختص المحكمة الجنائية الدولية بمحاكمة الأشخاص

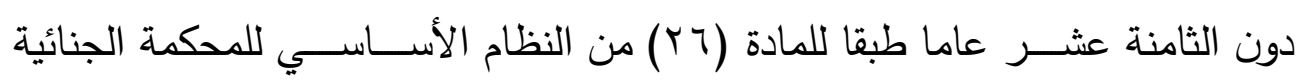
الدولية. وهذا متوافق مع اتفاقية حقوق الطفل. بما أخذت به النظم العقابية الرئيسية في

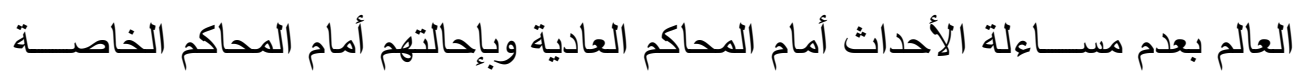

V-أوامر الرؤساء ومقتضيات القانون: في حالة ارتكاب أي شخص لجريمة من الجرائم التي تدخل في اختصـاص المحكمة، لا يعفى الثخص من المسئولية الجنائية إذا كان ارتكابه لتلك الجريمة قد تم امتثالاً لأمر حكومة أو رئيس، عسـكرياً كان أو مدنياً، عدا لأل

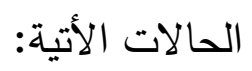

*-إذا كان على الشخص التزام قانوني بإطاعة أوامر الحكومة أو الرئيس المعني. *-إذا لم يكن الشخص على علم بأن الأمر غير مشروع.

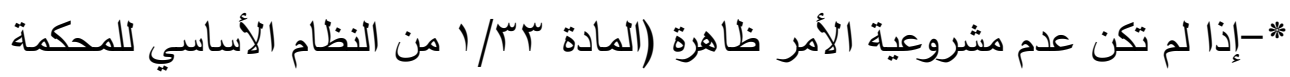
الجنائية الدولية) وقد وضع النظام الأساسي معيارً للعلم بعدم المشروعية وهي الحالات

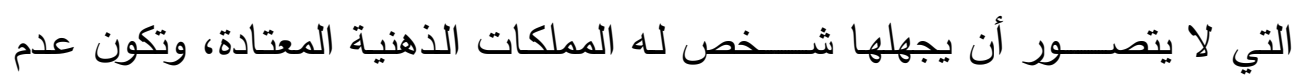
المشـروعية ظاهرة في حالة هذه الأوامر مثال: إذا كان مضــمون أمر الرئيس بارتكاب

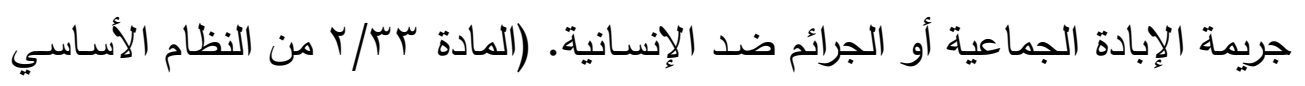

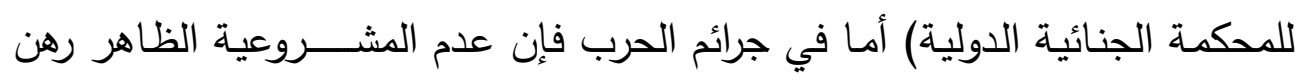
بتقدير المحكمة (r).

(1 ) رفيق، بوهرار(· ( • (זم). اختصاص المحكمة الجنائية الدائمة رسالة ماجستير جامعة الإخوة متتوري، قسنطينة، الجزائر ،ص ع ع-10

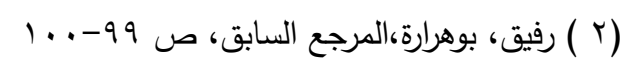




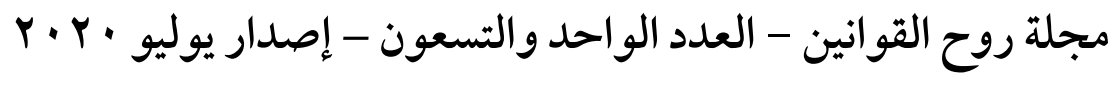

ثالثا: توفر الاختصساص الككاني: تختص المحكمة الجنائية الدولية بالجرائم في الحالات

الآتية:

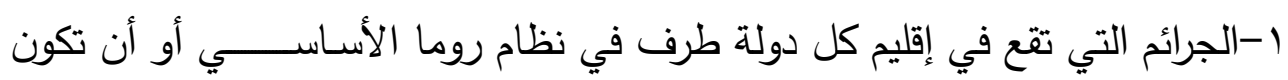

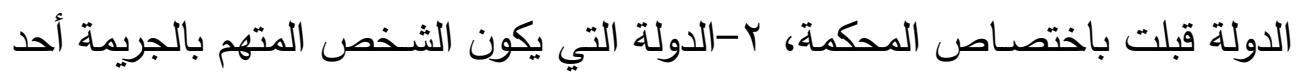

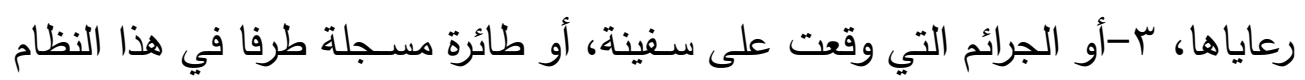

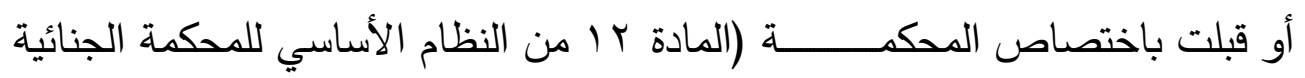

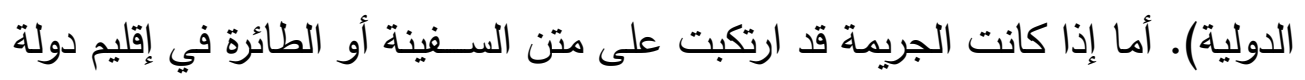

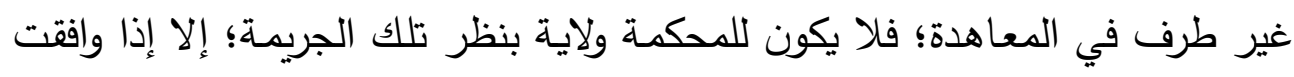

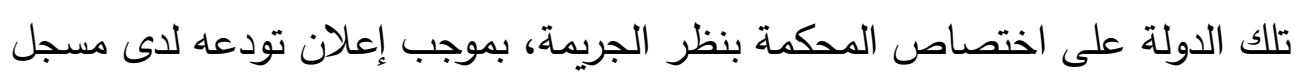

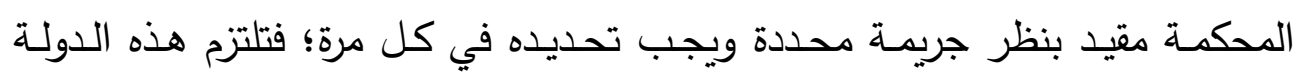

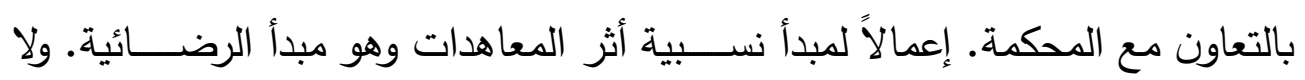

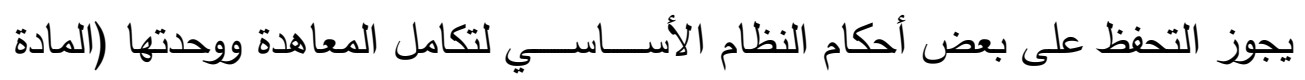
• ب ا من النظام الأساسي للمحكمة الجنائية الدولية) ((). وقد وردت استثناءًات:

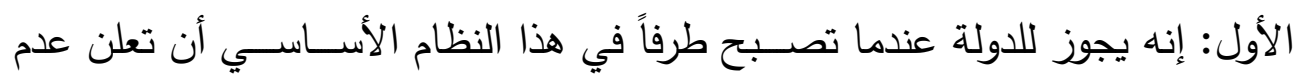

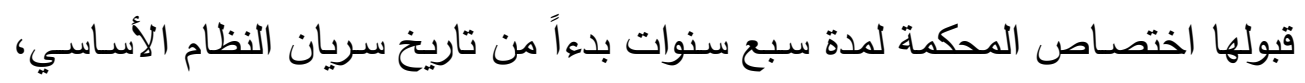

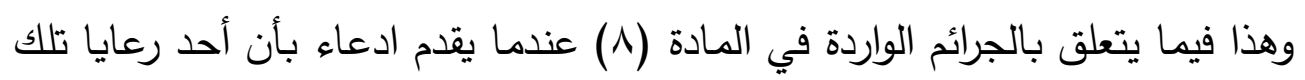

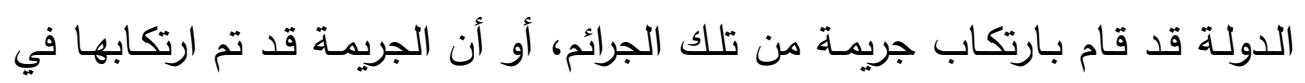
أراضيها. (المادة گ Y ا من النظام الأساسي للمحكمة الجنائية الدولية).

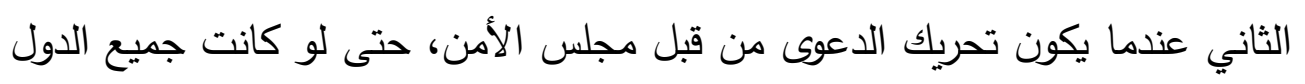

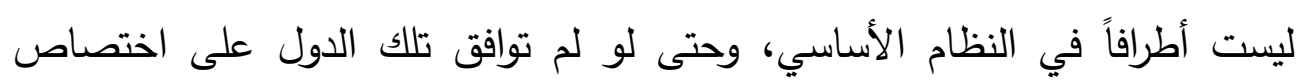

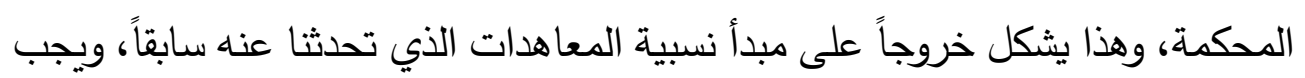


أن تتعاون معها الدول ذات العلاقة بالجريمة، وإلا فإن ذلك سيكون مدعاة لإثارة المشاكل

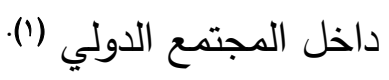

\section{الإلب البرابع}

\section{عدم إرجاء التهقيـق أو المقاضاة هبلس الأهن}

يقصد بارجاء التحقيق أو المقاضاة هي إعطاء مجلس الأمن الحق في أن يطلب من المحكمة بموجب الفصل السابع من ميثاق الأمم المتحدة إيقاف إجراءات التحقيق والمباشرة بها مدة سنة كاملة ويجوز للمجلس تجديد هذا الطلب بالشروط ذاتها وذلك حسب (المادة 7 ( ) من النظام الأساسي تحت بند "إرجاء التحقيق أو المقاضاة ويؤخذ على هذا النص ما يأتي: 1-إن هذا مساس بحياد واستقلال المحكمة ب-إنه مساس بمصالح التحقيق مما يؤدي إليه من ضياع الكثير من الأدلة بسبب عدم البدء أو المضي في تحقيق أو مقاضاة بموجب هذا النظام الأساسي لمدة اثني عشر شهراً بناءً على طلب من مجلس الأمن لأن المحكمة لا تستطيع السير في أيّ شكوى بشروط منها التالي: ا-أن يكون طلب الإرجاء للمحكمة مبنيا على قرار يصدره مجلس الأمن في أي مرحلة كانت عليها ابتداءً من التحقيق وإلى ما قبل إصدار الحكم، وذلك دون مراعاة لأي اعتبار آخر ، بما في ذلك المجني عليه الذي لم يحسب له أي حسابه ץ-أن يتصرف مجلس الأمن بالإرجاء للتحقيق أو المحاكمة بموجب الفصل السابع من ميثاق الأمم المتحدة بشكل يهدد السلم والأمن الدوليين. r-أن يكون إيقاف التحقيق أو المحاكمة لمدة محددة لا تزيد على باله شهرا إلا أن المادة 17 من النظام الأساسي للمحكمة تسمح للمجلس بتجديد الطلب بالثروط ذاتها

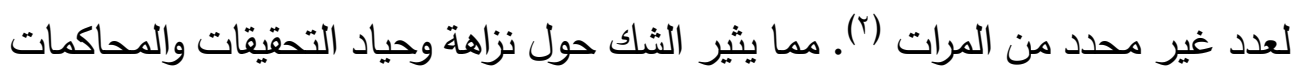

( (1 ) د.عبد اللطيف، براء منذر كمال، علاقات المحكمة الجنائية الدولية، المرجع السابق، صو 9. ( (1) محمد هاشم ماقوار، حق مجلس الأمن في وقف إجراءات التحقيق والدحاكمة بالدحكمة الجنائية الدولية،

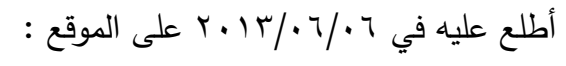
www.aladel.gov.ly/main/modules/sections/item.php?itemid=r^. 
r.r. · مجلة روح القوانين - العدد الواحد والتسعون - إصدار يوليو

الجنائية الدولية (1). وتجميد إجراءات المحاكمة الجنائية الدولية وأكدت إيطاليا على "أنه

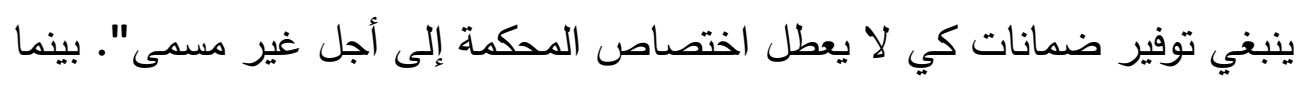

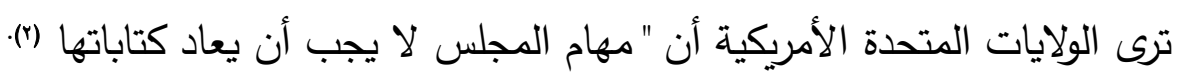

\section{المالب الخاهس}

\section{اتخاذ الإذن بالتمقيق هن الدائرة التههيدية}

\section{وأثره على حقوق الجنبي عليه}

يلزم لكي يبدأ المدعى العام القيام بإجراءات الاستقصاء والتحقيق الابتدائي، أولا أن

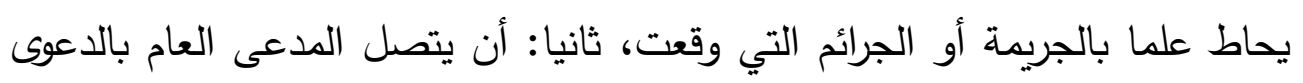

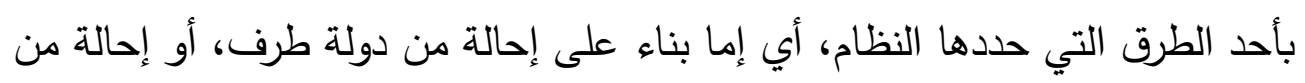

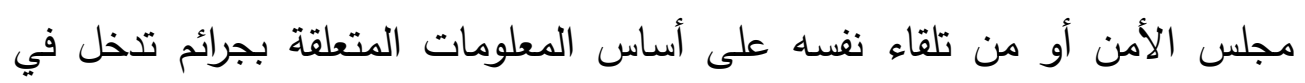

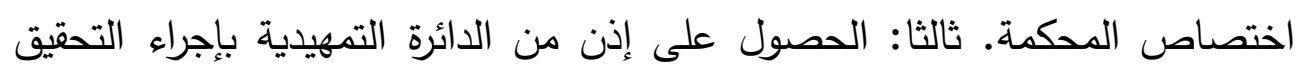

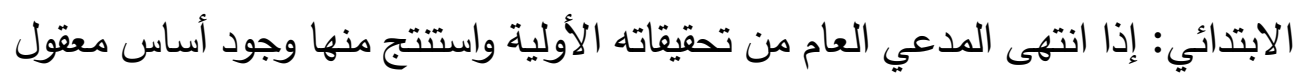

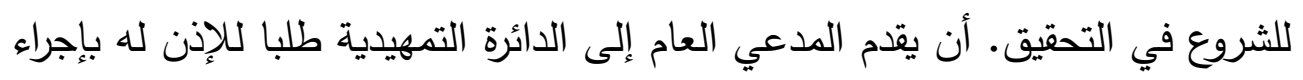

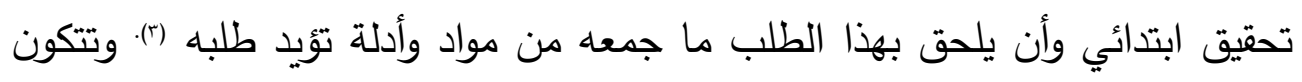

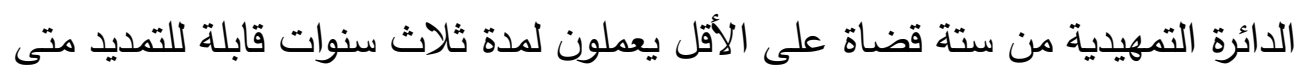

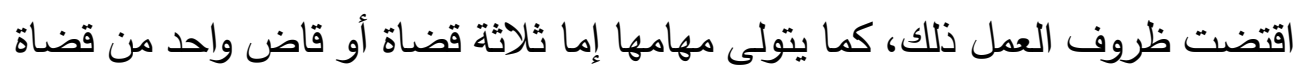

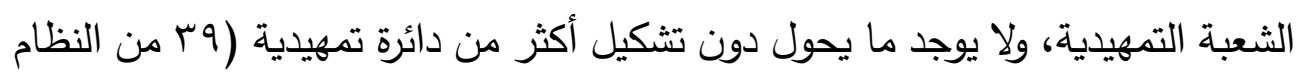
الأساسي).ويجوز للدائرة التمهيدية عقد جلسات خاصة للنظر في الإجراء الذي يتعين

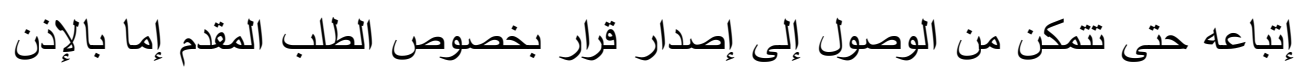

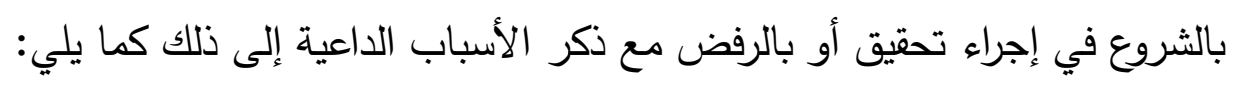

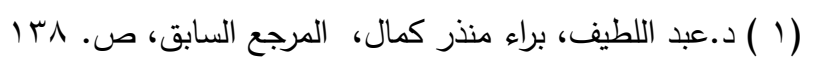

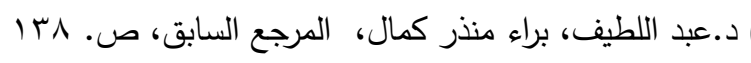

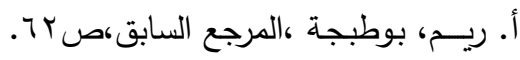


الحالة الأولي: أن تأذن الدائرة التمهيدية بإجراء التحقيق: يقدم المدعي العام طلب الإذن بالثروع في إجراء تحقيق إلى الدائرة التمهيدية. ويشترط أن يكون الطلب كتابة ومشفوعاً بأية أدلة مؤيدة للطلب لإجراء التحقيق الابتدائي. وذلك بوجود أسباب تدعوه إلى البدء في التحقيق وهذا ما أكدته قاعدة ^ءء من قواعد الإجراءات والإثبات خاصة إذا استتتج المدعي العام أن هناك أساسا معقولا للشروع في إجراء التحقيق في حالة حصوله على معلومات من مصادر موثوقة ويراها ملائمة بعد أن يقوم المدعي العام بتحليل جدية

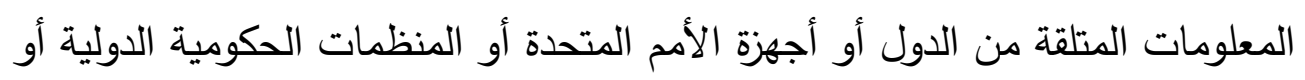
غير الحكومية، أو أية مصادر أخرى موثوق بها وفقا للمادة 10 من النظام الأساسي الأوداي للمحكمة الجنائية الدولية. باعتباره الجهة المكلفة بالمتابعة (المدعي العام) (()-وهذا الطلب يخضع للسلطة التقديرية للدائرة التمهيدية بعد الدراسة الجدية للطلب. وتختص الدائرة التمهيدية بمنح الإذن بالتحقيق إذا رأت بعد دراستها للطلب وللمواد المؤيدة، أن هناك

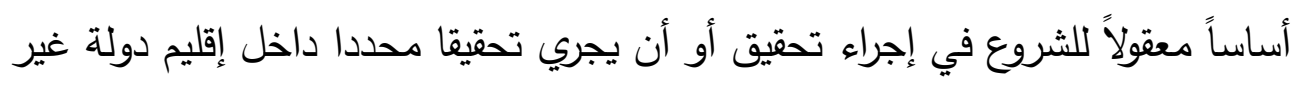
قادرة على التعاون في إطار اختصاص المحكمة وذلك دون المساس بما تقرره المحكمة فيما بعد بشأن الاختصاص ومقبولية الدعوى (المادة 0 / /ء من النظام الأساسي للمحكمة الجنائية الدولية) (†). وتكون الموافقة بأغلبية الأصوات بعد مراجعة قانونية من قبل الدائرة. ويصدر القرار بهذا الشأن مشفوعا بالأسباب التي دعته لإصداره وهذا ما بينته القاعدة

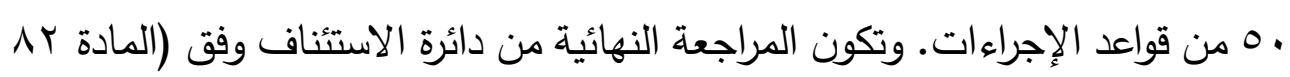

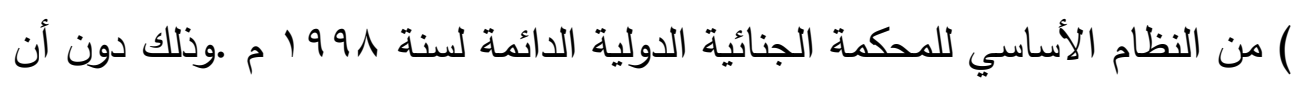
يخل ذلك بقرار المحكمة وسلطتها التقديرية في تقدير قبول الدعوى من عدمه (الدائرة

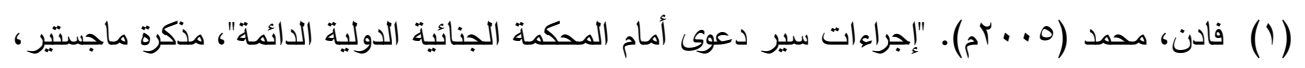

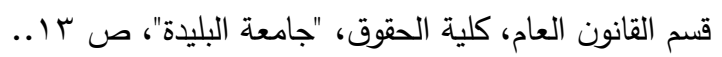

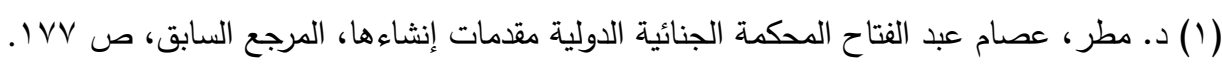




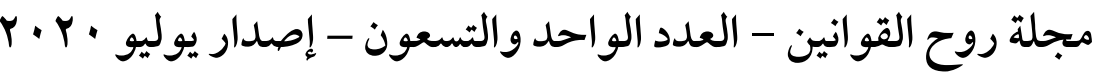

الابتدائية) عند الفصل في الدعوى كما أن الدائرة التمهيدية هي التي تصدر الأمر

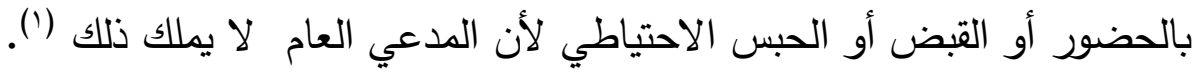
الحالة الثانية أن ترفض الدائرة التمهيدية الإذن بإجراء التحقيق: إن الدائرة التمهيدية

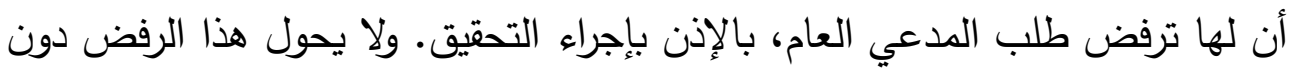

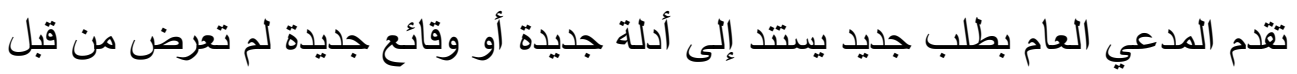

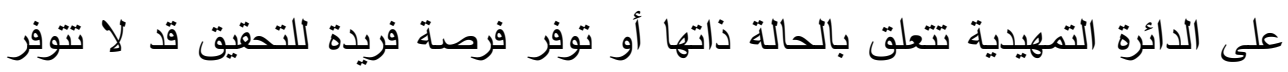

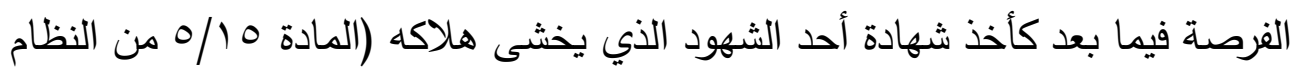

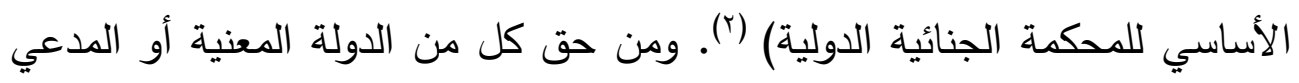

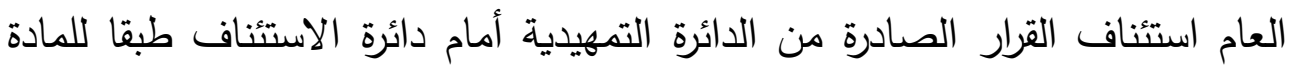
r/A / التي تعطي الحق في استئناف القرارات المتعلقة بالاختصاص والمقبولية خلال مدة لا تتجاوز خمسة أيام من تاريخ إخطار الطرف مقدم الاستئناف بالقرار (القاعدة ـ 1، القواعد والإجراءات والإثبات) (†). ويجوز النظر في الإستئناف بصفة مستعجلة.

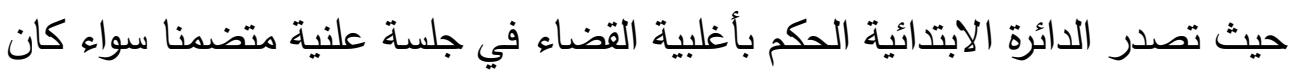
بتأييد القرار أو رفضه أو نقضه أو تعديله، كما يجوز للدولة التي سبق لها وأن طعنت الته

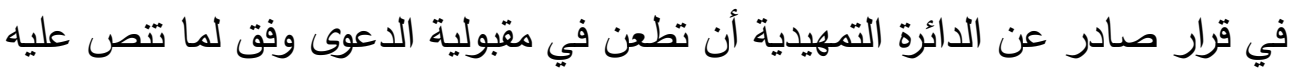
المادة 19 من نظام روما الأساسي (\&). الحالة الثالثة: اهتناع المدعي العام عن تشريك الدعوى الجنائية الدولية بين هبدئي

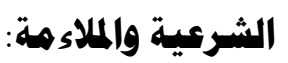
تخضع إلزامية جهة الادعاء، أو النيابة العامة بتحريك الدعوى الجنائية لمبدأين:

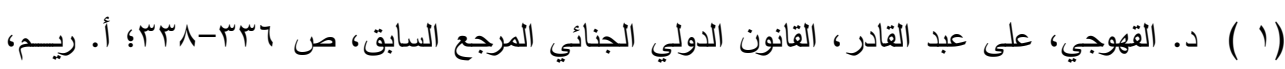

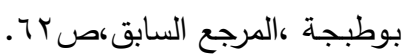

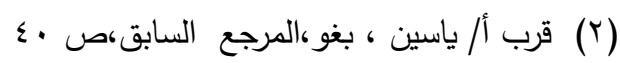

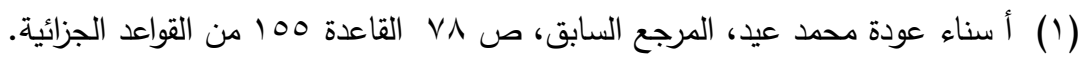

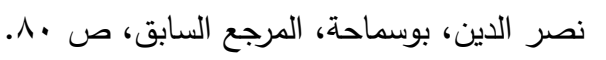


ا - مبدأ الثرعية الجنائية ومضمونه إلزام المدعي العام وجوبا بتحريك الدعوى الجنائية، سواء إلى قضاء التحقيق أو إلى قضاء الحكم، في جميع الجرائم التي يتصل بها علمه

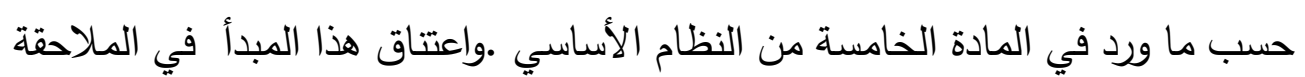
الذي يحقق المساواة بين المجني عليه والمتهم أمام القانون بما يحقق فكرة العدالة(1).إذ إن جميع الضحايا في الجرائم المختلفة والمدعي العام في الجرائم الدولية من أصحاب مصالح متساوية في معاقبة الجاني (؟).إضافة إلى أن الدعوى تهدف إلى فرض تدابير الدفاع الاجتماعي وصيانة للنظام العام .إذ به يتحقق أمن الناس في أنفسهم وأعراضهم

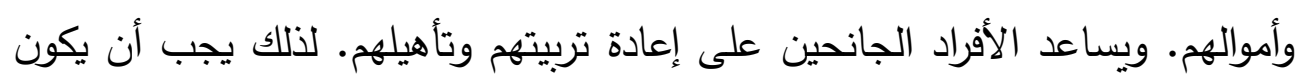
تحريك الدعوى الجنائية إلزامية (r). المبدأ الثاني: مبدأ الملاعمة يستند إلى فكرة جوهرية مقتضاها أن المدعي العام هو الأمين على أمر الدعوى الجنائية باعتبارها ممثلة للمجتمع في أمر تطبيق القانون الدولي الجنائي، فإن من حقه أن يوازن بين المصلحة التي قد تعود على المجتمع من تحريك الدعوى الجنائية أو عدم تحريكها، وقد اعتنق قانون الإجراءات المصري مبدأ "ملاءمة تحريك الدعوى الجنائية. واتجهت إليه التشريعات الجنائية ومنها نظام روما الأساسي للمحكمة الجنائية الدولية إلى أن الدعوى الجنائية الدولية تخضع لمبدأ الملاءمة بإطلاق حرية المدعي العام في تحريك الدعوى الجنائية عند علمه بوقوع الجريمة لتوفر أركان الجريمة وشروط المسؤولية عنها تحت رقابة الدائرة التمهيدية أمر تحريك أو يترك له له

(1 ) د. سرور، أحمد فتحي الوسيط في قانون الإجراءات الجنائية، المرجع السابق، ص • ب ب. معتق هذا الدذهب

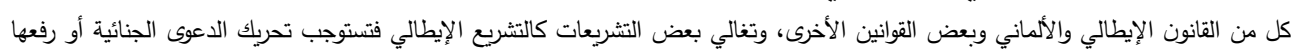
ولو كان بهاف الحصول على أمر بالحفظ.

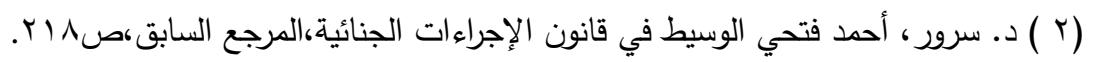

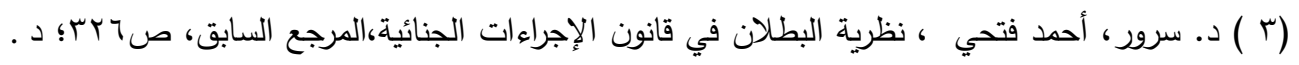

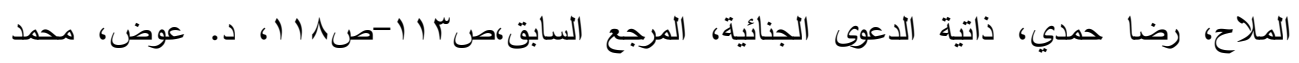

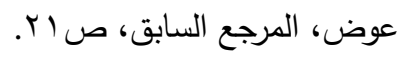




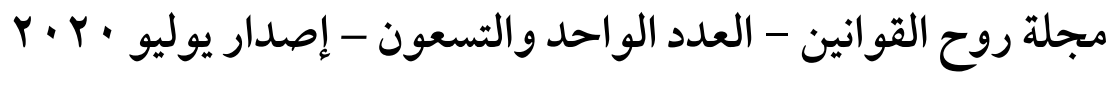

عدم تحريك الدعوى الجنائية الدولية (()وبتطبيق تلك المبادئ اختصاص المحكمة

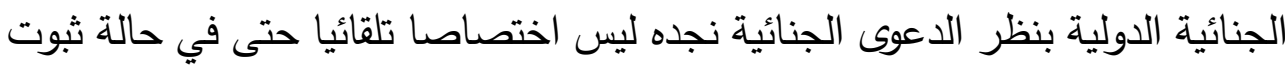

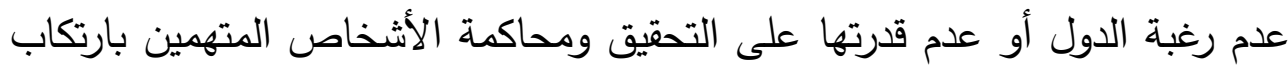

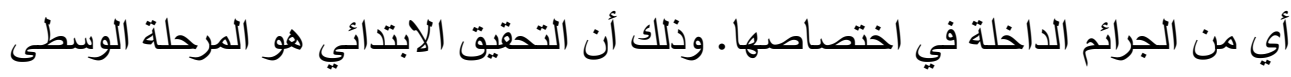

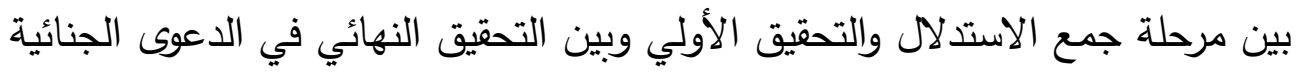

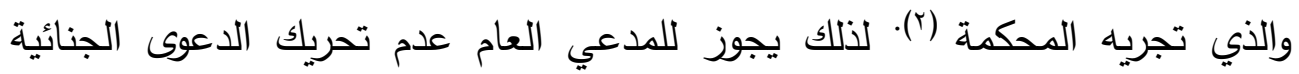

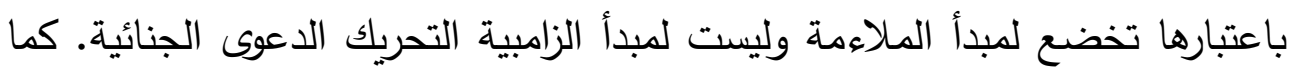

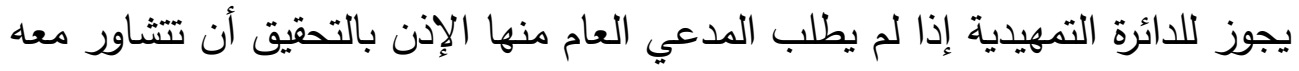

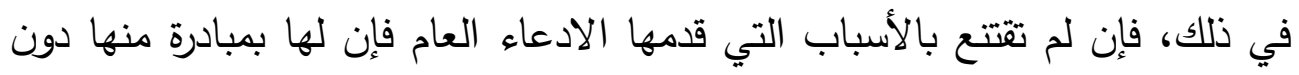

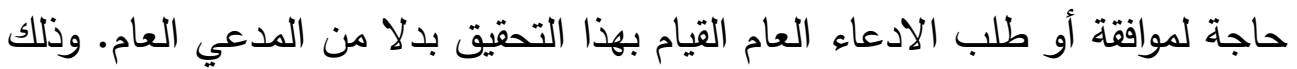

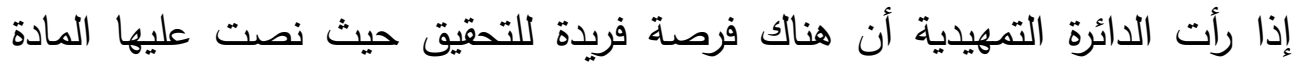

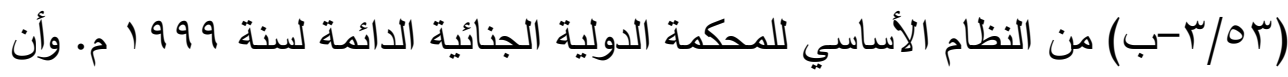
تستفر عن سبب عدم طلب الادعاء العام مثل هذا الإجراء. ويحق له استئناف قرارها

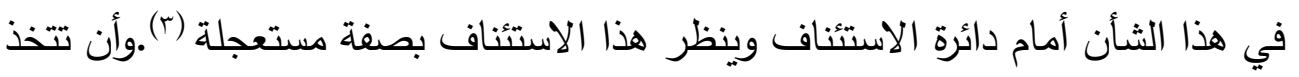

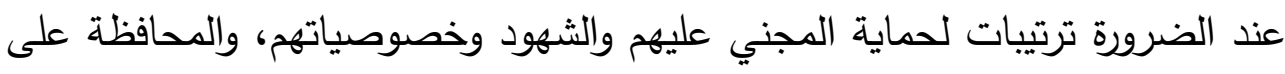

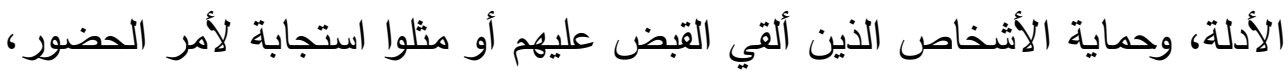

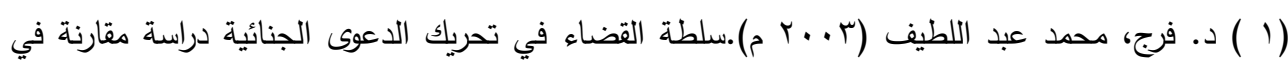

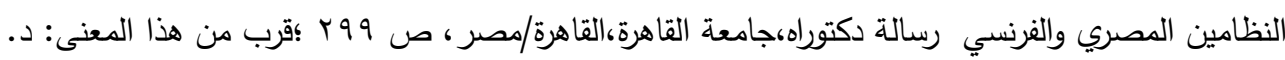

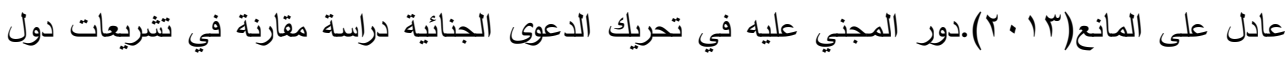

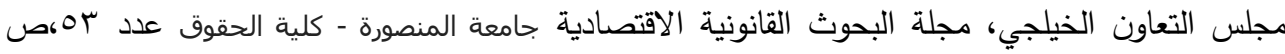

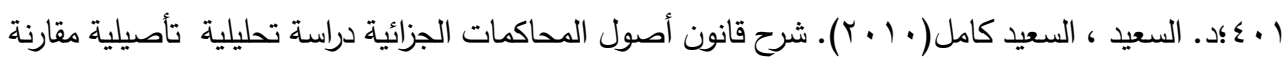

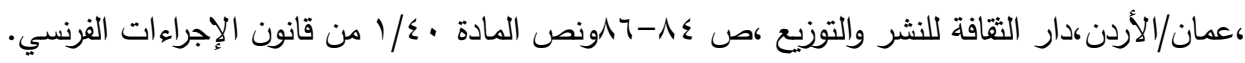

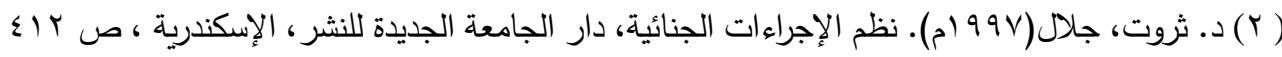

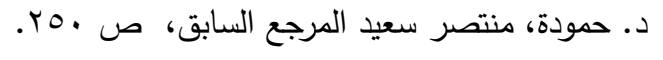


ه - ضمانات الحماية الإجرائية لحقوق المجني عليه أمام سلطة التحقيق في ظل نظام المحكمة الجنائية الدولية لسنة 991 ام

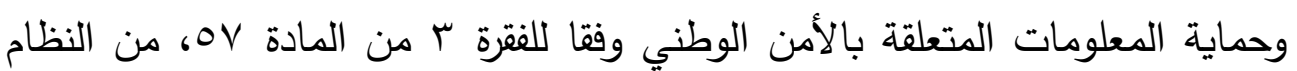

الأساسي للمحكمة الجنائية الدولية.

\section{المطلب السادس \\ وجود اتهام حسب النظام الإجرائي المتبع

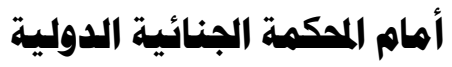

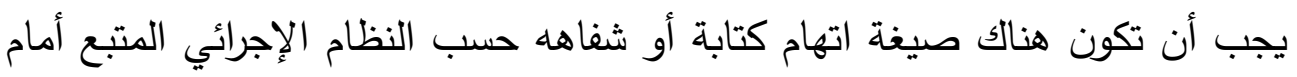

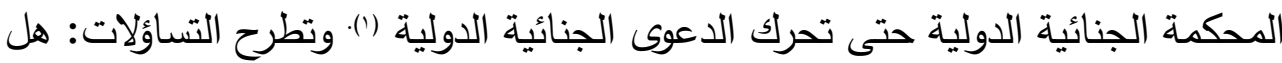

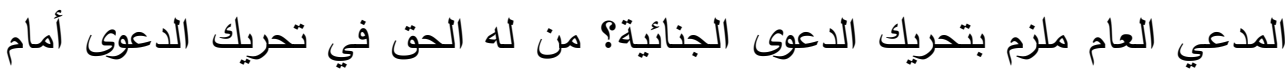

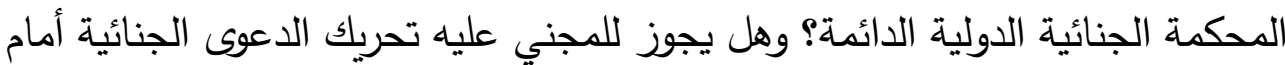

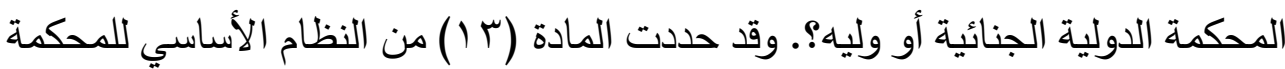
ثلاثة أجهزة تختص بآلية تحريك الدعوى العمومية وهي الدول الأطراف في اتفاقية إنثاء المحكمة الجنائية الدولية، والمدعي العام فتكون الثكوى عن طريق الددعي العام شخصيا، إذا علم بوقوع الجريمة من تلقاء نفسه حسب (المادة 0 1) وكنلك مجلس الأمن

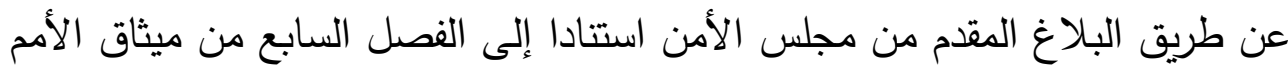

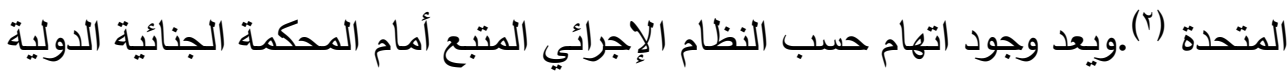

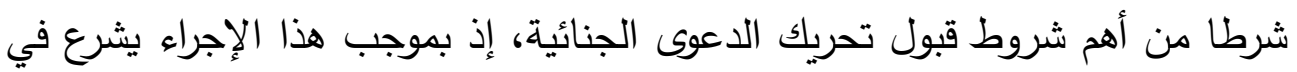

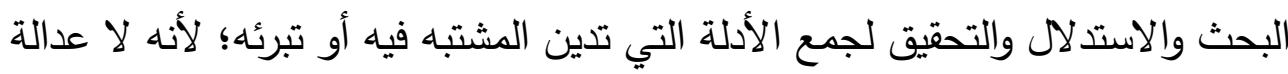

$$
\text { ( ( ) د. عوض، محمد محى الدين حقوق المجني عليه في الدعوى العومية، المرجع السابق، ص Oب. }
$$

La personne physique qui a subit un préjudice. $\mathrm{Y}$ compris une atteinte à son intégrité physique ou mentale, $(Y)$ une souffrance morale ou une perte matérielle. Directement causé par des actes ou des Omissions qui enfreignent la législation pénal d'un état membre".

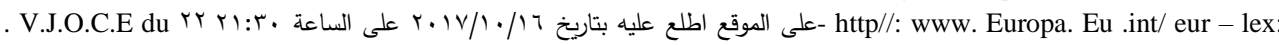




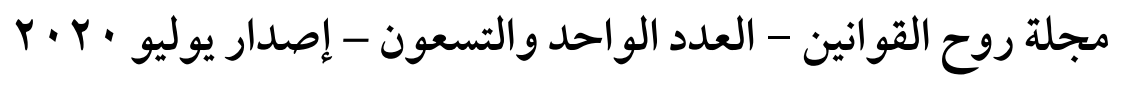

ما لم توجد أجهزة محايدة ومستقلة تسهر على حماية الأفراد من الجرائم ضد الإنسانية

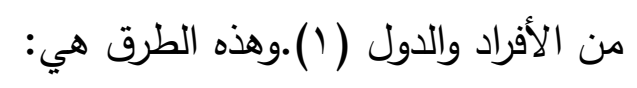

أولا: الإحالة هن الدول الأطراف: تمتلك الدول الأطراف في اتفاقية روما اختصاص التهن بتحريك

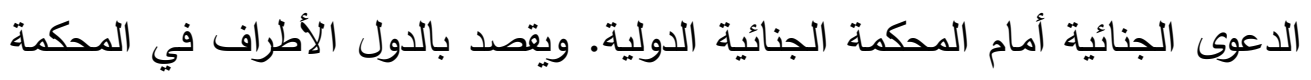

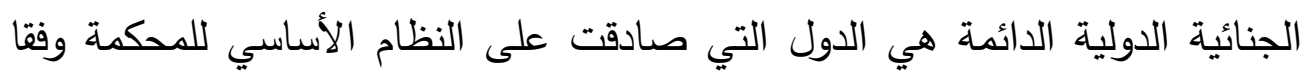

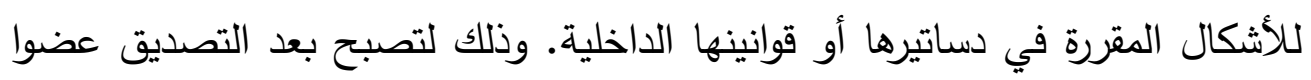

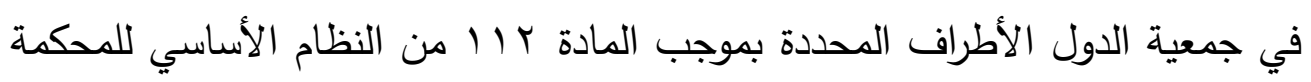

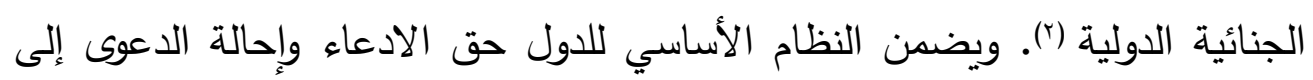

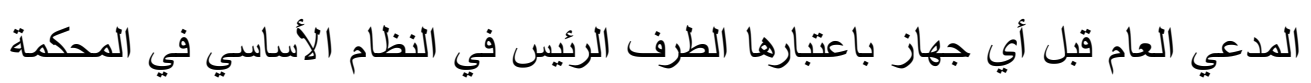
الجنائية الدولية (ץ). وذلك في حالتين هما:

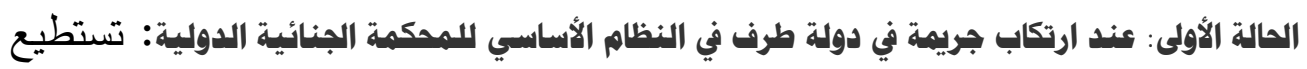

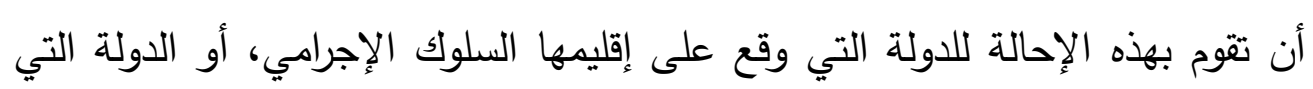

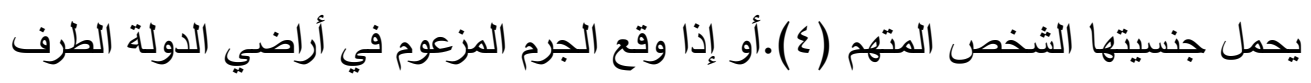

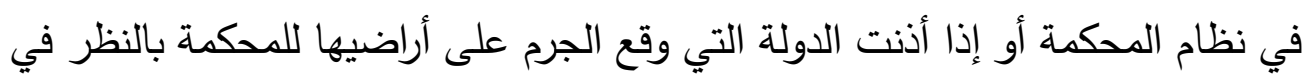

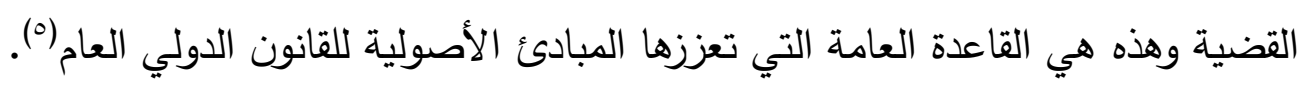

(1 ) د. شديفات صفوان محمد(10 • r م).اختصاص المدعي العام لاي المحكمة الجنائية الدولية المجلة

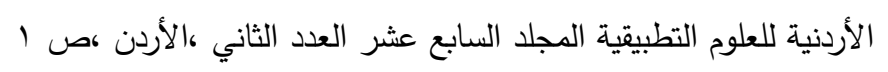

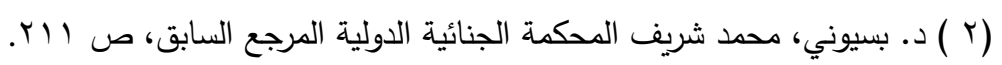

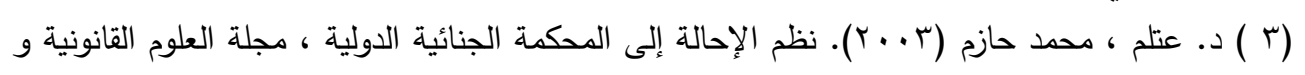

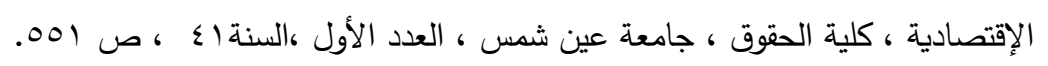

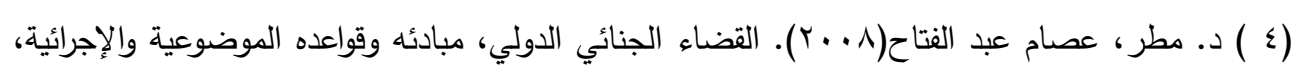

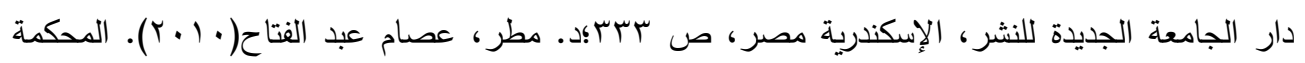

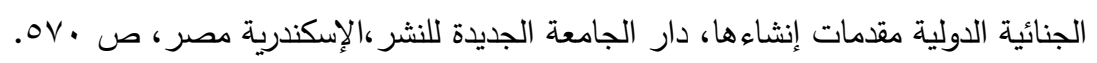

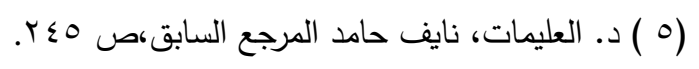
$(r \vee \wedge)$ 
وتقدم الدولة للمدعي العام طلب إجراء تحقيق في الدعوى بتوجيه الاتهام لشخص معين. وتقدم ما في متتاولها من مستندات مؤيدة لادعائها التي تقيد في الإسناد المادي والمعنوي للجاني بارتكاب الجريمة. ويمكن للأمم المتحدة ومجلس الأمن والأطراف والمنظمات القانونية مساعدة تلك الدولة في تطبيق العدالة الجنائية بسبب ضعف أجهزتها التنفيذية.

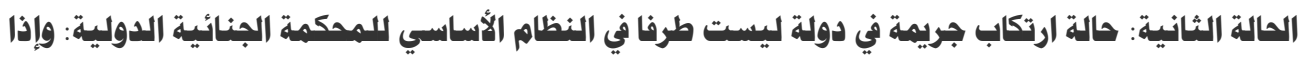
وقعت الجريمة على أراضيها ولم تعلن تعهدها بالالتزام بالنظام الأساسي للمحكمة الجنائية الدولية. وهنا إشكال إذا لم تحريك الدعوى الجنائية فإن الجريمة ومرتكبها ستكون بمنأى عن مساءلته قانونيا فلا يتحقق القصاص للمجني عليه ولا تتحقق عالمية اختصاص المحكمة بالجرائم الدولية. كذلك إذا اتخذ المدعي العام إجراءات تحريك الدعوى الجنائية تجاه الجريمة في دولة غير طرف في النظام الأساسي للمحكمة الجنائية الدولية فإنه يعد تجاوزاً لدستورها واستقلالها إذا لم توفر بشأنها حالة اختصاص المحكمة الجنائية الدولية وفقا للمادة (Y// / T) منه. إلا في صورتين هما: الصورة الأولى: إذا أحال مجلس الأمن وفقاً لأحكام الفصل السابع من ميثاق الأمم المتحدة جريمة أو أكثر من الجرائم المنصوص عليها ضمن المادة (0) من النظام الأساس للمحكمة بصورة شكوى يقدمها إلى المدعي العام للمحكمة بناء على قرار يتخذه المجلس بهذا الخصوص وفقا لما جاء في المادة (r/T/ من النظام الأساس للمحكمة مثل: استخدام روسيا والصين حق النقض(حق الفيتو) باعتبارهما عضوين دائمين في مجلس الأمن لهما، ضد مشروع قرار يتعلق بإحالة الوضع في سوريا إلى المحكمة الجنائية الدولية و يدين القهع فيها(').وقد قام المدعي العام لدى المحكمة بفتح تحقيقات في كل من الوضع في أوغندا الوضع في الكونغو الديمقراطية ،والوضع في أفريقيا الوسطى. وهذا بناء على طلب من الدول الأطراف في نظام روما الأساسي (؟). كما 


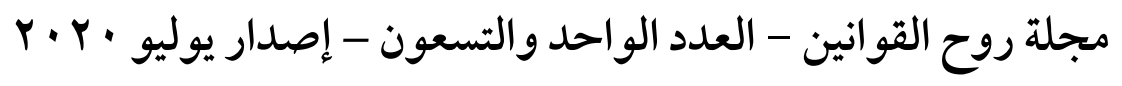

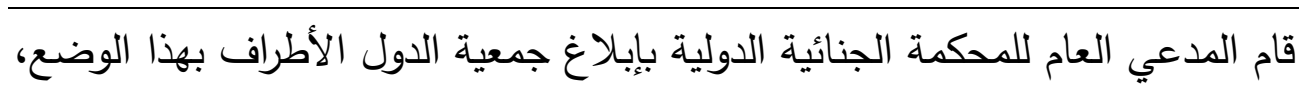

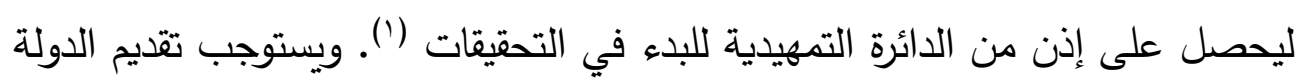
الطرف إلى المدعي العام ببلاغ حول حالة محددة لجريمة توافر شرطين هما:

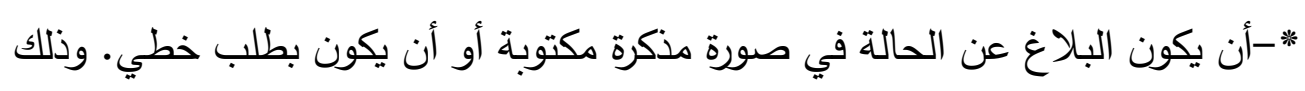

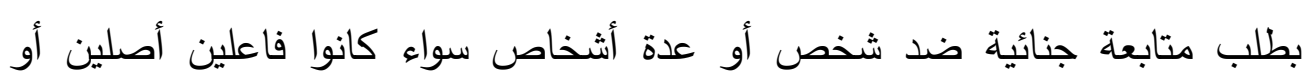

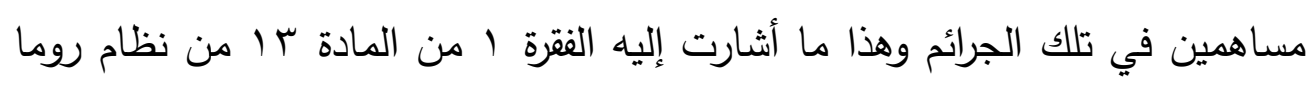

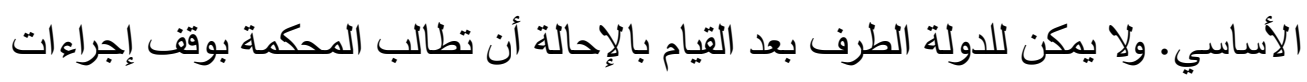

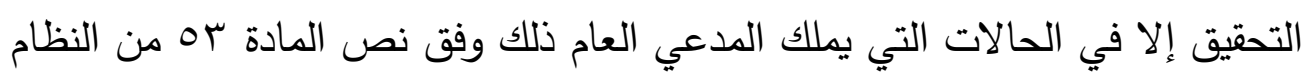
الأساسي للمحكمة الجنائية الدولية.

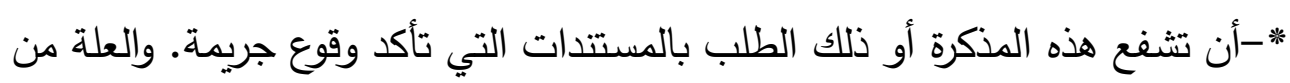

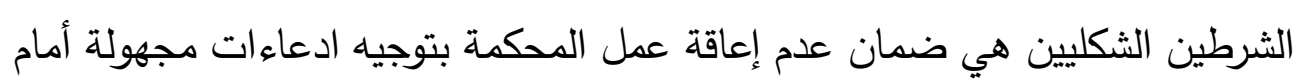

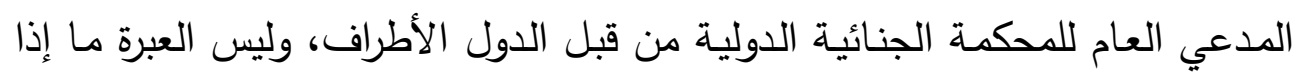

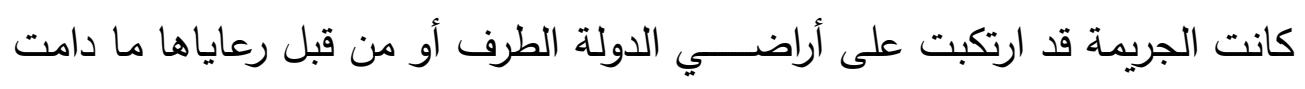

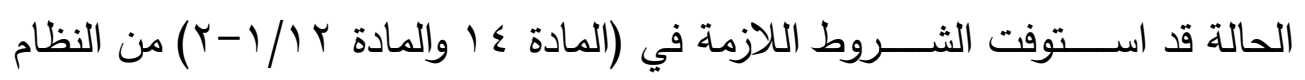
الأساسي للمحكمة الجنائية الدولية (†).

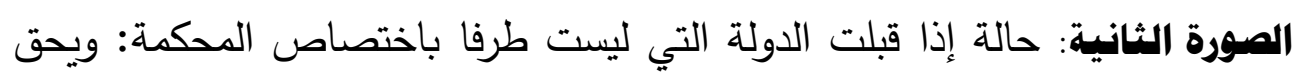

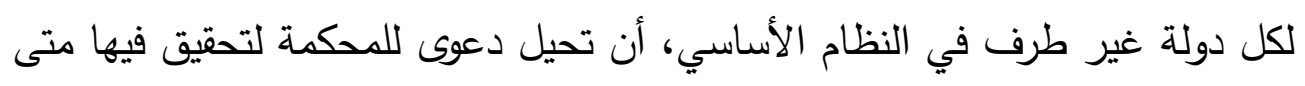

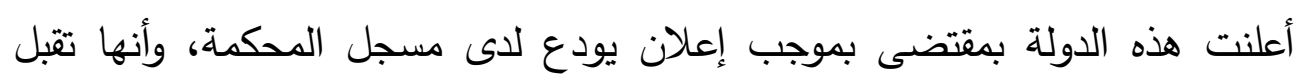

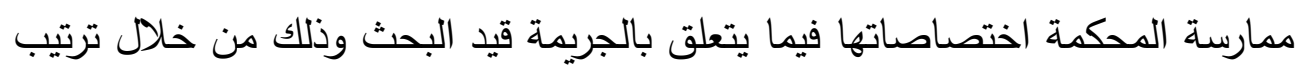

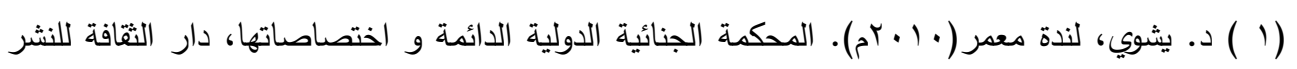

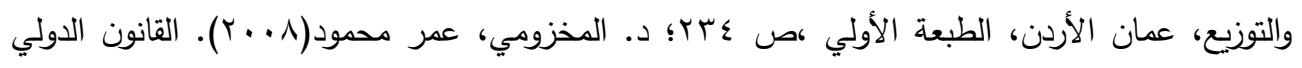

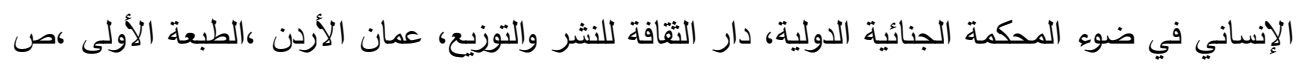

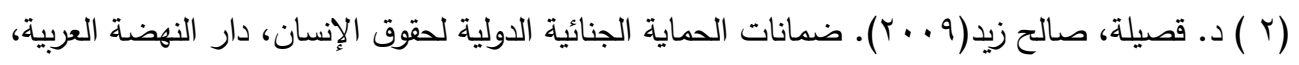

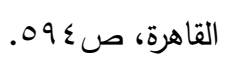
(r^. $)$ 


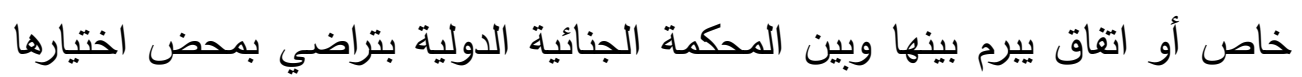

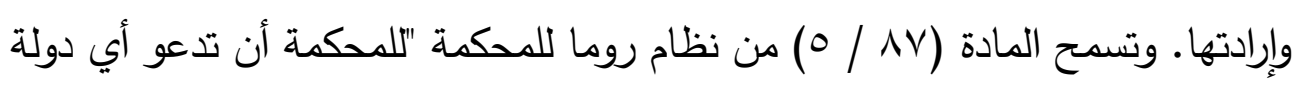

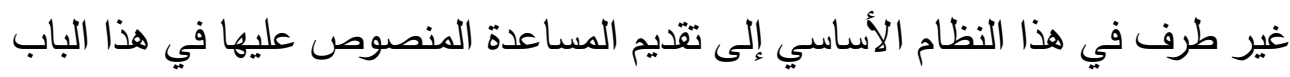

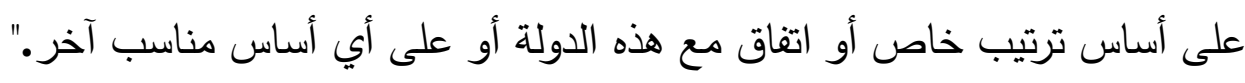

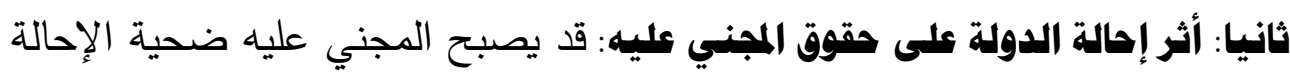

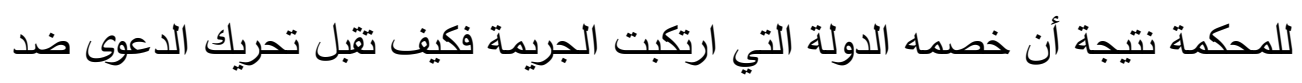

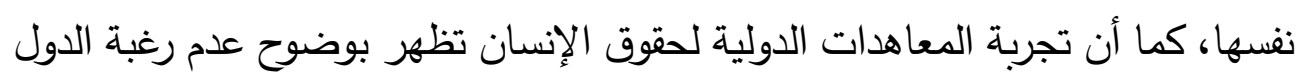

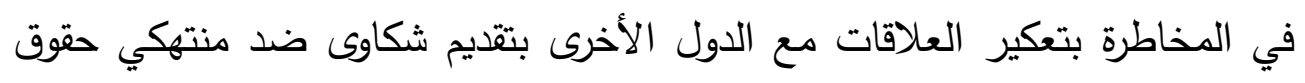

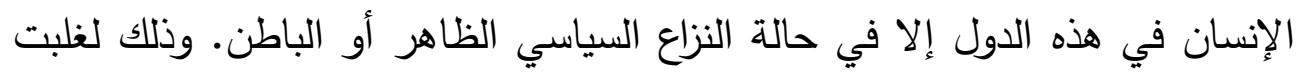

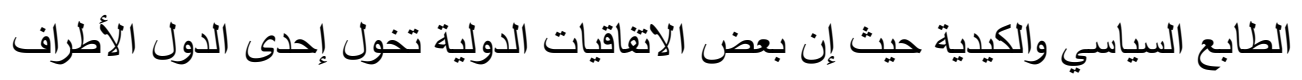

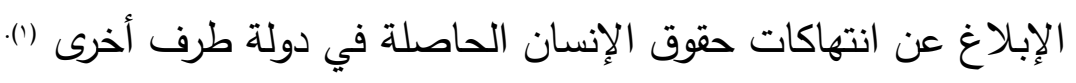

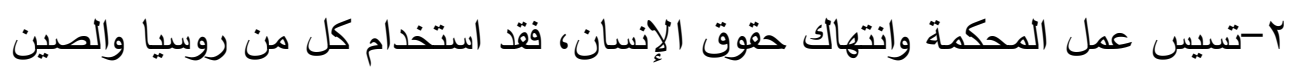

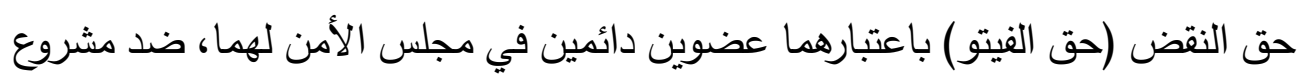

قرار يتعلق بإحالة الوضع في سوريا إلى المحكمة الجنائية الدولية ويدين القيع فئيها.

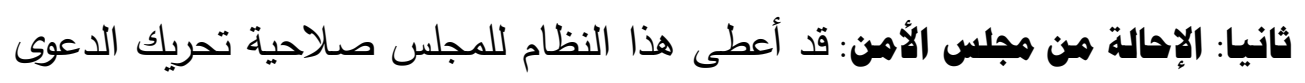

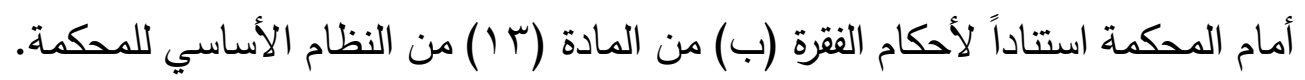

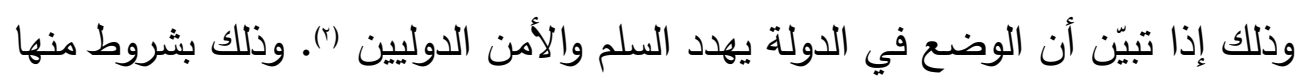

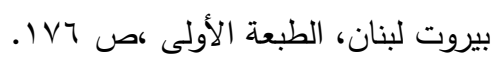

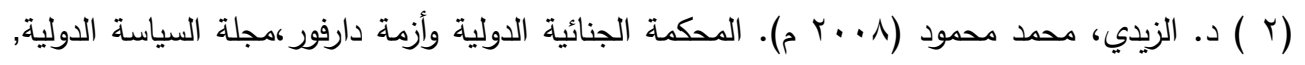

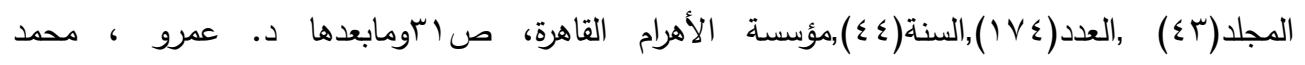

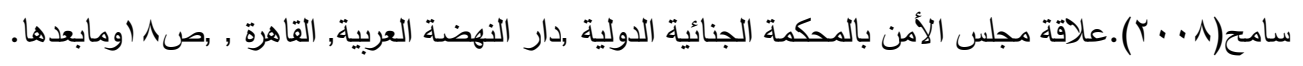




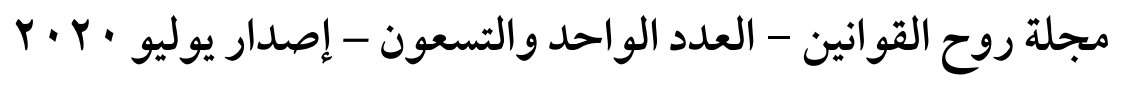

الثرط الأول: أن تكون إحالة مجلس الأمن دعوى جنائية دولية إلى المدعي العام تستند

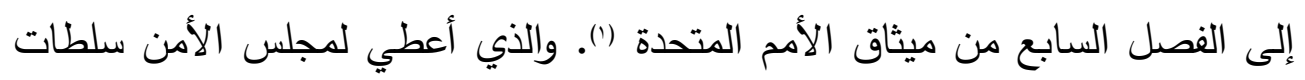

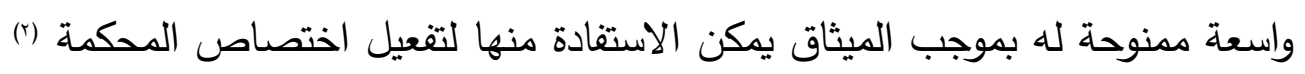

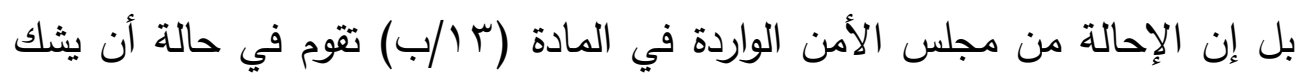

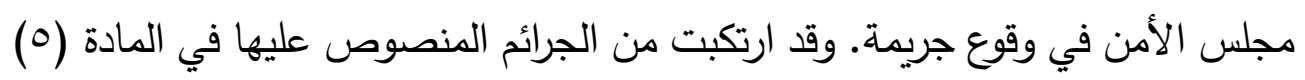

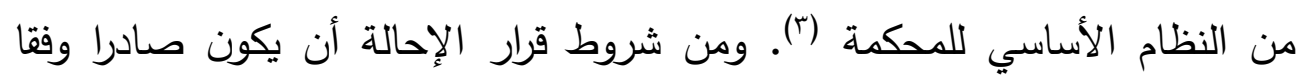

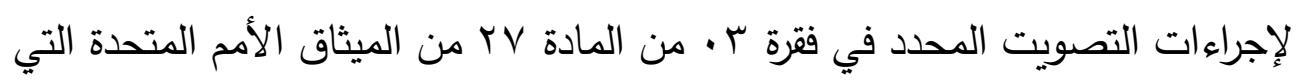

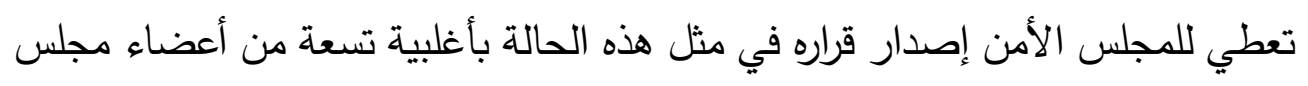

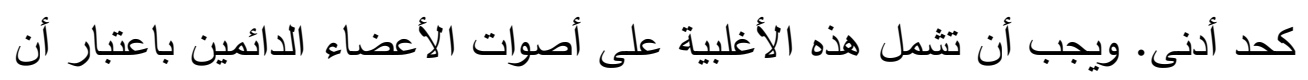

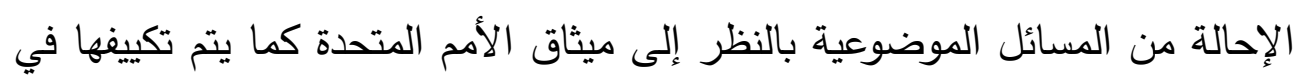
حالة الثك على أنها من المسائل الموضوعية.

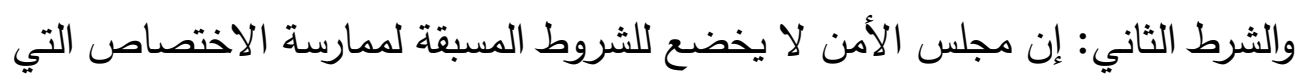

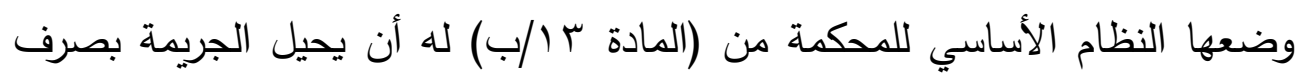

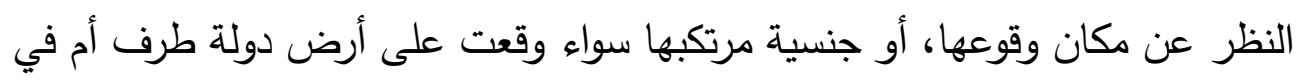

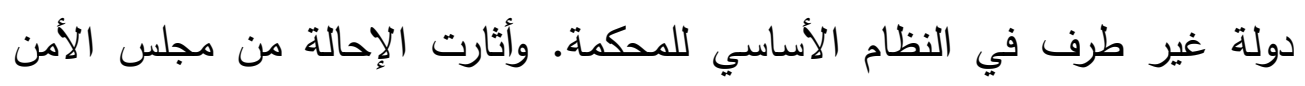

( ( ) حدان، أمينة(9 . . r). حماية المدنيين في الأراضي الفلسطينية المحتلة، رسالة ماجستير ، جامعة النجاح الوطنية،صو9 (1)

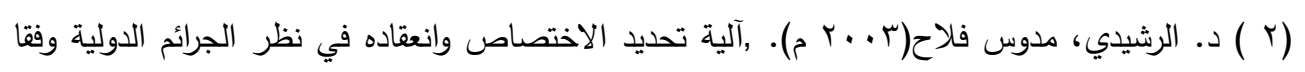

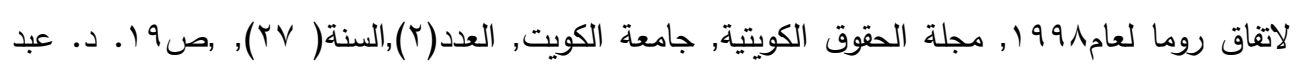

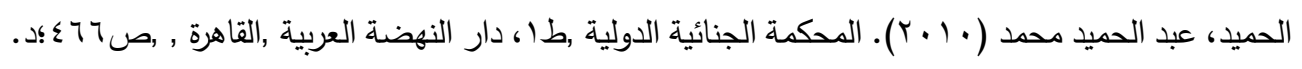

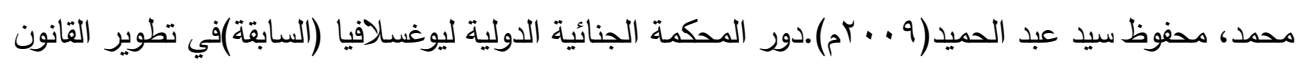

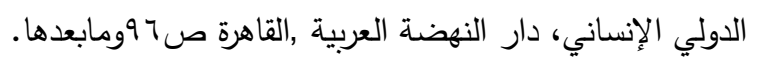

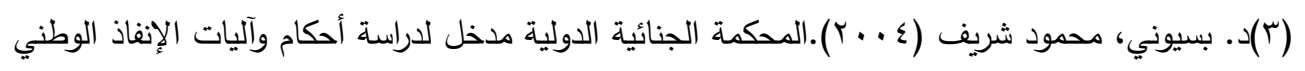

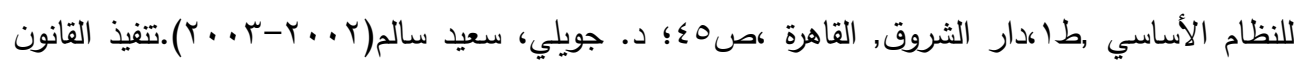

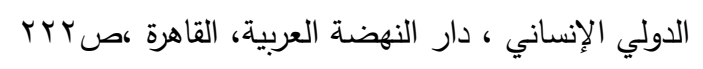
(ror) 


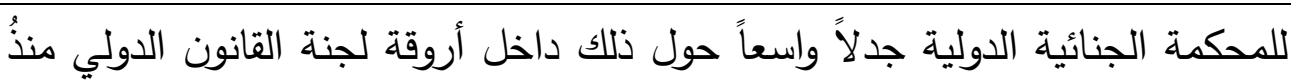

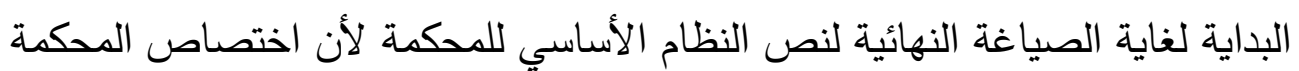

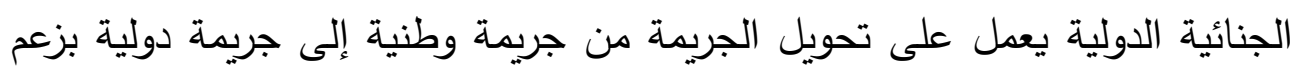

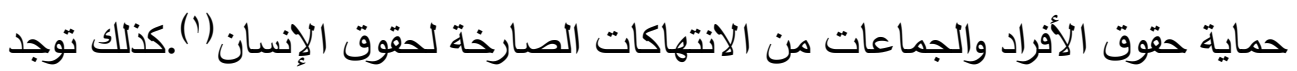
خشية من الهيمنة السياسية للدول الكبرى على المحكمة إذا أنيط بالمجلس تفعيل

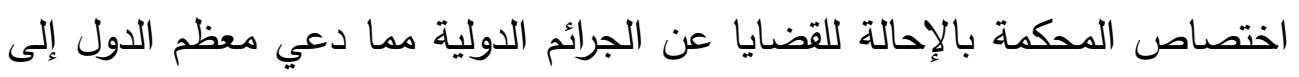

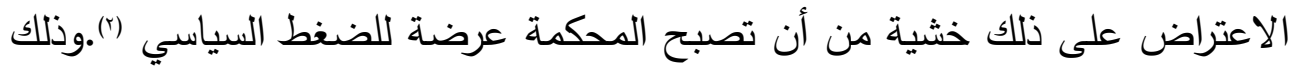

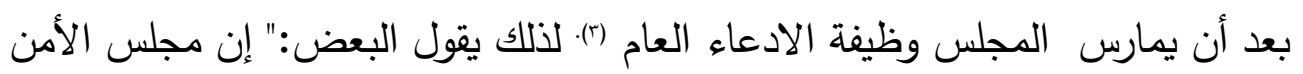

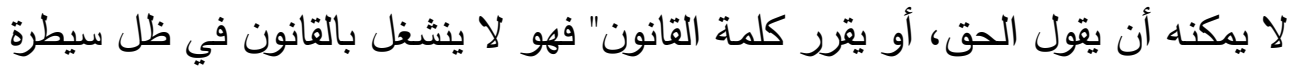

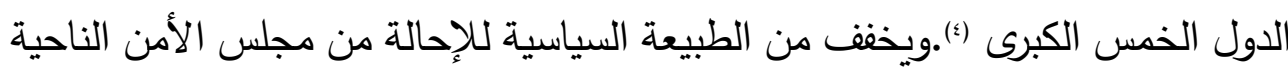

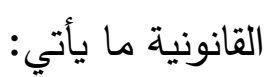
أ-يذهب أغلب المتخصصين في القانون الدولي بأن الإحالة الصادرة عن المجلس لها

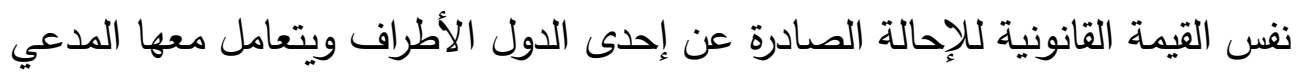

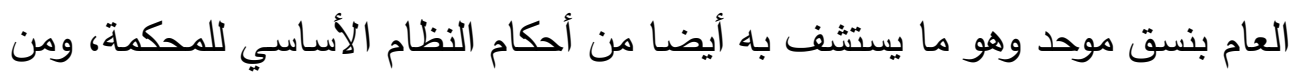

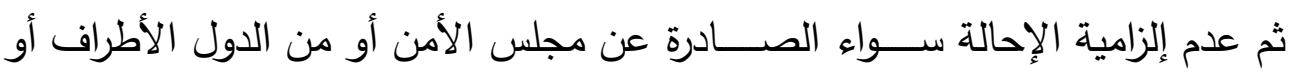

( ( ) د. الزيدي، محمد محمود (^ . . r م). المحكمة الجنائية الدولية وأزمة دارفور ، مجلة السياسة الدولية,

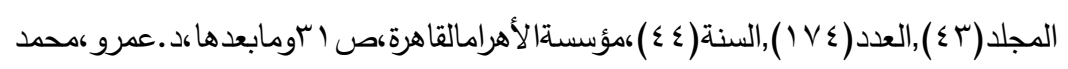

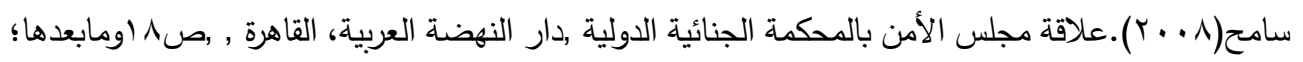

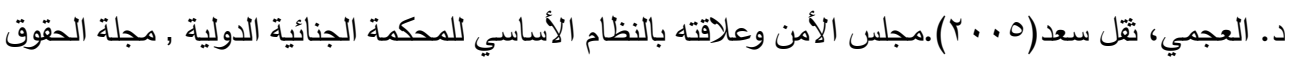

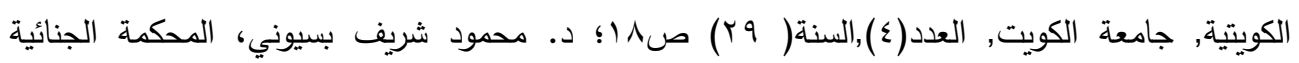

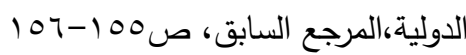

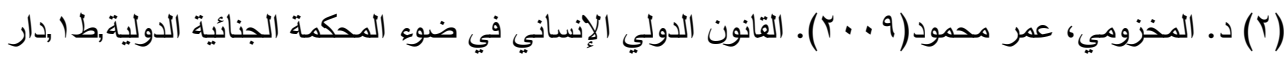

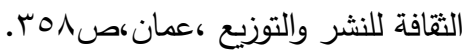
(r) د. لعبيدي، الأزهر ( • • (ץ). حدود سلطات مجلس الأمن في عمل المحكمة الجنائية الدولية ردار النهضة العربية القاهرة، صدهء.

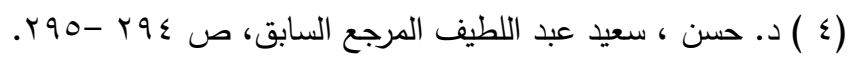
(ror) 


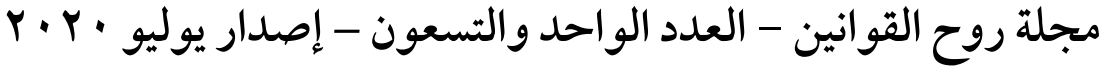

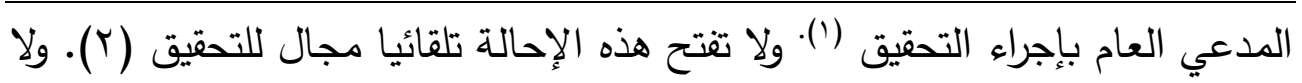

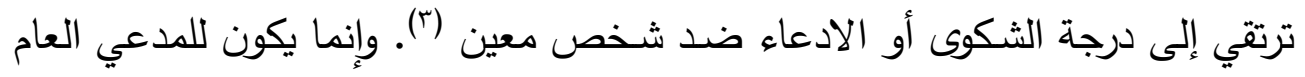

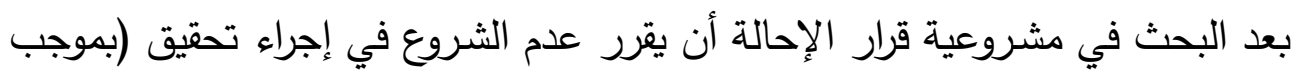

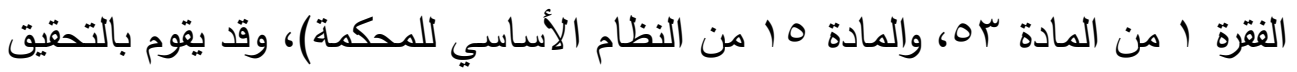

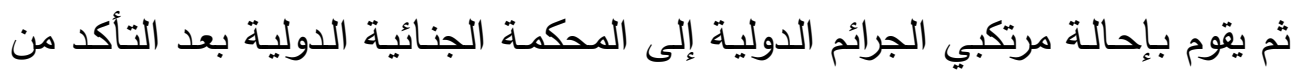

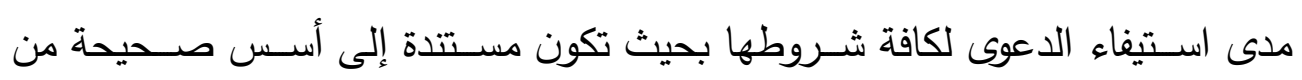
الوقائع والقانون (؛). وهذا أقل ضـرر من اســتخدام سـلطته في تثـكيل محاكم جنائية

مؤقتة.

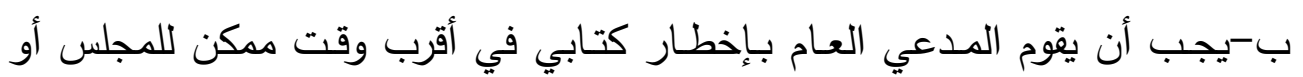

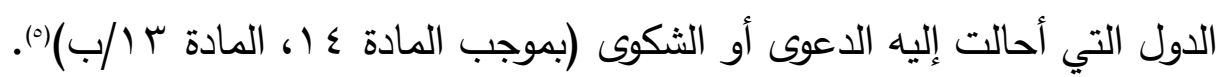

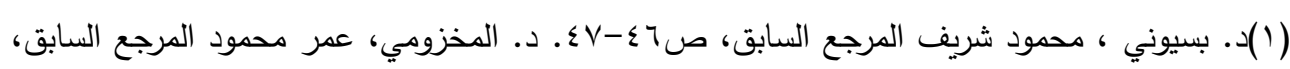

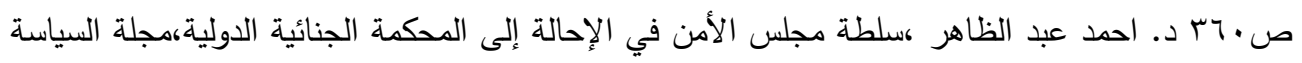

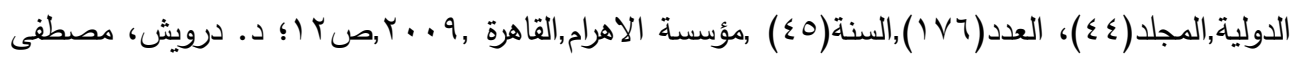

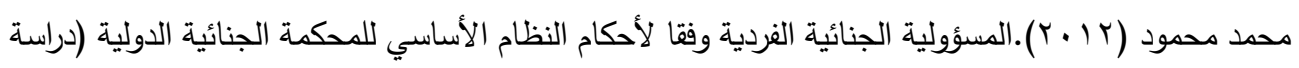

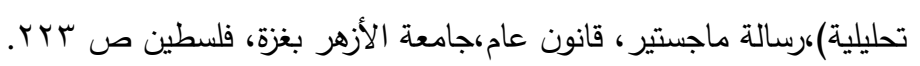

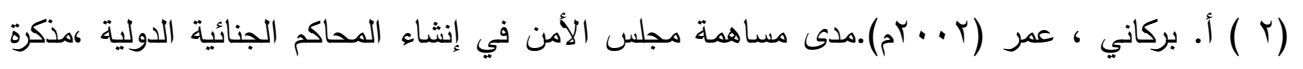

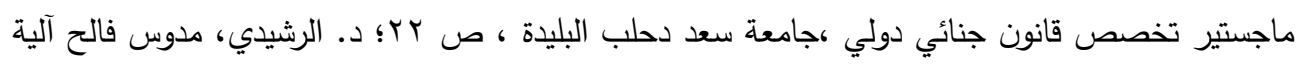

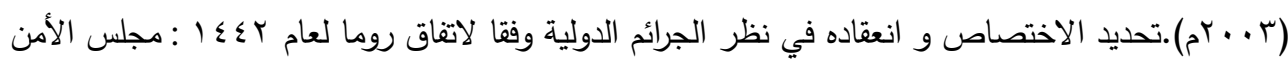

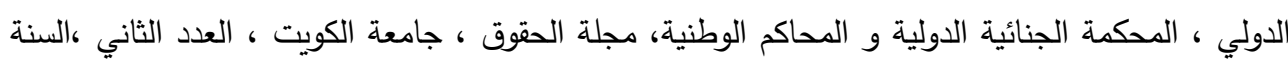

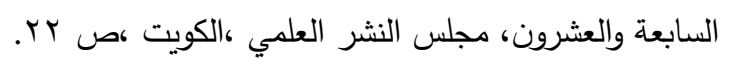

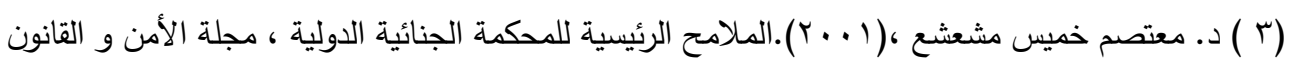

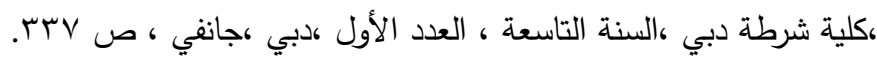

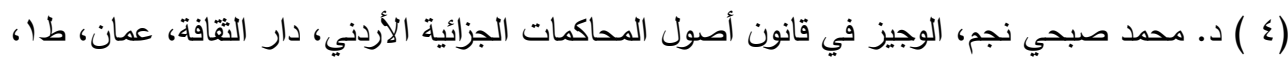
r.V.صن/991

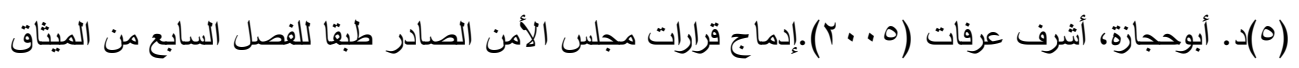

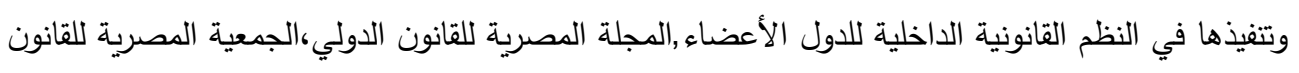




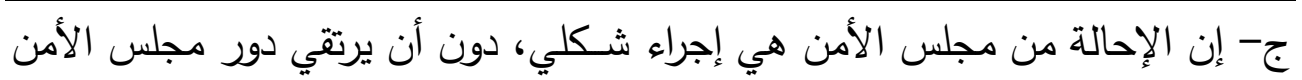

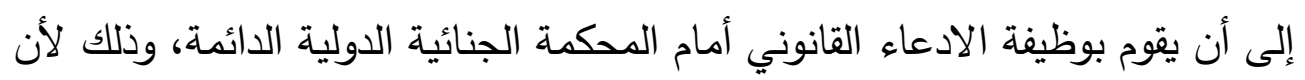

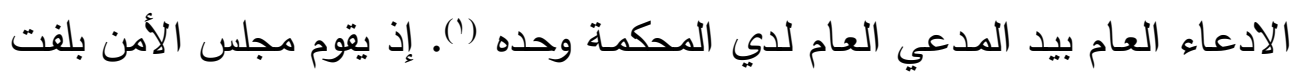

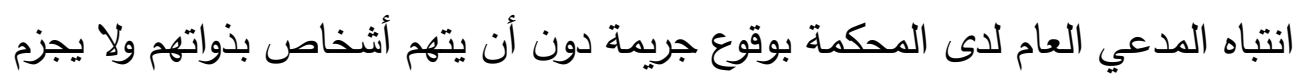

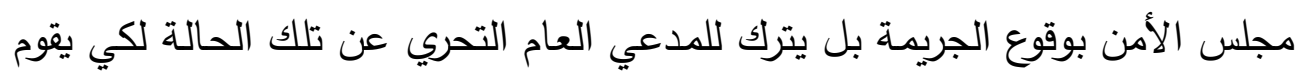

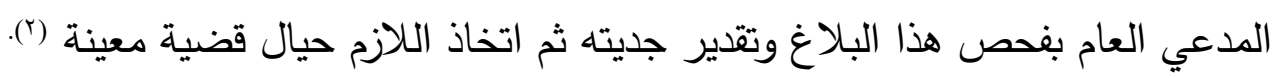

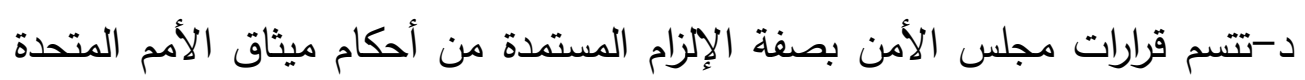

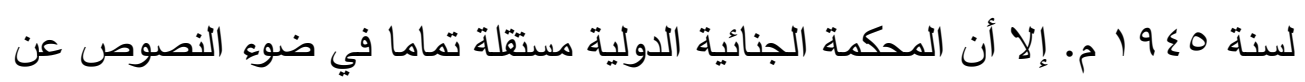

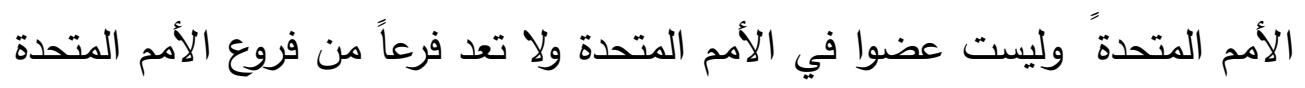

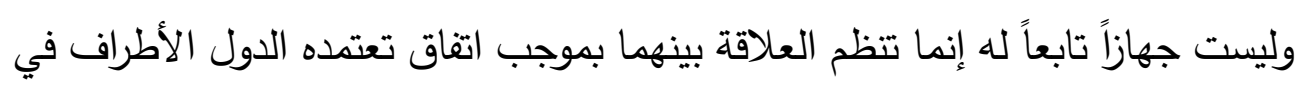
النظام ("). (5)

\section{ثالثا: الإحالة هن المدعي العام المشكمة: -}

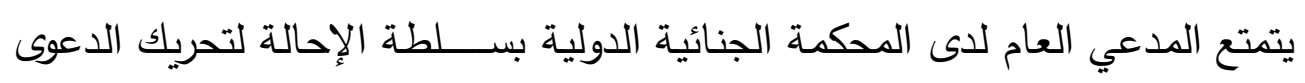

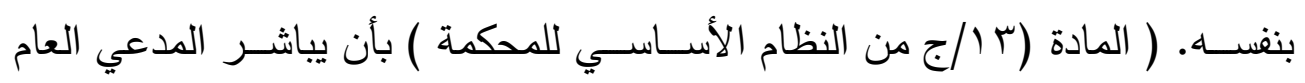

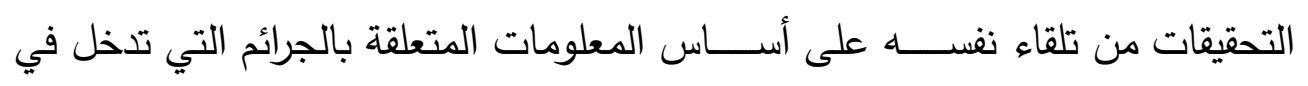
اختصاص المحكمة من تلقاء نفسه وذلك في حالتين هما: الحالة الأولى :إذا ارتكبت جريمة في إقليم دولة طرف في النظام الأساسي للمحكمة أو الون فئاء

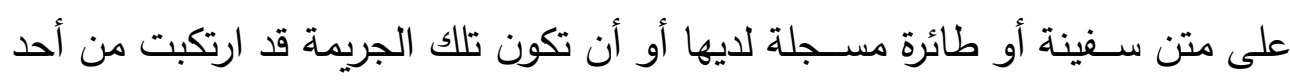

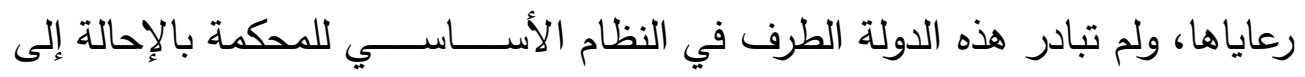

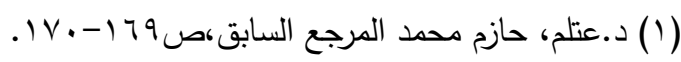

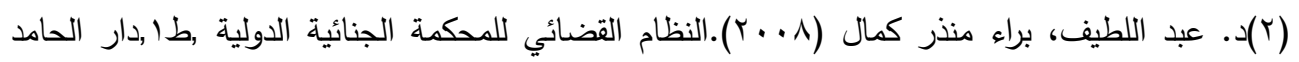

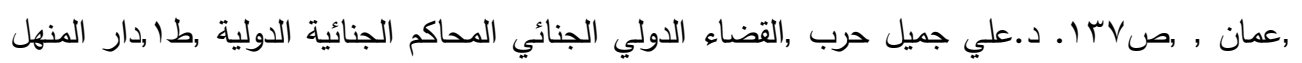

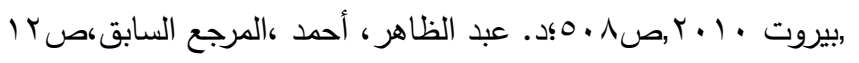

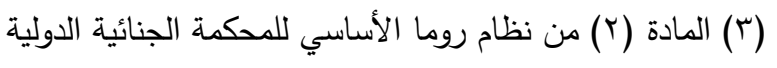


r.r. · مجلة روح القوانين - العدد الواحد والتسعون - إصدار يوليو

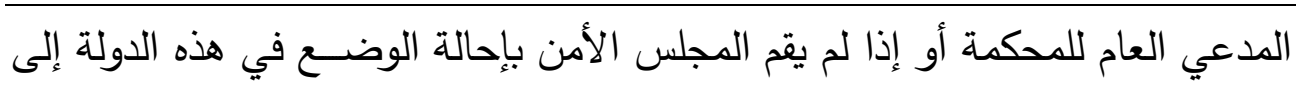
الدمعي العام للدحكمة (1).

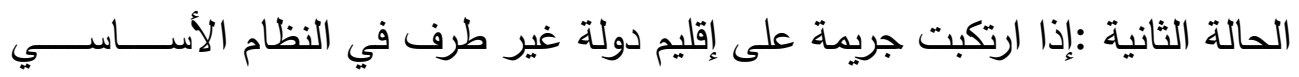

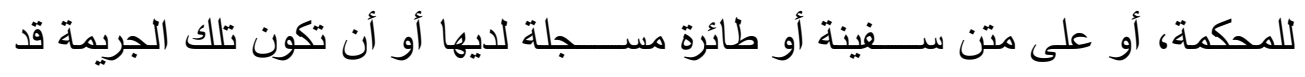
ارتكبت من أحد رعاياها، وتكون هذه الدولة قد قبلت باختصـاص المحكمة، ولم يبادر

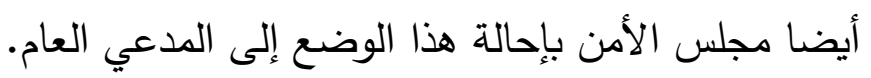

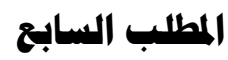

\section{تقدير دور السياسة الإجرائية في حق الجني عليه في تثريك الدعوى الجنائية الدولية}

إن الدعوي هي الوسيلة القانونية لتقرير الحق في العقاب على العي وقورع جريمة من الجرائم المنصوص عليها في المادة (0) من النظام الأساسي على إقليمها. ويطرح التساؤل:

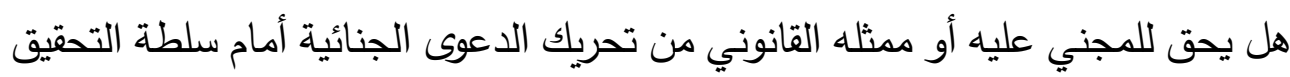

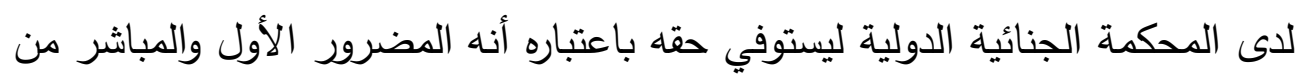

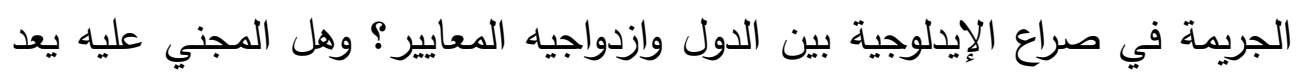

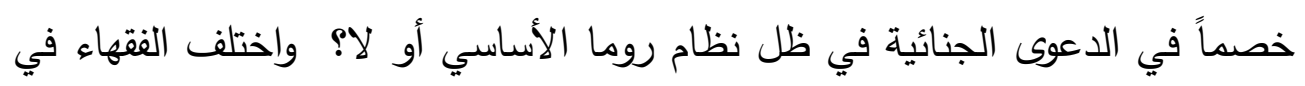

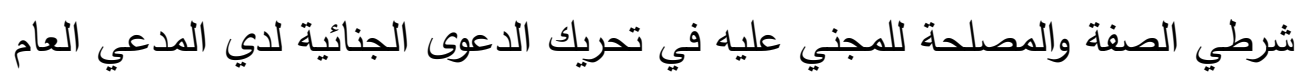
أمام المحكمة الجنائية الدولية. وذلك على الوجه الآتي:

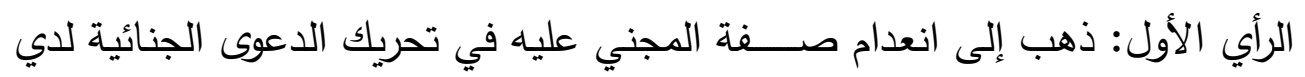

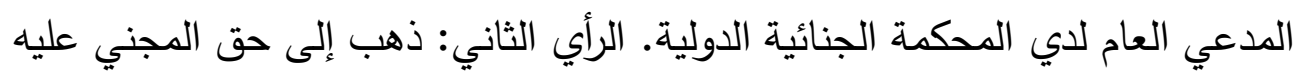

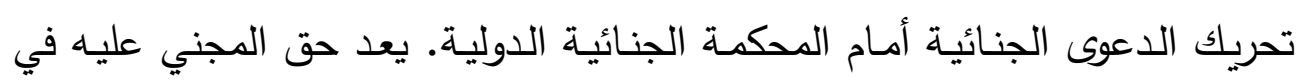

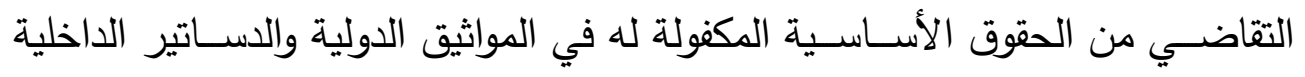
لتمكينه من الدفاع عن مصالحه التي أهدرتها الجريمة.

Jules Basdavant, Le veto dans L'organisation des Nations Unies, Revue de politique étrangère, Année 


\section{الرأي الأول: ذهب إلى انعدام صفة المنبي عليه في تمريك الدمعى الجنائية لدي المدمي} العام للدي المكمة الجنـانية الدوليسة. وهذا الرأي قائم على اســـتئثار المدعي العام والدائرة التمهيدية بمقاليد الدعوى الجنائية وانفرادهما التام بحق الاتهام وتقليص دور

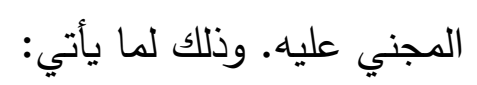
ا- إن الجرائم الدولية تسم بسمات فنية بحتة مما يجعل الإخبار عنها من المجني عليه أمراً غير متصور • وذلك بسبب أن هذه الجرائم تقع دون أن تكتشف لدي كثير من الأفراد بل لو تم كشفها فإنه يخاف من بطش السلطة أو الجاني نتيجة الإبلاغ عن الجريمة. إذ إن الجرائم الداخلة في اختصاص المحكمة الجنائية الدولية جرائم غالبا لا لإلإل تقع إلا في إطار صراعات مسلحة دولية أو غير دولية تؤدي إلى تهدد السلم والأمن الدوليين. وإن المتهم قد يكون من ذوي البطش فلا يجترئ أحد على اتهامه. كما قد

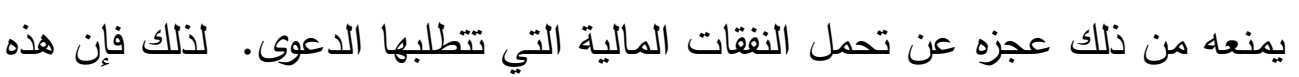
الجرائم تتطلب كفاءة وكفاية في أجهزة العدالة الجنائية وقياسات خاصة للتحقق من وقوعها مثال: جرائم الإبادة الجماعية. كما أن المجني عليه هو المجتمع الذي تمثله النيابة العامة في تحربك الدعوى الجنائية دون اعتداد بدور الفرد المجني عليه ('). ويجاب على هذا الاعتراض بأن دور المجني عليه ليس بديلاً عن المدعي العام إنما

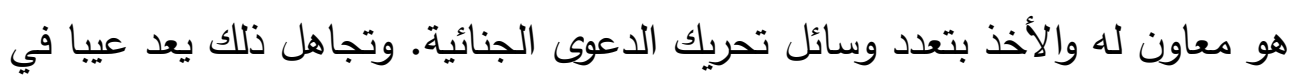
النظام القانوني فبدلاً من تعزيز دور المجني عليه نتيجة ضعفه فتم نزع دوره كاملا في الاعوى الجنائية في الجرائم الدولية. r-إن الأفراد لا يمتلكون "ثخصية قانونية دولية" معترفًا بها بموجب القانون الدولي. ومن ثم يتعذر على المجني عليهم أن يمارسوا حقوقهم أمام المحاكم الجنائية الدولية التي تقرر العقوبات الملائمة والتعويض عن الإجحاف الذي وقع عليهم. r-حداثة نظام الثكاوى الفردية أمام المحاكم الجنائية الدولية لإنصاف المجني عليه، نتيجة أن وصول المجني عليهح للعدالة الدولية أمر حديث العهد. لذلك لم يضع القانون لإن التهام

$$
\text { V.-TV (1) د.النعيمي،أسامة أحمد،المرجع السابق،ص V. }
$$




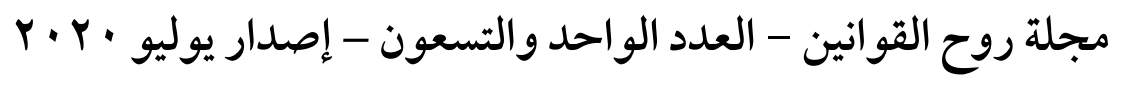

الدولي في اعتباره حقوق المجني عليهم. فكان المجني عليه مجرد شاهداً في القضية في محاكمات نورمبرج عام 9 19، وكذلك أمام المحكمتين الجنائيتين الدوليتين اللتان أنشئيا

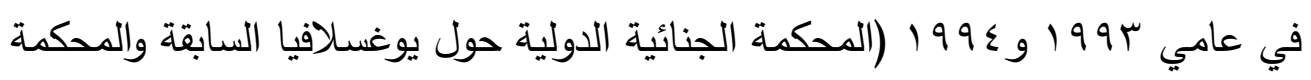
الجنائية الدولية حول رواندا)، وفي نظام روما الأساسي للدحكمة الجنائية الدولية تم

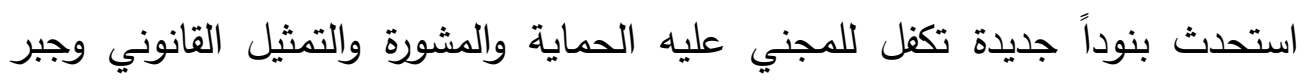

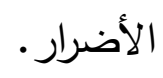

ع-غياب آلية قضائية دولية عالمية لحماية ضحايا الجريمة الدولية تختص بتلقي

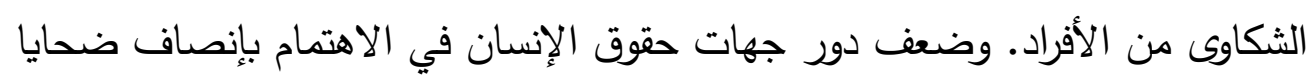

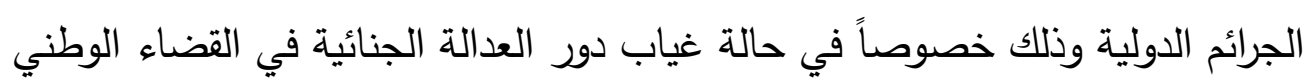

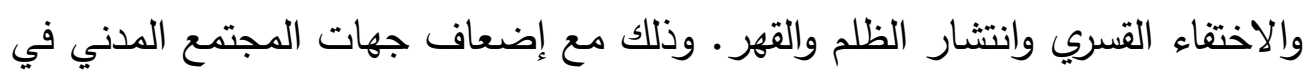

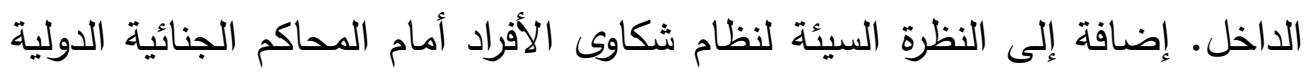
وذلك من قبل بعض الأنظمة السياسية إذ تعتبرها الدولة تدخلا في الثؤون الداخلية.

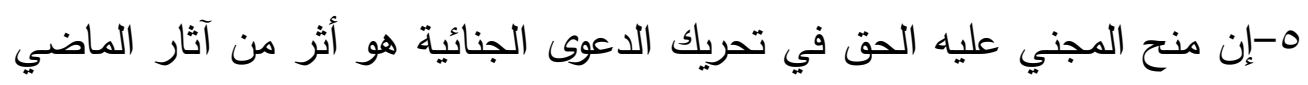

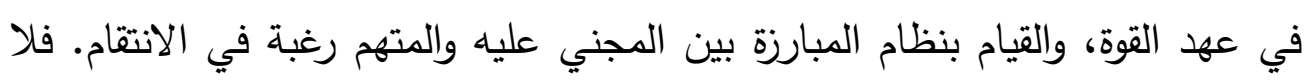

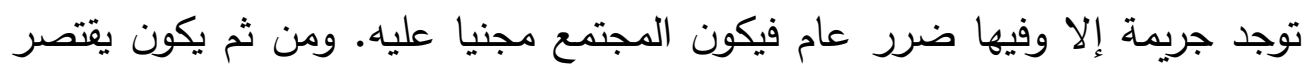

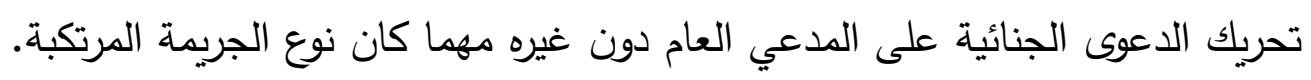

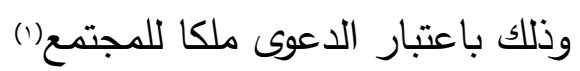
צ-إن المجني عليهم، برّغم أنّهم قد عانوا من فظائع بشعة، إلا أنهم غير مؤهّلين للظهور

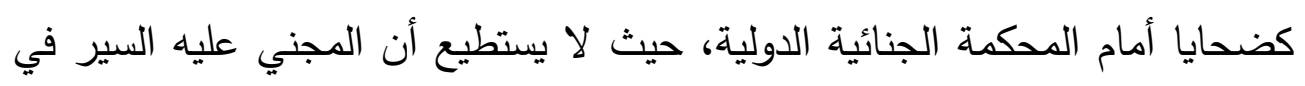

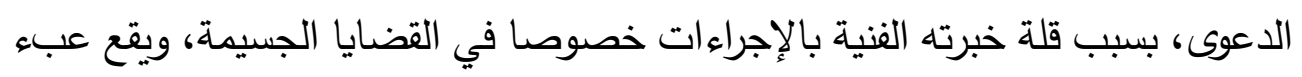

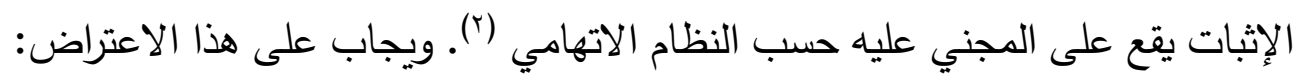

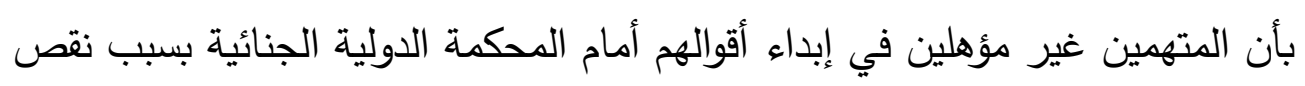

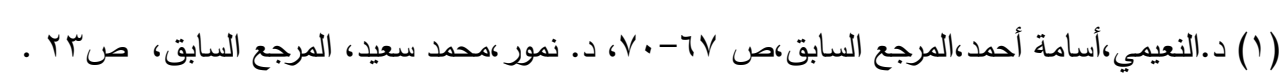

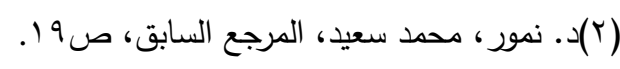
$(\mathrm{M \Lambda})$ 


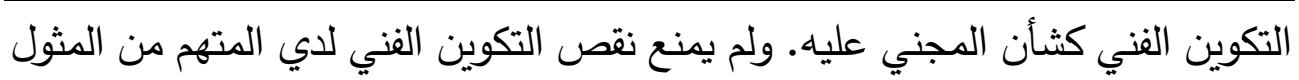

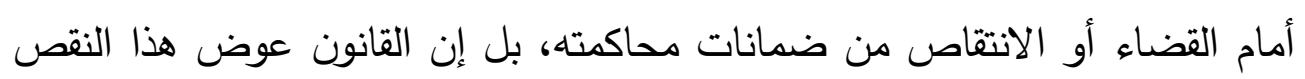

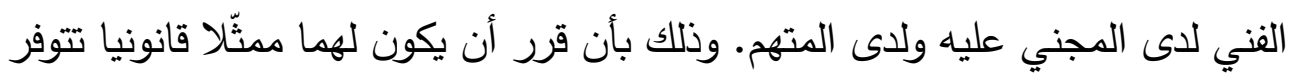

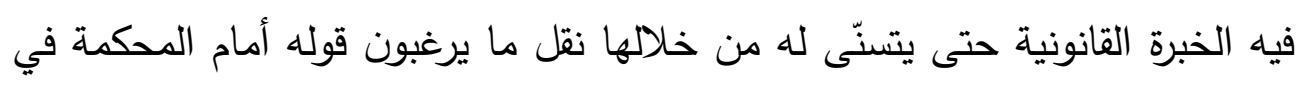

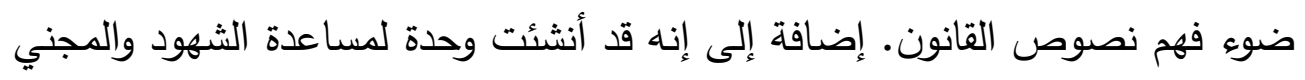

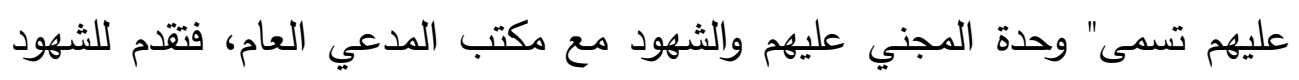

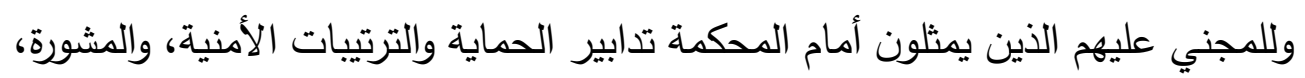

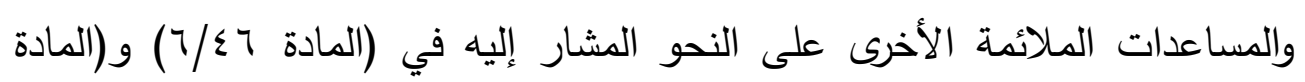

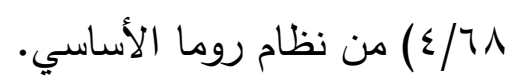

V-إن المجني عليه قد يتخذ الدعوى الجنائية، وسيلة للابتزاز والتهديد والتشهير والكيد

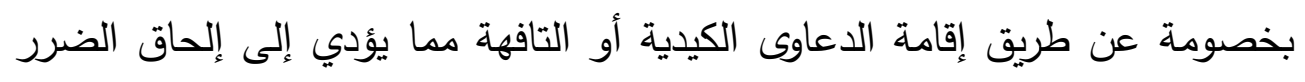

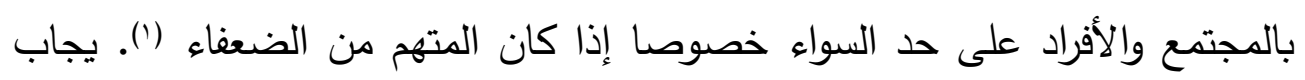

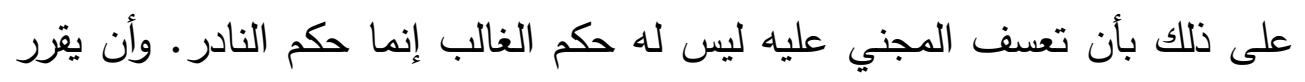

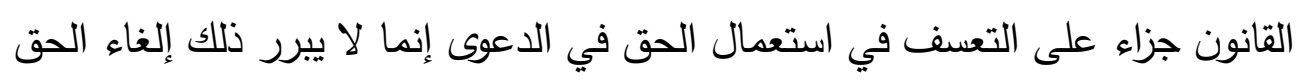

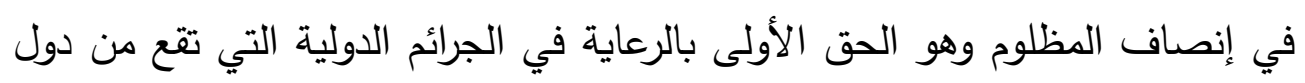

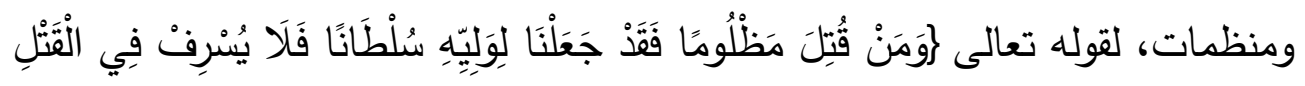

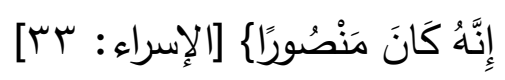

ᄉ-1إنه توجد إشكالية في كيفية إعلام المجني عليهم (الضحايا) بحقّ الششاركة في

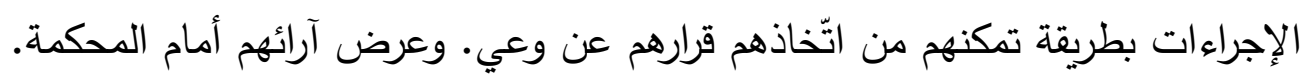

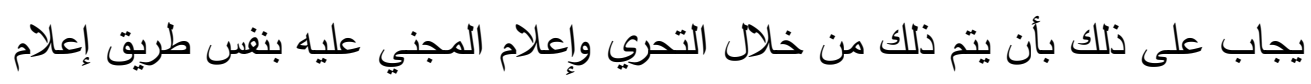

( (1) د. عوض، محمد محي الدين، حقوق المجني عليه في الدعوى العمومية ، المرجع السابق، ص •ب- 
r.r. · مجلة روح القوانين - العدد الواحد والتسعون - إصدار يوليو

المتهم بالتهم، بل لو كان للمجني عليه الحق في أن يكون خصما في الدعوى الجنائية

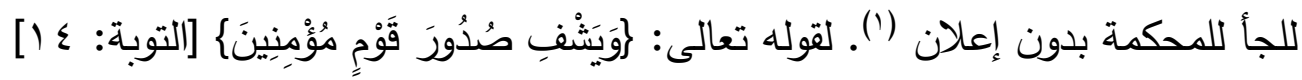

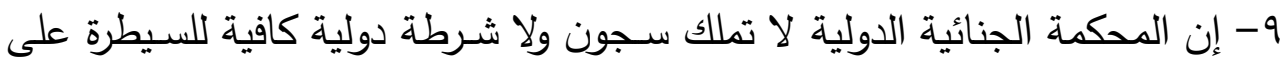

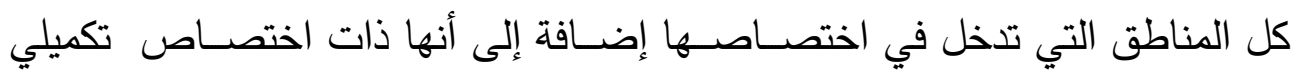
عالمي (Y).وإنما تتحصـــر ســـلطتها في طلب التعاون من مجلس الأمن والدول

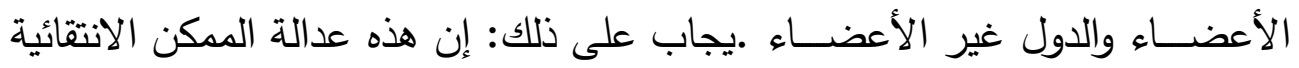

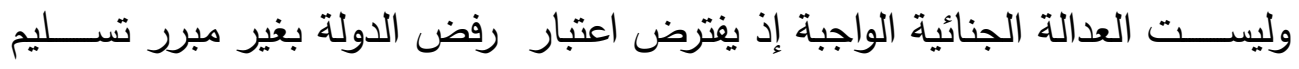

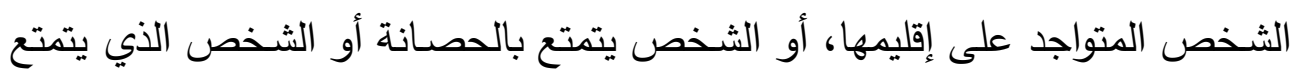

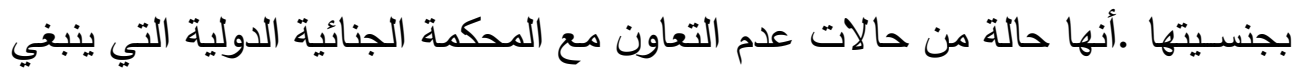

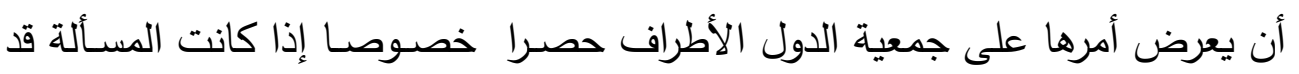

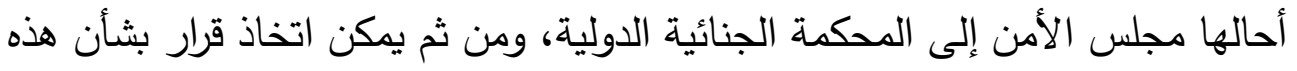

الدولة الرافضة على أنها لا ترغب في التعاون مع الدحكمة الجنائية الدولية(r).

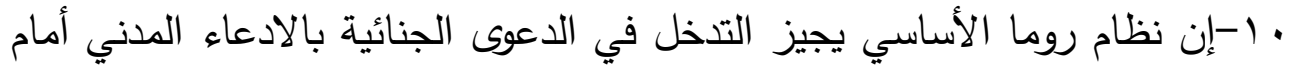

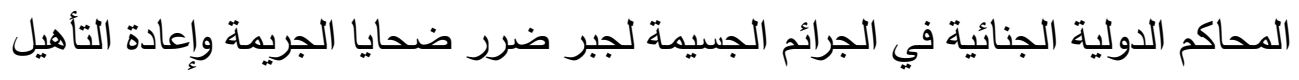
حسب (المادة Vo) من نظام روما الأساسي. كما تعطيه القوانين الإجرائية الوطنية تحريك الدعوى الجنائية استثناءً في الجرائم غير الجسيمة بصفته مضرور من الجيان الجريمة

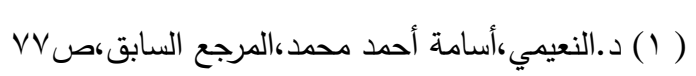

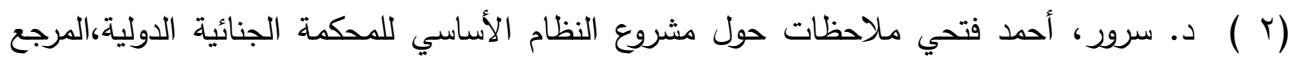

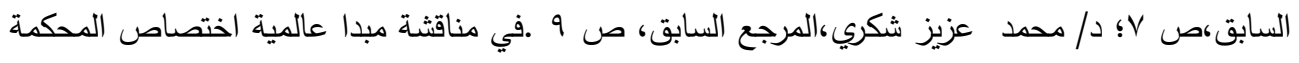

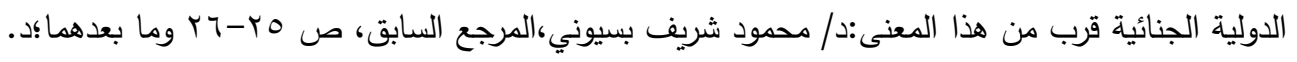

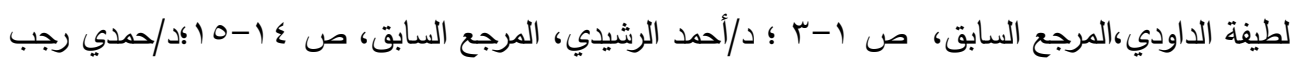

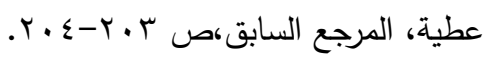
(r) د. راضي، مازن ليلو( (1) +ץ). محاكمة الرؤساء في القانون الجنائي الدولي، طبعة الأولى، مؤسسة 
وليس بصفته مجنيا عليه (').لتدارك إهمال أو سهو النيابة في أداء وظيفتها وتتحقق ورقابته في تقدير ملاعمة تحريك الدعوى الجنائية وإرضاء المجني عليه بالحصول على تعويض مع ضمان عدم تعارض الحكم الصادر في الدعوى المدنية مع الحكم في الاعوى الجنائية (؟). يرد على ذلك بأن حق المجني عليه في الدعوى الجنائية لا يقل عن حقه في التعويض وكان يجب معالجة المساوئ التي أفرزها النظام التتقيبي في ظل إقرار مبدأ "ملاءمة تحربك الدعوى الجنائية" والتي فاقت جسامتها ما كان يأمل منها (ّ). ا ا- إن السماح للمجني عليه بتحريك الدعوى الجنائية، أو الدعوى المدنية أمام القضاء الجنائي، يجعل القضايا تتراكم أمام القضاء الجنائي، فيعطل بذلك القضاء الجنائي عن أداء وظيفته في المجال الجنائي؛ يجاب على ذلك بأن: الأصل يجب على النظم القانونية معالجة أسباب البط، وإبدالها بمحاكمة ناجزة غير متسرعة ليس البديل إلغاء لدور المجني عليه بل إنه يمنح إمكانية الجمع بين الاتهام العام والاتهام الخاص والادعاء المدني مما يوفر الوقت والجهد والنفقات (๕).والاستفادة من سرعة القضاء الجنائي ودقة لهن التحقيق في الدعوى وجمع الأدلة الجنائية. حجج هذا الرأي الأول فيها إقرار بانتقاص من حماية حقوق المجني عليه الذي كان ضحية الجريمة الدولية في عصر ازدهار حماية حقوق الإنسان. ومن ثم يمكن للمحكمة الجنائية الدولية استلام المعلومات من الأفراد بخصوص ادعاءات عن جرائم الإبادة الجماعية، وجرائم الحرب، والجرائم ضدّ الإنسانية مثلا.

( (1) د. عوض، محمد محي الدين، حقوق المجني عليه في الدعوى العمومية ، المرجع السابق، هامش ص $O N-O V$

$$
\begin{aligned}
& \text { د. عوض، محمد محي الدين،المرجع السابق، هامش ص 00-00. } \\
& \text { د. سعيد، محمد محمود المرجع السابق. }
\end{aligned}
$$

د. عبد الستار، فوزية(9/9 (1). حق المجني عليه في تحريك الدعوى الجنائية، بحث مقدم ، لمؤتمر ،

حقوق المجني عليه في الإجراءات الجنائية، المؤتمر الثالث المصرية في المصرية في الفترة من rار-ـا

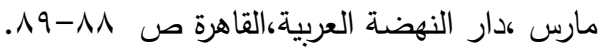




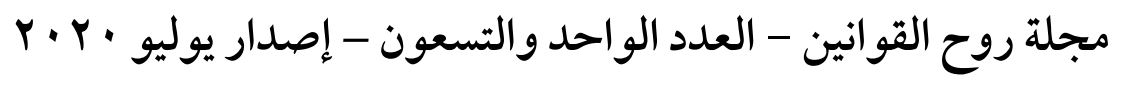

الرأي الثاني: ذهب إلى حق المني عليه تثريك الدعوى الجنائية أهام المكيمة الجنائية

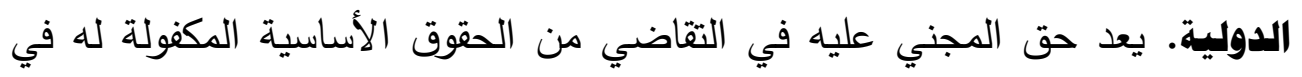
المواثيق الدولية والدساتير الداخلية لتمكينه من الدفاع عن مصالحيه فئ التي أهدرتها الجريمة

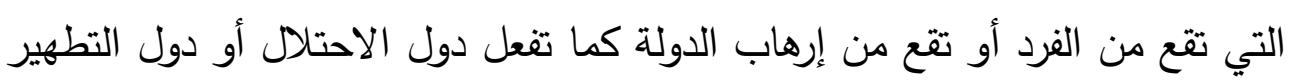

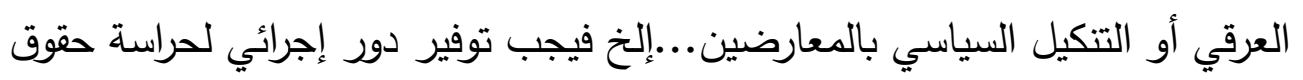

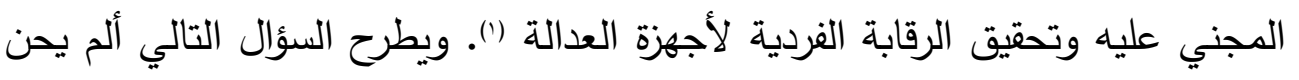

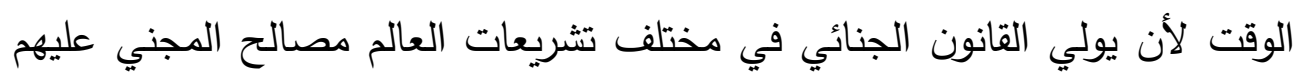

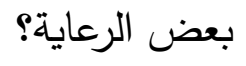

ا-يجب التخلي عن النظرة التقليدية القاصرة على أن أطراف الدعوى الجنائية هما

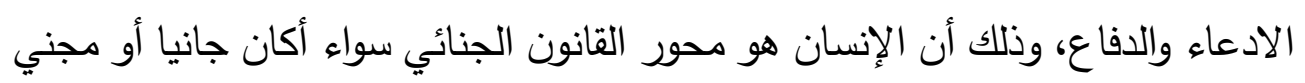

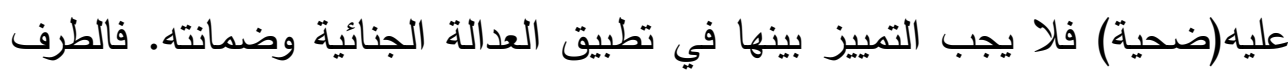
الأول المدعي العام: وهو الطرف الأقوى في الدعوى الجنائية أمام المحاكمة الجنائية

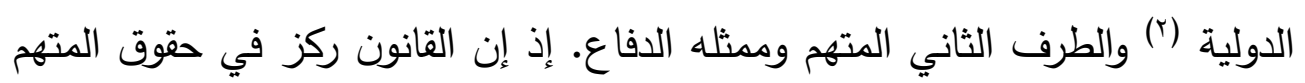

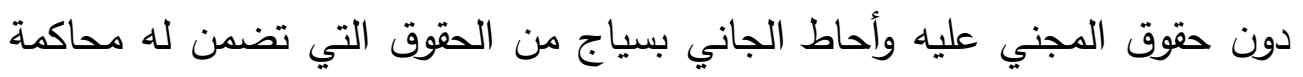

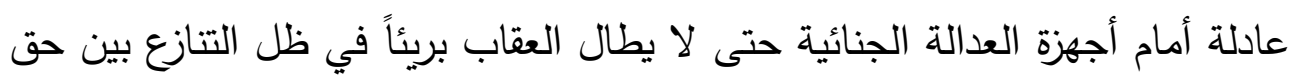

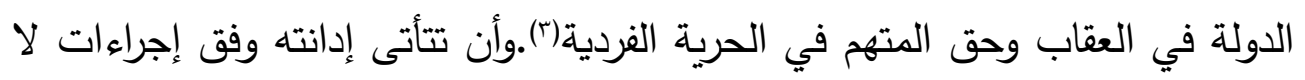

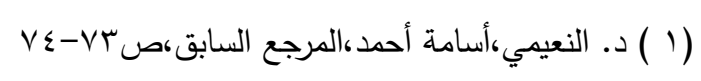

Prosecution in international criminal Law : Goldstone. James, more candour about criteria : The exercise of discretion of the prosecutor of the international criminal court, journal of international criminal justice, (JICJ), oxford, $\left.r \cdot 1 \cdot, p^{r} \wedge r_{-} \varepsilon \cdot\right\urcorner$. Martson danner, enhancing the legitimacy of prosecutorial discretion at the international criminal court, American journal of international law, (AJIL), New York, issue 9v, r..r, pp 01.-00 r Sergey, Vassiliev, The role and legal statue of the prosecutor in international criminal triale, in L.Reydans, C.Ryngaert, S.Parmentier, International prosecutions from Nuremberg to the Hague, oxford, oxford university press

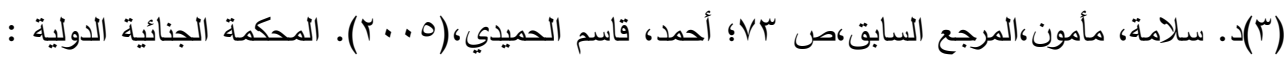

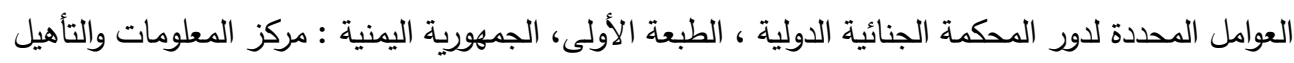

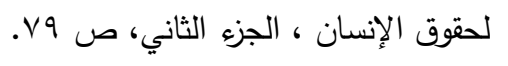




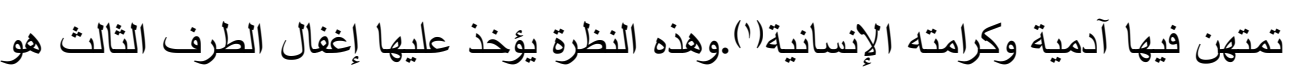

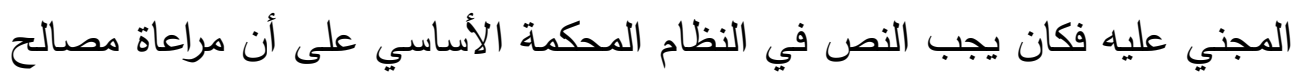
المجني عليه في ظل ندرة السوابق في النظام الأساسي للمحكمة أو في القواعد الإلئ الإجرائية

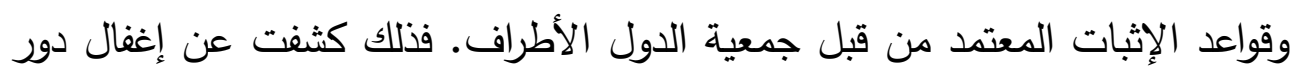

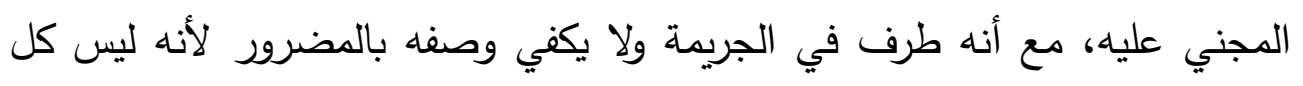

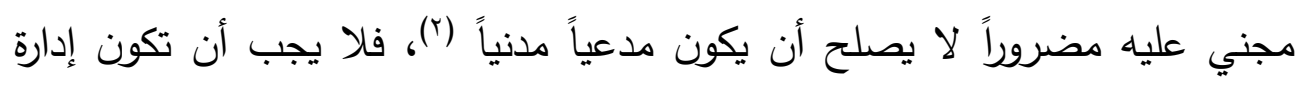

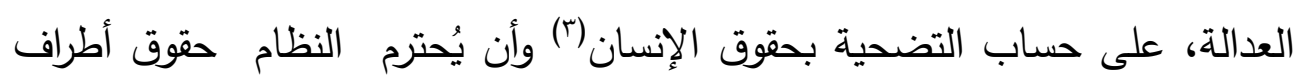

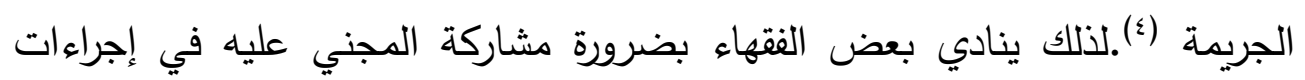

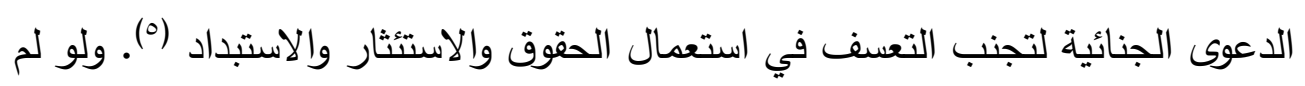

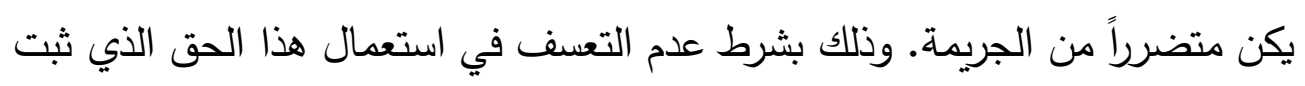

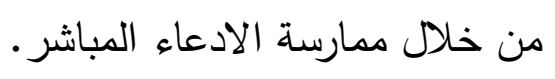

ب-الإخلال بالمساواة بين أطراف الجريمة الجني عليه والمتهم، تتهض مدونات

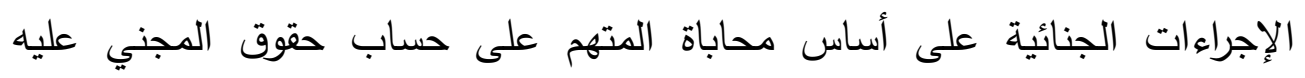

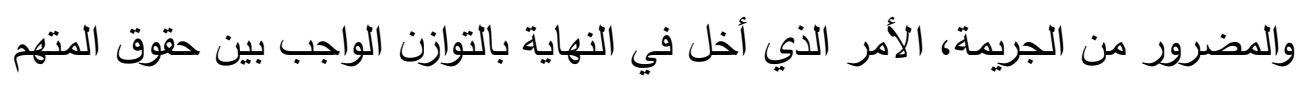

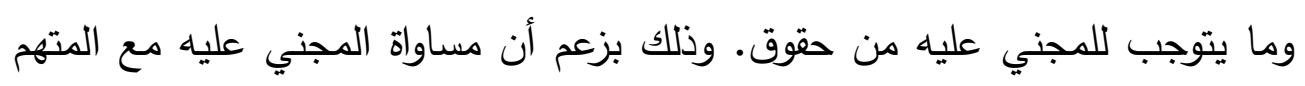

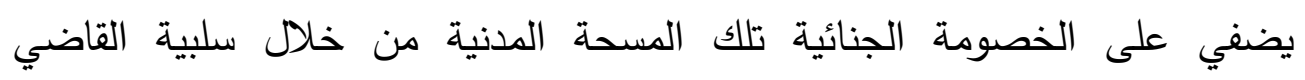

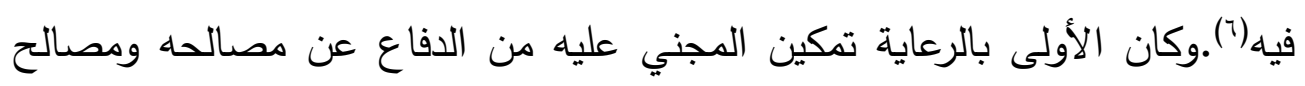

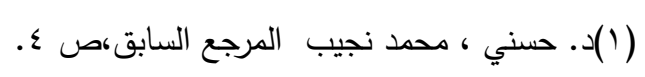

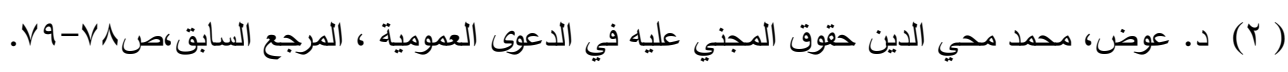

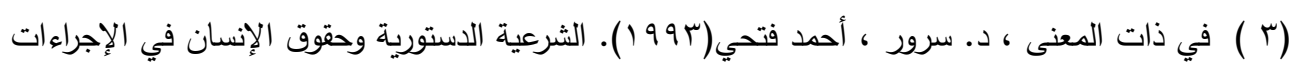

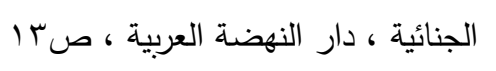

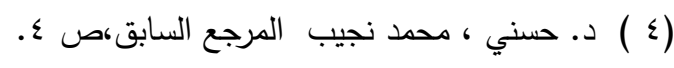

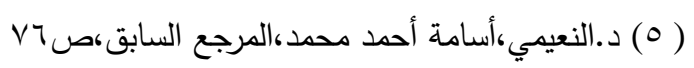

L. Rajapakse, Is a presumption of gulit or of innocence of an accused in a criminal

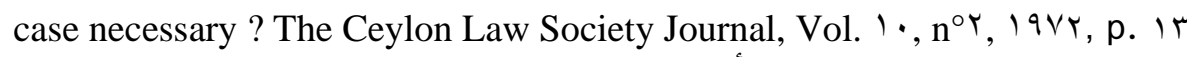

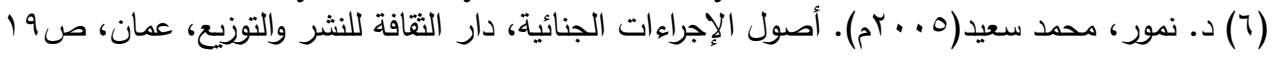




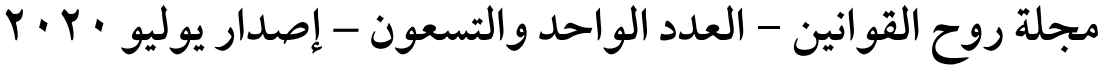

مجتمعه واستقرار آمنه سواء بتوقيع العقاب على الجاني أو الحصول على تعويض عما لماء

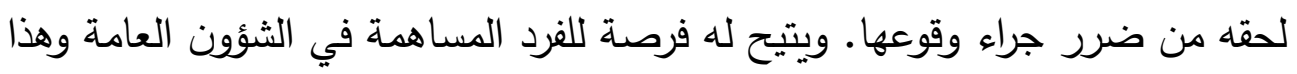

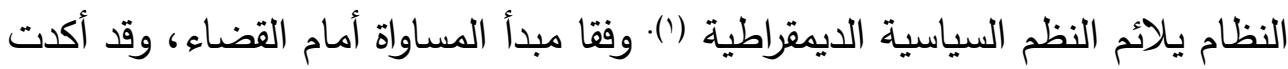

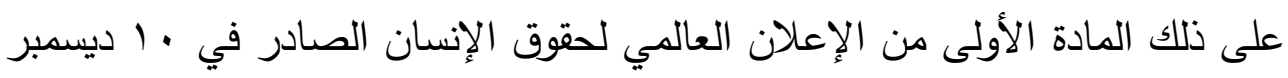

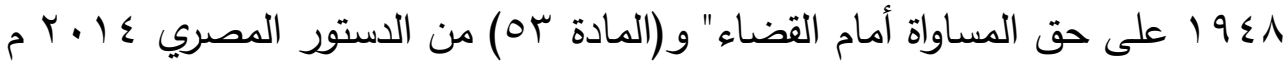

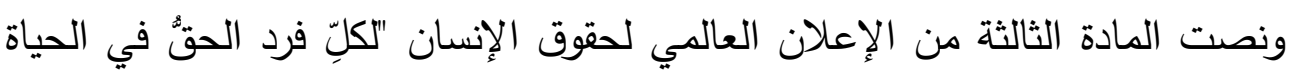

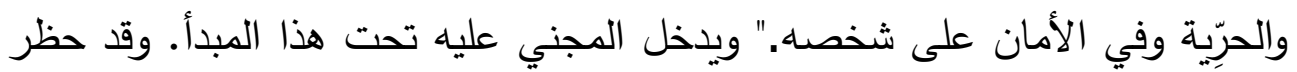

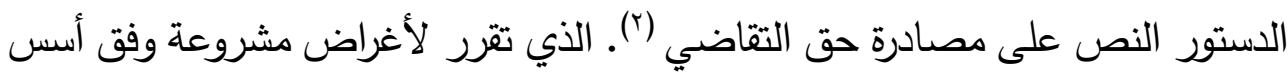

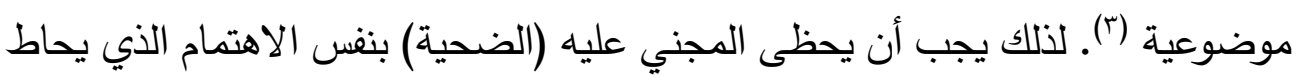
به المتهم في كل مراحل الدعوى الجنائية، وهذا لبلوغ السياسة الجنائية درجة من التوازن

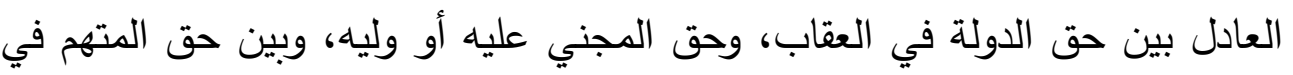

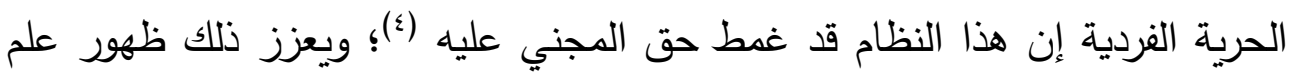
"المجني عليه". نتيجة إهمال الوضع السيء للمجني عليه في نظام العدالة الجنائية، إضافة إلى عجز الدولة عن حمايته بمنع وقوع الجريمة عليه ابتداء وملاحقة الجناة (ه).

(1) د. عبد الستار، فوزية (9V0). شرح قانون أصول المحاكمات الجزائية اللبناني، دار النهضة العربية،

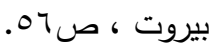
(r ) د د ـ عبد الله ، عبد الغنى بسيونى مبدأ المساواة أمام القضاء وحق التقاضي، منشأة المعارف، إسكندرية،

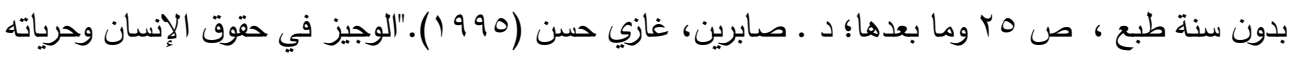

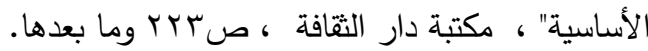

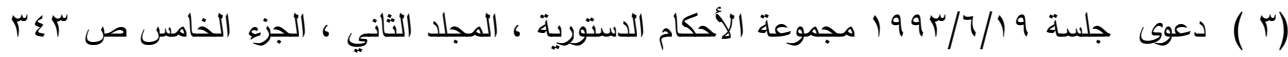

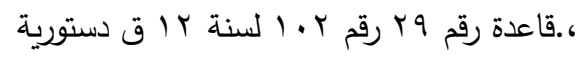

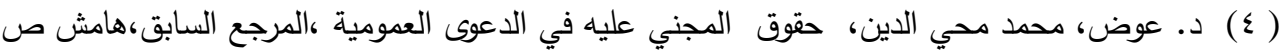
$.0 V-00$

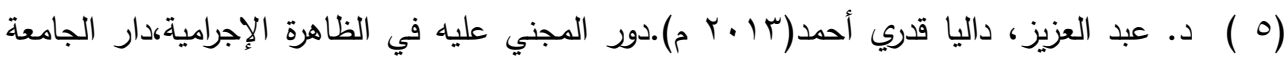

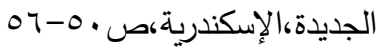




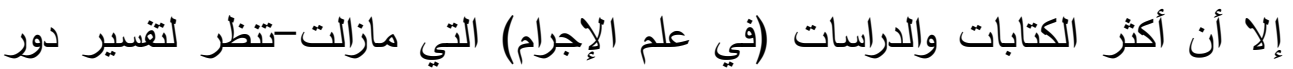

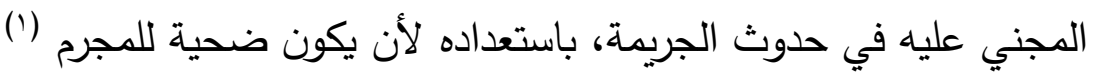

r-لم تنظم المواثيق الدولية حقوق المجني عليه حيث لم يضع القانون الدولي في اعتباره

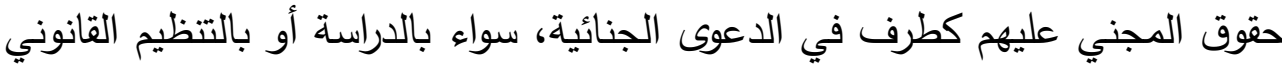

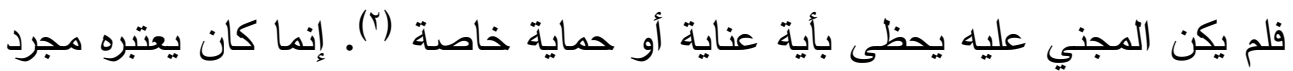

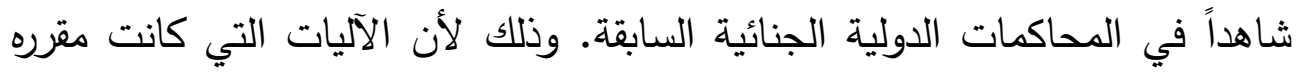

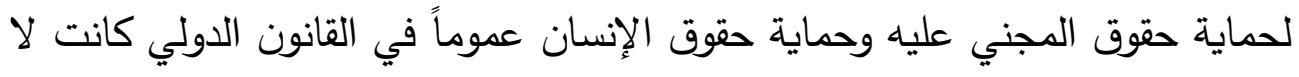

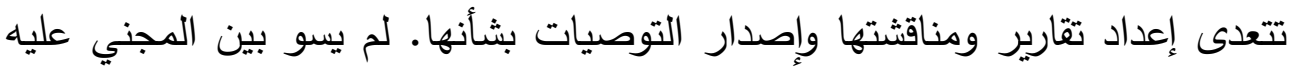

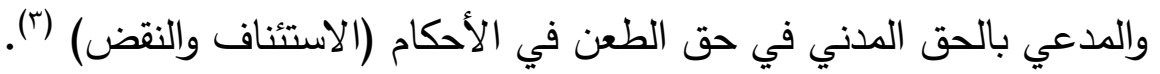

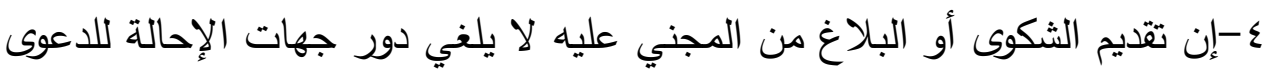

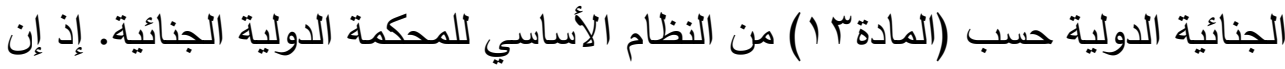

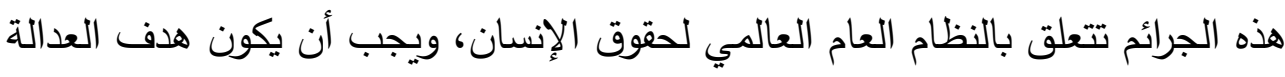

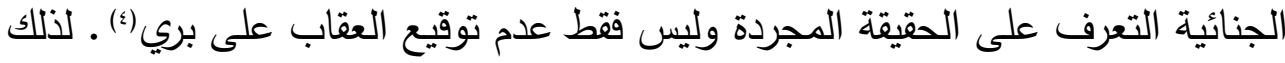

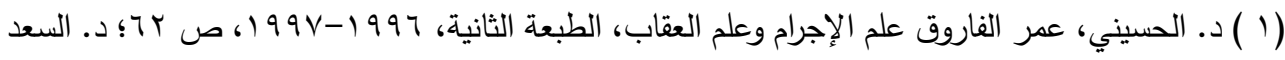
، صالح المرجع السابق ، ص /V وما بعدهاءد/ الفقي، أحمد عبد اللطيف ،المرجع السابق،ص إ؛ وما بعدها (Y ) د. الحسيني، عمر الفاروق المرجع السابق،ص r r7، حيث يقرر أن " أكثر الكتابات والدراسات ( في علم الإجرام) كانت- ومازالت- تتصب على تحديد علاقة المجني عليه بالمجرم من حيث استعداد الأول لأن

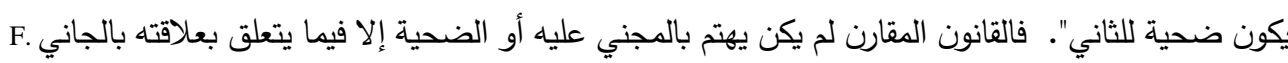
DOROY, " Le réexamen d'une décision pénale consécutif au prononcé d'un arrêt de condamnation de la CEDH, mise en œuvre de la réforme du 10 juin $r \cdots$, questions juridiques et problèmes pratiques", Droit pénal, juin $r \ldots r$,

chr. 11 .

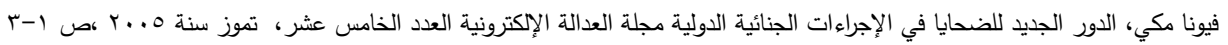
F. LOMBART, Les systèmes d'indemnisation des victimes d'actes de violence, Centre de recherches sociologiques sur le droit et les institutions pénales, Paris, 19^r; Y. CLAPOT, Indemnisation des victimes: les infractions pénales, dommage, préjudice, réparation, Paris, Editions ESKA, $199^{\circ}$ A. MBARGA, L'indemnisation publique des victimes d'infractions, L'indemnisation par le Fonds de garantie, Paris, L'Harmattan, $\uparrow \cdots$..; Ph. CASSON, Les fonds de garantie, Paris, LGDJ, 1999, préface de G. VINEY

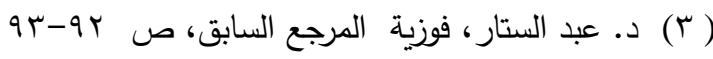

(ء)د. المرصفاوي، حسن صادق، المرصفاوي في التحقيق الجنائي - منشاة المعارف الإسكندرية - بدون تأريخ 


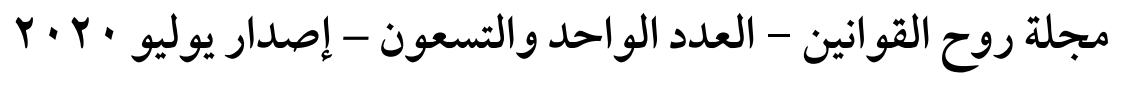

تميل غالبية القوانين الإجرائية الحديثة إلى عدم حصر الحق في تحريك الدعوى الجنائية

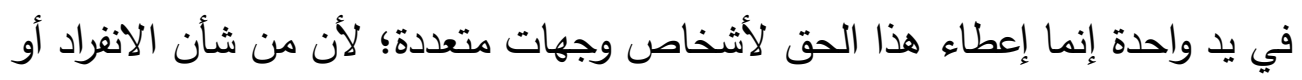

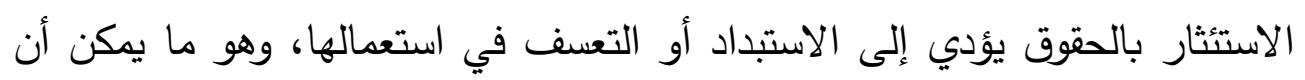

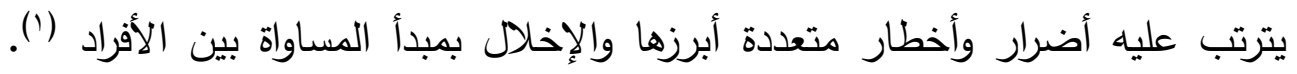

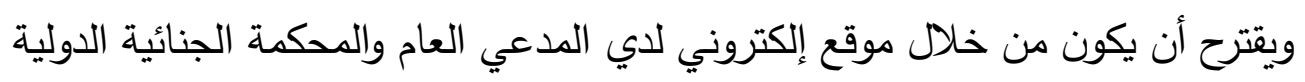

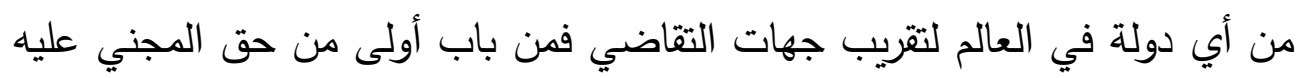

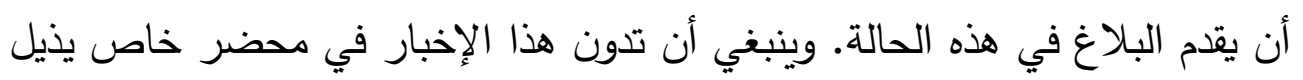

بتوقيع الهني عليه ويسلم لعضو التحقيق الأولي، أو عضو التحقيق الابتدائي (؟).

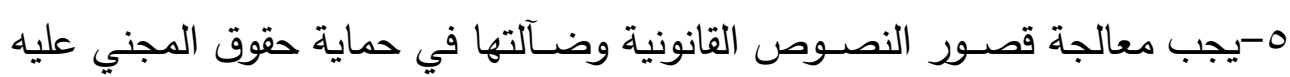
فأين التطور القانوني والقضائي والفقهي للدراسات والبحوث في الاهتمام بحماية حقوق الجاني

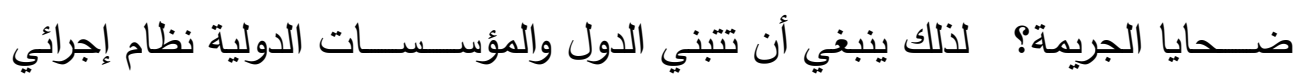

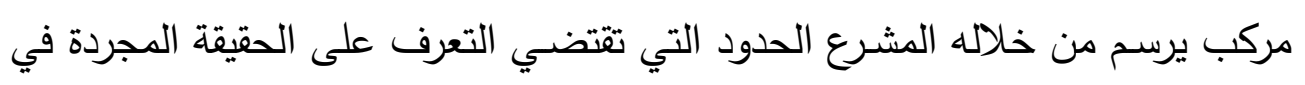

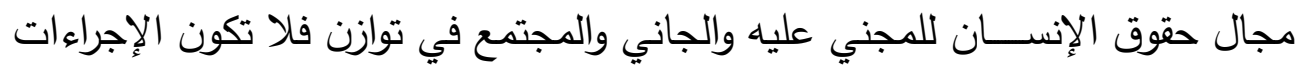

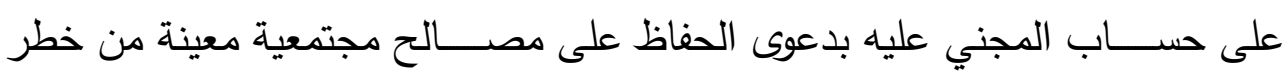
الجريمة ولا على حساب التضحية بالحريات الثخصية وسائر حقوق الإنسان المرتبطة

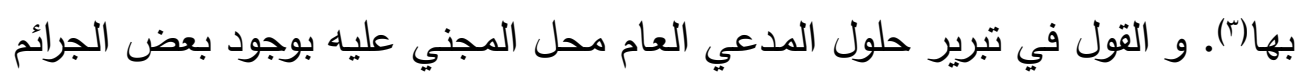

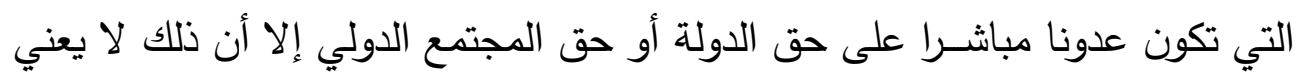

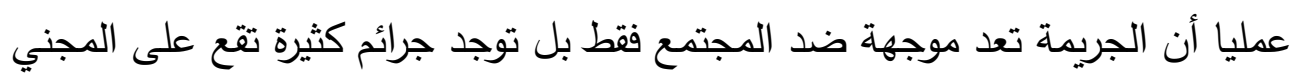

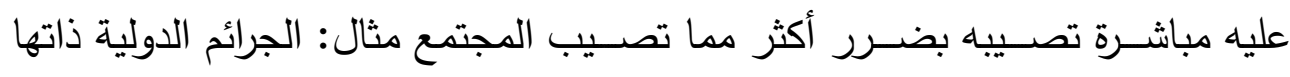

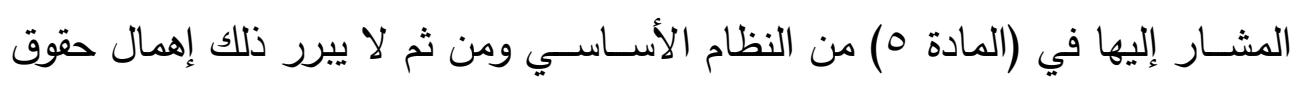

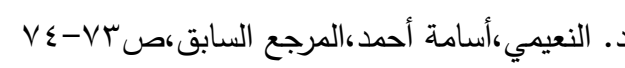

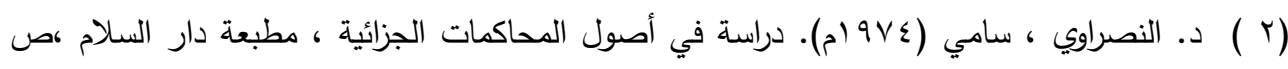




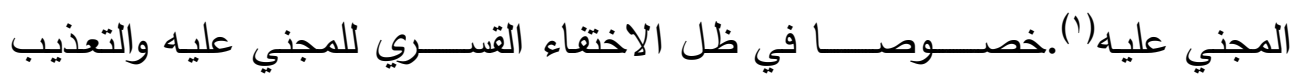
والاغتصـاب للوصـول لوسـائل الانتصـاف من حالات الاختفاء القسـري الذي تقوم به بعض المنظمات الإرهابية وبعض الدول وهي جرائم ضـــ الإنسـانية تصـيب المجني عليه وأسرته وتبقي من غير عقاب ولا تحقيق ولا تعويض عادي ولا يوجد ضمان لعدم

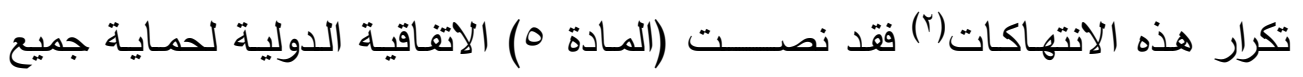
الأشخاص من الاختفاء القسري"

0-إن إشراك المجني عليه في الإجراءات الجنائية يسهم في دعم السلطات المختصة بالتحقيق والمحاكمة في إثبات الجرائم المرتكبة باعتبار أن المجني عليه عنصر هام من عناصر الإثبات الجريمة التي وقعت عليه (ץ). كما إن إسهام المجني عليه في الدعوى الجنائية يجعل المناقشة أمام القضاء الجنائي أكثر واقعية لظروف الجريمة وفيها تعويض الإن إنهام نفسي (؛) والتعويض النفسي مرتبط بمشاعر المجني عليه أو وليه وإحاطة القاضي بظروف الواقعة وبظروف المتهم في حياد ودقة دون حاجة لانتظار استحضار مشاعر المجني عليه (ن). وفيما سبق رد على هذا القول.

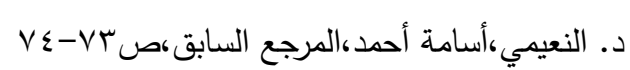

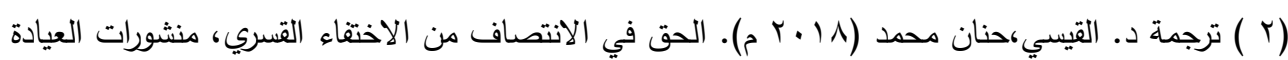

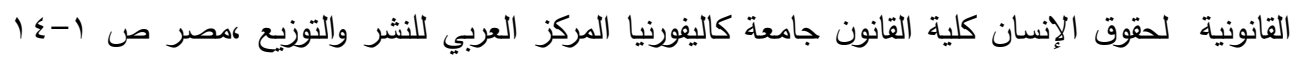

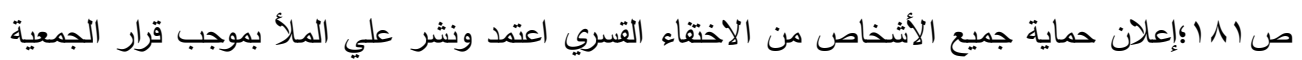

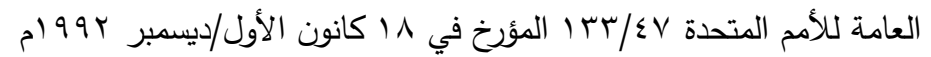
https://www.ohchr.org/ar/hrbodies/ced/pages/conventionced.asp

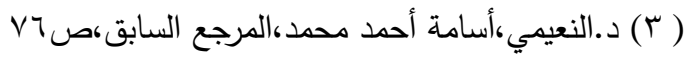

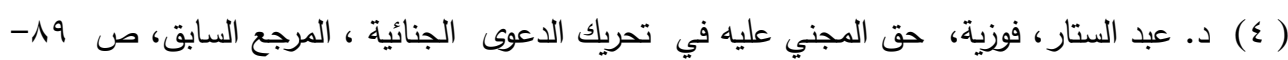

( 0) د. عبد الستار، فوزية، حق المجني عليه في تحريك الدعوى الجنائية ، المرجع السابق، ص 9 صـ- 
r.r. · مجلة روح القوانين - العدد الواحد والتسعون - إصدار يوليو

بناء عليه نرجح الرأي الثاني بأن تتبع السياسة الجنائية آليات لتفعيل دور المجني عليه

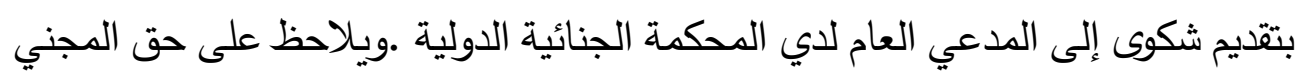
عليه في تحريك الدعوى الجنائية لدي أجهزة المحكمة الجنائية الدولية ما يأتي:

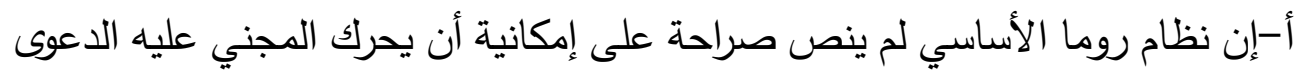

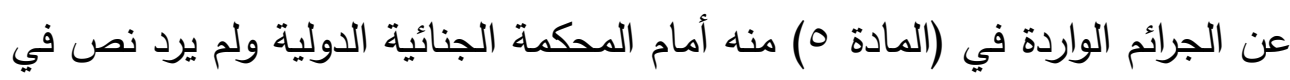

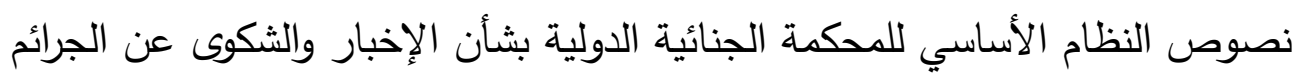

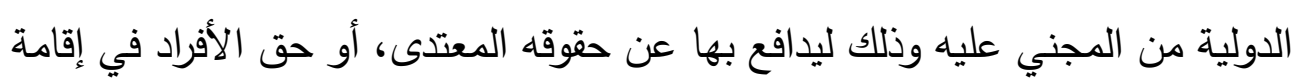

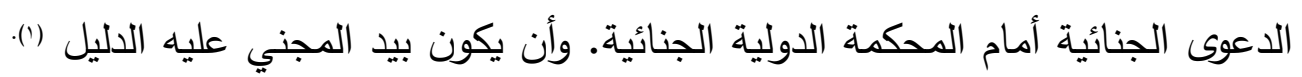

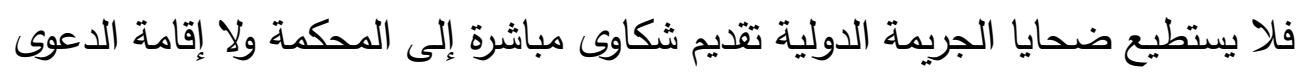

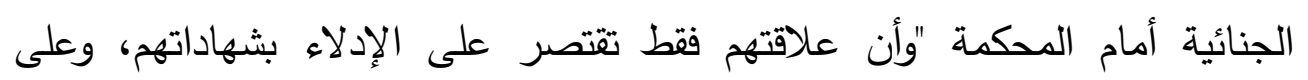

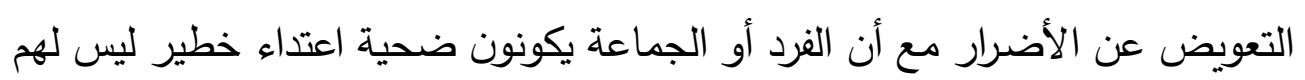

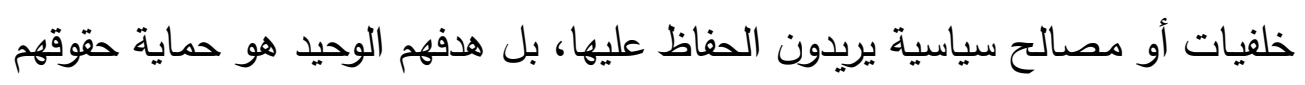

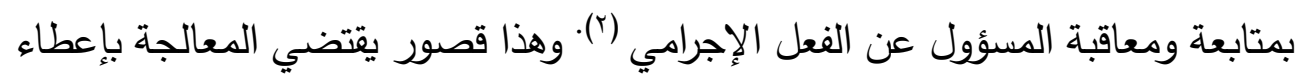
المجني عليه الحق في طلب تحريك الدعوى الجنائية أمام المحكمة الجنائية الدولية

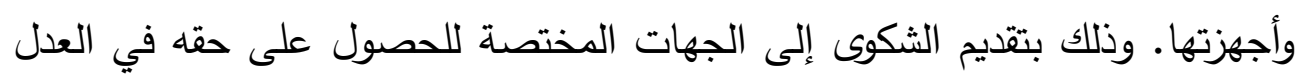

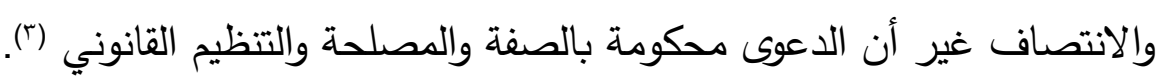

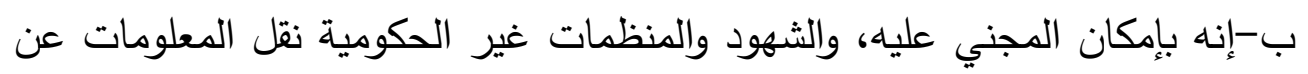
ارتكاب الجريمة الدولية وضحاياها إلى المدعي العام في الدحكمة الجنائية الدولية الذي ولئي

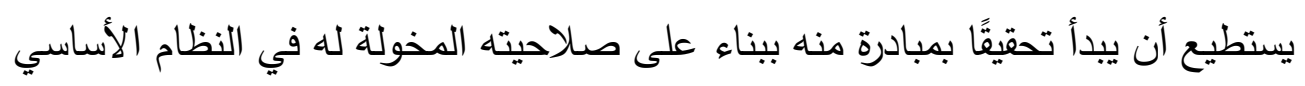

( 1) د. محمد محي الدين عوض (1919 م).حقوق المجني عليه في الإجراءات الجنائية ،المرجع السابق، صهب وما بعدها. (r ) سكاكني، باية(r . . rم). العدالة الجنائية الدولية ودورها في حماية حقوق الإنسان، دار هومة للطباعة

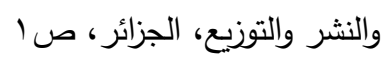

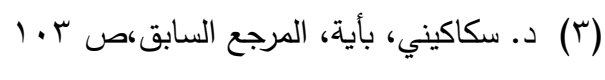
$($ ( $9 \wedge)$ 


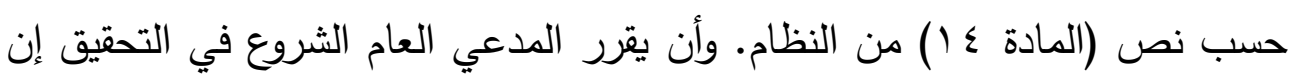

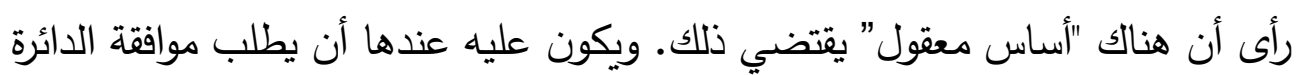

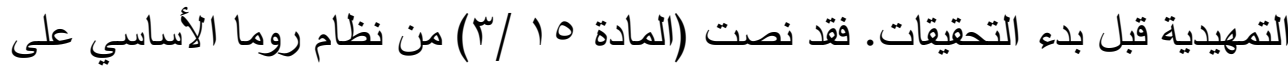
أن" يجوز للدني عليهج إجراء مرافعات لدى الدائرة التمهيدية وفقاً للقواعد الإجرائية وقواعد الإثبات." يقوم الددعى العام ومكتبه بإجراءات الاستدلال من خلال التحريات

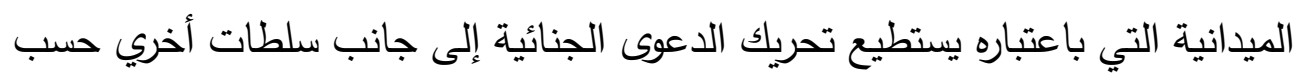

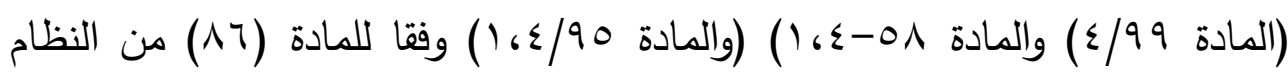

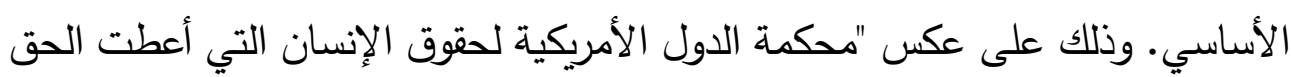
للأفراد بتقديم الالتماسات إلى لجنة الدول الأمريكية لحقوق الإنسان، حيث تقوم بفحصها،

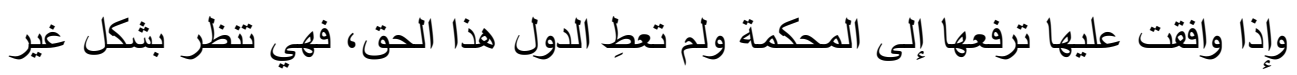

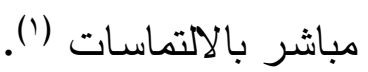

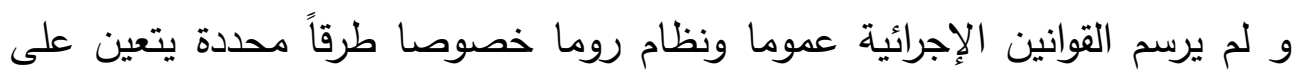

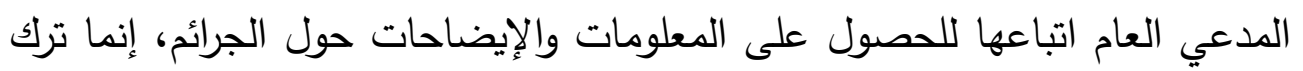

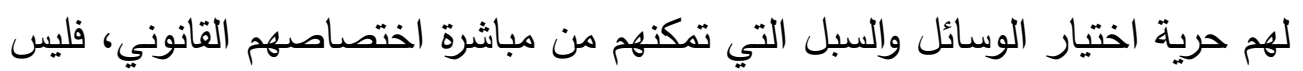

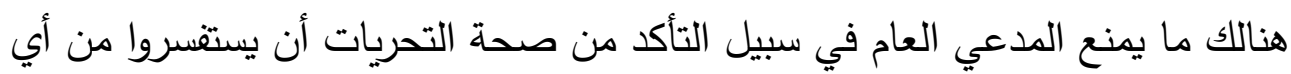
شخص كان ولو كان المجني عليه. ج-يحق لضحايا الجريمة الدولية ومنها جرائم الحرب بتقديم قضاياهم أمام المحاكم

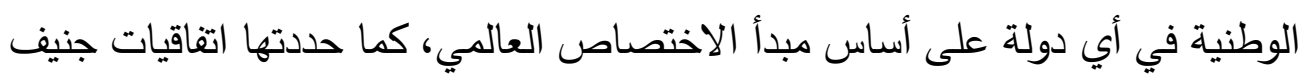

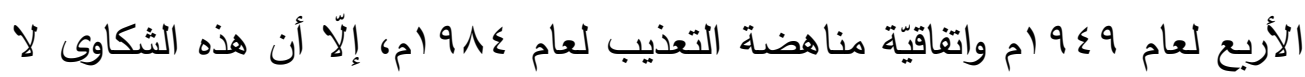

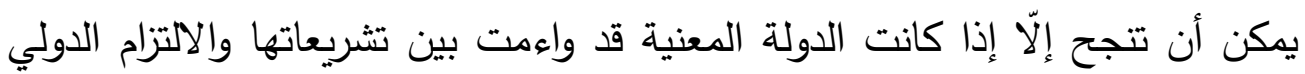

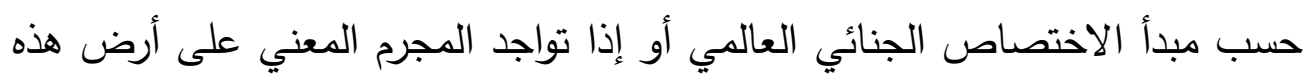

( (1 ) أ.الكردي، انتصار علي محمود،( (991 (م ).إشكالات إنشاء الدحكمة الجنائية الدولية (رسالة ماجستير)،

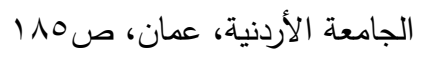


F. r. · مجلة روح القوانين - العدد الواحد والتسعون - إصدار يوليو

الدولة. فمن باب أولى يكون هذا الحق لضحايا الجريمة الدولية أمام الدحكة الجنائية الدولية الدائمة صاحبة الاختصاص العالمي فيحق لهم تقديم الثكوى أمامها.

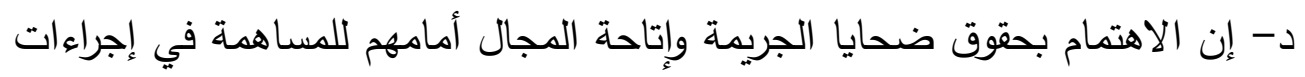

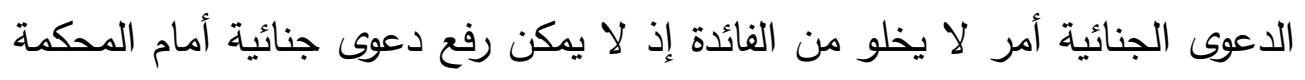

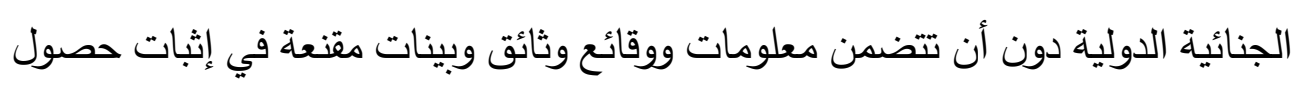

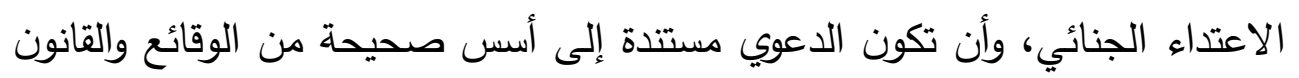

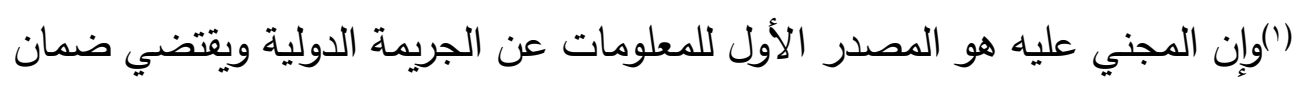

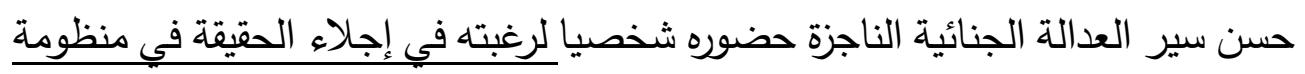

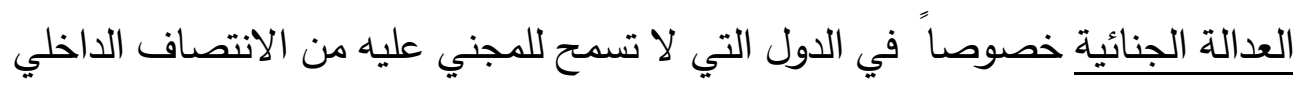

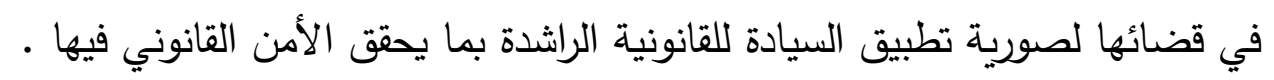

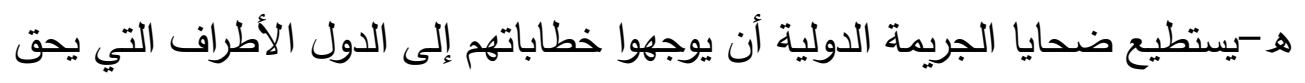

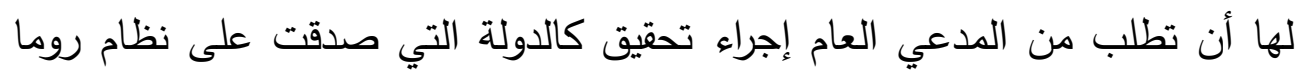

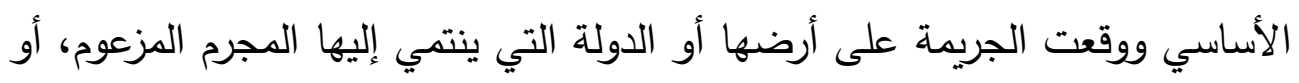

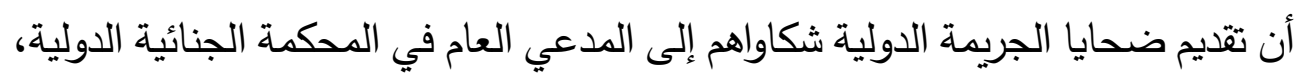

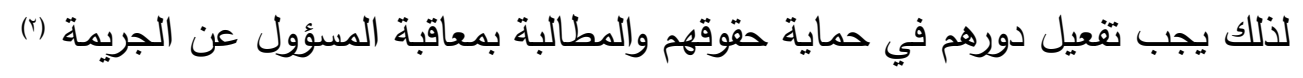

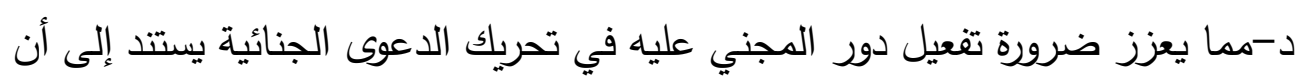
النظام الأساسي للمحكمة الجنائية الدولية لم يضع جزاء على على فلى عدم اتخاذ إجراءات

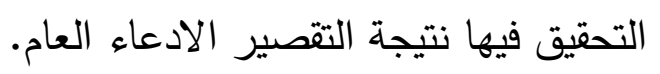

( (1). نجم، محمد صبحي (1991 م). الوجيز في قانون أصول المحاكمات الجزائية الأردني، دار الثقافة، عمان، طا، صY.r.

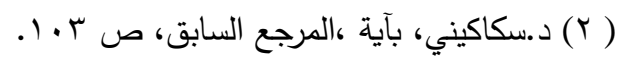
$(\varepsilon \cdots)$ 


\section{المبحث الرابع}

\section{حقوق المجني عليه الجريمة أثناء التحقيق الابتدائي}

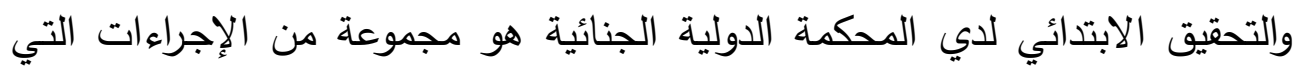

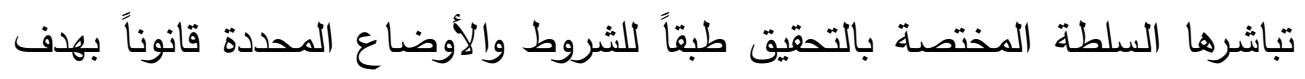

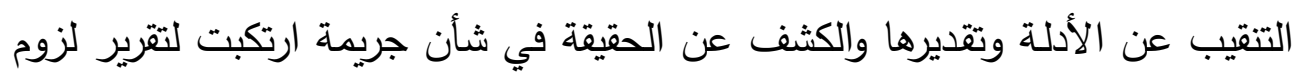

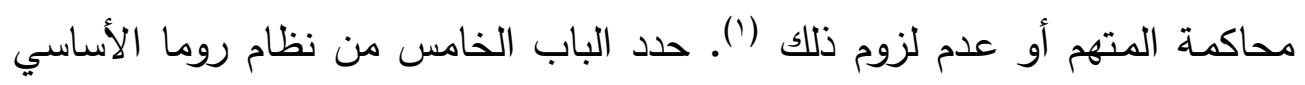
مجموعة من الإجراءات الشكلية للتحقيق الابتدائي ويترتب على مخالفة هذا لـاب الثكل

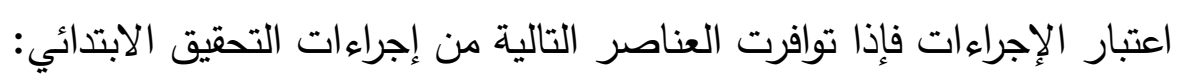

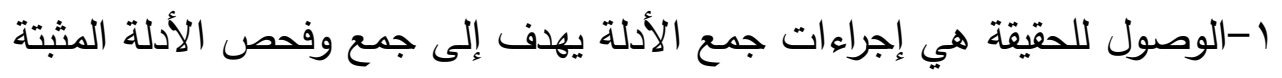

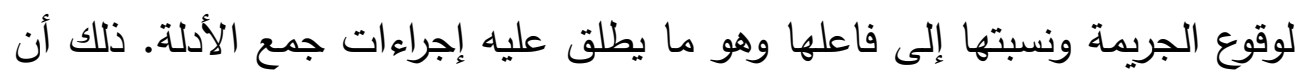

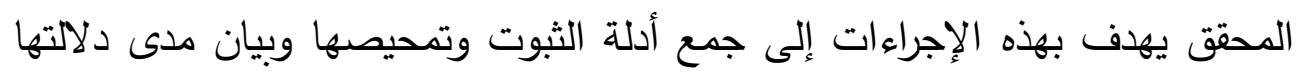
على وقوع الفعل من جانب المتهم. ب-الإجراءات الاحتياطية قبل المتهم هو اتخاذ الوسائل اللازمة قبل المتهم لمنعه من الته

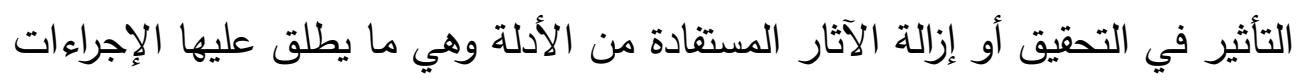
الاحتياطية قبل المتهم (") .

\section{المطلب الأول}

\section{حق الجني عليه في حياد سلطة التحقيق الدولية}

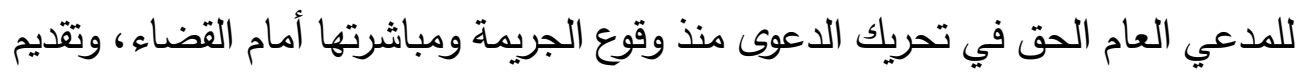
الطلبات وإثارة الدفوع بوصفه الجهة التي تحتكر وظيفة الادعاء أو الاتهام حتى اقتضاء

(1 ) د. جوخدار، حسن(^ . ㄷم). التحقيق الابتدائي في قانون أصول المحاكمات الجزائية، دار الثقافة للنشر

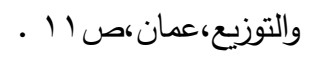

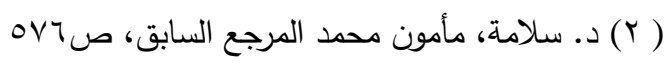




\section{مجلة روح القوانين - العدد الواحد والتسعون - إصدار يوليو · ·.}

حق العقاب، ويمده النظام الأساسي بمجموعة من السلطات والاختصاصات من أجل

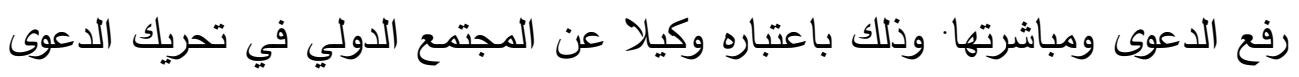

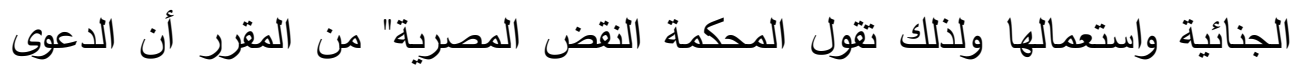

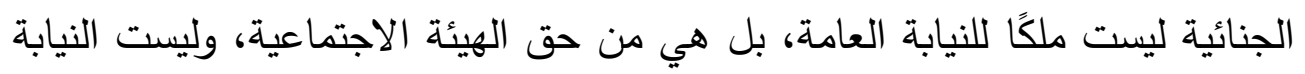

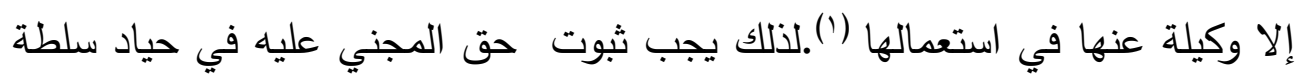
التحقيق والعلم بإجراءات التحقيق وحضورها. ولم يكتف النظام الأساسي للمحكمة الجنائية الدولية بإسناد وظيفة التعات الاتهام إلى المداعي

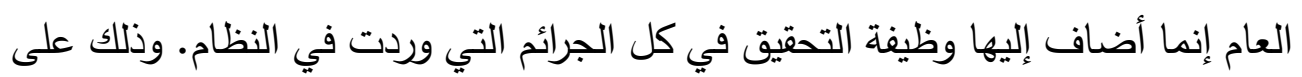

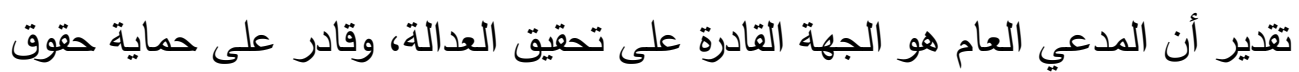
الأفراد؛ والأمر الذي يفضي إلى كفالة حق المجتمع الدولي في العقاب على نحو صحئ الحئ.

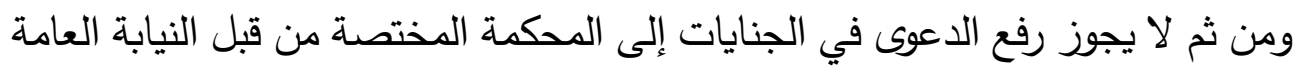

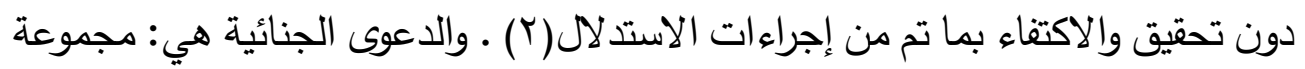

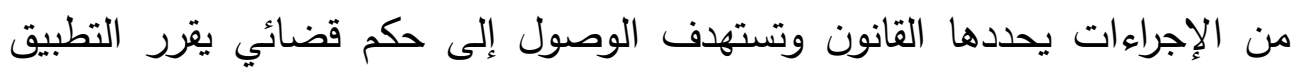

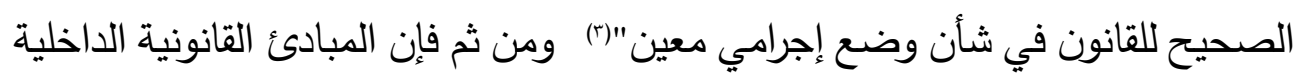
المستقرة في القانون الجنائي تقرر أن التحقيق في الجنايات وجوبي ومن ثم فالمين فالمدعي

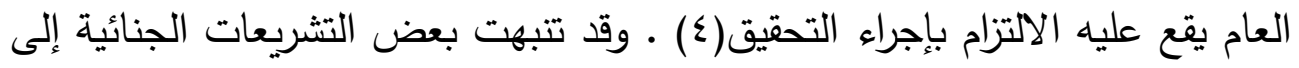

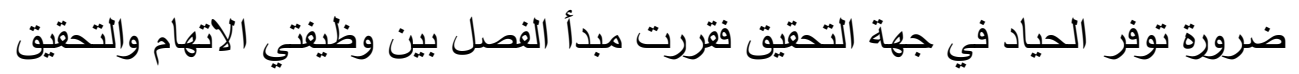

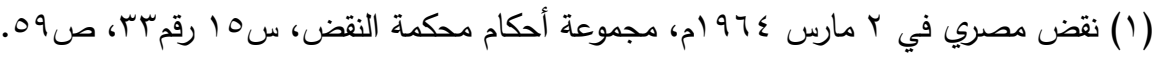

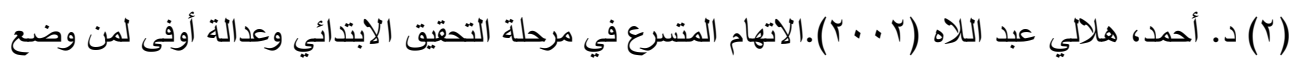

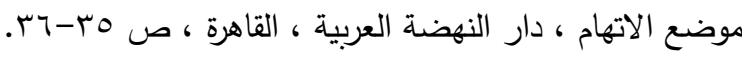

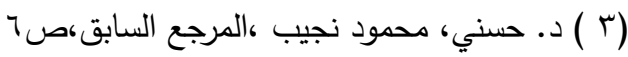
A.VITU: procedure pénale. Press Universités De France. Paris $190 \mathrm{~V}$ p 10.

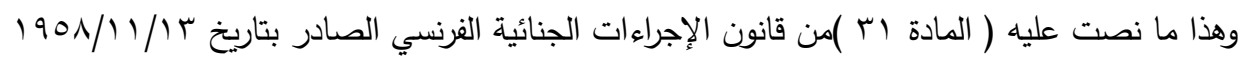

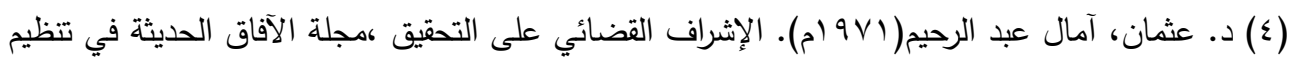

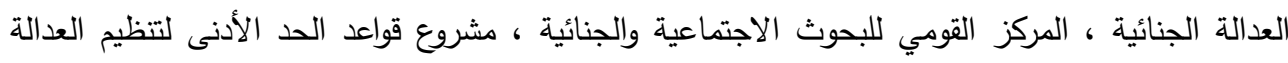

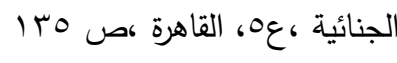


( (1).وقد تطرح التساؤلات: هل سلطة الاتهام تعد خصما في الدعوى الجنائية الدولية يؤثر على حياد المدعي العام؟ وهل المدعي العام ملزم بتحريك الدعوى الجنائية؟ وهذا نتناوله كما يأتي:

أولا: الهياد النراهة للمدعي العام: إن القضاء الحيادي النزيه هو الساحة الوحيدة المخولة حقا بالفصل في المنازعات بين المتقاضين أيا كان نوعها. وذلك أن هذا القضاء وحد هو القادر على تحقيق العدل الذي ينشده الجميع قضاة ومتقاضين فلاعدل ولاعدالة بغير حياد بل يصبح القضاء بغير حياد واحة للظلم والفساد والاستبداد، وخصوصا في الجرائم الدولية التي تتصارع فيها الأيدولوجيات والقوى الكبرى المهيمنة على إجراءات التحقيق حيث يمكن أن تعطل التحقيق (r). والمقصود بالحياد هو التجرد حيال النزاع المعروض من أية مصلحة ذاتية ومن شأن ذلك جعل المحقق مؤهل لإنجاز عمله بنزاهة (r). أو الحياد هو البحث عن الحقيقة مجردة بكل الوسائل الممكنة دون التأثر برأي لهائ مسبق. ومن ثم على المدعي العام ألا تكون له آراء مسبقة عن أية قضية ينظرها، وألا تكون له مصلحة في النتيجة التي ينتهي إليها نظر القضية ويجب ألا يسلك سبيلاً يرجّح مصلحة طرف على طرف أخر، كما في حالة الإحالة والارجاء الصادرة من مجلس الأمن. كما يجب أن تتاح للمدعي العام فرصة العمل بعيداً عن أي تأثير ، سواء كان مباشر أو غير مباشر ، وبعيداً عن وسائل الإغراء أو الضغط أو التهديد أياً كان مصدره (). ومن ثم لا يجوز للمدعي العام أو لنوابه أن يشتركوا في أية قضية يكون حيادهم

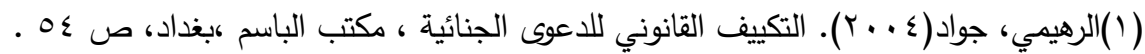

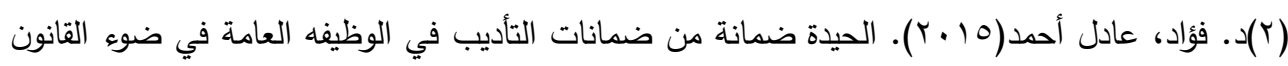

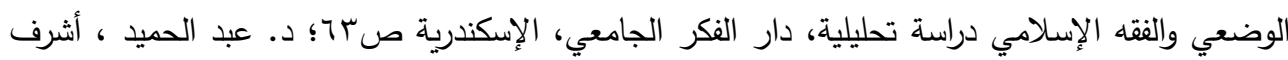

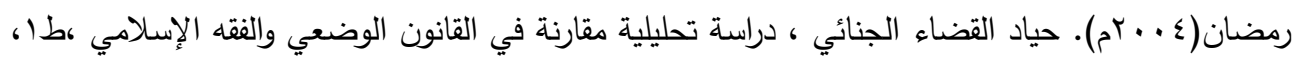

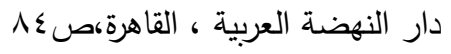

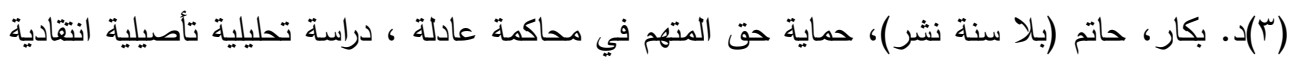

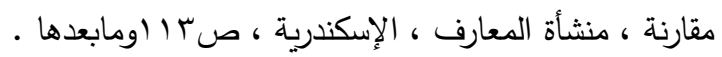

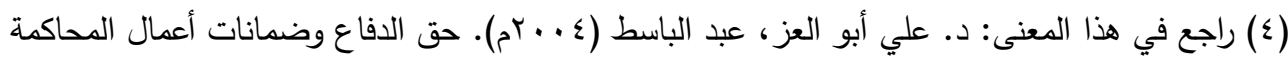

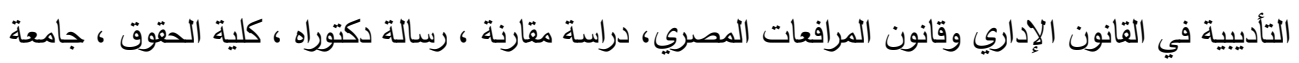




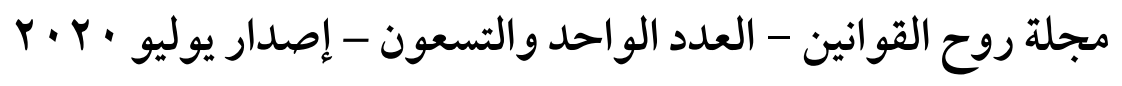

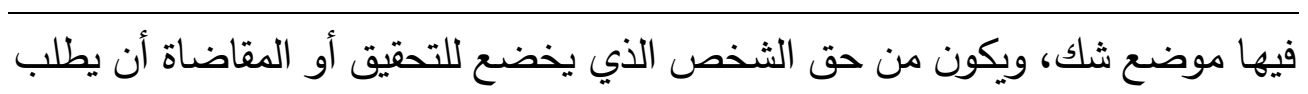

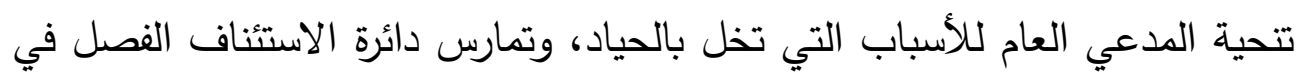

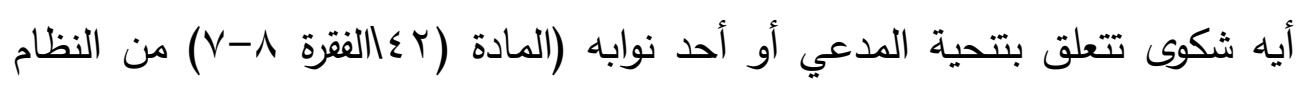

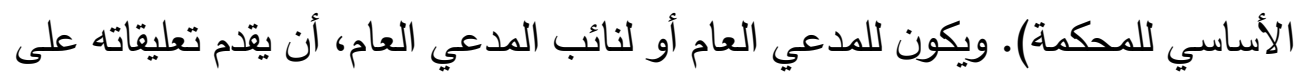

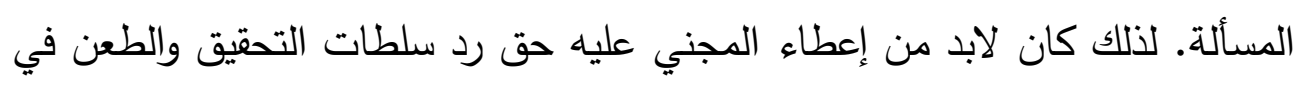

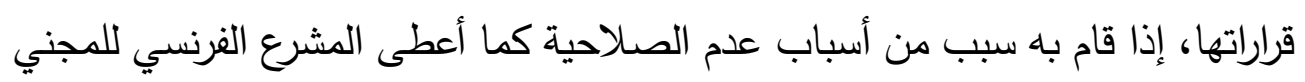

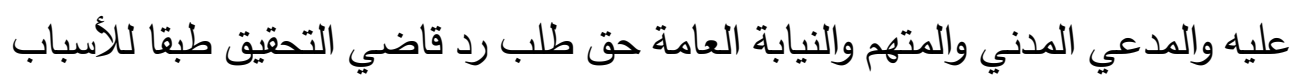
المحدة بالقانون () ثانيا: أهمية حياد المدعي العام وتأثيره على المركز القانوني للهجني عليهيه: وللمجني

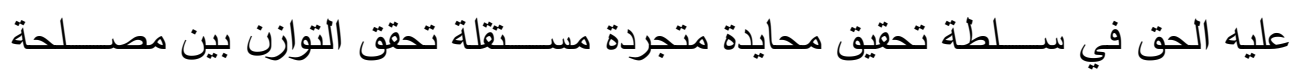

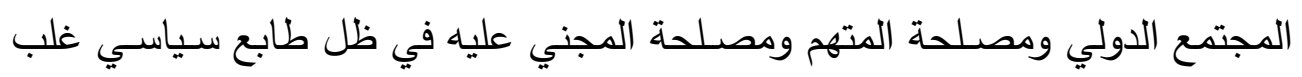

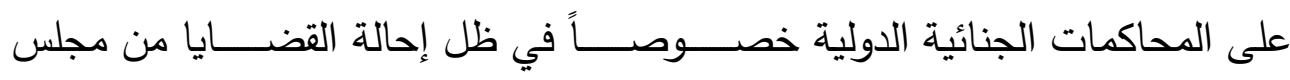

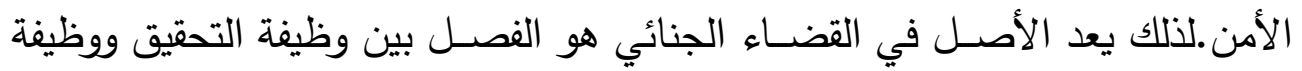

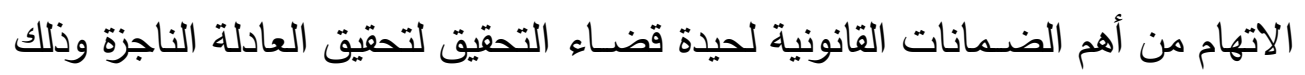

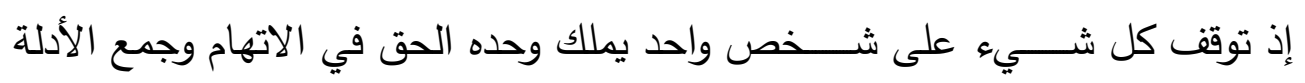

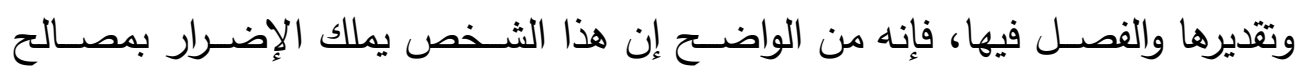

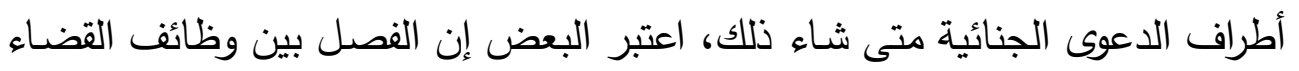

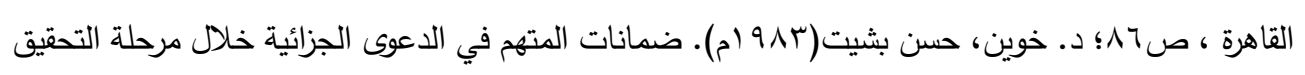

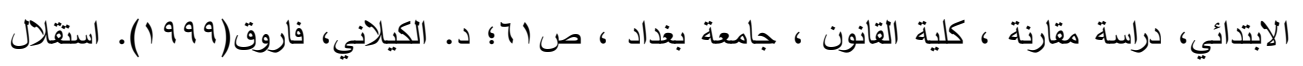

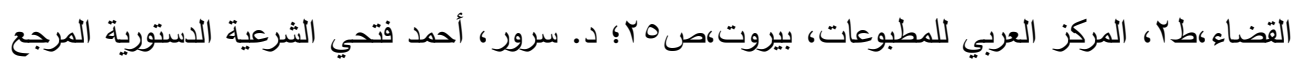

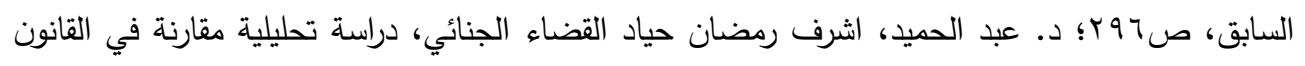

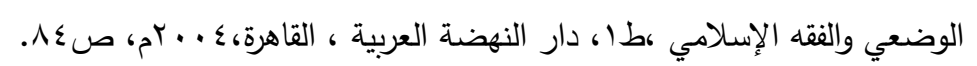

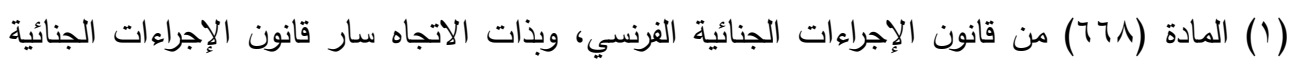

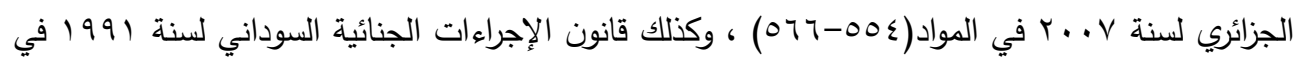

المادة (Ir). 
الجنائي، أشبه بالفصـل بين السـلطات التشـريعية والتنفيذية والقضـائية وتحقيق الرقابة المتبادلة الفعالة(') ـ إذ إن دور سـلطة الاتهام، هي تحريك الدعوى الجنائية، ثم تجميع الأدلة التي تســـاند الاتهام، وتدعيمها لدى القضــــاء، ويمثل الاتهام دور الادعاء في في في الدعوى الجنائي، ومن ثم فسـطة الاتهام تعد خصـما في الدعوى الجنائية فقد تقصـر، أو تقف موقفا في غير مصلحة الخصوم. أما التحقيق الابتدائي هو التتقيب عن جميع أدلة الدعوى التي تخدم الحقيقة سـواء في صـالح المتهم، أو في صـالح المجني عليه في حيدة تامة، وبغير رأي مســبق فيها (؟)ويقتضــي الحياد توفر رقابة على المدعي

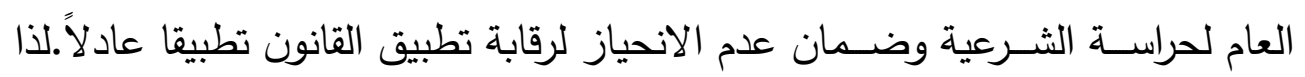
فإن الجمع بين ســـلطتي الاتهام والتحقيق في يد المدعي العام يهدد الحق والحريـة

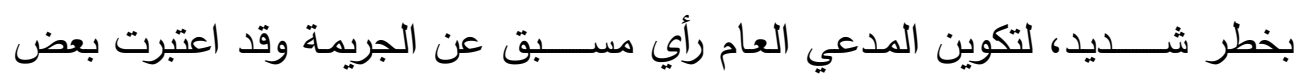
التشريعات، أن ذلك يعد سببا من أسباب عدم الصلاحية خصوصاً في حالات الإحالة من مجلس الأمن مما يجعل عمله عرضة للأهواء السياسية (r). وتحرص القوانين في كل دول العالم على أن يتوافر في أجهزة العدالة، أكبر قدر من

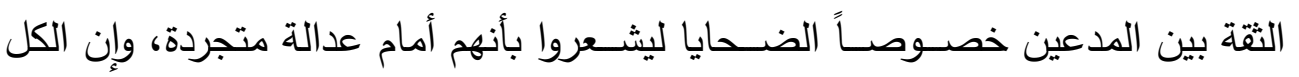
سـواسية أمام القضـاء العادل، وعدم الميل إلى أي منهم على حسـاب الآخر ، ومتجردا من كل اعتبار شخصس. ومعلوم أن الجهات التي تتولى التحقيق هي من البشر وهي

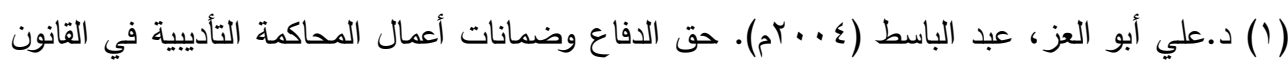

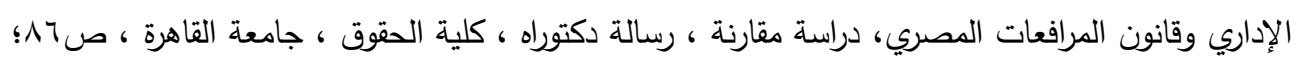

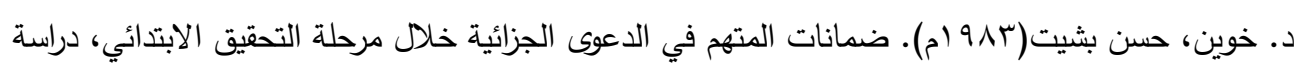

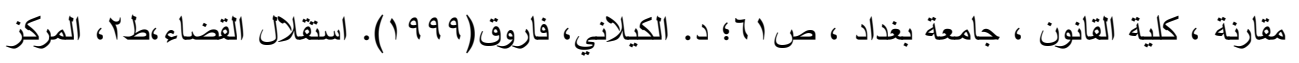

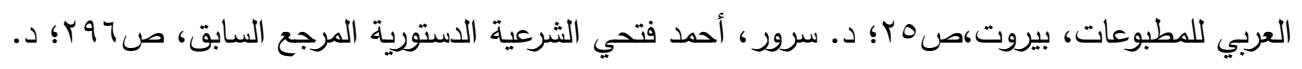

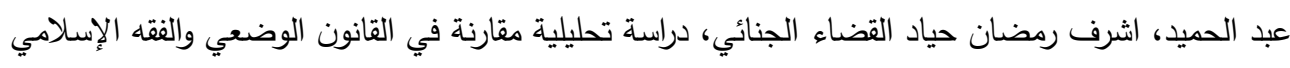

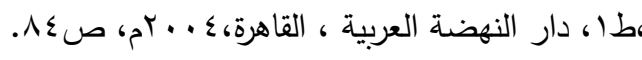

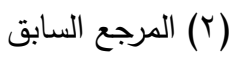

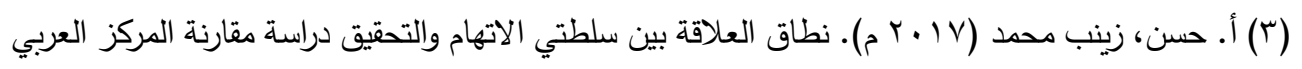

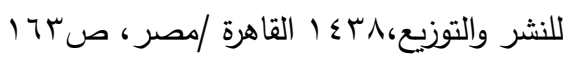
$\{.0)$ 
F. r. · مجلة روح القوانين - العدد الواحد والتسعون - إصدار يوليو

غير معصـــومـة من الخطأ، ومن الخير للعدالة أن يفتح باب الطعن في إجراءات

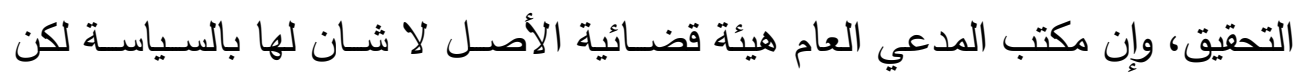

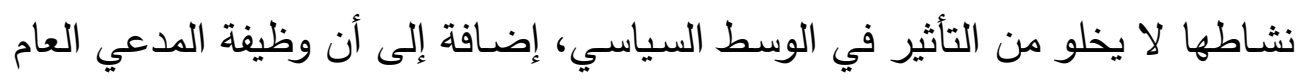

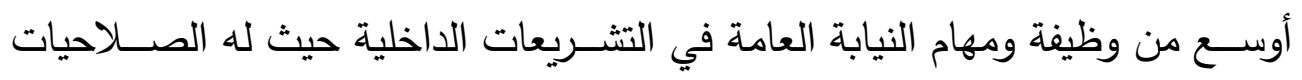

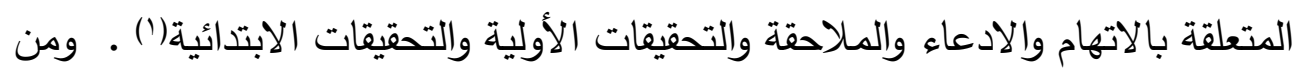

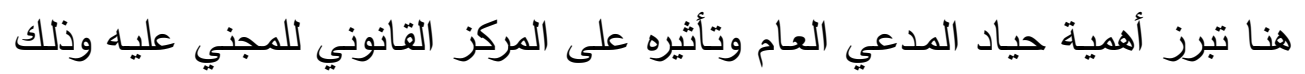
كما يأتي: ا-إن الرقابة على ســلطة التحقيق يحمل جهات التحقيق على مضــــاعفة الجهد في

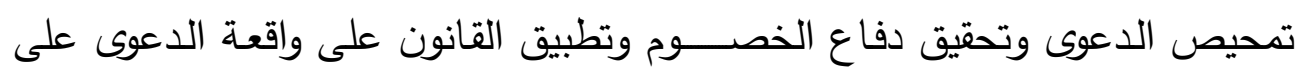
وجها الصحيح. ب- إن الطعن ينقل الـدعوى من جهـة تحقيق دنيـا إلى جهـة تحقيق عليـا، فيهبط

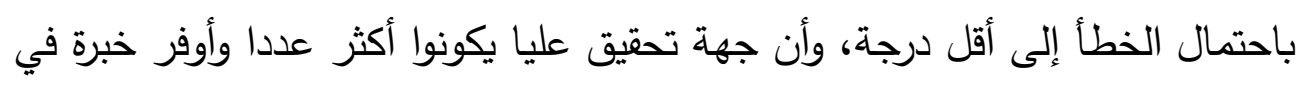
استجلاء ما يشوب القضية من غموض. r-درء شبهة تأثر المحقق بصالحه الثخصي أو بصلة خاصة، أو برأي سبق أن أبداه في الدعوى، صيانة لمكانة القضاء، وعلو كلمته في أعين الناس (r).

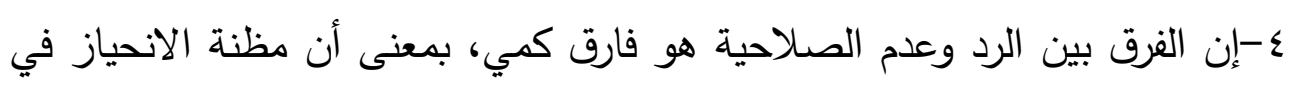

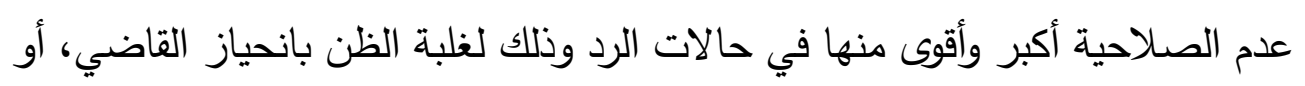

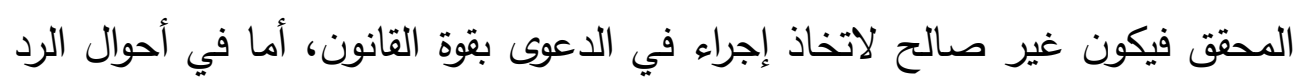

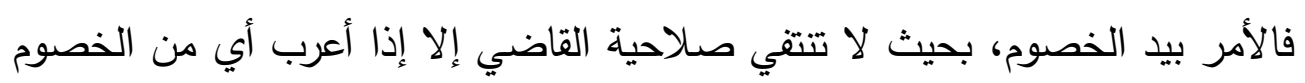

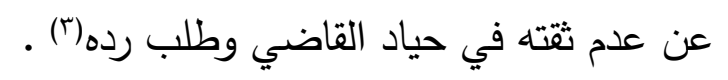

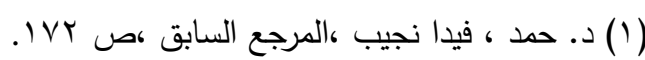

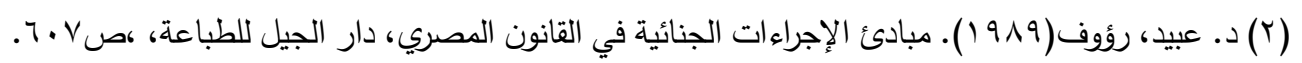

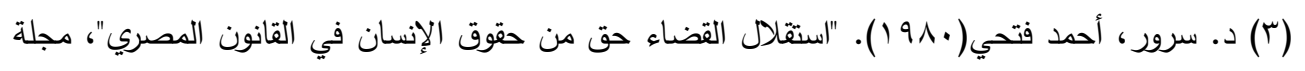

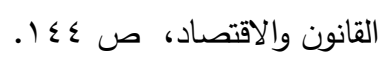




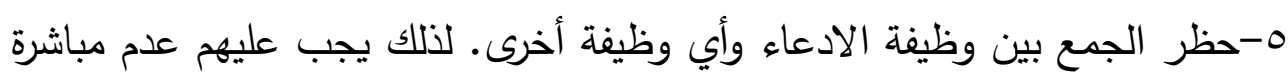

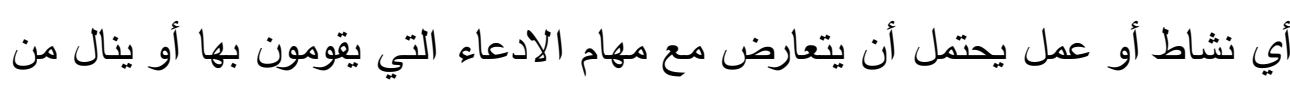

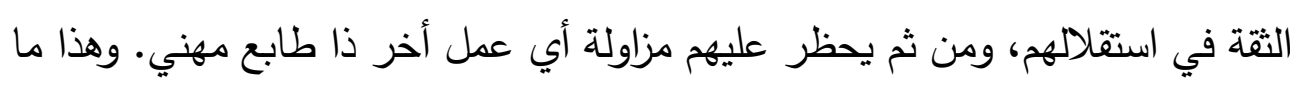

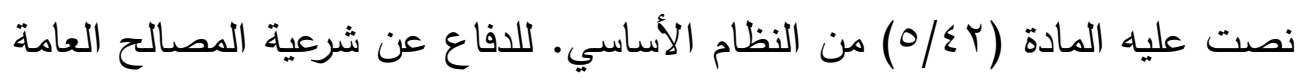

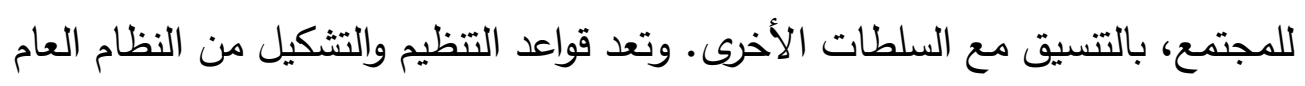
(1). وذلك بغرض صحة الإجراءات وسريان أثارها فقد استوجب القانون شروطاً تتعلق

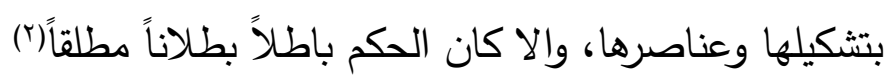

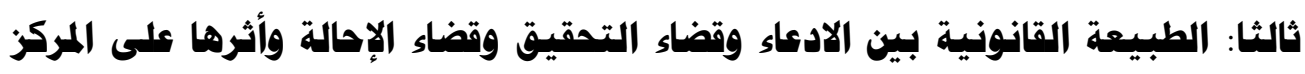

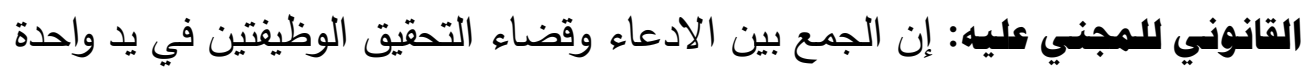

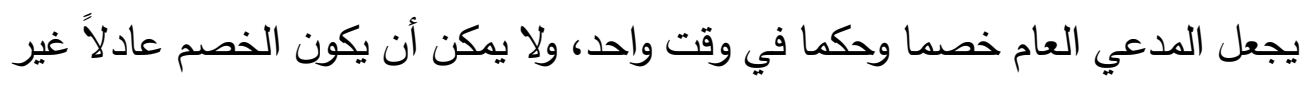

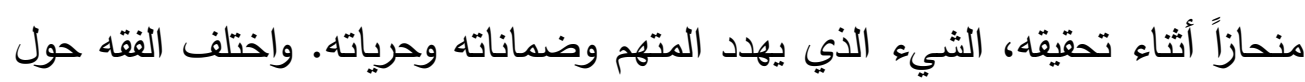
الطبيعة القانونية بين الادعاء وقضاء التحقيق وقضاء الإحالة لدى للدئه للهام

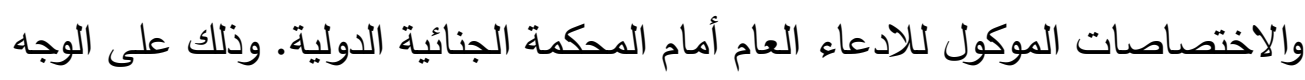
الآتي:

الرأي الأول: ذهب إلى ضرورة الجمع بين الادعاء وقضاء التحقيق وقضاء الإحالة

لاي سلطة واحدة لتبسيط الإجراءات الجنائية:

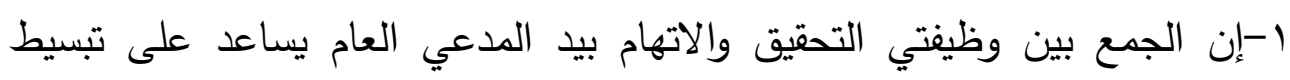

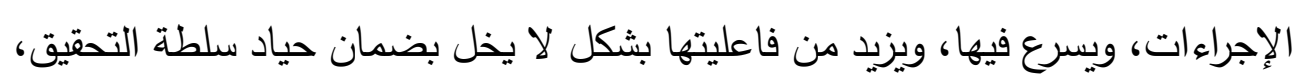

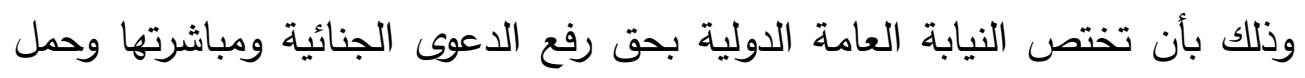

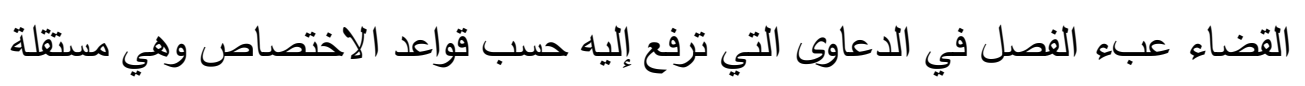
عن القضاء وهي تتصرف باسم المجتمع. لذلك لا يوجد ما يدعو إلى الخوف من إساءة ليه

(1) د. الغريب، محمد عيد (.... (†).النظام العام الإجرائي ومدى الحماية التي يكفلها القانون الجنائي، دار

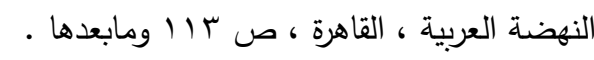

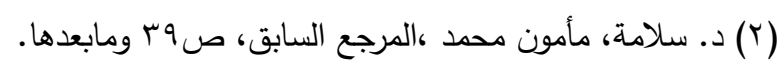
$(\varepsilon \cdot v)$ 
F. r. · مجلة روح القوانين - العدد الواحد والتسعون - إصدار يوليو

استعمال هذه السلطة وعندما تستعجل في إجراءات التحقيق تحت رقابة القضاء الحارس الطياء

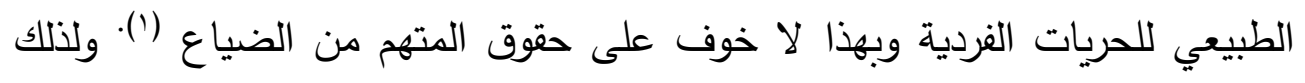

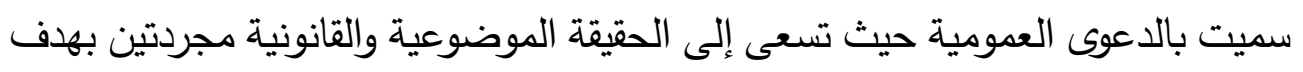

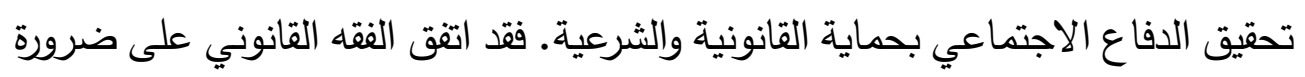

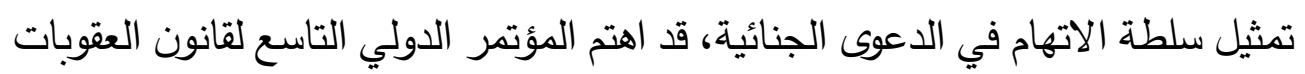

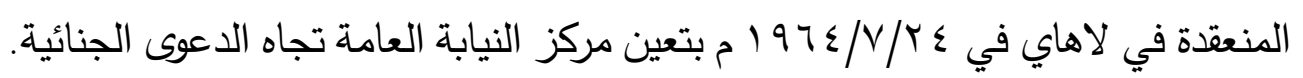

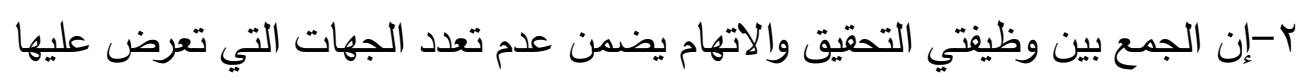
أدلة التحقيق، وذلك لأن وجود التعدد في الجهات قد يؤدي إلى تشتيت الأدلة واختلافها،

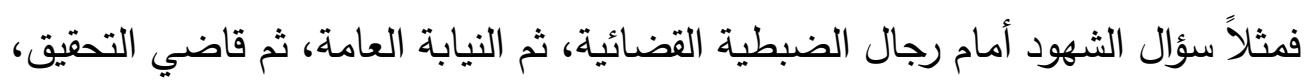

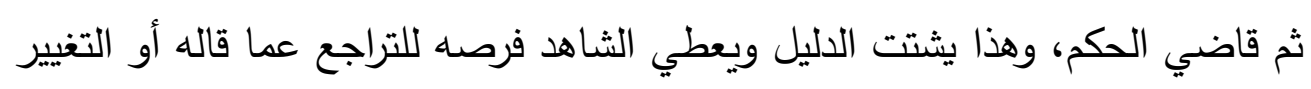
فيه أو نسيان ما حدث عند الواقعة.

وذهب الرأي الثاني إلى أنه يجب التفرقة بين الادعاء وقضاء التحقيق وقضاء الإحالة

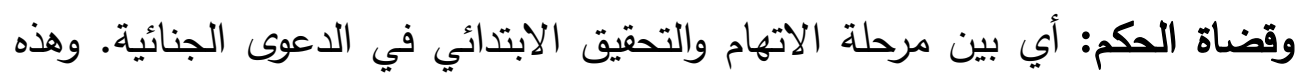

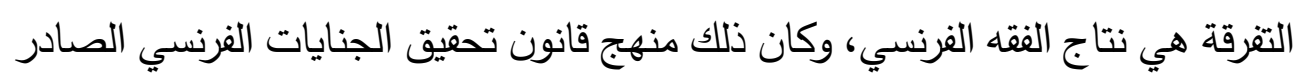

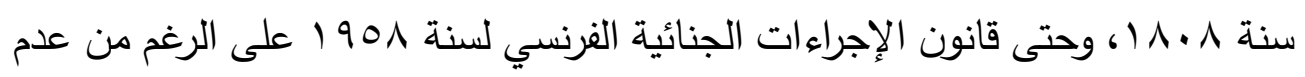
وجود نصوص صريحة بذلك(ب) ـ ويستند لما يأتي:

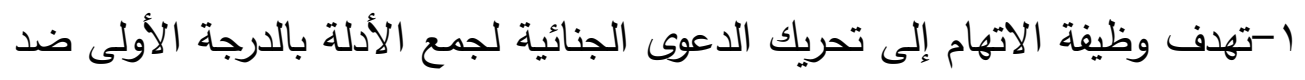

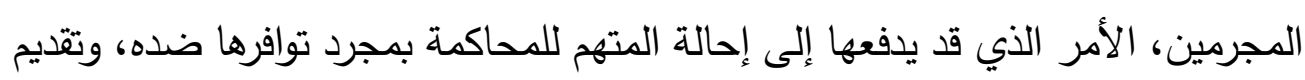

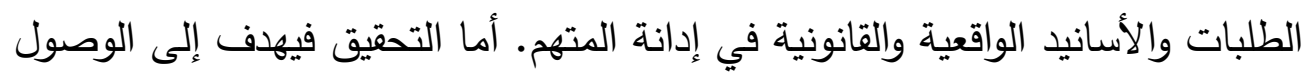

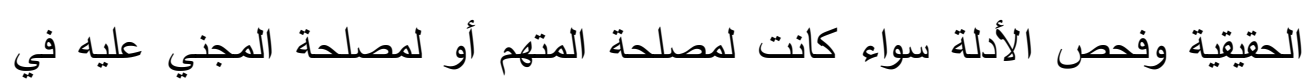

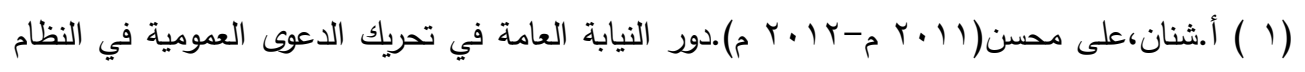

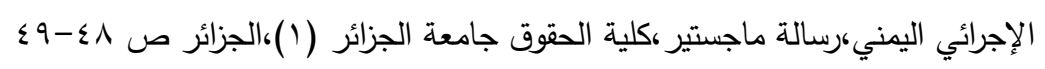

Esper (B.) : La Separationdes Fonctions des Justice repressiv Travaux et recherches de L' universite de Paris ( $Y$ ) P.U.F I १YY .P. 9 . $(\varepsilon \cdot \Lambda)$ 
القصاص العادل وتعويضه عن الأضرار أو لمصلحة الجماعة في تحقيق الاستقرار للتلك فهو عمل يتطلب ثقافة خاصة ومعرفة واسعة بالقوانين والعلوم الاجتماعية والنفسية

ץ-التخصص في ممارسة العمل الإجرائي: يقوم التخصص على توزيع العمل وإيجاد

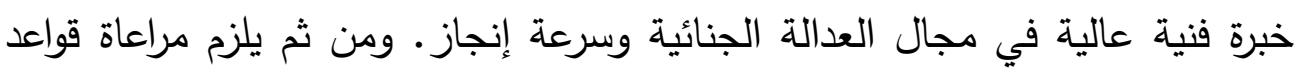

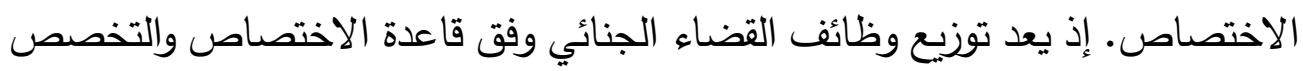

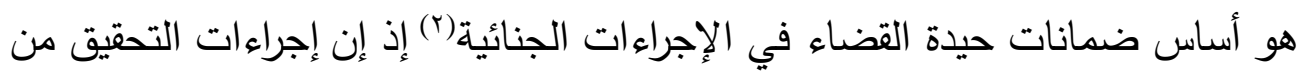

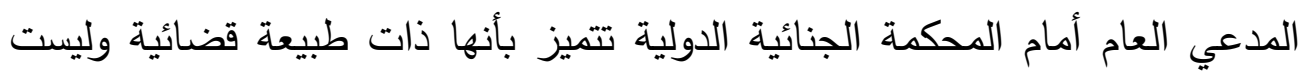

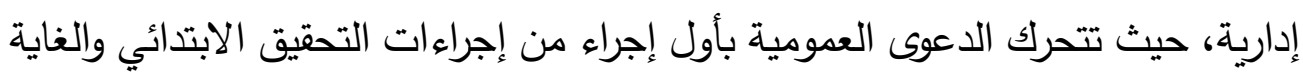
منه تفيد في كثف الحقيقة سواء بالإيجاب أم بالسلب وتمحيص أدلة الجريمة وأدلة

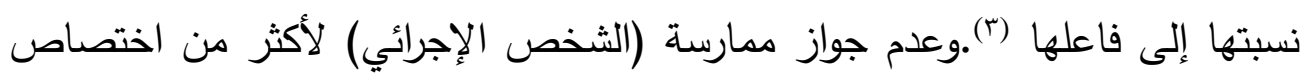

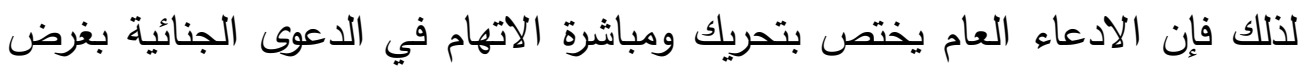

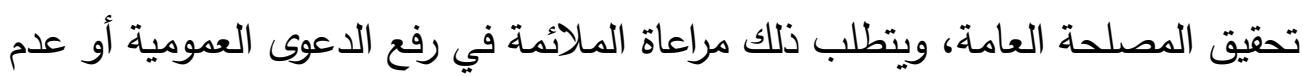
رفعها وذلك ضمان للحماية الفعالة للمني عليه من الجريمة، وحسن إدارة نظام العدالة

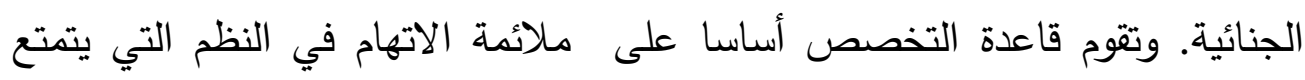

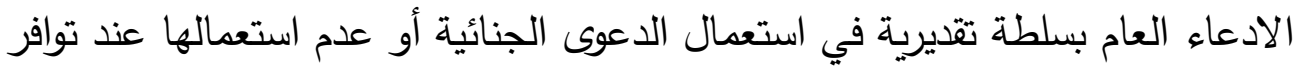

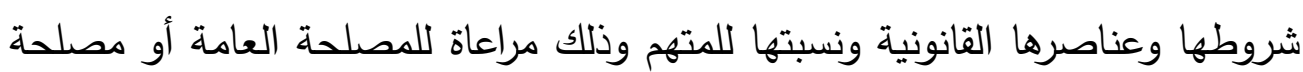

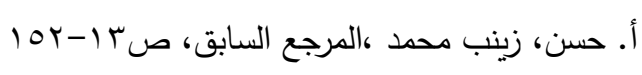

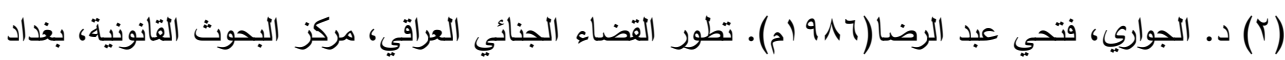

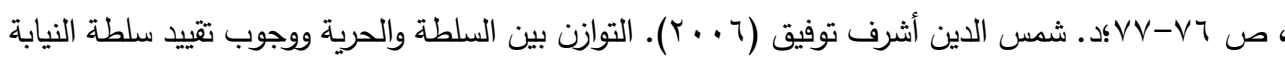

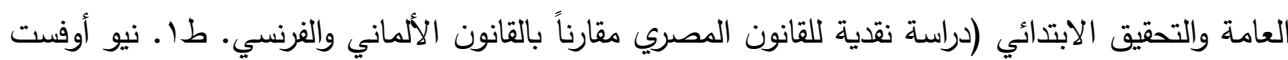

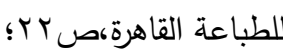

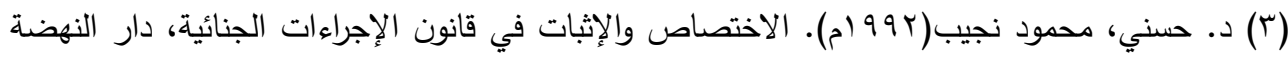

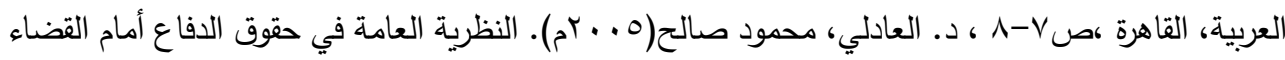

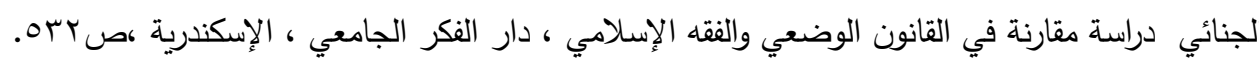


r.r. · مجلة روح القوانين - العدد الواحد والتسعون - إصدار يوليو

المتهم أو المجني عليه في الجريمة(') و تختص سلطة التحقيق بالمسائل التحقيقية

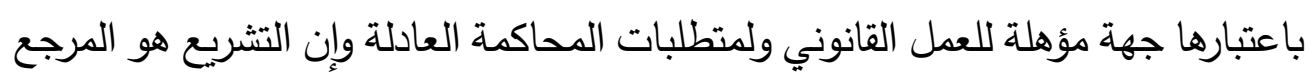

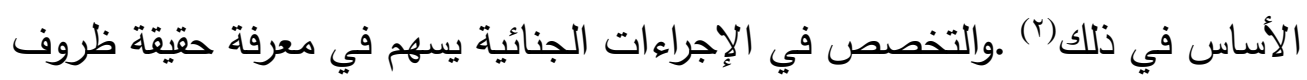

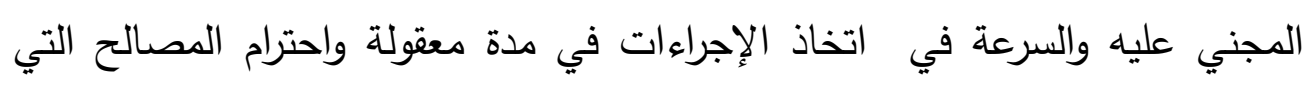

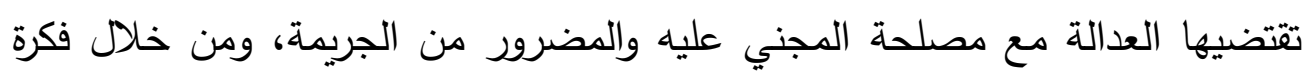

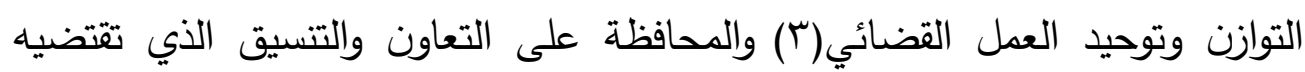

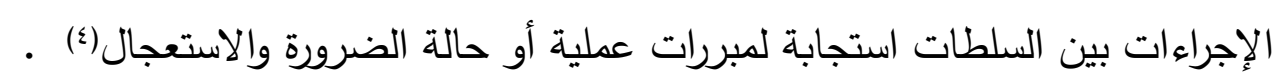
r-عدم الجمع بين سلطة الخصم والحكم: إن المدعى العام يحل محل النيابة العامة

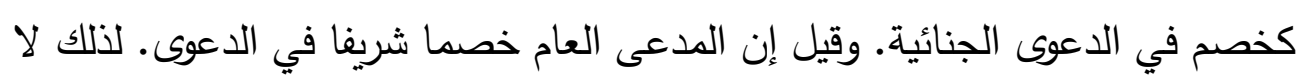

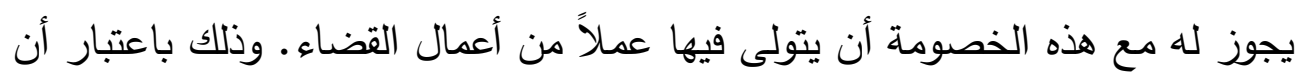

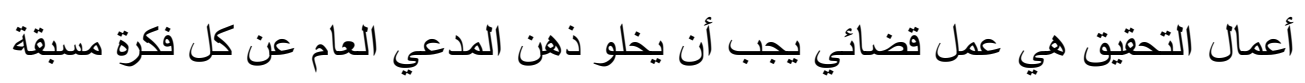

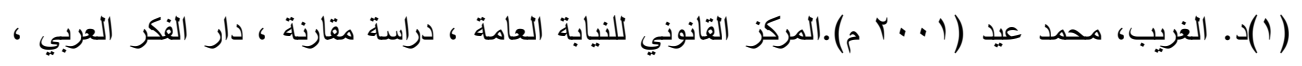

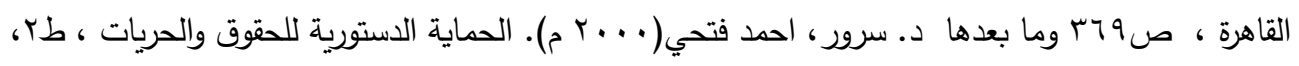

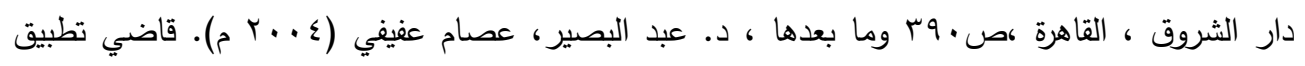

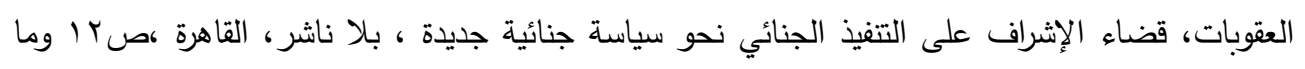

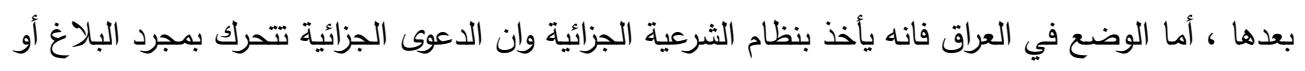

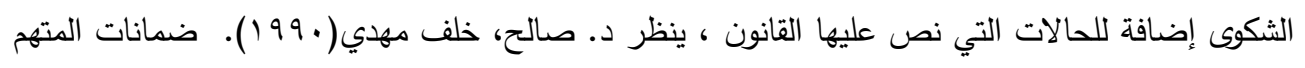

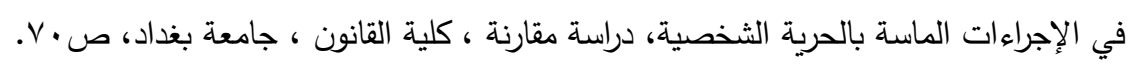

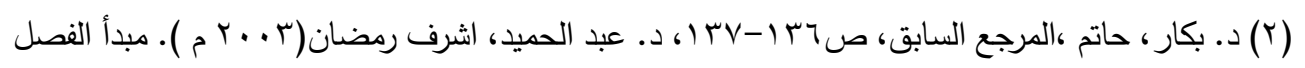

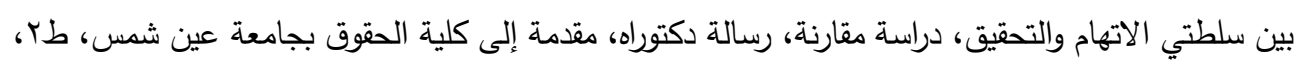

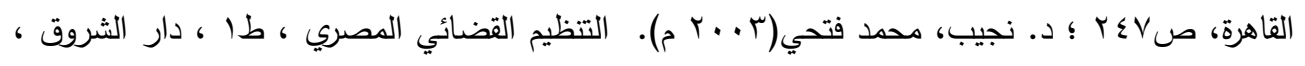

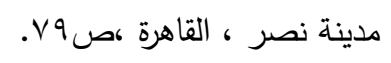

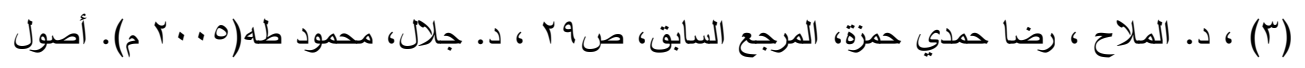

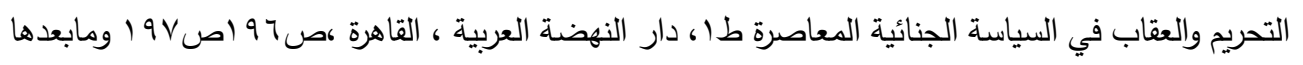

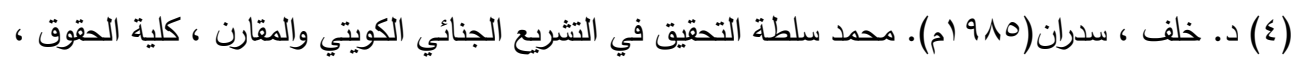
جامعة القاهرة ،صVVIا. 


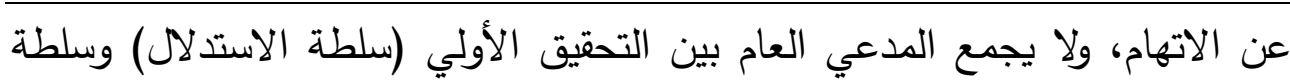

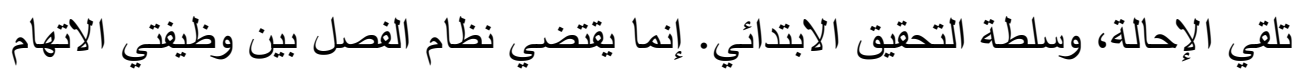

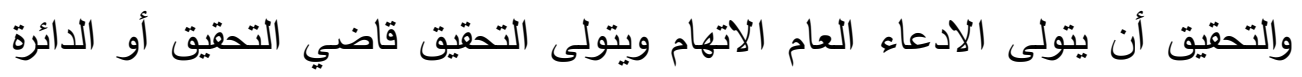

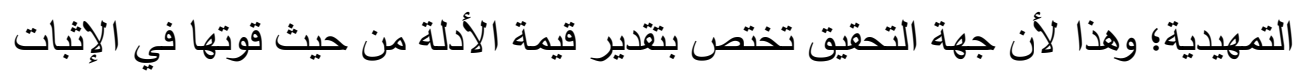
(') كما أن سلطة التحقيق تملك حفظ التحقيق لعدم وجود أساس قانوني أو واقعي لإقامة الإنة

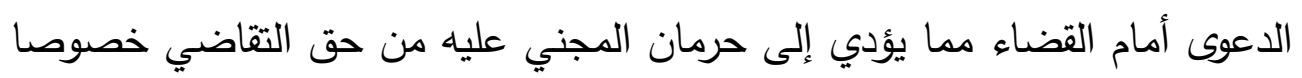

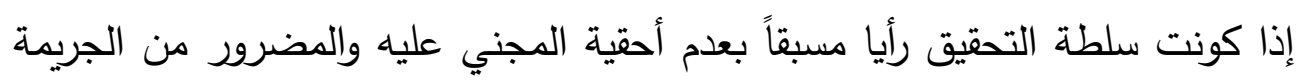

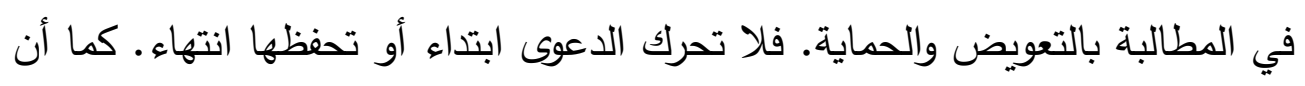

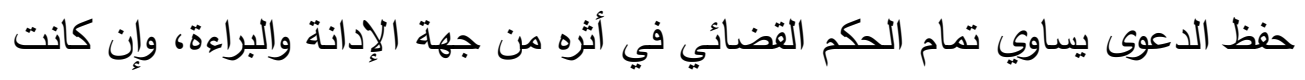

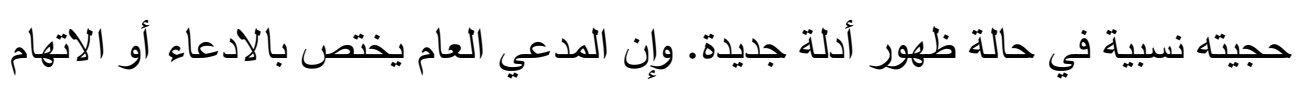

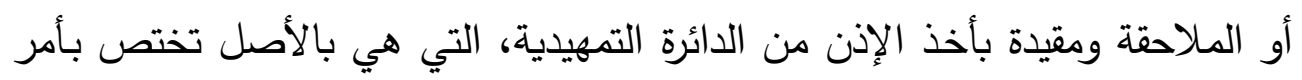
الحضور أو القبض أو الحبس الاحتياطي (المواد ب إلى إلى 10 من النظام الأساسي).

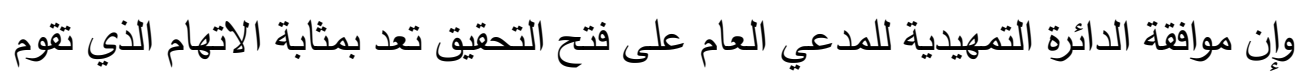

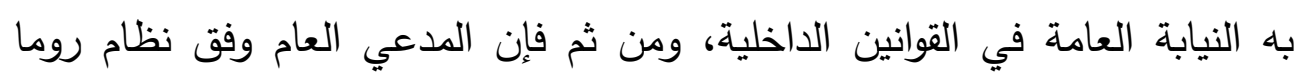

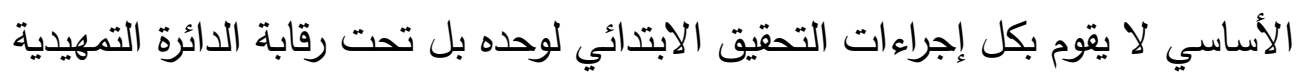

ـ-إن الجهة التي مارست وظيفة من وظائف القضاء الجنائي، لا يجوز لها ممارسة

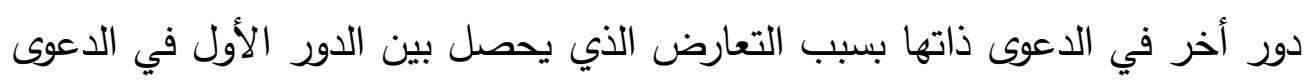

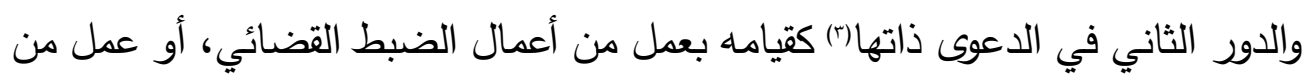

( ()الأستاذ العكيلي، عبد الأمير (9V0 (م).أصول الإجراءات الجنائية في قانون أصول المحاكمات الجزائية

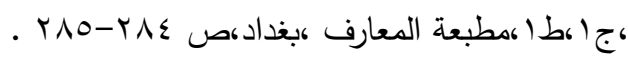
(ץ) د. الحديثي، عمر فخري عبد الرزاق(· ( • (r). حق المتهم في محاكمة عادلة ،دراسة مقارنة، دار الثقافة

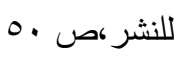

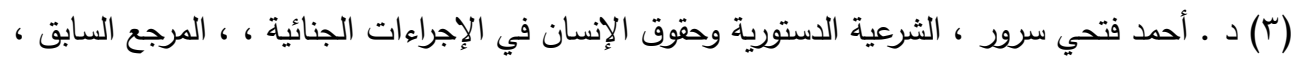

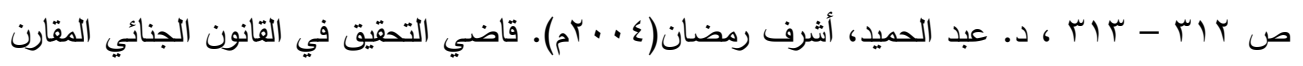


r.r. · مجلة روح القوانين - العدد الواحد والتسعون - إصدار يوليو

أعمال التحقيق أو الإحالة مما يجعل له راياً مسبقاً في الدعوى وذلك ينطوي على إخلالا

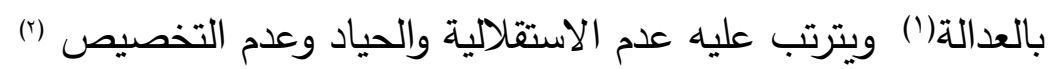
ه-إن كان الرأي الغالب أن يطلق على المدعي العام الخصم الثريف أو الخصم الثكلي

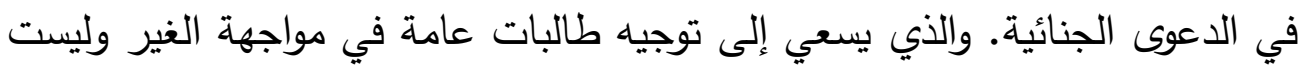

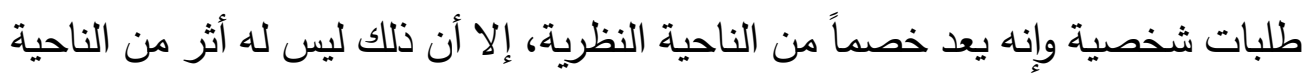
العملية، فهو خصم عادل وشريف يحرص على براءة البريء وإدانة المجرم، ويقوم

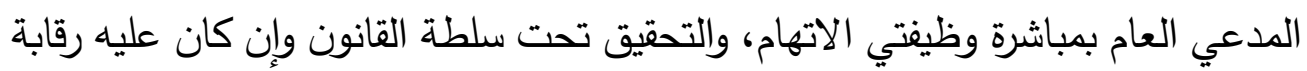

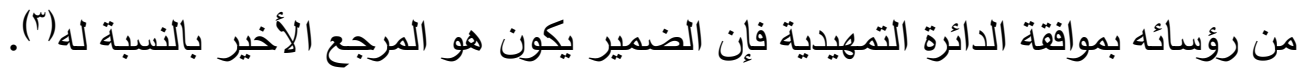
رابعا: حق المني عليه في استقلال المدعي العام عن القضساء: يعد مكتب المدعي العام

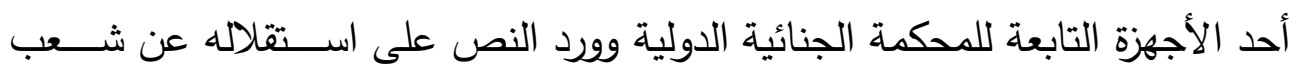

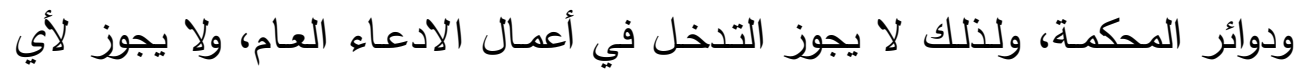

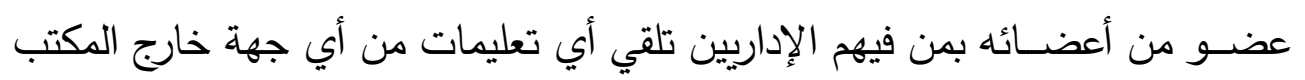

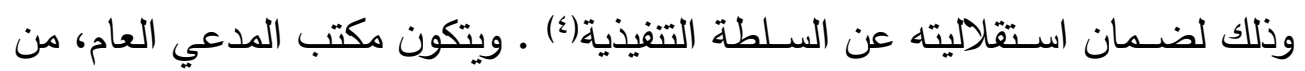

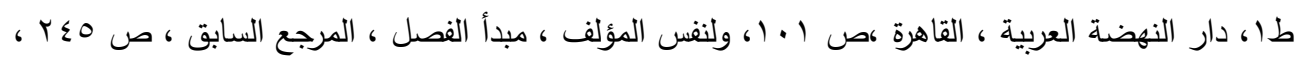

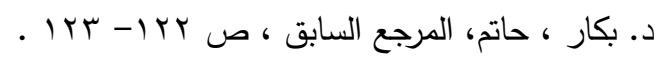

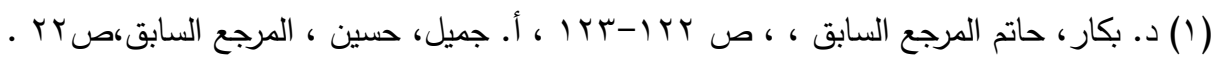

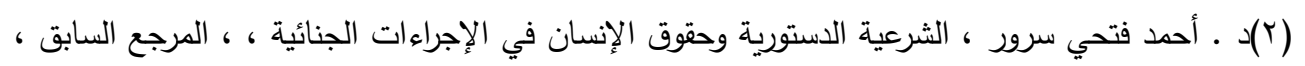

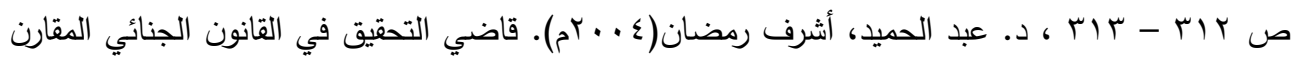

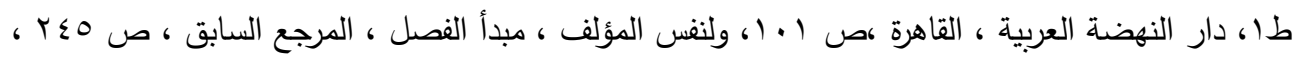

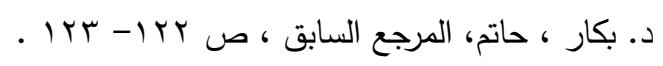

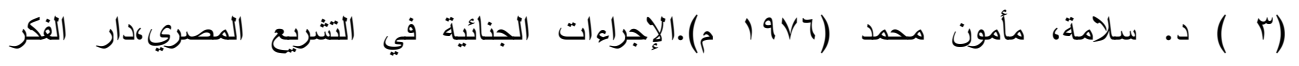

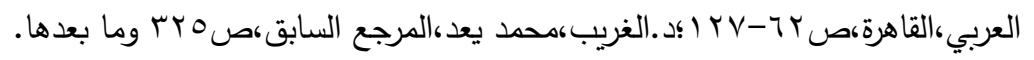

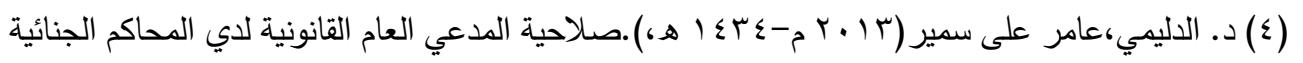

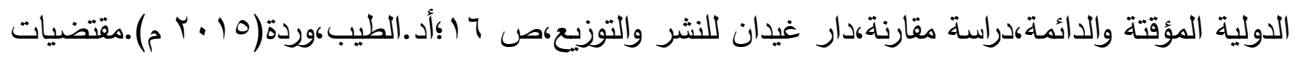


المدعي العام ونائب أو أكثر وعدد من المســتشــارين ومن ذوي الخبرة، ومن موظفي المكتب. ويمكن يناط بهم الاضطلاع بأية أعمال يكون مطلوباً من المدعي العام القيام بها، بالإضـافة إلى المسـتشـارين من ذوي الخبرة القانونية والمحققين. ويتولى المدعي رئاســــة المكتب، وأنـا يتمتع بكامل الصـــلاحيات والســلطـة الكاملة في تتظيم وإدارة المكتب، وبما في ذلك موظفو المكتب والمرافق والموارد الأخرى. ويشترط في المدعي العام ونوابه أن يكونوا من جنسيات مختلفة حسب المادة (Y ع/ء)

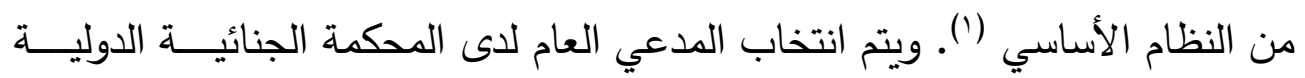
بطريقــة الاقتــراع الــسري وبالأغلبية المطلقة لأعضاء جمعية الدول الأطراف، ويتم انتخاب نوابه بنفس الطريقة من ضـــمن قائمة المرشــين التي يقوم بتقديمها المدعي العام بنفسه لجمعية الدول الأطراف، وتكون مدة تـولي مهامهم لمدة تسع سنوات ما لم تتقرر مدة أقصـر وفقا للمادة (Y/Y/Y) من النظام الأسـاسـي. حيث يقوم بتسـية ثلاثثة مرشحين لكل منصب مقرر شغله من مناصب نواب المدعى العام ويتولى النائب العام ونوابه مهامهم لمدة تسـع ســوات ما لم تقرر لهم مدة أقصـر وقت انتخابهح ولا يجوز إعادة انتخابهم (r). ويجب توافر عدة شــروط فيمن يجري اختياره مدعيا عاما أو نائبا

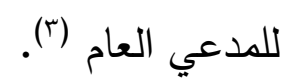

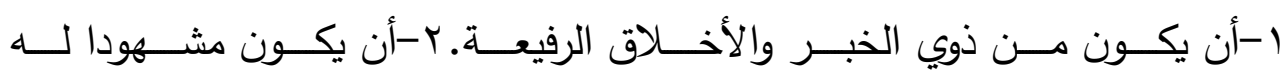

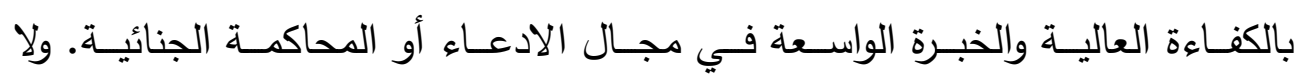

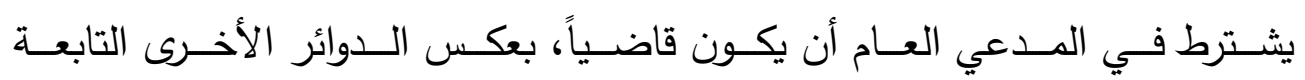
للمحكمة فيشترط أن يكون جميعهم قضاة.

العدالة أمام المحكمة الجنائية الدولية الدائمة،المركز القومي للأصدارات القانونية ،القاهرة ص ابr المادة

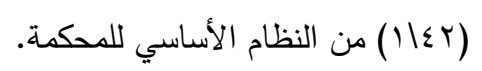

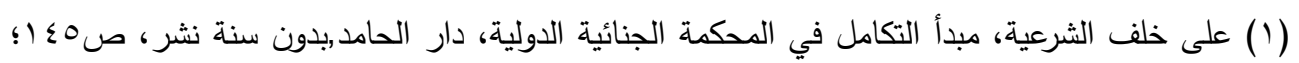

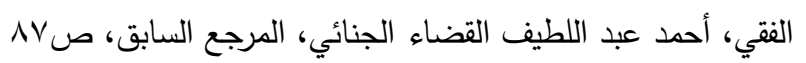

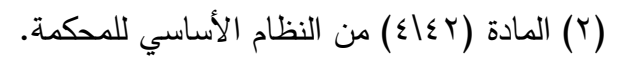

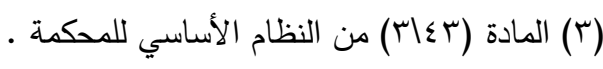


r. r. • مجلة روح القوانين - العدد الواحد والتسعون - إصدار يوليو

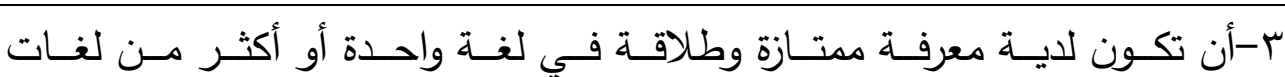
المحكمة على الأقل. - ان.

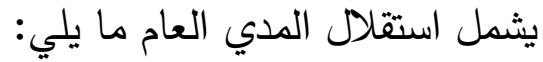

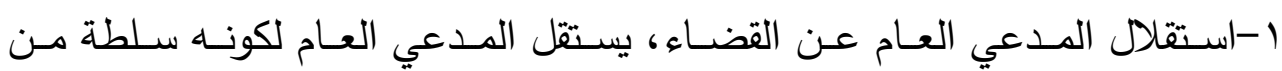

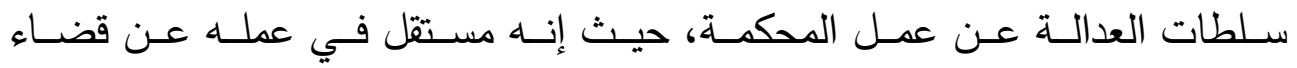

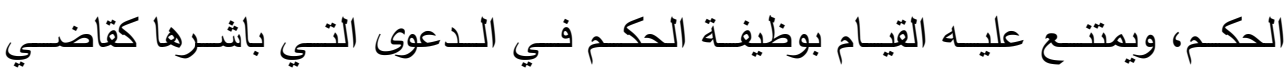

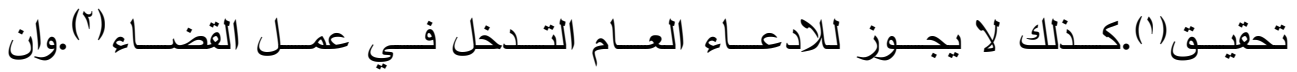

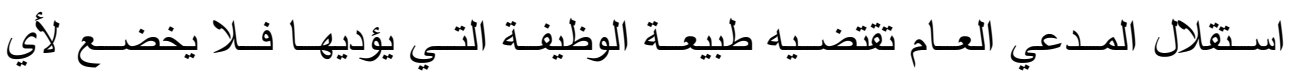

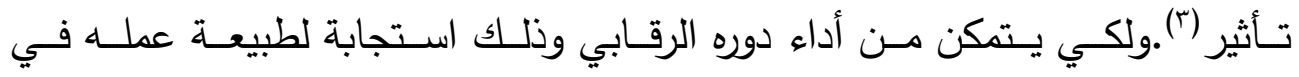

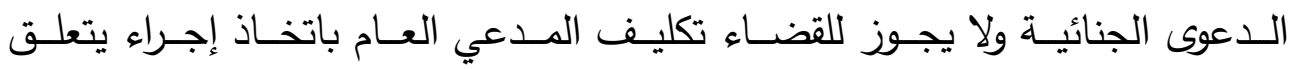

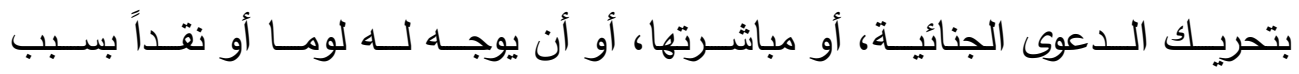

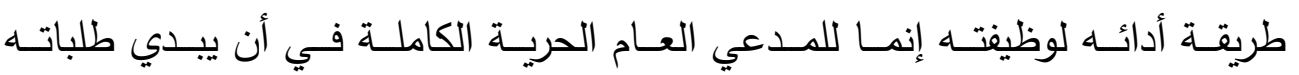

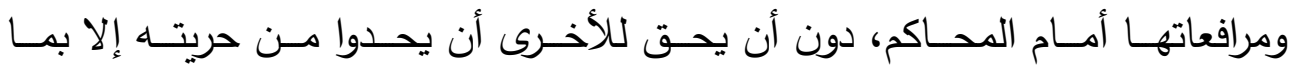

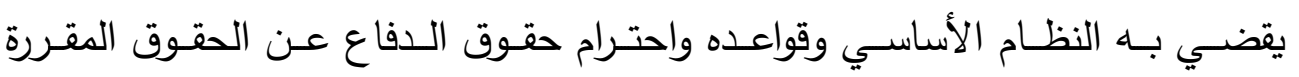

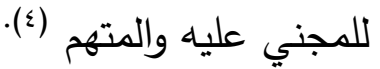

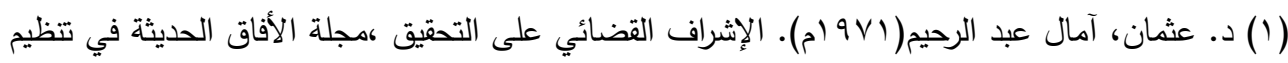
العدالة الجنائية ، المركز القومي للبحوث الاجتماعية والجنائية ، مشروع قواعد الحد الأدنى لتتظيم العدالة التئي

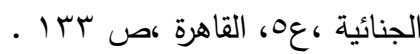

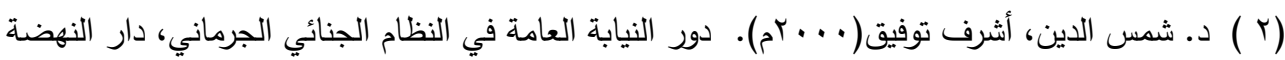

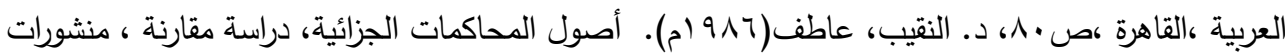
عويدان ، بيروت ،ص101-. ד؛ الوسواسي، غسان جميل(911 (). الادعاء العام، مركز البحوث القانونية ،

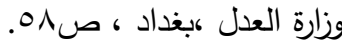
الأستاذ العكيلي، عبد الأمير \& د. سليم ابراهيم حربة(911 (1) أصول المحاكمات الجزائية، ج)، مديرية

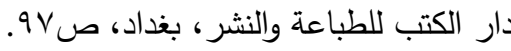

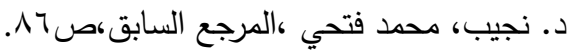


r-يتمتع مكتب المدعي العام بالسـلطة التقديرية في اسـتخدام وسـائل التحقيق وكل ما يؤدي إلى كثـف الحقيقة وذلك وفق للضــوابط القانونية في النظام الأسـاسـي ويمتلك

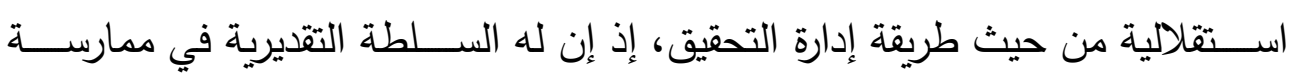

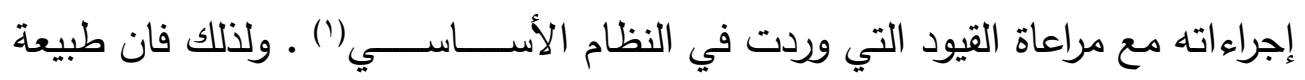
التحقيق وإجراءاته والقرارات الصـادرة بشـأنه تسـتـعي اسـتقلاليته وتجعله مبرراً للحفاظ على الحياد وضـمان حقوق أشـخاص الدعوى، وحماية حق التقاضـي وتأكيداً لضـرورة الفصل بين الاتهام والتحقيق كالاستجواب(؟) . ب-يتـولى المـدعي رئاســة مكتـب الادعـاء العـام، ويتمتـع بكامـل الصــلاحيات

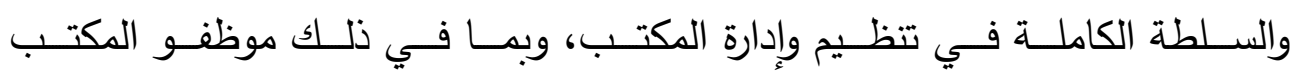

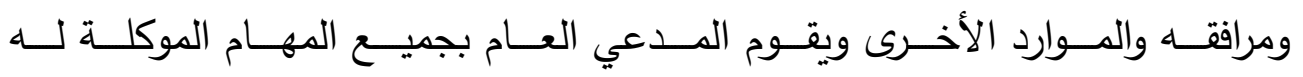
باستقلالية عن بقية أجهزة المحكمة وذلك لطبيعتها. ع-المــدعي العـام يقـوم بجميـع المهـام الموكلـة لـهـ باسـتقلالية عـن بقيــة أجهـزة

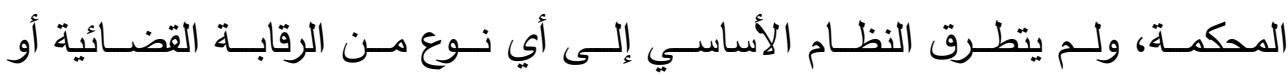

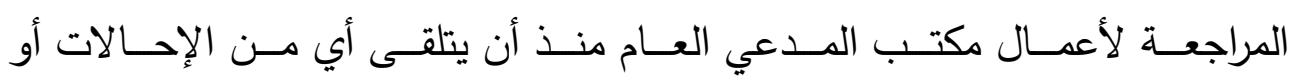

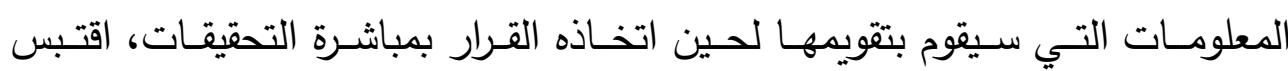
النظـام الأساسـي مدــا هـو معدـول بـهـ فـي الأنظمــة الجنائيــة الوطنيــة إلا أن الاقتبـاس جـاء ناقصــاً و خاليـاً مـن الرقابـة علـى المـدعي العـام ، كمــا هـو قـائم

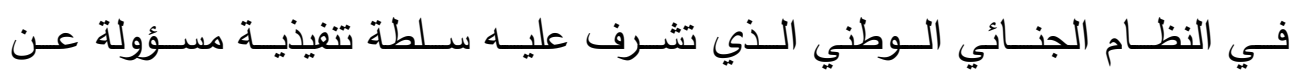
تصرفاته (ץ).وذلك بنوعين من الرقابة على المدعي العام هما:

( () د. عبد الحميد ، أشرف رمضان(ع . . rم). قاضي التحقيق في القانون الجنائي المقارن طا، دار النهضة

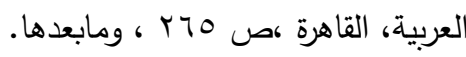

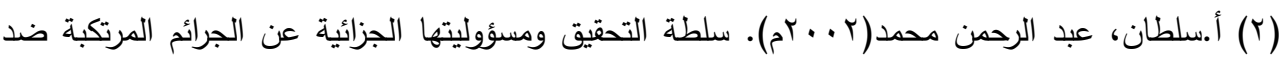

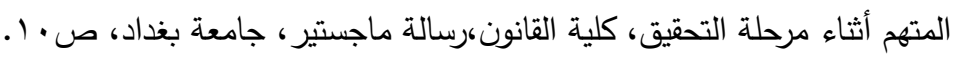

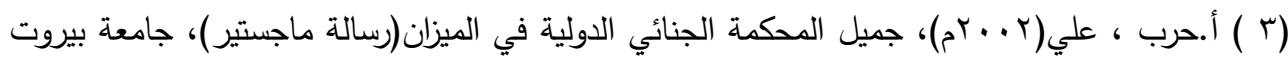
العربية ، لبنان، صبه. 
r.r. · مجلة روح القوانين - العدد الواحد والتسعون - إصدار يوليو

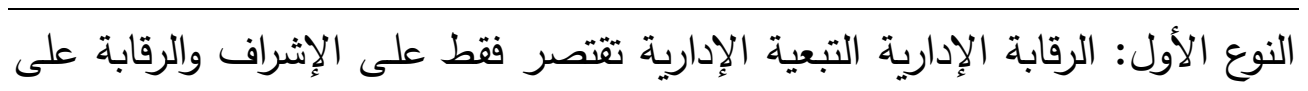

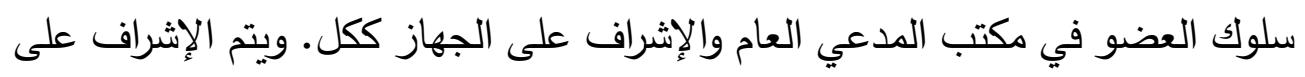
أعضاء مكتب الددعي العام بحكم كونهم موظفين دوليين، وليس المقصود بالرقابة

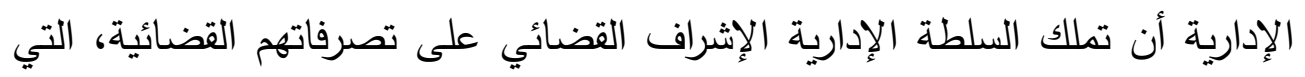

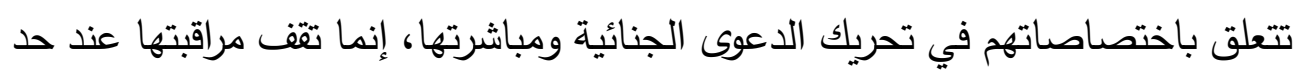

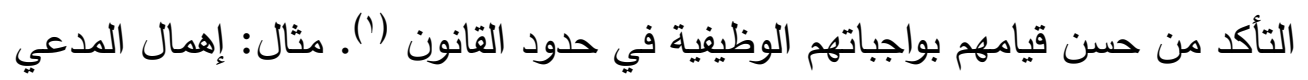

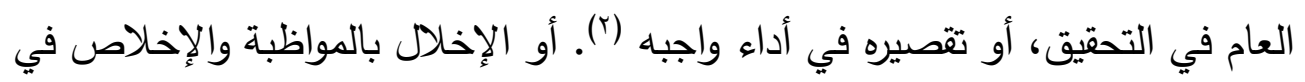

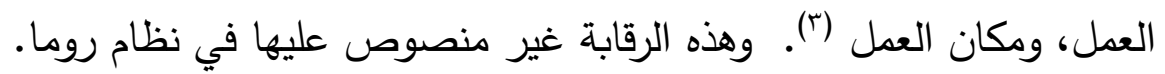

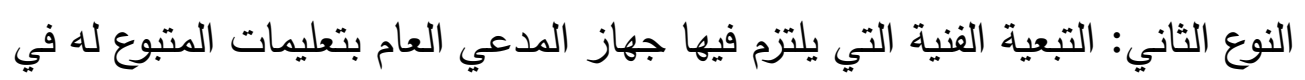

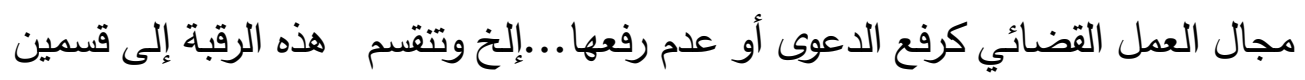
هما: القسم الأول: التبعية في أعمال الاتهام وحدها والقسم الثاني: التبعية في أعمال التحقيق (ई). وجد استثناء على ذلك إذا استتنج المدعي العام أن هناك أساساً معقولاً

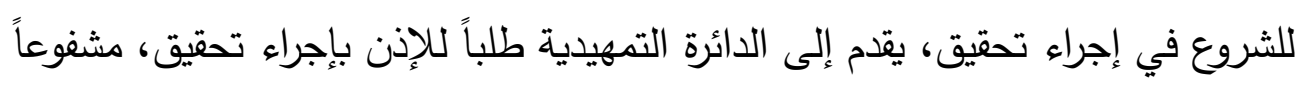

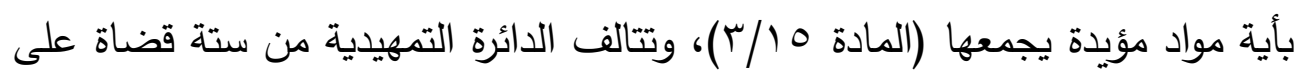

(1) د. مهدي ، عبد الرعوف المرجع السابق، ص اجب؛د. بهنام، رمسيس، الإجراءات الجنائية تأصيلا

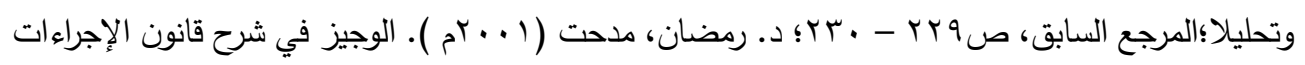

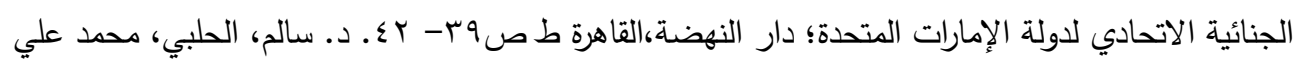

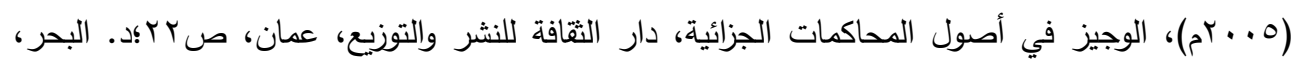

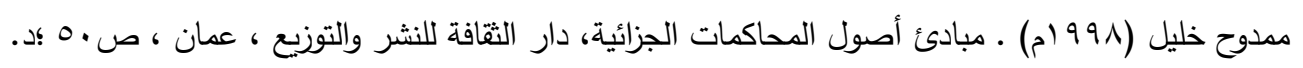

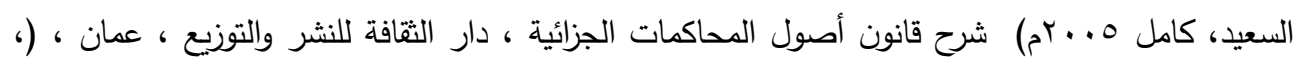

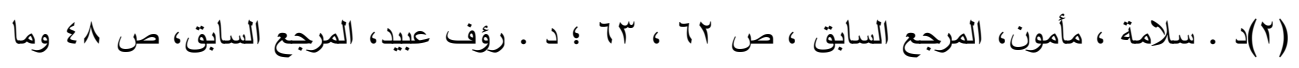

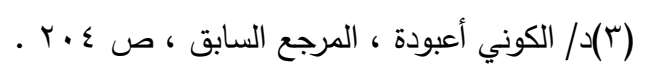

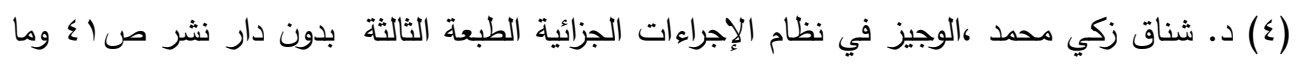




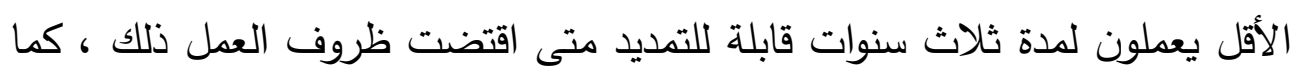

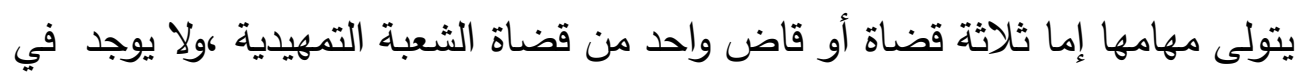

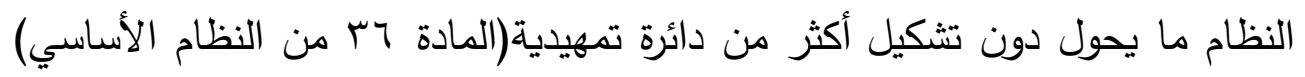

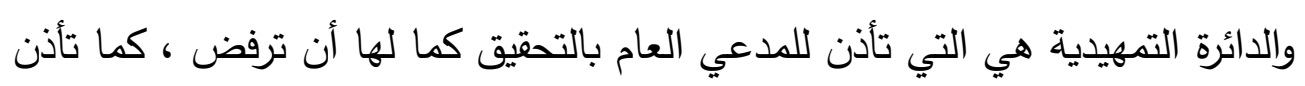

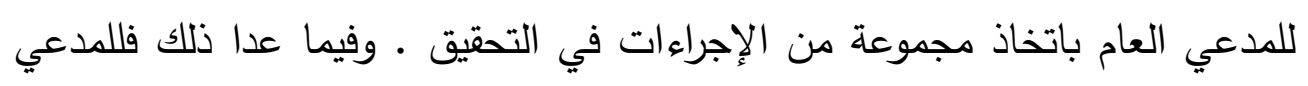

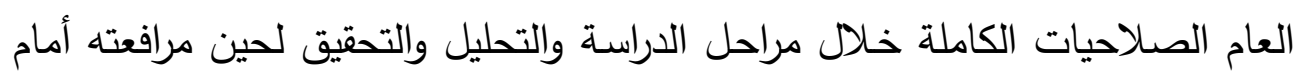

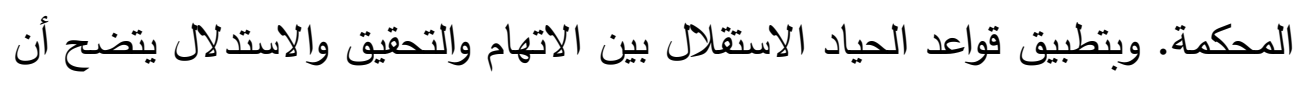

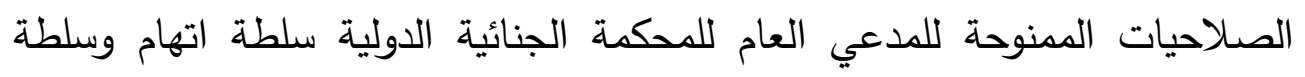

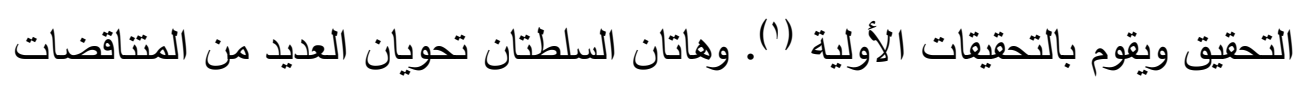

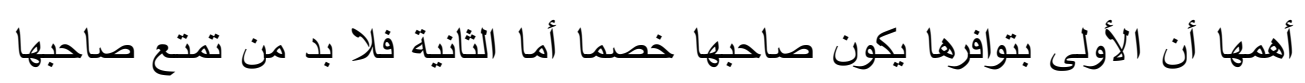

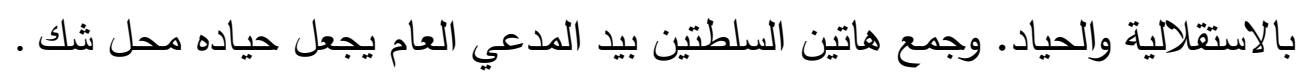

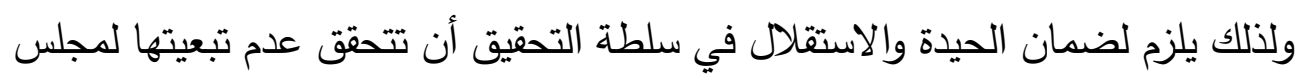
الأمن أو غلبت الطابع السياسي، وأن نتحقق من الفصل بين سلطتي الاتهام والتحقيق

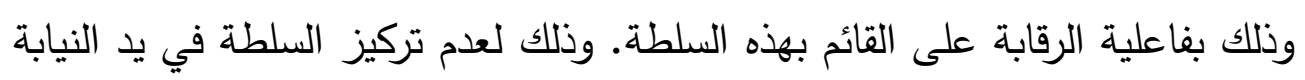
العامة حفاظاً على الحرية الفردية (). وقد أخذ على النظام التتقيبي عدم أخذه بمبدأ

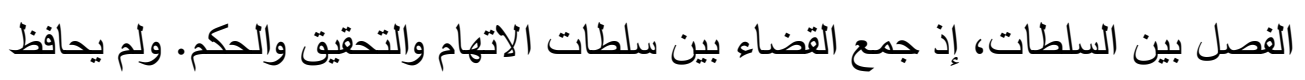

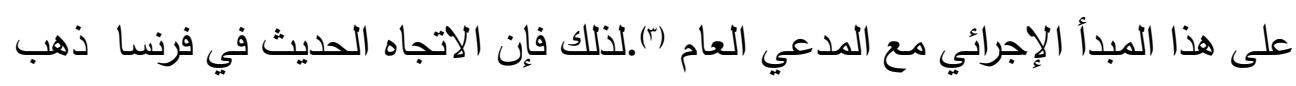

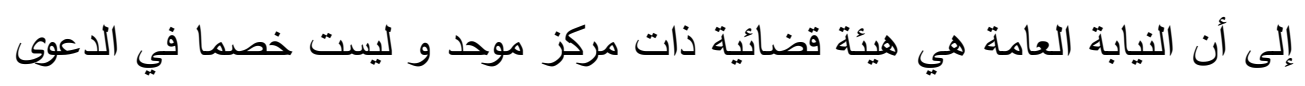

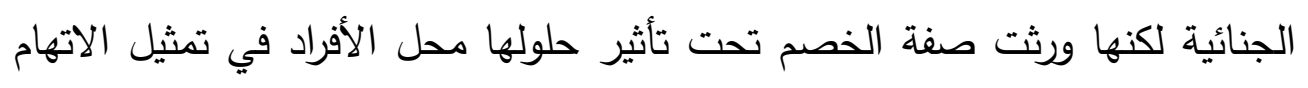

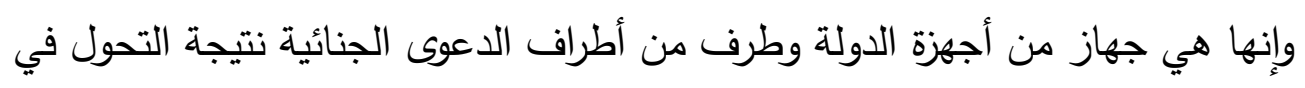
أغراض العقوبة ومقاصدها من الانتقام الفردي تجاه الجاني إلى التقويم والإصلاح

( ( ) القاعدة رقم 0 . من القواعد الإجرائية و قواعد الإثبات للمحكمة الجنائية الدولية

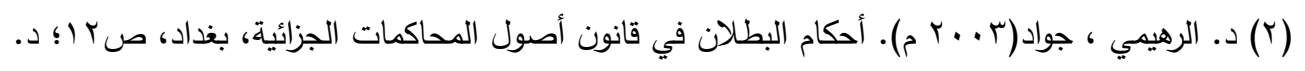

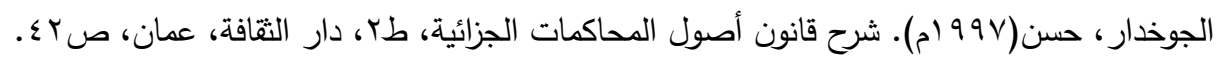

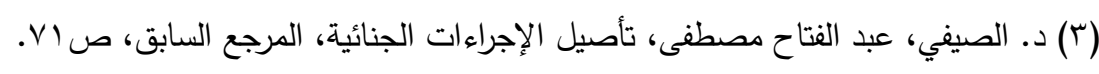


F. r. · مجلة روح القوانين - العدد الواحد والتسعون - إصدار يوليو

والعلاج وحماية المجتمع والحفاظ على حقوق المجني عليه وحماية الثرعية وحسن سير

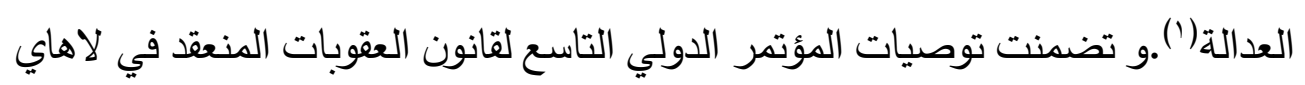
عام ـ 9 ام أن النيابة العامة هي حارس المصالح العامة والضامن للتطبيق الصحيح

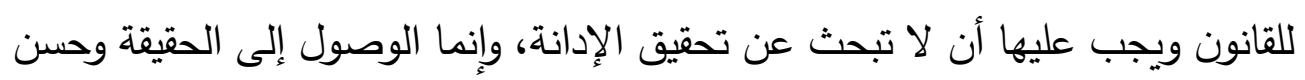

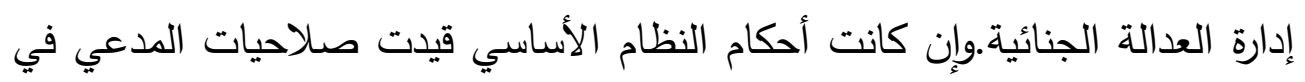

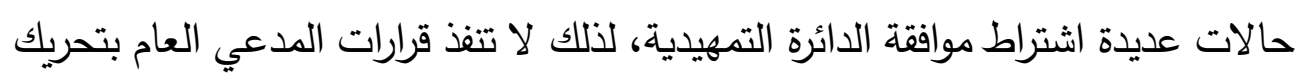

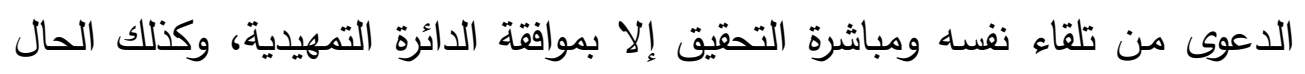

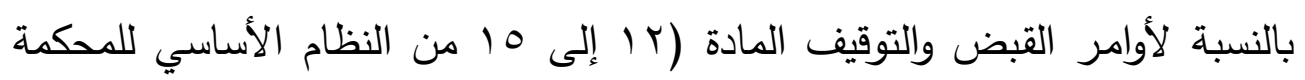

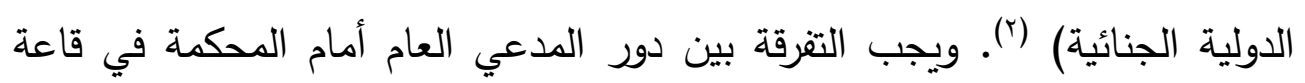
الجلسة فهو خصم أما قبل الجلسة فلا يكون خصما بحال من حال (r). خاهسا: العزل هن الوظيفة :نصت (المادة 7؟) من النظام الأساسي للدحكمة الجنائية

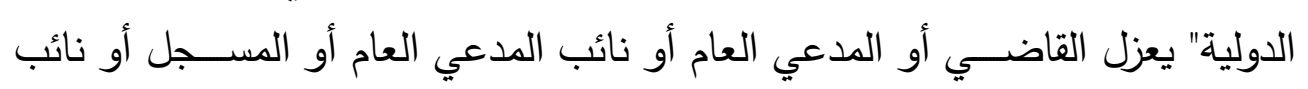

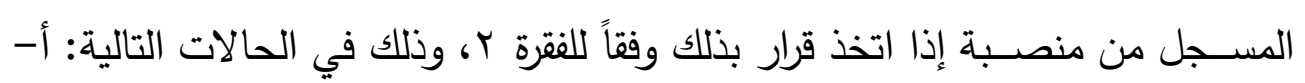

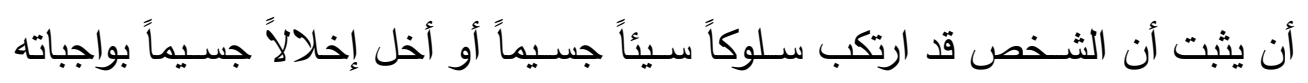
بمقتضـى هذا النظام الأسـاسـي، على النحو المنصــوص عليه في القواعد الإجرائية

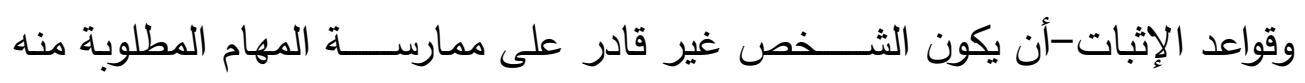
بموجب هذا النظام الأسـاسـي، وتتخذ جمعية الدول الأطراف، بالاقتراع السـري القرار

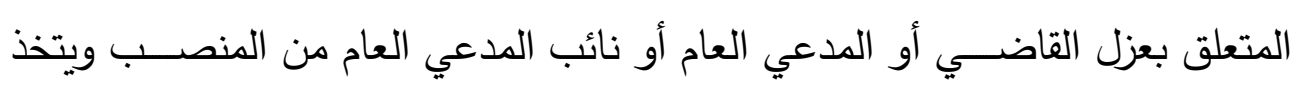

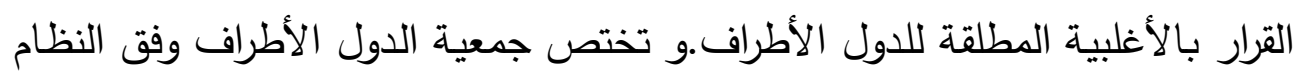

( ) د. سلامة، مأمون محمد (19V7 م). الإجراءات الجنائية في التشريع المصري دار الفكر

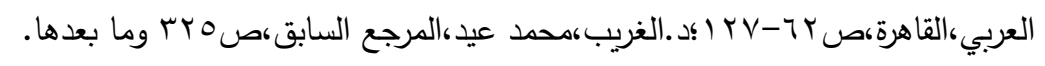

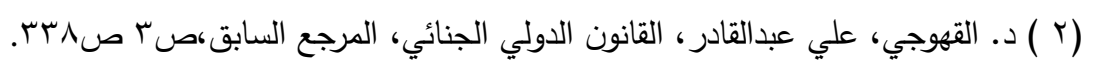

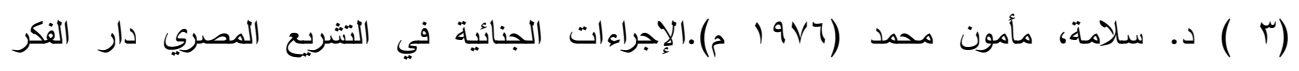

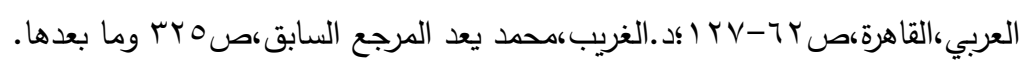




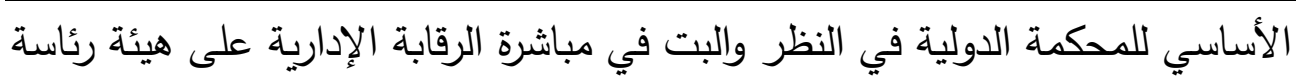

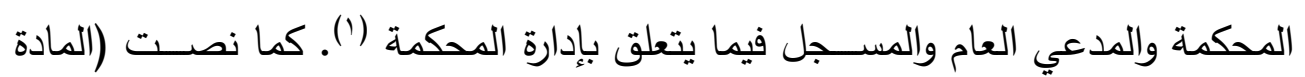

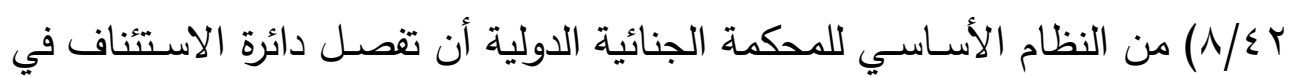

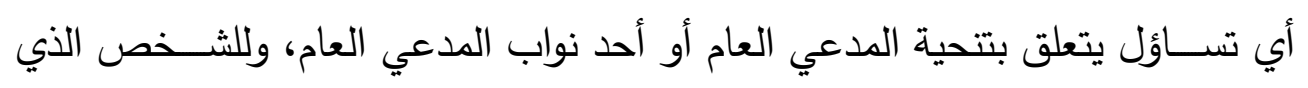

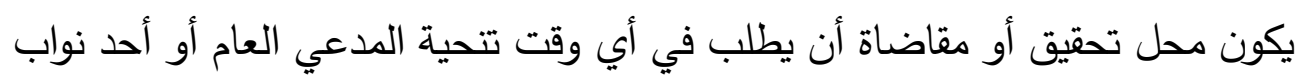

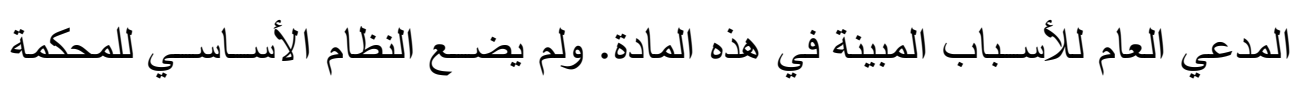

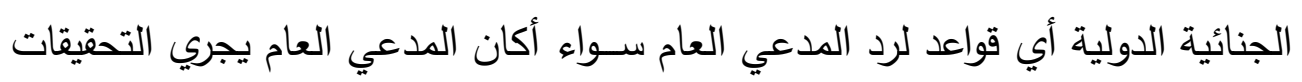

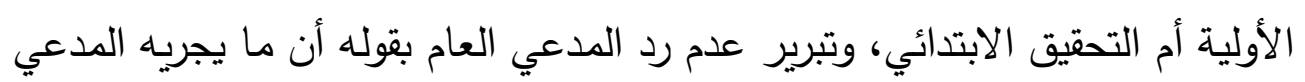

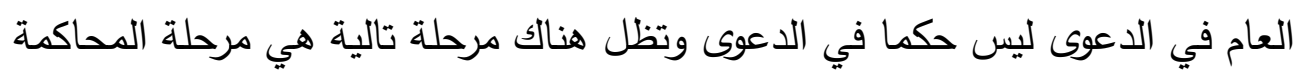

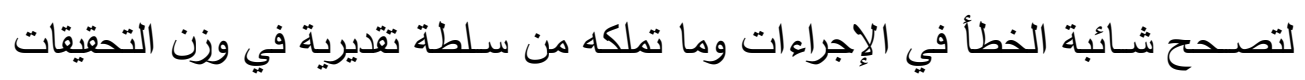

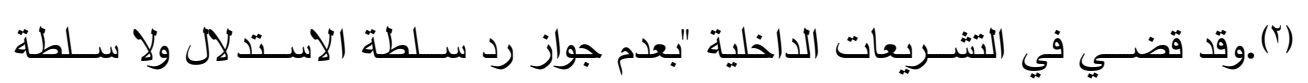

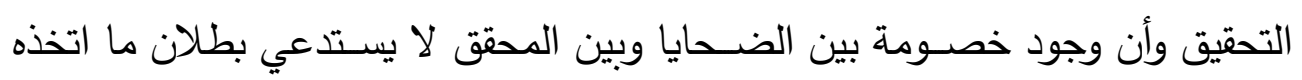

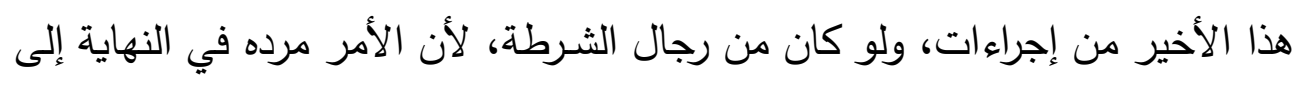

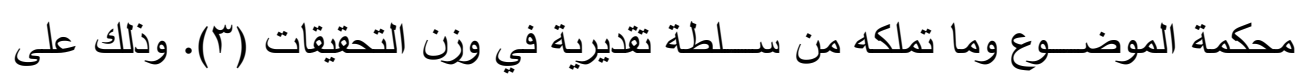

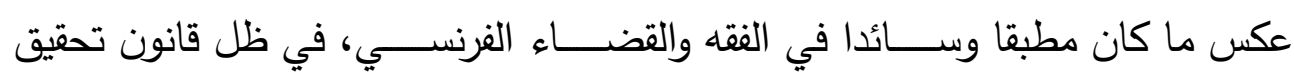

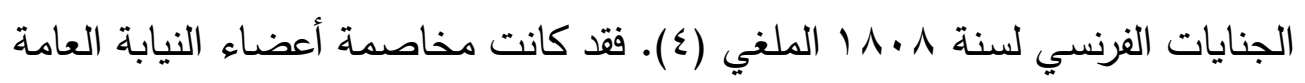

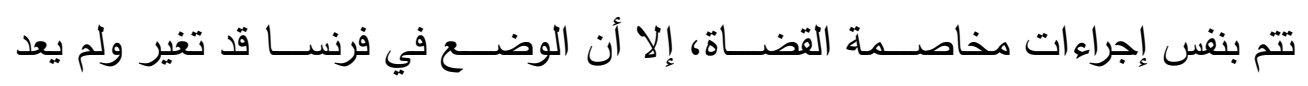
بالإمكان مخاصمتهم(0) - (0)

$$
\begin{aligned}
& \text { (1 ) د. المخزومي، عمر محمود ،المرجع السابق،صلم • بومابعدها. }
\end{aligned}
$$

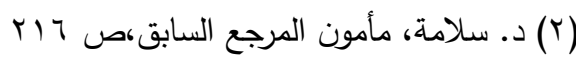

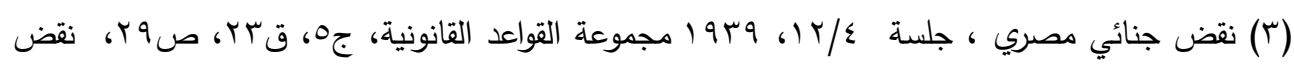

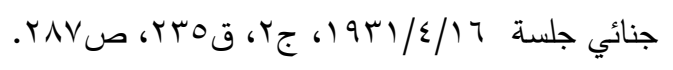

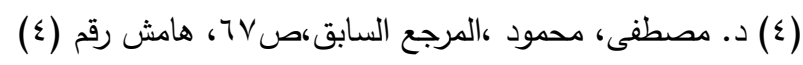

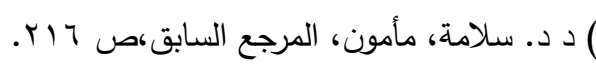




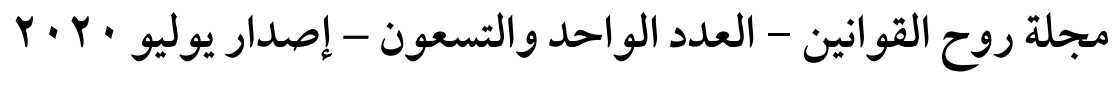

الخلاصة أن الإجراءات التي يتولاها المدعي العام هي الإجراءات التي يقوم بها قاضي

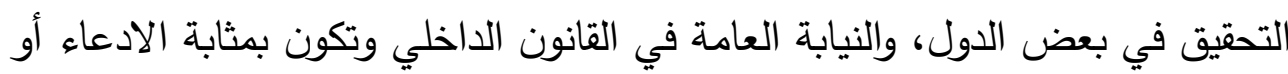

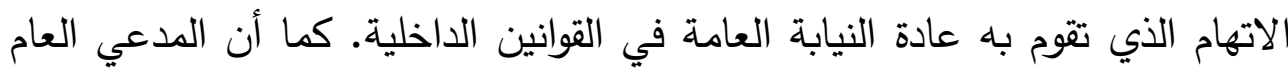

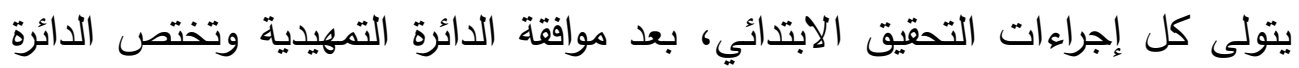

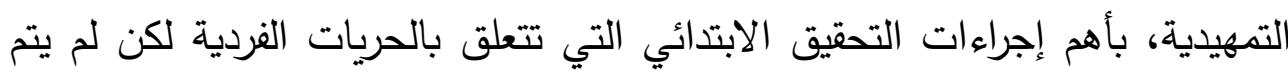

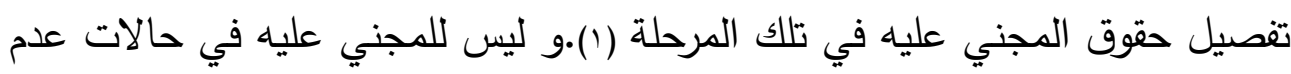

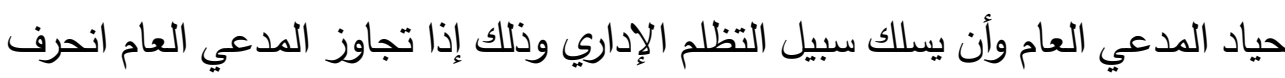

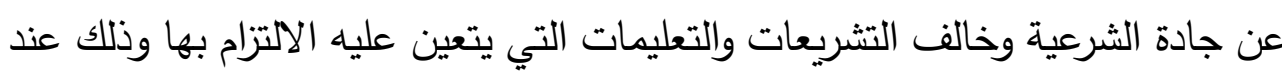

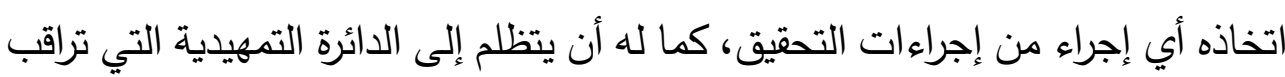

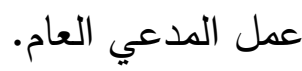

\section{المطلب الثاني}

\section{هق المهني عليه في العلم بإهراءات التمقيق}

إن الدعوى الجنائية تقوم بين والمتهم والادعاء العام، لكن الاتجاه الحديث نادي بأن

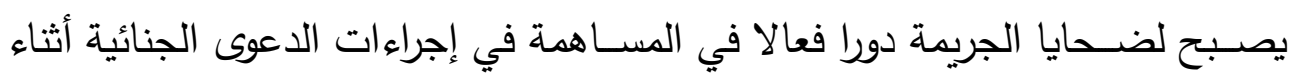
سيرها وحتى صدور الحكم النهائي فيها. ويتولى الددعي العام مهني التحقيق والاتهام

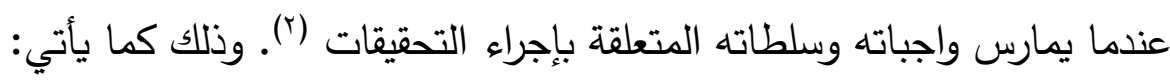

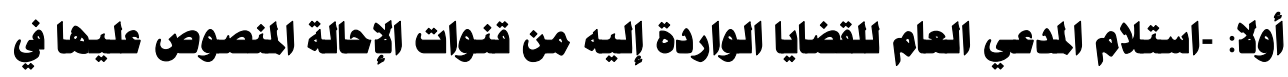
النظام الأساسي: يقوم المدعي العام بإجراءات التحقيق الابتدائيّ في الدعوى الجنائية،

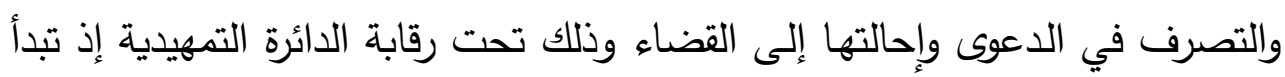
الدعوى بالطلب المقدم من الدول الأطراف أو القرار الصادر من مجلس الأمن والموجَّه

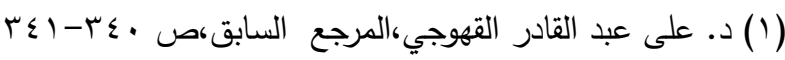

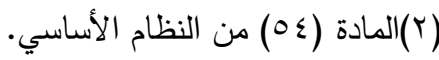


إلى مكتب المدعي العام للمحكمة الجنائيّة الدوليّة، أو بناء على مباشرة مدعي عام المحكمة بالثروع في تحريكها من تلقاء نفسه بوصفه ممثلاً للمجتمع الدوليّ، بإقامة الدعوى أمام هيئة القضاء في المحكمة الجنائيّة الدوليّة، وإسناد الجريمة إلى متهح معين بالذات. وهذه الإجراءات عبارة عن حلقات متصلة، فإذا بطل إحداها استتبعه بطلان ما لحقها من إجراءات، ولذلك تُعدّ هذه العملية دقيقة ومهمة جداً، إذ إنّ الدعوى بكاملها مبنية على هذه المرحلة في إجراءاتها ونتائجها. ويقتضي حياد المدعي العام التمتع بخاصتي الاستقلالية والحيدة، وذلك تأكيداً لسيادة الثرعية الجنائية الدولية بحلقاتها الثلاثة، التي تبررها المصلحة العامة الدولية بهدف تطبيق القانون بكثف الحقائق ومعرفة الفاعلين ودوافعهم والمحافظة على السلامة العامة بحماية الحقوق والحريات سواء كانت للمتهم أو للمني عليه، لتحقيق العدالة الجنائية على أفضل وجه لكي يحيل أمام القضاء ملفاً مستكمل الجوانب وجاهزاً للحكم والإدانة وإيقاع القصاص بالمجرمين ('). ثانيا: تقديم المعلومات إلى المدعي العام: إن يقوم المدعي العام بالتحقيق في ظروف التجريم والتبرئة على حد سواء وذلك باتخاذ التدابير المناسبة لضمان فعالية التحقيق في الجرائم التي تدخل في اختصاص المحكمة والمقاضاة عليها تلقي جميع الوقائع والأدلة المتصلة بتقدير ما إذا كانت هناك مسؤولية جنائية أم لا، بموجب هذا النظام

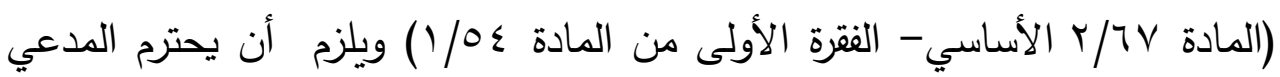
العام احتراما كاملا حقوق الأشخاص الناشئة بموجب هذا النظام الأساسي وأن يحترم مصالح المجني عليه والثهود وظروفهم الشخصية (()وأن يشمل ما يلي: ا-إن يقوم المدعي العام بعمليات جمع الأدلة والتنقيب عنها وفحصــها، وتحديد مدى صلاحيتها وقوتها، واتخاذ كافة الإجراءات اللازمة للتحقيق، وطلب حضور الأشخاص له محل التحقيق والمجني عليهم و الثـهود أو استجوابهه، وأن يلتمس تعاون أي دولة أو وإن

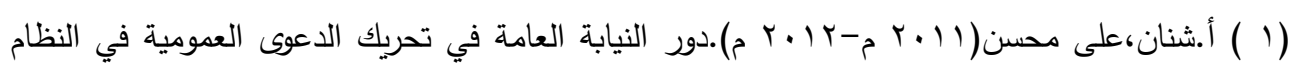

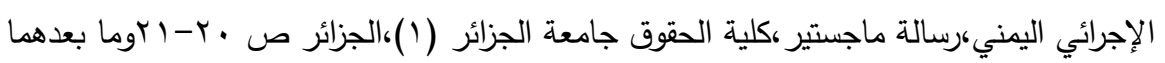

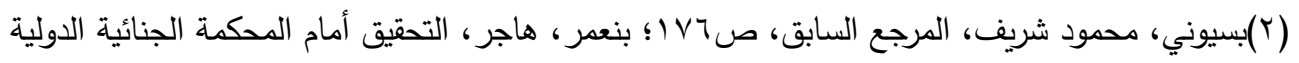

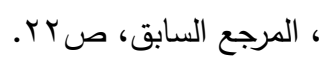




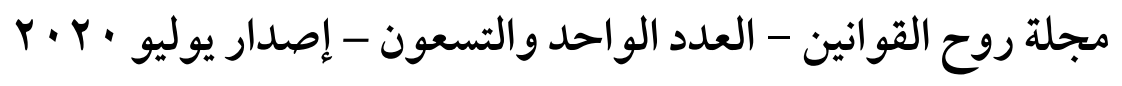

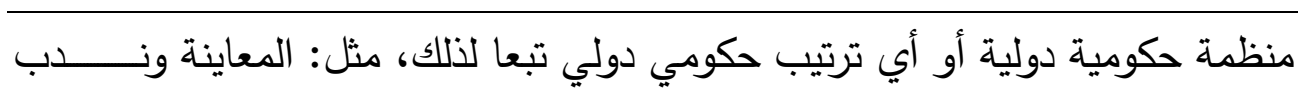

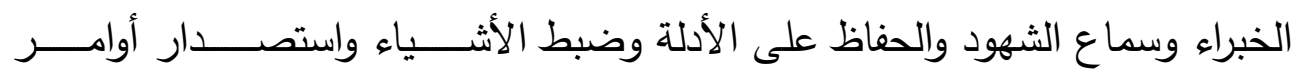

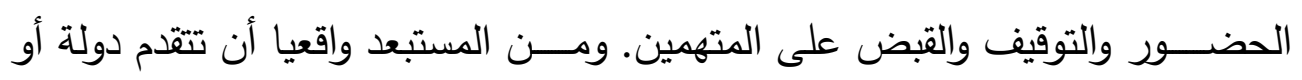

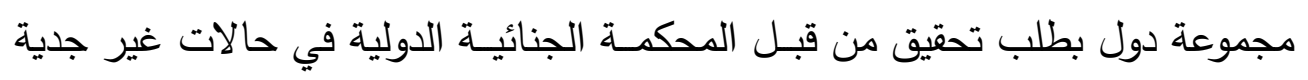
حسب المادة با من النظام الأساسي. r- لا يملك المدعي العام صلاحيات إجبارية على الدول لتستقبله على إقليمها وتسمح الفانس

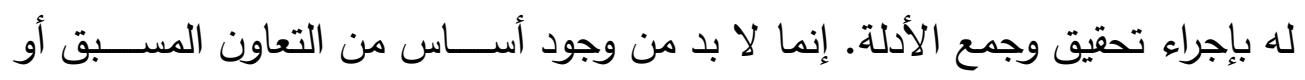

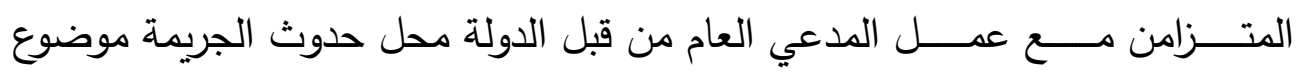

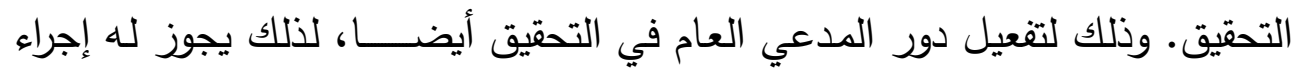

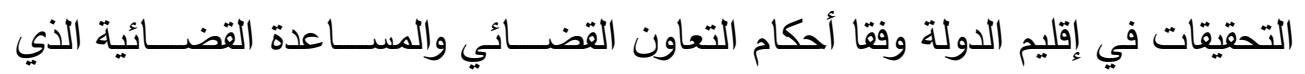
بمقتضـــاه تلتزم الدولة بالتعاون التام مع المحكمة فيما تجريه من تحقيقات في الجرائم

والمقاضاة عليها أو على النحو الذي تأذن به الدائرة التمهيدية (').

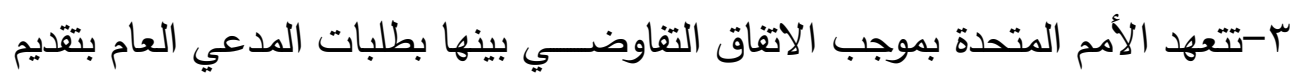

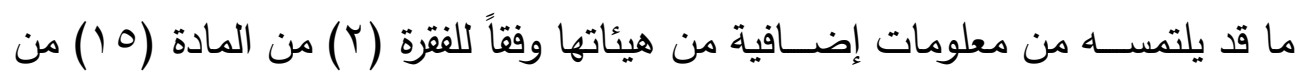
النظام الأساسي، وذلك بخصوص التحقيقات التي يباشرها من تلقاء نفسه. كما ينبغي

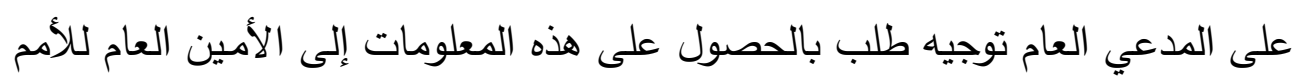

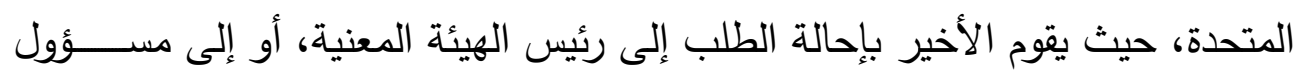

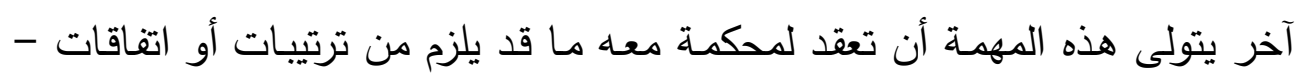

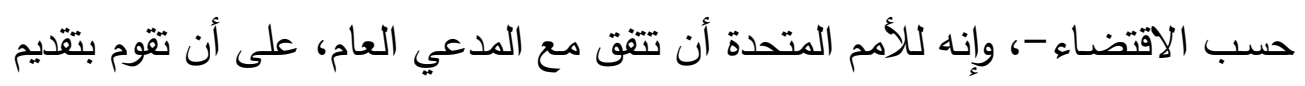

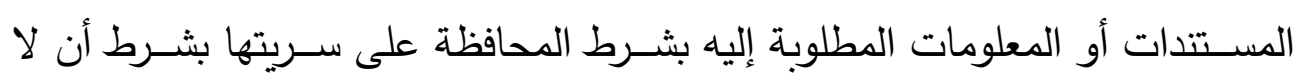

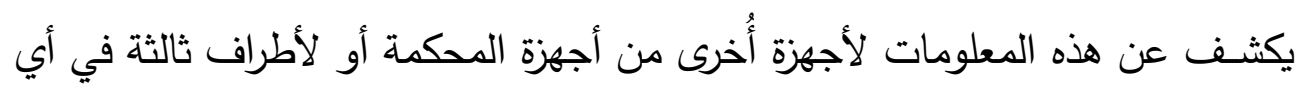

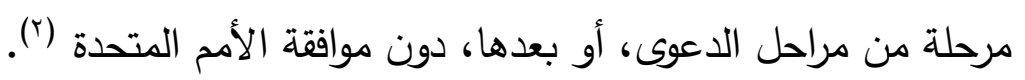

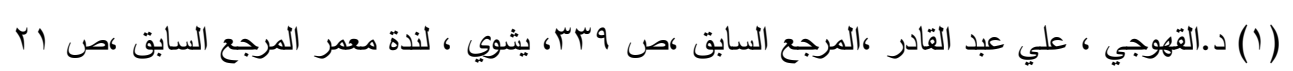

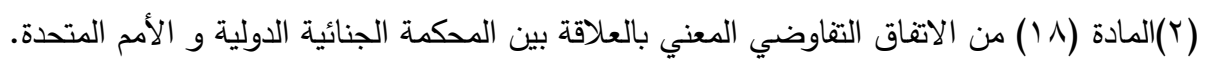


وقد أبرم مكتب المدعي العـام للمحكمة الجنائيـة الدولية اتفاق تعاون مع المنظمـة

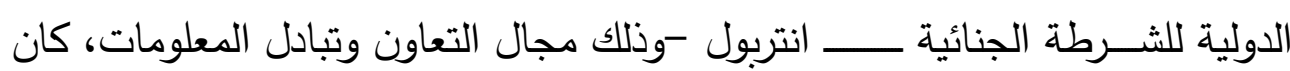
الغرض منه الوقاية من الإجرام والعدالة الجنائية وكذا تبادل المعلومات الثرطية وإجراء التحليلات الجنائية والبحث عن المجرمين الفارين وإصـــدار وتعميم نشــرات الانتربول والوصول إلى شبكة اتصالات الانتربول و قواعد بياناته ('). ثالثا: يمنح النظام الأسساسي ههلة شسهر واحد هن تاريخ تلقي ذلك الإشسعار، إذ يجوز للدولة في غضــــونه أن تبلغ المحكمة أنها أجرت تحقيق مع رعاياها أو مع غيرهم في هي حدود ولايتها القضـائية (r).ويجوز للدولة خلال شـهر من تلقيها الإخطار من المدعي العام أن تقدم طلبا خطيا إلى المدعي العام تطلب منه معلومات إضـافية تسـاعدها في التحقيق (r).وذلك دون الإخلال بمدة الثهر المسموح بها، ويجب على المدعي العام أن يعجل بالجواب عليها، إذا لم تطلب الدولة الإحالة وحصـل المدعي العام على إذن من

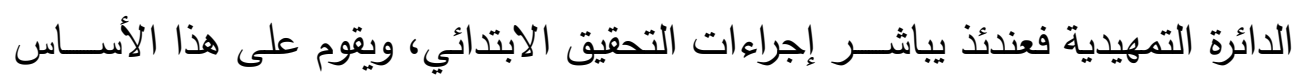
بالتوســع في التحقيق. كما أنه يجوز للمدعي العام طلب معلومات إضـــافية من تلك إلك

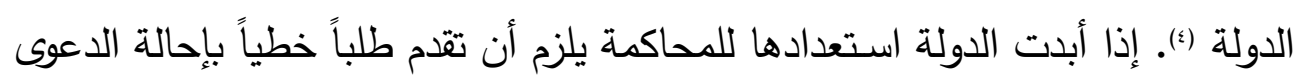

\section{رابعا: تنازل المدعي العام عن التحقيق لصالح ولاية الدولة حسب هبدأ التكاهل:}

إن تتازل المدعي العام عن التحقيق لصالح ولاية الدولة حسب مبدأ التكامل، إنما يكون بعد تقديم المدعي العام التماس إلى الدائرة التمهيدية بالأسس التي استتد إليها في ذلك.

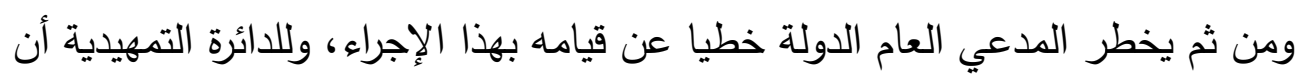
تعقد جلسة خاصة للبت في الطلب بعد فحص الأوراق والمعلومات للوصول إلى الإجراء

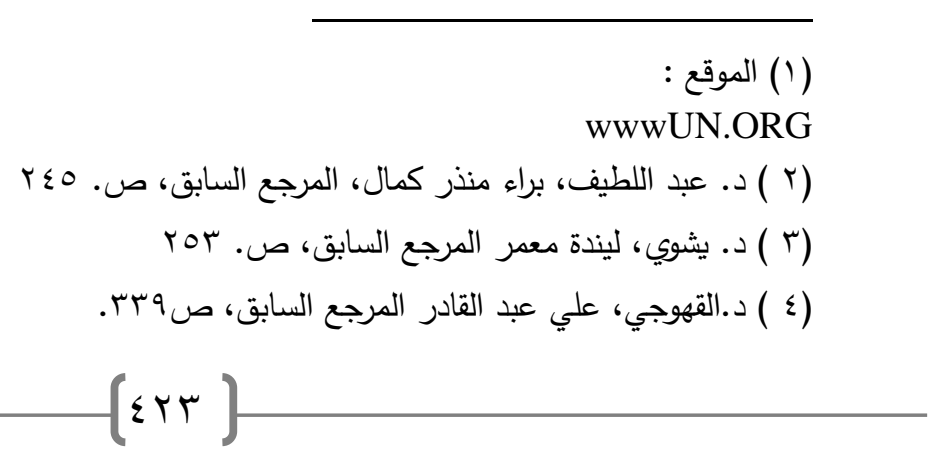


r.r. · مجلة روح القوانين - العدد الواحد والتسعون - إصدار يوليو

الذي يجب إتباعه، وللدائرة التمهيدية أن تسترشد في ذلك بعوامل مقبولية الدعوى الواردة

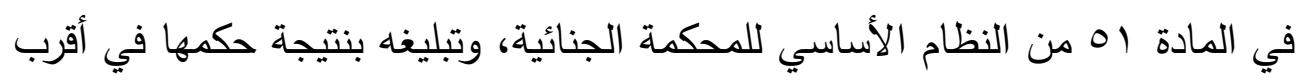
وقت ممكن إلى كل من المدعي العام والدولة متضمنا الأساس الذي استندت إليه ('). ويجوز للدولة المعنية والمدعي العام استئناف القرار الصادر عن الدائية الدائرة التمهيدية أمام

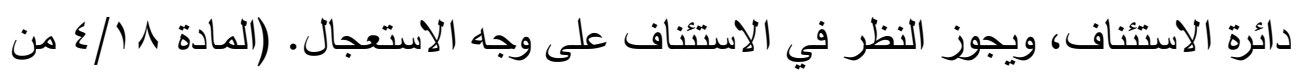
النظام الأساسي) (النيان خامسسا: المتابعة القانونية: ويجب على الدولة خلال نفس المدة(شـــر ) تبليخ المحكمة

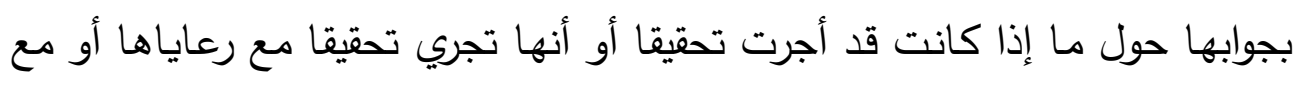

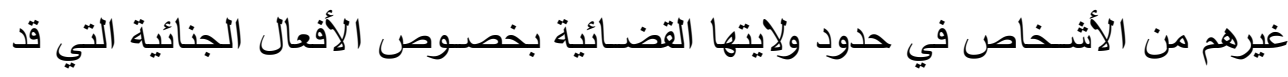

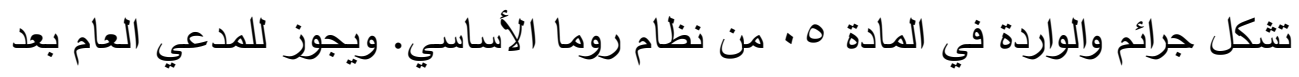

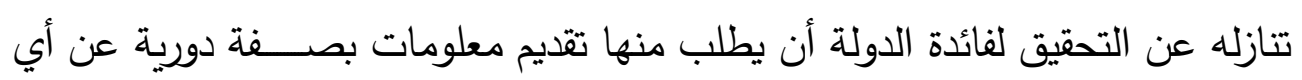

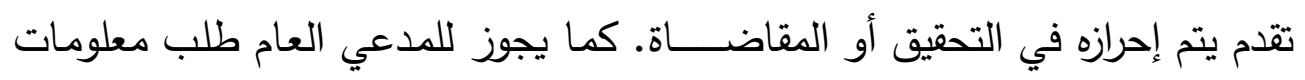

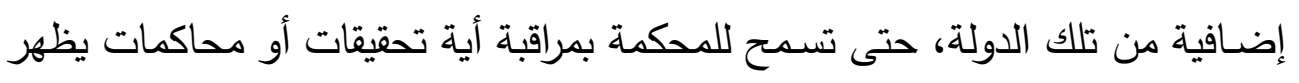

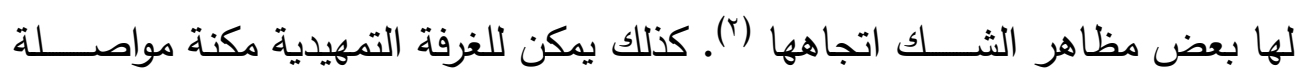
التحقيق التمهيدي وذلك إذا سـنحت فرصــة فريدة أو كان هناك احتمال بعدم إمكانية

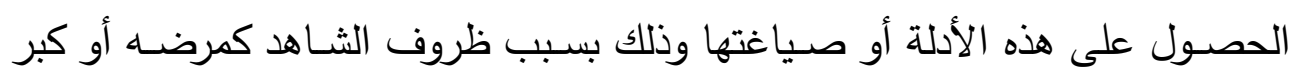

$$
\text { سنه أو بسبب إمكانية طمس معالم الجريمة. }
$$

\section{سادسا: إلغاء تنازل المدعي العام:}

و للمدعي العام أن يعيد النظر في تنازله عن التحقيق للدولة بعد ستة أشهر من تاريخ التهاري

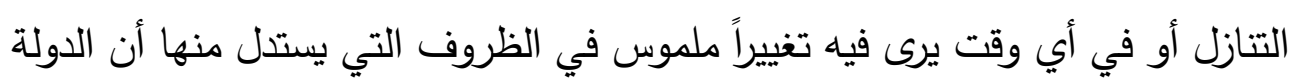

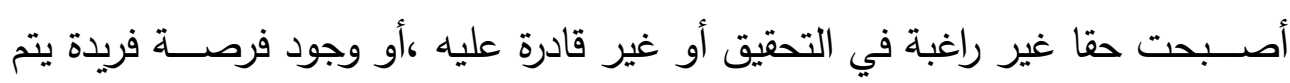

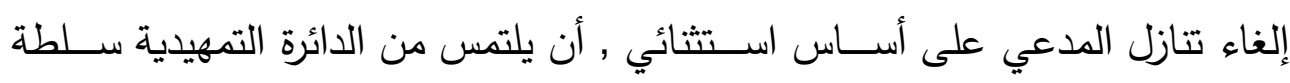

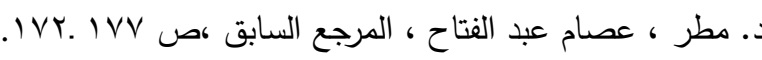

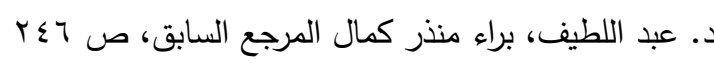




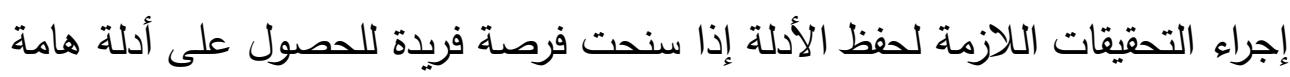

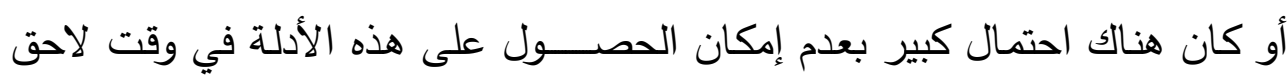

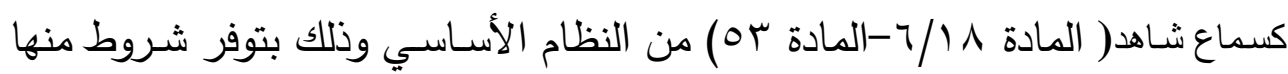

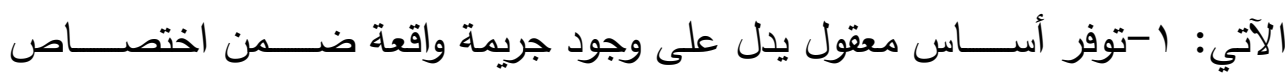

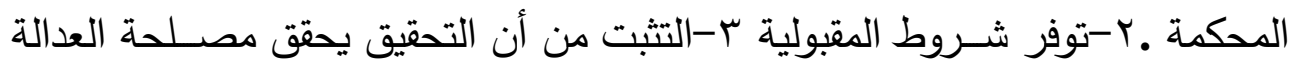

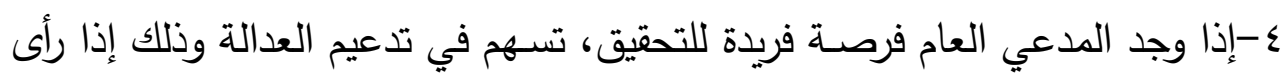

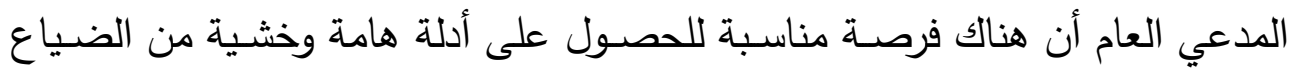

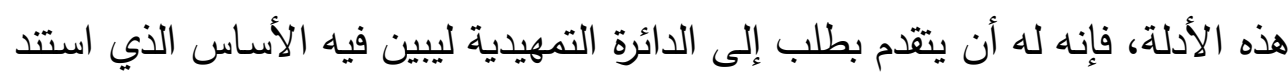

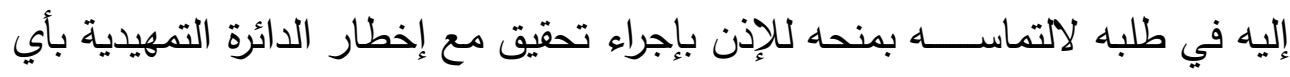

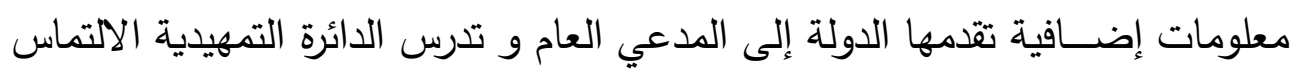

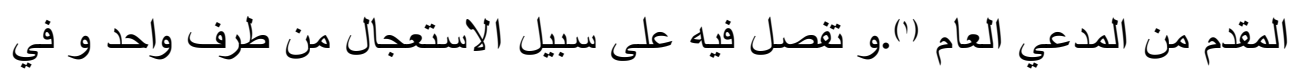

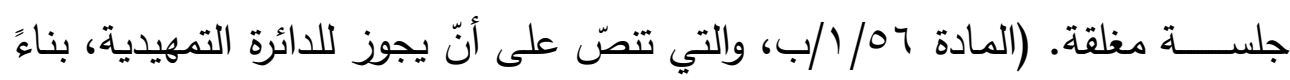

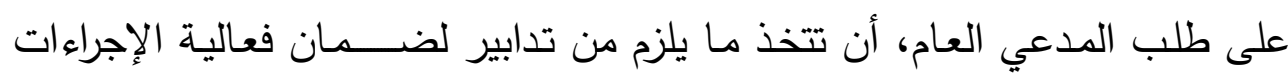

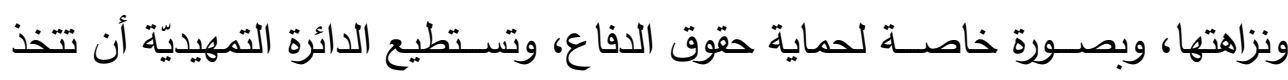

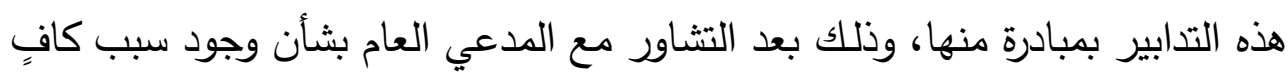

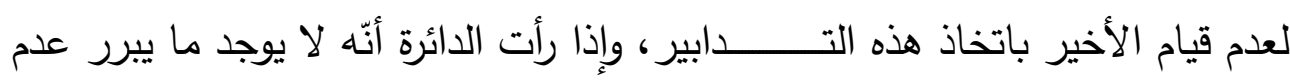

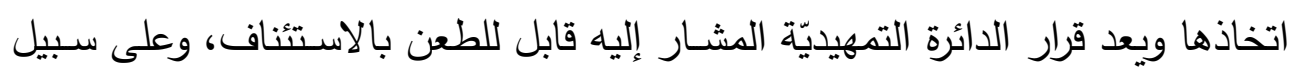
الاستعجال أمام الدائرة الاستئنافيّة.

(1 ) القهوجي، علي عبد القادر المرجع السابق، صqجr؟؛ نصر الدين، بوسماحة، الدرجع السابق، الجزء الأول، ص 1 الن. 


$$
\text { r.r. · مجلة روح القوانين - العدد الواحد والتسعون - إصدار يوليو }
$$

\section{سابعا: حق المني عليه في الإخطار بقرارات سلطة التحقيق لدى المكمة الجنائية}

الدوولية:

إن الوظيفة الأساسية للتحقيق الابتدائي، هي البحث عن أدلة الجريمة المنسوبة للمتهر كأبة

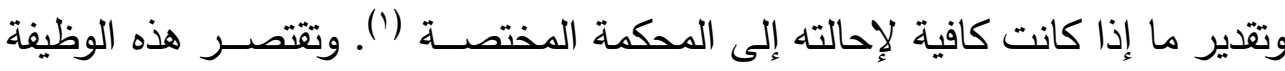

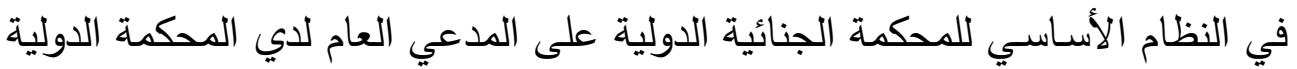
الجنائية تحت إثراف الدائرة التمهيدية وذلك تمهيدا لتقديم المتهم إلى المحاكمة الجنائية

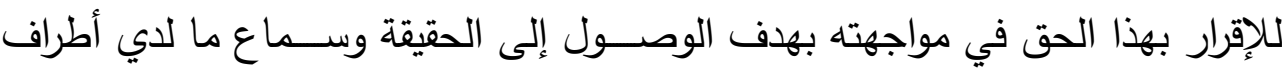

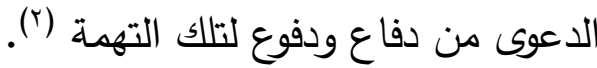
والحق في الإخطار للمجني عليه هو حق فرعي آخر للمشاركة للمجني عليه في

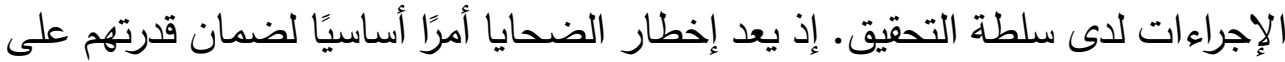
ممارسة حقهم في المشاركة .وهذا الحق معترف به، بالتزام المدعي العام الصريح

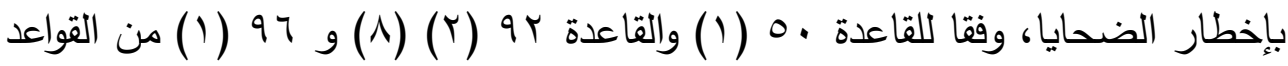
الإجرائية وقواعد الإثبات. ومن ثم للضحايا الحق الصريح في أن يتم إخطارهم بالقرارات التي يتخذها المدعي العام بنفس الطريقة التي يتبعها مكتب المدعي العام، ووفقًا للمادة

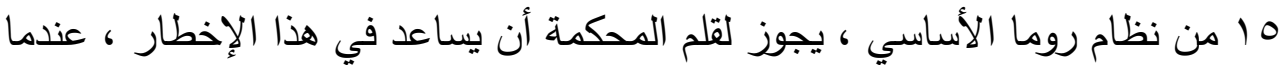

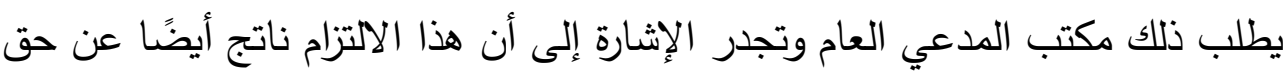

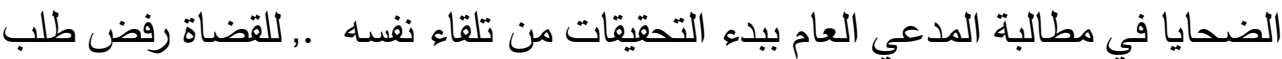
المشاركة إذا رأوا أن الثخص لا يفي بالمتطلبات اللازمة للتأهل كضحية أمام المحكمة ويرتبط هذا الحكم بحق المجني عليه في تقديم طلب جديد في مرحلة لاحقة، وفقًا للقاعدة 19 (ץ) من القواعد الإجرائية وقواعد الإثبات، كذلك للمجني عليه الحق في سحب طلب

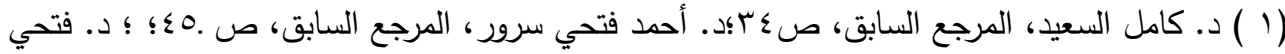

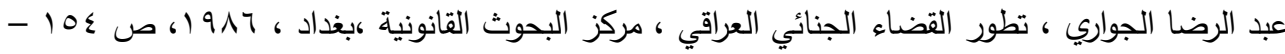

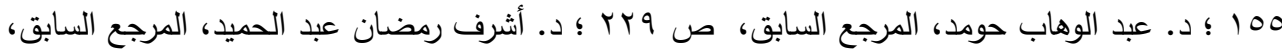




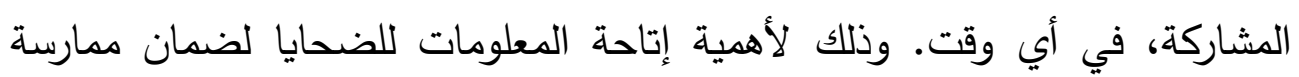

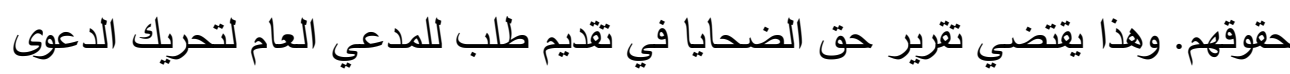

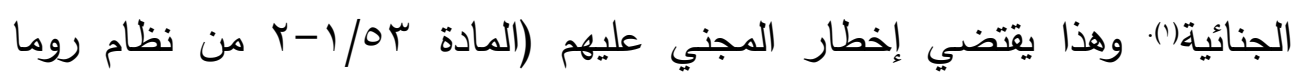

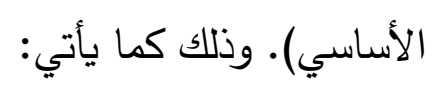
ا-إخطار الضحايا بشأن قُّار المدعي العام بعدم الثروع في التحقيق أو بعدم المقاضاة:

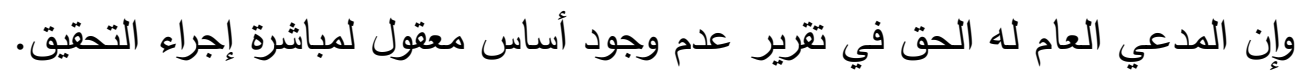

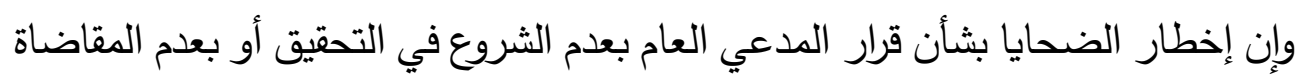

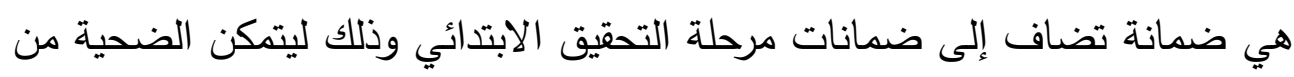

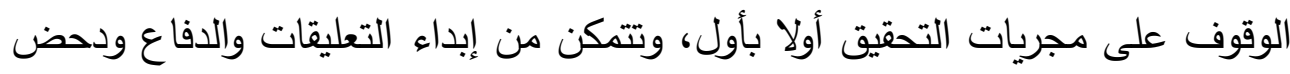

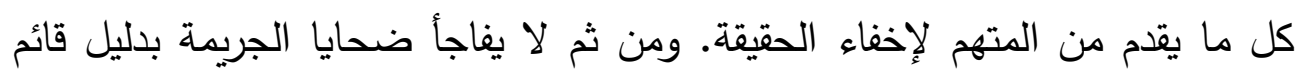

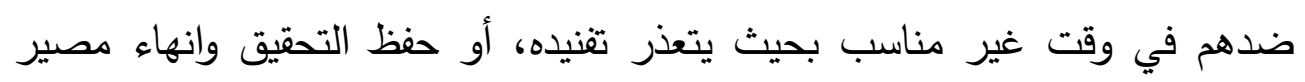

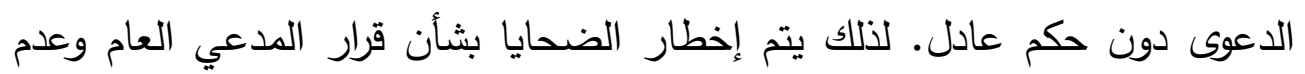

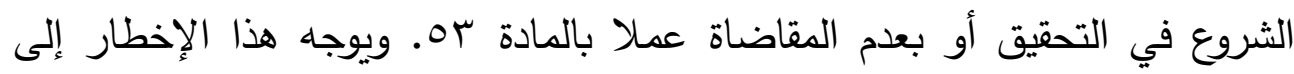

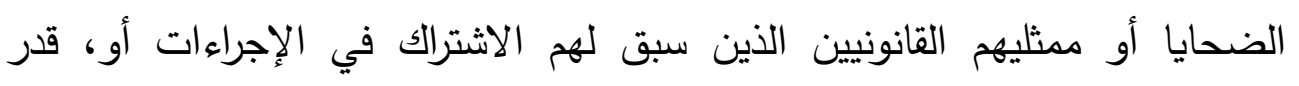

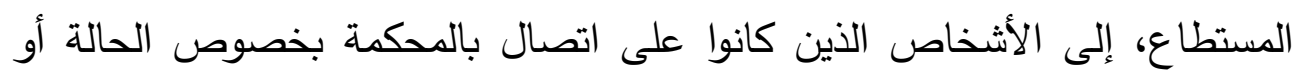

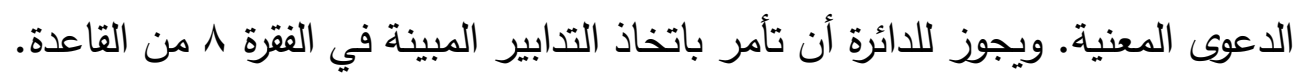

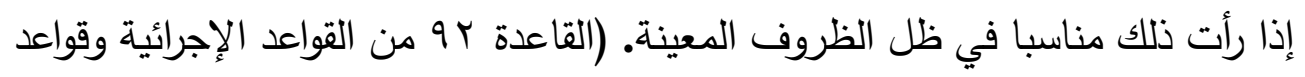

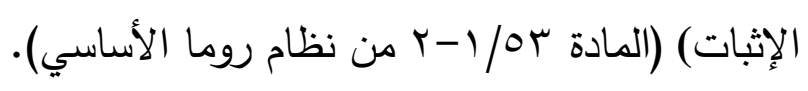

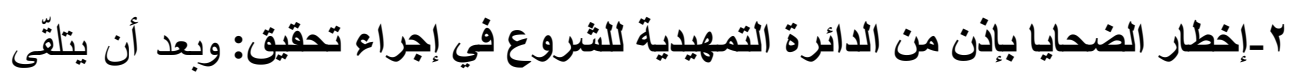

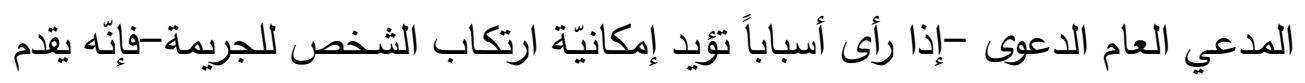

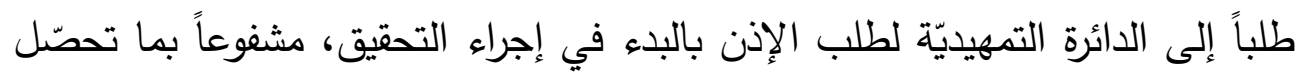

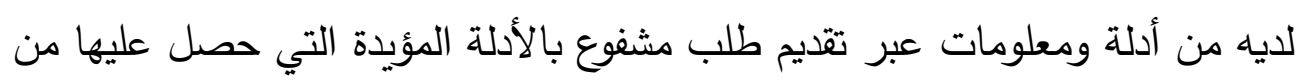


r.r. · مجلة روح القوانين - العدد الواحد والتسعون - إصدار يوليو

الأطراف المحيلة مجلس الأمن والدول الأطراف أو من التحقيق الأولى الذي قام به.

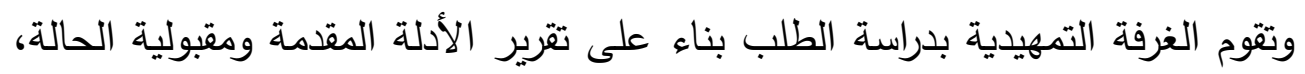
ويكون قرار الغرفة التمهيدية كما سبق بين أمرين هما: الأول: منح الادعاء الإدنة

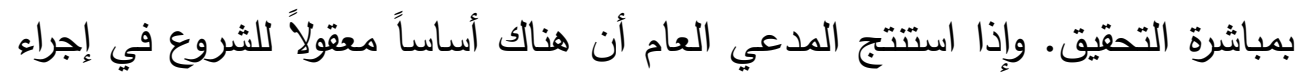

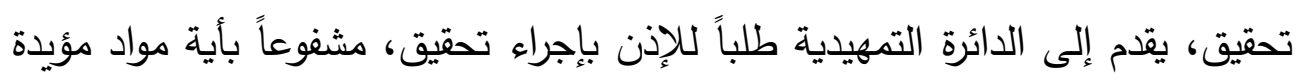
يجمعها ويجوز للمني عليهم إجراء مرافعات لدى الدائرة التمهيدية وفقاً للقواعد الإجرائية

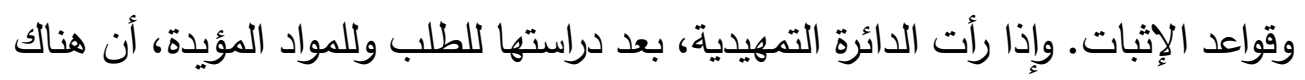

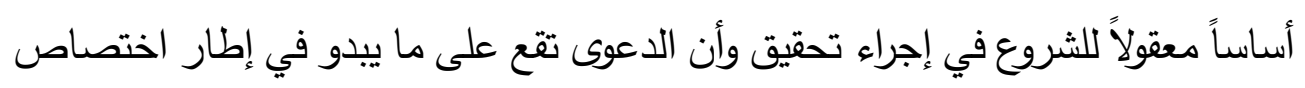

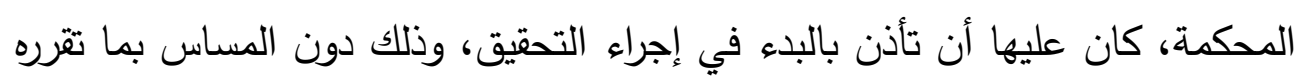

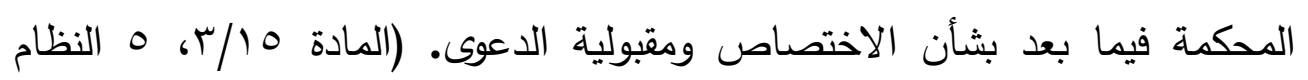
الأساسي للمحكمة الجنائية الدولية).

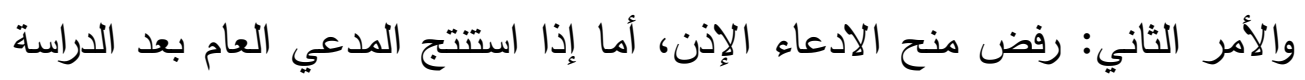

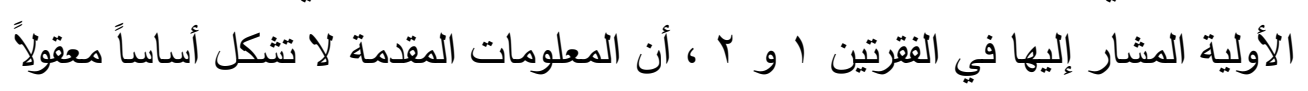

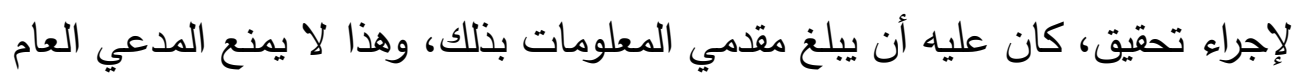

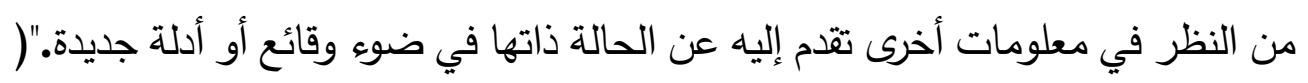

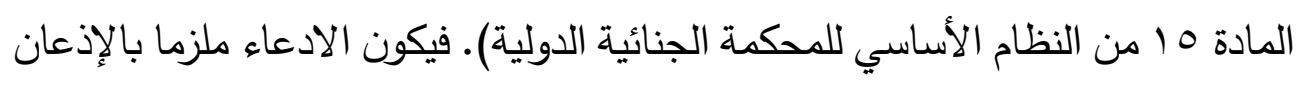

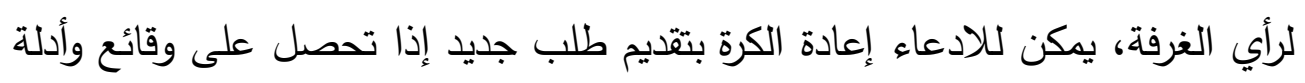

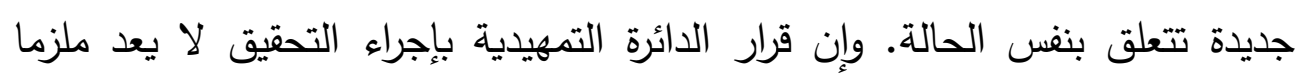

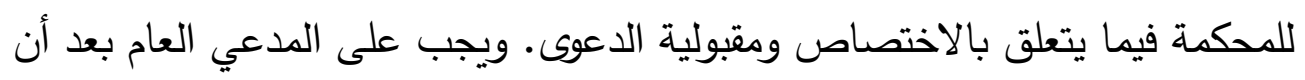

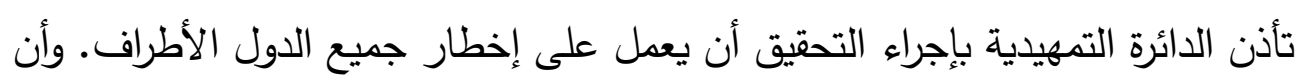

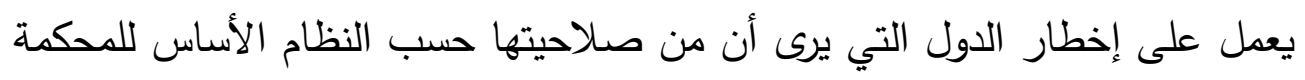

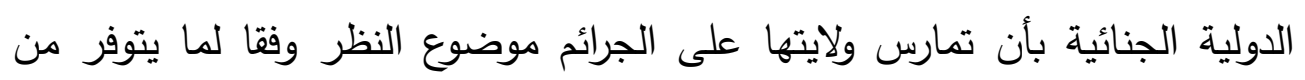

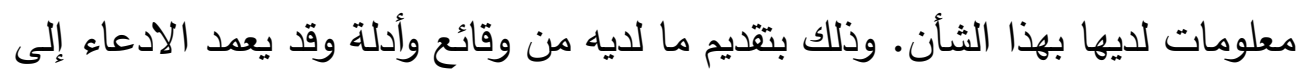


السرية في ذكر الوقائع والأدلة التي بحوزته ((). ويفهم من نظام روما الأساسي إنه يلزم ألا يحتوي إخطار المدعي العام إلا على معلومات محددة بالقدر اللازم من الأفعال التي

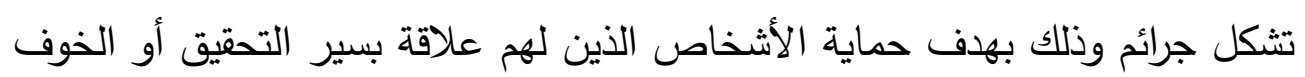
من إمكانية إتلاف أدلة الإثبات أو خشية هروب الجناة. لكن لم يرد نص على إخطار المجني عليهم بالحق في إعلامهم بإجراءات التحقيق سواء في حالة رفض الدائرة التمهيدية لقيام المدعي العام بالتحقيق (أي أمر بالحفظ) أو إذا قررت الدائرة الإذن بالتحقيق فيجب النص على حق المجني عليه في الإعلام بالبدء في التحقيق، أو الأمر بالحفظ. وهذا على خلاف ما هو متبع في القوانين الداخلية فإن النيابة العامة إذا أصدرت أمراً بالحفظ باعتبارها رئيسة الضبطية القضائية المهيمنة أن تعلنه للمجني عليه ولو لم يدع مدنيا. إما إن كان قد توفي فيتم الإعلان لورثته جملة في محل إقامته، (المادة r7 من قانون الإجراءات الجنائية المصري والمادة (Tr) من نظام الإجراءات الجزائية السعودي) (؟). كما أن من حق الشخص المشتبه فيه أثناء استجوابه بتبليغه بوجود أسباب تدعو للاعتقاد بارتكابه جريمة تدخل في اختصاص المحكمة وهذا الحق منصوص عليه أيضا في المادة و/Y من العهد الدولي للحقوق السياسية والمدنية

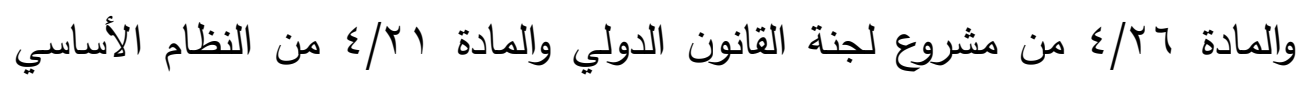

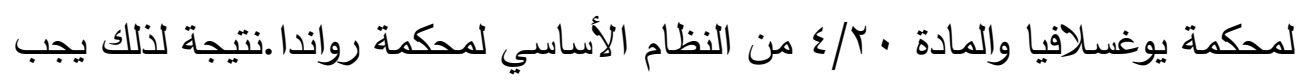
إخطار المجني عليه باليوم الذي يباشر فيه التحقيق، باعتبار المجني عليه من انتهكت

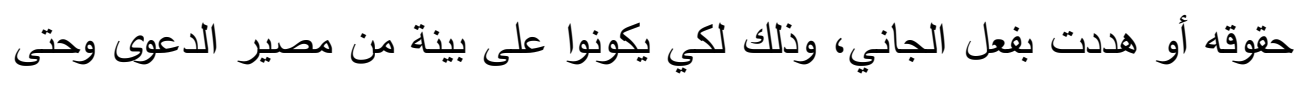
يتمكنوا من اتخاذ إجراء الطعن القانوني المخول لهم. وكذلك لحماية حقوق الضحايا

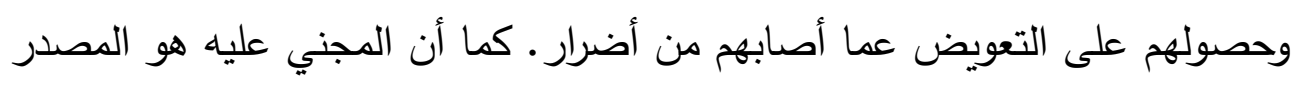

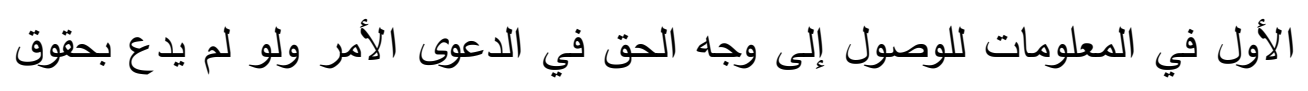

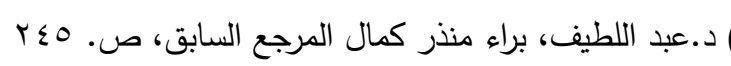

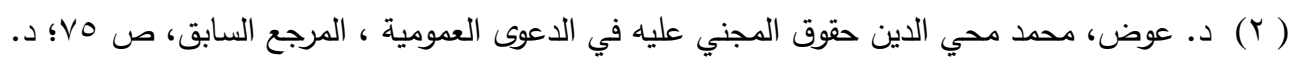

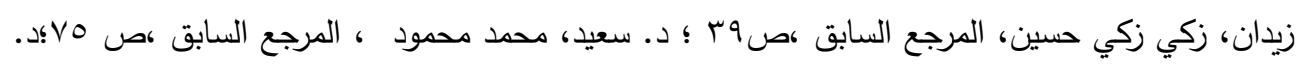

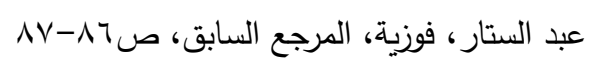


F. r. · مجلة روح القوانين - العدد الواحد والتسعون - إصدار يوليو

مدنية؛ وذلك لأن المجني عليه يساعد المدعي العام في جمع أدلة الاتهام، ويسهم في

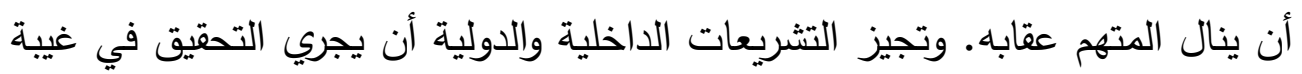

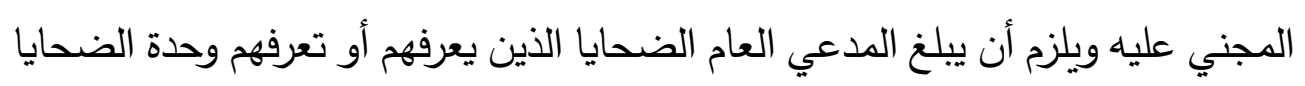

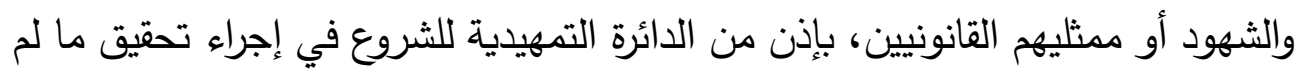

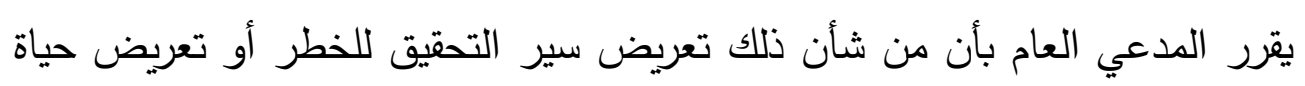

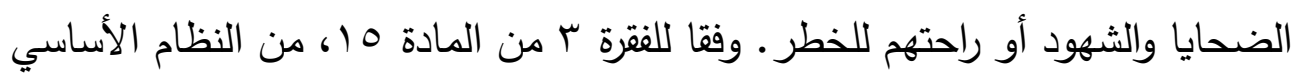

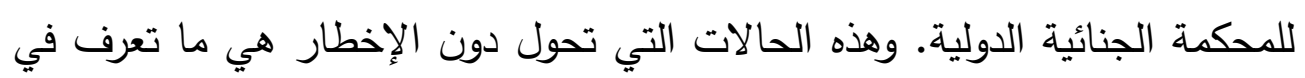

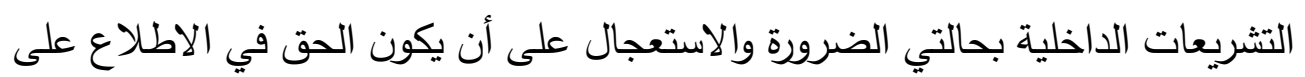
الإجراءات التي حصلت في غيبته في حالة الاستعجال بمجرد انتهاء تلك الضرورة.

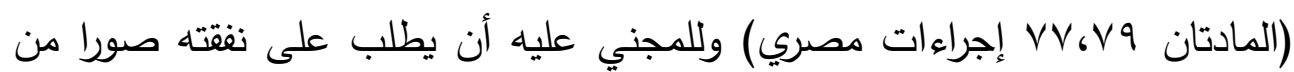

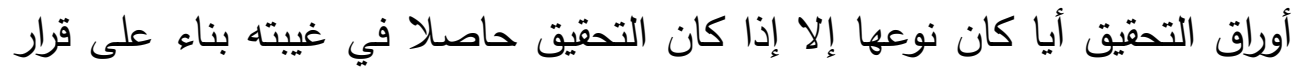
صادرا (المادة ؟1 إجراءات مصري) ولا شك في أن المجني عليه مفيد في التحقيق.

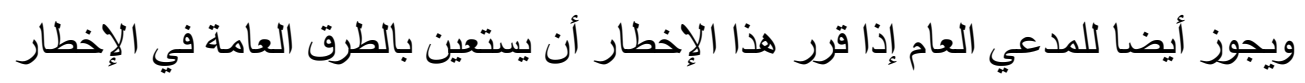

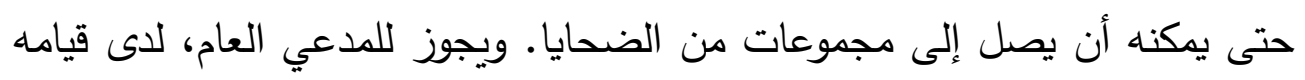

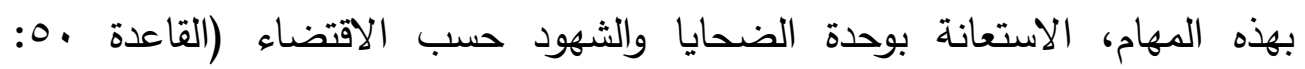

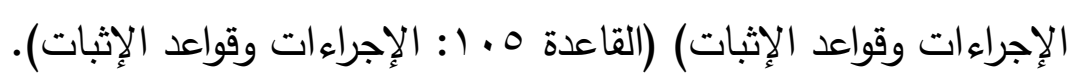

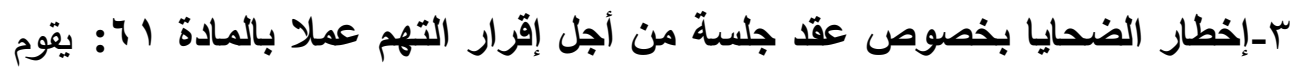

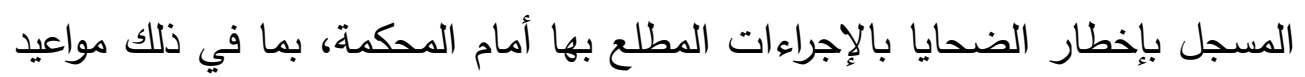
جلسات الاستماع أو أي تأجيل لها، وموعد النطق بالحاءل بالكم- الطلبات والبيانات

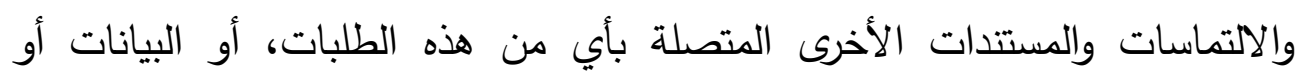

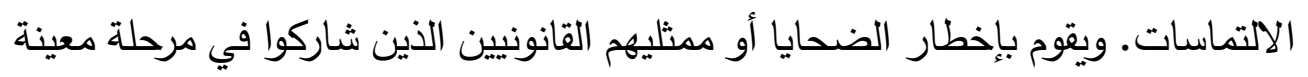

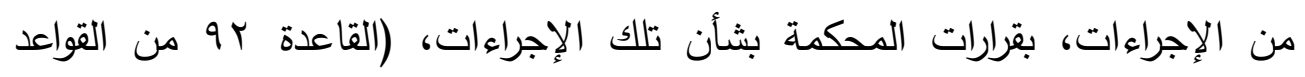

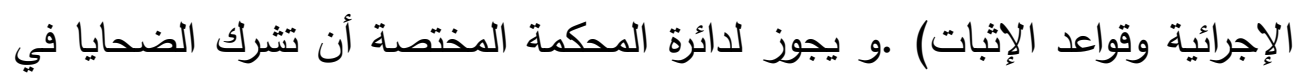

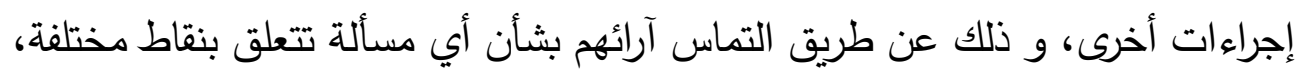




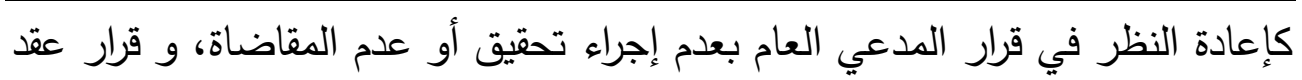
جلسة إقرار التهم، أو تعديل التهم ، و إجراء محاكمات جماعية أو فردية للمتهمين.

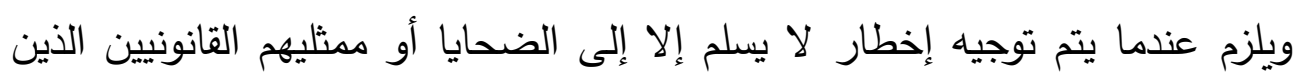

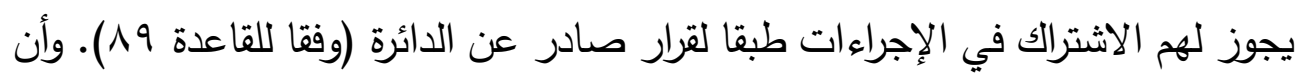

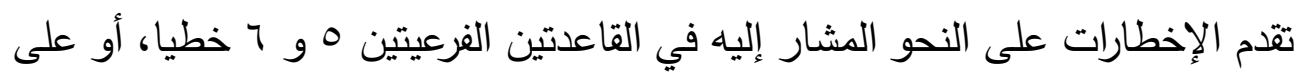

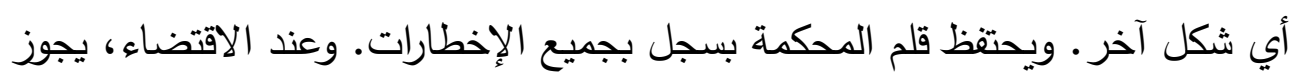

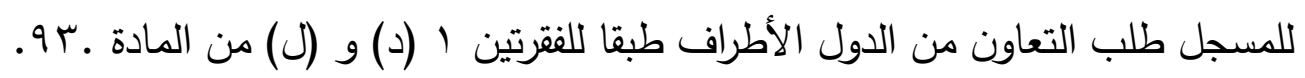

\section{المطلب الثالث}

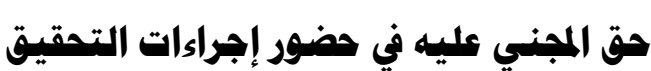

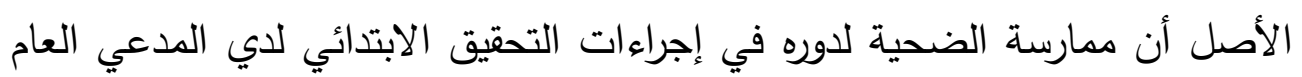

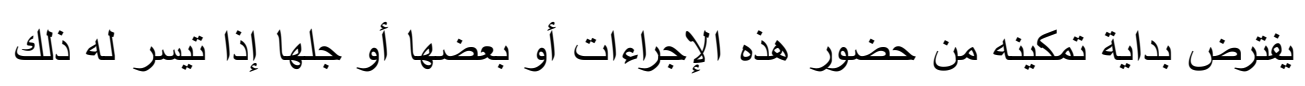

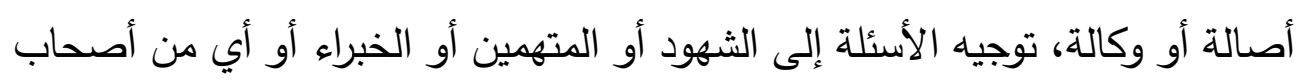

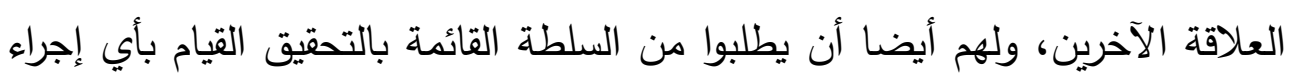

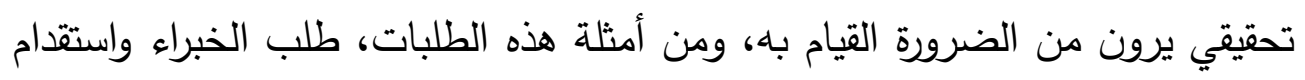
الشهود أو جلب أشخاص آخرين بصفة متهمين أو أن يطلبوا من هيئة التحقيق الانتقال

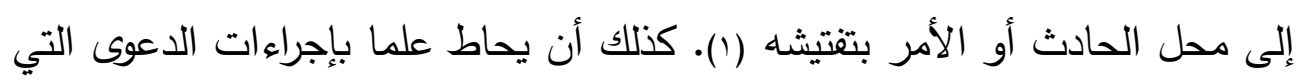

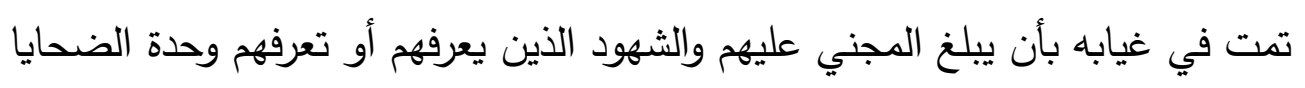
والثهود أو ممثليهم القانونيين، وله أن يستعين بالطرق العامة في الإخطار حتى يمكنه

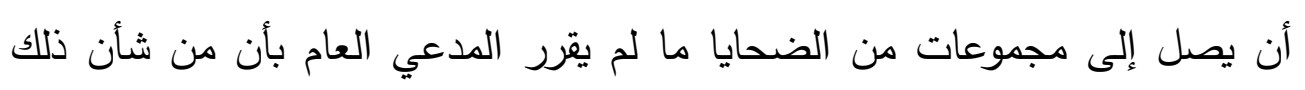

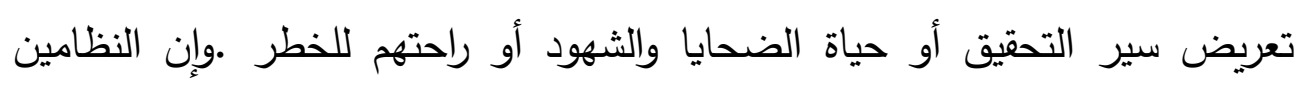

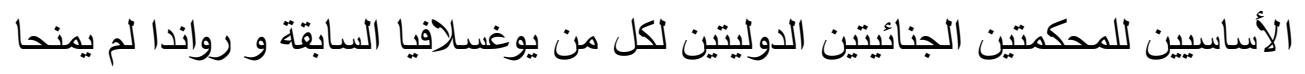

( (1) الأستاذ العكيلي، عبد الأمير أصول الإجراءات الجنائية في قانون أصول المحاكمات، جا ،المرجع السابق ، ص 9 . 
r.r. · مجلة روح القوانين - العدد الواحد والتسعون - إصدار يوليو

الضحايا أية إمكانية للتدخل للمجني عليهم ضحايا الجريمة الدولية بصفة للمشاركة في إجراءات التحقيق خلاف صفتهم كشهود على الجريمة.و إن النظام الذي تبناه

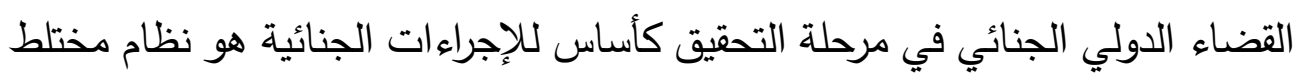

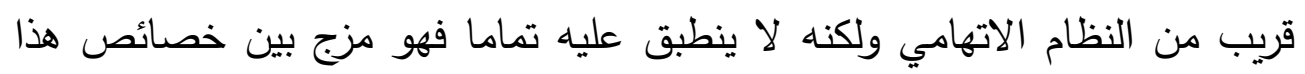

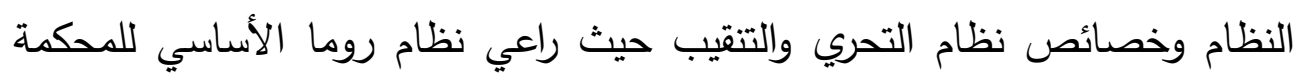
الدولية الجنائية بالتوفيق بين النظامين وهما النظام الاتهامي ونظام التحري والتتقيب راعي

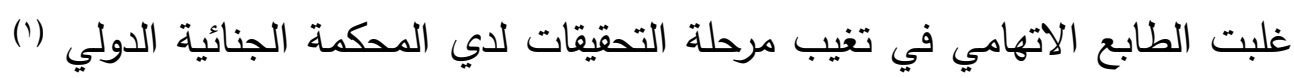

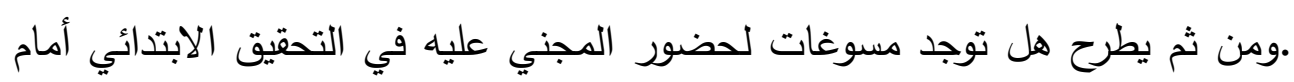

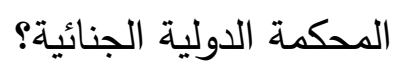

يتضح تباين موقف التشريعات الجنائية من حق المجني عليه وحقه بين اتجاهين هما:

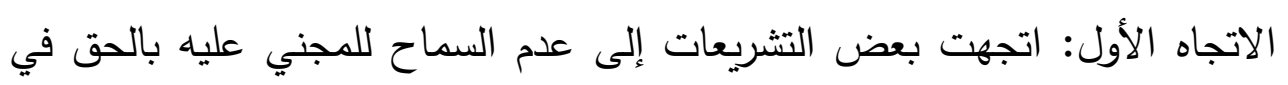
الحضور والاطلاع على إجراءات التحقيق وذلك باعتبار أن الددعي العام يمثله في الأني

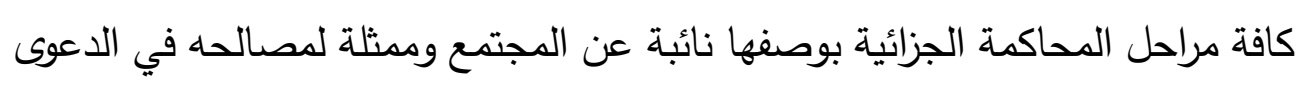

(ن) الجنائية

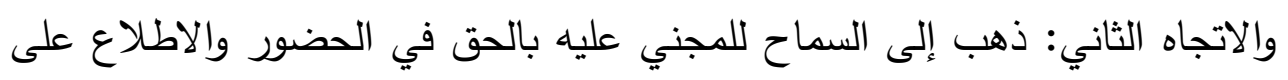

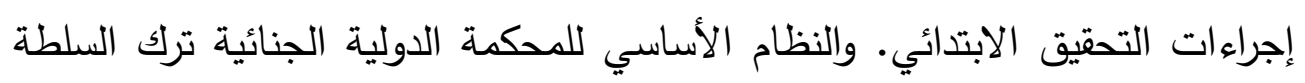

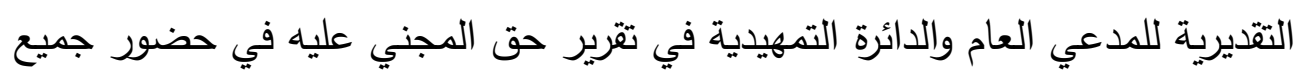

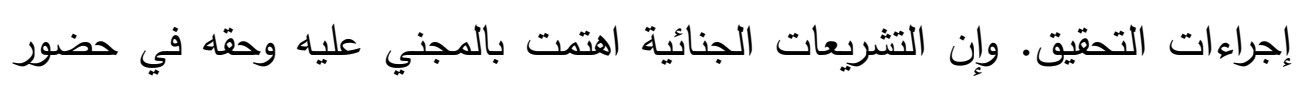

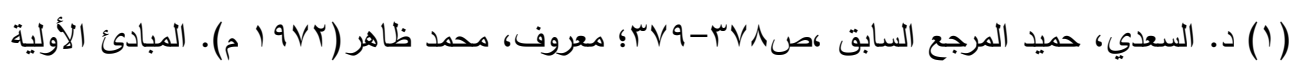

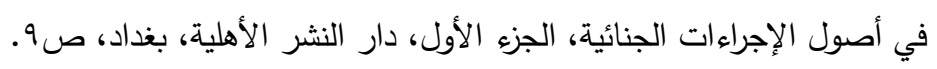

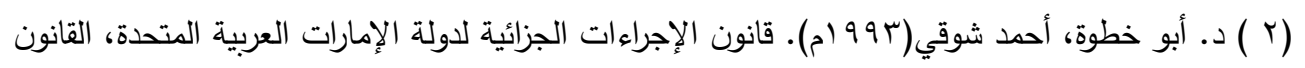

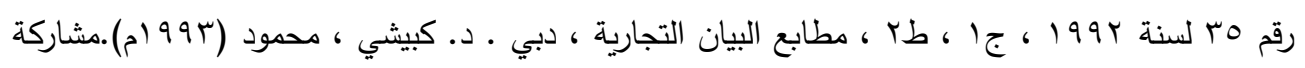

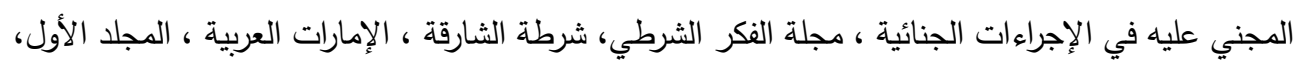

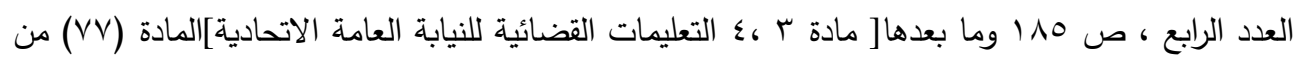

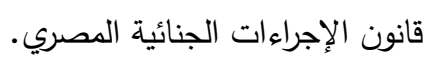


إجراءات الدعوى الجنائية وقد أزال المشرع السرية عن إجراءات التحقيق الابتدائي بالنسبة للخصوم ووكلائهم ومن بين هؤلاء المجني عليه (1).وذلك كما يلي: ا-إن يتمكن المجني عليه من الوقوف على مجريات التحقيق مما يحقق مبدأ المواجهة، وذلك بتمكين من تتعرض حقوقه ومصالحه لتصرف ما من الإحاطة به، حتى يستطيع إعداد دفاعه، أو على الأقل تقديم وجهة نظرة (Y). وإن يتمكن من إبداء التعليقات والدفاع ودحض كل ما يقدم من المتهم لإخفاء الحقيقة. وذلك حتى لا يفاجأ ضحايا الجريمة بدليل قائم ضدهم في وقت غير مناسب بحيث يتعذر تفنيده خصوصاً أن

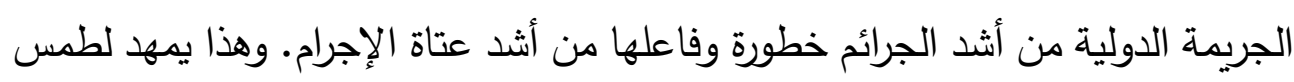
الأدلة وضياع الحق. كما يكون لله أثره في حمل القائم بالتحقيق على التزام الحيدة والتقييد بأحكام القانون (القاعدة .0 من القواعد الإجرائية و قواعد الإثبات للمحكمة الجنائية الدولية). وهذا يؤثر في حماية حقوق الضحايا خصوصا أن الدليل هو حياة الحق ومن ثم يلزم حضور المجني عليه. سواء تمت المشاركة بصفة شاهد أو بصفة ضحية مباشر (لمجني عليه) وغير مباشر (ذوي المجني عليه) قد يكون المجني عليه (الضحية المباشر) هو الشاهد الوحيد لكثف غموض وملابسات الواقعة الإجرامية، وبما يدلى بـاه من معلومات وشهادة صادقة يساعد الأجهزة المعنية في كثف غموض الجريمة وتقديم

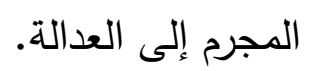
r-إن وجود الضحايا ومتابعتهم لإجراءات الدعوى الجنائية في دوائر التحقيق يعزز لايهم عنصر الثقة والطمأنينة في القائمين على التحقيق في تلك المرحلة وفي منظومة العدالة الجنائية، وأداء دورهم في الرقابة على أعمال السلطات المختصة الذي يكون لله أثره في حمل القائم بالتحقيق على التزام الحيدة والتقييد بأحكام القانون دون إغفال دور المجني عليه في إثبات الجريمة التي وقعت وفي التوصل إلى معرفة مرتكبها (. وقد قرر المشرع الفرنسي حقا للمجني عليه في ان يُخطر من قبل رجال الضبط القضائي 
F. r. · مجلة روح القوانين - العدد الواحد والتسعون - إصدار يوليو

بمجموعة من الحقوق (المادة 1/101 من قانون الإجراءات الجنائية الفرنسي الصادر

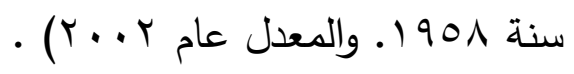
r-بإن حضور المجني عليه عند تحريك الدعوى الجنائية من جانب المدعي العام يمكنه

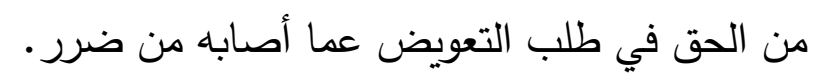

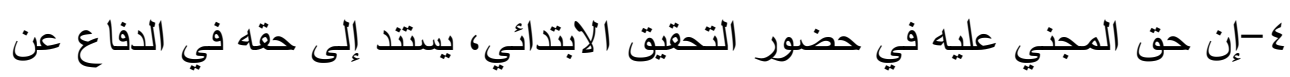

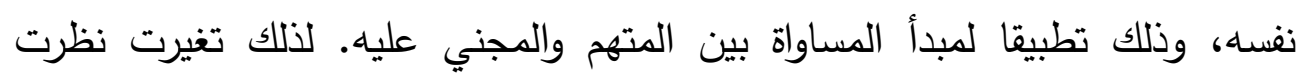

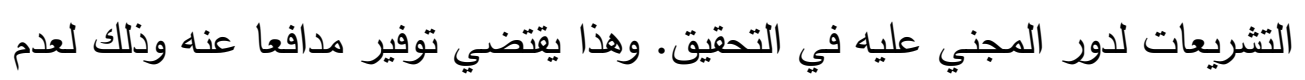

توفر الخبرة القانونية فيه حتى يشرف على التحقيق ويحفظ حقوقه مثل المتهم تماما.

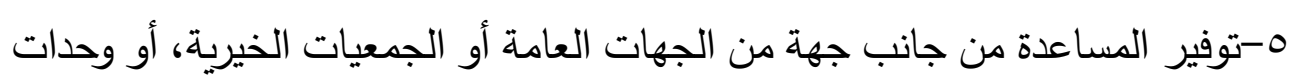

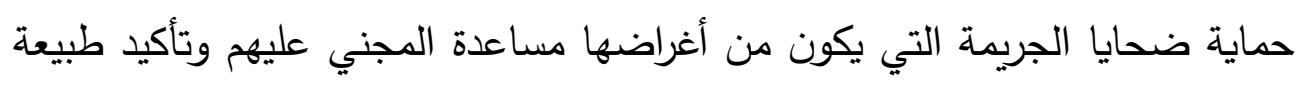

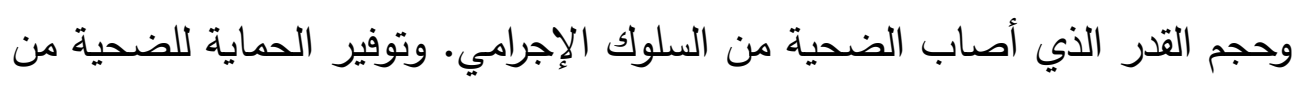
الوقوع في شباك الإجرام أو تكرراه مرة أخرى.

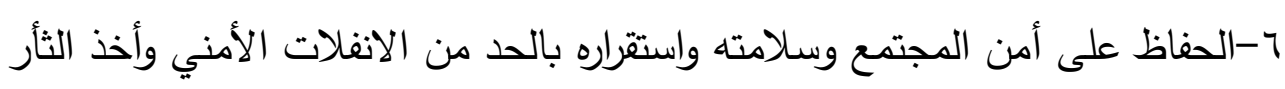
باليد. V- إمكانية زيادة فرص الصلح والتسوية خارج نظام العدالة القضائية وإجراءاتها المطولة. ^-إن الجريمة قد تقع على حقين هما حق عام، وحق خاص ولكل منهما دعوى تحميه.

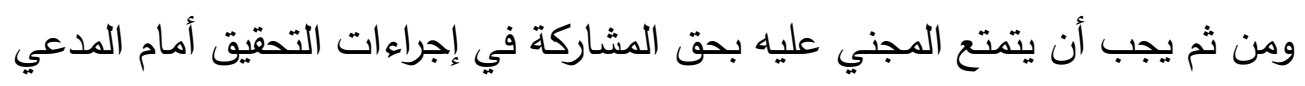

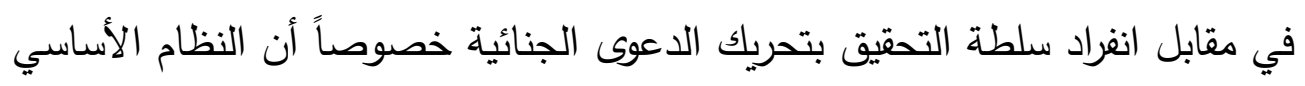

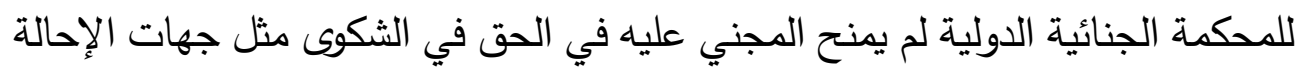

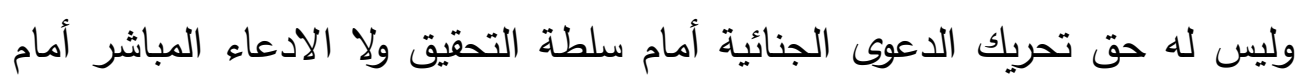
المحكمة الجنائية الدولية. ويطرح التساؤل: ما موقف النظام الأساسي للمحكمة الجنائية الدولية من حق المجني عليه في حضور إجراءات الدعوى الجزائية ومنها حضور إجراءات التحقيق الابتدائي

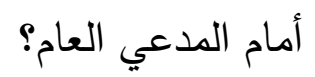


الجواب كما يأتي:

1-عهد النظام الأساسي في (المادة ه / 1 ) للمدعي العام البدء في التحقيق بعد التحقق من جدّيّة هذه الدعاوي وصحتها، وذلك بناءً على المعلومات التي يتلقاها من أي لي مصدر، بما في ذلك المجني عليهج، كما نصت (المادة 10 / مب) من النظام الأساسي للمحكمة الجنائية الدولية "إذا استنتج المدعي العام أن هنالك أساساً معقولاً للشروع في إجراء تحقيق يقدم إلى الدائرة التمهيدية طلباً للإذن بإجراء تحقيق, مشفوعاً بأية مواد إداد مؤيدة يجمعها كما يجوز للمني عليهم إجراء مرافعات لدى الدائرة التمهيدية وفقاً للقواعد الإجرائية وقواعد الإثبات."فإذا رأت الدائرة التمهيديّة سبباً كافِيا للبدء بالتحقيق فإنّها تُصدِر قراراً للمدعي العام بالموافقة على التحقيق. وقد نصت (المادة ؟ه / إب) من النظام الأساسي للمحكمة الجنائية الدولية على حضور المجني عليه التحقيق الابتدائي أمام المدعي العام إذ إن " للمدعي العام أن يجمع الأدلة وأن يفحصها وأن يطلب حضور الأشخاص محل التحقيق والمجني عليهح والثهود وأن يستجوبهم" إضافة لما تقضي التهي (المادة ج/ من النظام الأساسي للمحكمة الجنائية الدولية "تسمح المحكمة للمجني عليهم، حيثما تتأثر مصالحهم الشخصية، بعرض آرائهم وشواغلهم والنظر فيها في أي مرحلة من الإجراءات تراها المحكمة مناسبة وعلى نحو لا يمس أو يتعارض مع حقوق المتهم ومع مقتضيات إجراء محاكمة عادلة ونزيهة، ويجوز للممثلين القانونيين للمجني عليهم عرض هذه الآراء والشواغل حيثما تري المحكمة ذلك مناسباً وفقاً للقواعد الإجرائية وقواعد الإثبات." وجبر الأضرار والإجراءات التالية للمحاكمة. وإن للمدعي العام أن يباشر إجراءات التحقيق في غيبتهح متى رأى ضرورة أو حالة الاستعجال، ولهؤلاء الحق في الاطلاع على الأوراق المثبتة لهذه الإجراءات وللخصوم دائما الحق في استصحاب وكلائهم في التحقيق.

Y-نصت القاعدة الو من القواعد الإجرائية وقواعد الإثبات على أن الممثلين القانونيين

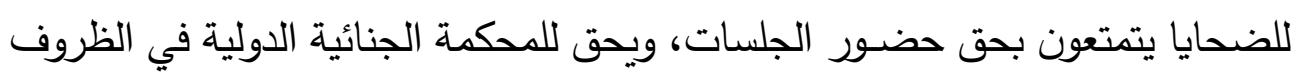
الاستثنائية فقط حصر مشاركتهم بفترة المرافعة لكن يجوز للممثلين القانونيين أن يطلبوا 
r.r. · مجلة روح القوانين - العدد الواحد والتسعون - إصدار يوليو

من المحكمة طرح الأسئلة مفيدة في إيضاح الحقيقة و تحقيق العدل إن ضحايا الجرائم

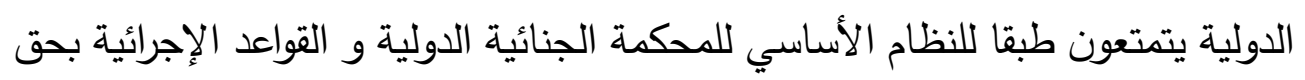

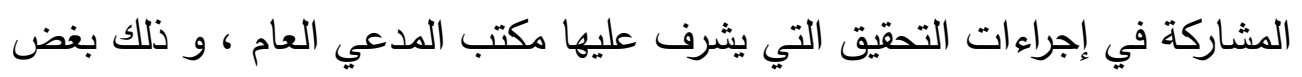
النظر عن الطريقة التي تمارس المحكمة اختصاصها ، سواء تمت بناء على تلقي إحالة من جهة مرخص لها بذلك ، أو بناء على قرار من المدعي العام من تلقاء نفسه.

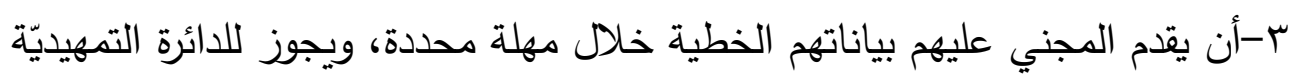

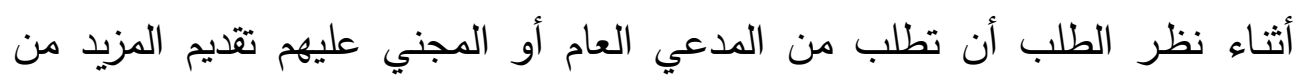

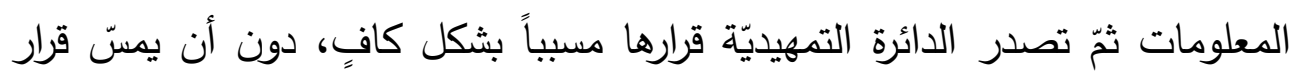
الدائرة هذا ما تقرره المحكمة -فيما بعد-فيما يتعلق بمسائل الاختصاص والمبنوليّة.

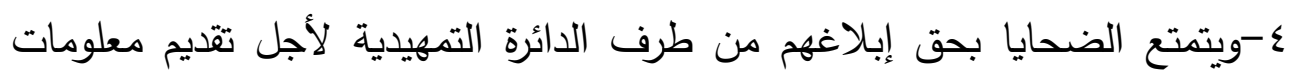

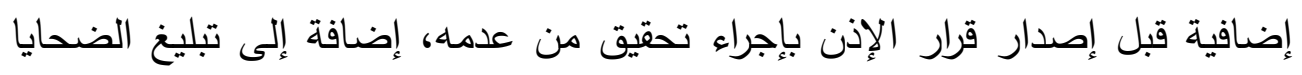
الذين قدموا بيانات بالقرار المتخذ طبقا للقاعدة ـ0 من القواعد الإجرائية وقواعد الإثبات.

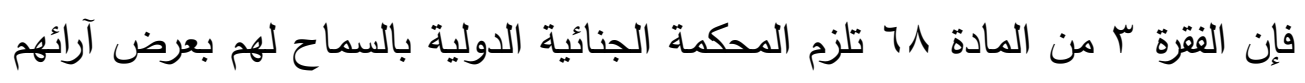

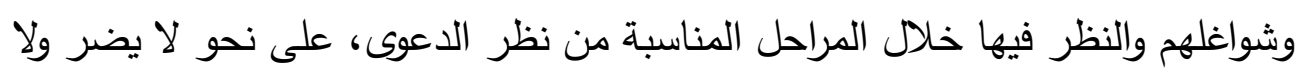

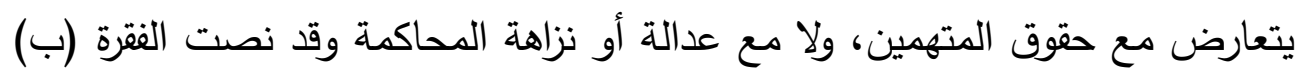

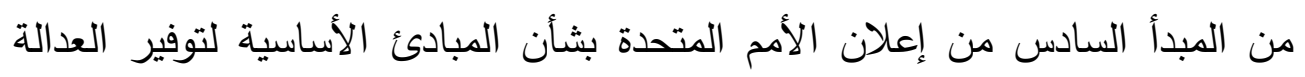

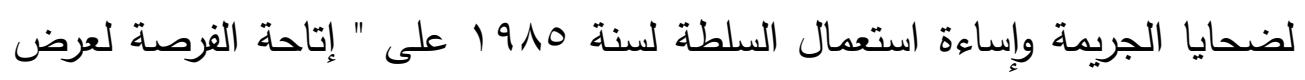

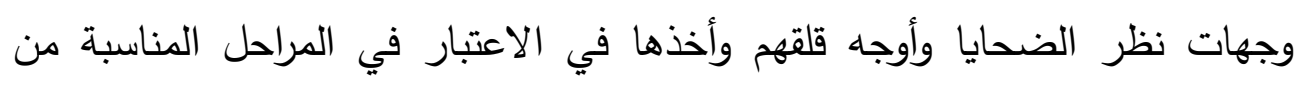

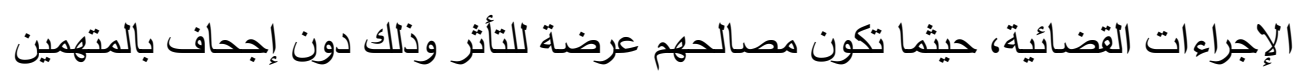
وبما يتمشى ونظام القضاء الجنائي الوطني ذي الصلة." ويخضع اشتراك الضحايا في جميع الإجراءات من حيث المبدأ إلى القاعدة 19 من القواعد الإجرائية وقواعد الإثبات.

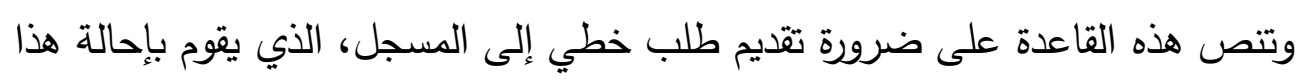

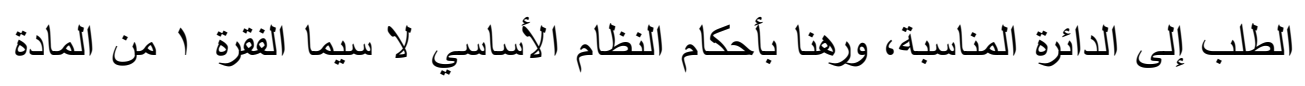

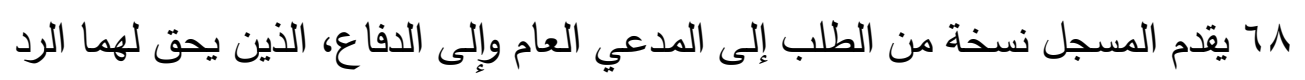




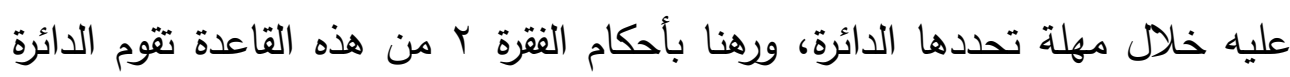
عندئذ بتحديد الإجراءات القانونية والطريقة التي تعتبر ملائمة للاشتراك فيها، والتي يمكن أن تتضمن الإدلاء ببيانات استهلالية وختامية.

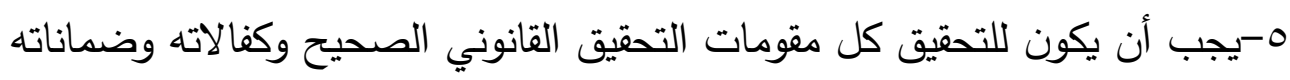

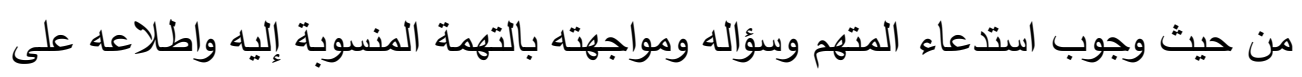
الأدلة التي تثبت وقوعها منه، وذلك ليتمكن من الوقوف على عناصر التحقيق وسند

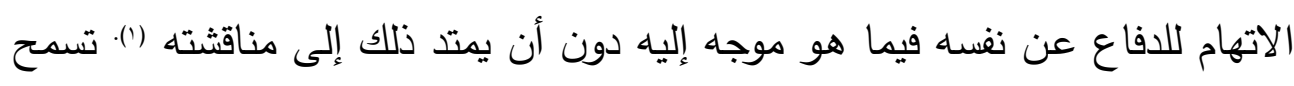

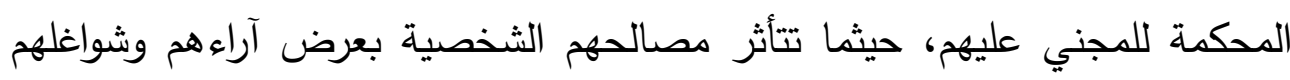

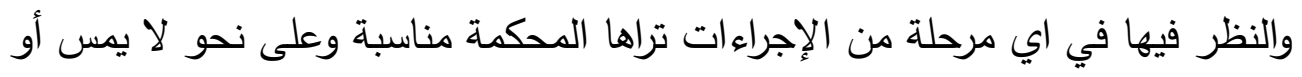

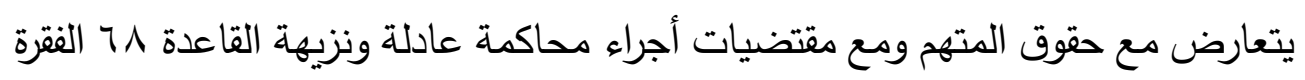
r ـ ـ ومما تقدم نجد ان الحق بالمشاركة مقيد بقيود تتمثل بالآتي: أ-أن تكون هنالك مصلحة خاصة بالتدخل في الإجراءات. وتعدد المشاركة المستقلة

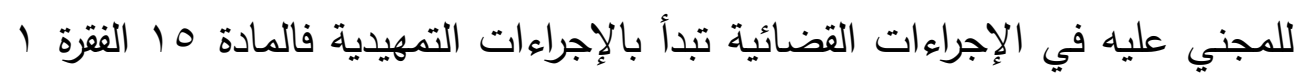

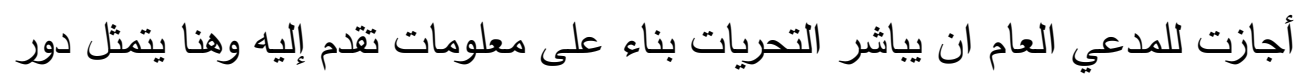

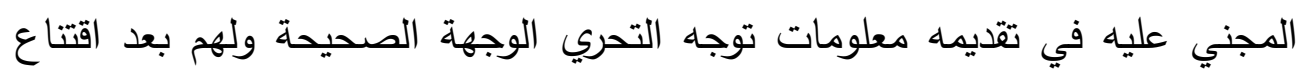

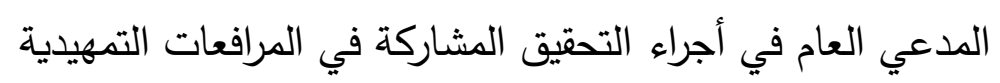

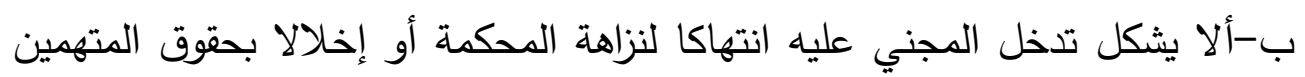
المادة 10 الفقرة ب كما للمجني عليهم الحق في الأخطار بشأن قرار الددعي العام بعدم الثروع في تحقيق او عدم المقاضاة طبقا للمادة سم كما للمجني عليهم الحق في تقديم مقترحاتهم فيما يتعلق بمدى اختصاص المحكمة بنظر الدعوى وتشكل مشاركة المجني عليه في لإني

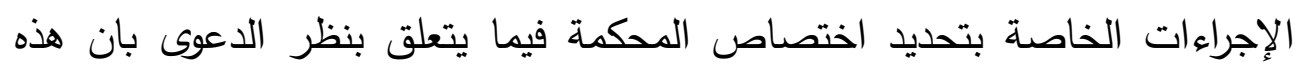

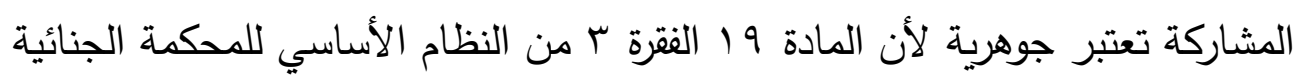




$$
\text { r. r. · مجلة روح القوانين - العدد الواحد والتسعون - إصدار يوليو }
$$

الدولية المجني عليهم الحق في تقديم ملاحظات فيما يتعلق بالمقبولية اي مدى

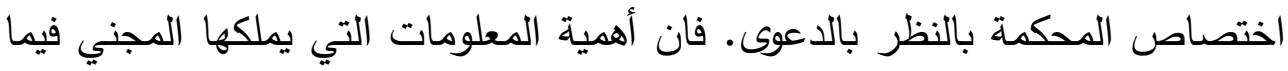

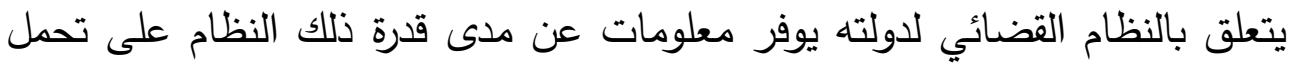

$$
\text { المسؤولية في القيام بالإجراءات القانونية (). }
$$

إن ممارسة المجني عليه لحقه في المشاركة بالإجراءات القضائية تأخذ أشكالا متعددة

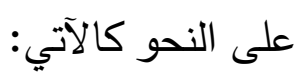

*-تقديم الدفوع سواء شفهية او تحريرية ما لم يقرر القاضي لظروف القضية أن تكون

الدفوع مكتوبة. - مان.

*--إن المجني عليه له قراءة أو الاستماع إلى الأدلة الدكتوبة او المسجلة.

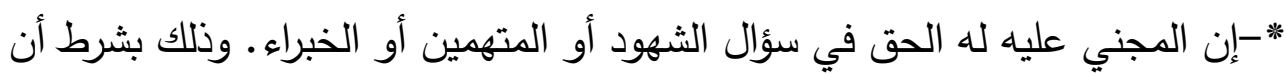

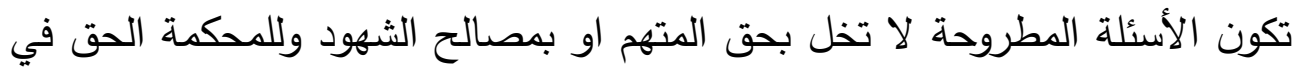
توجيه المجني عليهم بضرورة سلوك مسلك خاص بتوجيه الأسئلة.

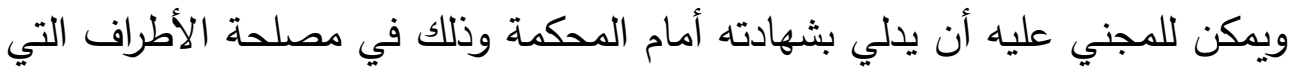
طلبت منه الشهادة فمشاركة المجني عليه بصفته هذة اختيارية يخدم مصالحة الثخصية بخلاف كونه شاهد فهو يخدم مصالح المحكمة والاطراف التي طلبت منه ذلك. بينما مشاركته كثاهد تكون على اساس طلب من المدعى عليه او المحكمة او أحد المجني عليهم المشتركين في اجراءات المحكمة.

\section{المطاب الرابع}

\section{حق الجني عليه في الحماية الجنائية}

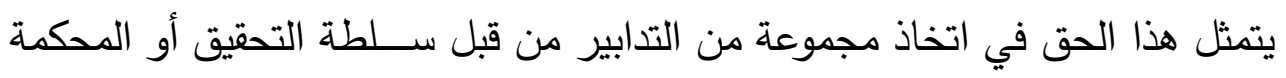

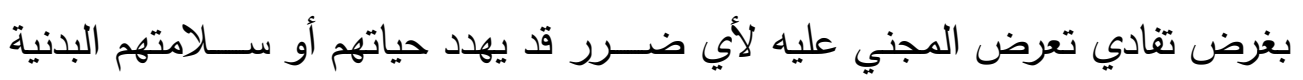

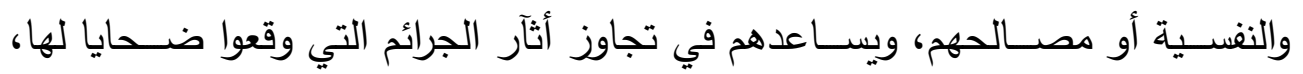


وتتتوع تلك التدابير بحســـب الغاية المرجوة منها، مثل: أن يتم توفير إقامـة مؤمنـة للمجني عليهم والثـهود وأسرهم. ويعد حضور المحامي ضمان لاحترام حقوق المجني

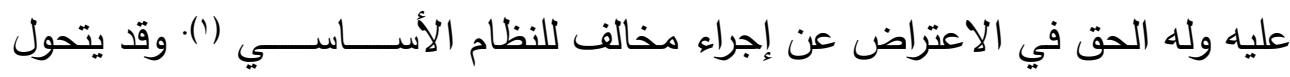
المتهم إلى مجني عليه إذا تعسفت السلطة معه في تعذيبه للنكاية السياسية، خصوصا في الجرائم السياسية. وقد قرر المواثيق الدولية حماية المجني عليه ونص المبدأ الرابع

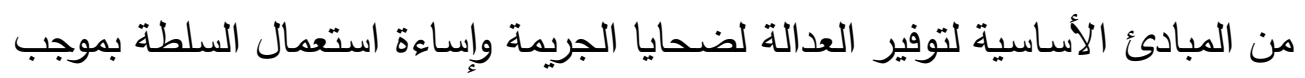

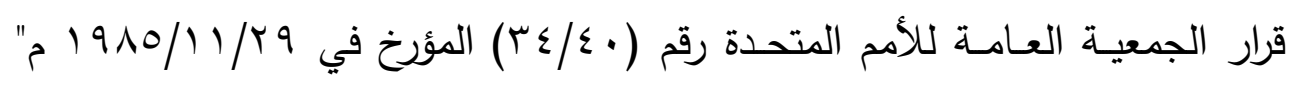
وينبغي معاملة الضـحايا برأفة واحترام لكرامتهم. ويحق لهم الوصـول إلى آليات العدالة

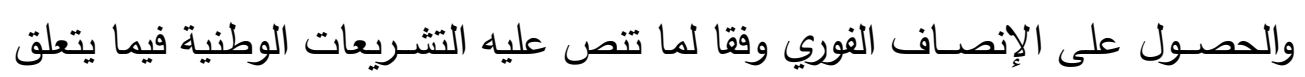
بالضرر الذي أصابهم. وحظر استعمال الأساليب اللاإنسانية أثناء التحقيق مع المجني

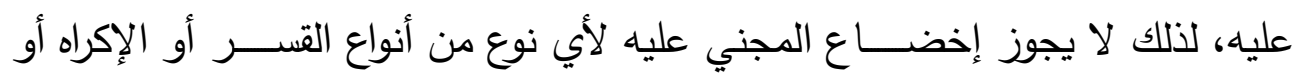
التهديد وهذا الأمر محظور في ظل القوانين الوطنية والاتفاقات الدولية حســب المادة

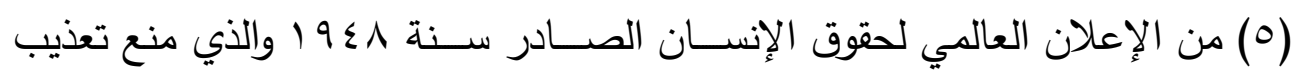
المتهم وأكدت ذلك المادة (V) من العهد الدولي للحقوق المدنية والسياسية كذلك نصت الإن المادة الأولى من إعلانا بشأن حماية جميع الأشخاص ضد التعذيب أو المعاملة غير

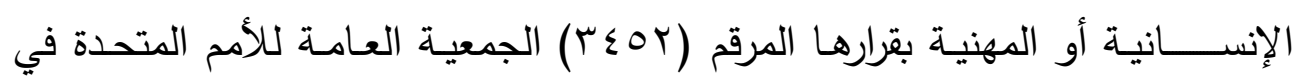

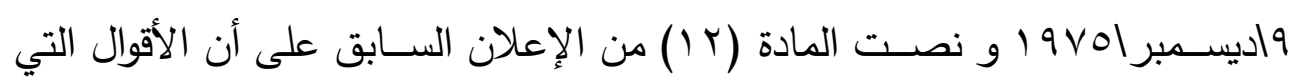
تصدرر بناء على تعذيب لا يمكن الاستتاد إليها كدليل في الدعوى؛ نتيجة أن التعذيب الإني يجعل أقواله موضع الثك ولا يمكن الاطمئنان إليها والركون لها ولا تصلح لإقامة حكم

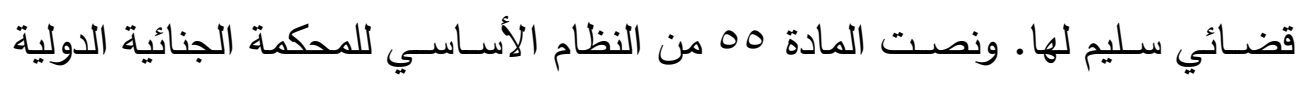

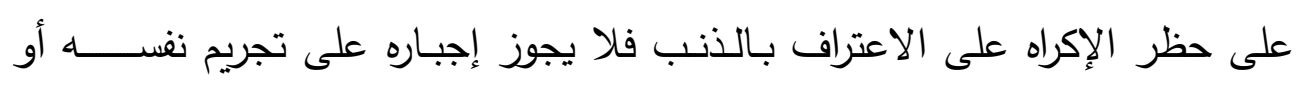
الاعتراف بأنـه مذنب في أيـة مرحلـة من مراحل التحقيق وحتى أثنـاء المحاكمـة. ولا

( (1). العيسي، طلال ياسين \&الحسناوي،(9 . . rم). علي جبار المحكمة الجنائية الدولية : دراسة قانونية ،

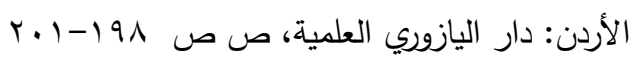


r.r. · مجلة روح القوانين - العدد الواحد والتسعون - إصدار يوليو

يجوز توقيف أي شخص وفقا لنظام روما الأساسي إلا في حالة توفر الأسباب الكافية

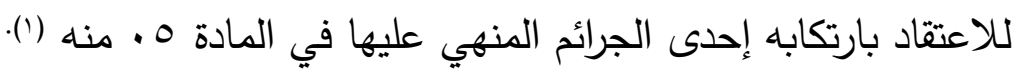
و الجهات التي تتولى نوفير الحماية هي على الوجه الآتي:

\section{أولا: دور وحدة الجني عليهم والشهود في حماية الجنبي عليه:}

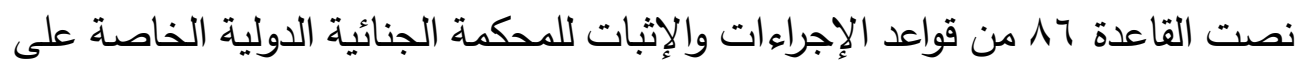

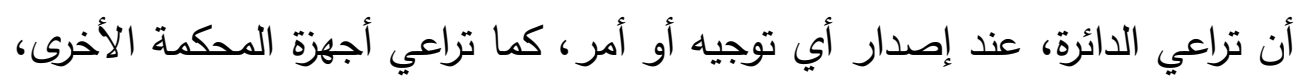

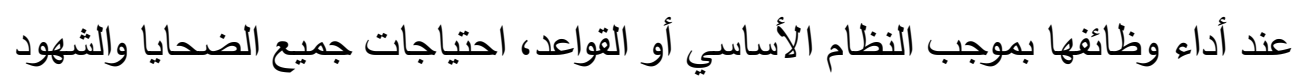

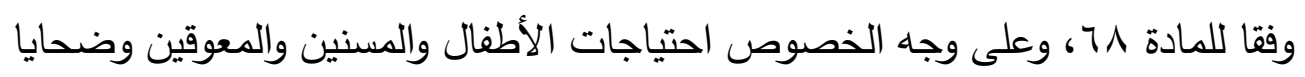
العنف الجنسي أو العنف القائم على نوع الجنس. وتتشا تحت ظل دائرة المسجل وحدة الهـا حماية المجني عليهم والثهود وترجع أهمية تشكيل هذه الوحدة الى سببين هما: أولهما

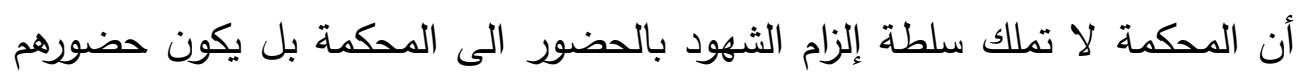

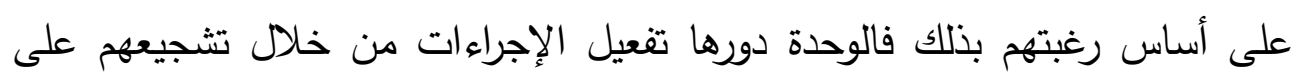

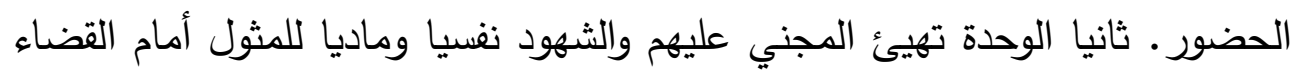

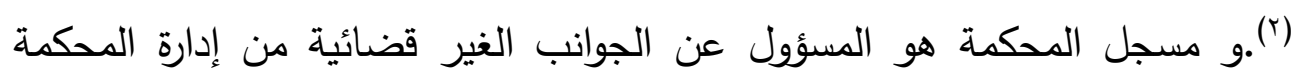

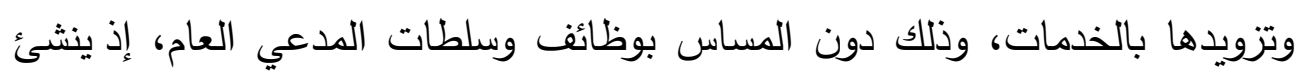
المسجل وحدة للمجني عليهم والثهود ضمن قلم المحكمة، وتوفر هذه الوحدة، بالتشاور

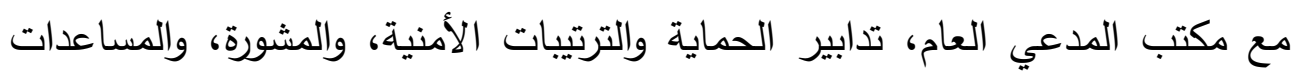

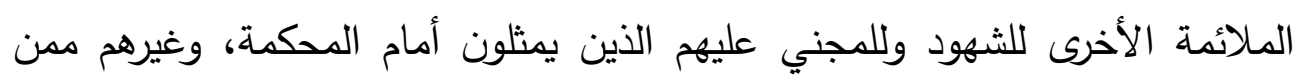

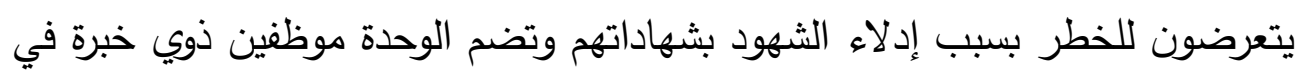

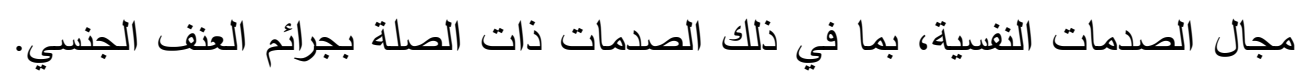

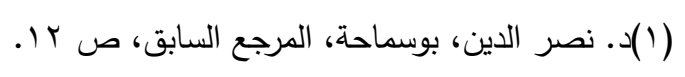

Thordis ingadottir and cesare p.r Romano, international criminal court the victims and witnesses unit (article ( $r$ ) $\varepsilon r-r$ of the Rome statute ) Discussion paper.march $r \ldots p r$ 


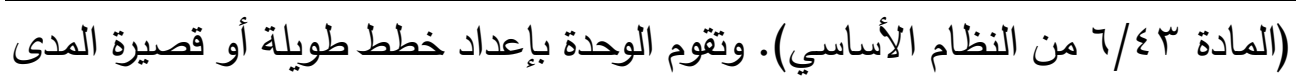
لتوفير كافة أنواع الحماية والمساعدة لهم وعلى المسجل إبلاغ المجني عليهم بإنشاء الوحدة والخدمات التي تقدمها ومن أهم مسؤولية تقع على عاتق هذه الوحدة ما يأتي: ا-ضمان سرية أماكن إقامة المجني عليهم او جنسياتهم وعوائلهم من الأشخاص الذين قد يلحقون أذى بهم وتشكيل وحدتين منفصلتين تعمل احدهما مع شهود المدعي العام

$$
\text { ( شهود الادعاء) والأخرى مع شهود المتهمين ( شهود الدفاع ) ونتئ }
$$

ץ-تقدم وحدة المجني عليهم المساعدة والمشورة النفسية والاجتماعية للضحايا وللشهود والمساعدة الطبيعية والرعاية الصحية لضحايا العنف الجنسي والأطفال والمسنين وبالمقابل تقدم المساعدة المالية للمعوزين والمشورة القانونية لأجهزة المحكمة لتوفير التدابير المناسبة والتدابير الأمنية ولرفع مستوى الوعي. r-أن تمد جسور العلاقة مع الدول والمنظمات الدولية الحكومية وغير الحكومية وذلك ولك الك لتلقي الدعم منها.

\section{ثانيا: دور المدعي العام في حماية المجني عليه:}

ويقتضي نظام روما حماية المجني عليه باتخاذ تدابير الحماية ومنها: ا-التزام المدعي العام خلال التحقيق أو المقاضاة باحترام مصالح المجني عليهم وأوضاعهم الشخصية، بما في ذلك السن والجنس والحالة الصحية، وأن يأخذ في

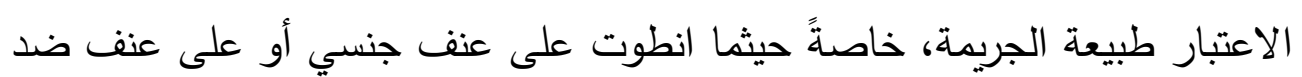

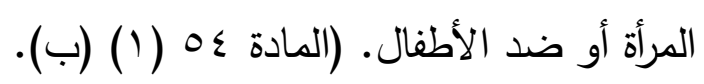

r-إن المدعي العام يلتزم باتخاذ التدابير المناسبة خاصةً خلال التحقيقات وعمليات الملاحقة القضائية لحماية أمن المجني عليهم والشهود وسلامتهم النفسية والبدنية وكرامتهم وخصوصياتهم. (المادة ^\ / / من النظام الأساسي للمحكمة الجنائية الدولية). إذ تلزم المحكمة المدعي العام باتخاذ تدابير من أجل حماية الضحايا والشهود، واتخاذ التدابير لضمان فعالية التحقيق في الجرائم التي تدخل في اختصاص المحكمة والمقاضاة عليها، ويحترم مصالح المجني عليهم والشهود وظروفهم الشخصية، بما في ذلك السن 
F. r. · مجلة روح القوانين - العدد الواحد والتسعون - إصدار يوليو

ونوع الجنس والصحة ويأخذ في الاعتبار طبيعة الجريمة وبخاصة عندما تتطوي الجريمة على عنف جنسي أو عنف بين الجنسين أو عن ضد الأطفال". وكذلك اتخاذ التدابير

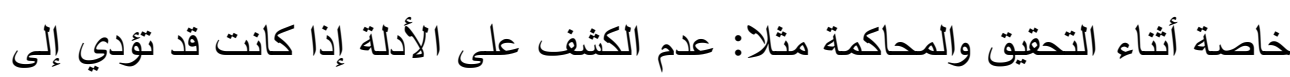
تعريض سلامة أي شاهد أو أسرته لخطر جسدي. r-يجوز للمدعي أن يطلب حضور الأشخاص محل التحقيق والمجني عليهم والثهود،

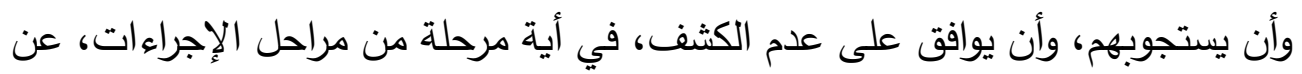

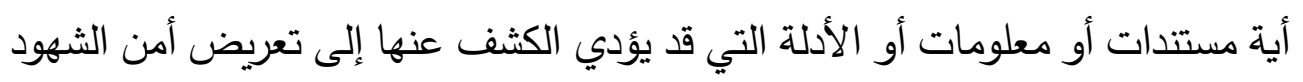

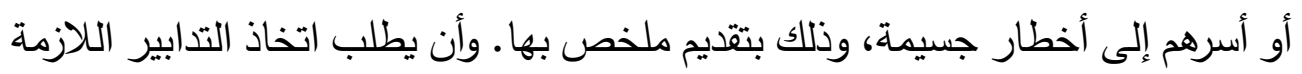

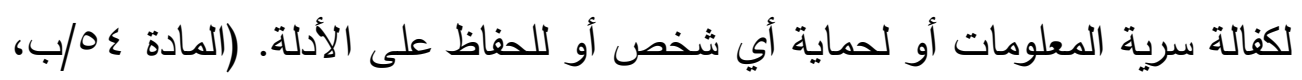

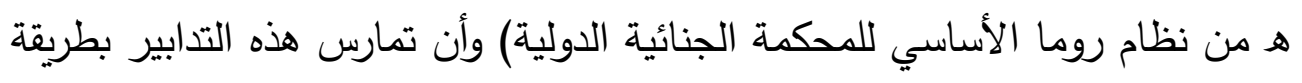
لا تمس حقوق المتهم أو تتعارض معها أو مع مقتضيات إجراء محاكمة عادلة ونزيهة.

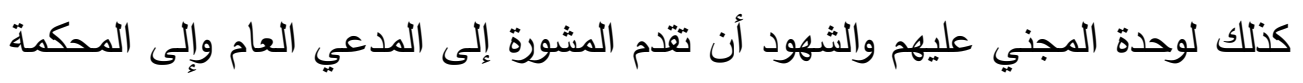

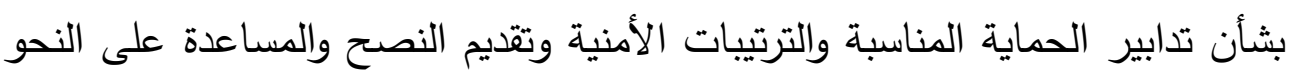

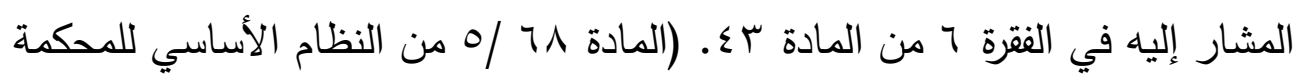
الجنائية الدولية).

ويلزم أن تتخذ هذه الإجراءات بالتعاون مع وحدة حماية المجني عليهم والثهود كذلك الكائل

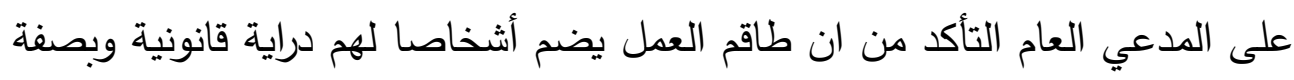

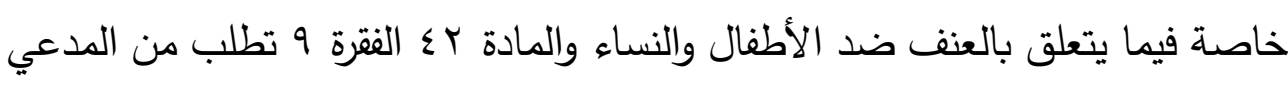

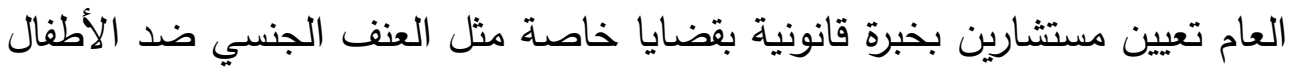

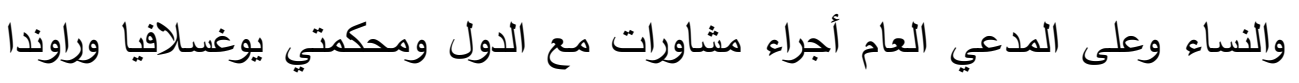
والمنظمات الدولية وغير الدولية.

ثالثا: دور الدائرة التمهيدية في حماية المني عليه: يدخل في وظائف الدائرة التمهيدية

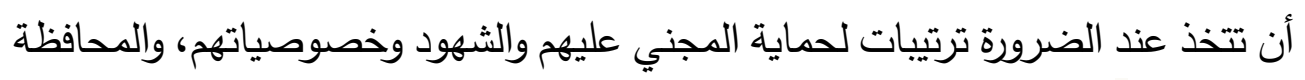

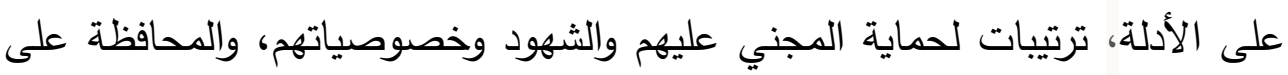


الأدلة وحماية الأشخاص الذين ألقى القبض عليهم أو مثلوا استجابة لأمر الحضور، وحماية المعلومات المتعلقة بالأمن الوطني (المادة /OV/OV، هـ من نظام روما الأساسي للمحكمة الجنائية الدولية) وأن تصدر ، بناءً على طلب المدعي العام، القرارات والأوامر اللازمة لأغراض التحقيق.

رابعا: دور الدائرة الابتدائية في حماية الجبني عليه: ويقع على عاتق المحكمة ان تتأكد من أن الإجر اءات التي اتخذت لحماية المجني عليهم فعالة وسريعة وعادلة وأن تتعقد في جو من الاحترام التام لحقوق المتهم والمراعاة الواجبة لحماية المجني عليهم والشهود. كحماية المعلومات السرية، وجمع الأدلة واتخاذ التدابير اللازمة لحماية المتهم والشهود والمجني عليهم. وهذا يعنى أن لغرف المحكمة الجنائية الدولية دور كبير في حماية

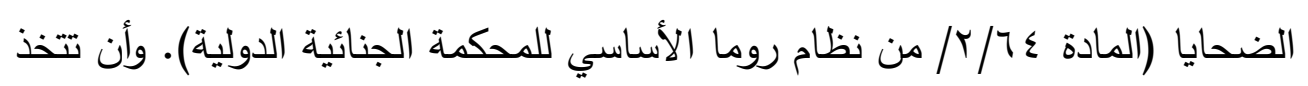
المحكمة التدابير المناسبة لحماية أمان المجني عليهم والثهود وسلامتهم البدنية والنفسية وكرامتهم وخصوصيتهم. وتعطي المحكمة في ذلك اعتباراً لجميع العوامل ذات الصلة

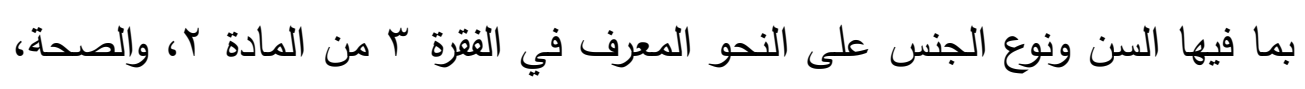
وطبيعة الجريمة، ولا سيما، عندما تتطوي الجريمة على عنف جنسي أو عنف بين الجنسين أو عنف ضد الأطفال ويتخذ المدعي العام هذه التدابير، وبخاصة في أثناء التحقيق في هذه الجرائم والمقاضاة عليها، ويجب ألا تمس هذه التدابير أو تتعارض مع حقوق المتهم أو مع مقتضيات إجراء محاكمة عادلة ونزيهة. و بينت القاعدة NV من

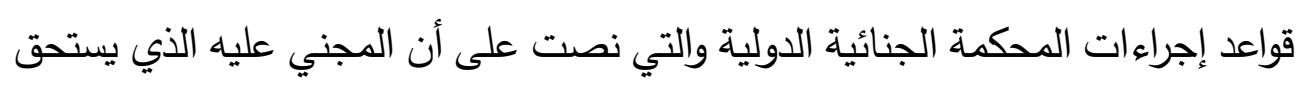
الحماية هو ذلك الشخص الذي ورد تعريفه في المادة 1 من قواعد الإجراءات إما الإجراءات المتخذة لتوفير الحماية فلم تنص المادة على إجراءات معينة بل أعطت سلطة تقديرية واسعة للمحكمة لتقرير تلك الإجراءات وحسب طبيعة كل قضية على حدة إنما أعطت القاعدة NV / Tن قواعد إجراءات المحكمة الجنائية الدولية "يجوز للدائرة أن تعقد جلسة بشأن طلب أو التماس مقدم بموجب، الفقرة ا من القاعدة وأن تكون هذه الجلسة سرية لتقرير إن كان ينبني الأمر باتخاذ تدابير لمنع الإفصاح علنا للجمهور أو لأبون

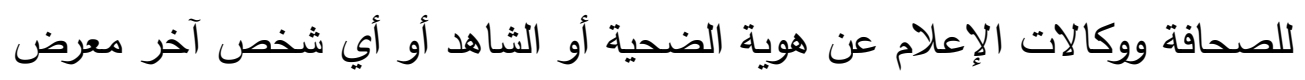


F. r. · مجلة روح القوانين - العدد الواحد والتسعون - إصدار يوليو

للخطر بسبب شهادة أدلى بها شاهد أو عن مكان أي منهم، فإن هذه التدابير مصممة

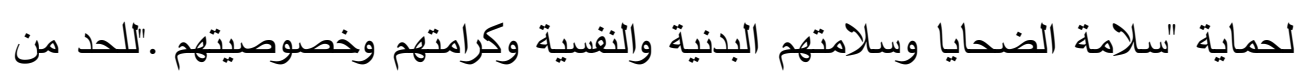

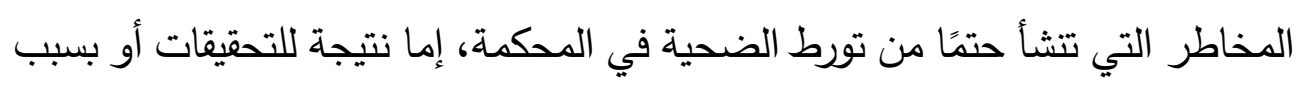

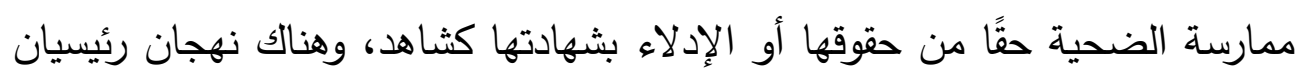
للحق في الحماية: - التماية ا-التدابير الوقائية العامة يجب تتفيذها في كل من مقر المحكمة وكذلك في مختلف

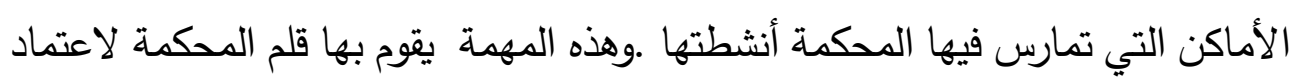

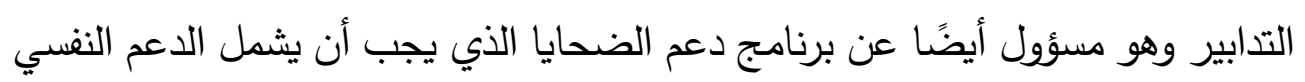

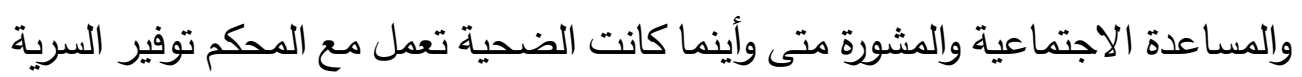
لجميع الاتصالات بين الضحايا والمحكمة، وذلك بإصدار أوامر منها:

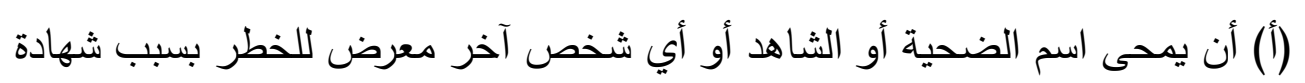

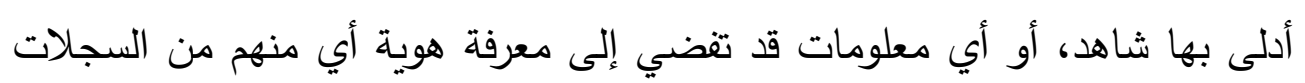

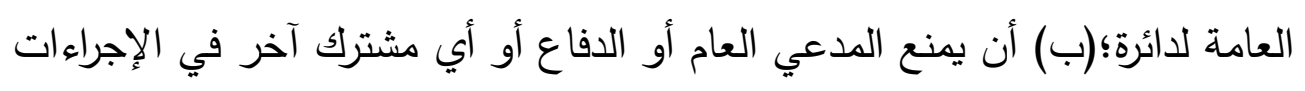

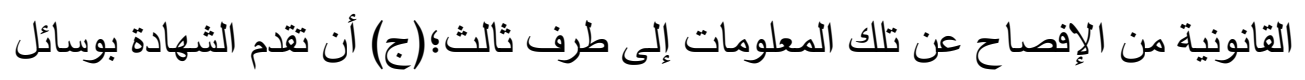

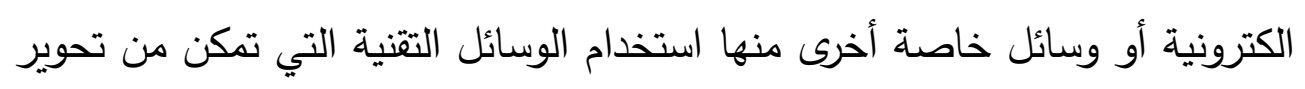

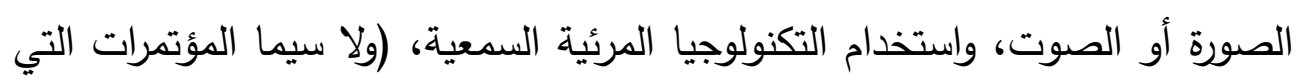

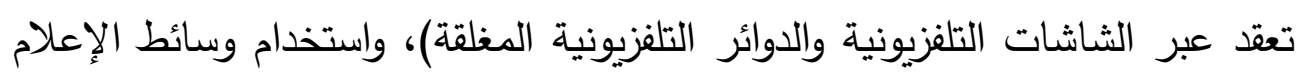
الصوتية على وجه الحصر؛(د) أن يستخدم اسم مستعار للضحية أو الثاهد أو أي أي الضئ

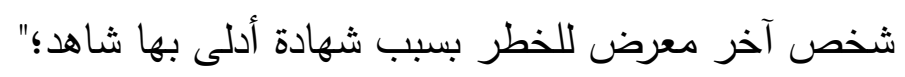

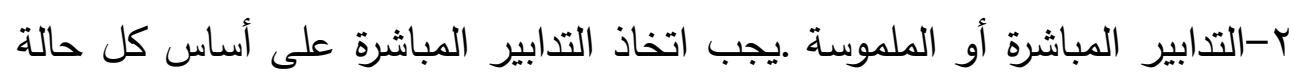

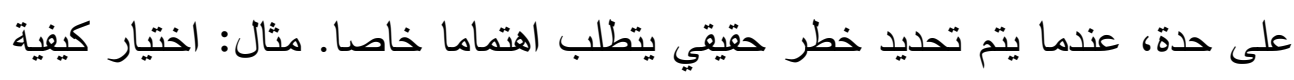

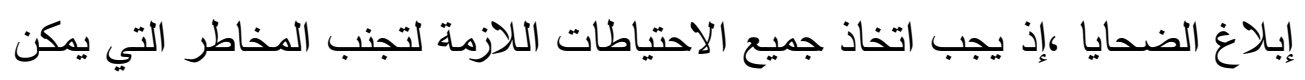

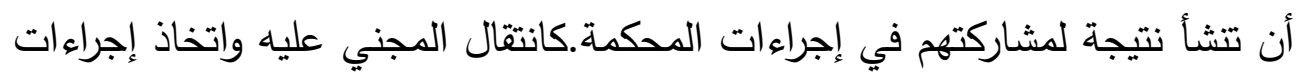

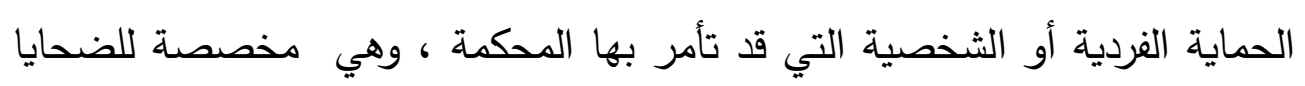


الذين يمثلون بالفعل أمام المحكمة مثال: إعادة التوطين ، ومرافقة الأشخاص الداعين و الغرض منهم هو تمكين الضحايا من الاتصال بالمحكمة بمزيد من الثقة وممارسة حقوقهم أو الإدلاء بشهادتهم في إجراءاتها فإن قلم المحكمة ملزم بالحفاظ على قاعدة بيانات إلكترونية آمنة تحتوي على معلومات عن الشهود والضحايا الذين يمثلون أمام المحكمة والأشخاص المعرضين للخطر ، من أجل مواصلة حمايتهم .وعلى هذا النحو، يلعب قلم المحكمة دورًا نشطًا في اعتماد تدابير وقائية لضمان سلامة الضحايا ورفاههم الجسدي والنفسي.

\section{خامسا: دور التعاون الدولي في هماية المهني عليه بعد الماكمة:}

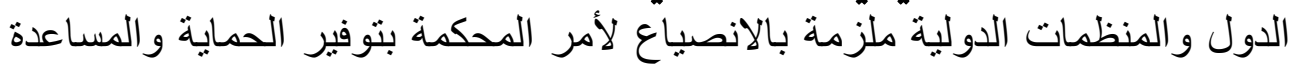

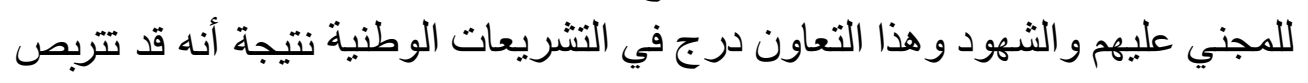
بالضحايا عدة مخاطر، أثناء إجراءات المحاكمة أو بعدها، ولهذا وضعت المحاكم الجنائية نظاما خاصا بحماية الضحايا بعد المحاكمة، إذ إن حق الضحية في الحماية ليس مرتبط بفترة معينة. وإن المخاطر المحيطة بالضحايا لا ترتبط بفترة معينة وتتنهي بانتهاء المحاكمة، فالخطر يستمر إلى ما بعد ذلك، لذلك ورد في القاعدة 7 الت 1/ من القواعد الإجرائية وقواعد الإثبات للمحكمة الجنائية الدولية، أنه يكون قلم المحكمة مسؤولا عن أداء المهام ...فيما يتصل بالضحايا والشهود يجوز للمسجل أن يتفاوض نيابة عن المحكمة مع الدول بثأن عقد اتفاقات لنقل وتقديم الخدمات في إقليم دولة للمصابين بصدمة أو المعرضين للتهديد من الضحايا أو الشهود وغيرهم ممن يواجهون أخطارا بسبب شهادة أدلى بها هؤلاء الشهود. ويجوز أن تظل هذه الاتفاقات سرية. ويعد هذا النص عاما، إذا لم يحدد التدابير التي يمكن اتخاذها في فترة إجراءات المحاكمة أو في فترة بعد المحاكمة، أضف إلى ذلك لم يعط أمثلة التدابير التي يمكن أن تتضمنها الاتفاقات الخاصة، وهو ما يعني إمكانية اللجوء إلى إعادة توطين الشخص المعني في دولة من الدول التي يوقع معها الاتفاق أو منحه هوية جديدة، وإذا كانت قوانين الدول تسمح بذلك. و أن تتخذ أشد الاحتياطات ربما يصبح الضحايا عرضة لمخاطر جسيمة بسبب تفاعلهم مع المحكمة، حيث يصبح من الضروري نقليهح إلى بلد آخر ، ولهذا فإن 


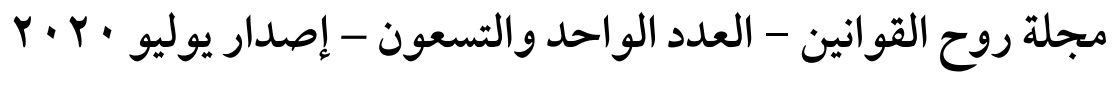

الدول الأطراف يجب أن تساعد المحكمة في إعادة توطين الضحايا المعرضين للخطر

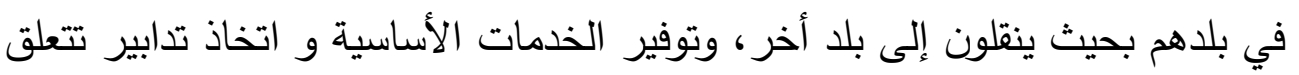
بإخفاء هوية الضحايا أو عقد جلسات مغلقة .وقد قامت المحكمة الجنائية الدولية ليوغسلافيا السابقة بإعادة توطين الضحايا في بلدان أخرى تحتفظ بسريتهم، يكون في بلد يعقد معه اتفاق لهذا الغرض عن طريق مسجل المحكمة، وقد وقعت محكمة

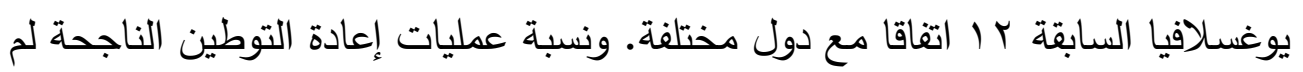
تتجاوز •؟ ٪، وهي نسبة غير مقبولة ويُطلب من الدول الأطراف اتخاذ تدابير عاجلة

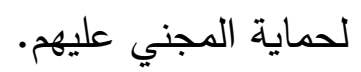

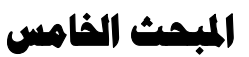 \\ هق الهنبي عليه في الدفاع أمام سلطة التمقيق في إطار العدالة المتوازنة}

يجب أن يســود المجتمع الدولي مجموعة النظم مهمتها تتظيم ســلوك الأفراد في الني كافة مجالات الحياة بما يحقق العدالة الجنائية خصوصاً تقع أثد الجرائم خطورة.

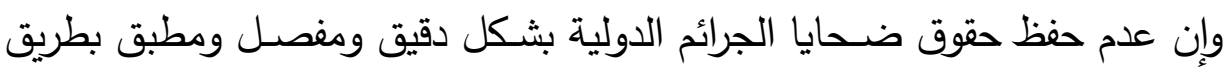

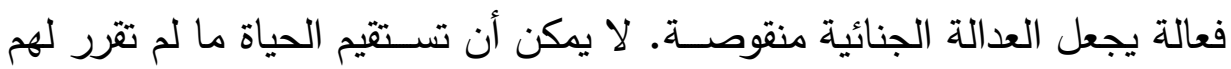

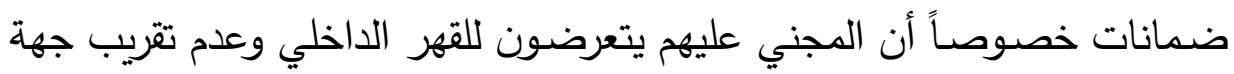

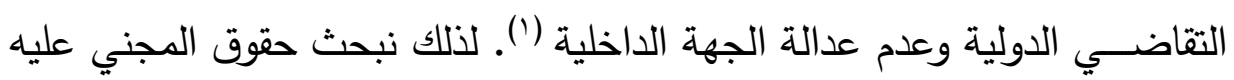
المتصلة بإجراءات حق الدفاع كما يأتي: 


\section{المطلب الأول}

\section{حق الجني عليه في علانية المشاركة في إجراءات التحقيق}

يعد مبدأ علانية إجراءات التحقيق في مواجهة الخصوم يعد من أهم ضمانات التحقيق.

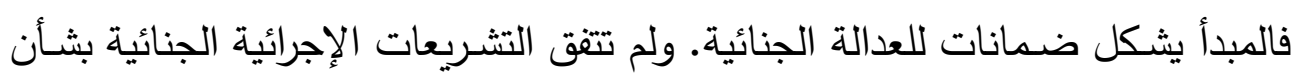

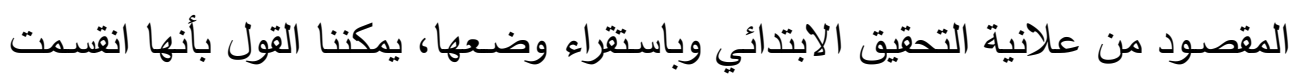

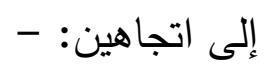

الاتجاه الأول: الأصـل علانية التحقيق للخصوم ووكلائهم دون الجمهور وهذه علانية

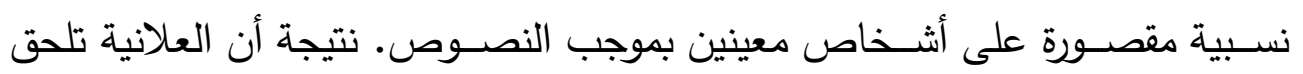

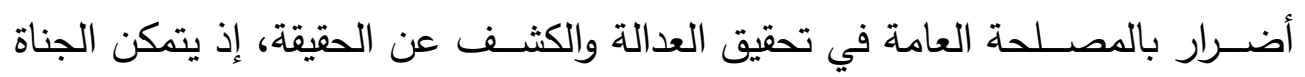

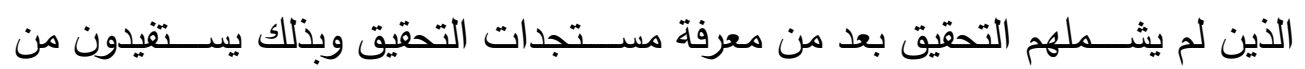

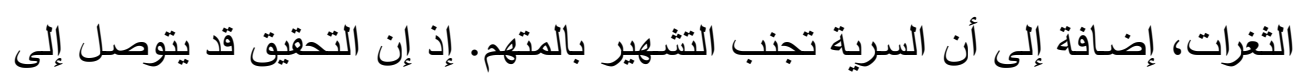

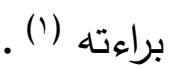
الاتجاه الثاني: الأصـل علانية التحقيق والاسـتثناء هو السـرية، والمقصـود من علانية

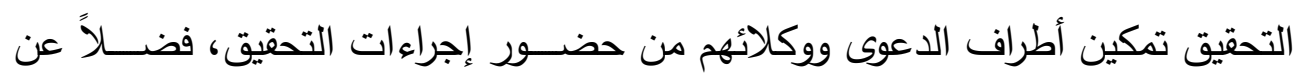

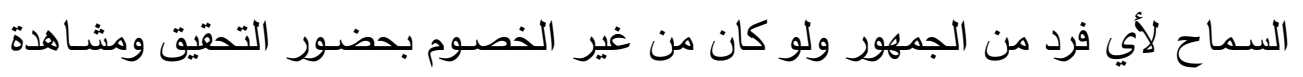

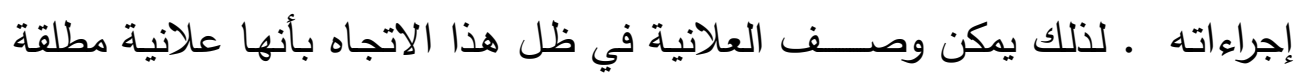

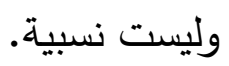

والاتجاه الأول هو المطبق في جل التثـــريعات. أما الاتجاه الثاني فهو الراجح عندي الذي يبيح حضور الجمهور الفعال الواعي والناقد والناقل للرأي العام ما يدور في أروقة الأدياه القضاء من احترام الضمانات وتحقيق العدالة ففيه ضمان ورقابة للجمهور على أعمال

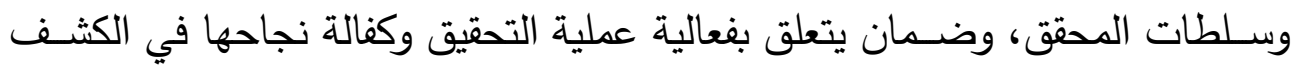

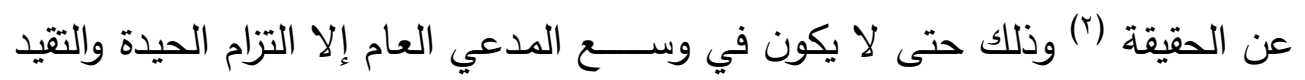

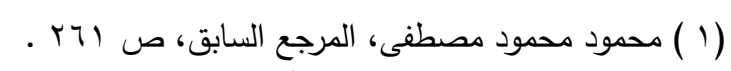

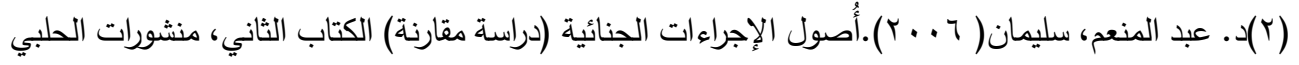

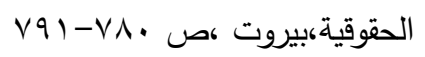


F. r. · مجلة روح القوانين - العدد الواحد والتسعون - إصدار يوليو بالأحكام وعدم اســخدام الوسـائل غير المشـروعة في التحقيق، كما أن في حضــور

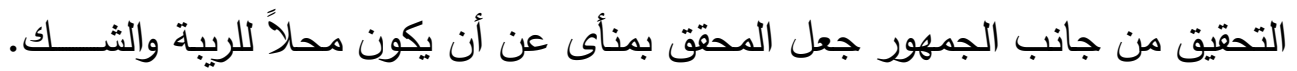

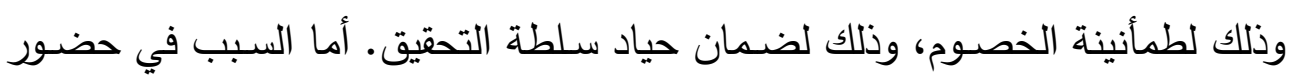
الخصوم ووكلائهم جميع إجراءات التحقيق، يعود إلى: ا-تمكين الجني عليه هن همارسة الرقابة على تلك الإجراءات الاطهئنان لسلاهة تلك الإجراءات وإثارة

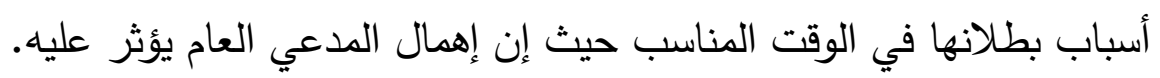

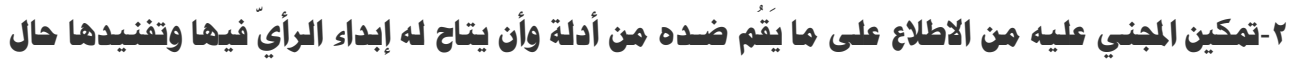

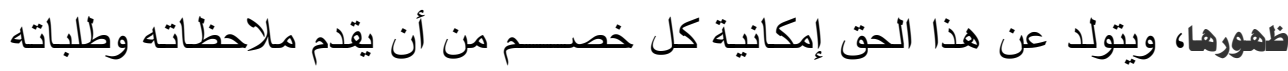

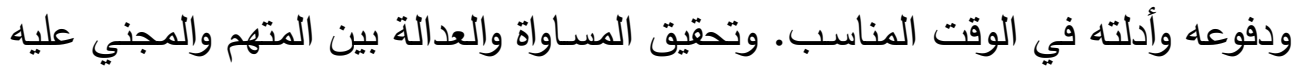

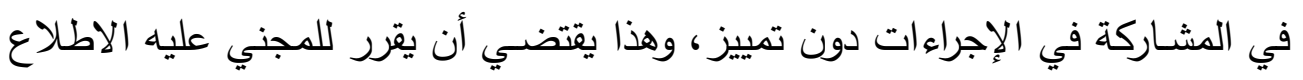

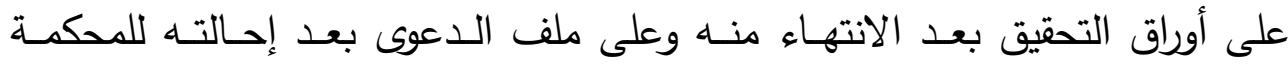

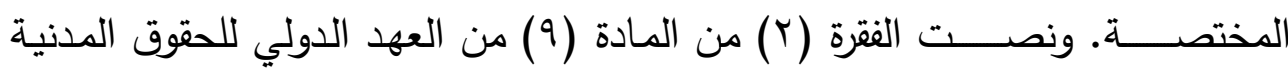

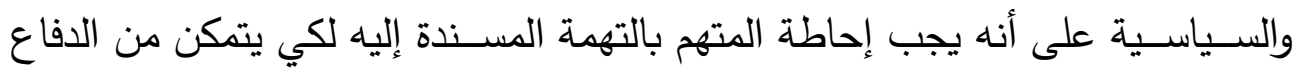

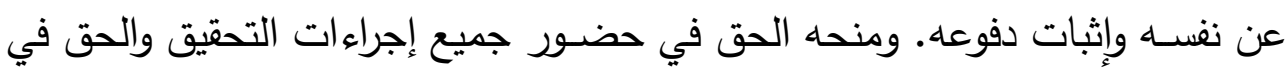

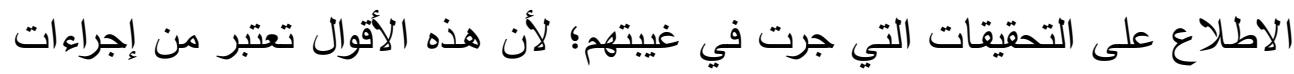

$$
\text { التحقيق بدون ادني منازع. }
$$

r-حق الجني عليه في حضور إجراءات التحقيق، تقتضى الشرعية الإجرائية ضمان حق المجني

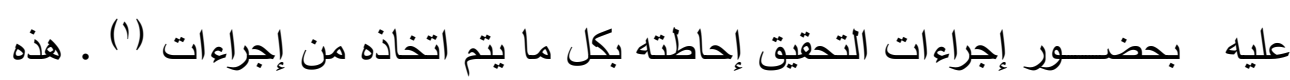

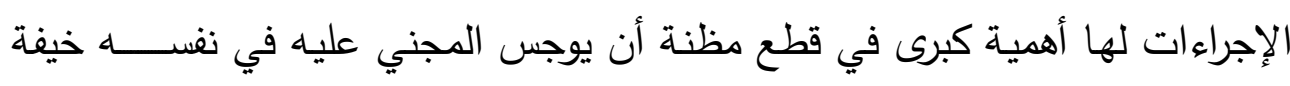

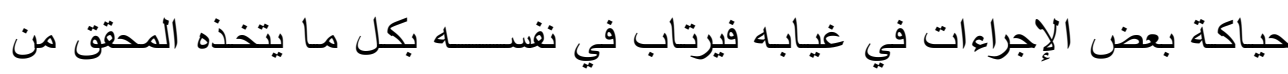

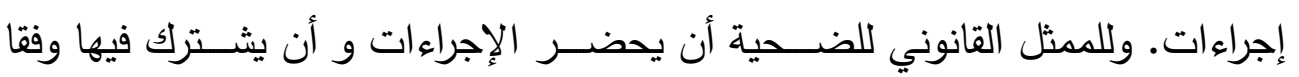

(1) د.الحسيني، سامي حسني (9Nv (م). ضمانات الدفاع دراسة مقارنة، مجلة الحقوق والثريعة، جامعة

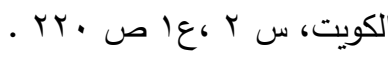


للشــروط الواردة في حكم الدائرة و وفقا لأي تعديل يجرى عليه بموجب القاعدتين 99

وقد أقر نظام روما الأساسي مبدأ علنية إجراءات التحقيق الابتدائي بالنسبة للخصوم. إذ نصت الفقرة الثانية من المادة ؟0 من النظام الأساسي الأصل في التحقيق علني بالنسبة للخصوم " أن يطلب حضور الأشخاص محل التحقيق والمجني عليهم والثهود وأن يستجوبهم. "فالعلانية في مرحلة التحقيق تكون للخصوم وليست للجمهور وذلك بحضور المجني عليه والمدعي بالحقوق المدنية والمتهم وللمسؤول عنها جميع إجراءات التحقيق بوصفه خصما وللمدعي العام ولوكلائهم أن يحضروا جميع إجراءات التحقيق بات التصني (المادة VVن قانون الإجراءات الجنائية المصري)، ومازال حق المجني عليه في

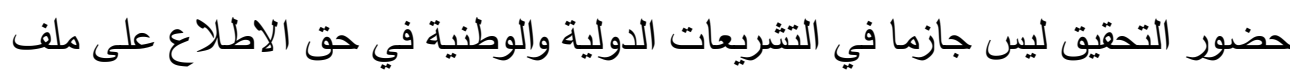
القضية. إذا كان الأصل هو حق الخصوم في حضور التحقيق، باعتبار أن هذا الحق

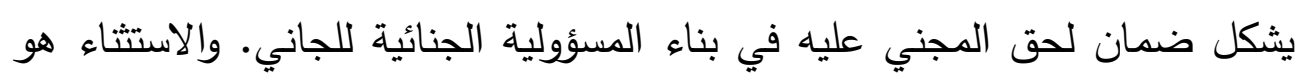
جعل هذه الإجراءات سرية في حالات وظروف خاصة تقررها المحكمة حسب نظامها الأساسي، ذلك غالبا ما يكون لحماية إجراءات التحقيق وللحيلولة دون الحصول على فرصة لهرب المجرم وإفلاته من العقاب والتي يستقل بتقدير السرية المدعي العام،

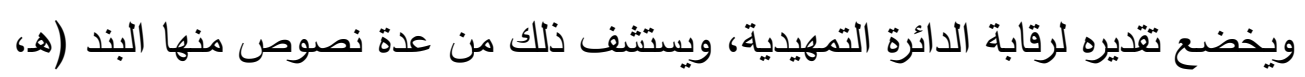
و) من الفقرة (r) من المادة (ع (ه) من النظام الأساسي والتي تتص "للمدعي العام...... أن يوافق على عدم الكثف في أية مرحلة من مراحل الإجراءات عن أية مستندات أو معلومات يحصل عليها بشرط المحافظة على سريتها ولغرض واحد وهو استقاء أدلة

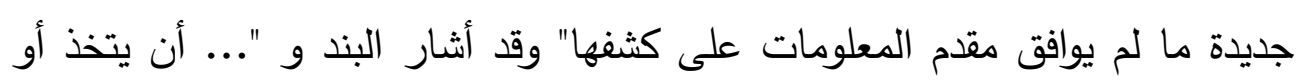
يطلب اتخاذ التدابير اللازمة لكفالة سرية المعلومات أو لحماية أي شخص للحفاظ على الأدلة". كما أن مبدأ سرية إجراءات التحقيق في مواجهة الجمهور من غير الخصوم لم 


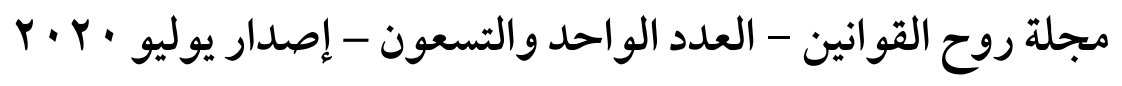

ينص النظام عليها إنما تستفاد من مفهوم المخالفة ('). وللسرية أهمية كبيرة في إظهار

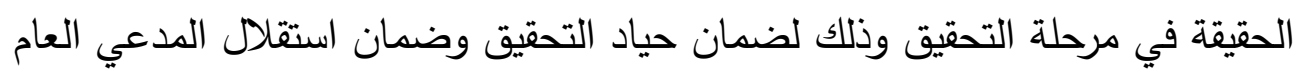

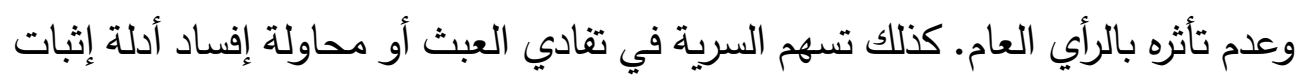

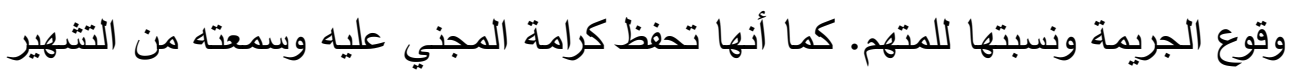
به أو الإساءة إليه قبل أن تثبت إدانته (†). ويجب على الجيات المدعي العام والمحقق وكاتبه

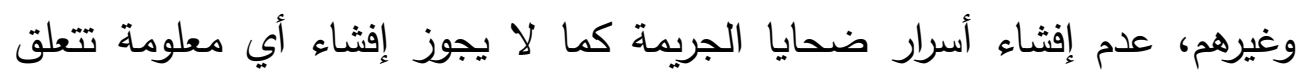

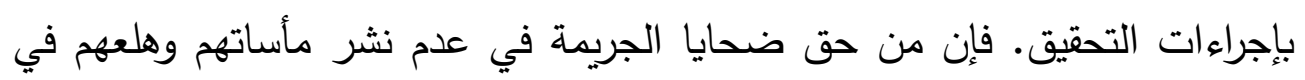

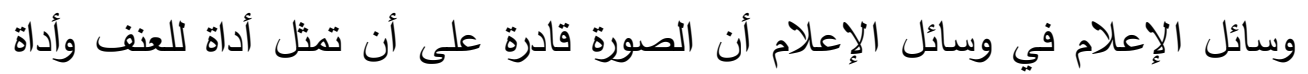

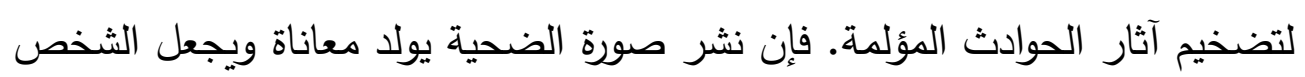

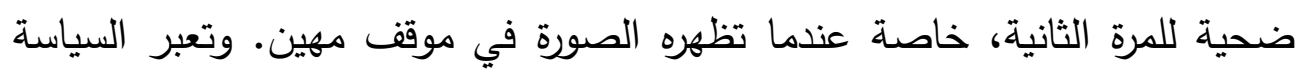

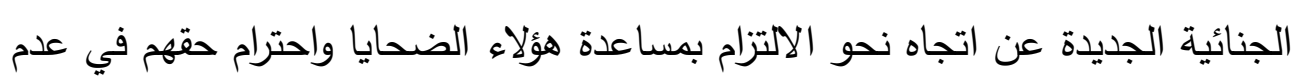

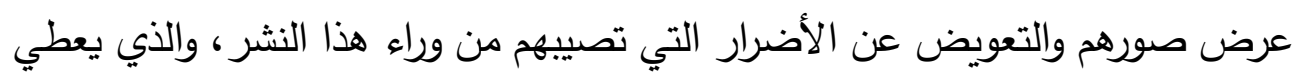
هؤلاء الضحايا الحق في التعويض، فضلا عن الجزاءات الجنائية الواردة في القانون

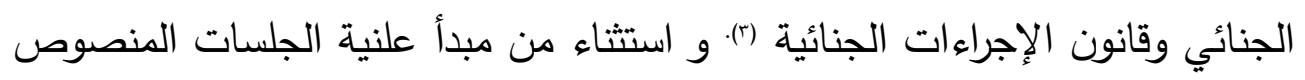

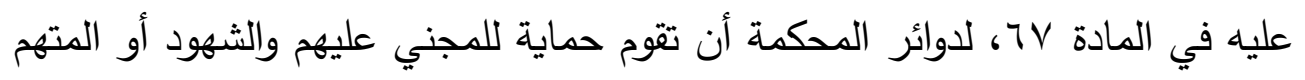

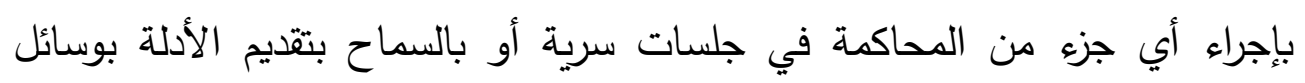

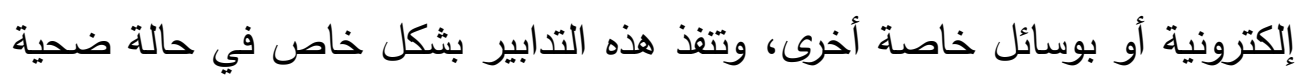

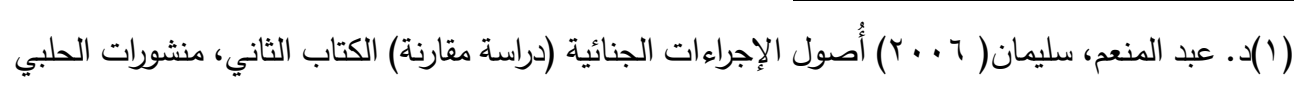

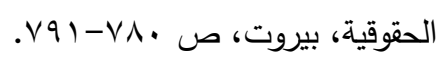

(r).. حسني، محمود نجيب( (1999) شرح قانون الإجراءات الجنائية، الطبعة الثالثة، دار النهضة العربية،

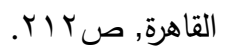

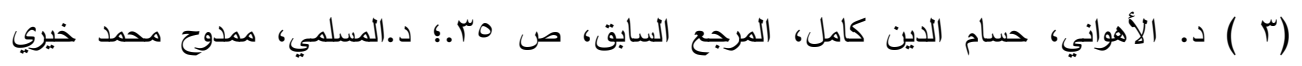

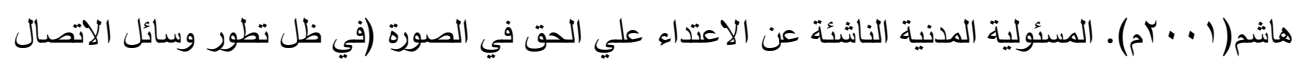

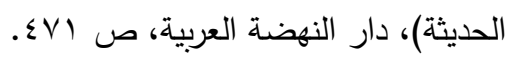




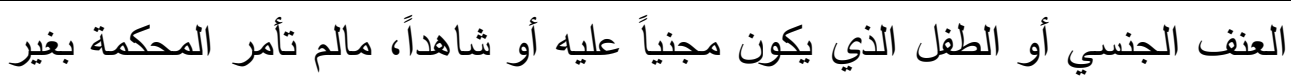

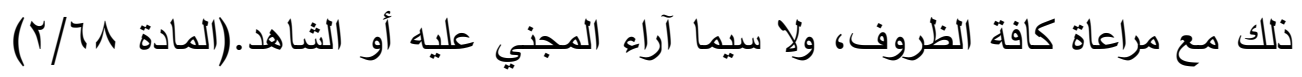
من النظام الأساسي.

ونصت قاعدة ا9 على أن يحق للممثل القانوني للضحية أن يحضر الإجراءات وأن

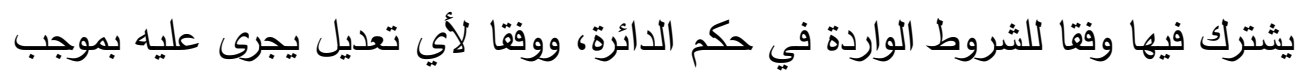
القاعدتين 91 و .9 9. ويشمل هذا الاشتراك في الجلسات، ما لم تر الدائرة المعنية، بسبب ملابسات الحالة، وأن يقتصر تدخل الممثل على الملاحظات المكتوبة أو البيانات.

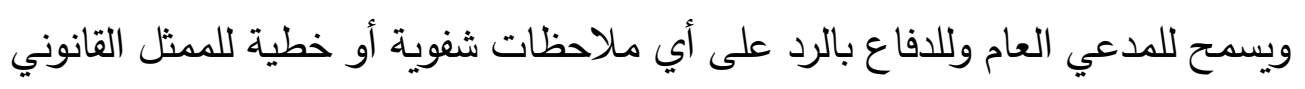

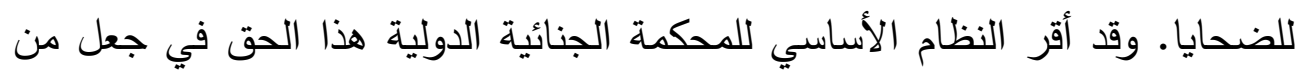

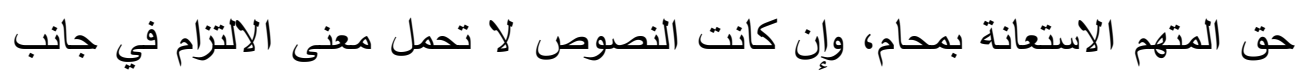

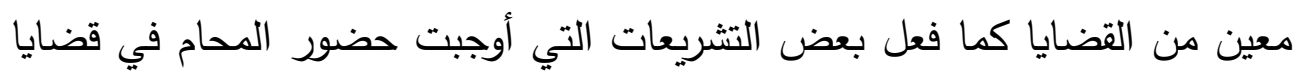
الجنايات ومن ثم من الضروري النص على وجوب حضور المحامي في الجرائم الدولية وكلها جسيمة .

\section{المالب الثاني}

\section{هق الهنبي عليه في التمثيل القانوني أمام سلطة التمقيق}

إن حق الدفاع أجمعت عليه كافة الثرائع من حيث الأصل. وهو مستمد من حق الإن

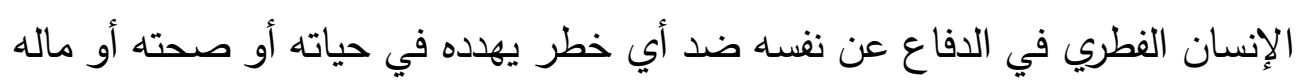

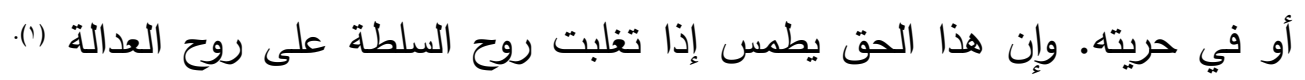

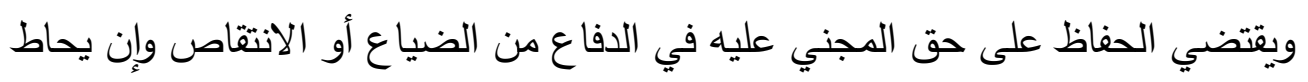

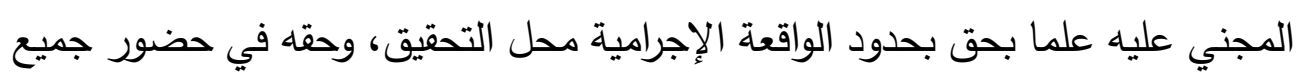
الإجراءات التي تقوم بها سلطة التحقيق، وحقه في الاستعانة بمحام، وأن يتمكن المجني 
r.r. · مجلة روح القوانين - العدد الواحد والتسعون - إصدار يوليو

عليه ومحاميه من الاطلاع على ملف التحقيق وحقه في الاتصال بمحاميه بحرية وتقديم الطلبات والدفوع وهذا ما يتم تتاوله تفصيلاً في ضوء النظام الأساسي للمحكمة الجنائية الدولية. ومن هذه الحقوق كما يأتي:

أولا: هق الهني عليه في التمثيل القانوني: أوجبت أغلبية التثريعات على تتبيه المتهم

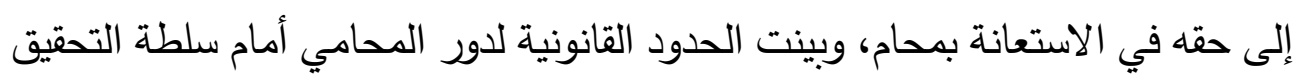

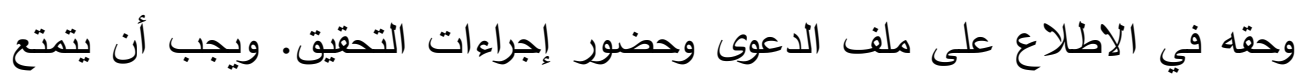

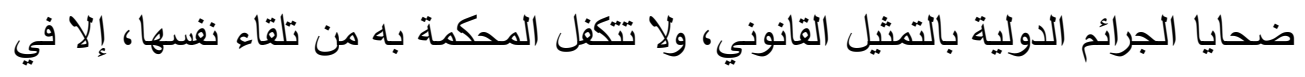

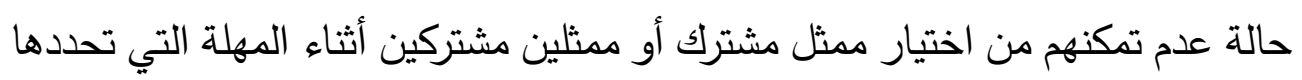

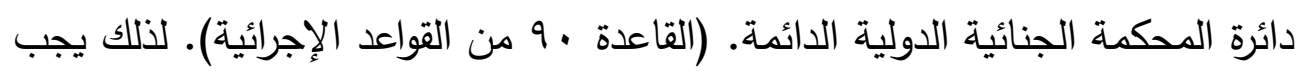

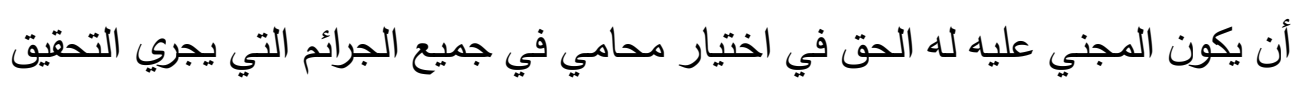

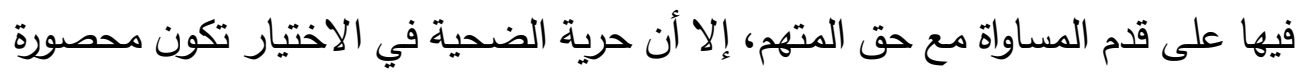

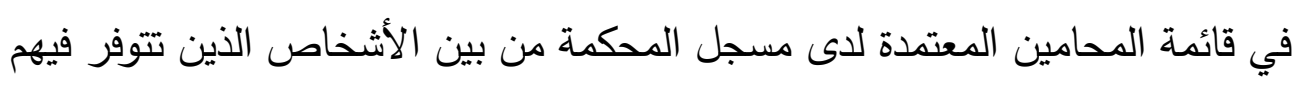

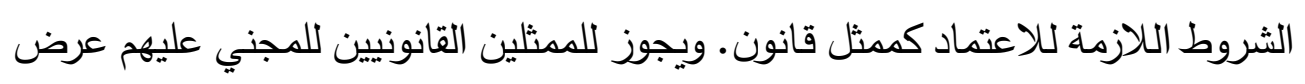

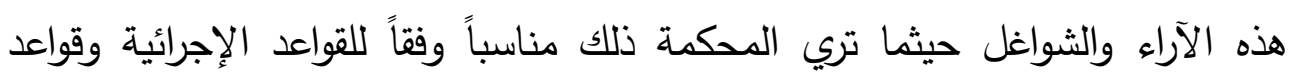

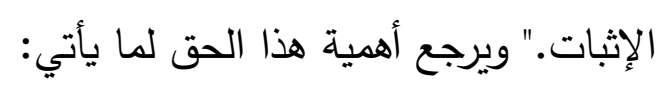

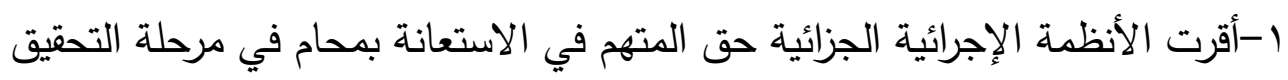

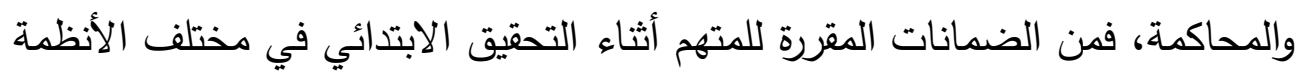

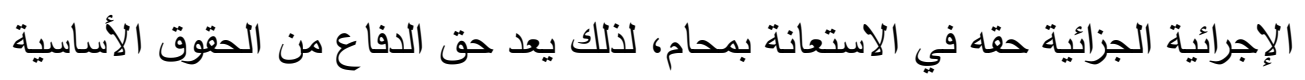

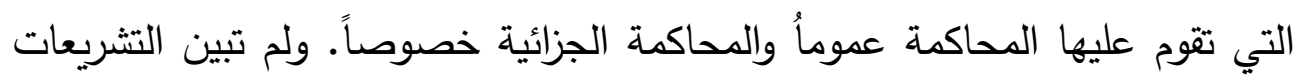
المقصود بحق الدفاع. وتكتفى بوضع إطار هو حق المتهم في محاكمة عادلة مؤسسة على إجراءات مشروعة. ويمكن تعريف حق الافاع بأنه هو مجموعة من الأنشطة الإجرائية التي يباشرها المدعي عليه أو المتهم بنفسه أو بواسطة من يمثله سواء باء بالوكالة

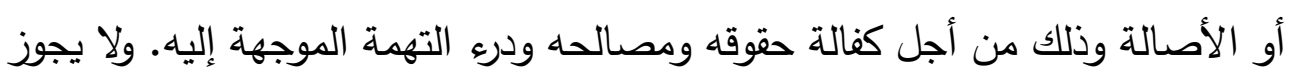
الحكم على شخص دون تمكينه من حق الدفاع وإن لمحاماة جزء متمم للجسم القضائي 


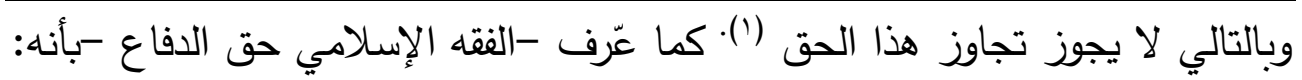

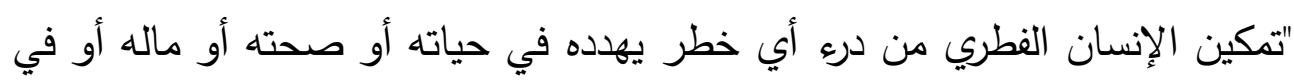

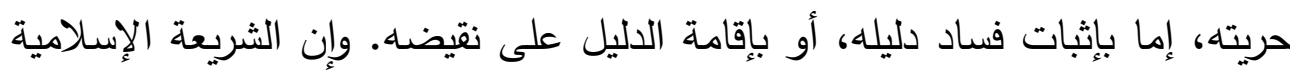

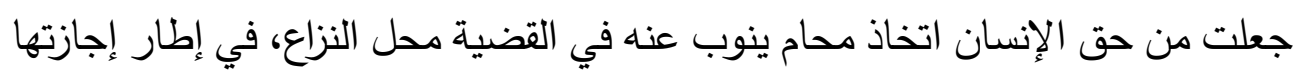

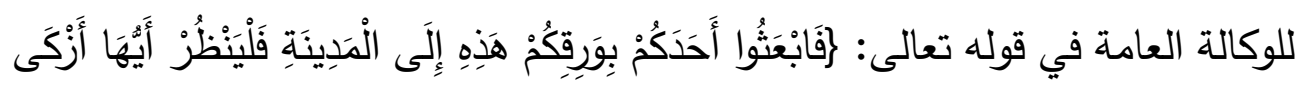

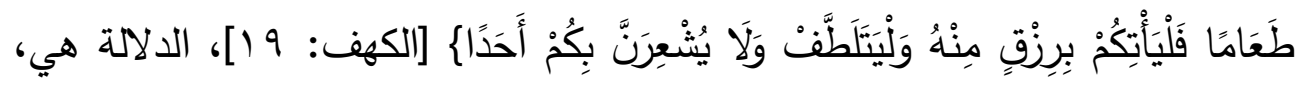

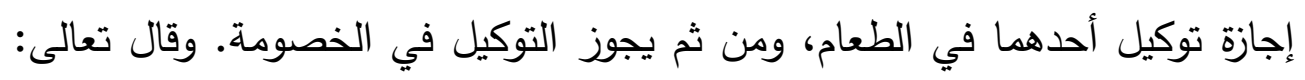

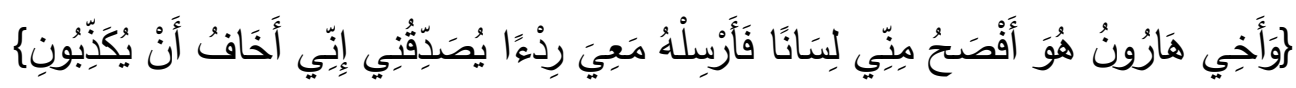

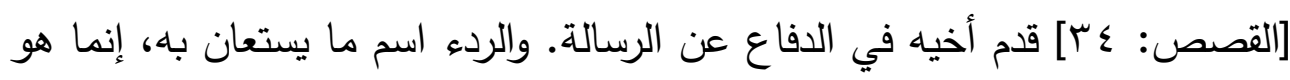

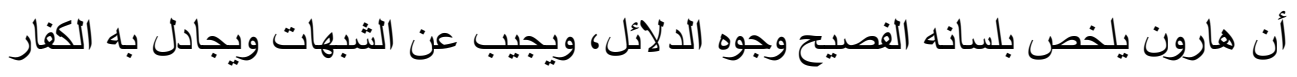

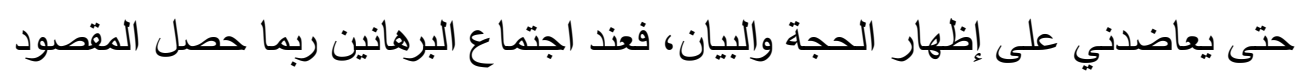

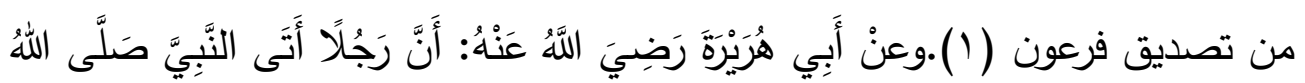

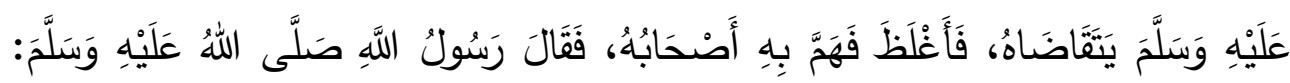

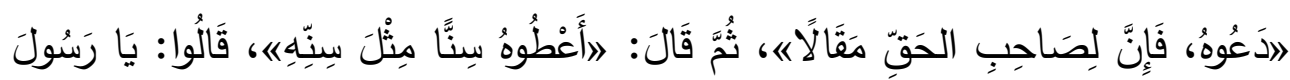

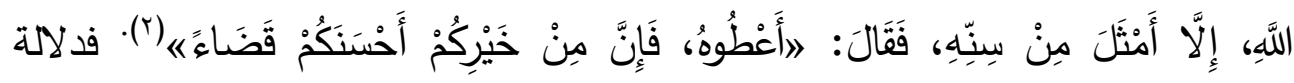

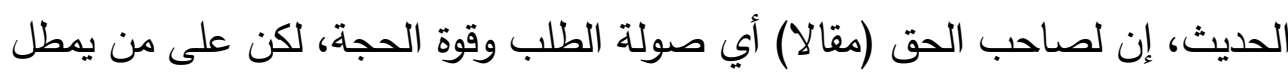

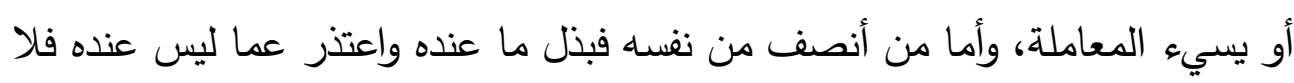

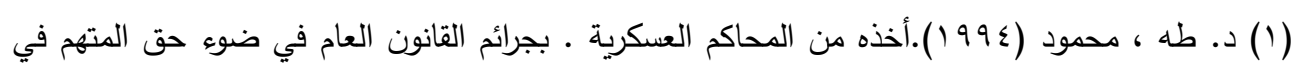

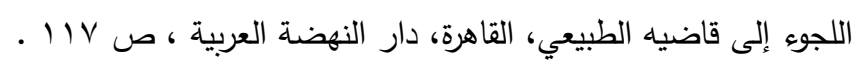

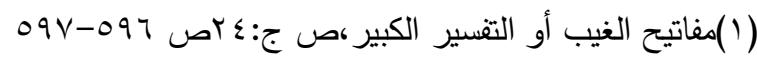

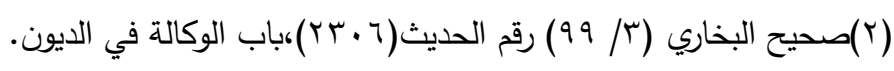
(sor) 
r.r. · مجلة روح القوانين - العدد الواحد والتسعون - إصدار يوليو

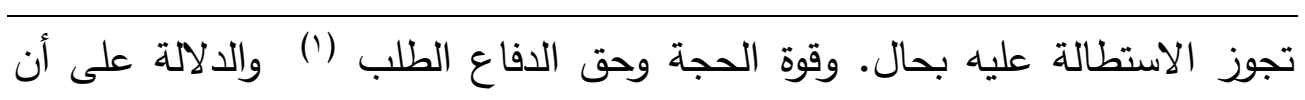
الوكالة في قضاء الديون وجميع الحقوق جائزة (ץ).

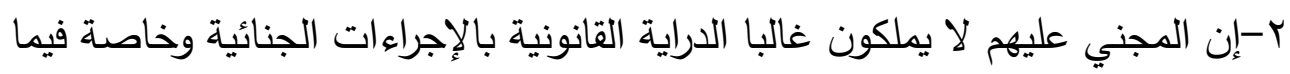

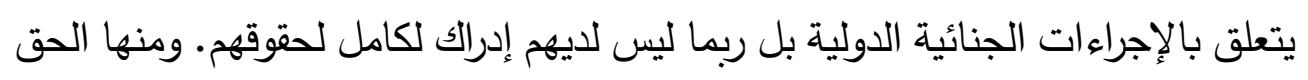

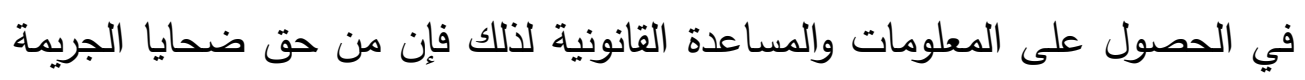

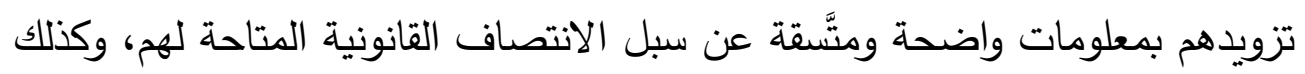

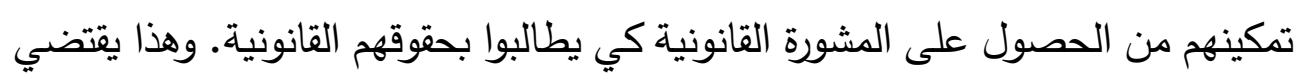

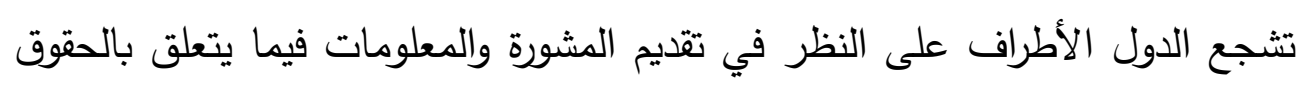
القانونية بلغة يمكن للضحايا فهمها. وينبغي للمسؤولين الذين يكون لهم التصال مباشر

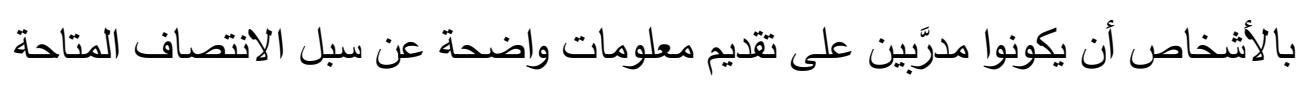

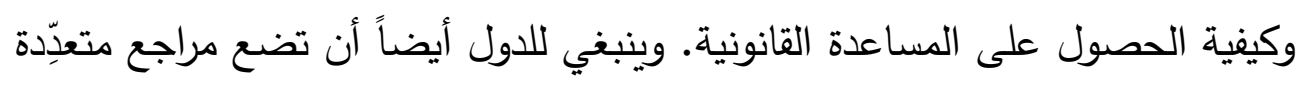

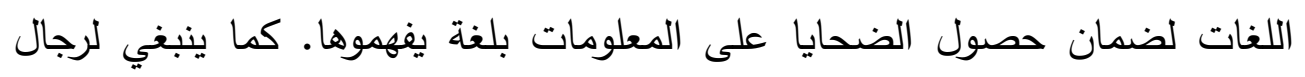

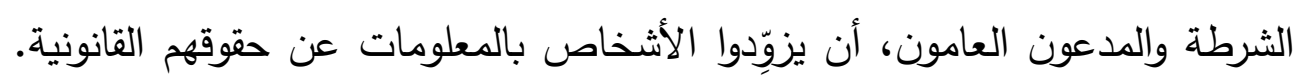

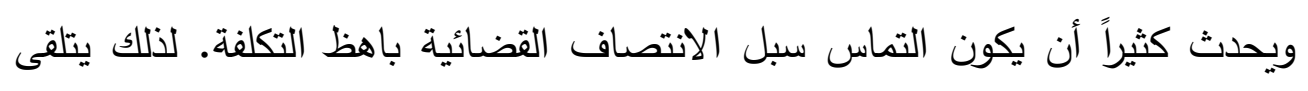

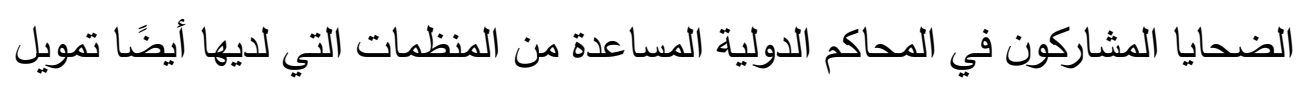

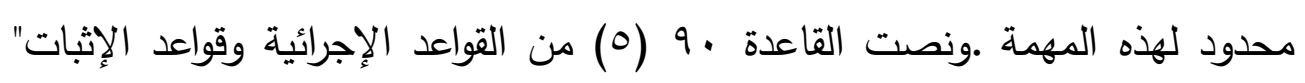

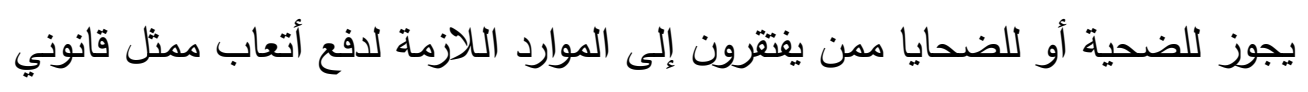

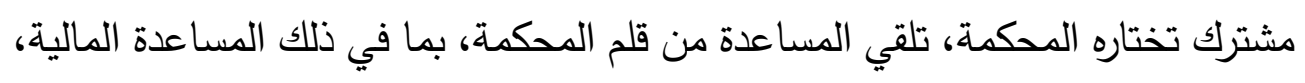

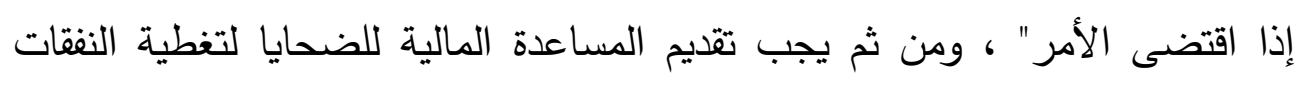

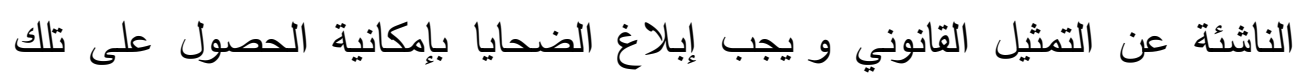

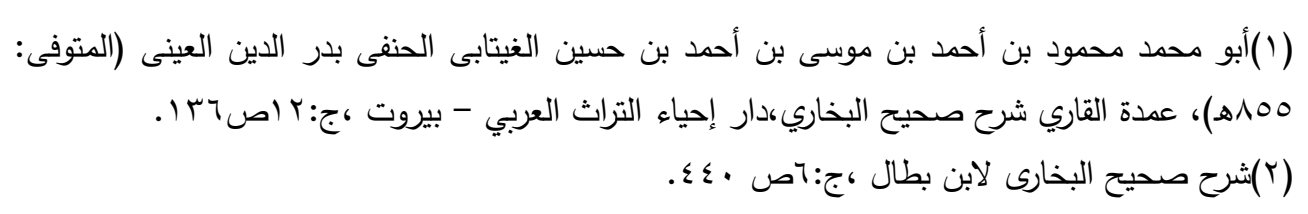
$\{\varepsilon 0 \leqslant\}$ 
المساعدة القانونية المجانية ويتم تحديد نطاقها من قبل قلم المحكمة بالتشاور مع الدائرة ذات الصلة من أجل الوصول إلى هذه المساعدة ، فيعد المسجل استمارة طلب لتحديد

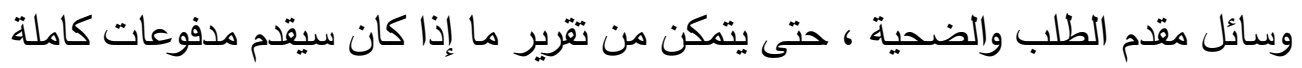

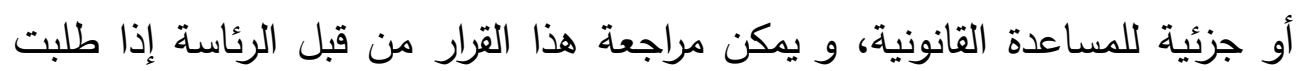
الضحية ذلك ('). ץ-إن الجريمة التي تدخل في اختصاص المحكمة قد أصابت العديد من الأشخاص الذين لديهم رغبة بالمشاركة في إجراءات التحقيق ويضاف الى ذلك أن أنت اختيار الممثل القانوني من قبل المجني عليهم يعزز حقوقهم ويمنع إطالة الإجراءات وتأخر المحاكمة.

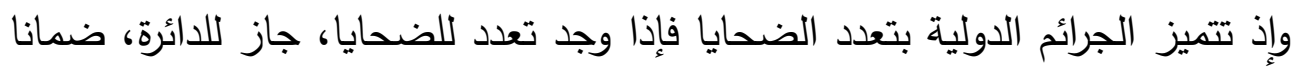
لفعالية الإجراءات، أن تدعوا الضحايا أو مجموعات معينة من الضحايا، إلى اختيار ممثل قانوني مشترك أو ممثلين قانونيين مشتركين، ويجوز لقلم المحكمة أن يقدم الفاء

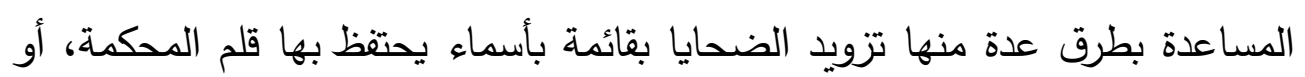
اقتراح ممثل قانوني مشترك أو أكثر . غير أنه قد تظهر مشكلة عملية وتتمثل في كثرة

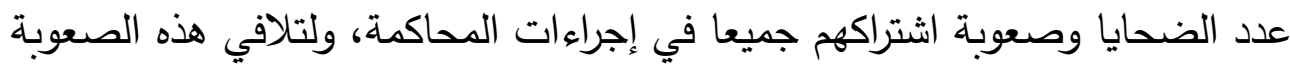

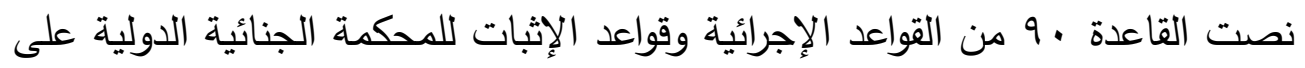

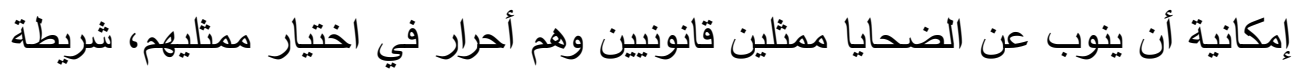

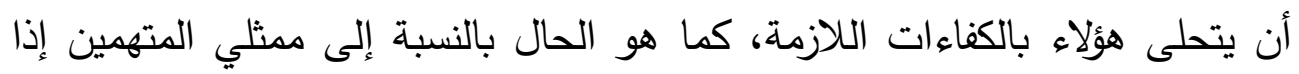

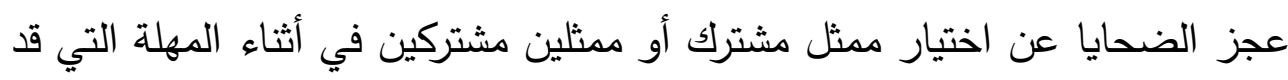
تحددها الدائرة، جاز للدائرة أن تطلب من المسجل التبل التيار ممثل قانوني واحد أو أكثر .

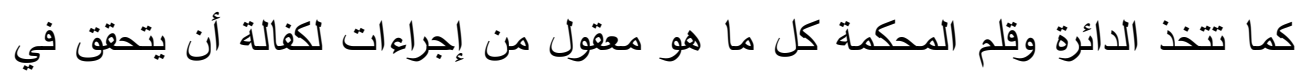
اختيار الممثلين القانونيين المشتركين تمثيل المصالح المميزة لكل الضحايا، ولا سيما لهرل 


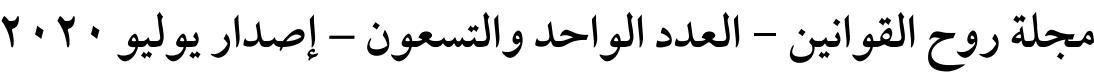

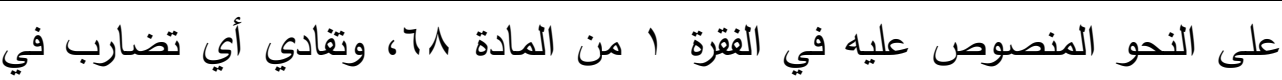
المصالح.

ع-إن المساهمة الفعلية لضحايا الجرائم الدولية في الإجراءات أمام المحكمة الجنائية

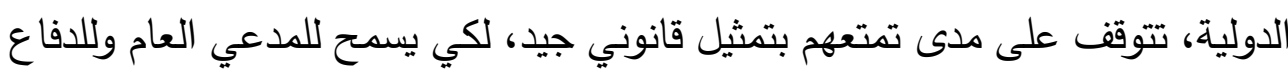

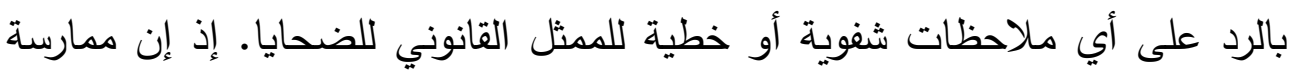
ضحايا الجرائم الدولية لحقوقهم في إطار أية دعوى قضائية جنائية وطنية أو دولية فإنه

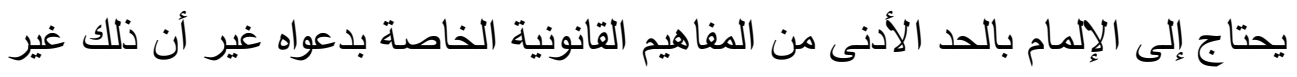
متوفر في غالب الأحيان لدى ضحايا الجرائم الدولية لثدة تعقيد الإجراءات القضائية الإئية

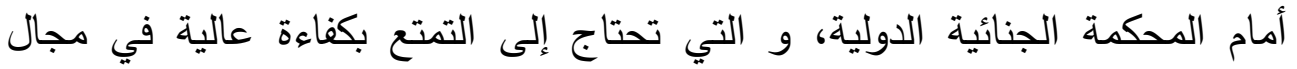

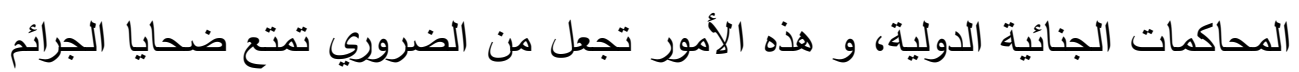

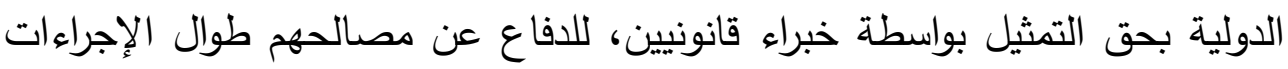

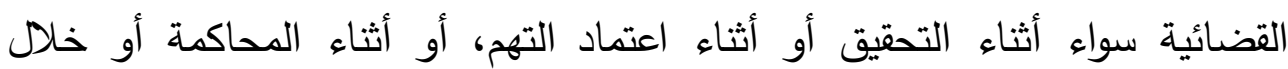

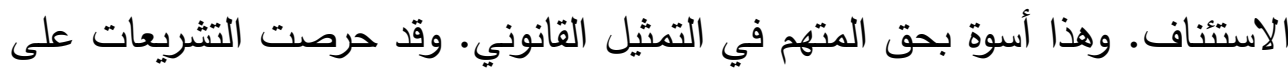

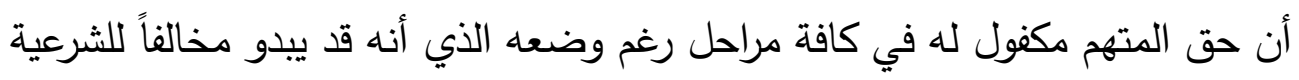

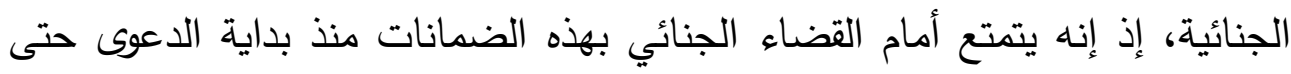

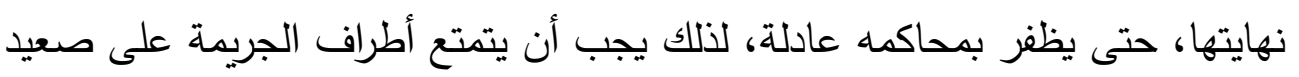

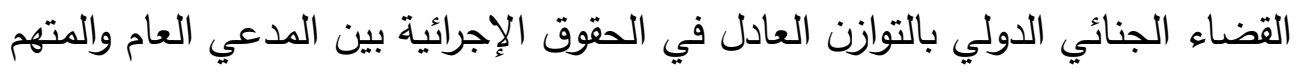

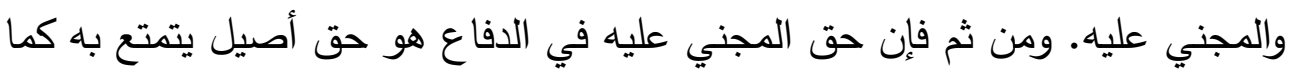
يتمتع به المتهم على قدم المساواة.

ه-إن مبدأ المساواة أمام القضاء يفرض لفأ أن تحظى الضحية بنفس الاهتمام الذي يحاط

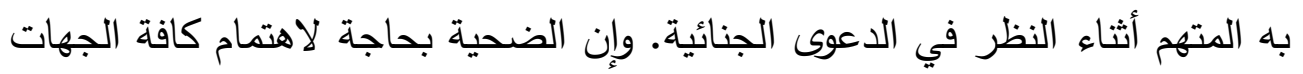

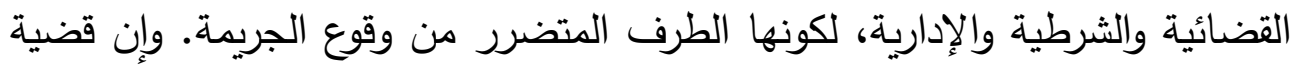
المساواة أمام القانون بين أطراف الدعوى الجنائية، ليست مثارة فقط بين المتهم والمجني لكني

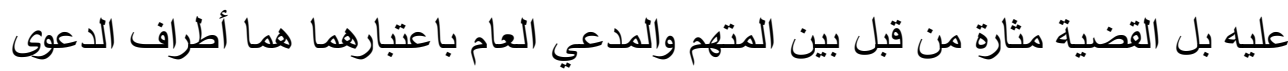


الجنائية دون غيرهما خصوصا أن المدعي العام يتمتع بسلطة واسعة في الدعوى الجنائية، مما اقتضي المطالبة بالمساواة بين الادعاء والاتهام.

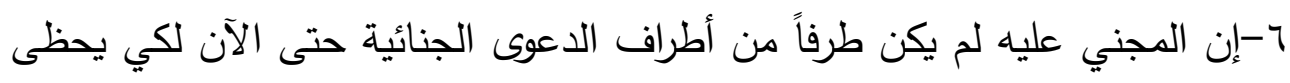
المجني عليه بنفس الاهتمام الذي يحاط به المتهم أثناء النظر في الدعوى الجنائية. خصوصاً أن من يمارس هذه السلطة نيابة عن المجتمع هو جهاز مكتب المدعي العام المكون من موظفين عموميين دوليين، يتأثرون بالجانب السياسي والايدلوجيا والعنصرية فونية والهوى لذلك يحتاجون للمراقبة من المجني عليه باعتبارها طرفا في الجريمة والمضرور الأول من الجريمة. وإن الحاجة إلى العدالة الجنائية وجودتها وجدواها مطلبا سماويا وقانونيا. وهذا يقتضي في القائم على العمل أن يكون متقننا لعمله ودين لربه وأن الوظيفة عنده تكليف محاط بالخشية من الله تعالى. خصوصاً أن المجني عليه يحترق بنيران الجريمة فلا يوجد تكافئ نفسي بين اهتمام المجني عليه والمدعي العام ومن ثم فقد يهمل المدعى العام في تحريك واستعمال الدعوى الجنائية الدولية تحت ضغط الأيدولوجيات وعدم وجود قوات شرطة وسجون لدي المحكمة. إذ تعتمد المحكمة على التعاون من

الدول والمنظمات المعنية. V- قيل إن المدعي العام يحل محل المجني عليه فإن نظام روما لم أخذ بمبدأ الثرعية في مباشرة الاتهام العام وإلزامية تحريك الدعوى الجنائية والذي يلزم المدعي العام بإحالة ما يتصل بعلمه من توفر العناصر القانونية للواقعة الإجرامية وإثبات إسنادها ماديا

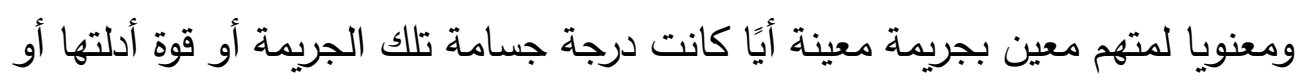
الظروف والملابسات التي سبقت أو عاصرت أو تلت ارتكابها (') وأن هذا المبدأ فيه لا لا

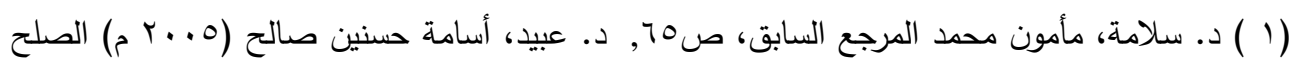

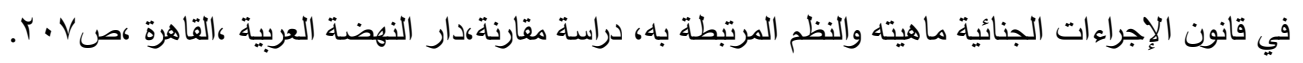


F. r. · مجلة روح القوانين - العدد الواحد والتسعون - إصدار يوليو

يملك المدعي العام استبعاد أي جريمة من عرضها على القضاء تحقيقا لمبدأ وجوب التباء الشرعية الإجرائية في الاتهام وأن الجريمة ليست معلقة على شكوى أو طلب أو أو إذن (1).

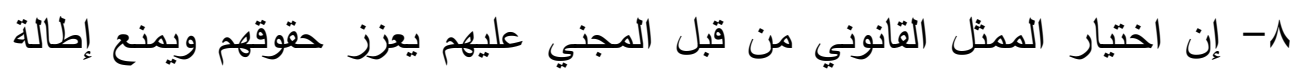

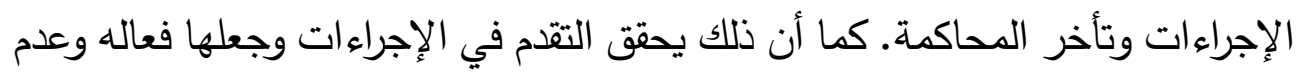

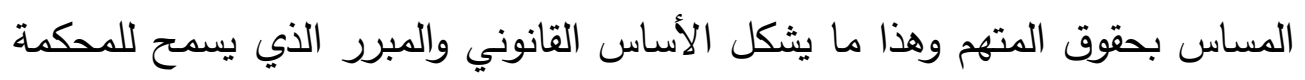

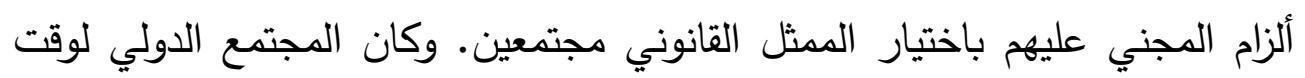

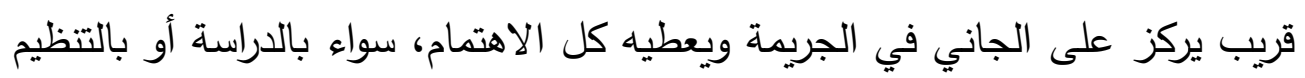
القانوني وإن كان لم يصل للعدالة المثلي إنما تحددت ملامح مركزه القانوني. أما المركز

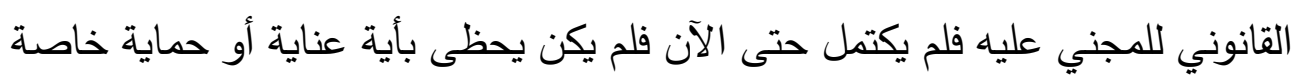

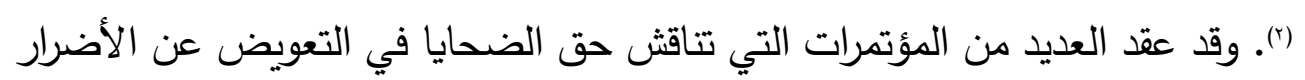

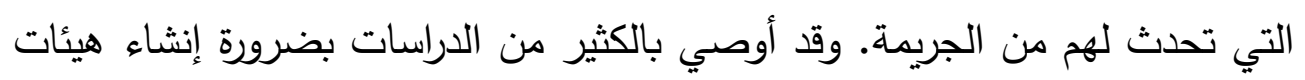

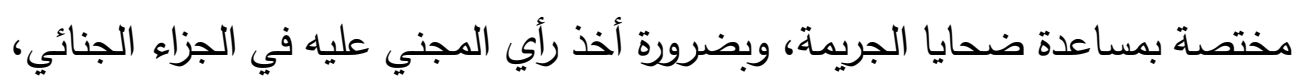

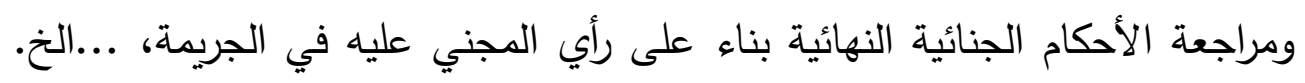

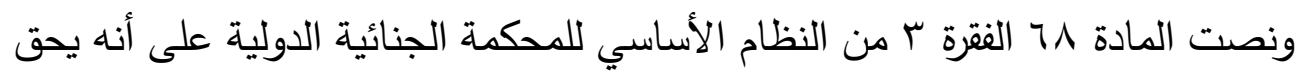

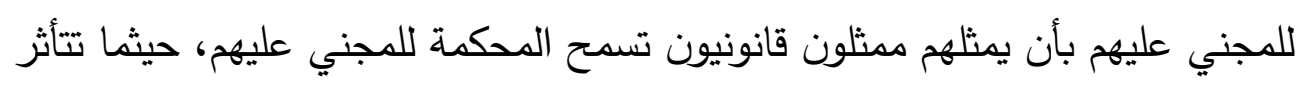

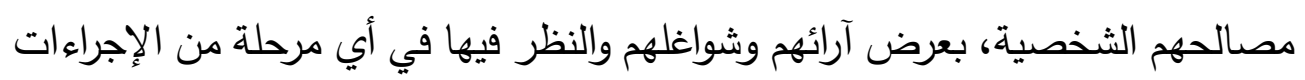

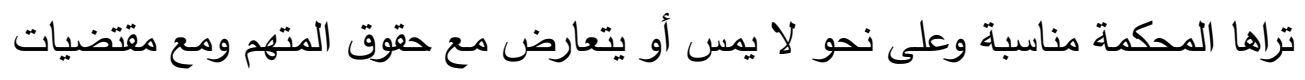

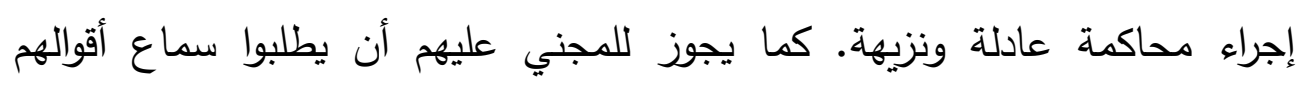

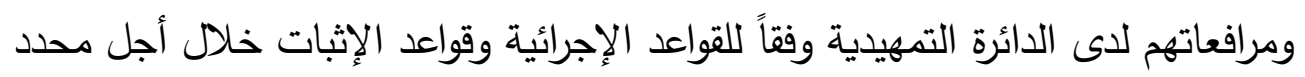

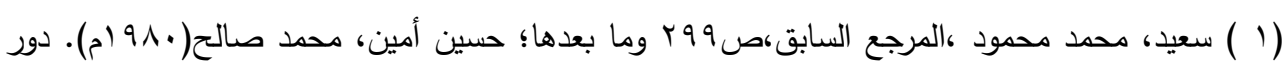

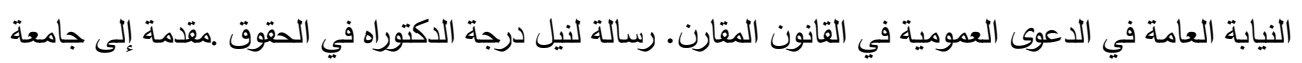

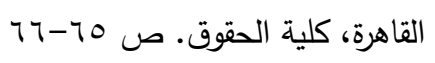

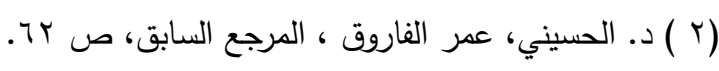
$\{\leqslant 0 \wedge)$ 
وأن يقدموا بيانات خطية إلى الدائرة التمهيدية التي يجوز لها بدورها طلب معلومات

إضافية من المدعي العام أو من أحد الضحايا الذي تقدم بيانات بهذا الثأن (1). ويتضح إن حق الاستعانة بالمحامي هو أن يكون بجانب الإنسان شخص ييصره بحقوقه ويبث لديه الطمأنينة. لكن لم ترد نصوص بنفس التوازي في العدالة لحماية المجني عليه بحيث يستطيع ضحية الجريمة أن يسهم في إجراءات الدعوى الجنائية دفاعا عن مصالحه المدنية، وإثبات خطأ المتهم والضرر الذي سببه والرابطة السببية بينهما، وذلك حتى يتمكن من أن يلقي بالاتهامات على المتهم لإدانته والحصول على التعويض منه، ولا يتأتى ذلك إلا من خلال إعطائه الحق بتقديم الدفوع والطلبات و تتص بعض لإن القوانين الداخلية -على تمكين الخصوم الدعوى الجنائية من حضور إجراءات التحقيق بوجوب إخطار الخصوم باليوم الذي يباشر فيه القاضي إجراءات التحقيق ،و بالمكان الذي تباشر فيه هذه الإجراءات (المادة VA من قانون الإجراءات الجنائية المصري). الأصل أن المجني عليه حر في اختيار ممثله القانوني إلا أن هذا الحق ليس مطلقا بل

يرد قيود منها:

أ-اختيار الممثل القانوني من قبل مجموعة المجني عليهم: يختار المجني عليهم الممثل القانوني العام أي بعد التشاور فيما بينهم ويمكن لمسجل المحكمة أبداء المساعدة في تحديد الممثلين القانونين المؤهلين. وذلك حسب القاعدة 1 القواعد الإجرائية والإثبات لدي المحكمة الجنائية الدولية "يكون قلم المحكمة مسؤولا عن أداء المهام التالية وفقا للنظام الأساسي والقواعد: (ب) مساعدتهم -الضحايا- في الحصول على المشورة القانونية وتتظيم تمثيلهم القانوني، وتقديم الدعم والمساعدة والمعلومات الكافية إلى ممثليهم القانونيين، بما في ذلك التسهيلات، بحسب الاقتضاء، لكي يؤدوا واجبهم مباشرة، بغرض حماية حقوقهم خلال جميع مراحل الإجراءات وفقا للقواعد 9 إلى (9؛؛" كما بينت القاعدة V/ V/ه القواعد الإجرائية والإثبات لدي المحكمة الجنائية الدولية التعاون مع الدول، عند الاقتضاء، 
F. r. · مجلة روح القوانين - العدد الواحد والتسعون - إصدار يوليو

لتوفير أي من التدابير المنصوص عليها في هذه القاعدة؛ بالنسبة إلى الثهود، إرشادهم

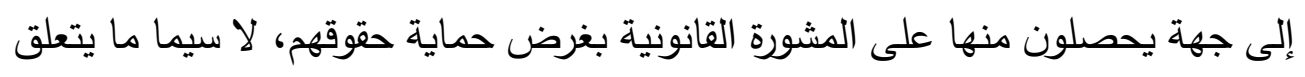

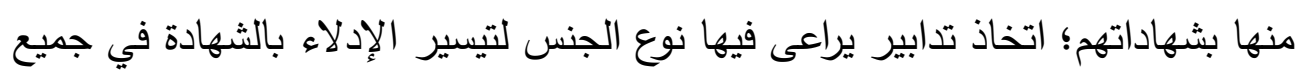

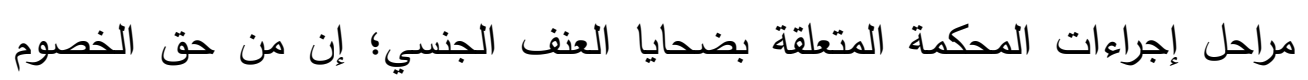

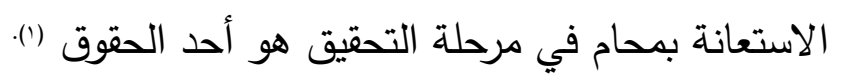

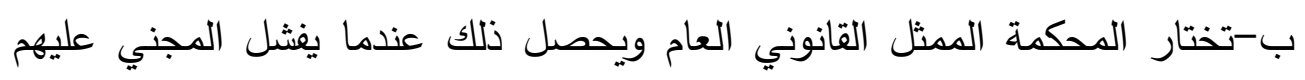

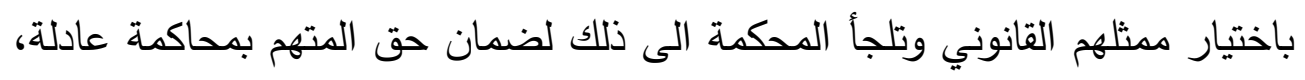

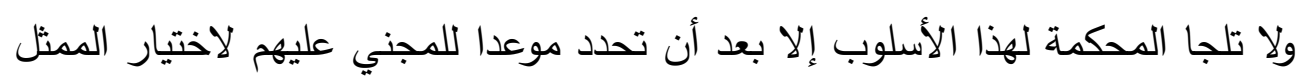

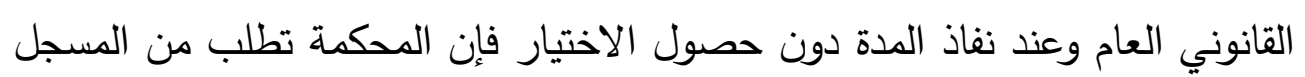

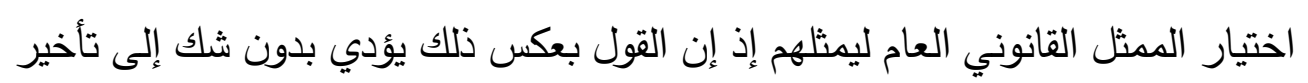

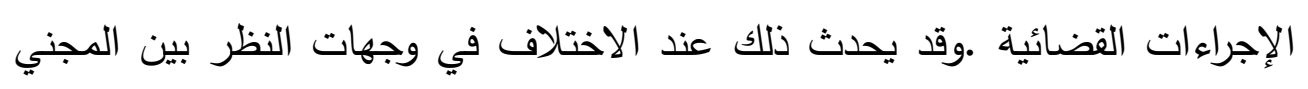

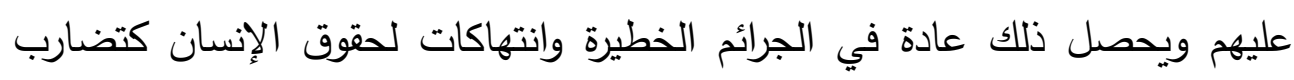

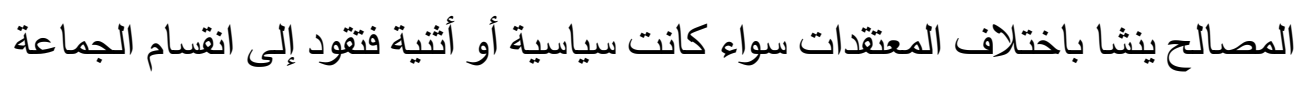

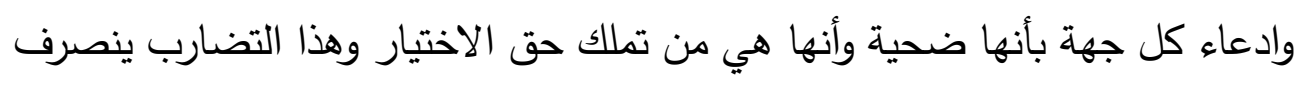

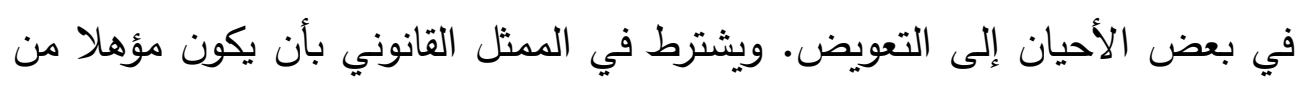

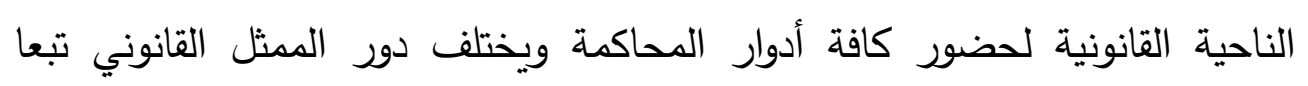

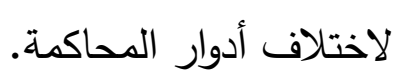
المرحلة الأولى: مرحلة إجراءات التحقيق والتي يعمل الممثل القانوني على ما يلي: لإكلي: "*-بناء الثقة بينه وبين الموكلين.

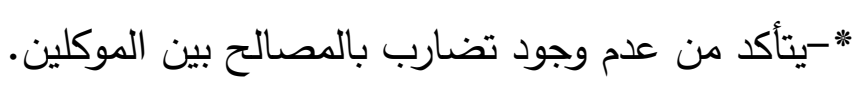

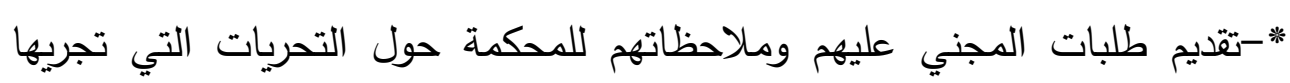
المحكمة ويجب أن تكون الملاحظات مفيدة لمصلحة المجني عليهم ومصلحة العدالة.

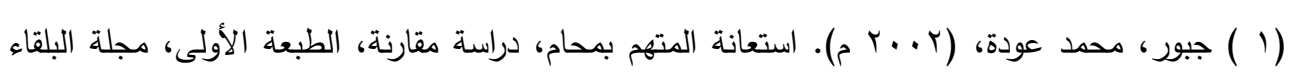

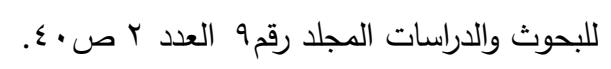
$(\leqslant 7$. 
*-تيناقش المجي عليهم من خلال ممثليهم مدى اختصاص المحكمة بنظر الدعوى المعروضة عليها كما أن الممثل القانوني في هذه المرحلة يبحث عن توفير المساعدة للمجني عليه.

*-يطلب الممثل القانوني توفير الحماية للمجني عليه وخاصة بعد صدور أوامر القبض

$$
\text { بحق مرتكبي الجرائم. }
$$

المرحلة الثانية في مرحلة المحاكمة: يسهم الممثل القانوني فيما يأتي: *-مساعدة المجني عليه في توجيه الأسئلة للشهود وكذلك المحافظة على حقوق المجني

$$
\text { عليه في هذه المرحلة. }
$$

*-التأكد من أن حقوق المجني عليه مصانة في هذه المرحلة وعلى الممثل القانوني

تقديم طلب إلى هيئة المحكمة للاستماع للشهود (القاعدة الو الفقرةب ) . *-المطالبة بتعويض المجني عليهم إذ يؤدي الممثل القانوني دورا مركزيا في هذا

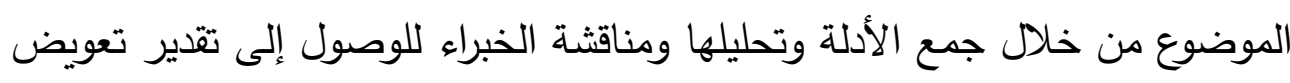
مناسب.

*-المطالبة بإصدار أوامر التنفيذ الخاصة بالتعويض ( "). ويشترط توفر الثروط في المحامي حسب القاعدة بr القواعد الإجرائية والإثبات لدى المحكمة الجنائية الدولية. ومنها: *-أن تكون للمحامي كفاءة مشهود بها في القانون الدولي أو الجنائي والإجراءات الجنائية. *-أن يلزم من خبرة ذات صلة، سواء كقاض أو مدع عام أو محام أو في أي منصب مماثل آخر، في الإجراءات الجنائية. *-أن يكون لهذا المحامي معرفة ممتازة بواحدة على الأقل من لغات العمل في المحكمة ويتحدث بها بطلاقة. ويمكن أن يساعد المحامي أشخاص آخرون، بمن فيهم أساتذة القانون الذين تتوافر فيهم الخبرة اللازمة.

The international criminal court :Ensuring an effective role for victims. / plq $^{19}(1)$ https://www.amnesty.org/en/documents/IOR $\varepsilon . / . ~ ๆ / / 999 /$ en 
r.r. · مجلة روح القوانين - العدد الواحد والتسعون - إصدار يوليو

*-سخضع المحامون، في أداء مهامهم، للنظام الأساسي، والقواعد، واللائحة، ومدونة

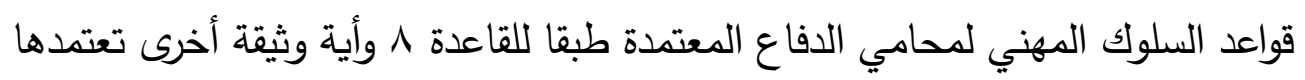

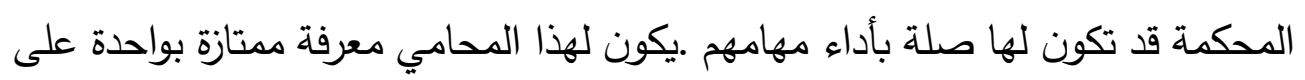

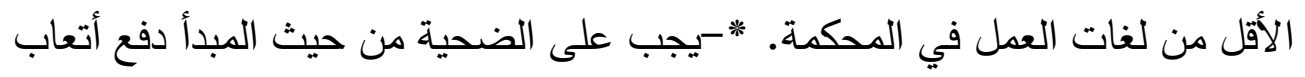

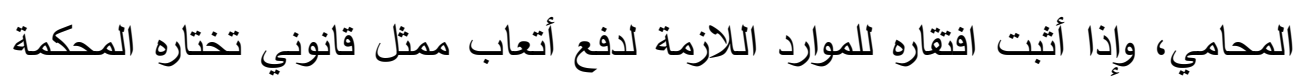
فيتلقى المساعدة من قلم المحكمة، بما في ذلك المساعدة المالية إذا اقتضى الأمر .

\section{ثانيا: هق المني عليه في الاطلاع على إهراءات التمقيق:}

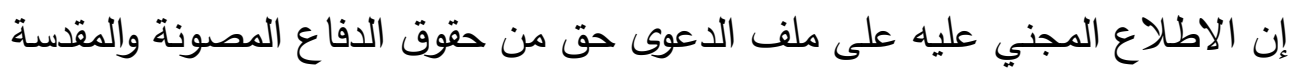

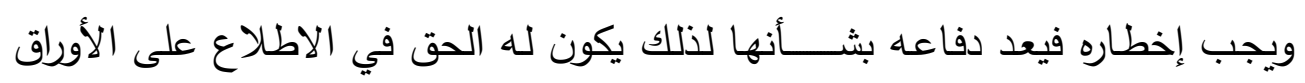

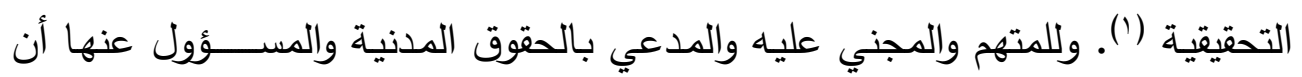

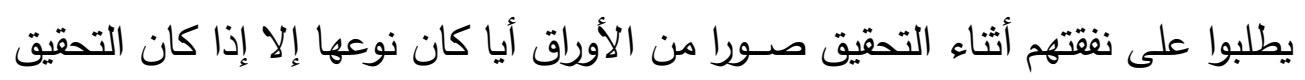

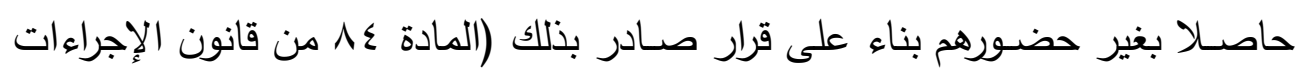

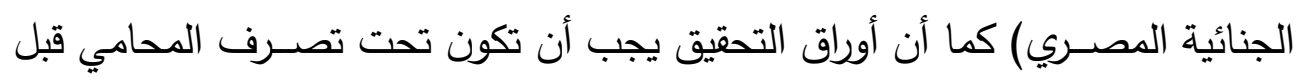

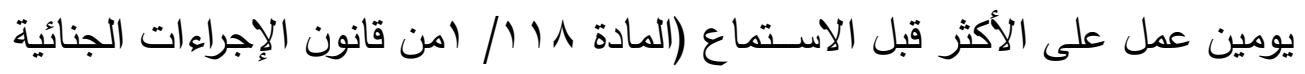

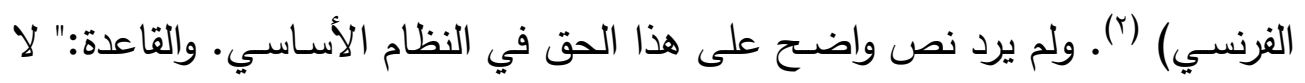

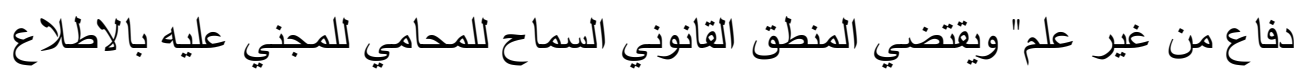

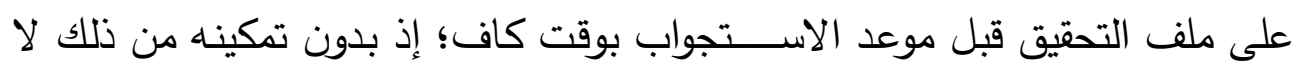

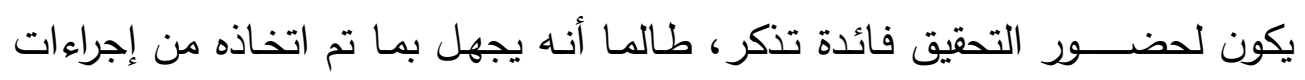

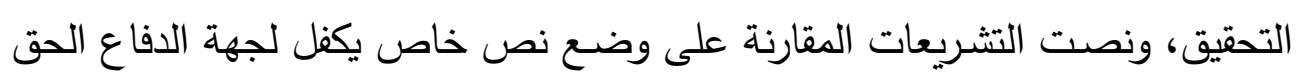

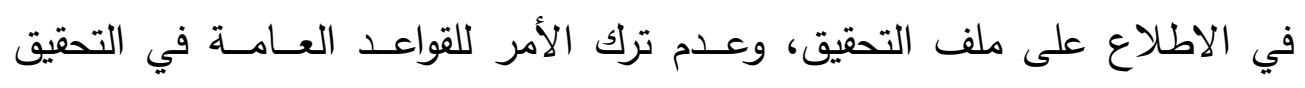

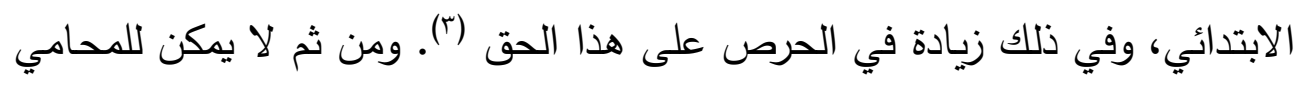

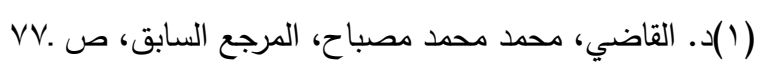

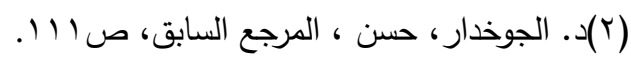

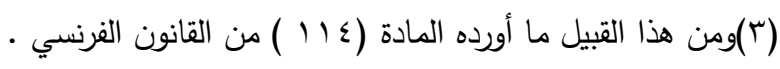

$$
\begin{aligned}
& \{\leqslant \pi r)
\end{aligned}
$$


أن يجهز دفـاعـه من غير الاطلاع عن ملف التحقيق. وإذا لم تمكنهـ جهـة التحقيق بذلك فهي تحرمه من حق أصـيل له وهو تقديم دفاعه ('). وقد خلا النظام الأسـاسـي للمحكمة الجنائية المعروف بنظام (روما ) من نص يقرر حق المجني علي الاطلاع على ملف التحقيق ،بل يخلو النظام من تقرر حقوق للمجني عليه بثــكل جازم و يعد ثغرة تشـريعية يتعين على الثـارع تلافيها يعد إعلام الضـحية (المجني عليه و المدعي بالحقوق المدنية و المســـؤول عنها) بحدود الواقعة الإجرامية محل التحقيق من أهم

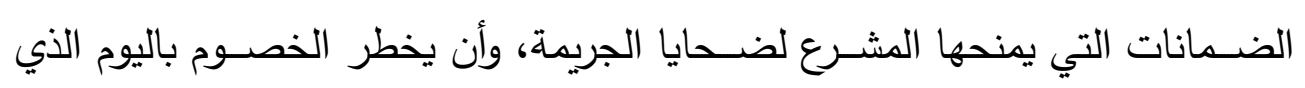
تباشــر فيه إجراءات التحقيق و بمكانها سولو متمثلا في شـــص محاميه- بجلســـة

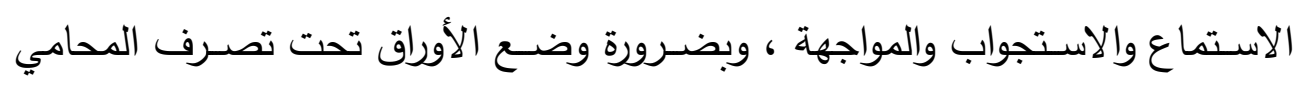

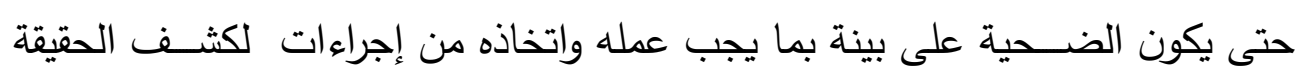
ضـــمان هام. بل إن بعض التشــريعات توجب على كل من المجني عليه و المدعي بالحقوق المدنية و المســـؤول عنها أن يعين لـه محلاً في البلدة الكائن فيها مركز

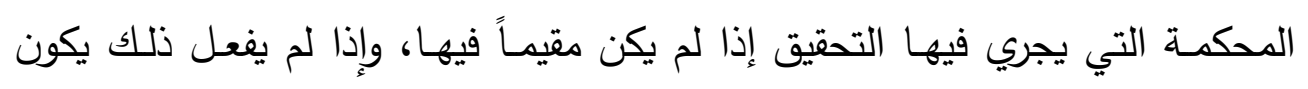

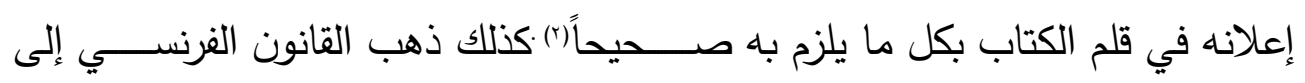
ضــــرورة إعلام المدعي المدني بقرارات انتهاء التحقيق بخطاب مســـــل خلال أربع وعشرين ساعة من صدورها · وذلك يعد من الضمانات التي تكفل حقوقهم، فنجد بأن

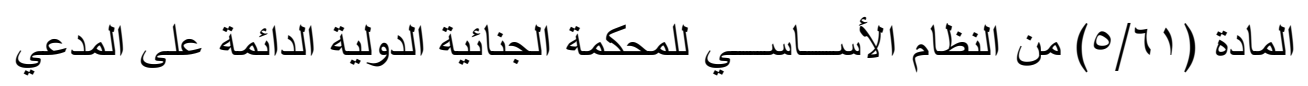
العام، أثناء الجلسـة، أن يدعم بالدليل الكافي كل تهمة من التهم لإثبات وجود أسـباب التهاب جوهرية تدعوه للاعتقاد بأن الثخص قد ارتكب الجريمة المنسوبة إليه. ويجوز أن يعمد لإنداء المدعي العام على أدلة أو عرض موجز للأدلة، ولا يكون بحاجة إلى استدعاء الثهود المتوقع إدلاؤهم بالثــــادة في المحاكمة. كذلك تقرر قيام المدعي العام خلال فترة معقولة تزويد المتهم بصورة من المستند المتضمن التهم التي يعتزم المدعي العام على بلى

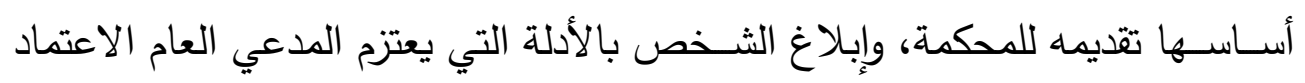




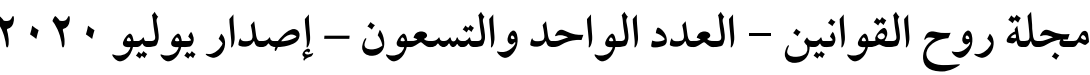

عليها في جلســة إقرار التهم ويجوز للدائرة التمهيدية أن تصـــر الأوامر بخصــوص الكس الكشف عن المعلومات.

\section{ثالثا: هرية الاتصال بين الثصم ومشاميه:}

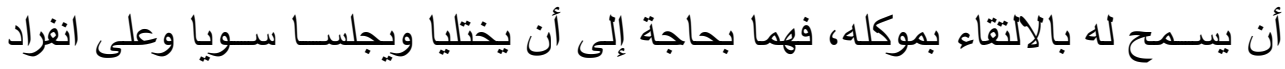

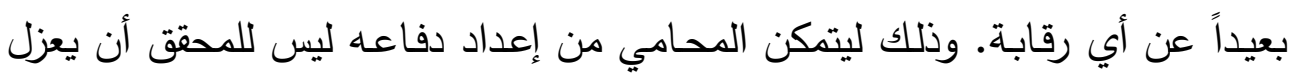

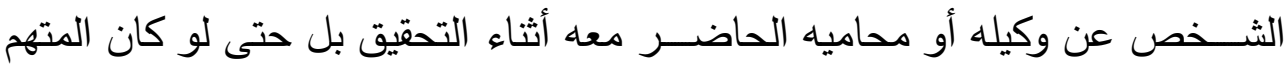
مسجونا.

رابعا: المق في تقديم الطابـات والدففوع: يجب أن يُّكن المحسامي من الدفاع عن

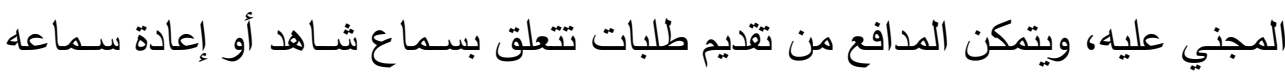

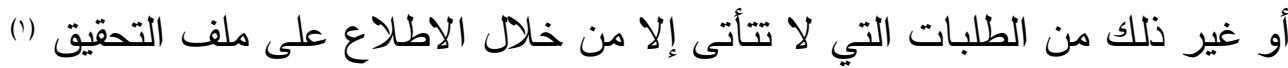

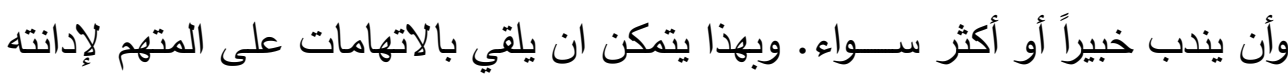

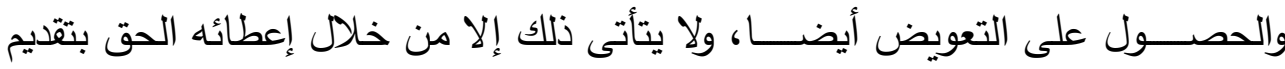

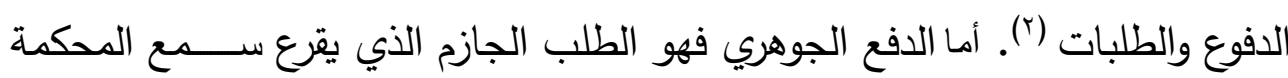

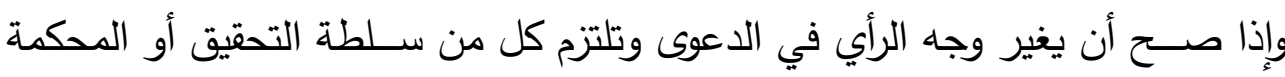

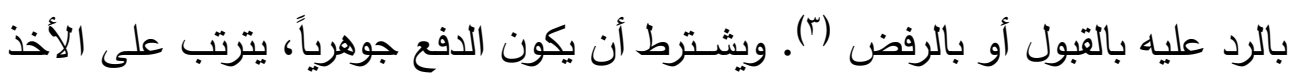

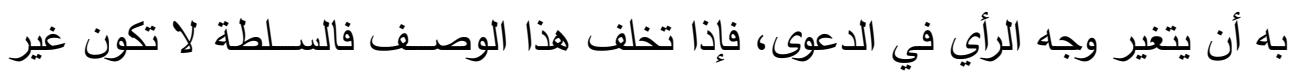

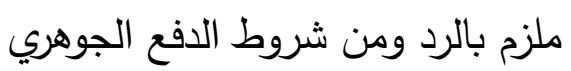

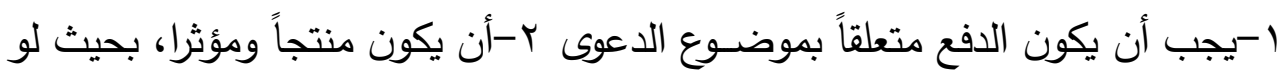

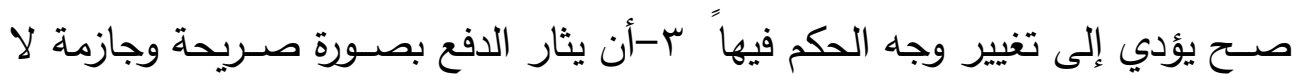
لبس فيه ــ-أن يكون للدفع وجود حقيقي في الأوراق، أي أن يكون الدفع ثابتاً في

( ) ) د.عبيد ، رعوف دور المحامي في التحقيق والمحاكمة ، مجلة مصر المعاصرة ، عدد شهر يوليو لعام

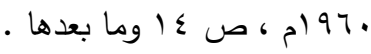

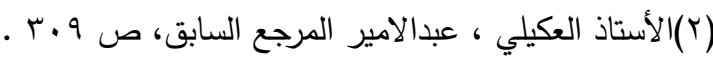

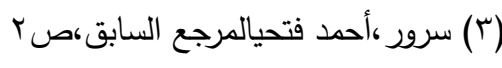


محضـر الجلسـة أو المذكرات التي يقدمها الخصـوم, 0-أن لا أن يتنازل من له الحق في إبداء الدفوع عنه صـراحة أو ضـــناً في الدفوع التي لا تتعلق بالنظام العام. ويلزم أن يكون مقدم الدفع أو وكيله لله مصلحة حالة وشخصية ومباشرة في الدفع. أما الدفوع المتعلقة بالنظام العام فلا يصــــح التنازل عنها مثال: الدفع بعدم جواز نظر الدعوى وله لسبق الفصل فيها والدفع بعدم الاختصاص وغيرها من الدفوع (') .وحق تقديم الطلبات من الحقوق المرتبطة بحق الدفاع، ومن ذلك طلب الاسـتماع لثـهادة شـاهد أو إعادة إجراء المعاينة أو الدفع بعدم صــحة واقعة (Y) وذلك لإظهار وجه الحق فيها، فإذا لم تر المحكمـة إجـابته لعدم حـاجـة الدعوى إليهه وجب الرد عليـه في الحكم بما يبرر رفضه، فإذا هي لم تفعل كان حكمها معيباً لقصوره في البيان(r) ومن خلال استعراضنا نظام روما لم نجد في نصوصه الواردة إعطاء حق لضحايا الجريمة بتقديم الدفوع والطلبات وتفنيد الأدلة. وهذا يقتضي الاهتمام بحقوق المجني عليه وأن يتبنى نظام روما العديد من النصوص الجديدة لحماية المجني عليه الجريمة. منها أنه يحق له الحضور في إجراءات التحقيق حتى لو لم يقم بالادعاء بالحق المدني إن الفقه استقر على أن صاحب الحق في تقديم الثكوى هو من توافرت فيه صفة المجني عليه، وليس المتضرر من الجريمة، كذلك ضمان حقه في التعويض عن الأضرار التي تحدث لهم من جراء الجرائم التي تقع عليهم ، وذلك بضمان الدولة بمساعدة ضحايا الجريمة، تعويضهم، وإنشاء صناديق ضمان لتعويض ضحايا الجريمة....الخ (£).

( ) د . عوض ، القانون الجنائي،(ع 197 ، ). محمد محي الدين إجراءاته في التشريعين الدصري و السوداني،

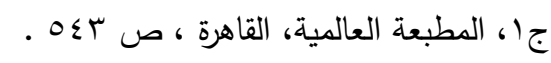

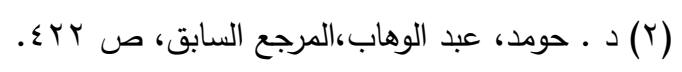

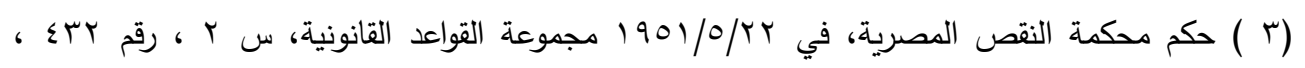

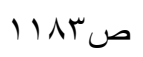

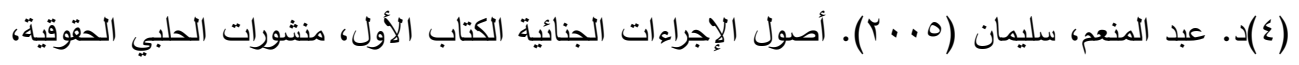

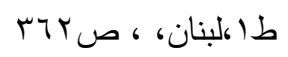




$$
\text { r.r. · مجلة روح القوانين - العدد الواحد والتسعون - إصدار يوليو }
$$

خامسسا: هق الاسـتعانة هجانا بمترجم: وذلك نظرا لأهمية هذا الحق في إقامة العدالة

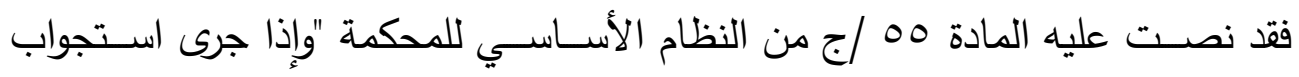

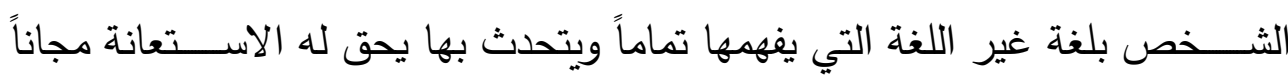

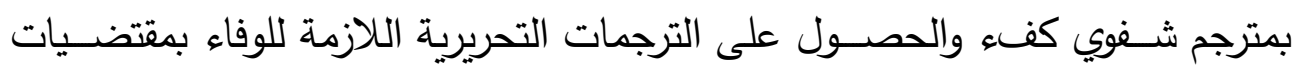

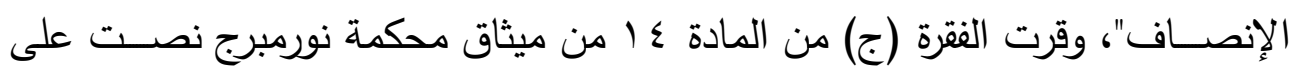

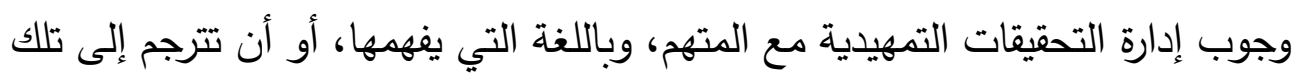

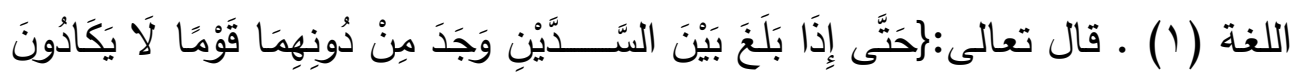

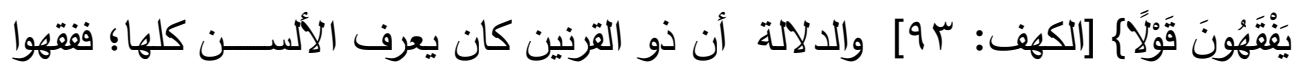

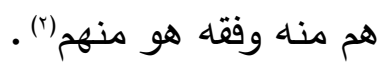

\section{المبلب الثالث}

\section{هق المني عليه في استثناف قرارات سلطة التمقيق}

يبتدئ التحقيق الابتدائي بتحريك الدعوى الجنائية من قبل المدعي العام، وينتهي بقرار

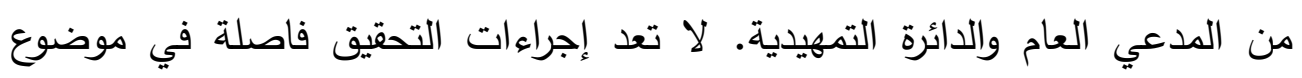

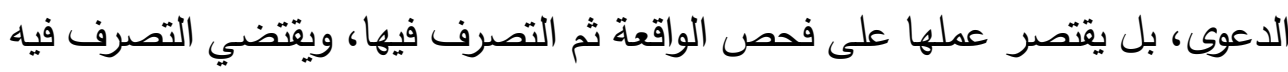

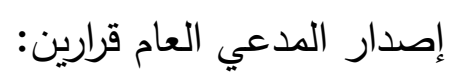

الأول: إحالة ملف الدعوى الجنائية، مقرونا بلائحة الاتهام، إلى المحكمة المختصة؛

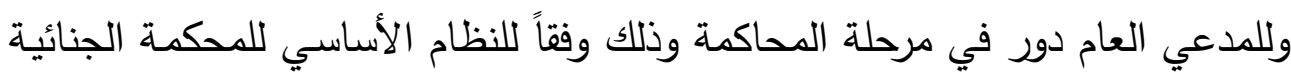

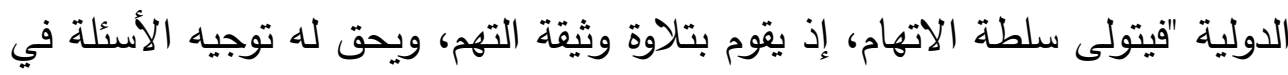

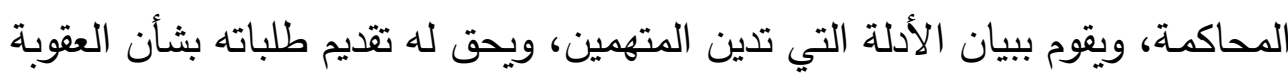

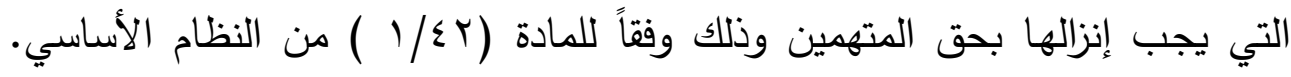
ويترتب على التصرف في التحقيق الابتدائي، خروج الدعوى الجنائية من حوزة المدعي

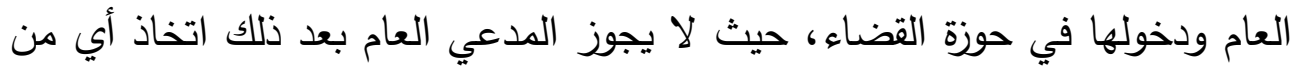

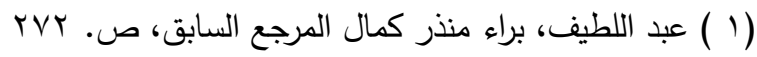

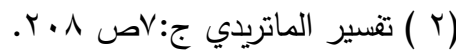


إجراءات التحقيق الابتدائي، إذ لزول ولايته عن التحقيق الابتدائي ما لم تدخل الدعوى في حوزته مرة ثانية بطريق قانوني (1).والقرار الثاني: حفظ الدعوى الجنائية. ويترتب على قرار الحفظ أو عدم الثروع في التحقيق ضرر للمجني عليه نتيجة يخل بحقه في

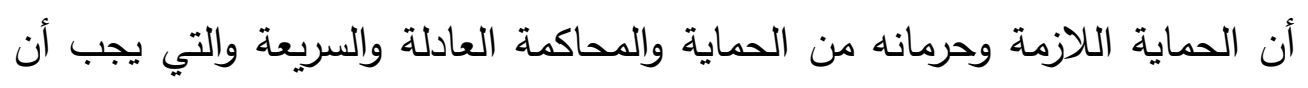
تتعقد في جو من الاحترام التام لحقوق المتهم والمراعاة الواجبة لحماية المجني عليهم والثهود.(المادة ؟ 7 من النظام الأساسي) ويجب على المدعي العام إعلان قرار المدعي العام بعدم الشروع في تحقيق أو عدم المقاضاة (طبقا للمادة سه من النظام الأساسي) لكن لم توجب إعلان المجني عليه، كما للمجني عليهم الحق في تقديم مقترحاتهم فيما يتعلق بمدى اختصاص المحكمة بنظر الدعوى. وأن يتمكنوا من اتخاذ إجراءات الطعن القانوني وتشكل مشاركة المجني عليه في الإجراءات الخاصة بتحديد اختصاص المحكمة فيما يتعلق بنظر الدعوى بأن هذه المشاركة تعتبر جوهرية لأن المادة 19 الفقرة r من النظام الأساسي للمحكمة الجنائية الدولية تعطي للمجني عليهم الحق في تقديم ملاحظات فيما يتعلق بالمقبولية أي مدى اختصاص المحكمة بالنظر بالدعوى.كما

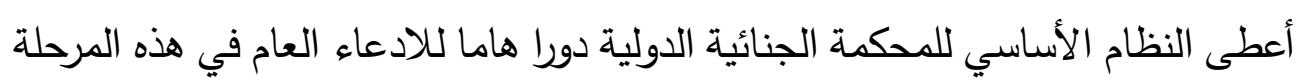
فيما يتعلق بالاستئناف وإعادة النظر بالحكم، إذ يجوز لله استئناف حكم الإدانة الصادر

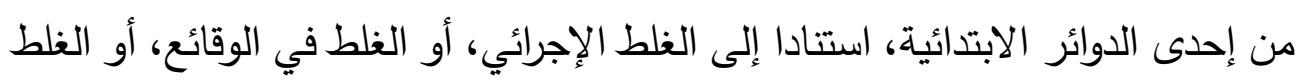
في القانون طبقا للفقرة الفرعية / /أ من المادة إحم من النظام الأساسي للمحكمة الجنائية الدولية .وإن قراره بعدم إجراء تحقيق أو عدم المتابعة، حيث يمكن استئنافه من قبل الدولة القائمة بالإحالة أو مجلس الأمن في غضون لو جو يوما من الإخطار ، أو من قبل الدائرة التمهيدية من تلقاء نفسها، إذا كان القرار مبني على مدى خطورة الجريمة وفي الإحني هذه الحالة لا يصبح قرار المدعي العام نافذا إلا بعد اعتماده من طرف الدائرة التمهيدية طبقا للمادة سه من النظام الأساسي للمحكمة الجنائية الدولية، أما ضحايا الجرائم الدولية فلا يجوز لهم تقديم استئناف ضد قرارات المدعي العام .وليس للمجني عليهم أو لمثثليهم 


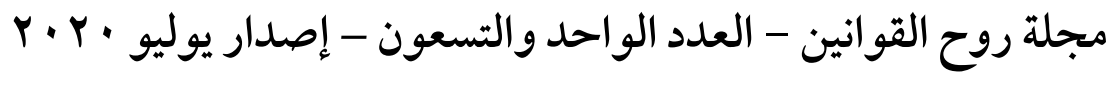

استئناف قرار الإدانة، إذ إن الإجراءات أمام المحكمة الجنائية الدولية ترمي بالدرجة

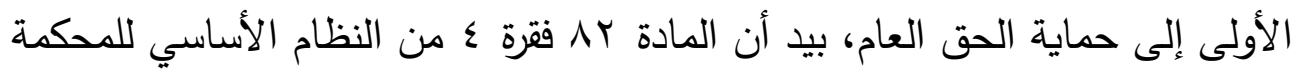

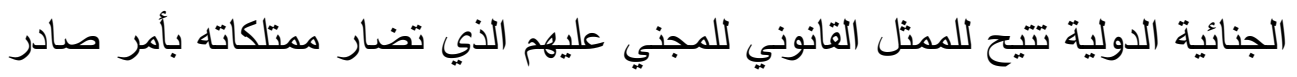

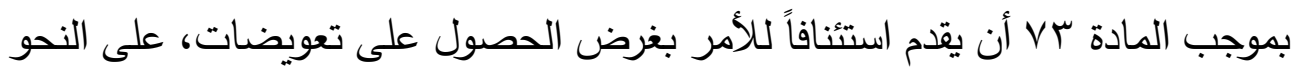
المنصوص عليه في القواعد الإجرائية وقواعد الإثبات. كذلك ليس للدول صفة تخولها

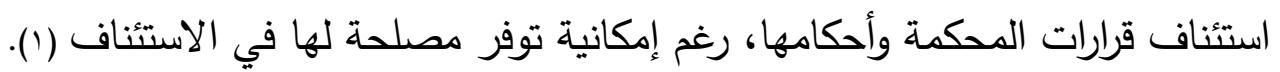

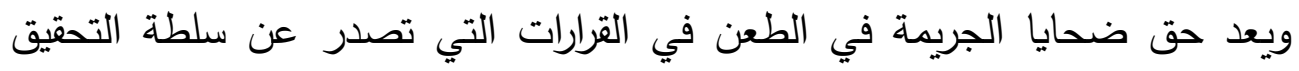
الابتدائي أثناء سير التحقيق أو بعد الانتهاء منه من أهم الحقوق الإجرائية المكفولة له له لهن

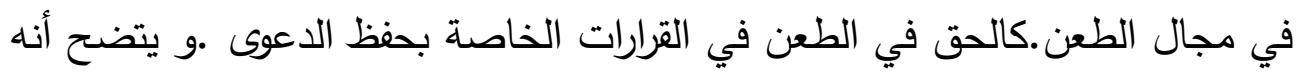

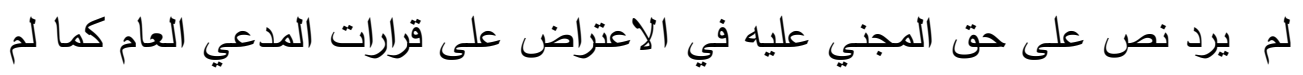

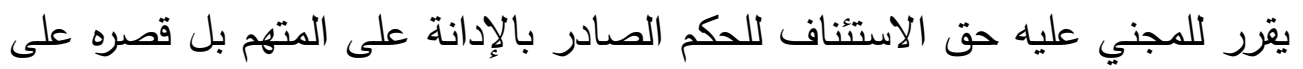

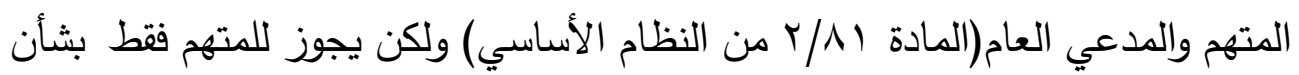

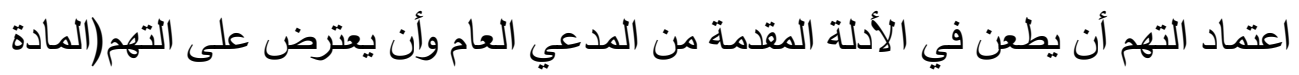

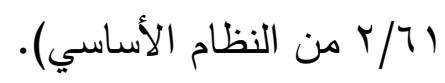

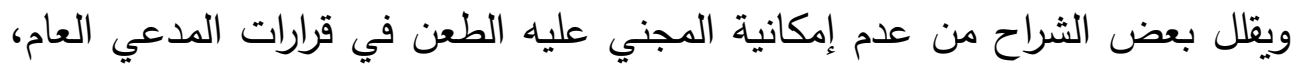

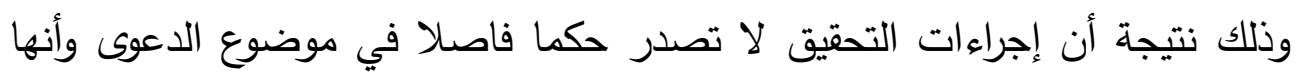

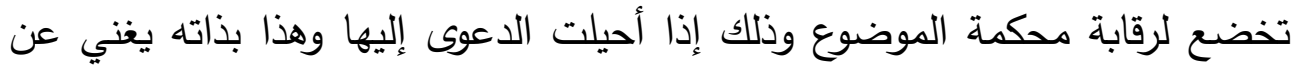
الطعن في إجراءات التحقيق عقب صدورها، حيث إن الخصم يمكنه ان يدفع أمام

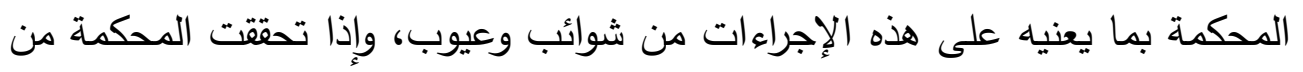

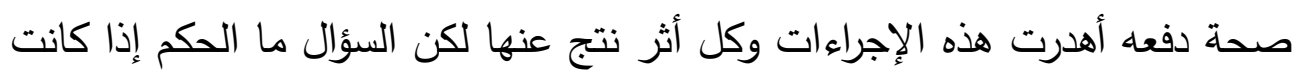

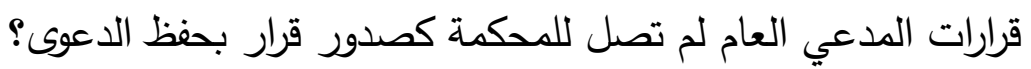




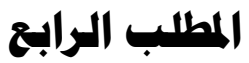

\section{تدوين إجراءات التمقيق أهام المدعي العام}

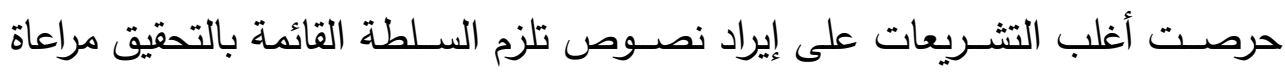

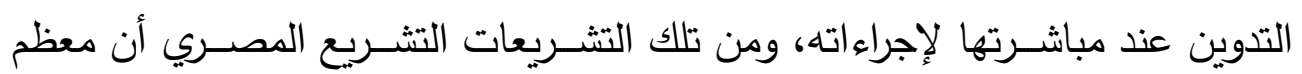

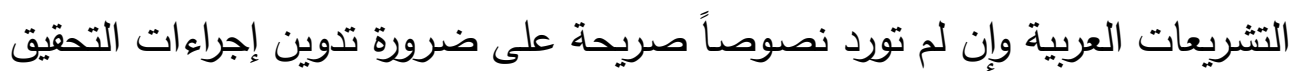

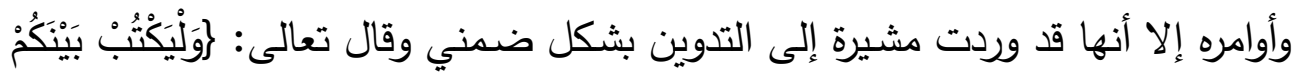

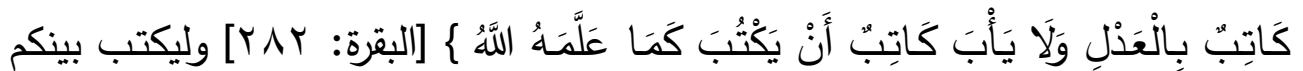
كاتب بالعدل لأن العدل هو ما علمه الله، لأن الكاتب بالعدل إنما يكتب ما يملى عليه،

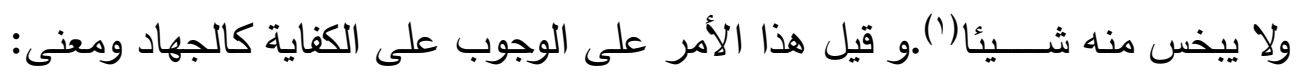

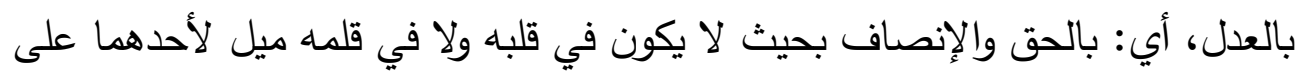

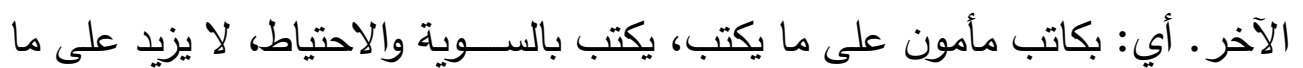

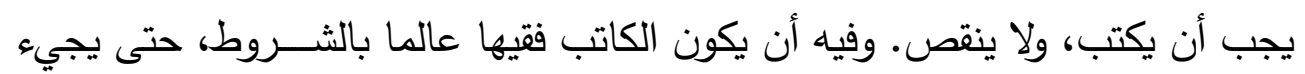

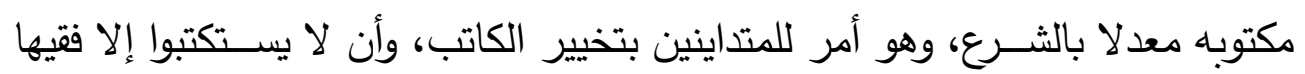

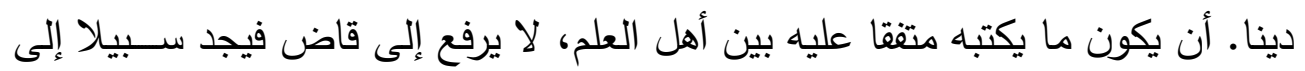

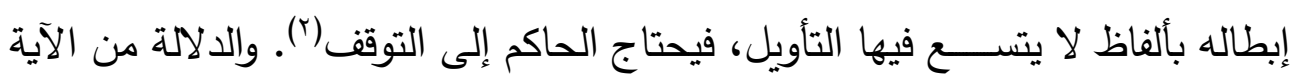

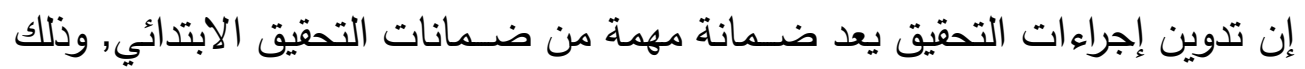

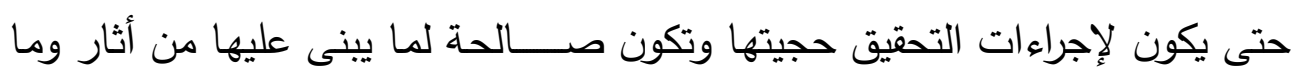

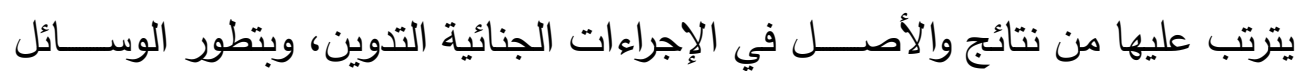

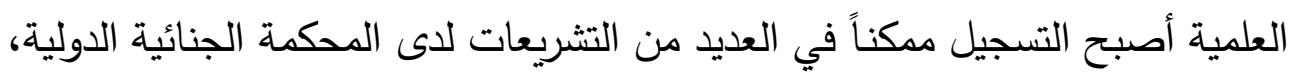

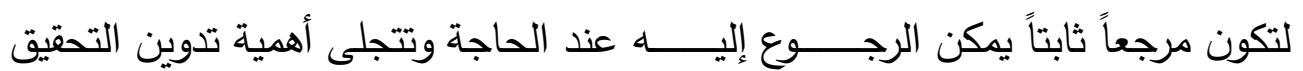

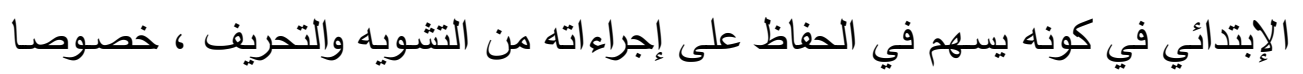

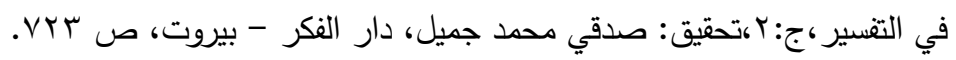




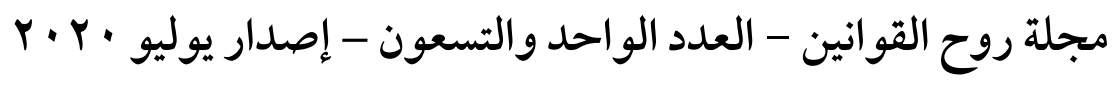

وأن إجراءات التحقيق متعددة وأساليب مباشرتها مختلفة ، فضلا عن أن إنجاز بعضها

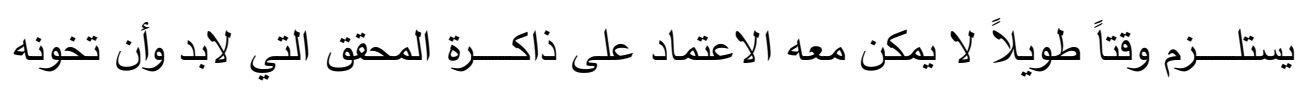

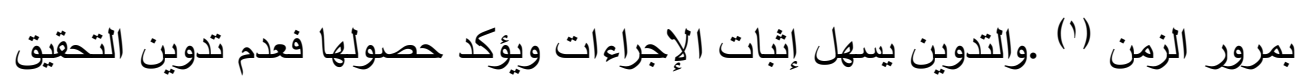

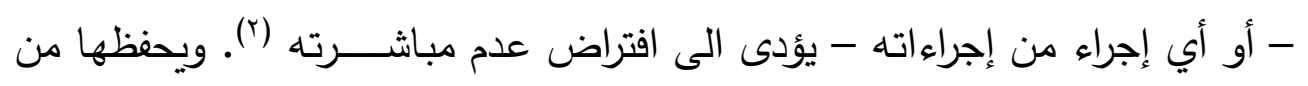

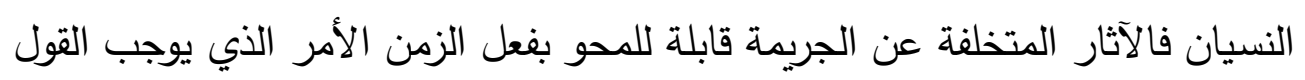

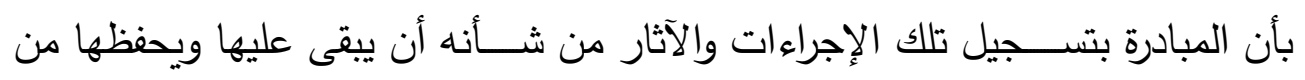

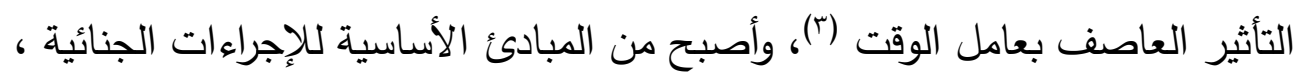

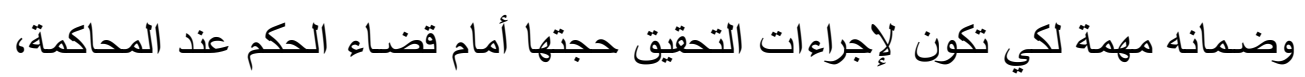
كما أنه يمكن السلطة المشرفة على التحقيق من مراقبة سير التحقيق للتأكد من صحته

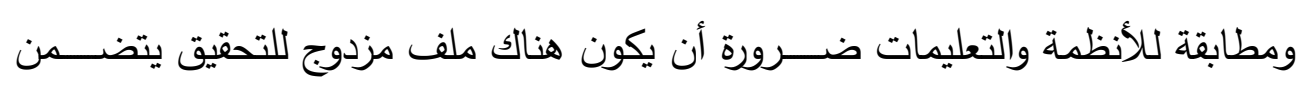

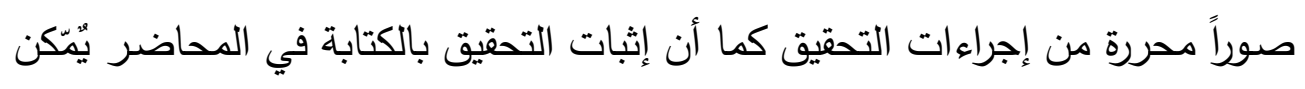

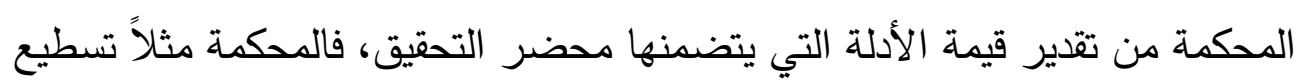

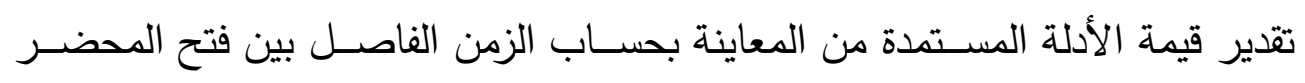

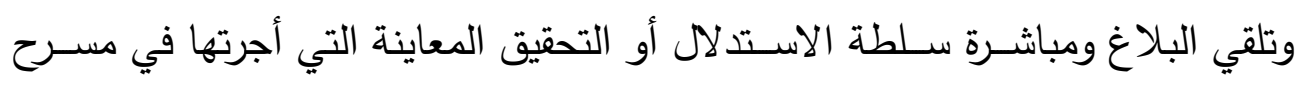

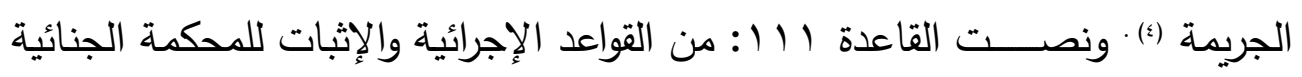

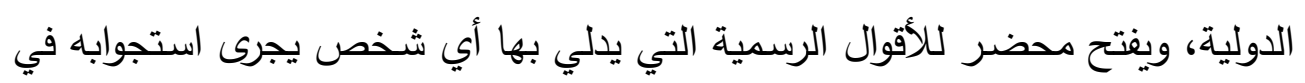

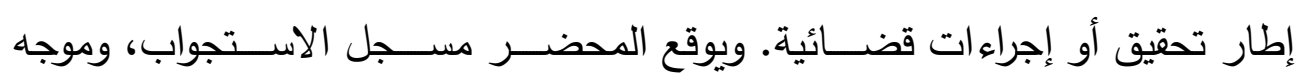

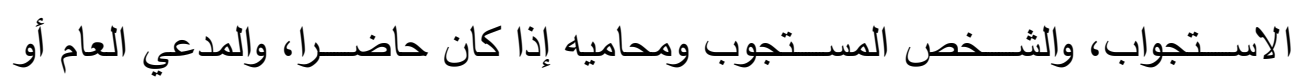

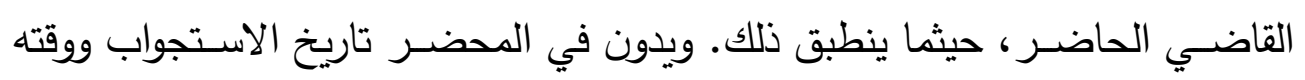

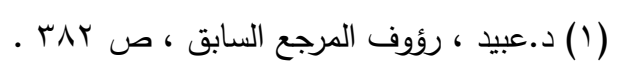

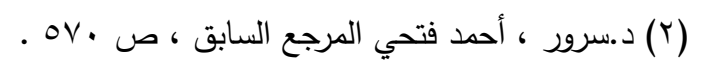

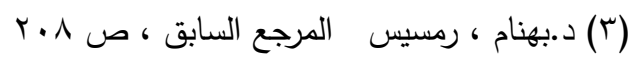

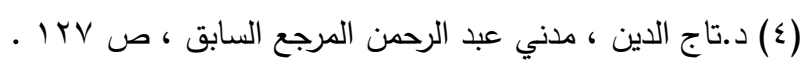

$$
\begin{aligned}
& \{\varepsilon \vee \cdot
\end{aligned}
$$




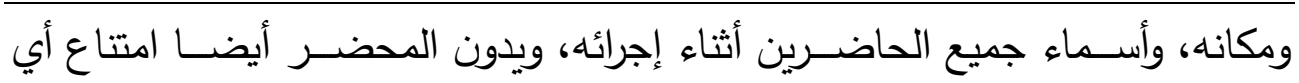
شخص عن التوقيع والأسباب التي دعت إلى ذلك.

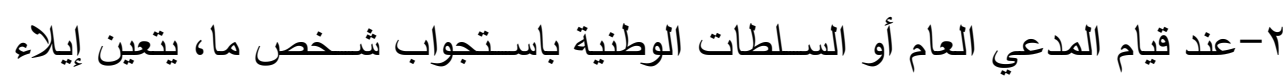

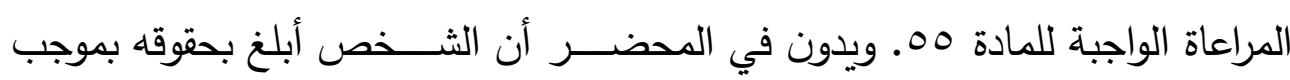

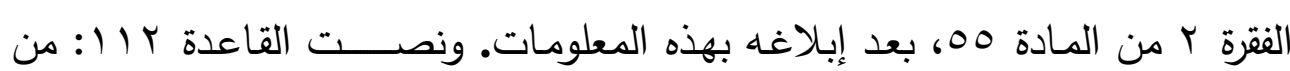
القواعد الإجرائية والإثبات للمحكمة الجنائية الدولية.

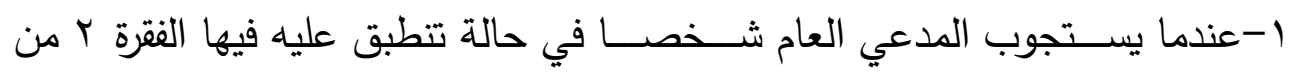

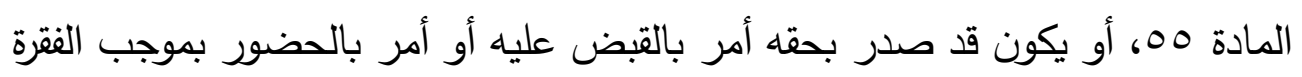

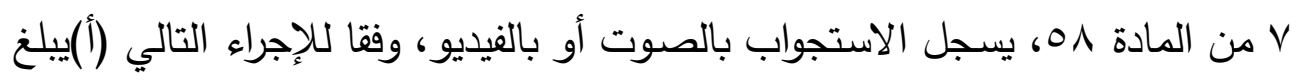

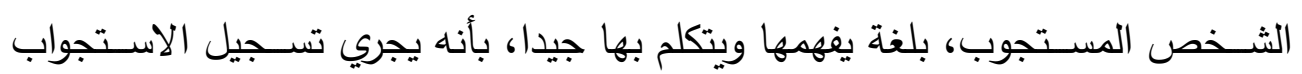

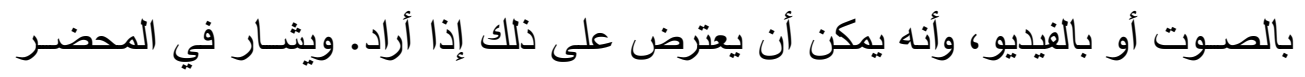

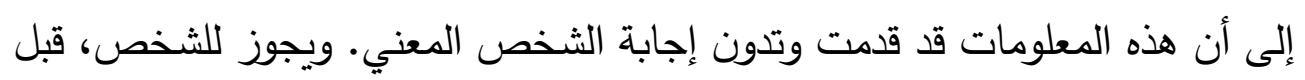

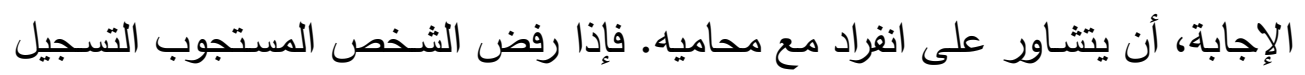

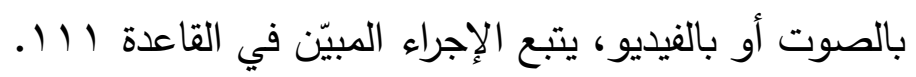

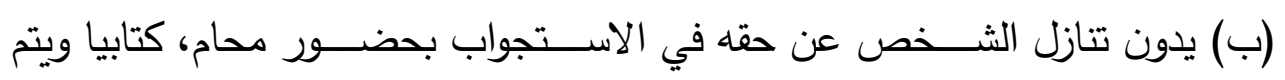

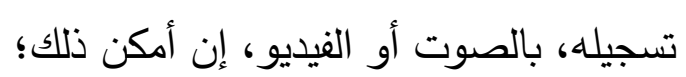
(ج) في حالة حدوث توقف أثناء الاستجواب، تسجل واقعة ووقت التوقف قلت دبل انتهاء

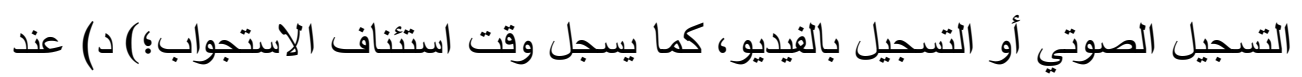

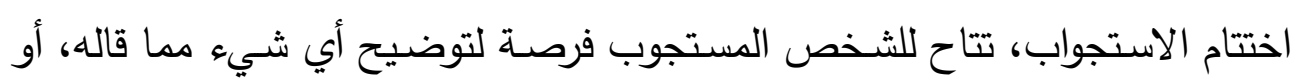

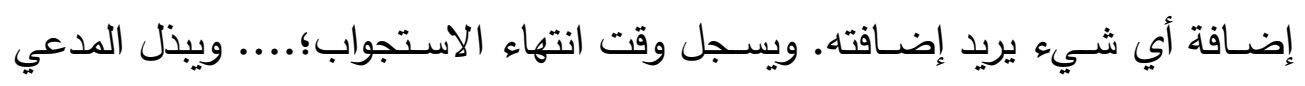

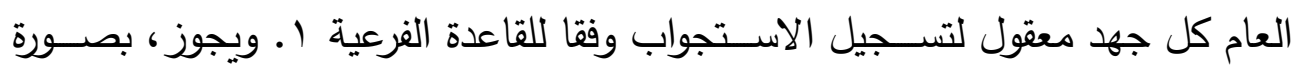

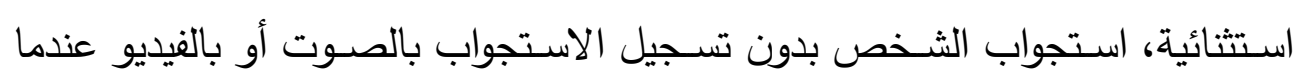

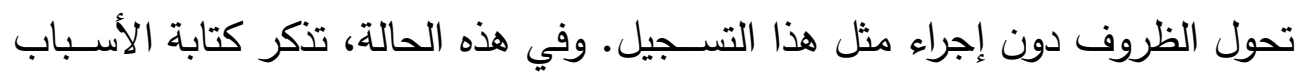

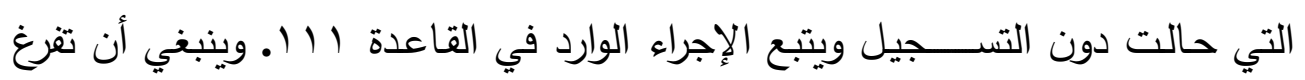




$$
\text { r. r. · مجلة روح القوانين - العدد الواحد والتسعون - إصدار يوليو }
$$

الأقوال في محضــر ويوقع عليه من المحقق وكاتب المحضــر ومن أدلى بأقواله في

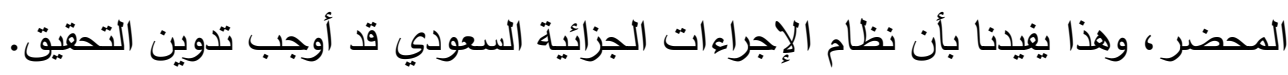

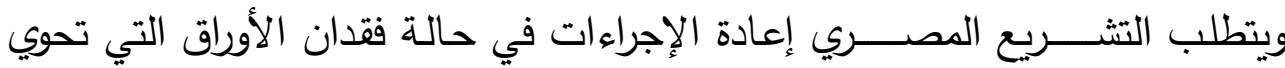

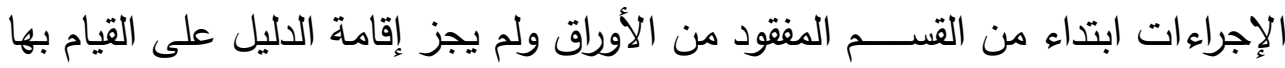

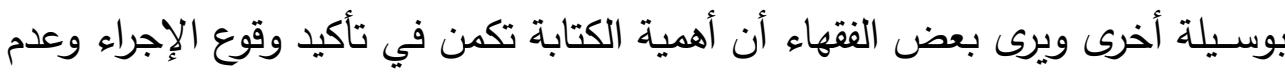
المنازعة في وقوعه. المادة (10) من قانون الإجراءات الجنائية.

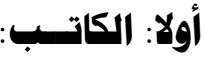

بينت القاعدة (1) (1) من قواعد التحقيق والإثبات لاى المحكمة الجنائية الدولية

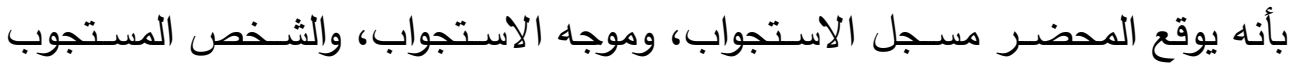

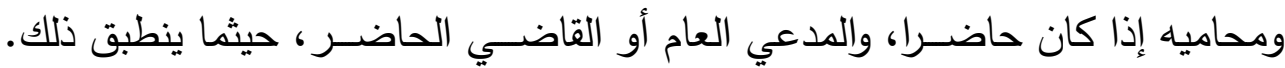

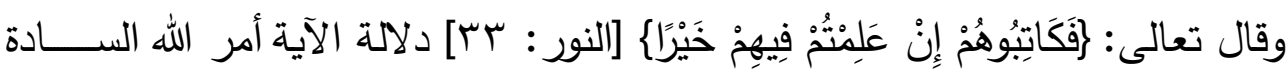

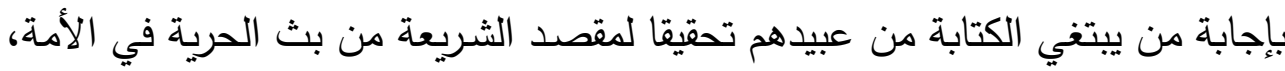

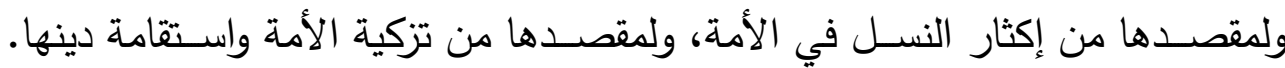

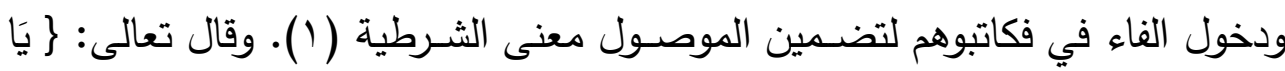

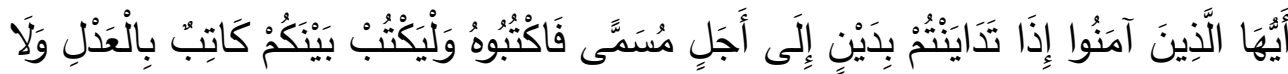

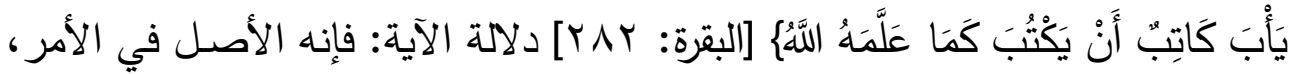

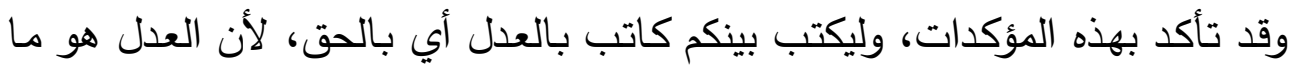

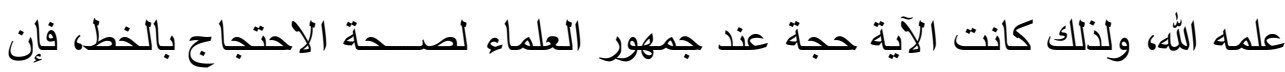

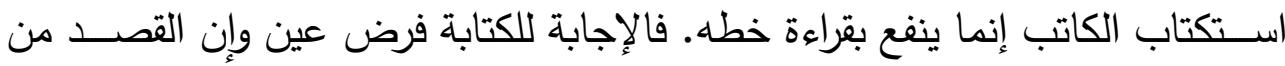

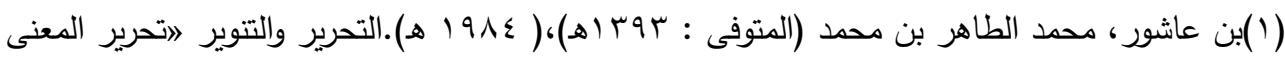

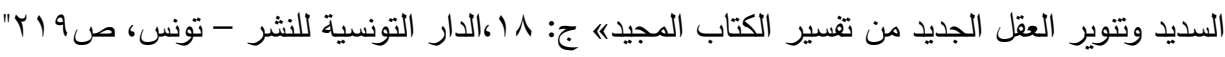
$\leqslant \vee r$ 
الأمر بالكتابة التوثق للحقوق وقطع أســـباب الخصـــومات، وتتظيم معاملات الأمة،

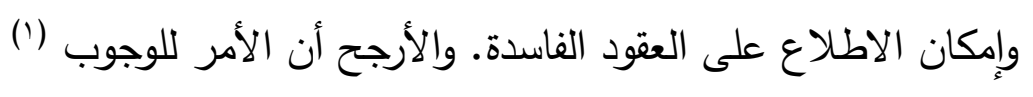

ويدون في المحضـر تاريخ الاسـتجواب ووقته ومكانه، وأســاء جميع الحاضـرين

أثثاء إجرائه، ويدون المحضـر أيضـا امتناع أي شـخص عن التوقيع والأسـباب التي التي دعت إلى ذلك. فالقاعدة العامة في إجراءات التقاضــي هي الكتابة وتدوين الإجراءات

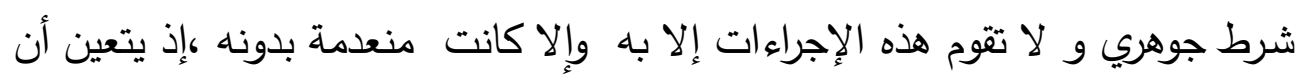

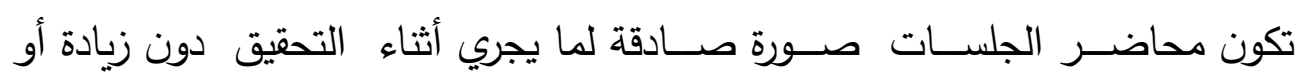
نقصـــان أو تغيير في الألفاظ وإلا طعن فيه بالتزوير ، ويراعى بقدر الإمكان تدوين

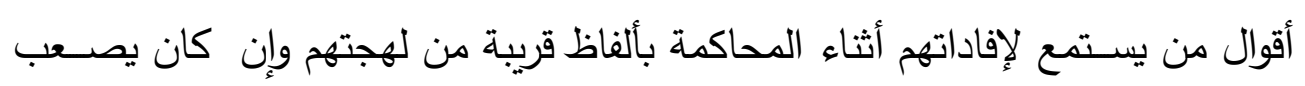

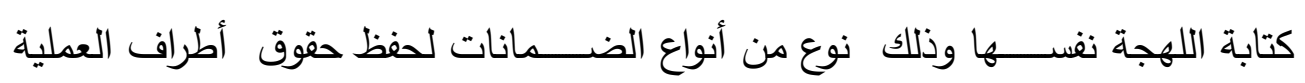
القضائية خصوصاً في الدعاوى الجنائية ويجب المبادرة بتسجيل الإجراءات والآثار القابلة للمحو في جميع مراحل الدعوى الجنائية لمـا من شـــأنه أن يبقى عليها ويحفظها من التأثير العاصف بعامل الوقت(Y)،لكن هذا لا يمنع من التوسع في شرح الطلبات أو الرد باللجوء إلى الطريق الثـــفوي بنـاء على طلب من الأطراف أو من القاضي.

وقد حرصـــت الأنظمة الإجرائية على اشــتراط وجود كاتب لتدوين التحقيق وأن يجلس الى جوار المحقق ليقوم بـالعمل الكتابي الذي يمليـه عليـه المحقق من خلال تحقيقه مع أطراف التحقيق، لذلك يجب أن يحضر جلسات التحقيق كاتب يتولى تحرير محضر التحقيق تحت إشراف عضو النيابة. ويبين في المحضر اسم المدعي العام ،

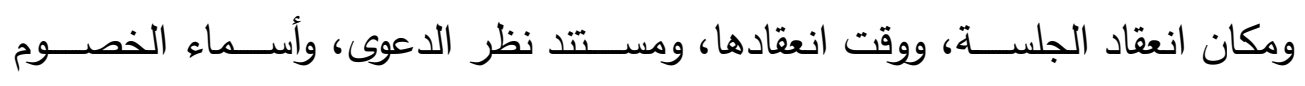
الحاضرين، والمدافعين عنهم، وأقوالهم وطلباتهم، وملخص مرافعاتهم، والأدلة كالثهادة ومهاء ومهاء

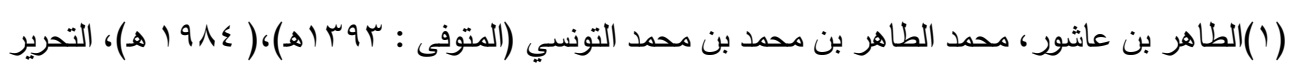

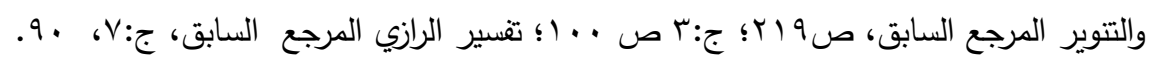

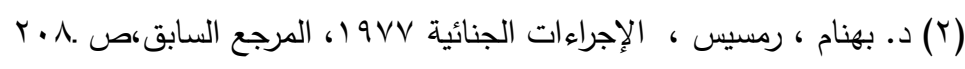




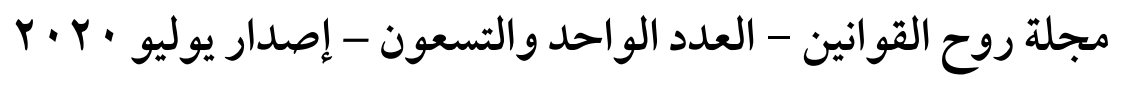

وغيرها، وجميع الإجراءات التي تتخذ في التحقيق فإن امتنع أحدهم عن التوقيع أُثبت

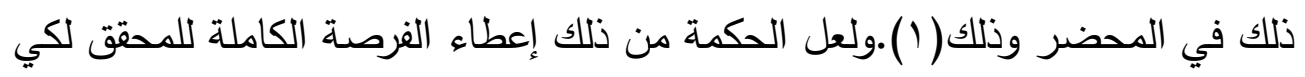

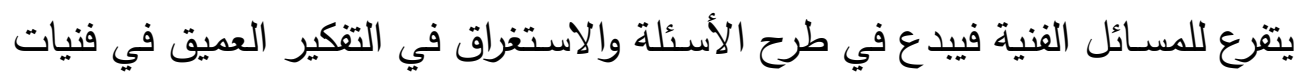

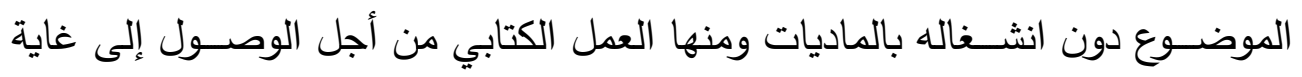

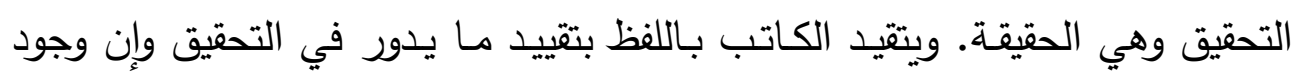

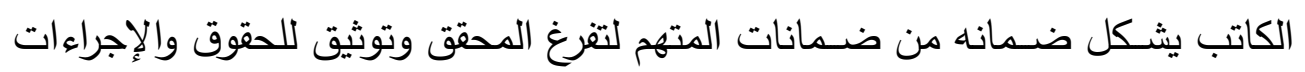

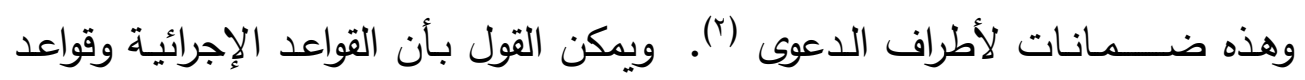
الإثبات فرقت بين أمرين هما: الأول: اشترطت تواجد الكاتب مع المحقق في إجراء من إجراءات التحقيق كإجراء الاســـتواب مثلا، فإن تخلف الكاتب يجعل الإجراء باطلا بطلانـا مطلقا متعلقا

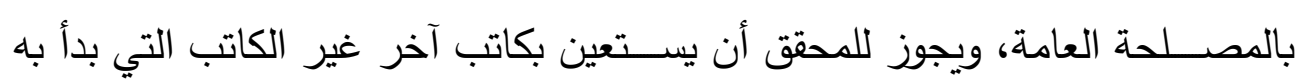

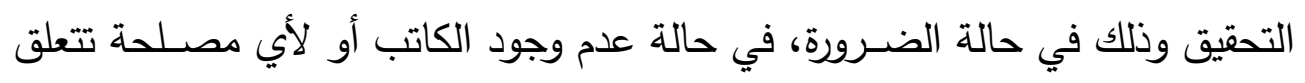

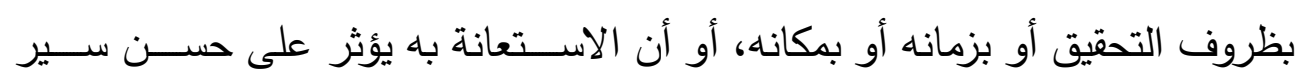

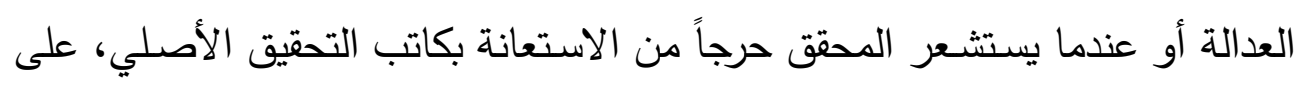

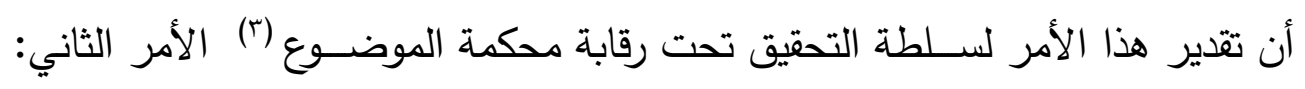

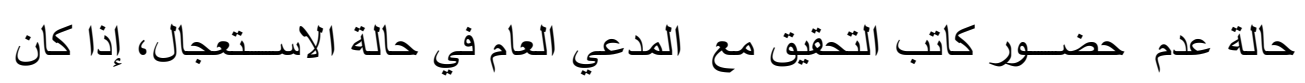

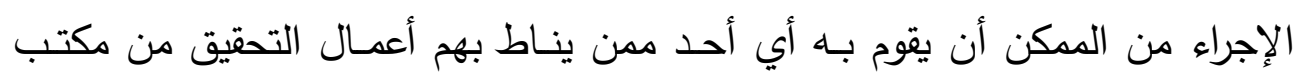

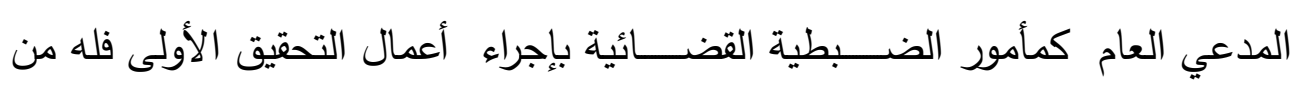

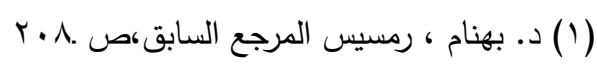

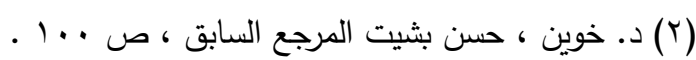

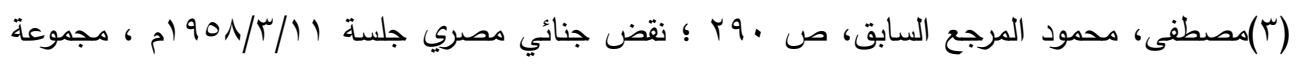

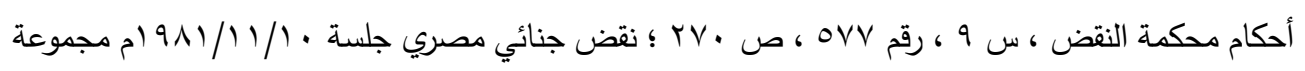

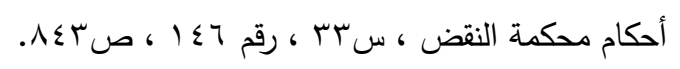


الاختصاص ما خوله القانون الداخلي لسائر رجال الضبطية القضائية () ـ فإن قام به المدعي العام لدي المحكمة الجنائية الدولية فإن البطلان هنا يكون نســبـى لا يحول ذلك من التعويل على هذا الإجراء باعتباره من أعمال الاســـــلال، ولا يجوز إثارت

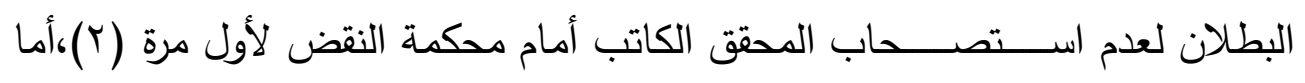
قاضـــى التحقيق بالدائرة التمهيدية فلا يجوز لله القيام بتدوين هذه الإجراءات بنفســـهـ لأنه لم يمنح قاضـى التحقيق صفة الضبطية القضـائية. ذهب رأي إلى صحة الإجراء إذا تولاه المحقق بنفسه تحقيقاً وكتابةً (r).

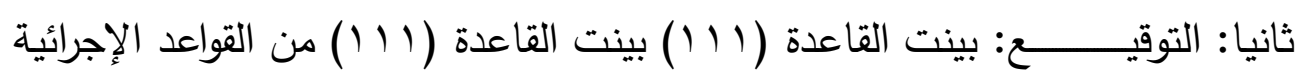
والإثبات لدى المحكمة الجنائية الدولية بأنه يوقع المحضـر مســـل الاســتجواب أي لإي

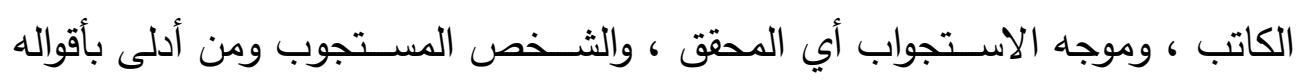

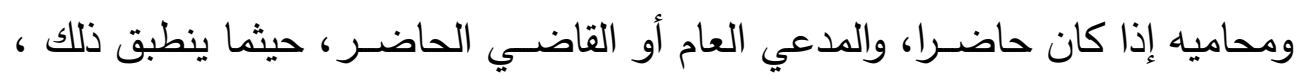
ويعد التوقيع على محاضر التحقيق بمثابة التأكيد على صحة ما جاء بهذه المحاضر ، وأنه تم تحت سـع وبصر أطرافه الذين وقعوا عليها، وهو أيضـاً إقرار ممن وقع عليها بصـــحة ما أورد به من أقوال، كما أن ذلك يدعو الى الثقة والاطمئنان لما تم بها من وفئ

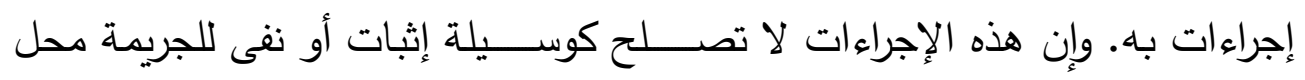

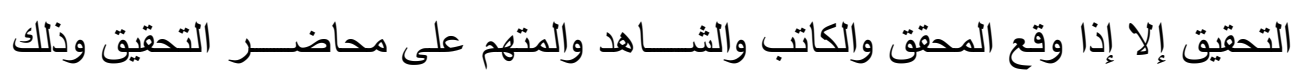
باعتبار أنها من الأوراق الرسـمية التي يجب أن تحمل بذاتها دليل صـــتها ومقومات

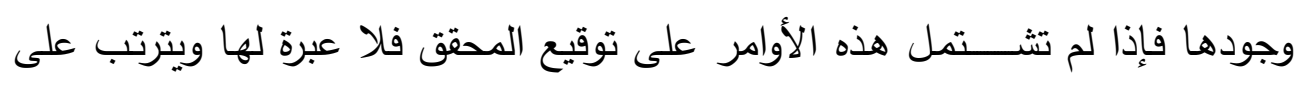

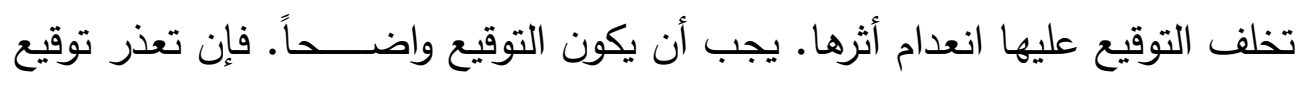

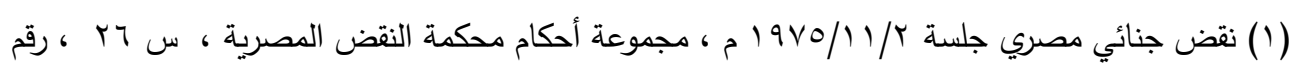

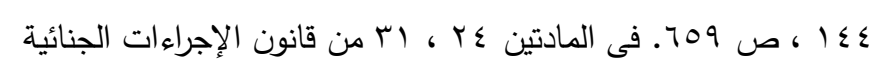

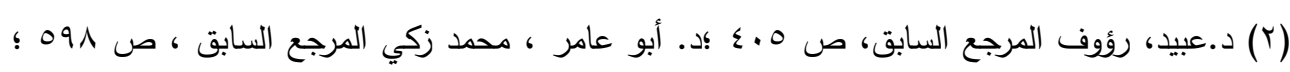

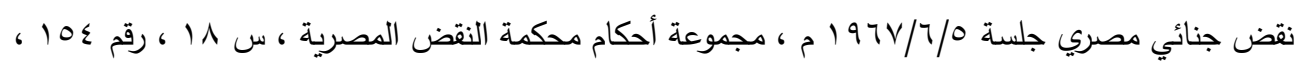
ص VTV (r) د.المرصفاوى، حسن صادق المرجع السابق، ص بـ بـ. ( $\leqslant \vee 0)$ 
F. r. · مجلة روح القوانين - العدد الواحد والتسعون - إصدار يوليو

الشـاهد كأن يمتنع عن التوقيع أو لا يستطيع التوقيع فإن لم يكن يجيد الكتابة بأن كان

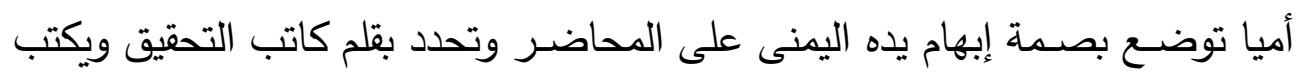

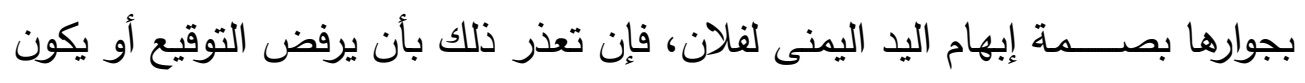

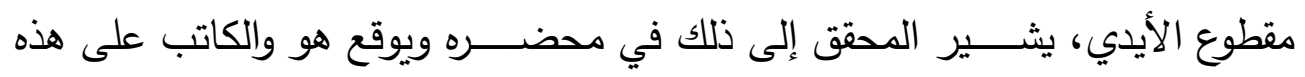

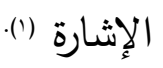

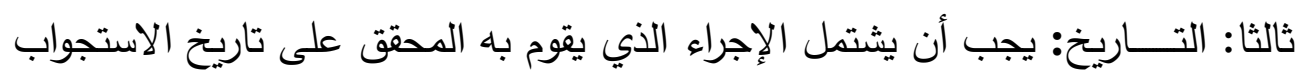

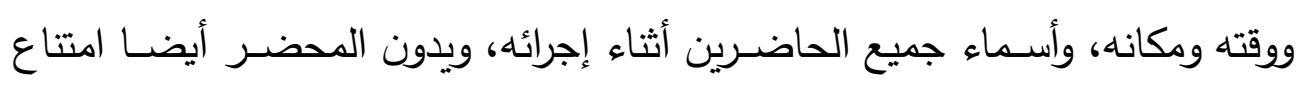

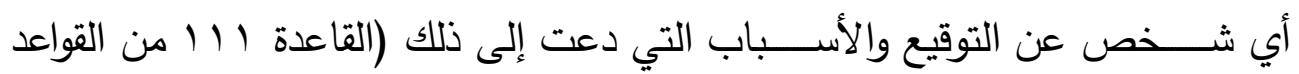

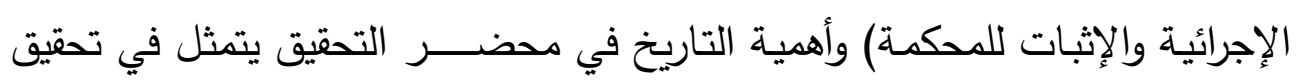

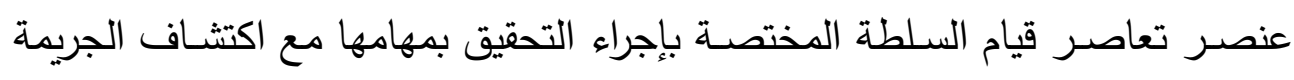
فإثبات التاريخ في محاضر التحقيق ييسر معرفة وقت تحرير المحضر والظروف التي

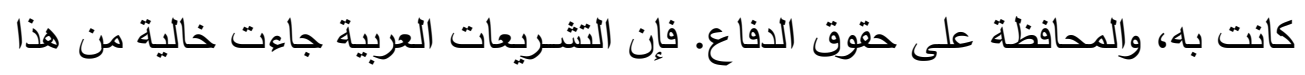

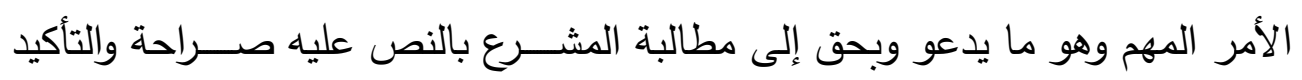

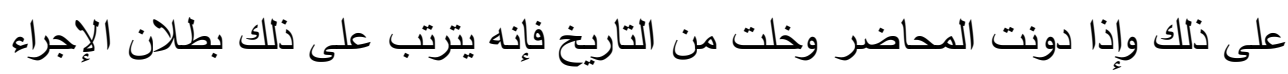

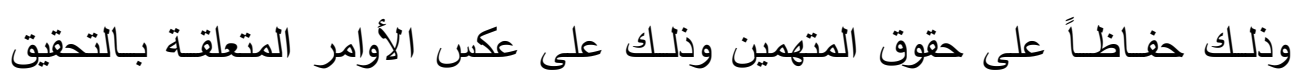
كالتكليف بالحضــور وأمر الضـبط والإحضـار فقد أهتم نظام الإجراءات الجزائية بها وأوجب ذكر تاريخ الأمر وساعة الحضور وتاريخه.

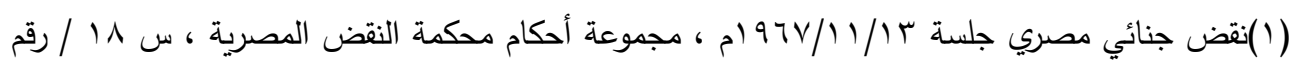

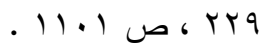




\section{البمثث السادس}

\section{حق المجني عليه في جبر الضرر الناتج عن الجرائم الدولية}

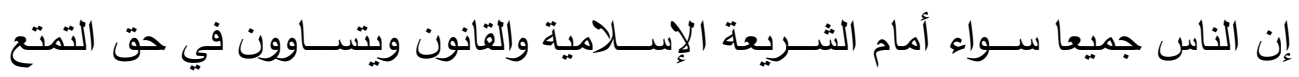

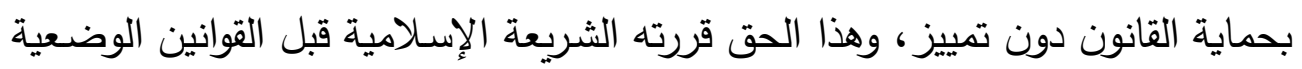

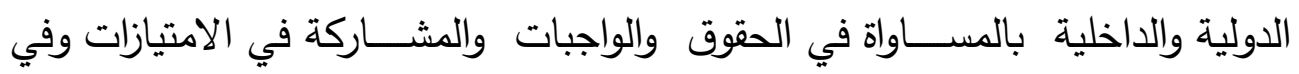

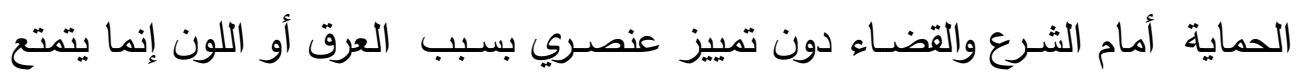

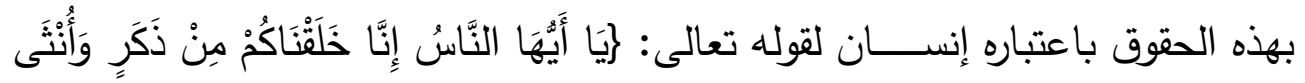

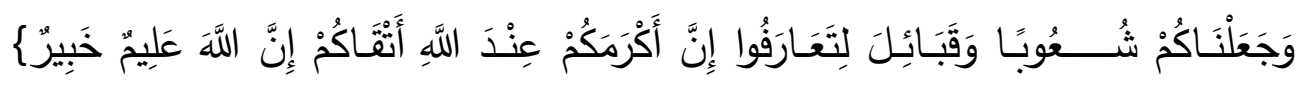

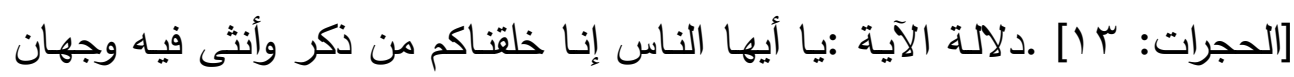

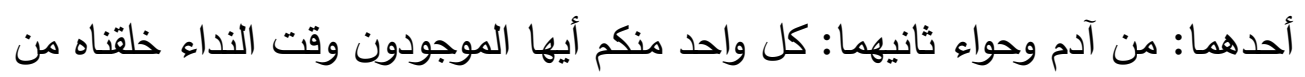

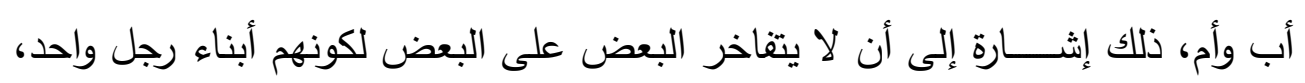

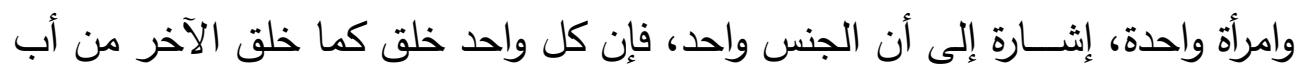

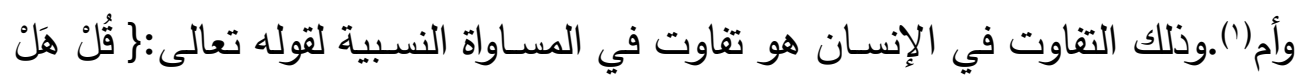

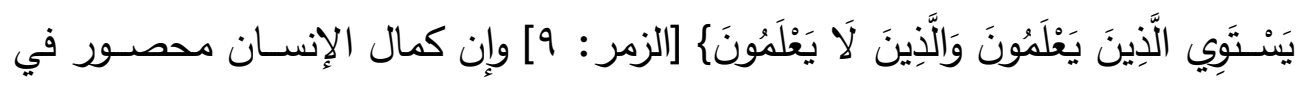

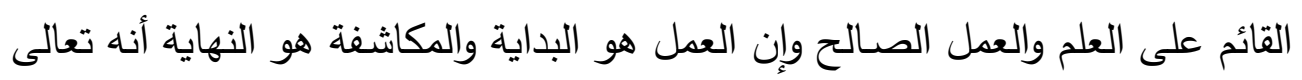

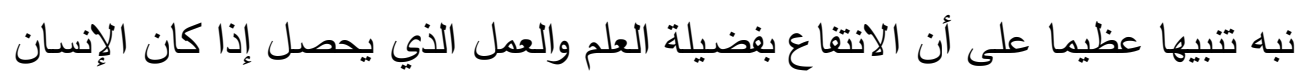

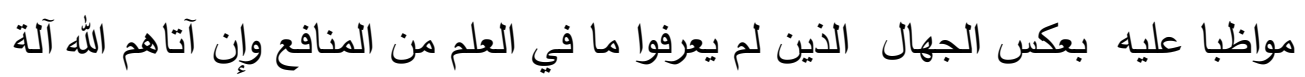

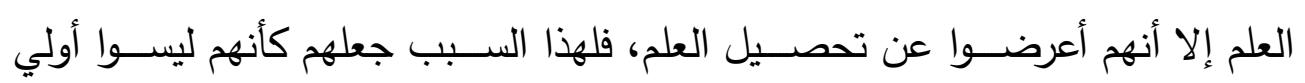

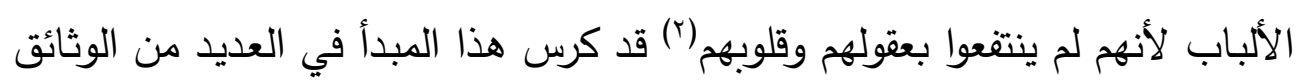

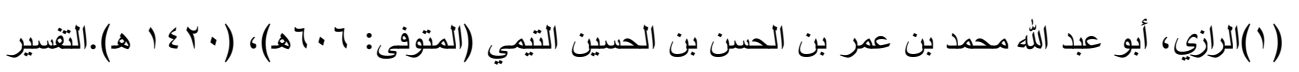

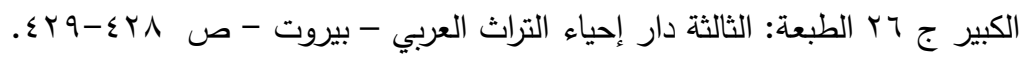

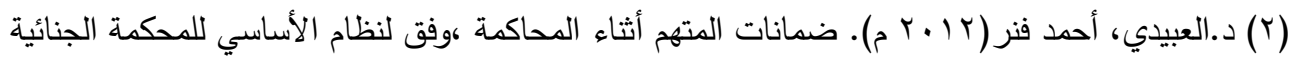

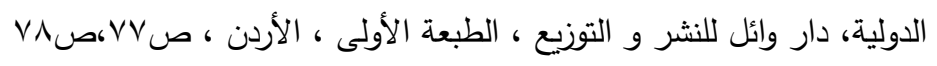




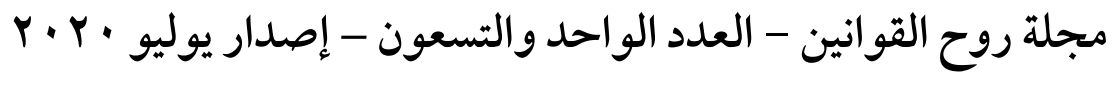

والمعاهدات الدولية كالإعلان العالمي لحقوق الإنسان و المواطن لسنة VA9 (1).وتثير

المعالجة القانونية لموضوع حدود التعويض عن الضرر الناجم عن الجرائم الدولية. وتطرح التساؤلات: ما الوضع القانوني لتعويض المتضررين في النظام الأساسي؟ وما

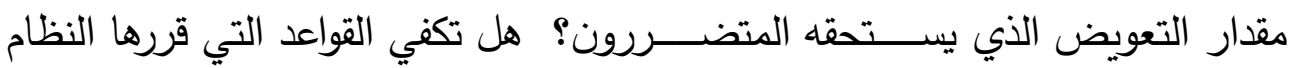

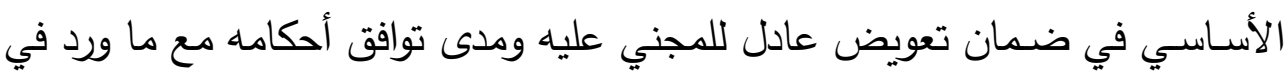
الاتفاقيات والعهود الدولية والإقليمية؟ وهل الأمر يحتاج إلى تدخل تشريعي بالتعديل أو الو

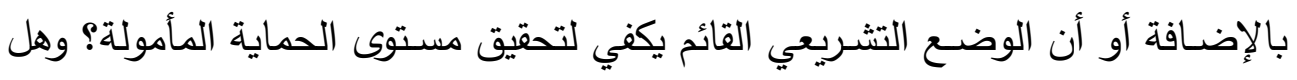

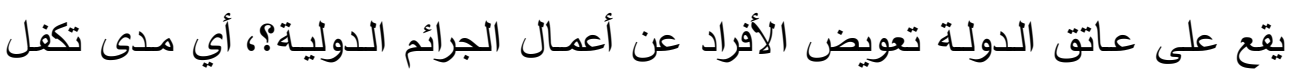

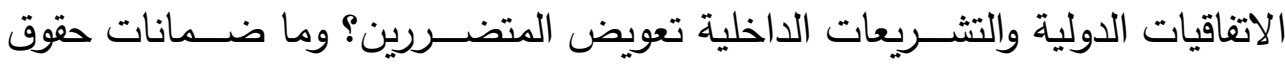

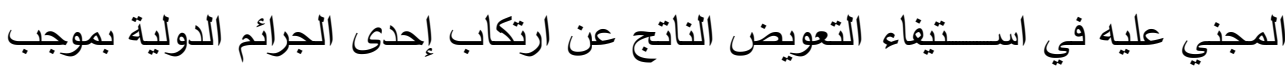

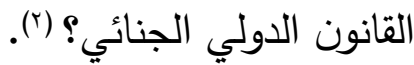

\section{المطلب الأول \\ الطبيعة القانونية لهق المني عليه في التعويض الإل}

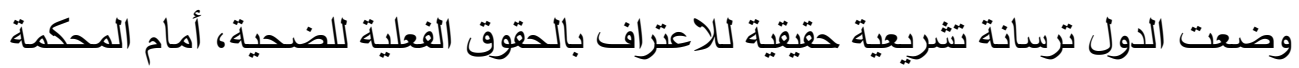
الجنائية، وكان دور المجني عليه غائبًا لعقود عديدة عن المحاكمة الجنائية، وذلك منذ

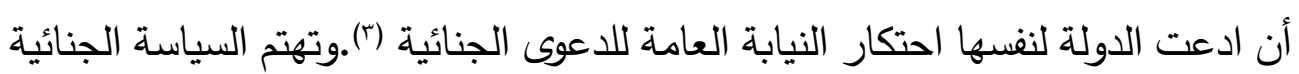
المعاصرة بالمتضرر من الجريمة وتحاول تيسير الإجراءات من أجل حصول المجني

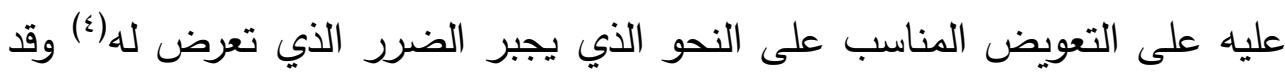

Jean Pierre ALLINNE, les victimes des oubliées de l'Histoire du Droit? In Euvre de justice et Victimes ( 1 ) (volume 1), extrait des sessions de formation du site de l'ENM.

$$
\begin{aligned}
& \text { (Y) حمد، فيدا نجيب، ، المرجع السابق، ص1/1) }
\end{aligned}
$$

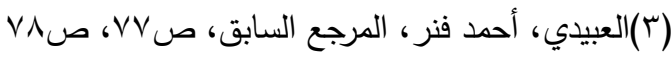

William Tallack, Reparation To The Injured And The Rights Of The Victims Of Crime To Compensation, $(\varepsilon)$ 
كان ذلك واضحاً في العديد من الاتفاقات الدولية، كما تحقق هذا التوجه من الناحية

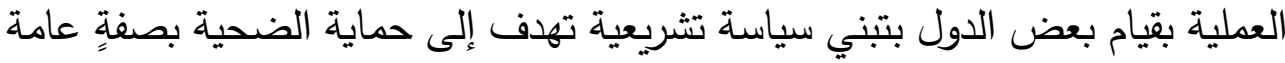
ومنها حماية ضحية الجرائم الدولية، بكفالة حق الضحية في التعويض عن الأضرار

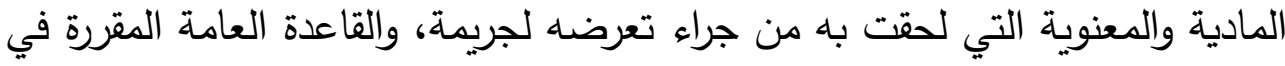

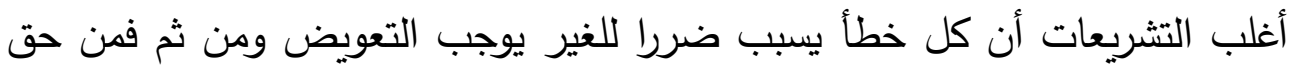

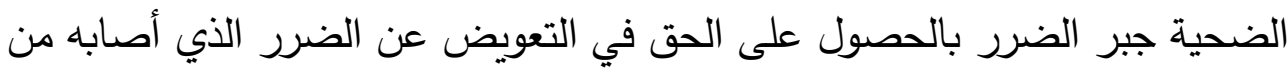

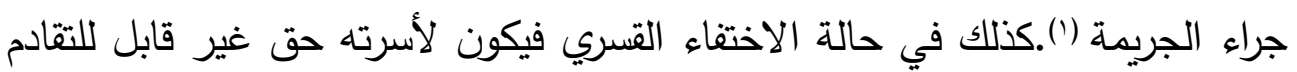
في إبلاغهم بذلك بوضع المجني عليه كما في حالة الاختفاء القسري، عندما يصبح

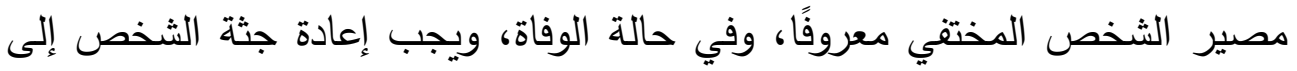

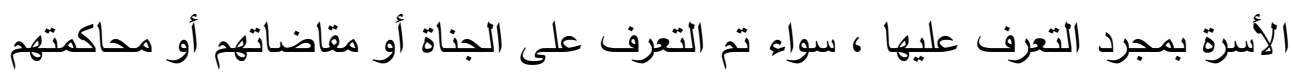
أم لا "، فليس من العدل أن ينصب جُل اهتمام المشرع على مرتكب الجريمة لتح (الجاني)

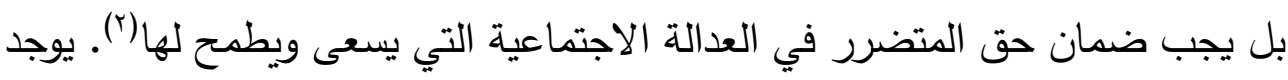
حاليًا اتجاهان رئيسيان متعارضان هما:

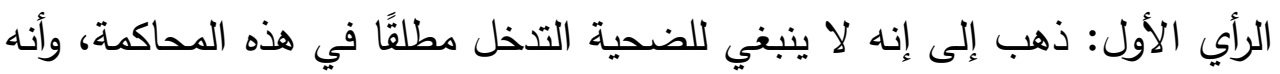
ينبغي استبعادها تمامًا، وإن تدخل الضحية في المجال الإجرامي يعد عودة إلى عصر لإسي

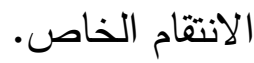
والاتجاه الثاني: يؤيد بعض الفقهاء أن يكون للضحية دوراً في المحاكمة الجنائية، وإن الضرر الذي لحق بالضحية لا يتم التشكيك فيه، بل يجب إصلاح حال المجني عليه

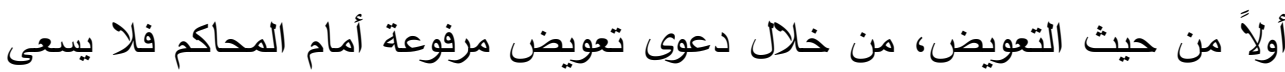
الضحايا إلى العدالة، ثانيا: من حيث الدعم النفسي، إذ إن المجني عليهم يطالبون قبل كل شيء بتأكيد الحقيقة، لضمان حقهم في الاعتراف بالصدمة التي عانوا منها ودعمهم الته 


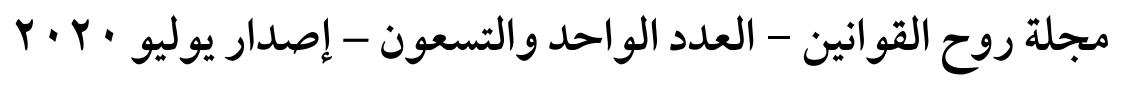

بالتعويض الثامل عنها (1). ويجوز أن يمتد هذا الحق أيضا إلى الجاني (مرتكب الفعل)

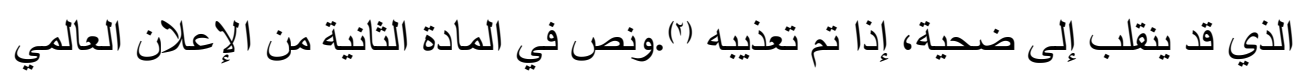

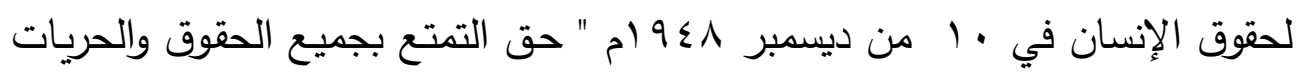

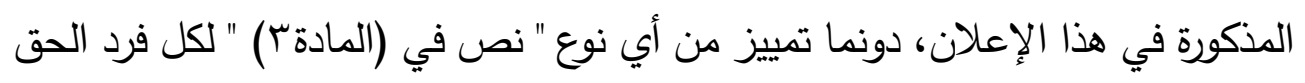

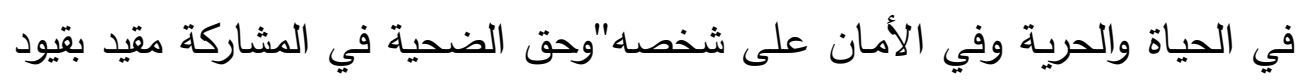

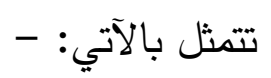
1-أن تكون هناك مصلحة خاصة بالتدخل في الإجراءات ب-ألا يشكل تدخل المجني

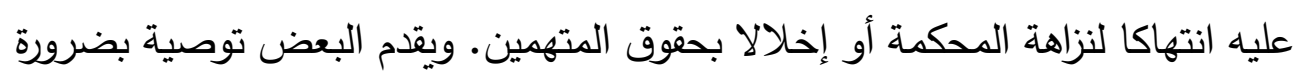
إعداد مشروع القواعد الإجرائية وقواعد الإثبات بشأن دور الضحايا أمام المحكمة الجنائية الدولية (r)

\section{المطاب الثاني \\ الأساس القانوني لهق الجني عليه في التعويض البني}

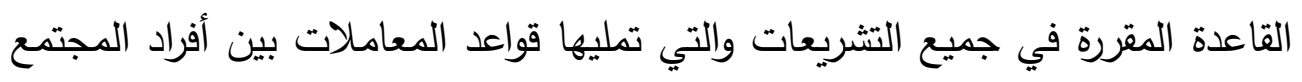

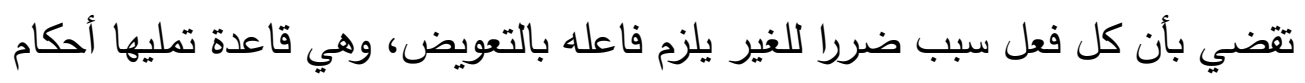

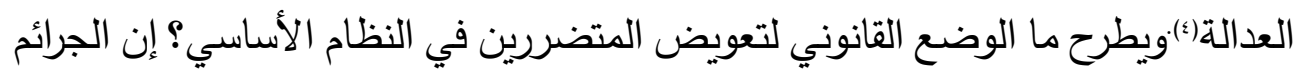

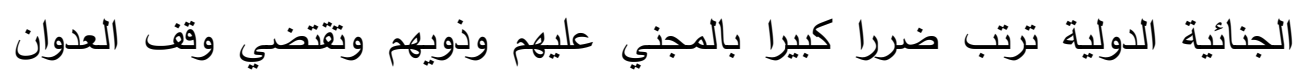

Jean Pierre ALLINNE, les victimes des oubliées de l'Histoire du Droit? In Euvre de justice et Victimes ( ।) (volume '), extrait des sessions de formation du site de l'ENM.

(Y) نجم ،محمد صبحي، (9/9 (م).دعوى التعويض أمام المحكمة الجنائية، مقال منشور ضمن أعمال المؤتمر

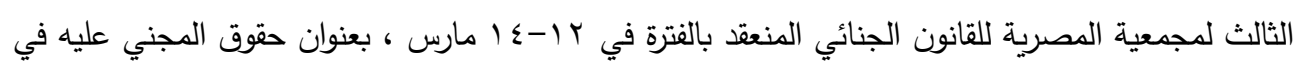

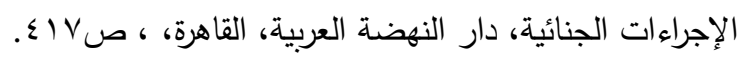

The International Criminal Court: Ensuring an effective role for victims - Memorandum for the Paris seminar, $(\Psi)$

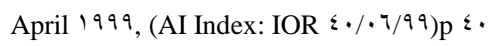

https://www.amnesty.org/.pdf

( ) د. المرصفاوي، حسن صادق دعوى التعويض أمام المحاكم الجنائية، المرجع السابق،ص r ب وما بعدها 
وتعويض المجني عليهم ودعمهم وحمايته وقد جاء هذا الحق بطيئاً في حماية المجني

$$
\text { عليه. وذلك لما يأتي: }
$$

أولا: هذا الحق متأصل في المادة Vo من نظام روما الأساسي. وذلك لضمان إنصاف ضـــحايا الجرائم الدولية والاسـتفادة من نظام التعويض المنصــوص عليه في القانون الدولي وقانون حقوق الإنسان ((). وذهب بعض الفقهاء إلى أنه قبل اعتماد اتفاقية روما

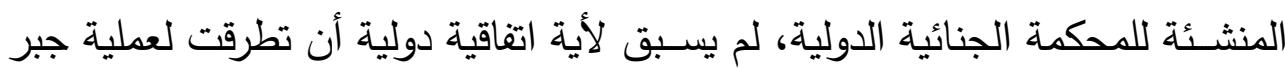
أضـرار المجني عليهم بالضـــانات والإجراءات نفسـها المنصــوص عليها في النظام الأساسي نتيجة للجرائم التي تقع ضمن اختصاص المحكمة. لذلك فإن الضحايا الذين لا يرغبون في المشـاركة في إجراءات المحكمة، سواء بسبب نقص المعلومات أو لأي ســـبب أخر ، فإن من حقهم أن يمارســــا الحق في طلب التعويض أما إعلان الأمم المتحدة بشـأن المبادئ الأسـاسـية لتوفير العدالة لضــايا الجريمة وإسـاءة اسـتعمال السـلطة أنه لم يتجاوز حد التأكيد على المبادئ الأسـاسية التي ينبغي أن تسـتد عليها حقوق الضــــايا، بما فيها جبر الأضــرار ، ولا شــك أن الاكتفاء بإقرار المبادئ دون تحديد الإجراءات والآليات القانونية التي تســـح بتجســـها على الواقع، ويجعل منها مبادئ وهمية. ثانيا: الحق في التعويض متأصـل في الثـريعة الإسـلامية قبل القوانين الوضـعية وقبل

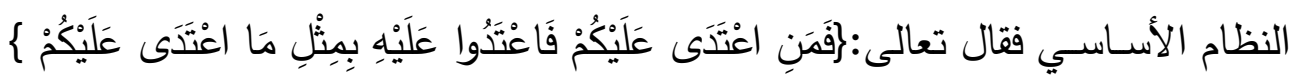

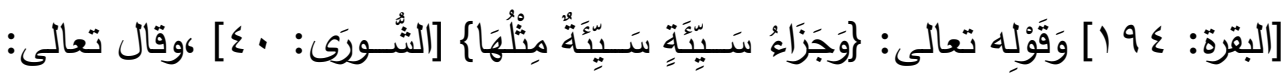

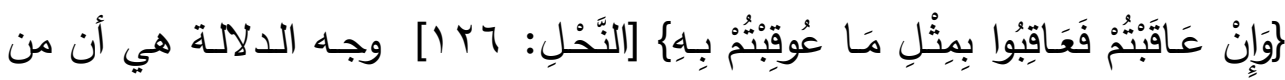
أصيب بمظلمة وعوقب بشيء جاز لله أن يستوفي من ظالمه مثل ما أصسابه، وبالتالي 
r. r · مجلة روح القوانين - العدد الواحد والتسعون - إصدار يوليو فهو يدل على مشــروعية التعويض المبني على العدل في الاســـتيفاء( (1).وقد تكون

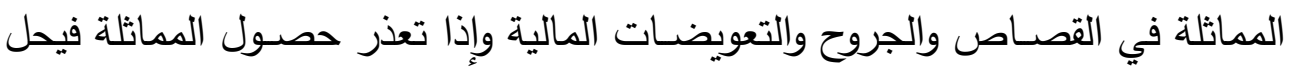
محلها التعويض وحكومة العدل، فقد راعت الثريعة الإسـلامية حمة الإنسان وحقوقه

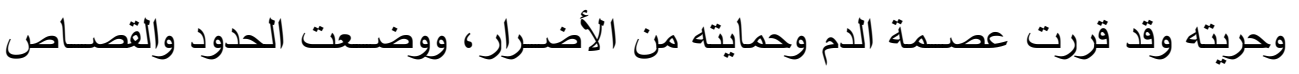
والتعزير لحماية حقوق حماية المجني عليه وكرامته فشملت حمايته من الضرر المادي

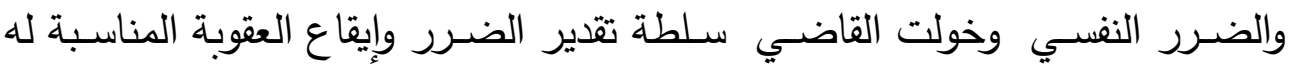

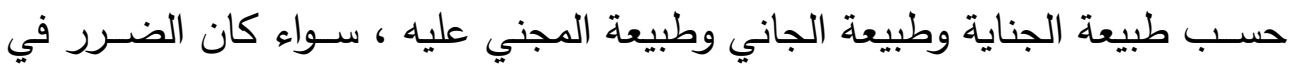

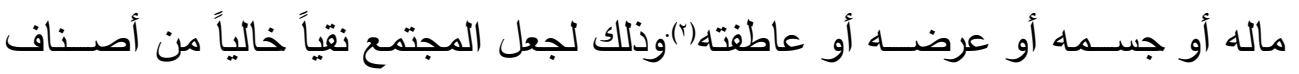
الفواحش والرذيلة والجرائم ومنها الجرائم الدولية .

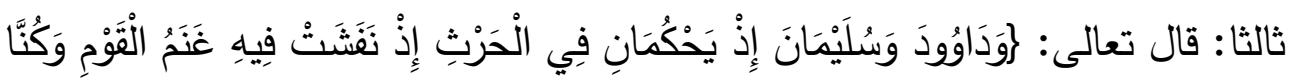

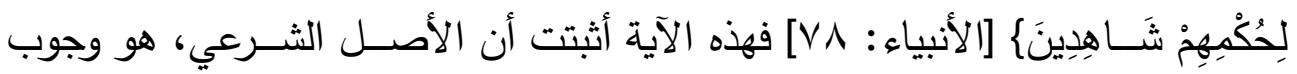

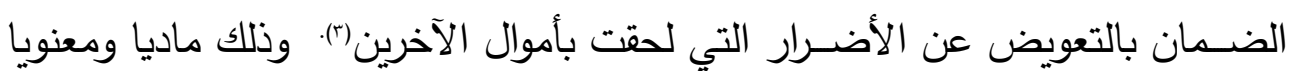
وهذا في شرع من قبلنا، إلا أن هذا الأمر متقرر في شريعتنا بأكثر من دليل.

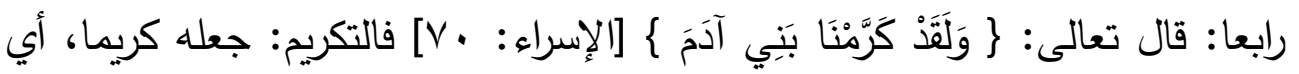

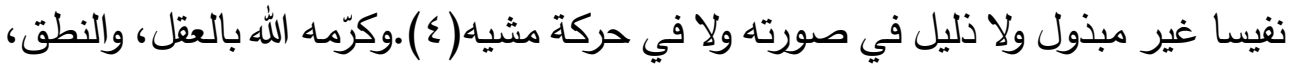

( (1)القرطبي، أبو عبد الله محد بن أحمد بن أبي بكر بن فرح الأنصاري الخزرجي شمس الدين (المتوفى:

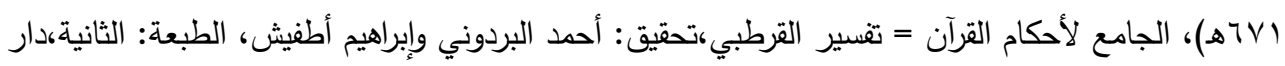

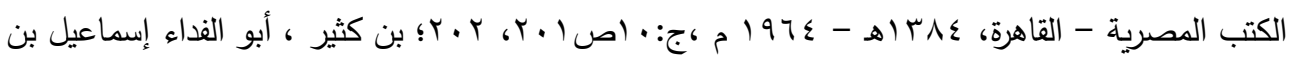

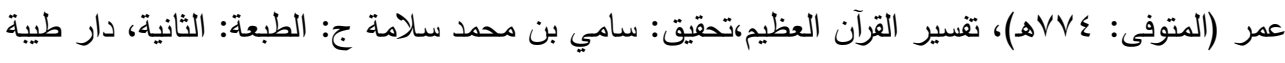

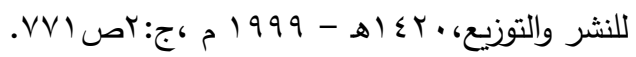

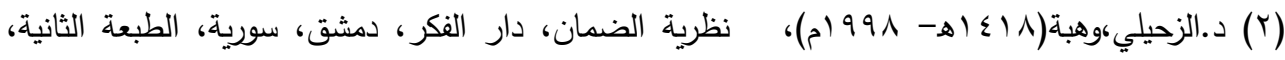


والتمييز ، والخط، والصورة الحسنة والقامة المعتدلة، وتدبير أمر المعاش والمعاد(1) وقبل تسليطهم على ما في الأرض وتسخيره لهم. لذلك لا يمتهن المجني عليه في كرامته بالضرر المادي والأدبي فأما الضرر المادي كالذي يصيب المجني عليه من ألم في جسمه، أو تلف في المال، أما الضرر الأدبي، فيشمل الإهانة التي تمس كرامة

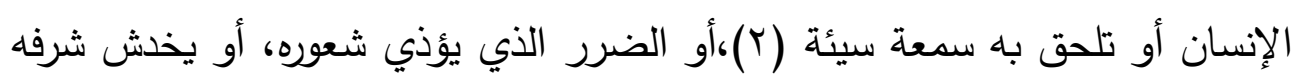

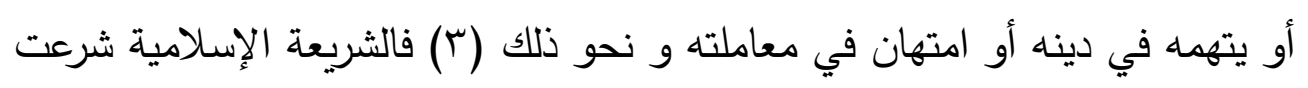

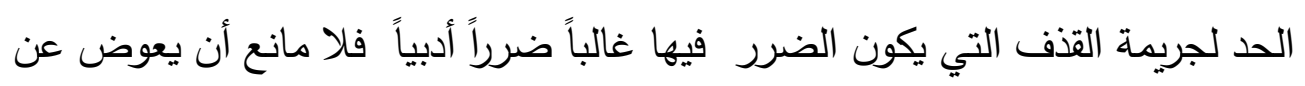
الأضرار المعنوية بالترضية وإزالة الضرر بقدر الإمكان وتعويضه بالمال، قال

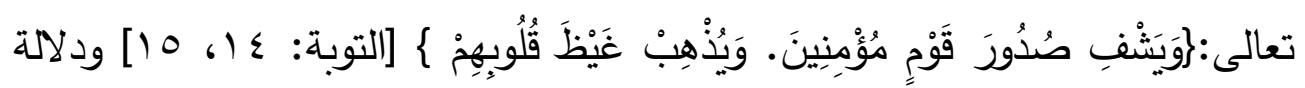

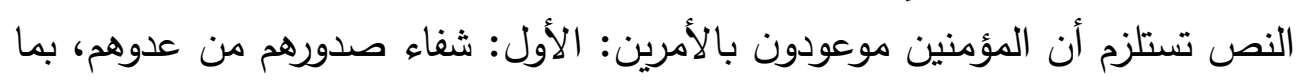
يحصل من المسرة والانشراح -بالنصر للمجني عليه-،والأمر الثاني: ذهاب غيظ قلوبهم لإزالة ما في النفوس من تعب الغيظ والحقد والغضب المشوب بإرادة الانتقام، شفاء

صدور المؤمنين كلهم بنصرة الحق والإخزاء للباطل : جزاء الإيذاء (ء).

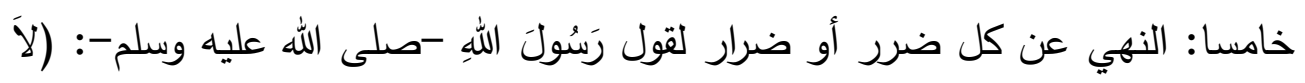

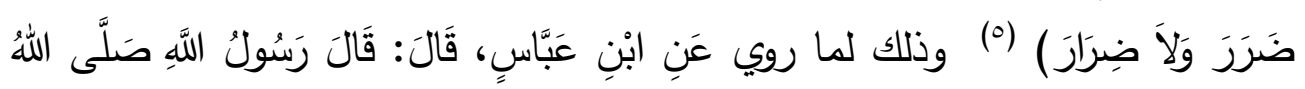

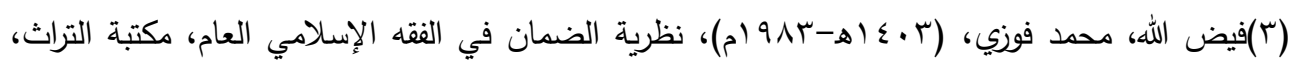

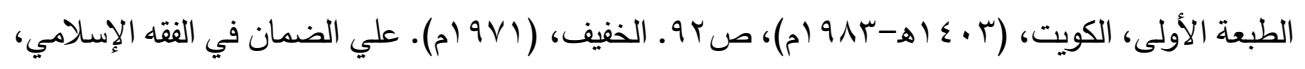

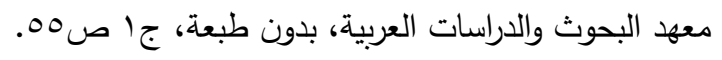

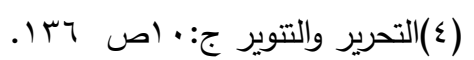

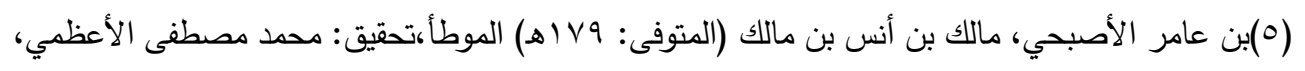

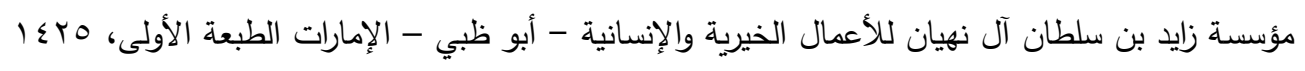

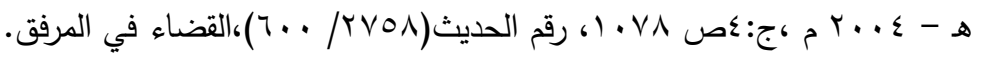




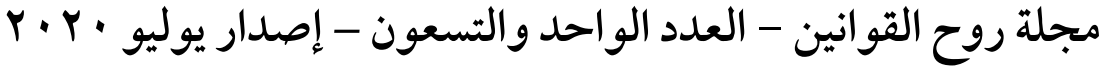

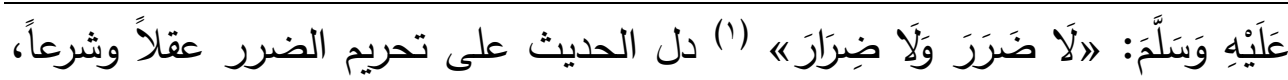

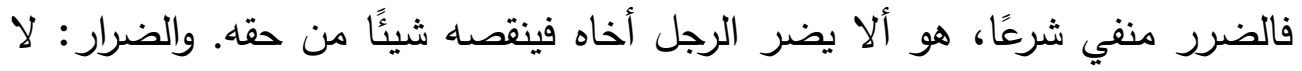

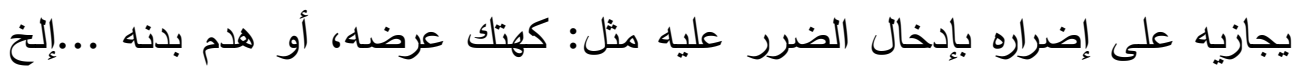

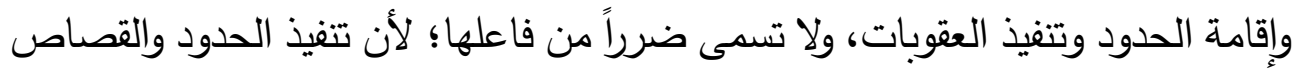
والتعزير هو امتثال لأمر الله بإقامة الحد على العاصي، فهو عقوبة من الله تعالى لإزالة

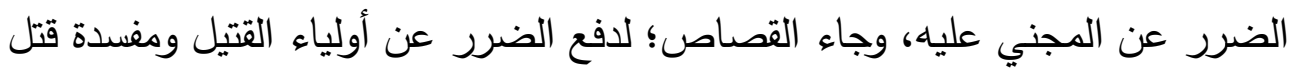

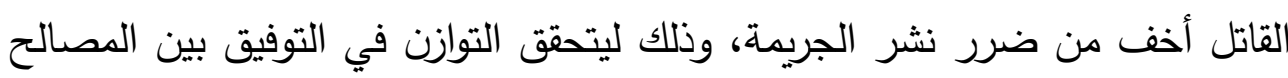

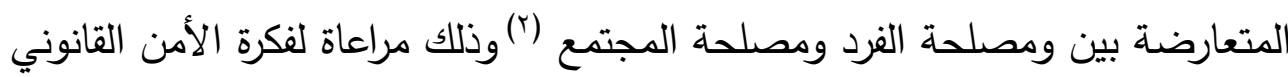

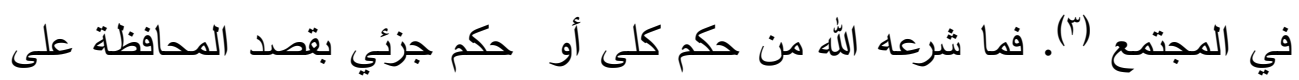

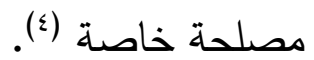

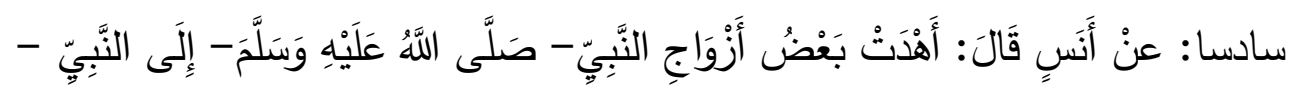

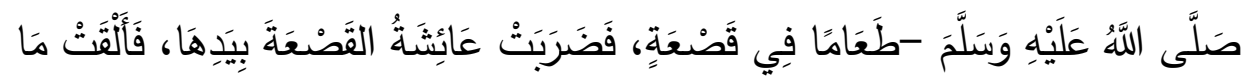

( (1)بن يزيد القزويني، ابن ماجة أبو عبد الله محمد (المتوفى: سYYYه)، سنن ابن ماجه،تحقيق: محمد فؤاد عبد

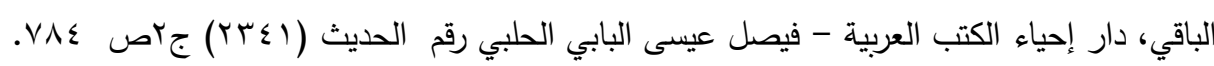

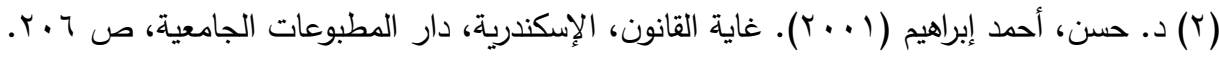

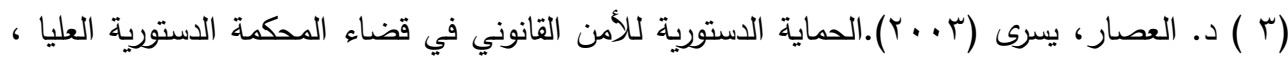

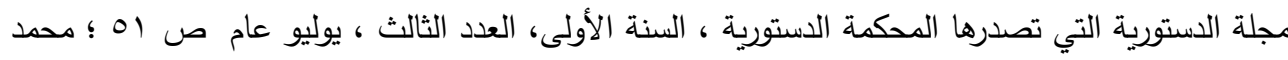

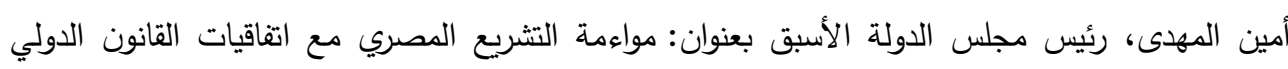

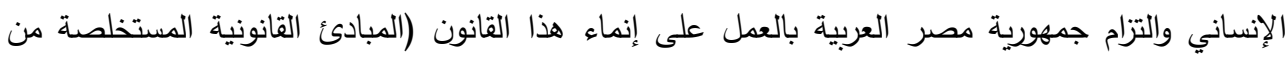

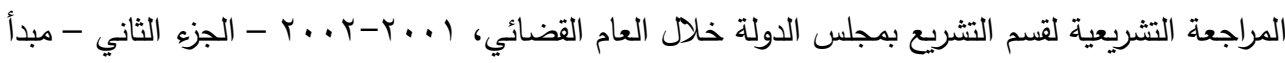

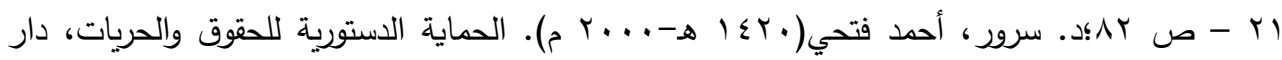

الثروق، الطبعة الثانية، ،ص1N وما بعدها.

Pierre Cambot, la protection constitutionnelle de la liberté indviduelle en France et en Espage Economica, $199{ }^{\prime}, \mathrm{p}, 1.9$

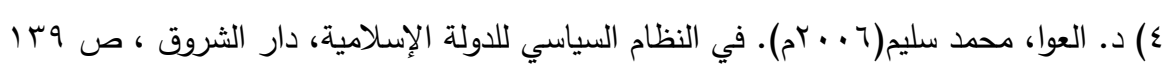




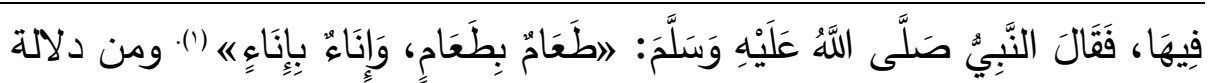
الحديث تمام التعويض العيني بإعادة الحال إلى مكان عليه.

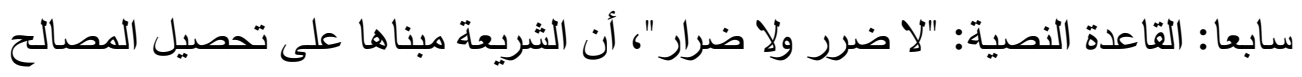

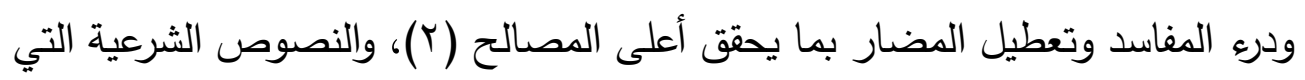

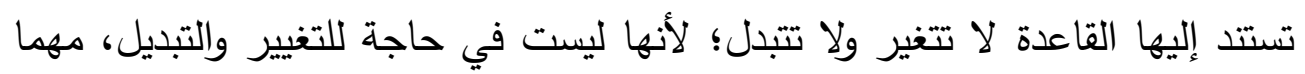

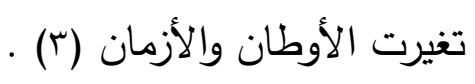

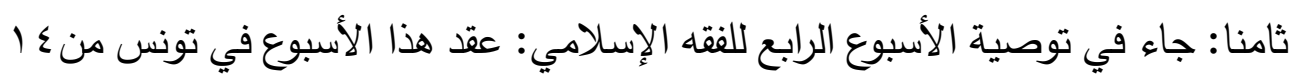

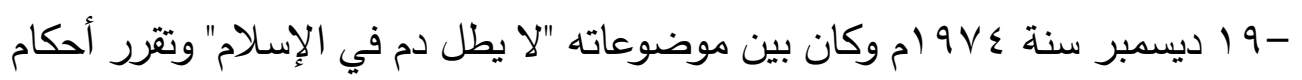

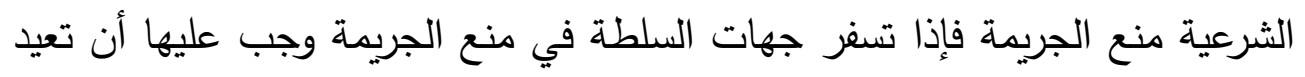

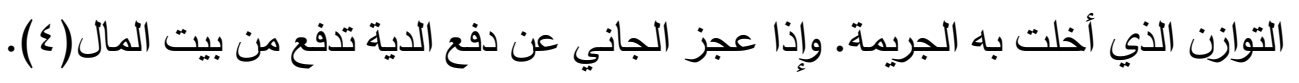

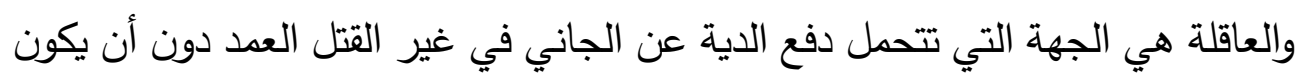

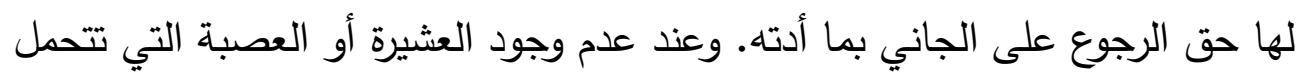
الدية، فإنه يجوز أن ينوب عنها عند الحاجة، التأمين الإسلامي (التعاوني أو التكافلي)

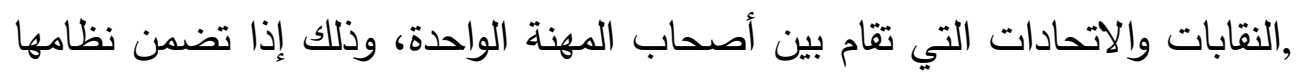

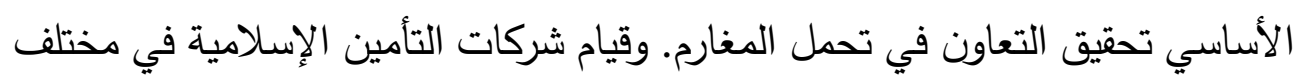

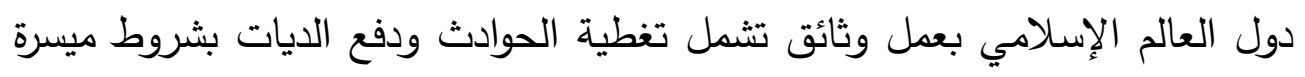

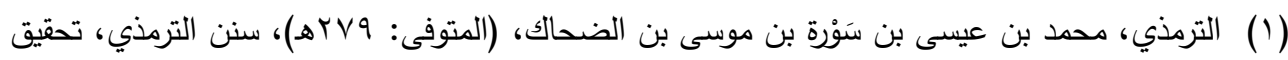

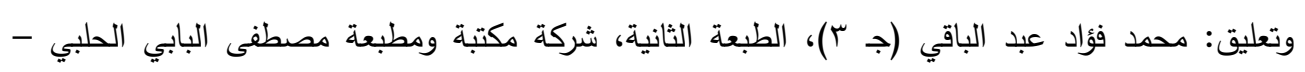

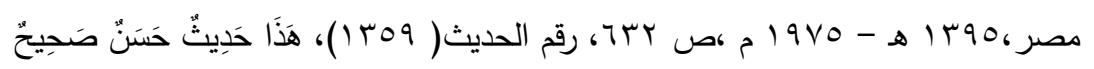

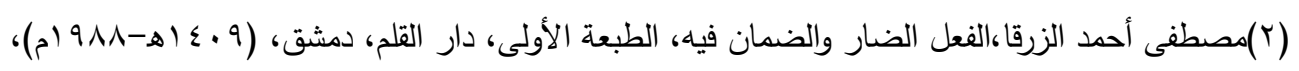

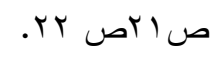

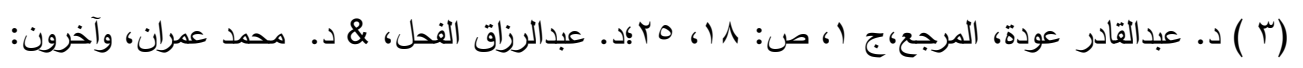

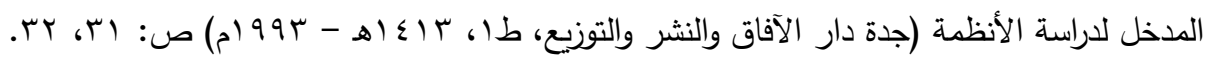

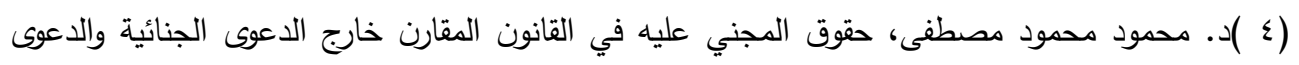

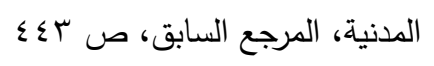
( $1 \wedge 0)$ 


$$
\text { r. r. · مجلة روح القوانين - العدد الواحد والتسعون - إصدار يوليو }
$$

وأقساط مناسبة( ().وقيل إنه في النظم القانونية الوضعية الدولية قبل تأسيس المحكمة

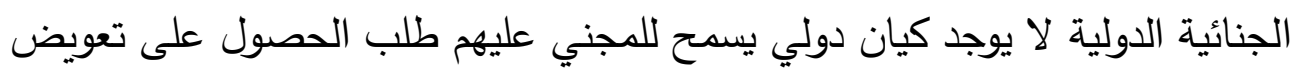

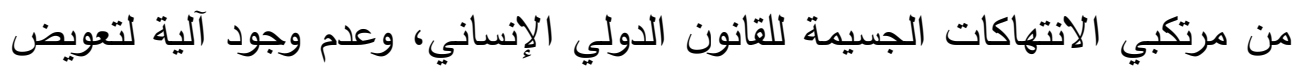

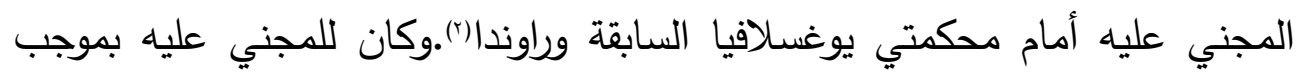
النظامين الأساسيين للمحكتين المذكورتين يوغسلافيا السابقة وراوندا اللجوء إلى القضاء

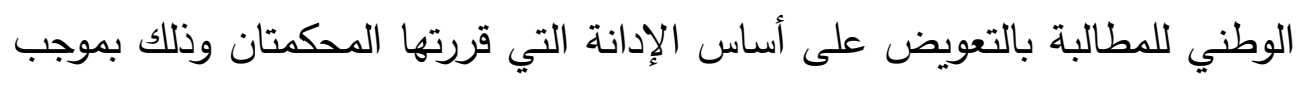

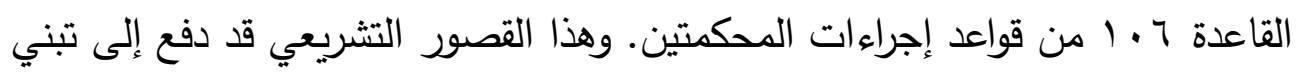

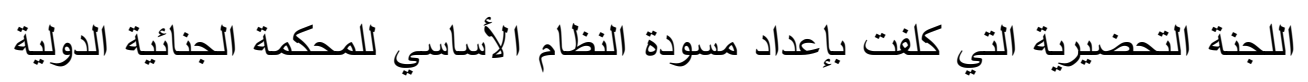

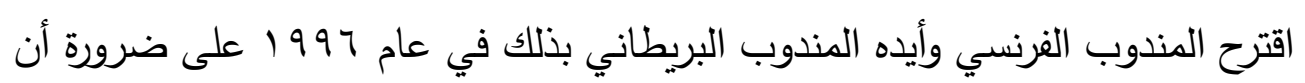

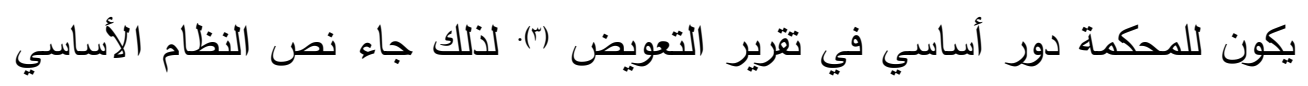

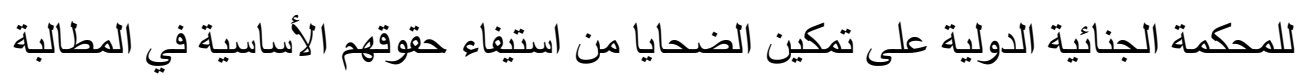

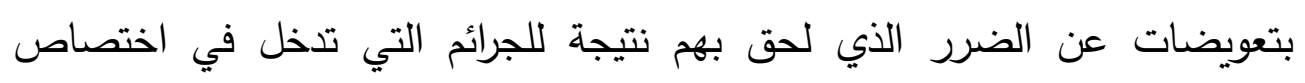

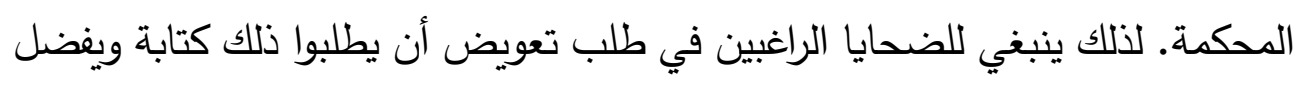

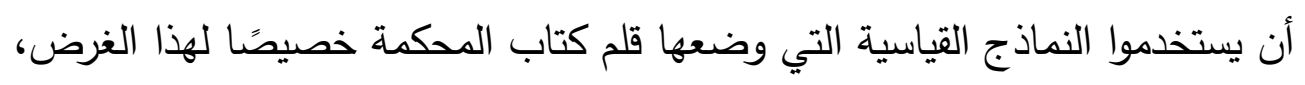

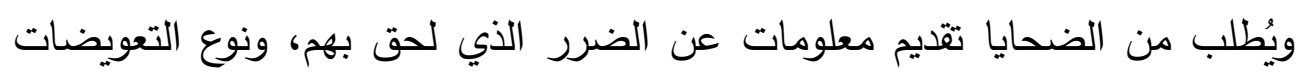

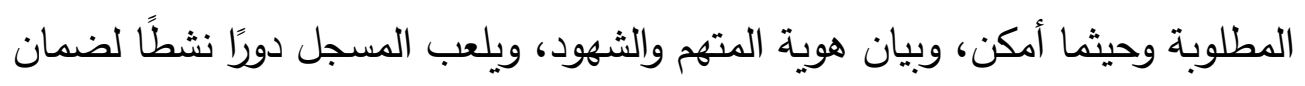

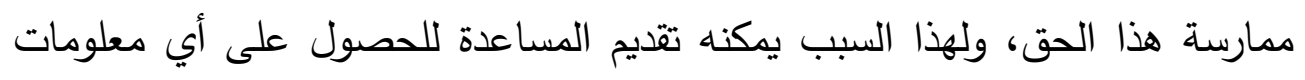
إضافية ضرورية لتبرير قرار المحكمة، علاوة على ذلك، مساعدة الضحايا على إكمال

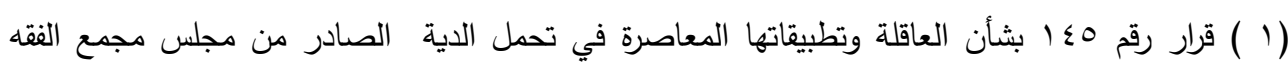
الإسلامي الدولي المنبثق عن منظمة المؤتمر الإسلامي المنعقد في دورته السادسة عشرة بدابي (دولة الإنة الإمارات

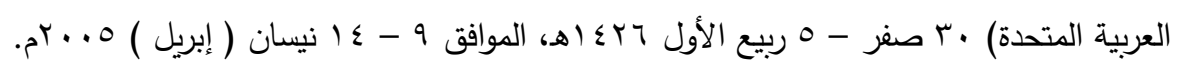


طلباتهم ، وفقًا للمادة V0 (1) من نظام روما الأساسي، وجبر أضرار المجني عليهم

\section{المطلب الثالث \\ الجهات المسؤولية عن تعويض المجني عليه}

يجب على الدول بأن تؤهن وتضمن التمتع الفعلي بحقوق الإنسان فوق أقاليمها. هذا الواجب منصوص في الشريعة الإسلامية وفي العديد من المعاهدات الدولية لحقوق لإن لهن الإنسان وإنه على الدولة أن تتخذ كل ما يلزم من إجراءات تشريعية وغيرها تقرير المسؤولية للجهات المسؤولة عن تعويض المجني عليه؟

أولا: هسؤوليهة الجاني عن تعويض المجني عليه: الأصل أن يتحمل الشخص المدان أو الجهة المسؤولية عن أفعاله تعويض المجني عليه، الأصل أن الجاني هو المسئول عن جبر الضرر الذي لحق بالضحية وقد قررت ذلك الفقرة r من المادة ه من النظام الأساسي للمحكمة الجنائية الدولية على أنه "للمحكمة أن تصدر أمراً مباشراً ضد شخص مدان تحدد فيه أشكالاً ملائمة من أشكال جبر أضرار المجني عليهم, أو فيما يخصهم, بما في ذلك رد الحقوق والتعويض ورد الاعتبار وللمحكمة أن تأمر، حيثما كان مناسباً, بتنفيذ قرار الجبر عن طريق الصندوق الاستئماني المنصوص عليه في المادة 9 V. " نصت (القاعدة ^ه من القواعد والإجراءات والإثبات) بأن " تصدر الأحكام الفردية بجبر الضرر في حق الشخص المدان مباشرة -بيجوز للمحكمة أن تأمر بأن يودع لدى الصندوق الاستئماني مبلخ الجبر المحكوم به ضد شخص مدان، عندما يستحيل أو يتعذر إصدار حكم فردي بجبر الضرر مباشرة لفائدة كل ضحية. ويكون مبلغ جبر الضرر المحكوم به المودع لاى الصندوق الاستئماني منفصلا عن كل موارد الصندوق الأخرى ويقدم إلى كل ضحية بأسرع ما يمكن يجوز للمحكمة أن تصدر في

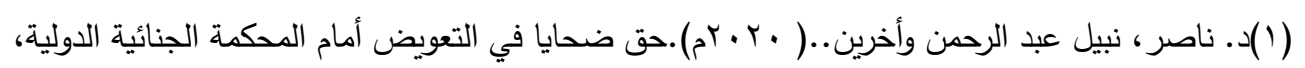

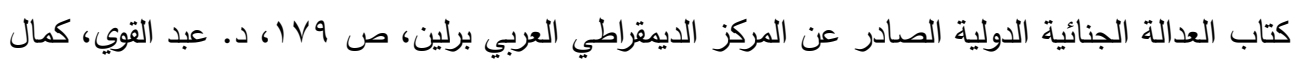

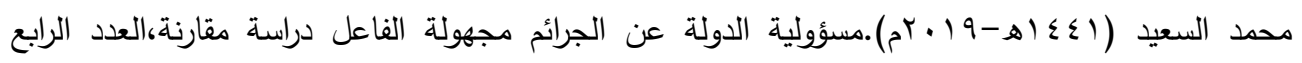
والثلاثون،الجزء الثاني،صل 1 ـ 0-1 ـ ـ. 


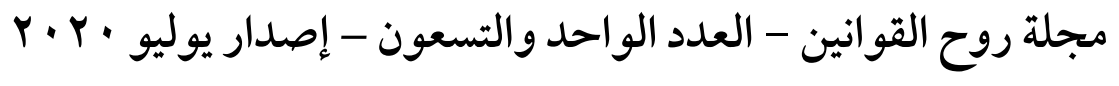

حق الثخص الددان أمرا بجبر الضرر عن طريق الصندوق الاستئماني عندما يكون

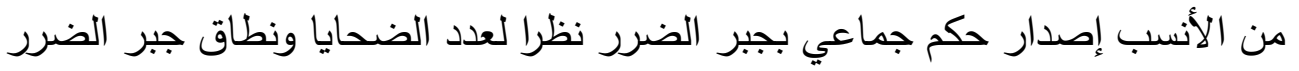

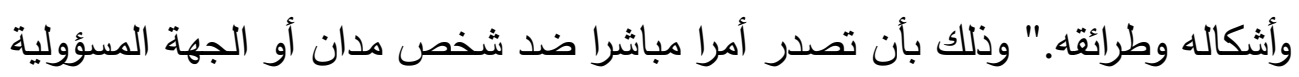

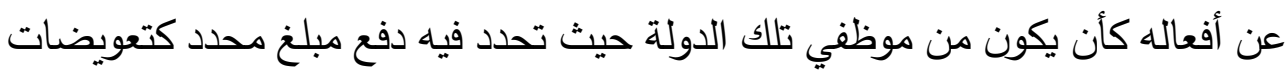

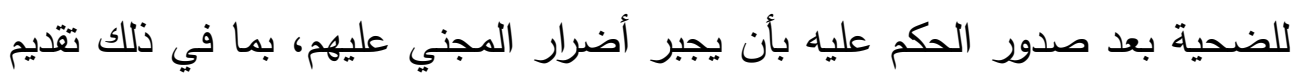

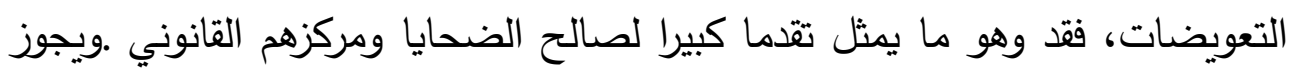

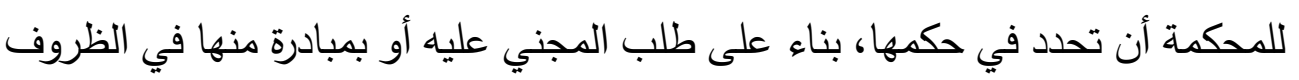

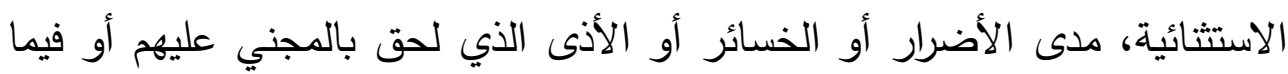

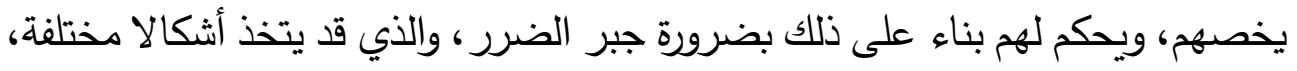

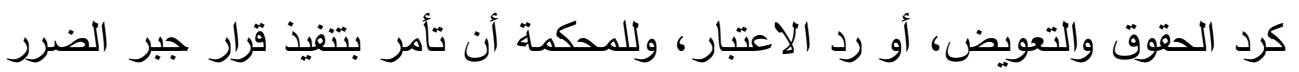

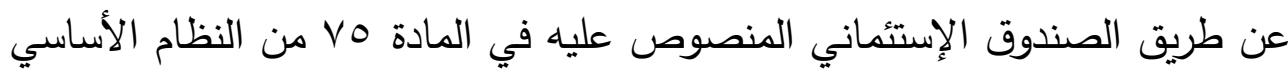
للمحكمة الجنائية الدولية (1).

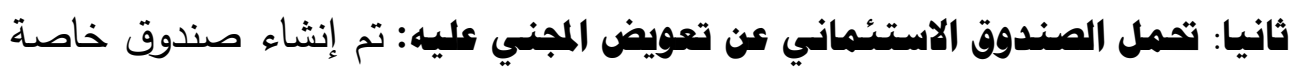
بدفع التعويض للضحايا، إذ نصت المادة V9 من النظام الأساسي للدحكمة الجنائية

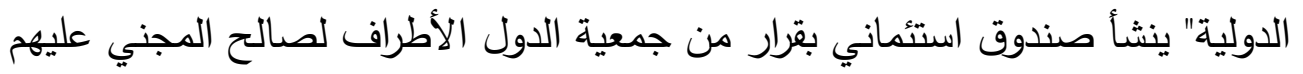

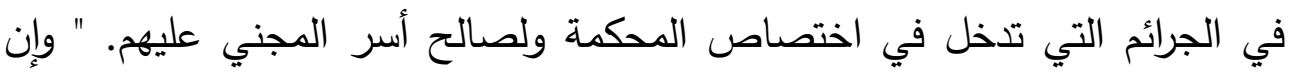

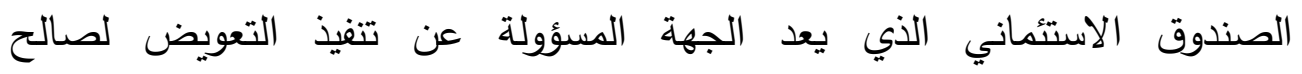
الضحايا.وهذا اتجاه سليم لصالح ضحايا الجرائم الدولية بصفة خاصة وللعدالة الجنائية الدولية بصفة عامة، إذ إن المحكمة الجنائية الدولية لها الحق في دعوة المتهم الددان

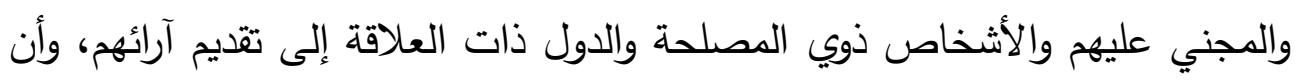

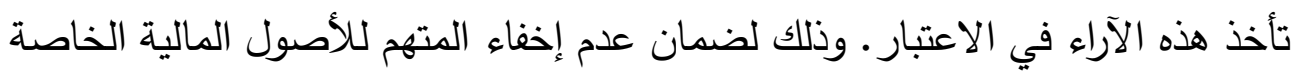

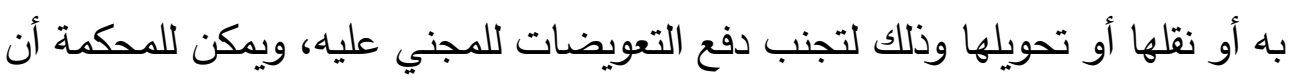
تتخذ تدابير وقائية لضمان الحفاظ على الأصول المملوكة للمتهم حتى يمكن مصادرتها 
لصالح المجني عليهج، إذا صدر حكم بإدانته (').وإذا عجزت الشخص المدان عن دفع التعويضات كاملة من أمواله أو عدم وجود موارد كافية لدى الشخص المدان لاستغلالها في دفع التعويض للمجني عليه فإن المحكمة تأمر بدفع تلك التعويضات عن طريق ودودئ الصندوق الاستئماني (r). ثالثا: هسؤولية الدولة عن تعويض المجني عليه: أثار موضوع مسؤولية الدولة عن تعويض ضحايا الجرائم بصورة عامة جدلاً فقهياً واسعاً بين معارض ومؤيد له وذلك على الوجه الآتي: الرأي الأول: ذهب إلى عدم التزام الدولة بدفع التعويض إلى المجني عليهح والرأي الثاني: ذهب إلى ضرورة إنشاء نظام لتعويض المجني عليهم من قبل التبل الدولة.

الرأي الأول: ذهب إلى عدم التزام الدولة بدفع التعويض إلى المجني عليهخ يستند إلى لما يأتي: ا - مبدأ شخصية العقوبة وكون الجريمة والعقوبة مرتبطة بالجاني (r). وذلك يفيد براءة ذمة الدولة من أي التزام تجاه ضحايا مختلف الجرائم؛ إذ إن الدولة مثقلة بكثير من

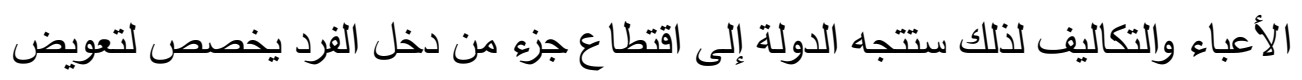
ضحايا الجريمة، وفي هذه الحالة يتحمل كل فرد نتيجة أخطاء لم يرتكبها وهذا على افتراض أن كل مواطن سيصبح يوماً ما ضحية)(ع).

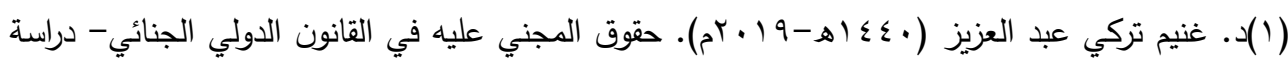
تأصيلية، رسالة دكتوراه، كلية العدالة الجنائية جامعة نايف العربية للعلوم الأمنية، الرياض، الهُونه المملكة العربية

$$
\text { السعودية، ص ع با أوما بعدها }
$$

Establishment of a fund for the benefit of victims of crimes within the jurisdiction of the Court, and of the families of such victims, Resolution ICC-ASP/ / Res. ${ }^{\Upsilon},{ }^{9}$ September $r \ldots r$

Bitti, G., et Gonzalez Rivas, G., "Reparations Provisions under the Rome Statute of the International Criminal ( $($ ) Court",in Permanent Court of Arbitration (ed.), Redressing Injustices Through Mass Claims Processes: Innovative

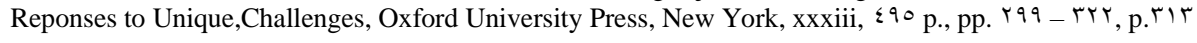

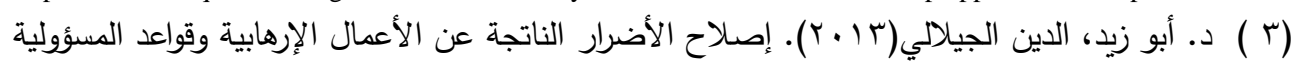

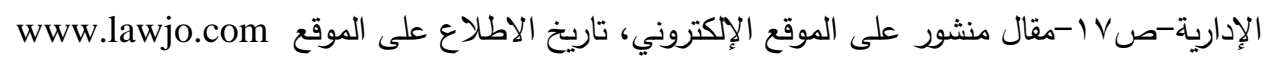

(ء ) د. الزهيري، رياض (^ . . r). دعوى مسؤولية الدول عن اعمالها الضاره، بحث منشور في النشرة القضائية

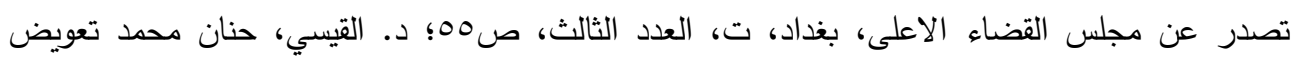




$$
\text { r.r. · مجلة روح القوانين - العدد الواحد والتسعون - إصدار يوليو }
$$

r- إن نظام المسؤولية الثخصية للجاني يكفي لحماية المتضرر، إضافة إلى ما تقدمه

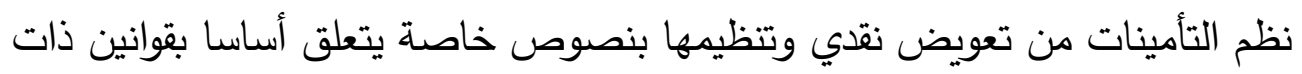
صبغة اجتماعية بحتة كقانون الضمان الاجتماعي والتأمينات الاجتماعية والمساعدات

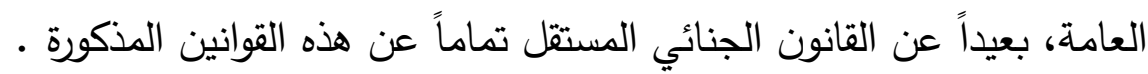

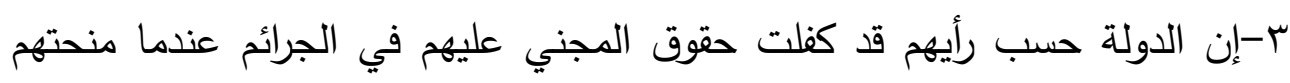

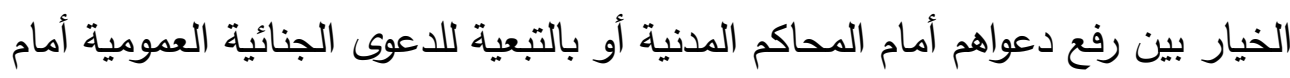
المحكمة التي تنظر الدعوى الجنائية.

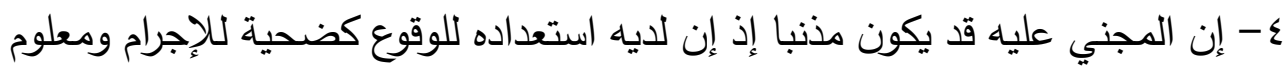

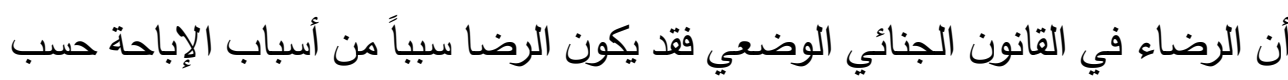

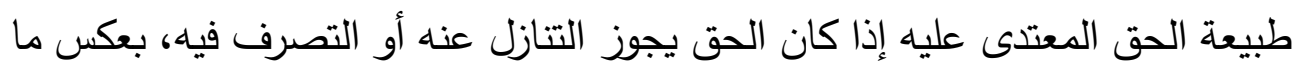

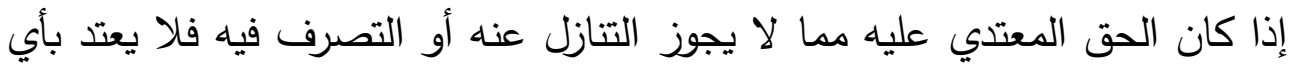

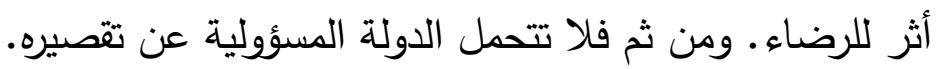

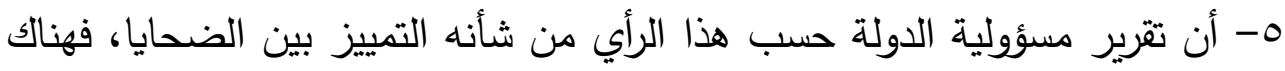

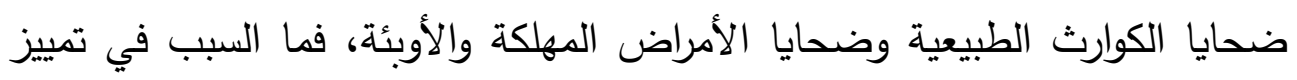
ضحايا الجريمة بأحكام خاصة، فشبكة الحماية الاجتماعية كفيلة بمساعدة هؤلاء المتضررين كغيرهم צ-التزام الدولة بالتعويض من شأنه أن يؤدي إلى إهدار المسؤولية الفردية وشخصية

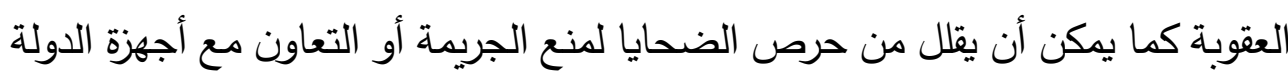

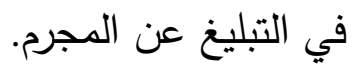
V-معظم الثرائع القديمة تبنت مبدأ عدم مسؤولية الدولة تجاه ضحايا الجرائم

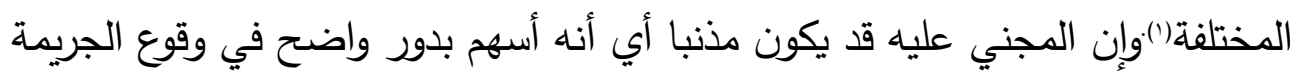

التضررين من النزاعات المسلحة,بحث منشور في مجلة دراسات قانونية تصدر عن بيت الحكمة , بغداد ,العدد 11, r. 11, r 
في حقه وعندئذ يطلق عليه " المجني عليه المذنب " إذ إن لديه استعداده للوقوع كضحية

الرأي الثاني: ذهب إلى ضرورة إنشاء نظام لتعويض المجني عليهم هن قبل الدولة لعدم

كفاية الوسائل التقليدية في التعويض بسبب صعوبات التقاضي وطول الإجراءات الطويلة أو عدم الملاءة المالية لمرتكبي هذه الجرائم وموقف المتضرر يستند إلى لما يأتي: ا-إن الدولة تكون مسؤولة بقوة القانون عن حماية كافة الأفراد من مخاطر الجريمة، مما يشير مسؤوليتها في منع وقوعها في إطار خطئها المرفقي بتقصيرها في أداء واجبها بالحفاظ على الأمن، وحماية المواطنين والمقيمين على أرضها. وإن دور التعويض لا يمكن بحال من الأحوال أن يجبر الضرر الناتج عن الجريمة ويقتصر فقط على تخفيف آثارها وجسامتها لذلك ينادي بتقرير حق المجني في الحصول على التعويض من الدولة (')وهذا ما أكدت عليه إحدى توصيات المؤتمر الدولي الحادي عشر لقانون العقوبات المنعقد ببودابست سنة \و ا والتي جاء فيها أن تعويض الدولة الممنوح للضحية هو حق وليس منحة(r) ونادت المؤتمرات الدولية بمسؤولية الدولة عن تعويض ضحايا الجريمة منها المؤتمر الدولي للسجون في باريس عام 9011، الذي نادي بضرورة أن تلتفت الدولة إلى المجني عليه، وأن تراعي ظروفه و أحواله أسوة بالجاني، و نادى المؤتمر الدولي للسجون المنعقد في ببروكسل بلجيكا عام . .9 ام بأن تتحمل الدولة تعويض المجني عليهم في الحالات التي لا يحصلون فيها على تعويض من الجاني بسبب إعساره كذلك مؤتمر" لوس أنجلس" بكاليفورنيا سنة 971 1، الذي جاء في

DAVID (ERIC): Le terrorisme, en droit international (déFinition, in crimination, répression) dansré Flexion sur .lla déFinition et la répression du Terrorisme Bruxelles, EdL 'U.L.L.B. 199 ₹. ҮА9

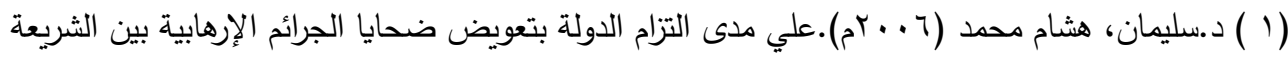
الإسلامية والقانون الوضعي بحث مقدم للحصول على درجة الماجستير في السياسة الجنائية-جامعة نايف العربية للعلوم الأمنية كلية الدراسات العليا-قسم العدالة الجنائية (تخصص سياسة جنائية) -الرياض -صلئه

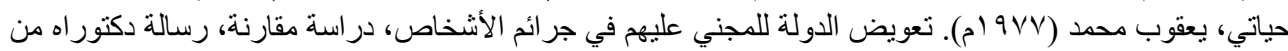

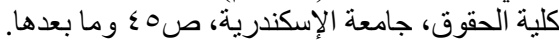

(Y ) د.محمود محمود مصطفى،حقوق المجني عليهم في القانون المقارن-مطبعة جامعة القاهرة،الطبعة الإنة

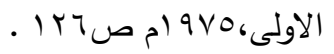


r.r. · مجلة روح القوانين - العدد الواحد والتسعون - إصدار يوليو

توصياته أنه ينبغي تعويض المجني عليهم من الدولة ثم دعا المؤتمر الدولي الثالث

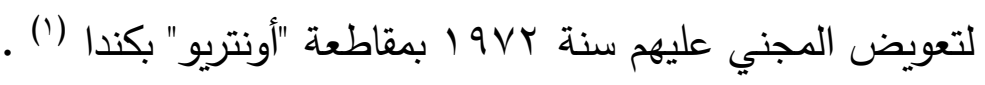

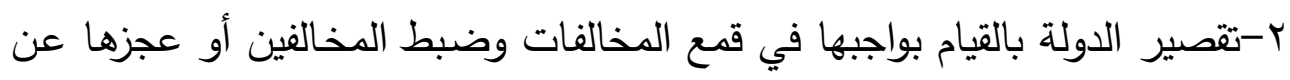

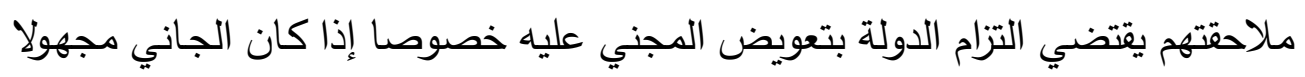

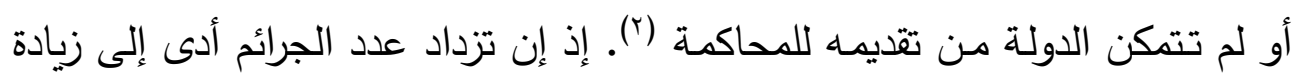

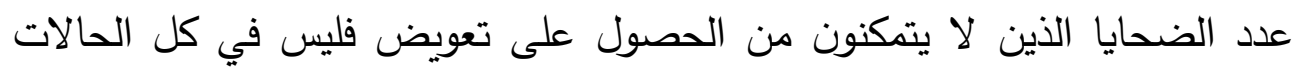

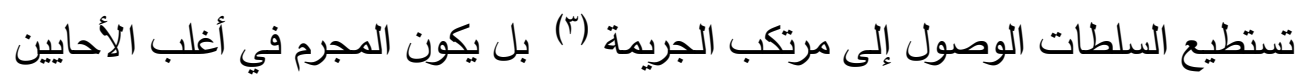

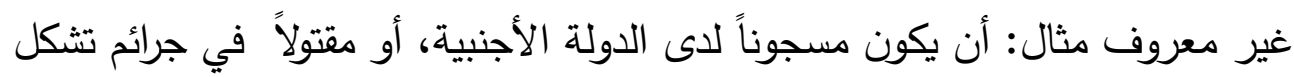

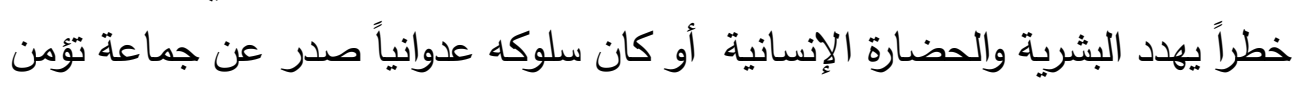

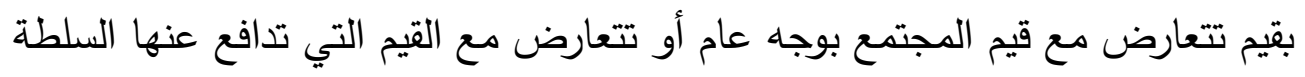
العامة كالصهيونية المتطرفة(؟).

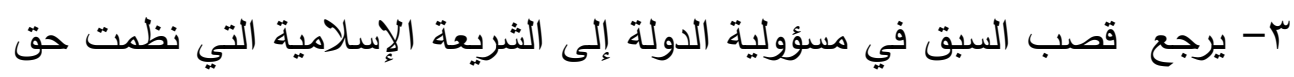

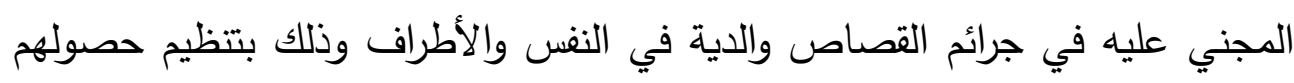

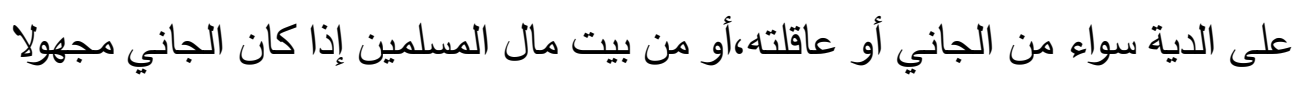

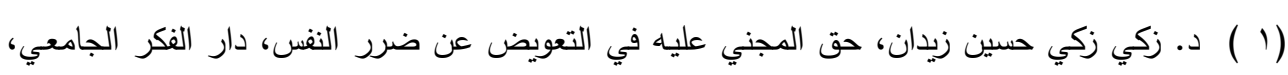

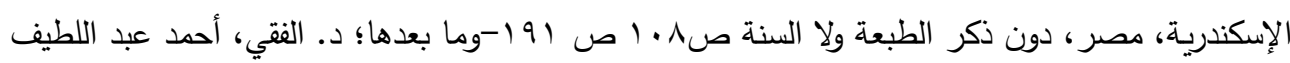

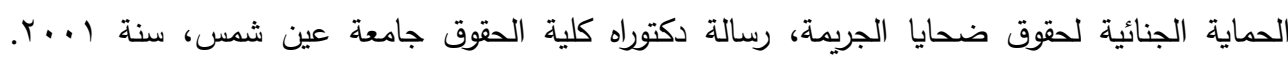

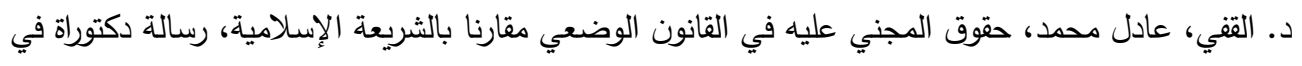

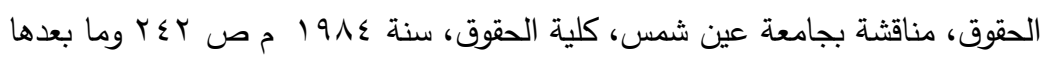

Ibid. ( $($ )

Sebastian Roche', 'Les victimes: de la communaute' a' l'assurance en passant par l'Etat', De'viance et Socie'te', .Vol. 19 (₹) (1990), pp. rov_rv.

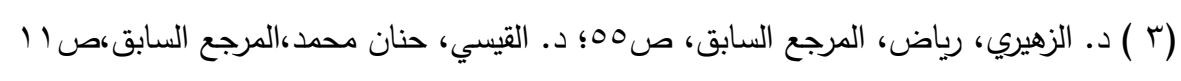


أو معسرا، أو إذا لم تستطع عاقلته دفع الدية(')، وذلك إعمالا للمبدأ الإسلامي الذي أرسى قواعده الإمام علي بن أبي طالب رضي الله عنه بقوله (لا يُطَل دم في الإسلام)

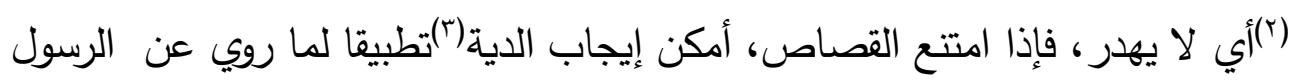

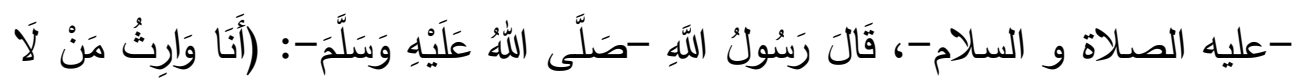

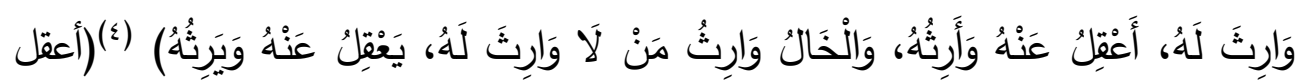

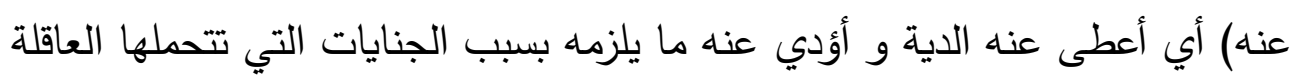
إذ إن الجاني في بعض الأحايين قد يكون معسراً كذلك ناقش مؤتمر الأسبوع الرابع للفقه

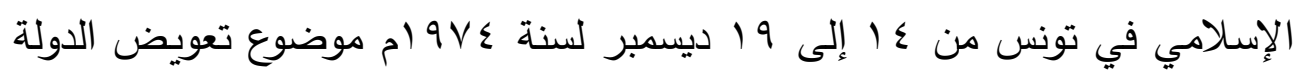

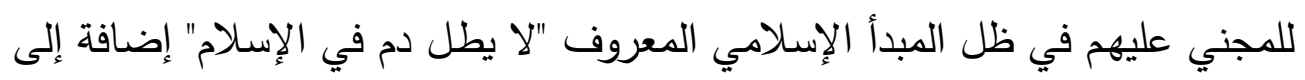

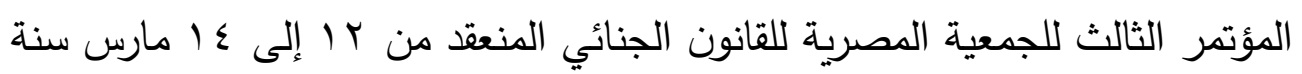
9 19 1 الذي أوصى بما يلي "التزام الدولة بدفع تعويض للمجني عليه أو لأسرته في

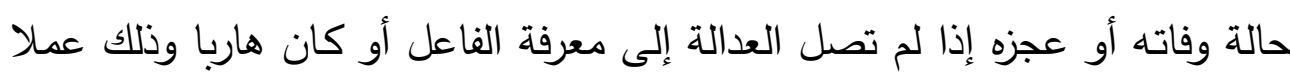
بأحكام الشريعة الإسلامية الغراء. ع-إن الفرد ملتزما بأداء الضرائب المقرة عليه من قبل الدولة. وهو يتحمل التكاليف العامة المفروضة عليه قانونا، وتستيفيد منها الدولة في إنجاز المشروعات العامة، فإنه بالمقابل من واجب الدولة اعتماد سياسة جنائية من أجل مكافحة الجرائم بشتى أنواعها

(1 ) د.خلفي،عبد الرحمن (1 1 ـ ـ م).مدى مسؤولية الدولة عن تعويض ضحايا الجريمة،مجلة الشريعة والقانون العدد V乏 ص ₹ وما بعدها

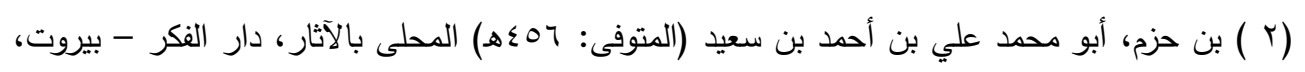

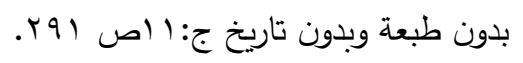

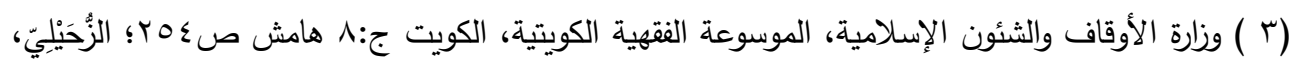

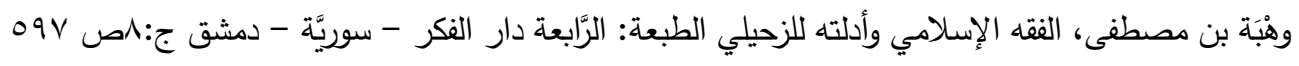

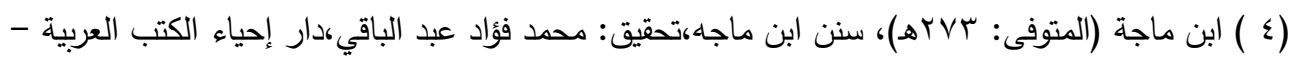

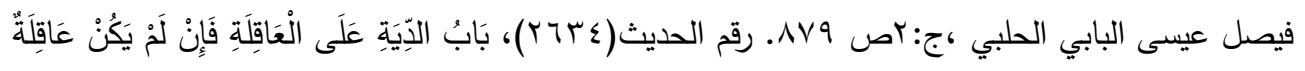

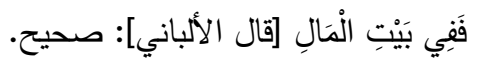




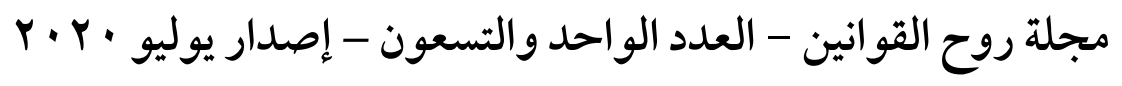

والسهر على تطبيق القانون العادل للوقاية من وقوع الجرائم ومعاقبة الجناة عن الجرائم

التي وقعت منهم (1). (1)

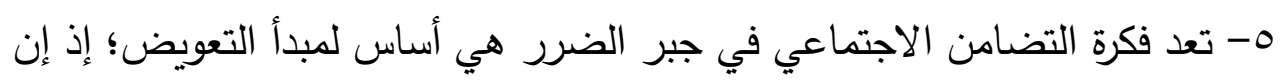

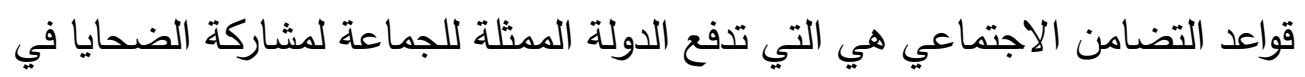
التخفيف من آلامهم-وإن كان ذلك مجرد حق نظري في كثير من الدول لم يتم تفعيله

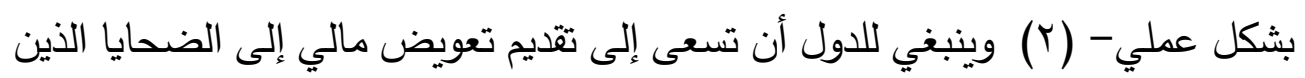

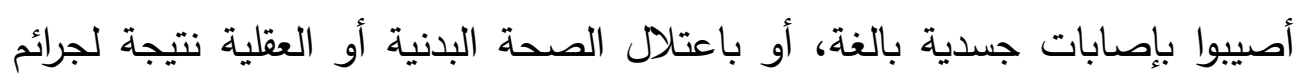

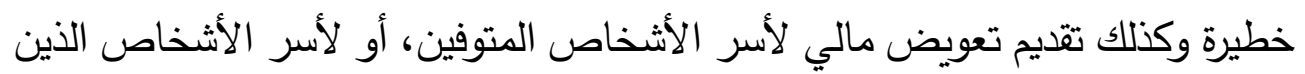

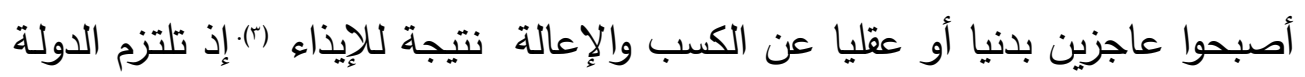

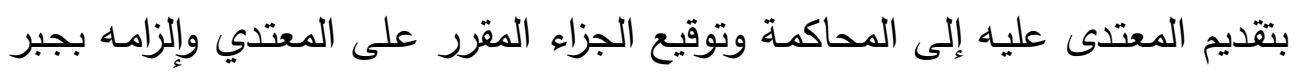

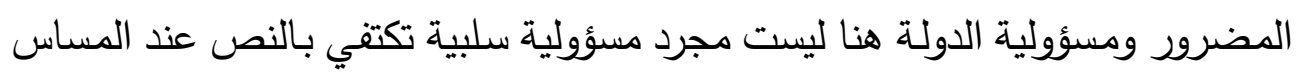

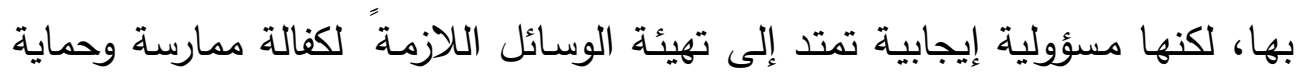
هذه الحقوق عمليا والعقاب على الاعتداء عليها (ع).

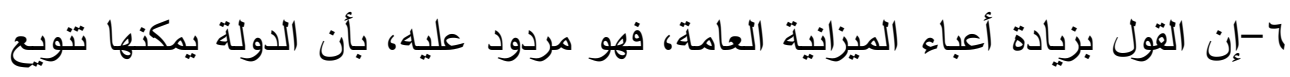

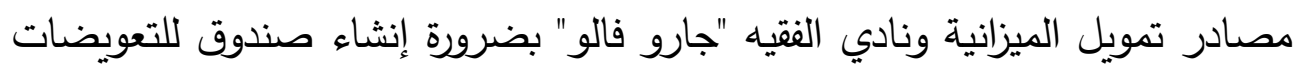

(1 ) د.العبودي ، محسن (•991).أساس مسؤولية الدولة عن المجني عليهم في القانون الجنائي والإداري

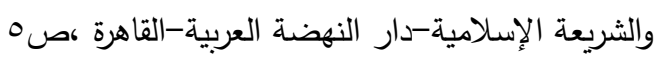
(Y ) مصباح، مصطفى (1997 ). وضع ضحايا الإجرام في النظام الجنائي - دراسة نقدية للنظام الجنائي في

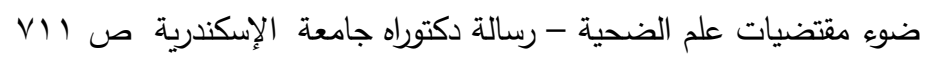

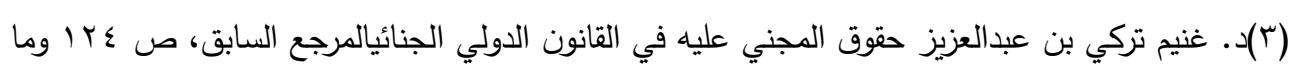

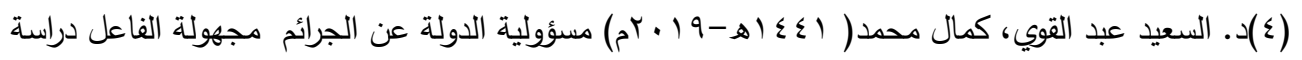

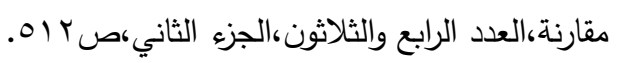
F. Megret, 'The International Criminal Court and the Failure to Mention Symbolic

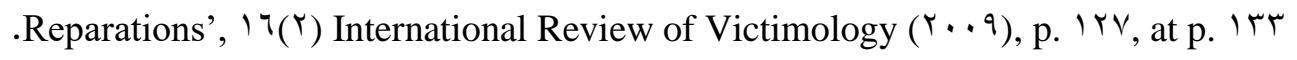


يتم صرف التعويضات المستحقة للمجني عليهم والضحايا من جراء الجرائم منه، وذلك

حالة عجزهم عن الحصول على تعويض من الجاني (').

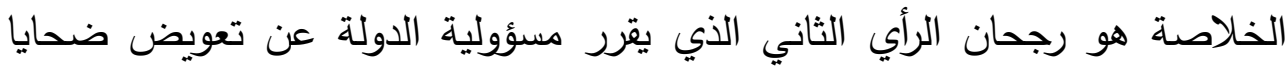

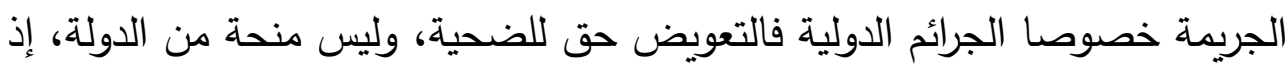

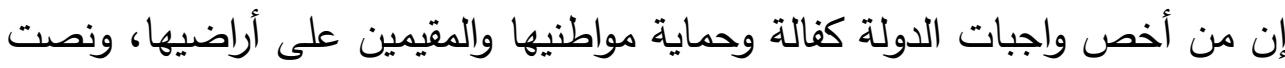

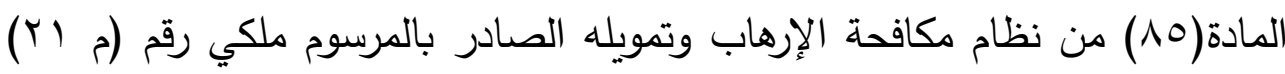

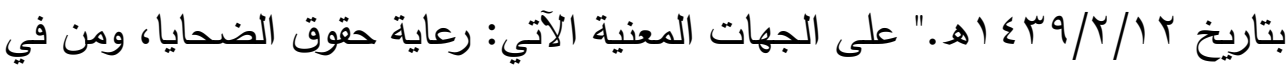
حكمه في الجرائم المنصوص عليها في النظام، من خلال توفير المساعدة والدعم الهابه المناسبين للمطالبة بحقوقهم" كما نصت المادة عه من قانون مكافحة الإرهاب المصري

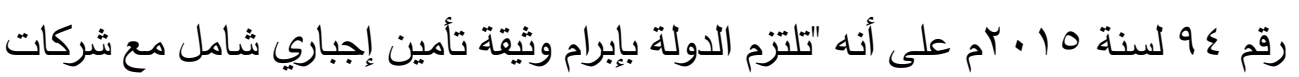

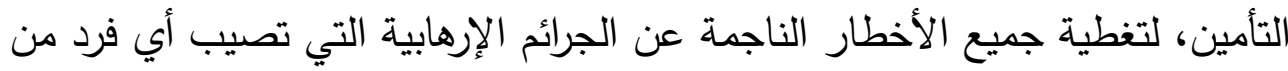

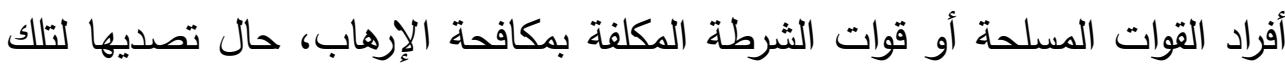

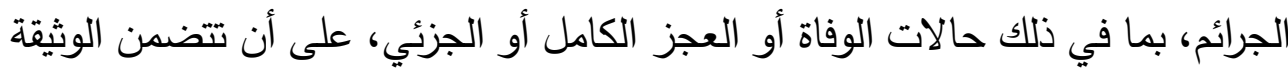
التزام الثركة بسداد تعويضات مؤقتة للمضرورين فور وقوع الخطر خصمًا من مبلغ

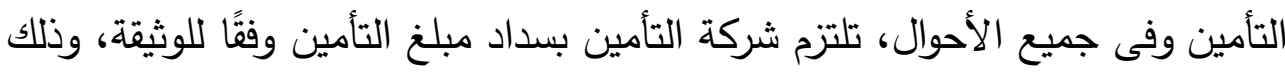

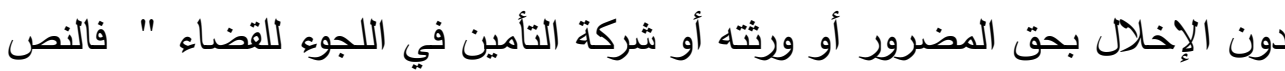
توجه بتعويض أسر ضحايا الجيش والثرطة، سواء الذين استهدفتهم العمليات الإرهابية

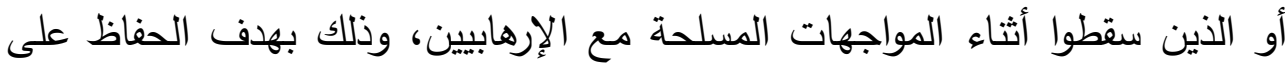

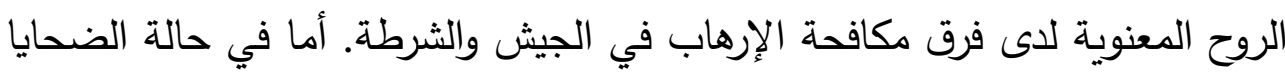
من المدنيين، فإن حصولهم على تعويضات يكون بقرار من رئيس مجلس الوزراء، ويتم

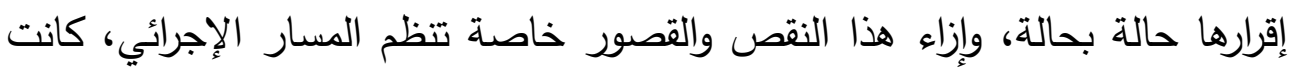




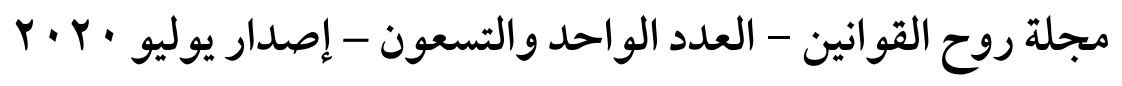
الحاجة ملحة للتنخل التشريعي لوضع نظام قانوني كامل من قواعد إجرائية وأخرى موضوعية لمواجهة تعويض ضحايا الجريمة. أما عن موقف النظام الأساسي للمحكمة الجنائية الدولية لسنة 991 ام (المعروف بنظة بنظام

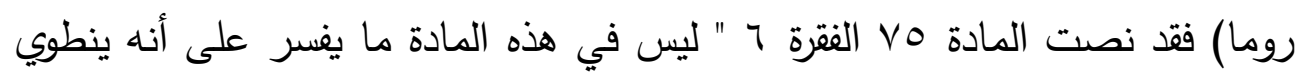

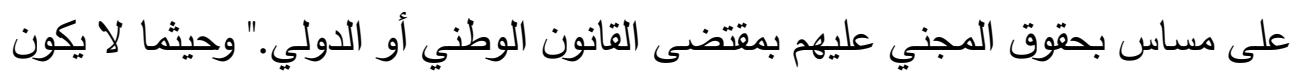

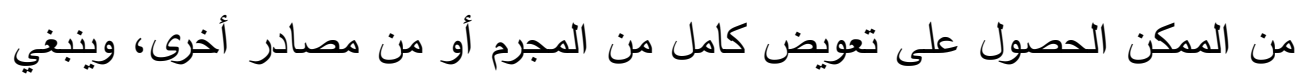

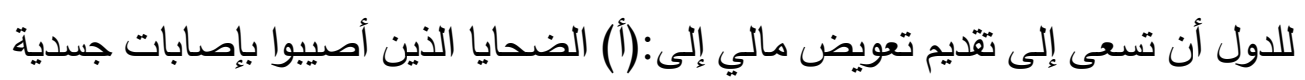

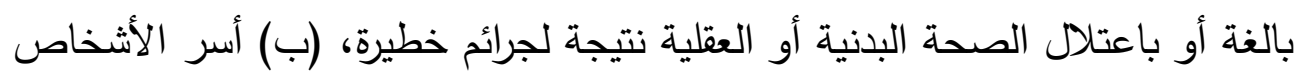

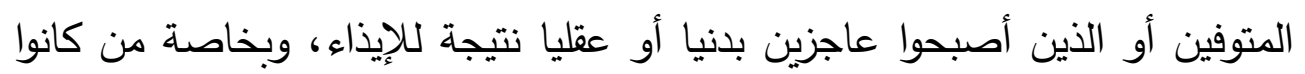

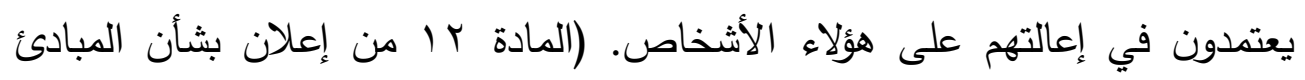

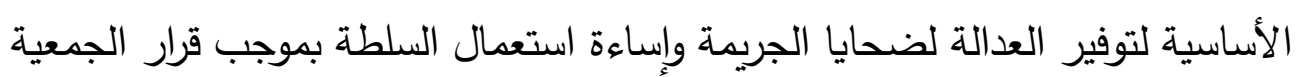

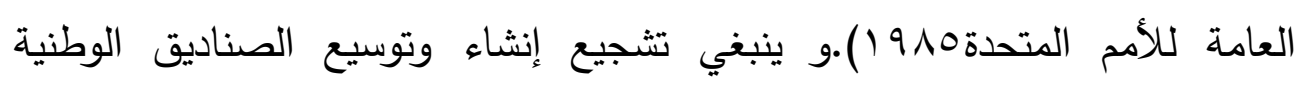

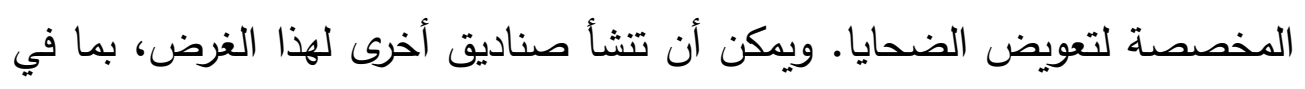

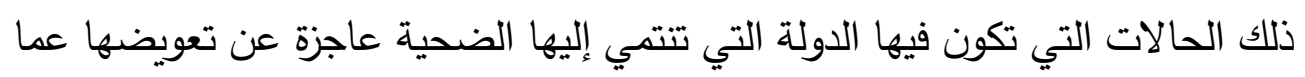

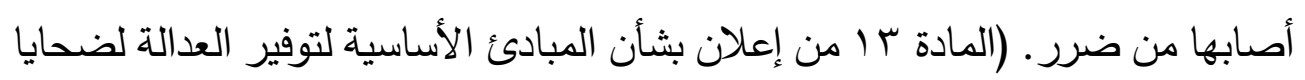

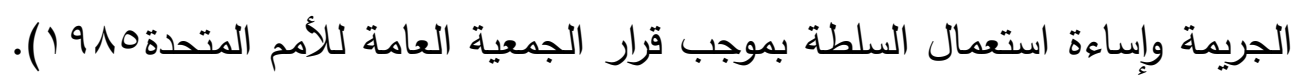

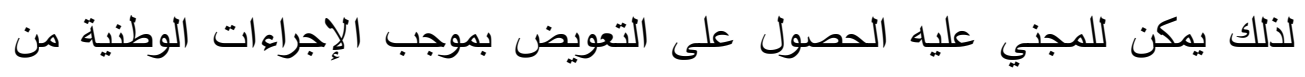

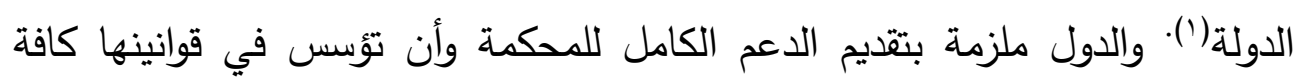
الإجراءات التي تفعل التعاون وذلك بأن تشريع الدول الأطراف قوانينها لتفعيل النظام

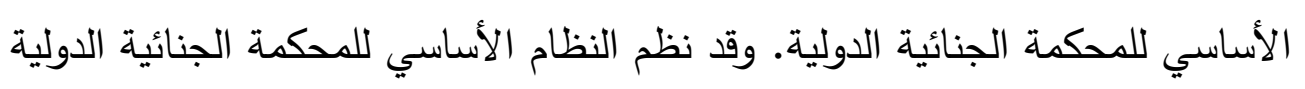

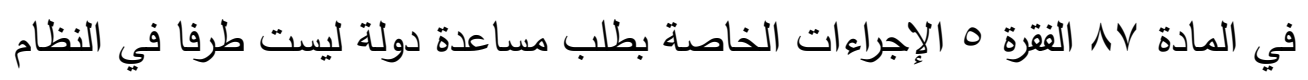

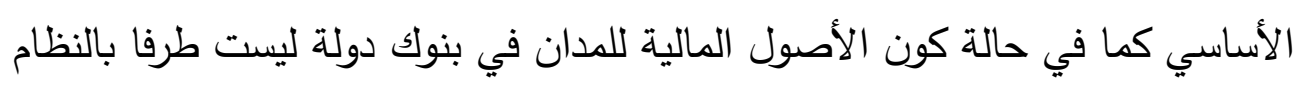


الأساسي ويكون طلب المساعدة على أساس اتفاق مؤقت او أي ترتيب آخر وفي حالة عدم تنفيذ الحكم بعد توقيع الاتفاق جاز للمحكمة ان تخطر جمعية الدول الأطراف أو أون مجلس الأمن بشرط أن يكون الأخير قد أحال المسألة الى مجلس الأمن (').

\section{الاطلب الرابع \\ صور تعويض المنبي عليه}

نصت المادة O من النظام الأساسي للمحكمة الجنائية الدولية للمحكمة أن تصدر أمراً مباشراً ضد شخص مدان تحدد فيه أشكالاً ملائمة من أشكال جبر أضرار المجني عليهم، أو فيما يخصهه، بما في ذلك رد الحقوق والتعويض ورد الاعتبار وللمحكمة أن

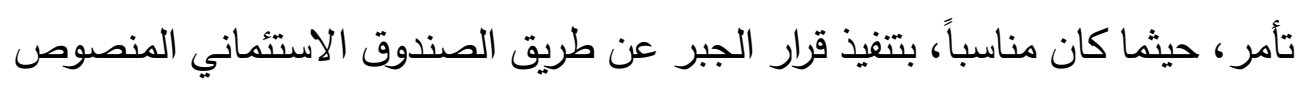
عليه في المادة 9." و ويتخذ تعويض المجني عليه أكثر من صورة على النحو الآتي: أولا: حق المجني عليه في التعويض: التعويض هو ما يلتزم به المسئول من دفع مبلغ

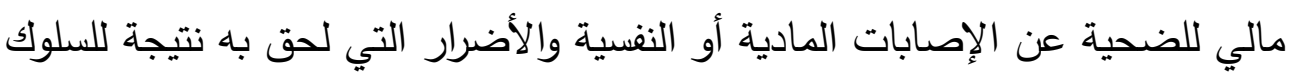
الإجرامي (؟). لذلك ينبغي أن يدفع المجرمون أو المسؤولون عن تصرفاتهم، تعويضا عادلا للضحايا أو لأسرهم. وينبغي أن يشمل هذا التعويض إعادة الممتلكات ومبلغا

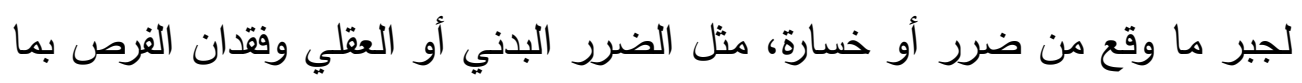

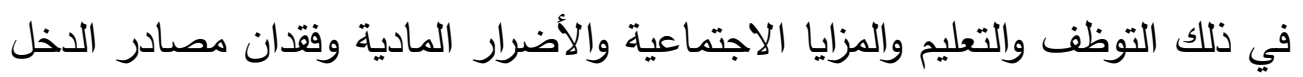
والضرر المعنوي إضافة إلى النفقات اللازمة للمساعدة القانونية أو المتخصصة والأدية ولدية والخدمات الطبية والنفسية والاجتماعية من خلال الوسائل الحكومية والتطوعية والمجتمعية والمحلية. كما ينبغي إبلاغ الضحايا بمدى توفر الخدمات الصحية

\footnotetext{
Redress ,State cooperation \& the rights of victims before the international criminal court, ${ }^{r} \cdots r, \mathrm{p}^{\vee}$

Lewis, P. and Friman, H., "Reparations to victims," in The International Criminal Court: Elements of Crimes and Rules of Procedure and Evidence (Lee, R.S. (ed.)), Transnational Publishers $(r \cdots 1),\{\wedge$. Reparations and the trust fund for victims, https://www.trustfundforvictims.org/index.php/en/what-we-do/reparation-orders $\mathrm{p}^{\Upsilon T} \mathrm{r}_{\mathrm{r}}$
} 


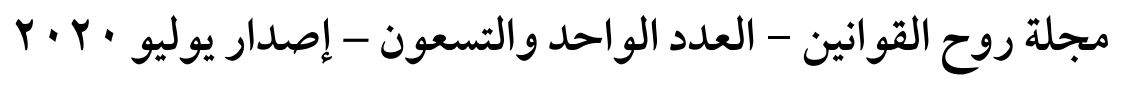

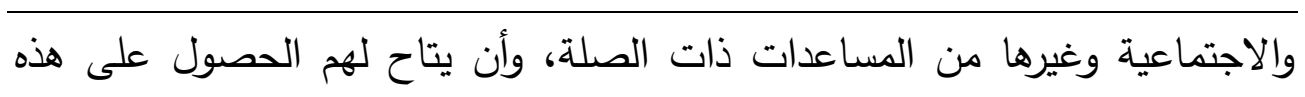

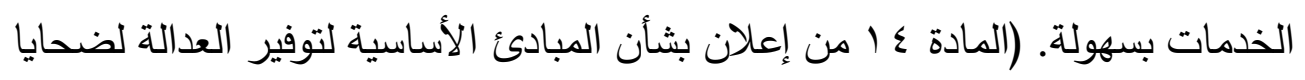

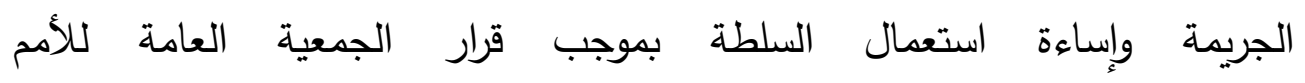

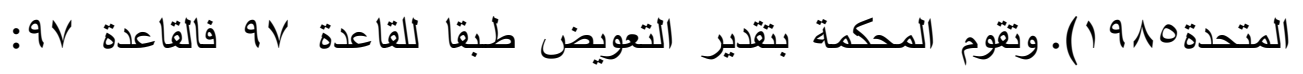

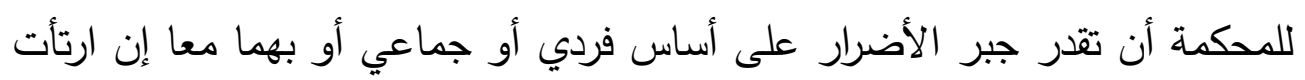

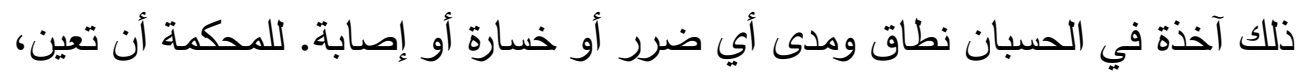

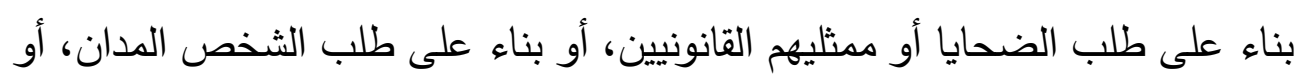

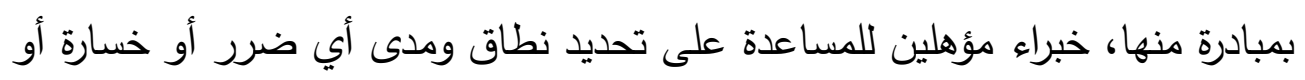

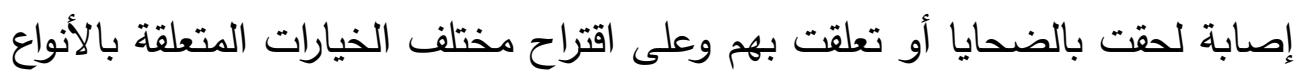

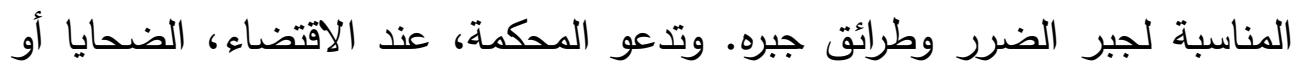

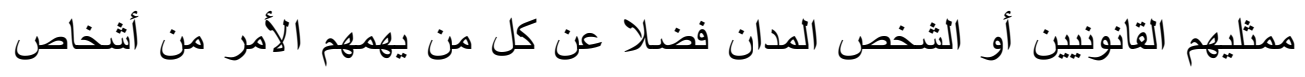

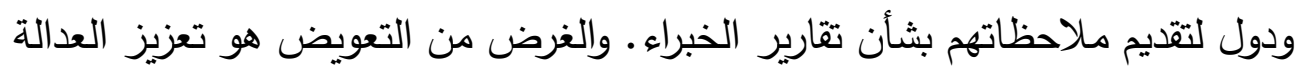

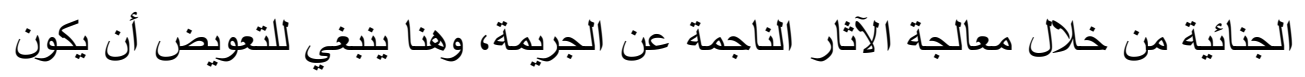

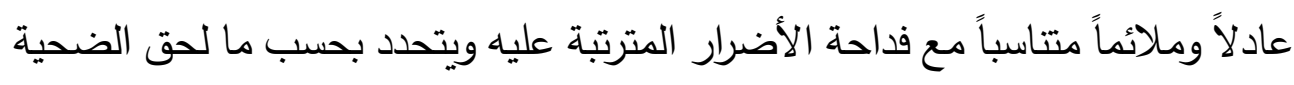

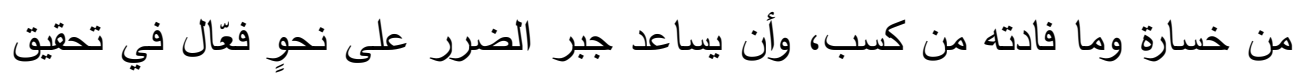

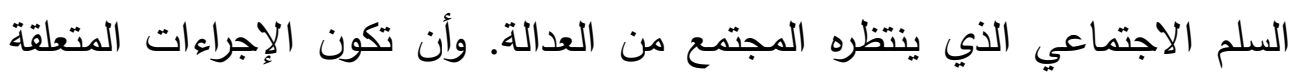

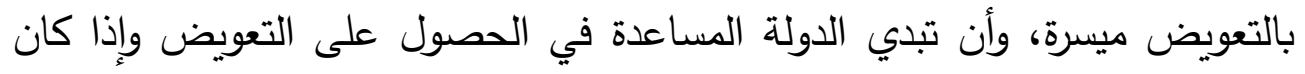

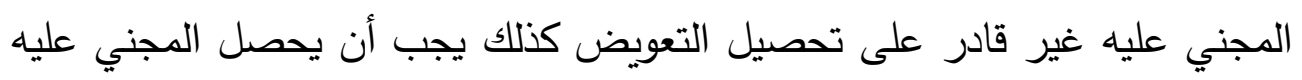

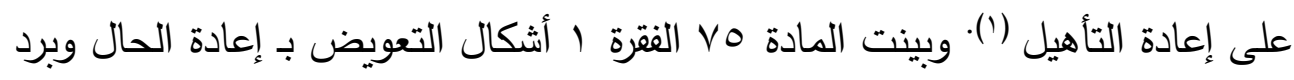

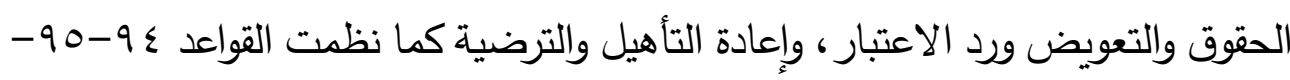

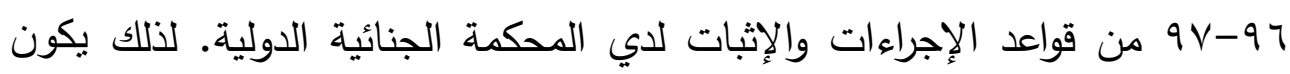

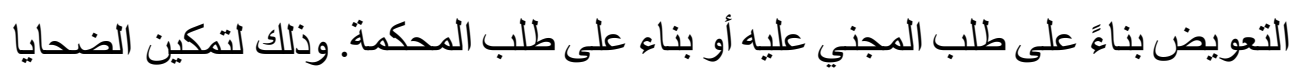
من المشاركة في الإجراءات القانونية كأصحاب مصلحة مستقلين لهم حق معترف بهاء 
في عرض آرائهم وشواغلهم. وللضحايا أيضًا الحق في الحماية والدعم الجسدي والنفسي، وطلب التعويض عن الضرر الذي لحق بهم من خلال الصندوق الاستئماني للضحايا. وذللك كما بأني:

الحالة الأولى: طلب التعويض هن قبل المبني عليه: تبدأ الإجراءات بناءً على طلب يتقدم به المجني عليه للحصول على التعويض ويتضمن الطلب التفاصيل الخاصة بالتعويض حسب ما هو منصوص عليه في القاعدة ؟9 من القواعد والإجراءات والإثبات على له الوجه الآتي:

1- يقدم طلب الضحايا لجبر الأضرار بموجب المادة 0 من النظام الأساسي خطيا ويودع لدى المسجل. ويجب أن يتضمن الطلب التفاصيل التالية: أولا: هوية مقدم الطلب وعنوانه؛ ثانيا: وصف للإصابة أو الخسارة أو الضرر؛ ثالثا:

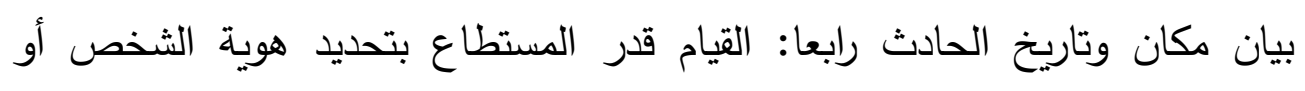
الأشخاص الذين يعتقد الضحية أنهم مسؤولون عن الإصابة أو الخسارة أو الضرر؛ خامسا: وصف للأصول أو الممتلكات أو غيرها من الأشياء المادية، عند المطالبة بردها؛ سادسا: مطالبات التعويض؛ المطالبات المتعلقة بأشكال أخرى من الانتصاف؛ والإدلاء قدر المستطاع بأي مستندات مؤيدة ذات صلة بالموضوع، بما فيها أسماء الشهود وعناوينهم. سابعا: تطلب المحكمة من المسجل، في بداية المحاكمة ورهنا بأي تدابير حماية، أن يخطر بالطلب الشخص أو الأشخاص المذكورين فيه أو في التهم وأن يخطر قدر المستطاع كل من يهههم الأمر من أثخاص أو دول. يودع من تم تبلغيهم أي بيان يقدم بموجب الفقرة r من المادة V0 لدى قلم المحكمة. الحالة الثانية: التعويض بناء على طلب هن المكمية: تخطر المحكمة المجني عليهم لغرض فسح المجال لهم لتقديم طلباتهم في الحالات التي تقرر فيها المحكمة أن تباشر إجراءاتها بمبادرة منها وفقا للفقرة ا من المادة ه V، وأن تطلب المحكمة إلى المسجل أن يخطر قدر الإمكان الضحايا بنيتها الشخص أو الأشخاص الذين تنظر المحكمة في إصدار حكم بحقهم، وأن يخطر قدر الإمكان الضحايا وكل من يهمهم الأمر من

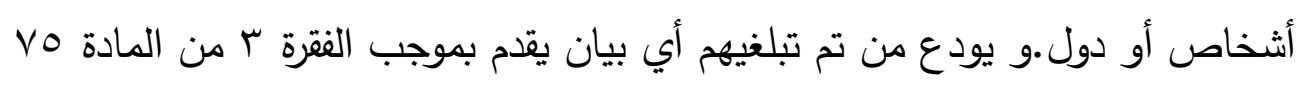


r. r · مجلة روح القوانين - العدد الواحد والتسعون - إصدار يوليو لاى قلم المحكمة ونتيجة للإخطار بموجب الفقرة المن من القاعدة: (أ) إذا قدم الضحية طلب جبر الضرر، فإنه يبت في طلبه هذا كما لو كان مقدما

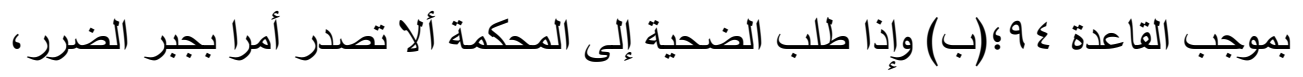

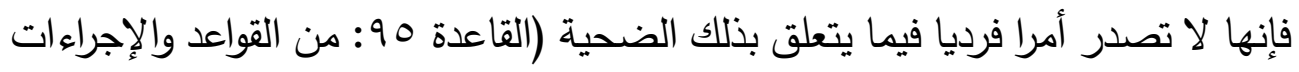

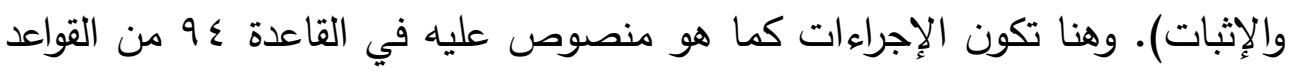

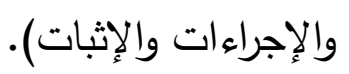

وتطبق المحكمة الجنائية الدولية المعايير الدولية بشأن الحق معالجة الانتهاكات

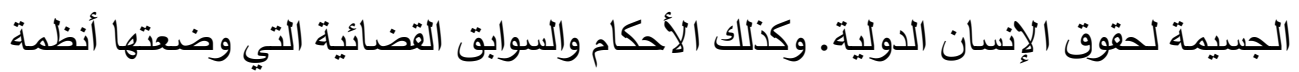

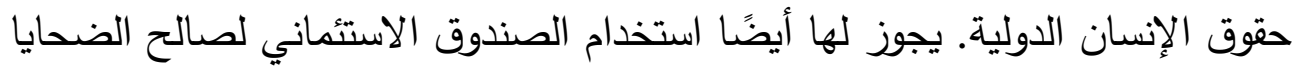

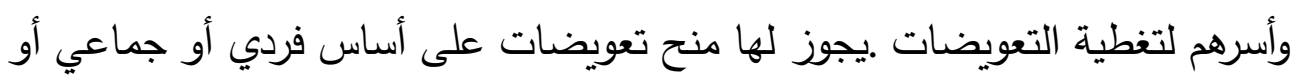

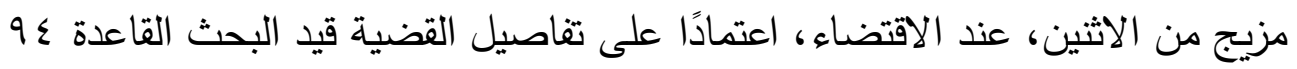

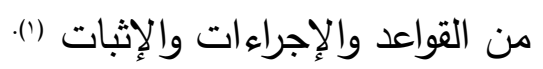
ثانيا: حق الجني عليه في إعادة التأهيل: يقصد بإعادة التأهيل مساعدة الضحايا على الإنى الاستمرار في العيش في ظروف عادية قدر المستطاع، والمساعدة على إعادة تعلم المهارات التي فقدتها بسبب الجريمة الدولية عن طريق توفير جملة من الخدمات

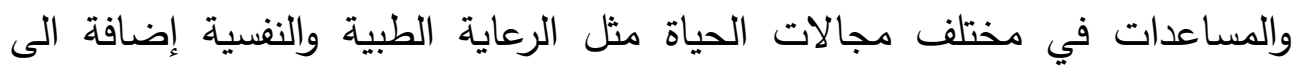

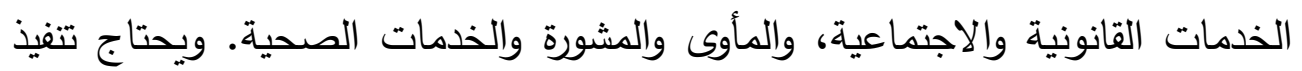

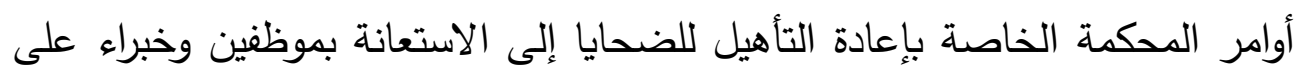

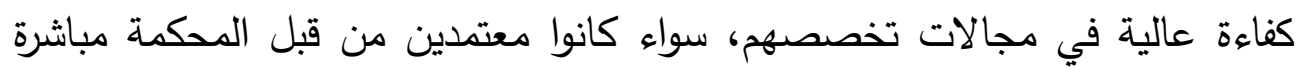
كالأخصائيين النفسانيين والاجتماعيين، أو عن طريق الاستعانة مباشرة بمنظمات تقداء

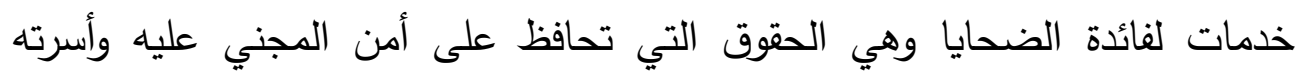
وممتلكاته وراحته النفسية ما يأتي:

Paulina Vega González, O papel das vítimas nos procedimentos perante o Tribunal Penal Internacional: ( 1) seus direitos e as primeiras decisões do tribunal, Rev. int. direitos human. vol. ${ }^{\Upsilon}$ no. ${ }^{\circ}$ São Paulo Dec. $Y$. . $~$ http://www.scielo.br/scielo.php?

$$
(0 . .)
$$


ا-الهق في الطمأنينة والارتياج النفسي: فمن حق المجني عليه الشعور بالهدوء والراحة النفسية والطمأنينة وذلك نتيجة أن المجني عليه بعد حدوث الجريمة مباشرة يكون في حالة نفسية وعصبية صعبة للغاية. وقد يفقد توازنه وهدوء أعصابه ويكون المجني عليه في أشد حالة عصبية والانفعال والقهر . فله الحق في ضمان سلامته وسلامة أسرهم والثهود المتقدمين لصالحهم من التخويف والانتقام (') r- الهقوق الصصية: تكون في معالجة المجني عليهم جراء إصابتهم حتى الثفاء التام من خلا الحصول على العلاج ومتابعة حالتهم المرضية والاستقرار في مراقبتها طبيا وإغاثة ضحايا الجريمة وإسعافهم قبل استفحال الجريمة والتسبب بالإيذاء الجسدي لهم. وتوفير مركز لعلاج الضحايا وتأهليهم ورعايتهم حتى يعودوا أعضاء نافعين ومنتجين

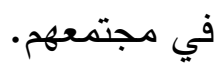
r- الهقوق الإنسانية: هي الحقوق التي تضمن للمجني عليهم معاملتهم معاملة إنسانية كريمة والمحافظة على كرامتهم ومشاعرهم وعدم جرح عواطفهم أحاسيسهم وإشعارها بكل سبل التعامل الإنسان لاتخاذ التدابير اللازمة للإقلال من إزعاجهم وحماية خصوصياتهم وإعداد برنامج تعليمية وتربوية تدربية والحق في حرية التعبير والحركة للمجني عليهم

$$
\text { وتتقلهم في الساحات الداخلية. }
$$

ع- الهقوق القانونية: هي التي يضمن بموجبها تطبيقا دقيقا للقوانين والتشريعات السارية المفعول بما يحقق الأمن القانوني للضحايا وبما يحقق الأمن القضائي للضحايا بمثولهم أمام القضاء وتمكين ضحايا الجريمة من الحصول على الإنصاف القضائي والقانوني وتعرفهم بحقوقهم القانونية في التماس العدل والإنصاف وسرعت تنفيذ البلاغات والأوامر والأحكام الخاصة بقضاياهم خصوصا تلك التي تقضي بمنح تعويضات لهم (؟).

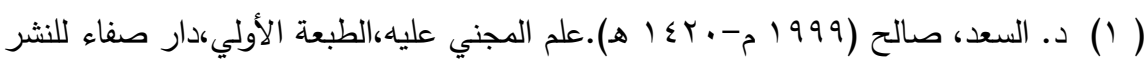

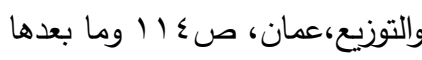

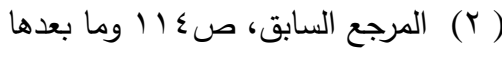


F. r. · مجلة روح القوانين - العدد الواحد والتسعون - إصدار يوليو

\section{ثالثا: حق الجذي عليه في استرداد الهقوق:}

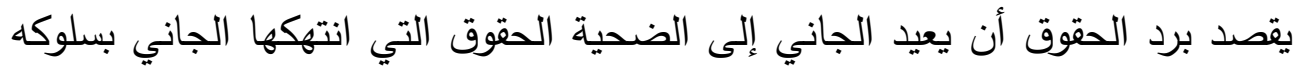

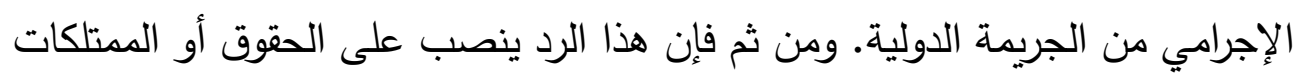

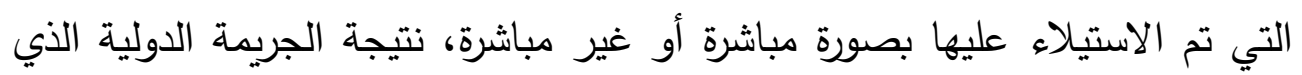

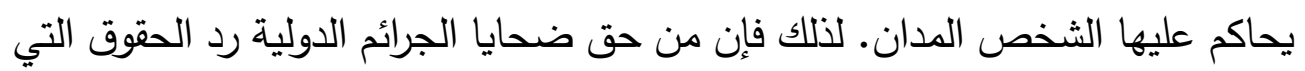

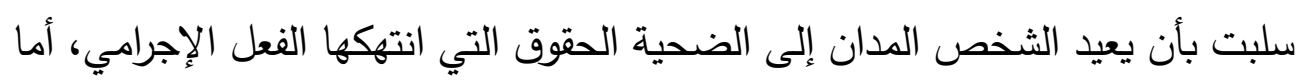

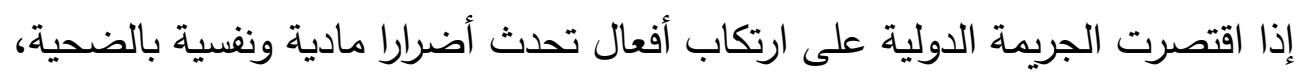

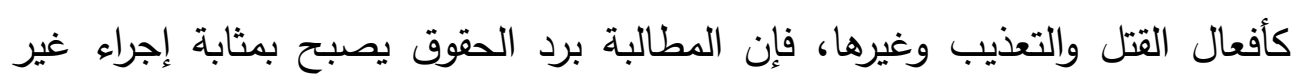
مناسب، مقارنة بالتعويض ورد الاعتبار .

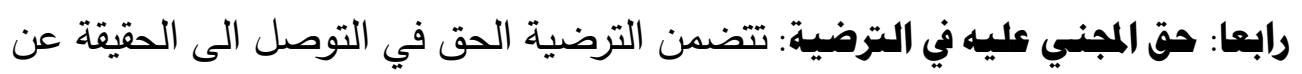
الجرائم الدولية التي وقعت على المجني عليه واتخاذ الخطوات اللازمة لينع استمرار

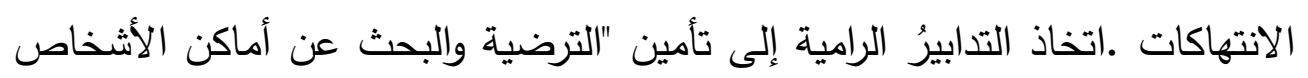

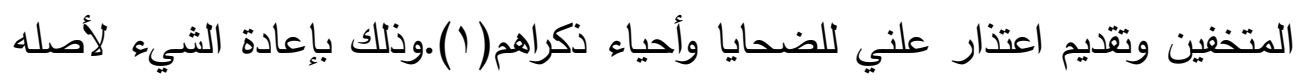

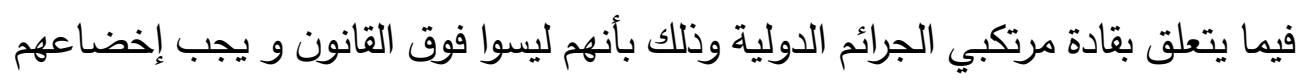

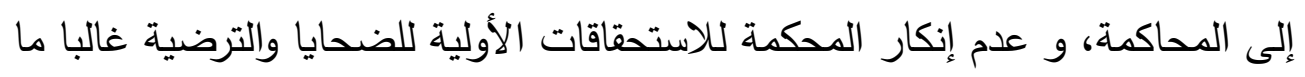
تكون في حالات الضرر المعنوي وتكون الترضية إما باعتذار رسمي والاعتراف بالجرائم المرتكبة، وتقديم اعتذار علني؛ وفرض عقوبات قضائية وإدارية على الأثخاص

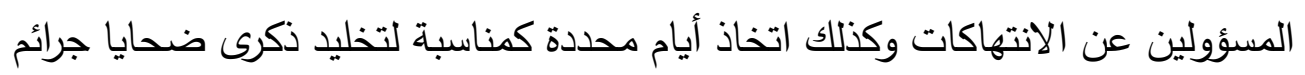

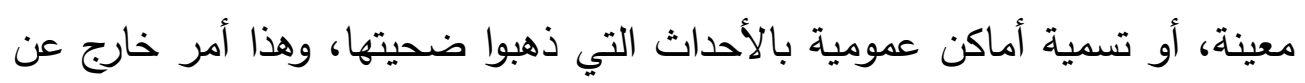

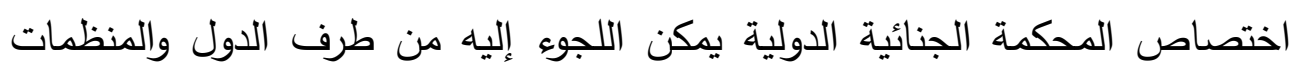

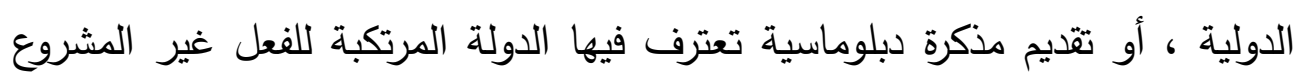

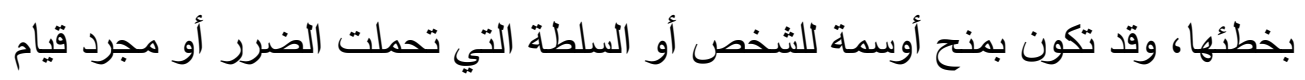

The UN Handbook on Justice for Victims on the use and application of Basic Principles of Justice for Victims ( $)$

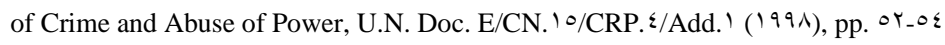


الدولة مرتكبة الفعل بالاعتراف بخطئها لارتكابها لهذا الفعل ومراعاة عدم ارتكابه لاحقابما يفيد أن الضمانات التي تأخذها الدول بعدم تكرار الانتهاكات، يشكل نوعا من الترضية (1).وذلك من أجل توفير نوع من الراحة النفسية للضحايا.

خاهسا: ضهانات عدم التكرار العدوان على المجني عليهم: ويقصد بهذا الحق أن تتخذ إجراءات ملموسة لمنع الجرائم في المستقبل على المجني عليه (ז) وذلك بضمان عدم التكرار في توجيه ضربات للمجني عليه والتي كثيراً ما تفضي إلى خلق بيئة تسمح بتفشي تجارب إهانة الكرامة الإنسانية دون أن تنال هذه الأعمال الإدانة العلنية أو العقاب الملائم. ويتم تقرير الحماية بأن يخبر الادعاء العام الدائرة التمهيدية في مرحلة مبكرة حتى تتدخل عن طريق إصدار الأوامر الإجراءات اللازم مثل الإذن بالقبض على لئ أحد المتهمين واستجوابه لمنع العدوان على المجني عليه وتكرار الجريمة أو قد تتدخل المحكمة مباشرة في سير الإجراءات في مرحلة التحقيق وذلك عن طريق قيامها بانتداب أحد قضاتها، لكي يقوم بمراقبة الرخص وإصدار التوصيات والأوامر بشأن الإجراءات الهامة في التحقيق، أو اتخاذ الإجراءات التي تلزم لحفظ الأدلة (ז) وتتطلب تلك الضمانات "إجراء التحقيق مع الجناة ومحاكمتهم ومعاقبتهم على نحو فعال ويجب منع تعرض المجني لوقوع الجرائم من جديد، بطرائق منها الإعادة الآمنة، ومنح الإقامة المؤقَّة أو الدائمة، وتعزيز التدابير القانونية، والمساعدة على الاندماج واتخاذ التدابير الكفيلة بمعالجة الأسباب الجذرية للجرائم الدولية. لذلك نصت المادة (r/OV-أ-ب) من النظام الأساسي للمحكمة الجنائية الدولية " أن تتخذ-الدائرة التمهيدية أو الابتدائية-عند الضرورة ترتيبات لحماية المجني عليهم والثهود وخصوصياتهج، والمحافظة على الأدلة،

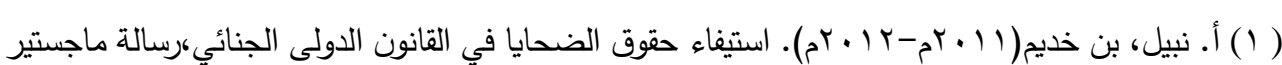

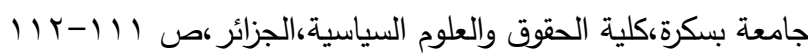

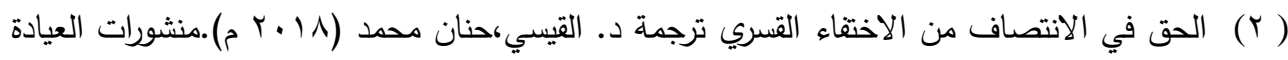

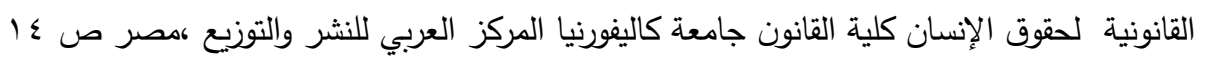

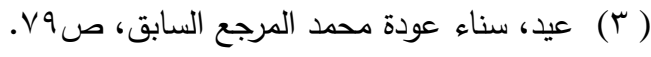
$(0, r)$ 


$$
\text { r. r. · مجلة روح القوانين - العدد الواحد والتسعون - إصدار يوليو }
$$

وحماية الأشخاص الذين ألقي القبض عليهم أو مثلوا استجابة لأمر الحضور، وحماية

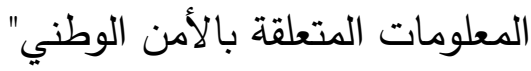

\section{سابعا: حق الضحايا في حفظ أسرارهم الشخصية: أوجب الثارع على سلطات التحقيق} وسلطات المحكمة حفظ أسرار الضحية وعدم الإفثاء بها إلا بالقدر اللازم لهصلحة الدعوى

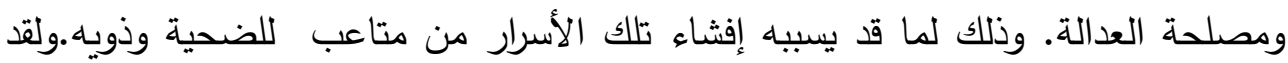

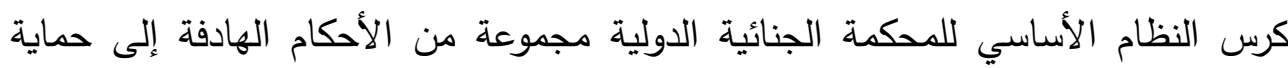

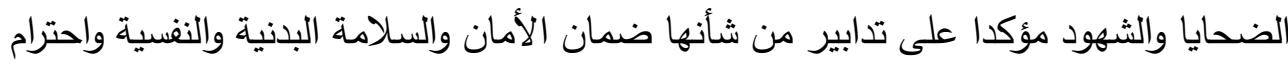

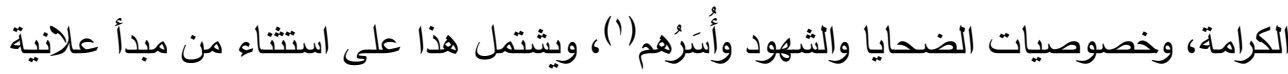

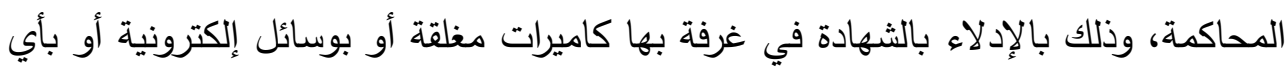

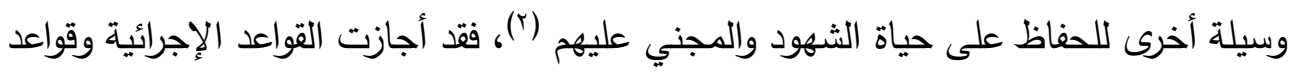

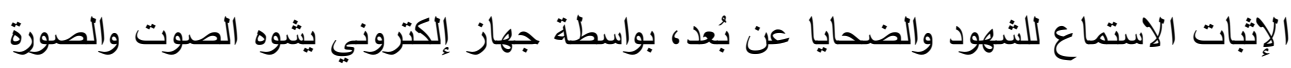

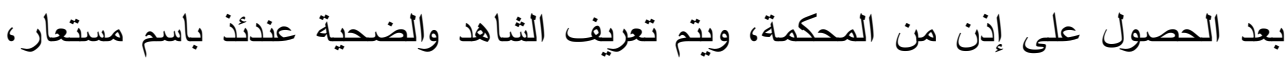

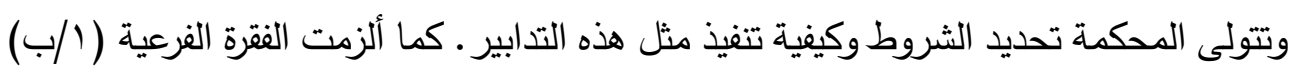

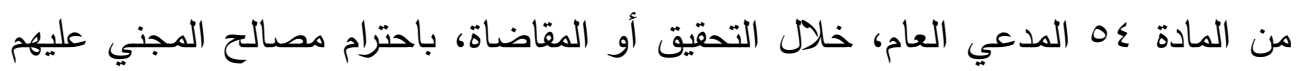

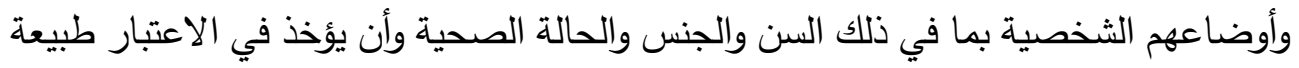

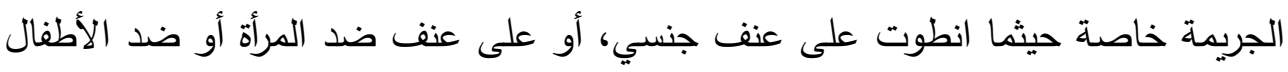

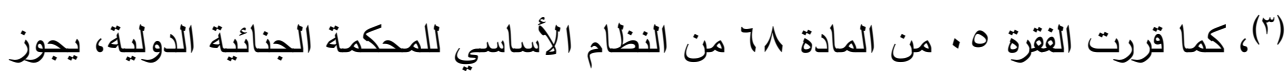

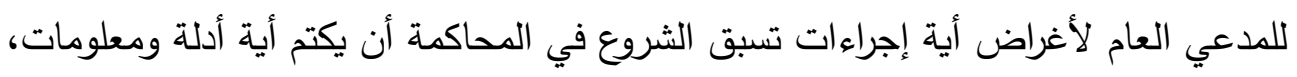

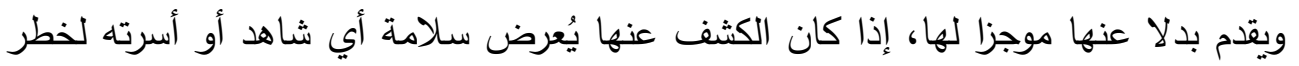

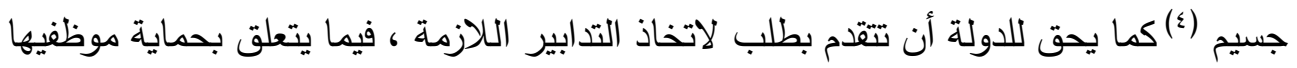

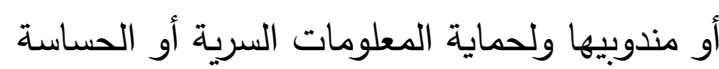

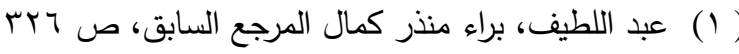

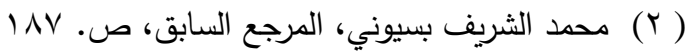

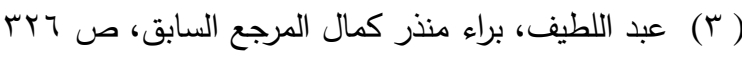

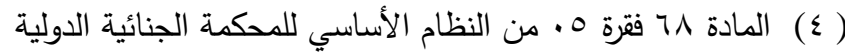
$(0, \varepsilon)$ 


\section{الخاتمهة}

يناقش هذا البحث "الحماية الإجرائية لحقوق المجني عليه أمام سلطة التحقيق في ظل نظام المحكمة الجنائية الدولية لسـنة 991 (ام، وفقا لأحكام النظام الأسـاسـي للمحكمة الدولية الجنائية والقواعد الإجرائية والإثبات. شـــــــ أواخر العقد الثاني من القرن

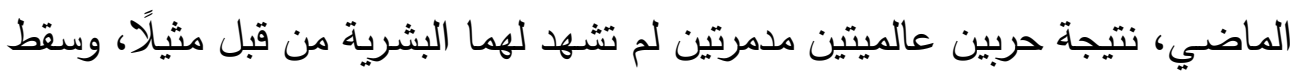
عشرات الملايين من الناس بين قتلى وجرحى وأسرى ولم يقتصر الضحايا على الجنود وحدهم، بل شمل كذلك المدنيين، فهدمت مساكنهم ودمرت مصانعهم ومتاجرهم وخربت كثيرًا من مدنهم (') ـ وتتباين الحقوق التي يتمتع بها المجني عليه أمام سـلطة التحقيق لاي المحكمة الجنائية الدولية نتيجة تزايد الصعوبات العملية والأيدلوجية على المستوي الدولي بين الدول في احترام حقوق الإنســان ونصــرة المظلوم. وقد خلص البحث إلى عدة نتائج منها: - n - إن الفقه القانوني تباين في المصــــلح الدال على المجني عليه فتارة يســــخدم مصطلح المجني عليه،أو مصطلح الضـية،أو مصطلح المضرور من الجريمة، أما مفهوم المجني عليه فتارة يســــخدم المعنى الضـــيق و وهو من وقعت عليه الجريمة ويترتب لله بعض الحقوق التي لا تبلغ مبلغ الثــــيك ولا الطرف في الدعوى الجنائية

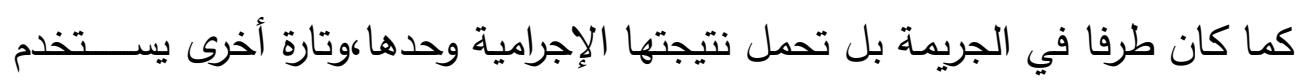
مصــطلح المدعي بالحق المدني أي المضــرور من الجريمة بصـــورة غير مباشــرة

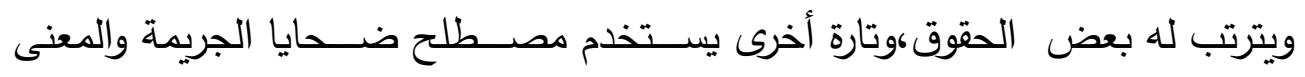
الراجح لدينا تتبي مصــلح المجني عليه بمعناه الواســح الذي يثـمل معناه من وقعت عليه الجريمة ولو في حالة شـروع أو المجني عليه غير المباشـر وأن يكون طرفا في

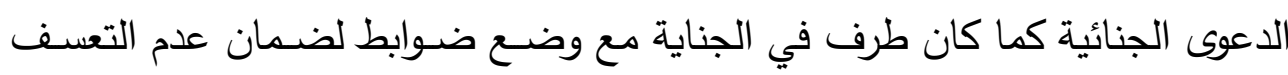
في استخدام الدعوى الجنائية من أي طرف من أطراف الدعوى الجنائية.

(1 ) .د.محمد عوض ،عوض ،فكرة المحكمة الجنائية الدولية: نشأتها وتطورها، الموقع على الثبكة الدولية: https://al-furqan.com/ar/ $(0.0)$ 


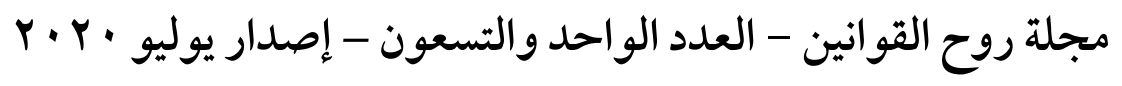
- إذ يفتقر المجني عليهم في الغالب، إلى إمكانيـة الوصــــول إلى إجراءات تقديم

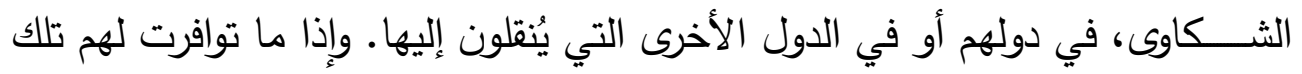

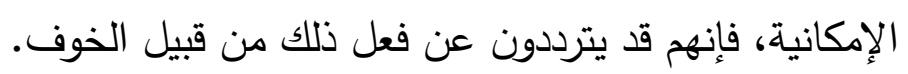

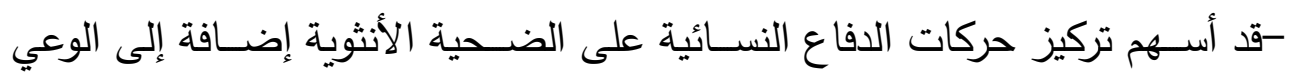

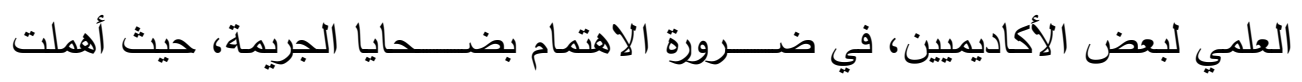
البحوث الجنائية عن الجريمة بشكل ملحوظ حقوق المجني عليه في التوازن في الميزان

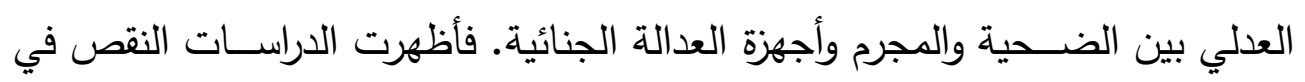
السـياسـة الجنائية الإجرائية التقليدية التي اقتصــرت على ألى أن أطراف الدعوى الجنائية،

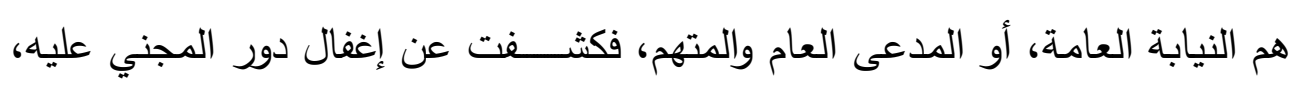

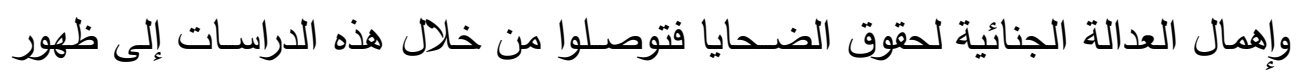

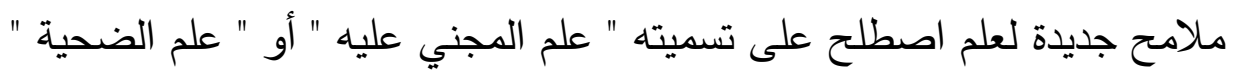
-

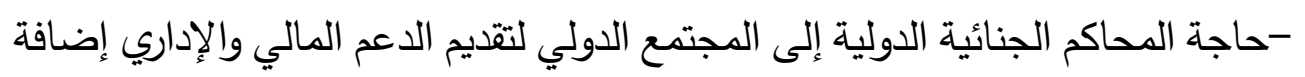
إلى اعتماد المحكمة على الدول في القبض على المتهمين وتسليمهم إليها.

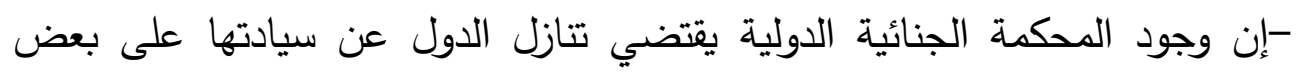

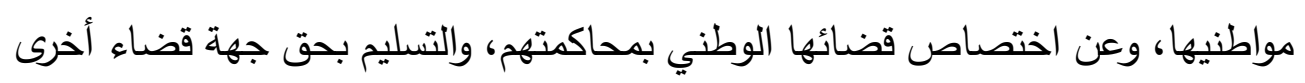
بتعقبهم وإرغامهم عن المثول أمامها والامتثال لمحاكتهم أمام قضاة آخرين، واحتمال ولهال الحكم عليهم بعقوبة يجري تتفيذها عليهم في دولة غير دولتهم، وهذا يجعل بعض الدان الدول

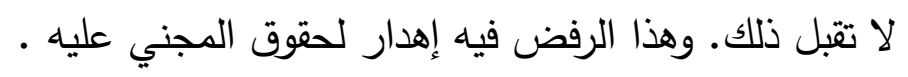

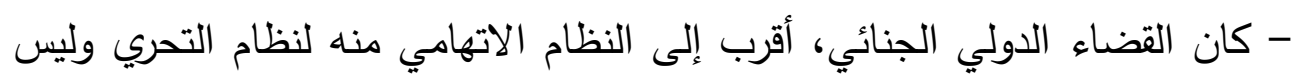
نظام إجرائي مستقل قائم بذاته، وقد قرر النظام الأساسي بعض التصام الحقوق للمجني عليها

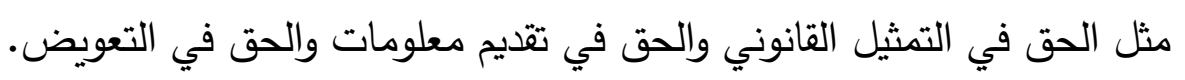

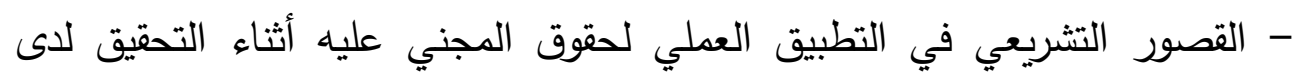

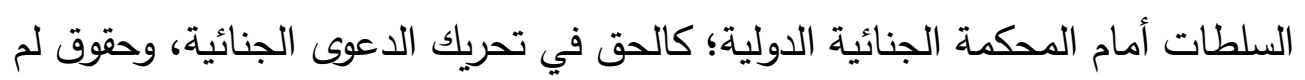




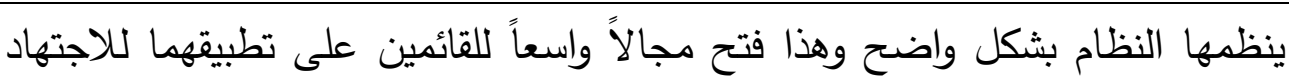

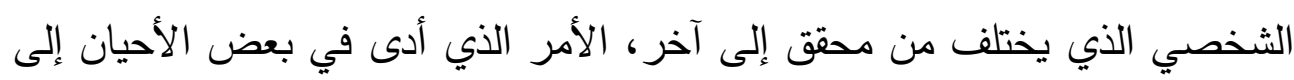

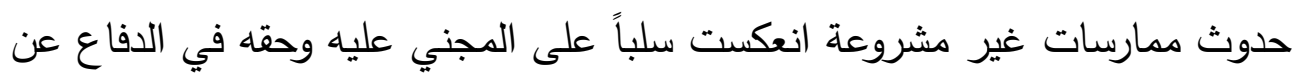

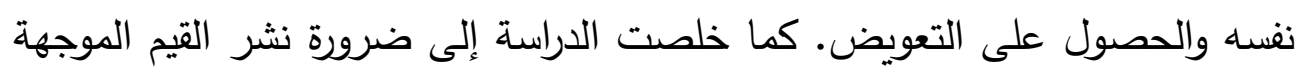

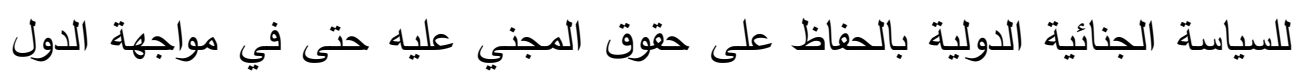

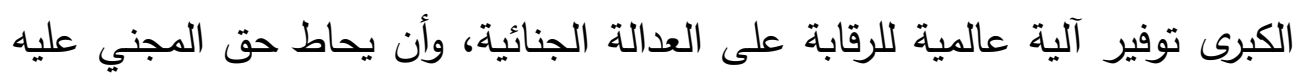

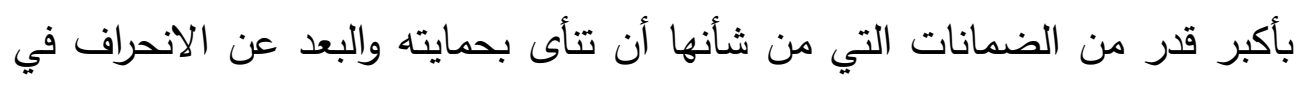
إهمال الحماية للمجني عليه وتفعيل دور المجني عليه في الرابطة الإجرائية.

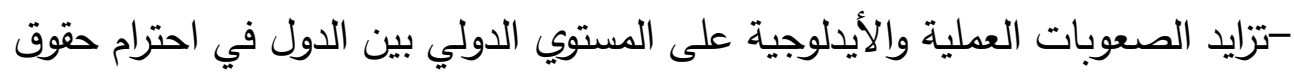

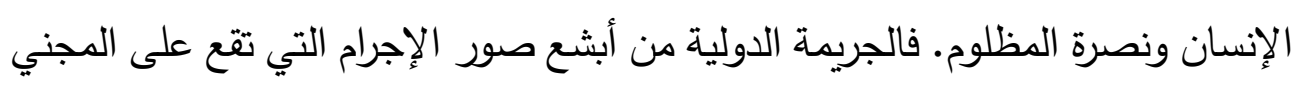

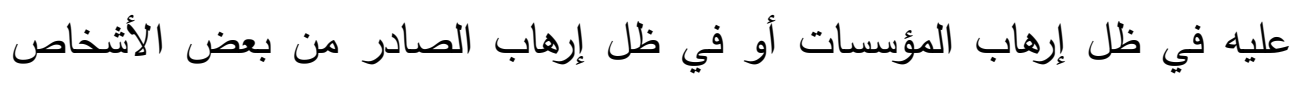

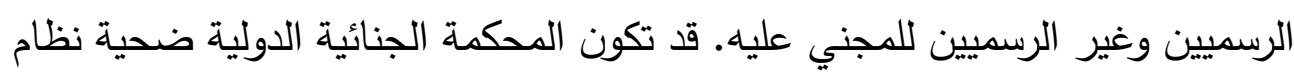

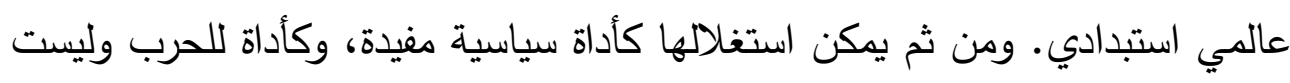

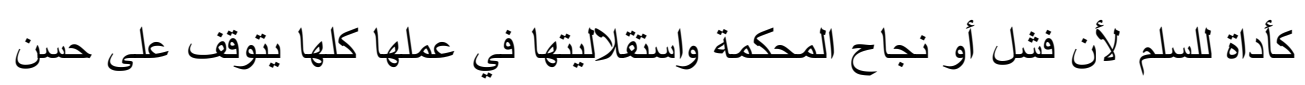

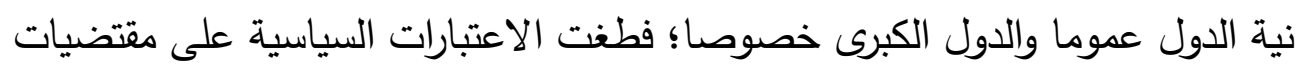

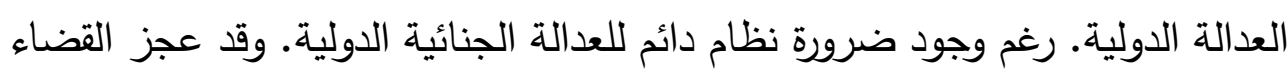

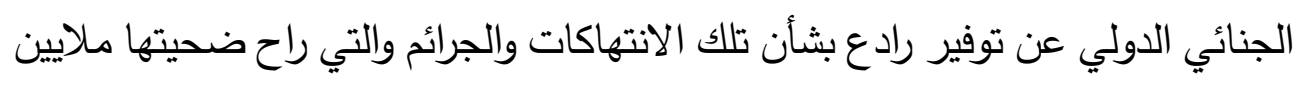
من الأبرياء قتلوا وشردوا وسجنوا وأسرو وشوهوا وعذبوا وانتهاك حرمات النساء والأطفال

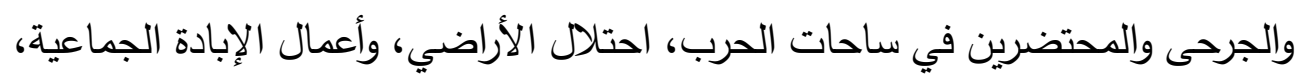

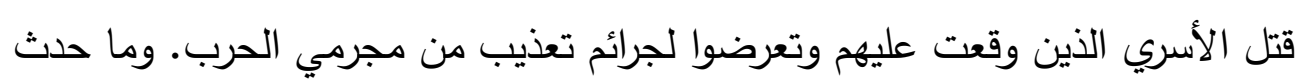

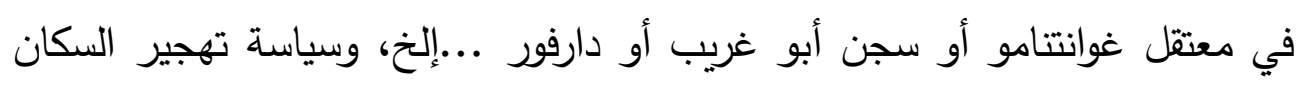

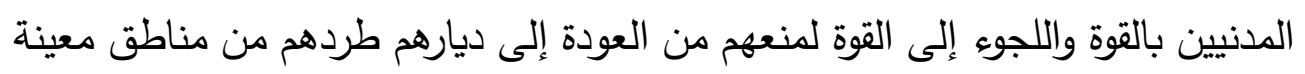
أو حبسهم حبساً مطلقاً في السجون بغير محاكمة عادلة. 
F. r. · مجلة روح القوانين - العدد الواحد والتسعون - إصدار يوليو

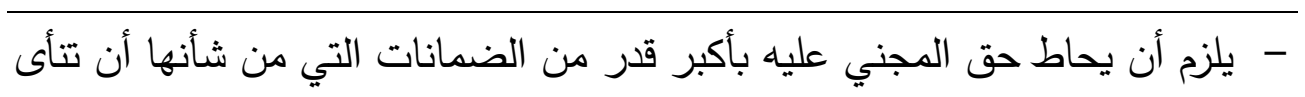

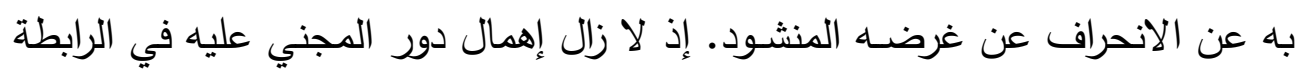

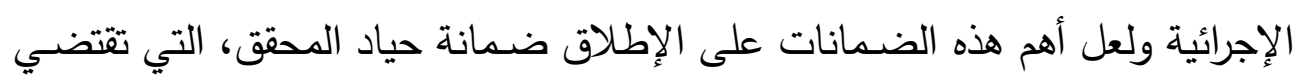

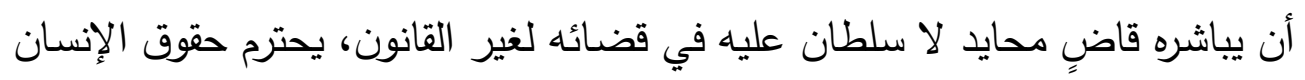

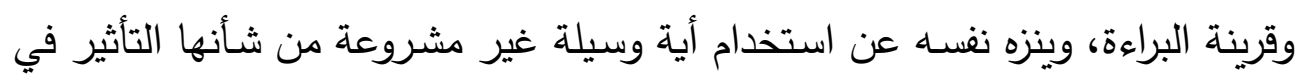

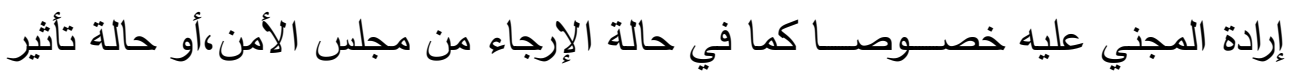
الدول صاحبة الايدلوجية. - تعديل نظام روما بالتتصيص على مسؤولية الأشـخاص المعنوية عن الجرائم التي التي

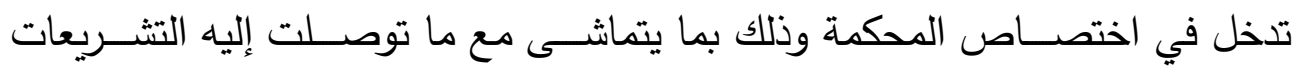

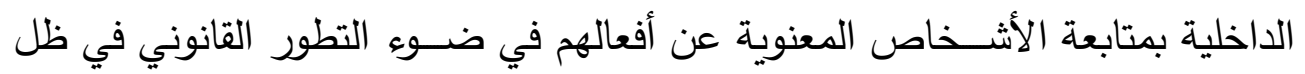
التشريعات الحديثة. - لم يتضمن النظام الأساســـي للمحكمة الجنائية الدولية النص على مفهوم المجني

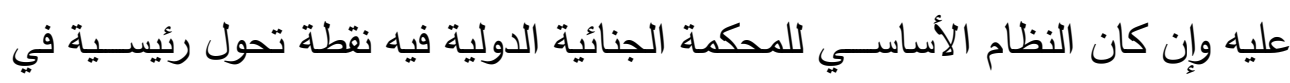
مسار تعزيز المركز القانوني للمجني عليهم في الجرائم الدولية.

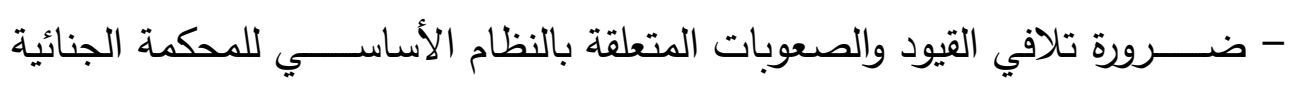

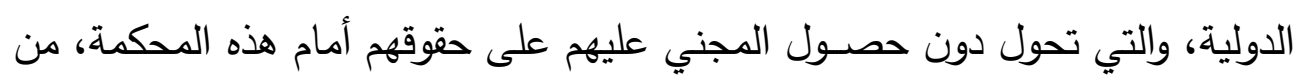
خلال النظر في إمكانية تعديل المواد المتصلة بذلك.

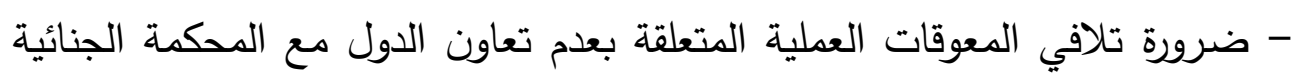

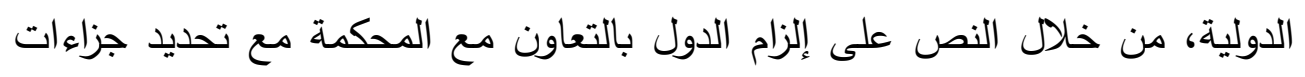

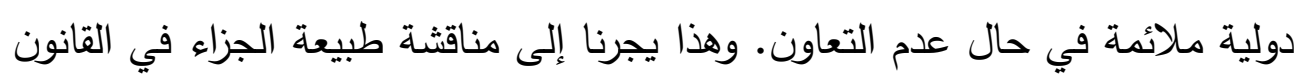
الدولي (العادي) ودوره في تحقيق ردع الجناة وحماية حقوق ضحايا الجريمة .

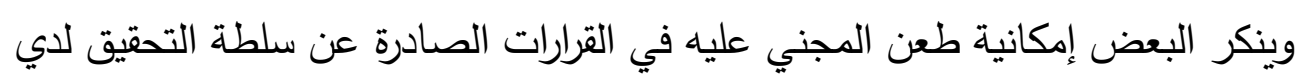
المحكمة الجنائية الدولية. التوصيات: $(0.1)$ 
أولا: وضع خطة بالاحتياج التشريعي لحماية حقوق المني عليهم في مواجهة المحكومين والحكام وتوفر وسائل إنصاف مباشرة مثل النيابة العامة مع وضع ضوابط

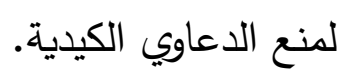

ثانيا: كفاية التشريع لحماية المجني عليه: رفع مستوى الآلية التشريعية لحماية حقوق المجني عليهم بنصوص دستورية تستقي من أحكام الوحي الشرعي الإسلامي في الثرع المبتدأ ومن الخبرة الإنسانية والدولية فيما فوض فيه الشارع الحكيم. ثالثا: التقليل من نصوص الإحالة وعدم الاكتفاء بنصوص الإحالة التشريعية بشأن حماية المجني عليه باللجوء للقياس على المضرور من الجريمة ويجب توحيد اسم الضحية لتطلق على المجني عليه والمضرور أو لفظ المظلوم كما ذكر القرآن الكريم. رابعا: وضع سقف للتشريع بوجود قيم شرعية ودستورية موجهة للتشريع، وإن التشريع له سقف من القيم التشريعية في الشريعة الإسلامية المتدرجة من قيم الحق الواجبة الإقامة إلى قيم الخير العام والخاص التي يحتاجها الناس إلى قيم الجمال والكمال التي تحسن وتطور وتمم حياة المجني عليه . 
r.r. · مجلة روح القوانين - العدد الواحد والتسعون - إصدار يوليو

\section{قائمة المراجع}

التفسير وعلوهه:

ا-بن كثير ، أبو الفداء إسماعيل بن عمر (المتوفى: ع \&هـ)، تفسير القرآن

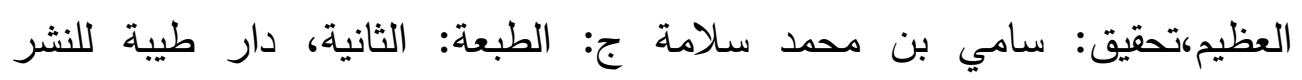

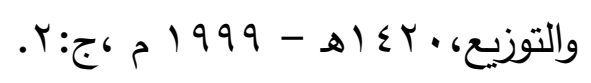

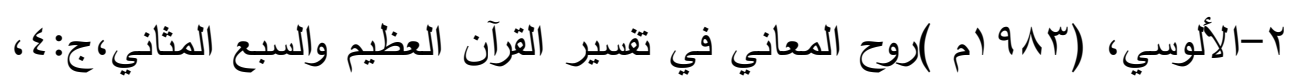
دار الفكر ،بيروت.

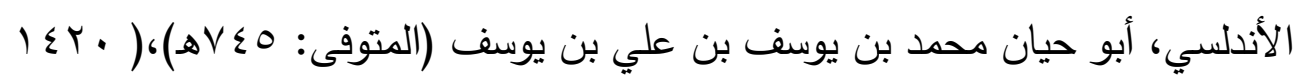

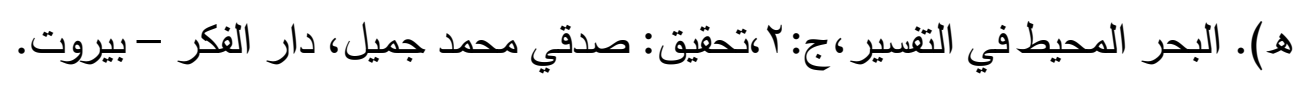

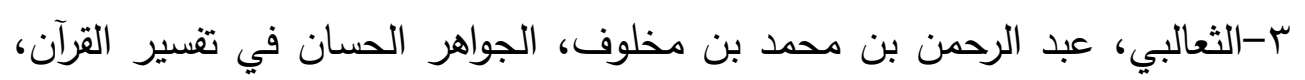

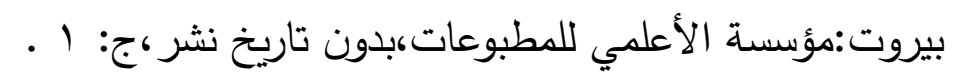

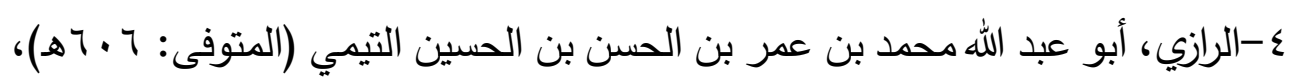

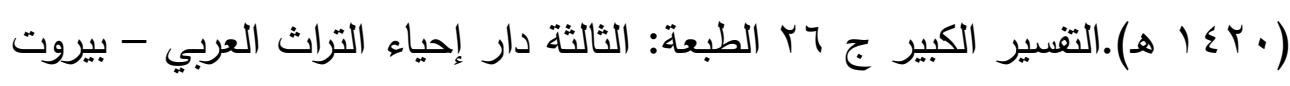

0-الثيخ /محمد بن عبد الله الأندلسي (ابن العربي) ، أحكام القرآن ،دار الكتب

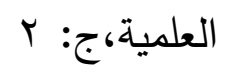

צ-أبو العباس، أحمد بن محمد بن المهدي بن عجيبة الحسني الإدريسي الشاذلي

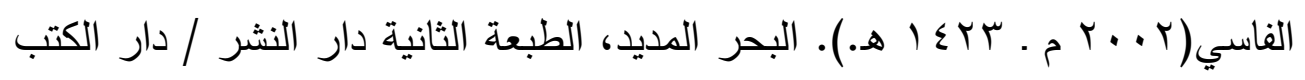

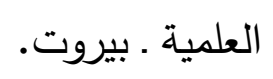

V-أبو زهرة، محمد بن أحمد بن مصطفى بن أحمد (المتوفى: ع ؟ با هـ) زهرة التقاسير،

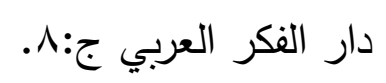

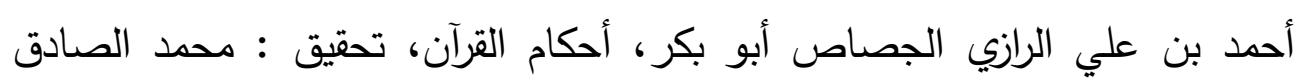

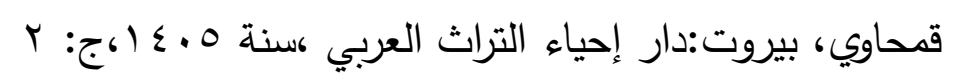




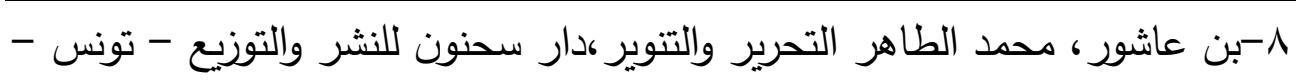

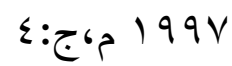

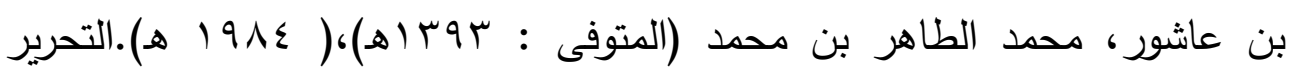
والتتوير 》تحرير المعنى السديد وتنوير العقل الجديد من تفسير الكتاب المجيده ج: 1 1،الدار التونسية للنشر - تونس الصديث وعلوهمه:

و-ابن عابدين، محمد أمين بن عمر عبد العزيز عابدين الدمشقي الحنفي(ب99 ( ). رد

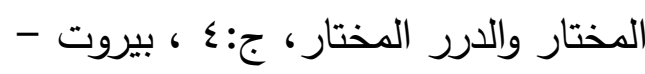
• ا-ابن عطية الأندلسي ، أبو محمد عبد الحق بن غالب بن عبد الرحمن بن تمام بروك

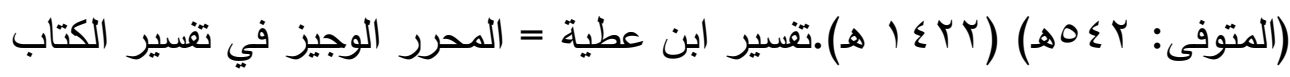
العزيز ، ج: الطبعة: الأولى تحقيق:عبد السلام عبد الشافي محمد، دار الكتب العلمية

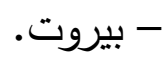

I ا-ابن ماجة (المتوفى: rVY Iه)، سنن ابن ماجه،تحقيق: محمد فؤاد عبد الباقي،دار إحياء الكتب العربية - فيصل عيسى البابي الحلبي ،ج: إص مV9. رقم

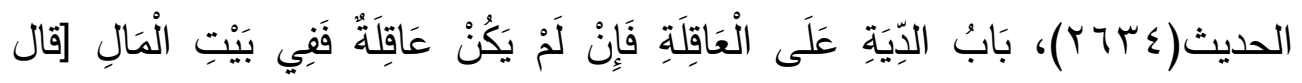

الألباني]: صحيح. r ا-الترمذي، محمد بن عيسى بن سَوْرة بن موسى بن الضحاك، (المتوفى:

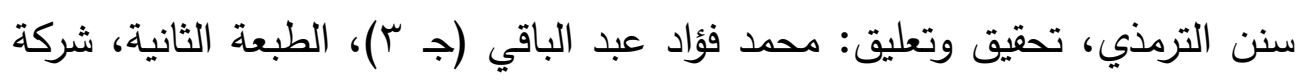

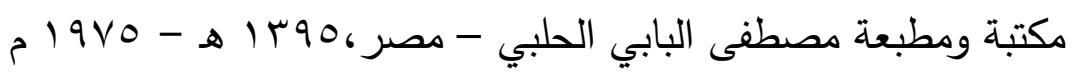

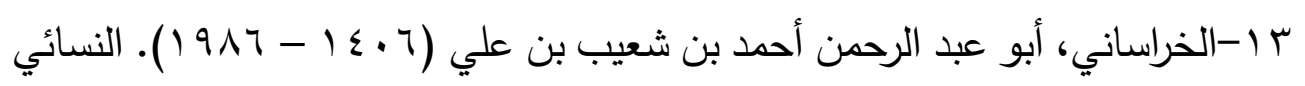
(المتوفى: ץ • rهـ)، المجتبى من السنن = السنن الصغرى للنسائي، ج: ، ،تحقيق: عبد الفتاح أبو غدة الطبعة: الثانية، مكتب المطبوعات الإسلامية - حلب. ع ا-أبو محمد محمود بن أحمد بن موسى بن أحمد بن حسين الغيتابى الحنفى بدر

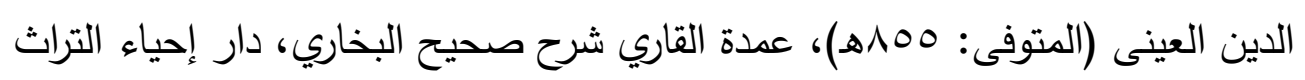

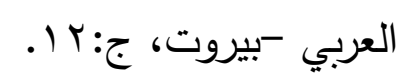


F. r. · مجلة روح القوانين - العدد الواحد والتسعون - إصدار يوليو

10-بن عامر الأصبحي، مالك بن أنس بن مالك (المتوفى: V9 اهـ) الموطأ،حقيق:

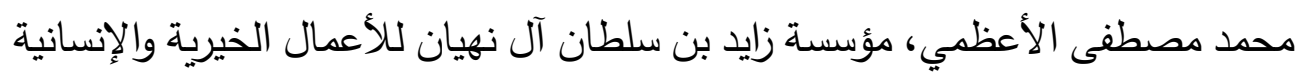

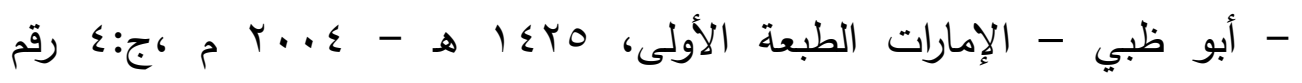

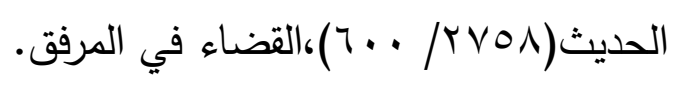

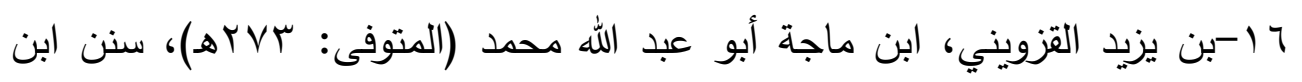

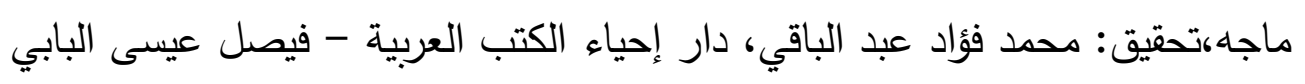

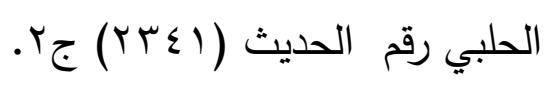

V ا-ابن أمير حاج، أبو عبد الله شمس الدين محمد بن محمد الحنفي (المتوفى:

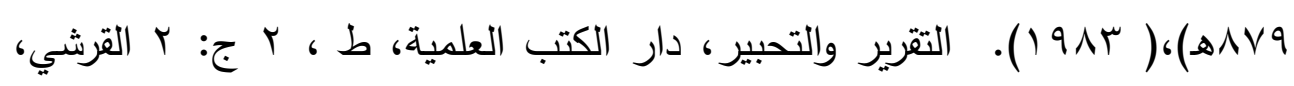

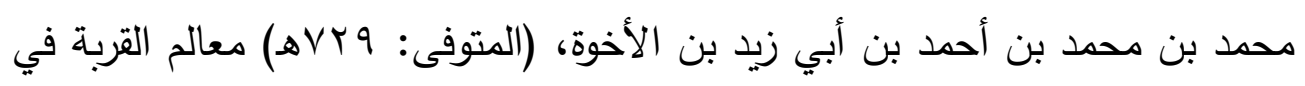

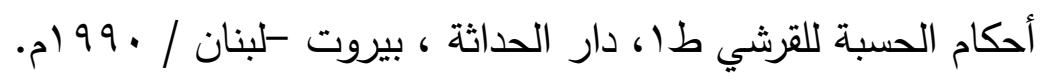

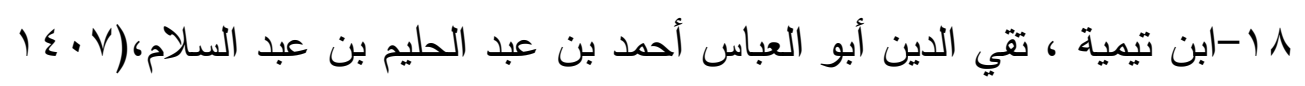

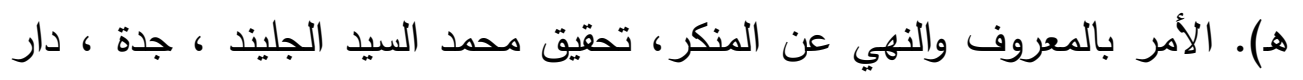

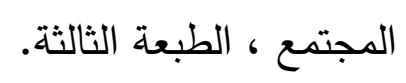

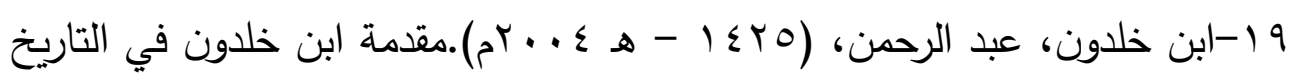

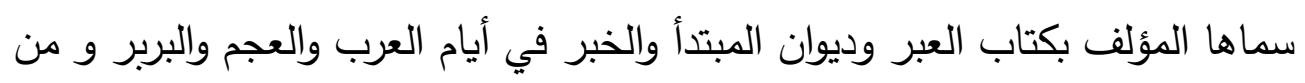

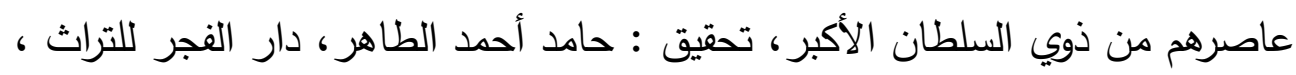

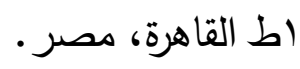

• r-الأحكام السلطانية للماوردي؛ أبو يعلى الفراء الأحكام السلطانية والولايات الدينية

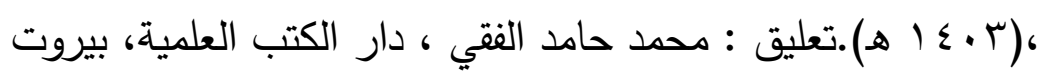

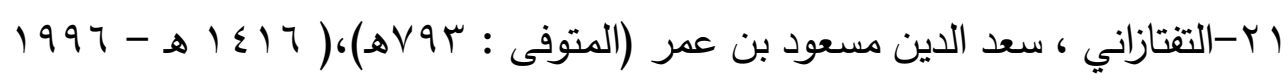

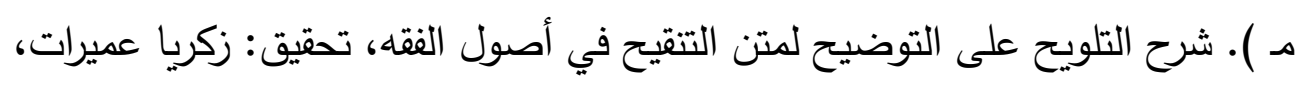

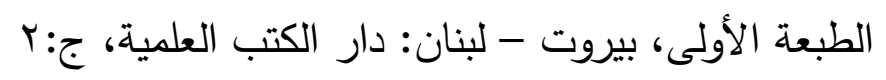


ץ Y-إمام، محمد كمال الدين(7 •ـ (هـ). أصول الحسبة في الإسلام، دار الهداية

بمدينة نصر ، مصر ب إن

إمام، محمد كمال الدين، أصول الحسبة في الإسلام،دراسة تأصيلية مقارنة ، منشأة المعارف بالإسكندرية إنة

بr-أبو البركات ، أحمد محمد الدردير حاشية الدسوقي على الثرح الكبير ج: ع تحقيق: محمد عليش، بيروت: دار الفكر .

\section{الكتب القانونية:}

ع ז- د. الألفي أحمد (909 (1).شرح قانون العقبات الليبي ، القسم العام ، الطبعة الأولى ، إسكندرية ، المكتب المصري الحديث للطباعة للنشر

هץ- د. الباشا ، فائزة يونس(ب ، . . rم). شرح قانون الإجراءات الجنائية الليبي، ج (،دار النهضة العربية ،القاهرة.

جr- د. البحر، ممدوح خليل(991 ()). مبادئ القانون، أصول المحاكمات الجزائية، دار الثقافة للنشر والتوزيع، عمان. V V- د. الجمال، مصطفى (991 19 م). تجديد النظرية العامة للقانون، نحو توظيف أصول الفقه الإسلامي في بناء أصول القانون، ج: ا الإسكندرية ^ץ- د. الجواري، فتحي عبد الرضا(7ه19 (م). تطور القضاء الجنائي العراقي، مركز البحوث القانونية، بغداد

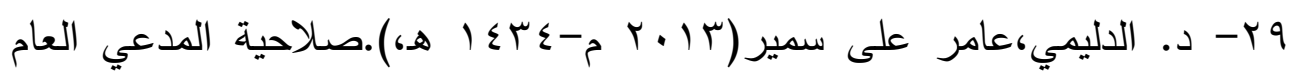
القانونية لدي المحاكم الجنائية الدولية المؤقتة والدائمة،دراسة مقارنة،دار غيدان للنشر

$$
\text { والتوزيـع. }
$$

• ب- د. الدين الجيلالي أبو زيد-إصلاح الأضرار الناتجة عن الأعمال الإرهابية وقواعد.

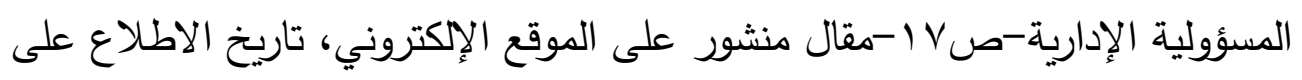

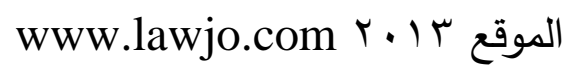


r.r. · مجلة روح القوانين - العدد الواحد والتسعون - إصدار يوليو

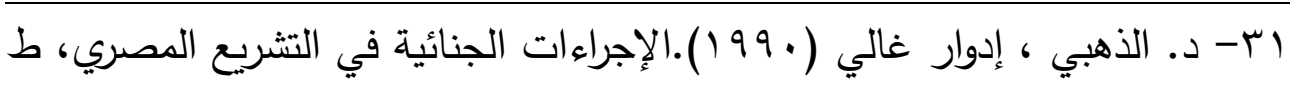

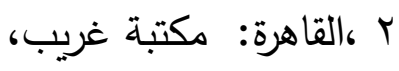

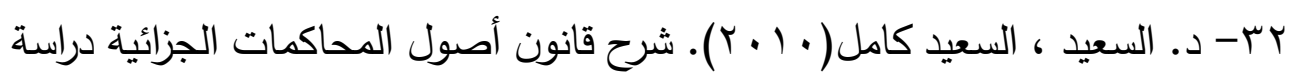

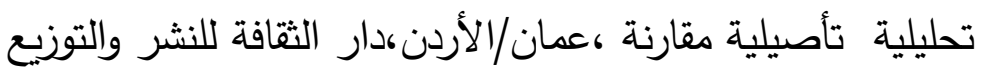

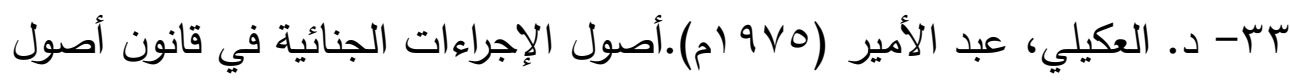

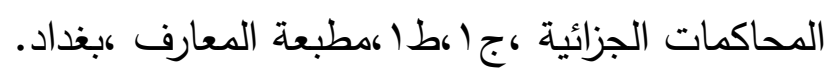

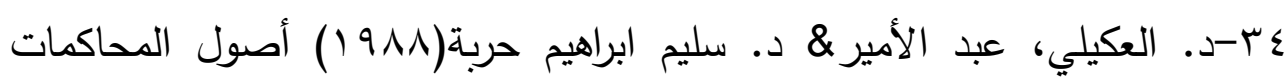

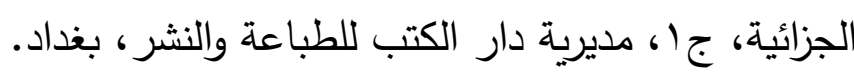

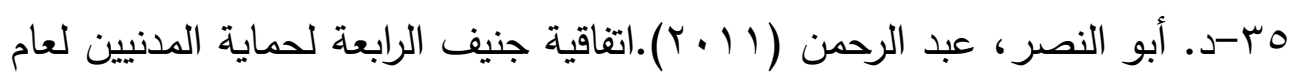

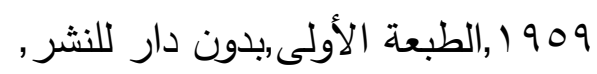
צr-د. أبو النصر ، عبد الرحمن( (. . rم). اتفاقية جنيف الرابعة وانطباقها في الأراضي داري المحتلة، غزة،ط ا؟

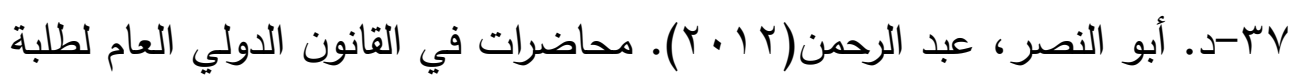

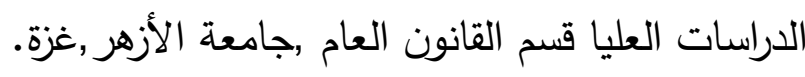

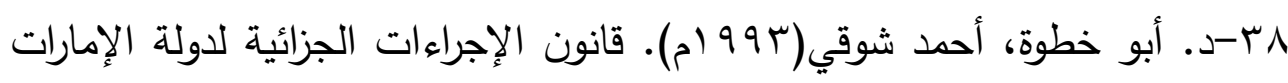

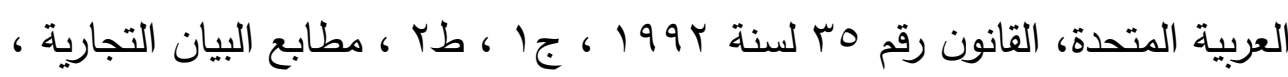

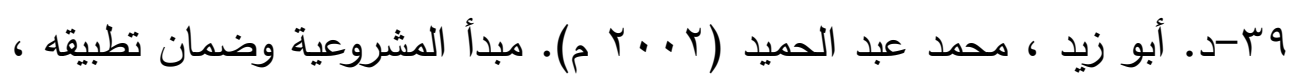
دار النهضة العربية، القاهزة

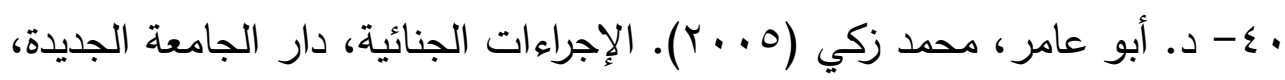
للنشر ، الإسكندرية اء- د. أبو عامر، محمد زكي(1) (1 بم). الإجراءات الجنائية، منشورات الحلبي

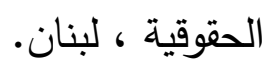


r بيان التطبيق في المملكة العربية السعودية ،الإسكندرية: المكتب العربي الحديث. بـ - د. أحمد، فؤاد عبد المنعم الدعوى الجزائية وإجراءات المحاكمة في نظام الإجراءات

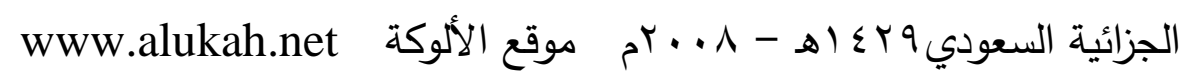

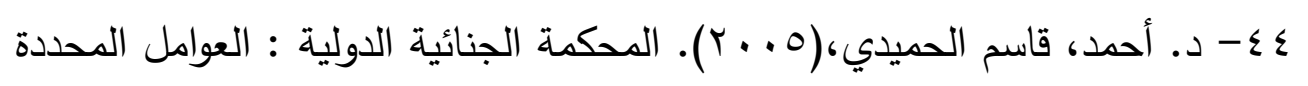
لدور المحكمة الجنائية الدولية ، الطبعة الأولى، الجمهورية اليمنية : مركز المعلومات والتأهيل لحقوق الإنسان ، الجزء الثاني

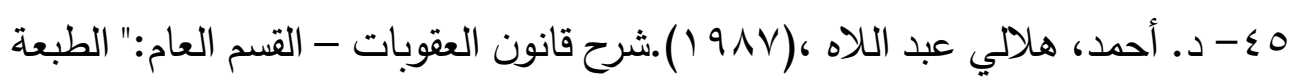

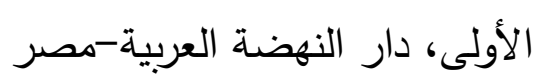

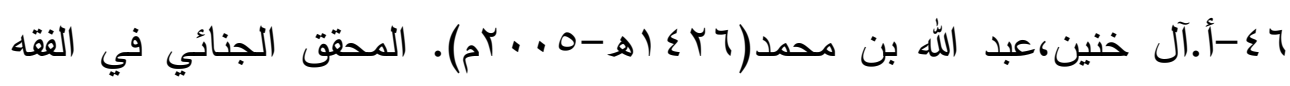
الإسلامي، مكتبة العبيكان،الطبعة الأولى.

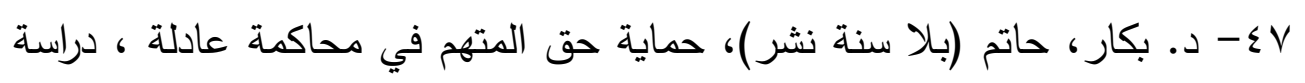

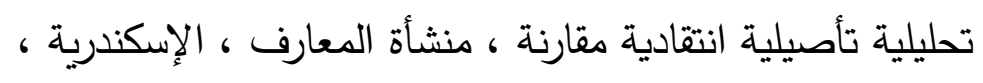
^ـ - د. بالا، أحمد عوض( • 99 (). الإجراءات الجنائية المقارنة والنظم الإجرائية في

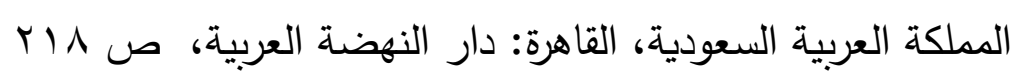

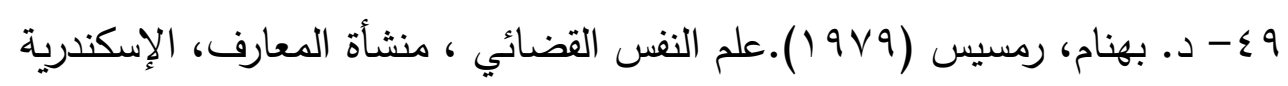
تقرير الفريق العامل،الفصل التاسع المجلة الدولية للصليب الأحمر، السنة التاسعة،

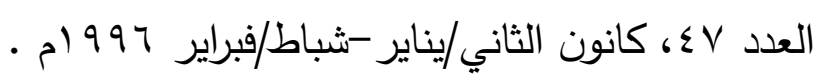
• 0- د. ثروت، جلال(9VV (م). نظم الإجراءات الجنائية، دار الجامعة الجديدة للنشر، الإسكندرية.

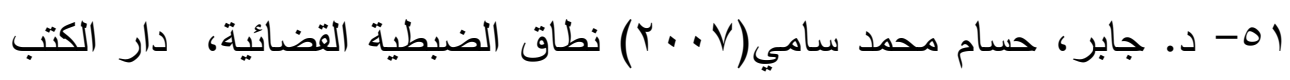
القانونية، مصر ror د. جاد، سامح (919 (،).العفو عن العقوبة في الفقه الإسلامي والقانون الوضعي، القاهرة. 
F. r. · مجلة روح القوانين - العدد الواحد والتسعون - إصدار يوليو

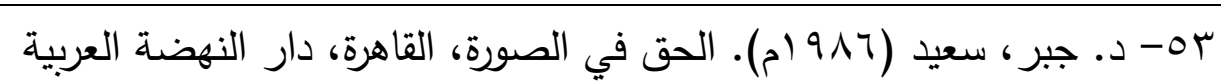

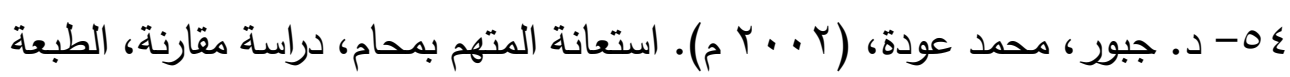

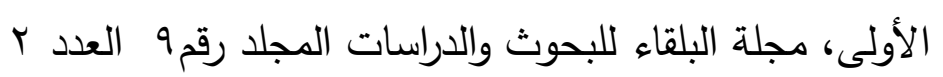
00- د. جلال، محمود طه(0 . . r م). أصول التحريم والعقاب في السياسة الجنائية

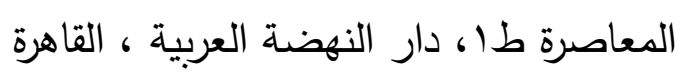

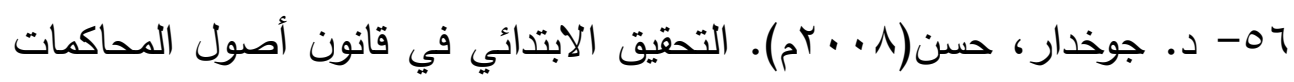
الجزائية، دار الثقافة للنشر والتوزيع،عمان.

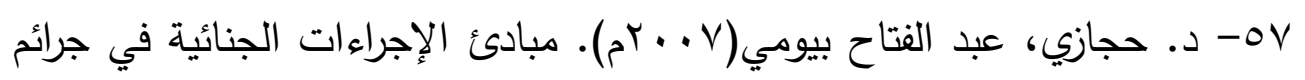

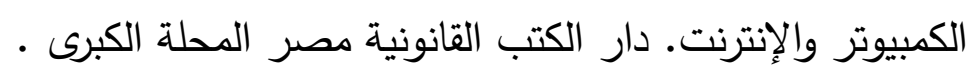

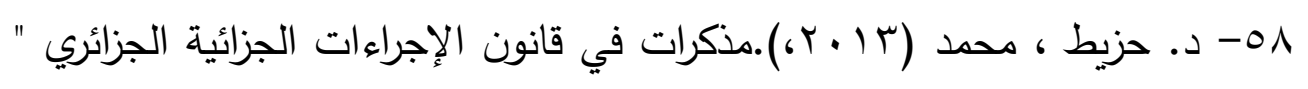
دار هومه للطباعة والنشر والتوزيع، بوزريعة، الجزائر .

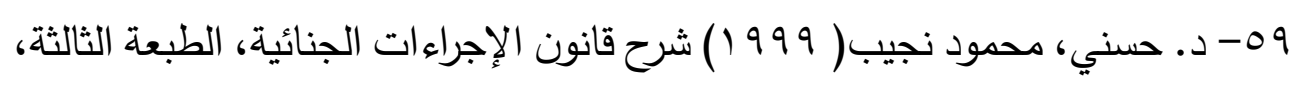
دار النهضة العربية، القاهرة.

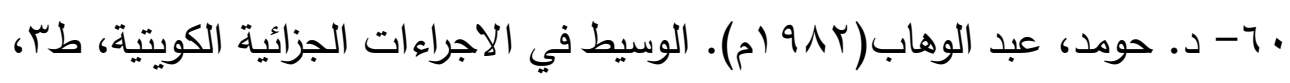
مطبعة جامعة الكويت آ- د. حومد، عبد الوهاب(9Av (ام). الإجرام الدولي، الطبعة الأولى، الكويت: مطبوعات جامعة الكويت

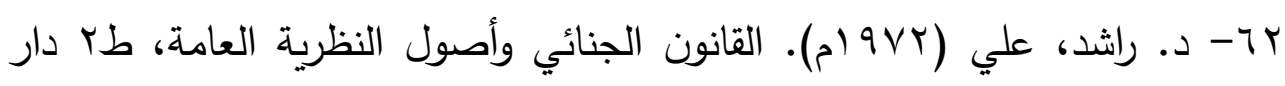
النهضة، القاهرة، القاهرة

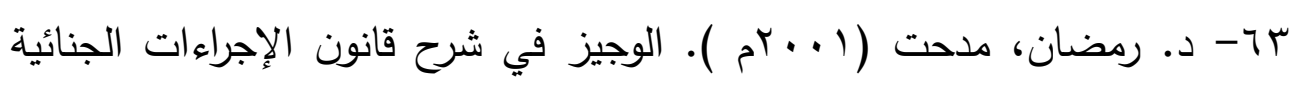

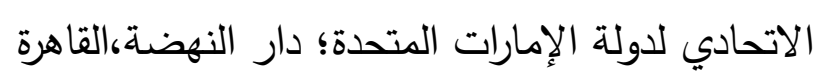

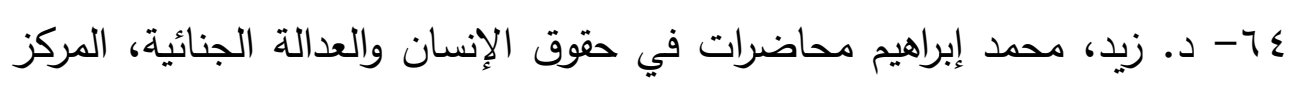

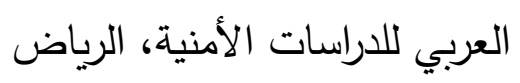


07- د. سالم، الحلبي، محمد علي (0 . . بم)، الوجيز في أصول المحاكمات الجزائية، دار الثقافة للنشر والتوزيع، عمان צ النهضة العربية،القاهرة سلامة، مأمون محمد( ه . . ب )قانون الإجراءات الجنائية معلقاً عليه بالفقه وأحكام النقض كدار الفكر العربي

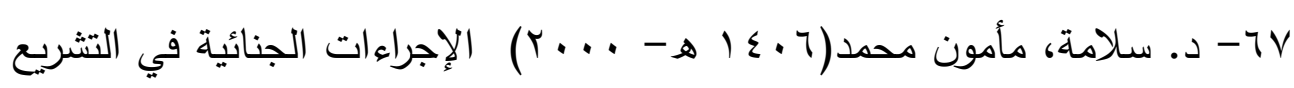
المصري، دار الفكر العربي،القاهرة،

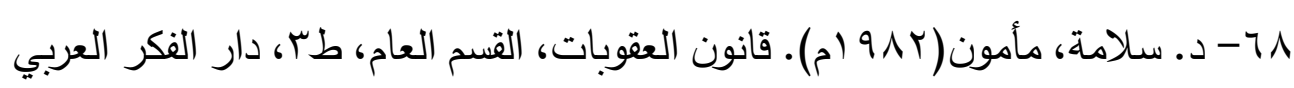
القاهرة 9 7- د. عبد الرحيم ، آمال عثان (9v0 (). شرح قانون الاجراءات الجنائية. دار النهضة العربية، القاهرة. • •- د. عبد الستار، .فوزية (7 919 ).شرح قانون الإجراءات الجنائية، القاهرة، دار النهضة العربية

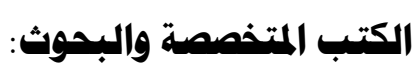
ا V-د. أحمد عبد الظاهر ،سلطة مجلس الأمن في الإحالة إلى المحكمة الجنائية

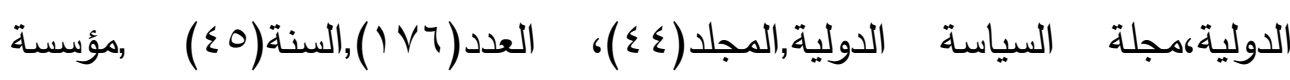

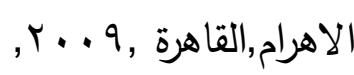

Y عليه في مجال استعمال الحق: دراسة مقارنه بالفكر الجنائي الإسلامي، دار النهضة

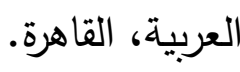

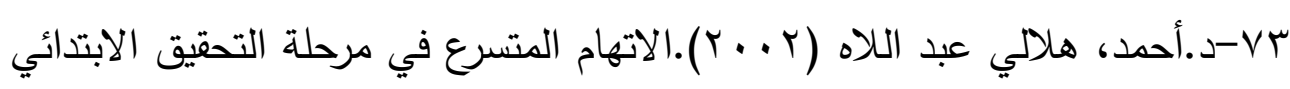
وعدالة أوفى لمن وضع موضع الاتهام ، دار النهضة العربية ، القاهرة . ع V-د.أوهايبية، عبد الله(ب ( †). شرح قانون الإجراءات الجزائية الجزائري " الطبعة الخامسة، دار هومه للطباعة والنشر والتوزيع، بوزريعة، الجزائر $(0) \mathrm{V})$ 


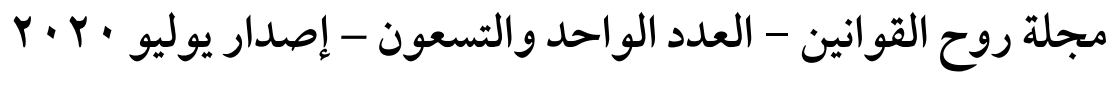

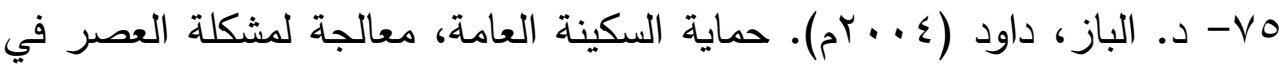
فرنسا ومصر ، الضوضاء دراسة تأصيلية مقارنة في القانون الإداري البيئي والثريعة دائه الإسلامية، دار الفكر الجامعي لوني

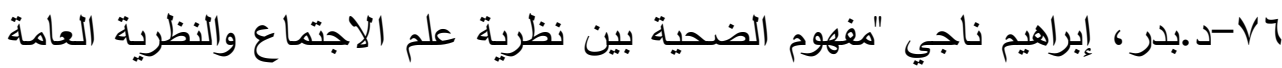

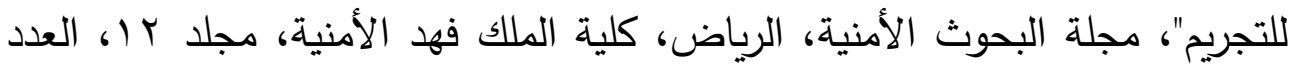
. YT

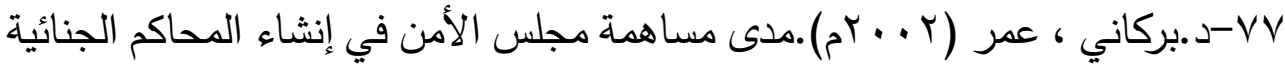

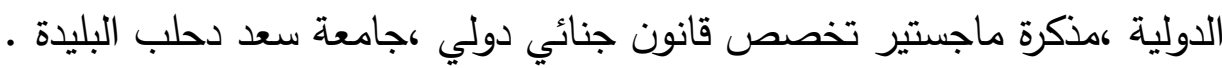

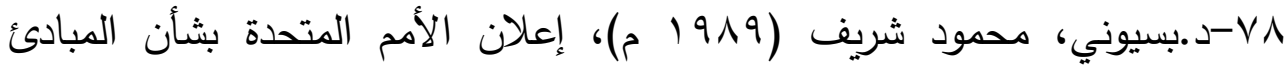

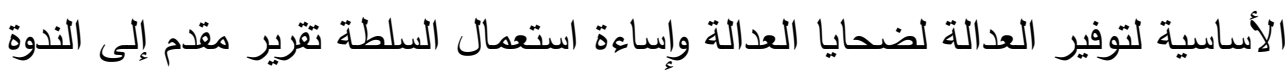
الدولية منشورات مركز الشرطة، القاهرة.

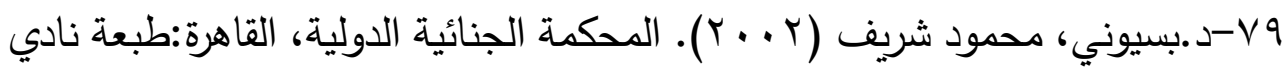
قضاة مصر،نفس المؤلف، المحكمة الجنائية الدولية، المعهد الدولي لحقوق الإنسان

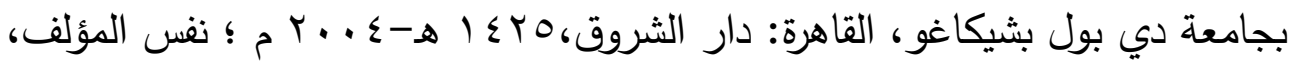

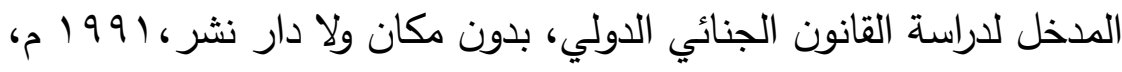

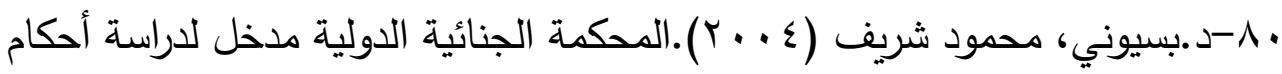

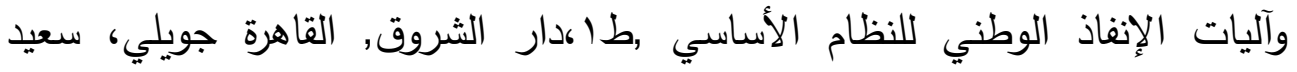

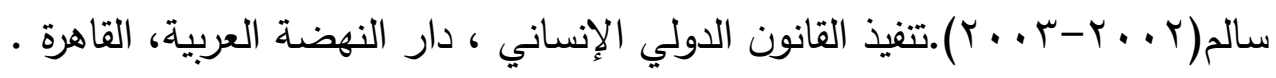

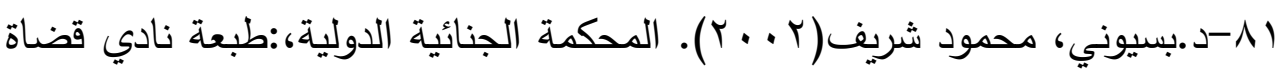
مصر، القاهرة ،ص گr- بـ نفس المؤلف، الدحكمة الجنائية الدولية، المعهد الدولي

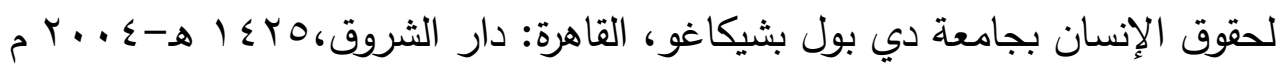

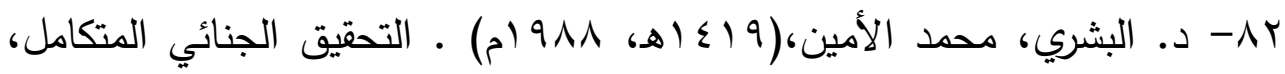
أكاديمة نايف العربية للعلوم الأمنية 


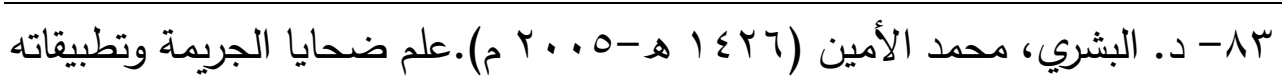
في الدول العربية الطبعة الأولى ،منشورات مركز الدراسات والبحوث جامعة نايف هُ العربية للعلوم الأمنية الرياض. ع^- د. البشري الشوربجي، دور النيابة العامة في كفالة حقوق المجني عليه في الي مصر كمجلة المحاماة العددان الأول والثاني-يناير وفبراير (99) (السنة الحادية والسبعون نفس المؤلف،(919 ( ). دور النيابة العامة في كفالة حقوق المجني عليه في مصر، بحث مقدم في المؤتمر الثالث للجمعية المصرية للقانون الجنائي بعنوان: "

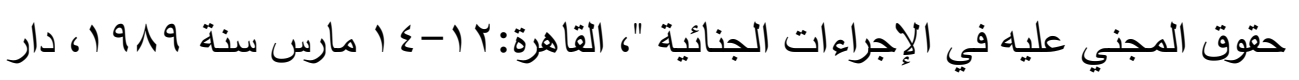
النهضة العربية، القاهرة.

ه1-د.الجرف، طعيمة(9V7 ( ). مبدأ المشروعية، دار النهضة العربية، القاهرة

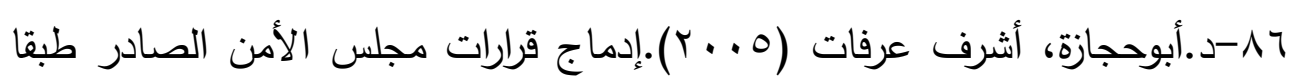
للفصل السابع من الميثاق وتتفيذها في النظم القانونية الداخلية للدول الأعضاء,المجلة المصرية للقانون الدولي،الجمعية المصرية للقانون الدولي,العدد ال ج،القاهرة.

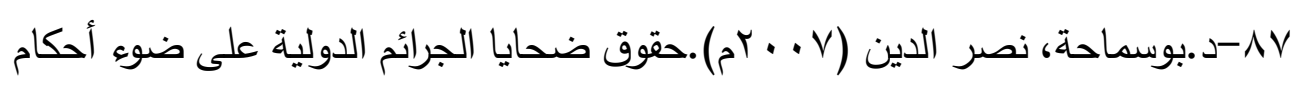
القانون الدولي، دار الفكر الجامعي، الإسكندرية، مصر ، الطبعة الأولى، V . . r م.

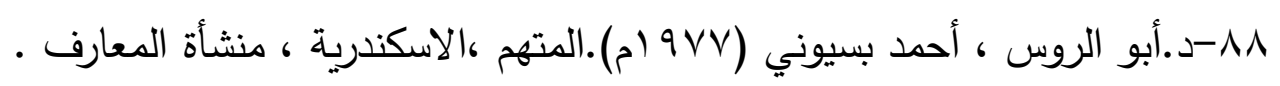

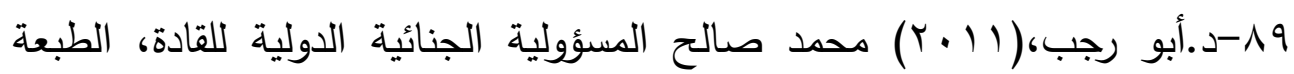

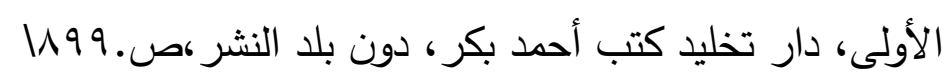
• 9-د.تركي بن عبد العزيز بن غنيم حقوق المجني عليه في القانون الدولي الجنائي دراسة تأصيلية، رسالة دكتوراه، كلية العدالة الجنائية جامعة نايف العربية للعلوم الأمنية،

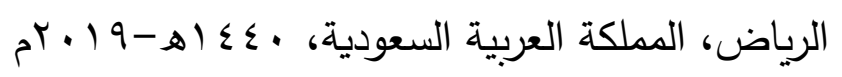
تركي بن عبدالعزيز بن غنيم حقوق المجني عليه في القانون الدولي الجنائي- دراسة تأصيلية، رسالة دكتوراه، كلية العدالة الجنائية جامعة نايف العربية للعلوم الأمنية،

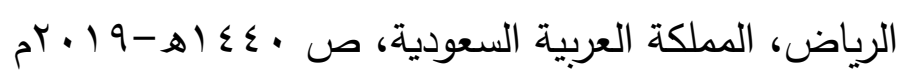


F. r. · مجلة روح القوانين - العدد الواحد والتسعون - إصدار يوليو

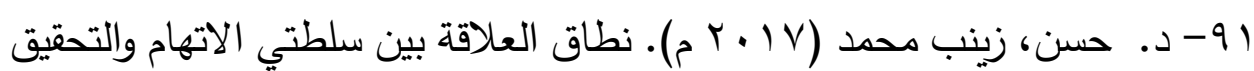

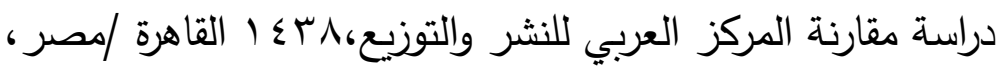

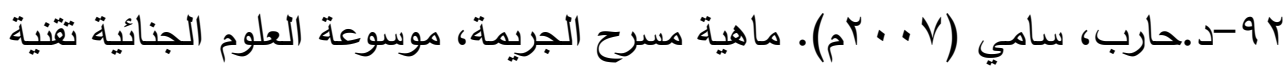

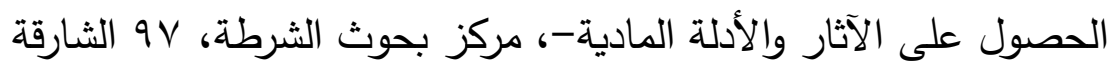

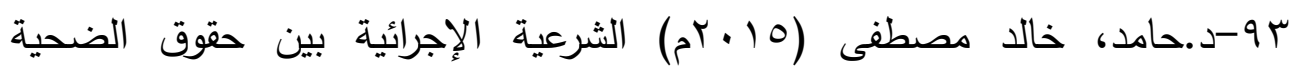
والمتهمهمجلة الثرعية والقانون،كلية القانون،جامعة الإمارات العربية المتحدة

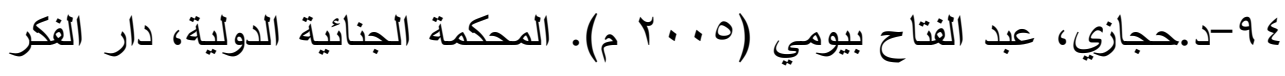
الجامعي، الإسكندرية

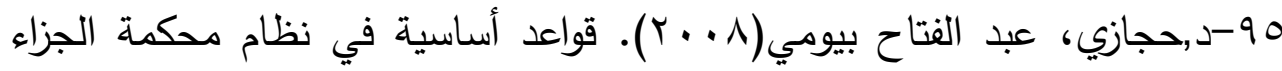

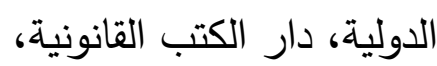
97-د.- الحق في الانتصاف من الاختفاء القسري ترجمة د. القيسي،حنان محمد

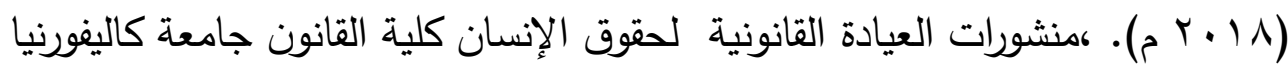
المركز العربي للنشر والتوزيع ،مصر .

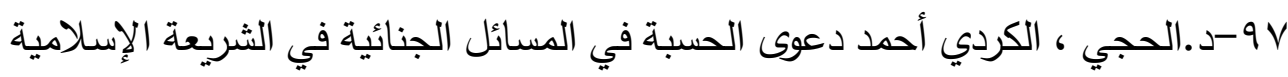
، مجلة كلية الآداب، جامعة بنغازي ، العدد: 0.

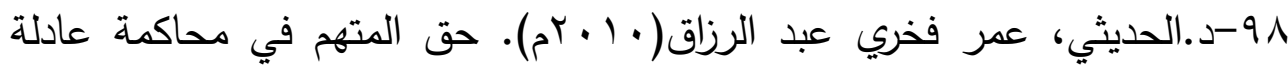
كوراسة مقارنة، دار الثقافة للنشر •

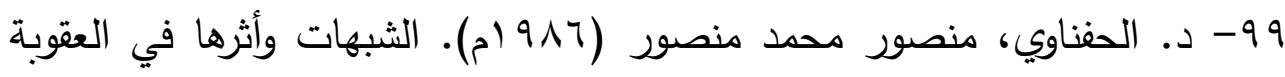

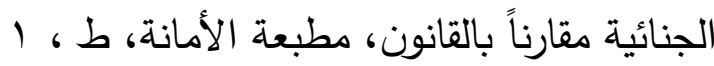

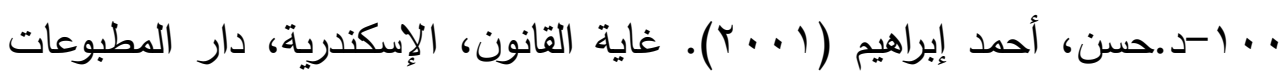

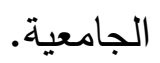

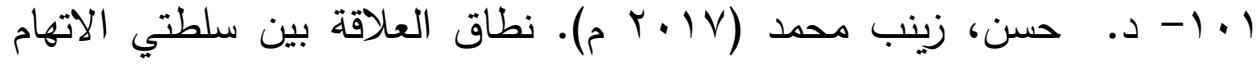

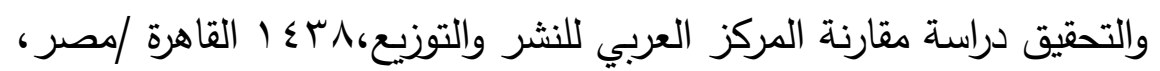


r • (-د.حسن، سعيد عبد اللطيف(ع ...rم). المحكمة الجنائية الدولية،القاهرة:دار النهضة العربية.

ץ. ا-د.حسن، عصام الدين محمد( . . . ץ). يوميات انتفاضة الأقصى، مركز القاهرة لدراسات حقوق الإنسان.

ـ. ا-د.حسني، محمود نجيب (1909 م- •197 م). دروس في القانون الجنائي الدولي،القاهرة: دار النهضة العربية،

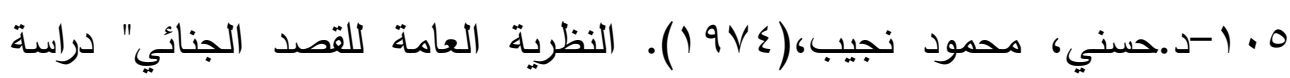
تأصيلية مقارنة للركن المعنوي في الجرائم العمدية"، دار النهضة العربية، القاهرة

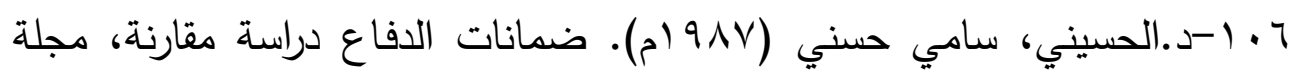

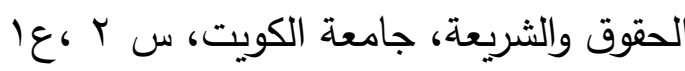

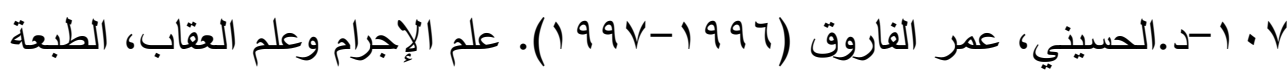
الثانية. ^ • ا-د.حشيش، أحمد محمد، أزمة قاعة البحث القانوني في ضوء مبدأ سمو القانون الإلهي على التشريع، مجلة مصر المعاصرة تصدرها الجمعية المصرية للاقتصاد السياسي والإحصاء والتشريع السنة السادسة والتسعون، العدد • ـ ؛، القاهرة. 9. 1-د.الحق في الانتصاف من الاختفاء القسري ترجمة د. القيسي،حنان محمد (1/ ( • م م). الحق في الانتصاف من الاختفاء القسري، منشورات العيادة القانونية لحقوق الإنسان كلية القانون جامعة كاليفورنيا المركز العربي للنشر والتوزيع ،مصر • • 11-د.الحكيم، ناصر مايع البهيان (V) . . . . .دور الضحية في حدوث الجريمة، أطروحة دكتوراه غير منشورة ، جامعة نايف للعلوم الأمنية ، الرياض . 111-د.الحلبي، محمد علي السالم(ب/9 ()). اختصاص رجل الضبط القضائي في التحري والاستدلال والتحقيق، مكتبة ذات السلاسل، الكويت . r ا ا-د.خلف ، سدران(900 (م). محمد سلطة التحقيق في التشريع الجنائي الكويتي والمقارن ، كلية الحقوق ، جامعة القاهرة 
F. r. • مجلة روح القوانين - العدد الواحد والتسعون - إصدار يوليو

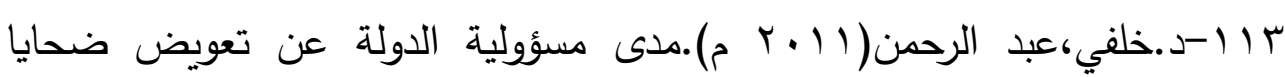
الجريمة،هجلة الشريعة والقانون العدد Vانع ع|(1- د. خلف، محمد محمود (9VT (1).حق الدفاع الثرعي في القانون الدولي الجنائي، دراسة تاصلية تحليلية مقارنة، مكتبة النهضة العربية، القاهرة، الطبعة الأولى. 10 11-د.الحلو، ماجد راغب (1910 م). القضاء الإداري، دار الطباعة الجامعية الإسكندرية،

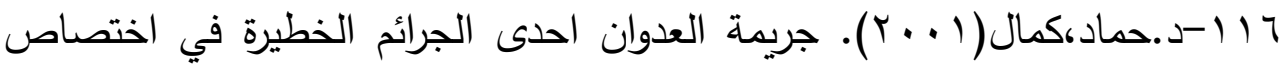
المحكمة الجنائية الدولية، ضمن الندوة العلمية(المحكمة الجنائية الدولية، تحدي الدئي

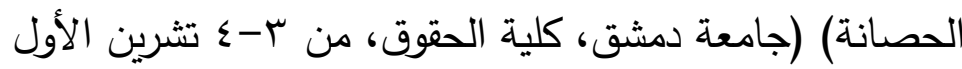

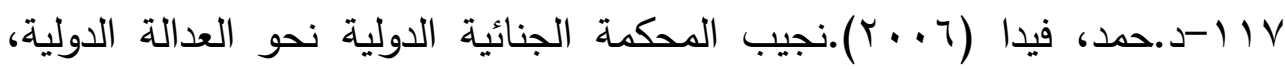

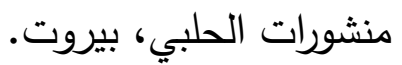

11/1-د.حمدان، أمينة(9 . . ب). حماية المدنيين في الأراضي الفلسطينية المحتلة، رسالة ماجستير ، جامعة النجاح الوطنية.

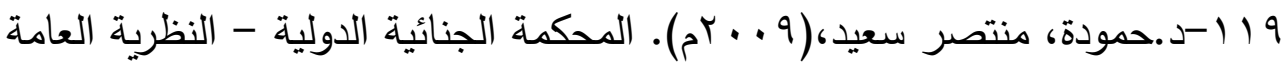

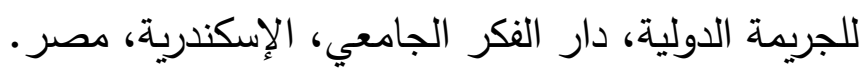

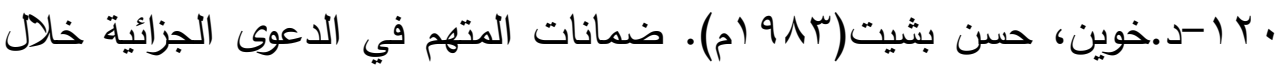

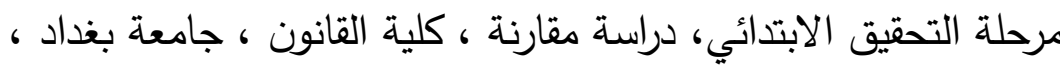

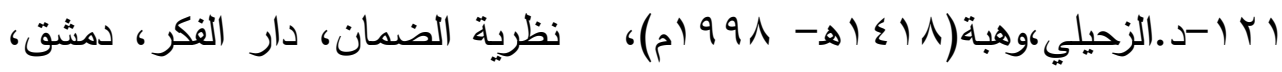

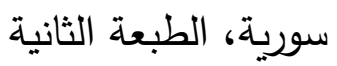

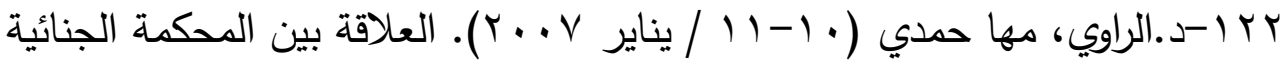

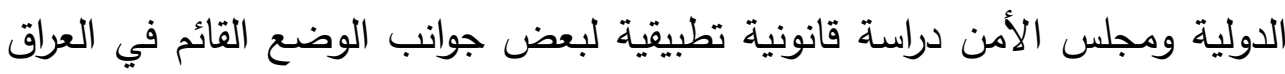
تحت الاحتلال، ورقة عمل مقدمة إلى الندوة الدولية حول المحكمة الجنائية الدولية

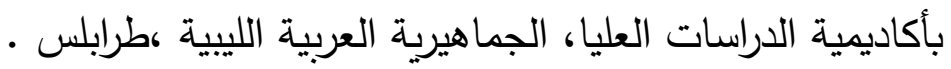


r آ ا-د.الرشيدي، مدوس فالح آلية (r . .rم).تحديد الاختصاص و انعقاده في نظر الجرائم الدولية وفقا لاتفاق روما لعام بــ ا : : مجلس الأمن الدولي ، المحكمة الجنائية الدولية و المحاكم الوطنية، مجلة الحقوق ، جامعة الكويت ، العدد الثاني ،السنة السابعة والعشرون، مجلس النشر العلمي ،الكويت .

ع ا -د.روبير شرفان (فرنسا)،المحكــة الجنائيـة الدولية تقدم وسـراب، ترجمة :د.الهادي حنيش، بحث مقدم للندوة العلمية حول " المحكمة الجنائية الدولية (الدائمة

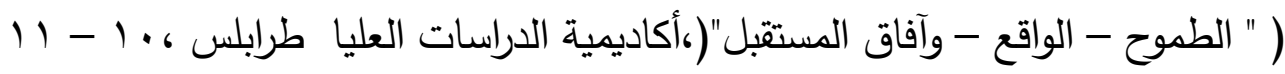

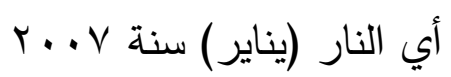

هץ ا-د.الزهيري، رياض (1 . . r). دعوى مسؤولية الدول عن اعمالها الضارة، بحث منشور في النشرة القضائية تصدر عن مجلس القضاء الاعلى، بغداد، ت، العدد الثالث، ج ب ا-د.زهير الحسيني، التدابير المضادة في القانون الدولي العام، منشورات جامعة

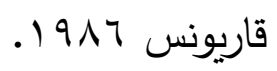
V T ا -د.زيدان، زكي زكي حسين ، حق المجني عليه في التعويض عن ضرر النفس، دار الفكر الجامعي، الإسكندريـة، مصر، دون ذكر الطبعة ولا السنة ^ץ ا -د.زيدان، زكي زكي حسين(ع . . ץ). حق المجني عليه في التعويض عن ضرر النفس في الفقه الإسلامي والقانون الوضعي، الطبعة الأولي، الإسكندرية: دار الفكر

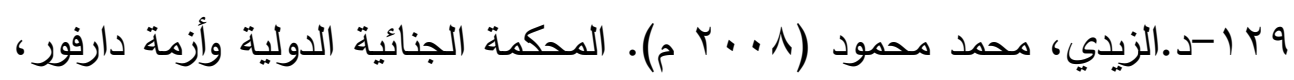

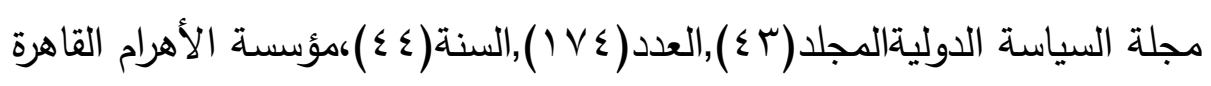
• با ا-د.الزيني، محمود عبد العزيز (ع . . F ). شكوى المجني عليه والآثار المترتبة عليها في الفقه الإسلامي والقانون الوضعي، الطبعة الأولى، الإسكندرية:دار الجامعة الجديدة للنشر

اسبا-د.دايانا جونستون ( الولايات المتحدة الأمريكية ) العدالة من أجل السلم أم من أجل الحرب ؟ المحكمة الجنائية الدولية لجمهورية يوغسلافيا السابقة كسابقة للمحكمة 
F. r. · مجلة روح القوانين - العدد الواحد والتسعون - إصدار يوليو

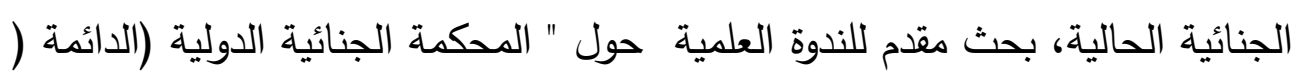

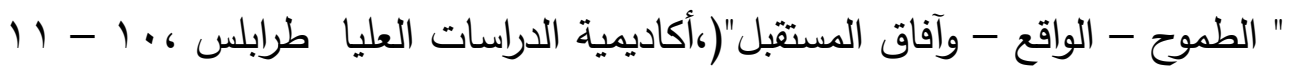

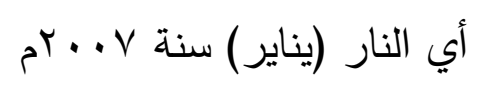

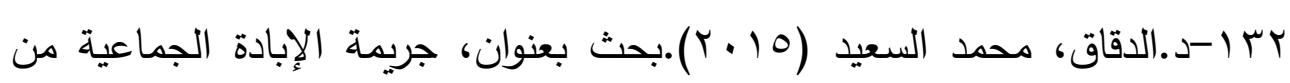
المنظورين الدولي والإسلامي، سلطنة عمان. بr ا-د.الذهبي، إدوار غالي ( 19 ( 1 م). دور النيابة العامة في تنظيم العدالة القضائية، بحث منشور في مجلة الافاق الحديثة ع ا - د. سالم الأوجلي، العلاقة بين المحكمة الجنائية الدولية والمحاكم الوطنية،

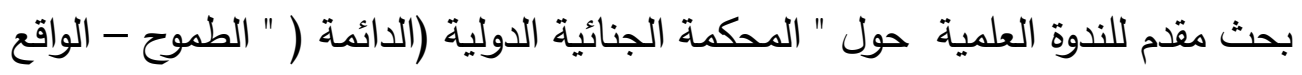

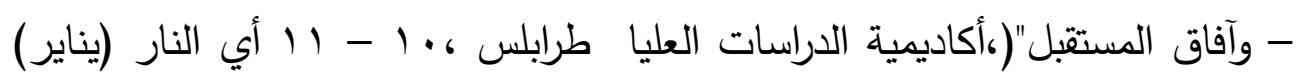
سنة V...

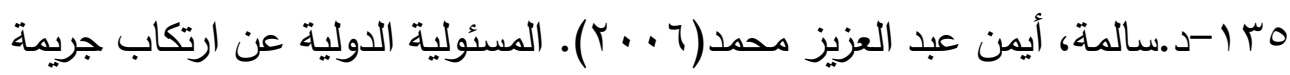

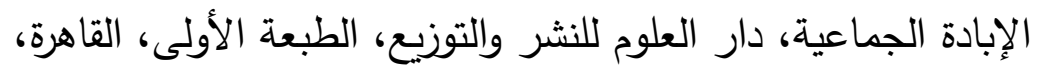

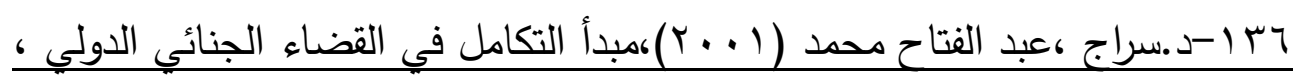

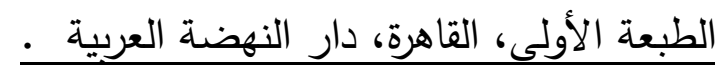

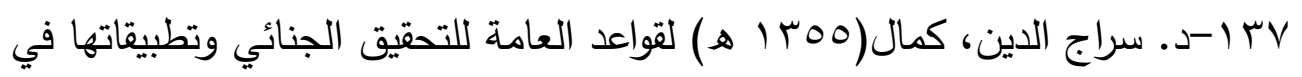

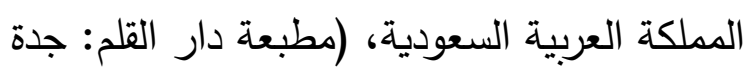

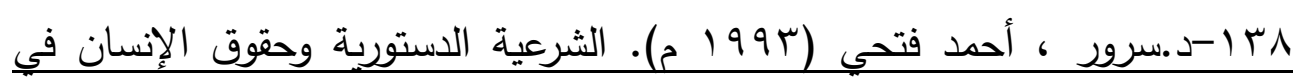
الإجراءات الجنائية ، دار النهضة العربية العبدية

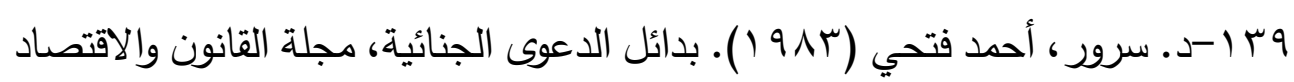

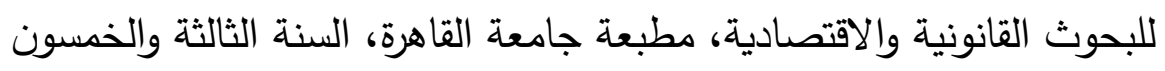

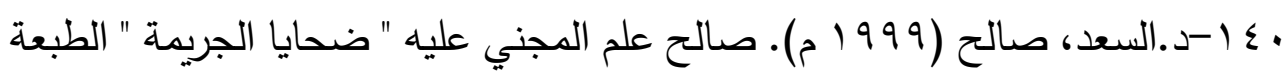
الأولى دار الصفاء للطباعة والنشر والتوزيع ، عمان 
اء ا-د.السعدي، حميد( (9VI ). مقدمة في دراسة القانون الدولي الجنائي، مطبعة المعارف، بغداد

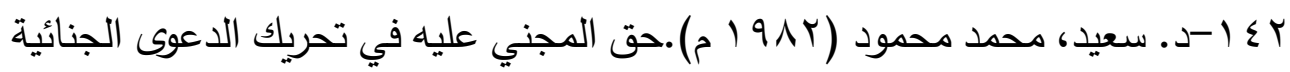
رسالة دكتوراه كلية الحقوق جامعة القاهرة

بـ إد.سعيد عبد اللطيف، المحكمة الجنائية الدولية،القاهرة،دار النهضة العربية، S r. E s

ـ ـ ا-د.سعيد، الهادي(9 (9 19) حقوق المجني عليه في الدعوى العمومية ، بحث مقدم في المؤتمر الثالث للجمعية المصرية للقانون الجنائي بعنوان: " حقوق المجني عليه في الإجراءات الجنائية ،القاهرة: ب ا-ع ا مارس سنة 9^9 (، دار النهضة العربية، القاهرة

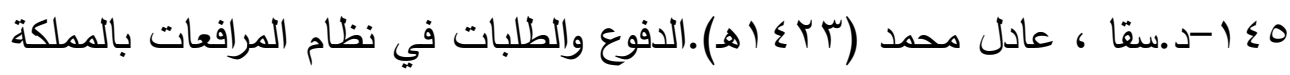
العربية السعودية ، جr ، الرياض ، الغرفة التجارية الصناعية جـ ا-د.سكاكني، باية(r . .rم). العدالة الجنائية الدولية ودورها في حماية حقوق الإنسان، دار هومة للطباعة والنشر والتوزيع، الجزائر IV وحقوقه في الفقه الإسلامي، الطبعة الأولي، القاهرة: دار الفكر العربي •

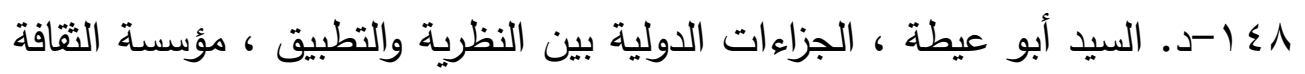

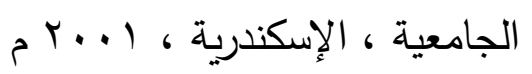

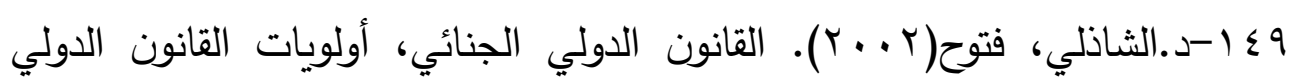
الجنائي، النظرية العامة للجريمة الدولية، دار المطبوعات الجامعية، الإسكندرية

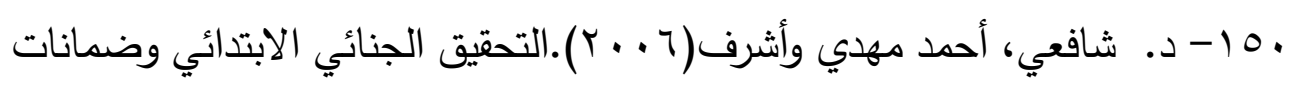
المتهم وحمايتها دار الكتب القانونية، مصر 10 ا-د.شمس الدين، أشرف توفيق( . . . rم). دور النيابة العامة في النظام الجنائي الجرماني، دار النهضة العربية ،القاهرة 
F. r. · مجلة روح القوانين - العدد الواحد والتسعون - إصدار يوليو

r 0 -د.شمس، أشرف توفيق (10 • r). التوازن بين السلطة والحرية وجوب تقييد سلطة

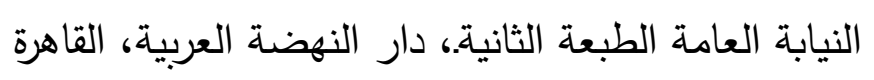

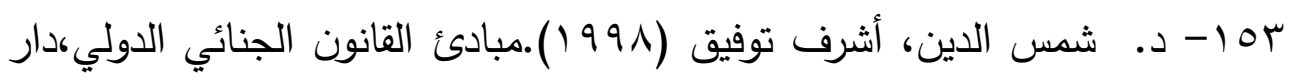
النهضة العربية،القاهرة ـ 1-د. الثوربجي، البشري (1991 م). دور النيابة العامة في كفالة حقوق المجني

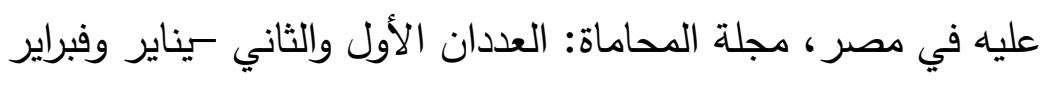

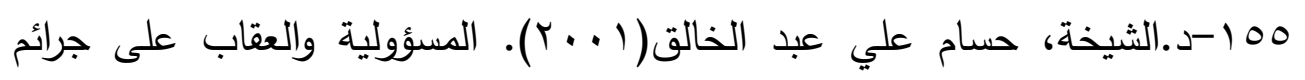
الحرب- دراسة تطبيقية على جرائم الحرب في البوسنة والهرسك، رسالة مقدمة لنيل شهادة الدكتوراه، كلية الحقوق، جامعة القاهرة

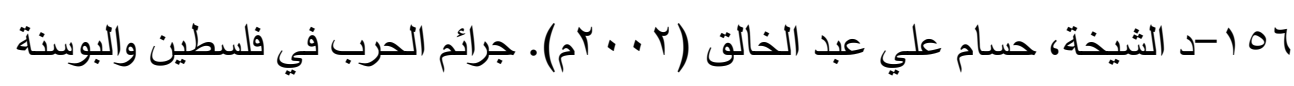

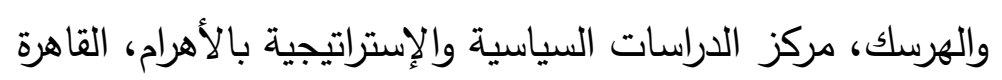
، 0 1-د.صابرين ، غازي حسن (1990)."الوجيز في حقوق الإنسان وحرياته الأساسية" ، مكتبة دار الثقافة

101 1-د.صالح، خلف مهدي( • 999 (1). ضمانات المتهم في الإجراءات الماسة بالحرية الشخصية، دراسة مقارنة ، كلية القانون ، جامعة بغداد.

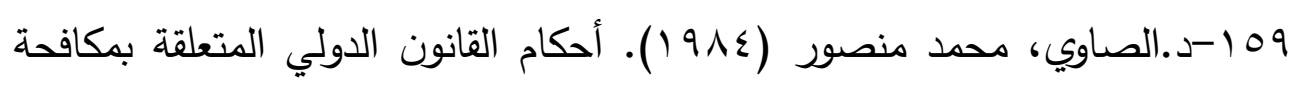
الجرائم ذات الطبيعة الدولية، دار المطبوعات الجامعية، الإسكندرية.

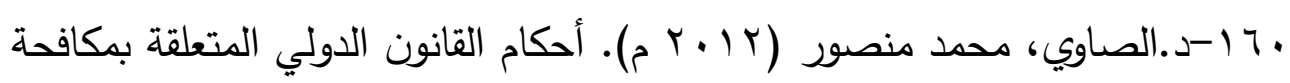

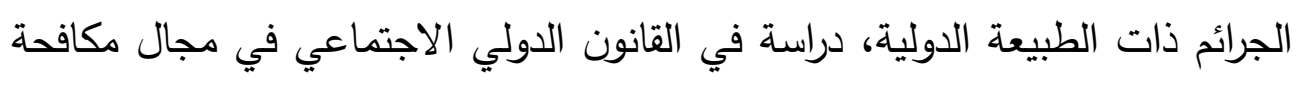

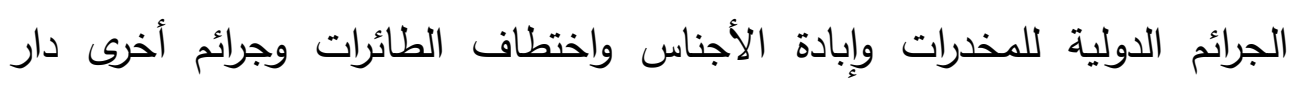
المطبوعات الجامعية، الإسكندرية

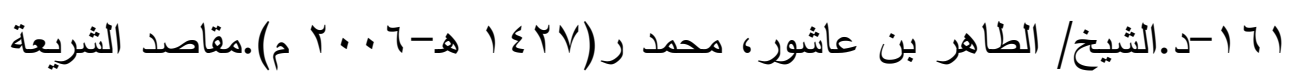
الإسلامية،تونس:دار سنحون،+القاهرة:دار السلام 
rT ا-د.الطيب،وردة(10 • r م).مقتضيات العدالة أمام المحكمة الجنائية الدولية الدائمة،المركز القومي للأصدارات القانونية ،القاهرة . بד ا-د.الطيف، عبد السلام (0. …أزمة دارفور بين التحديات الدولية والقانون الدولي الإنساني مجلة أكاديمية الدراسات العليا بجنزوو عدد خاص السنة السابعة، - الربيع

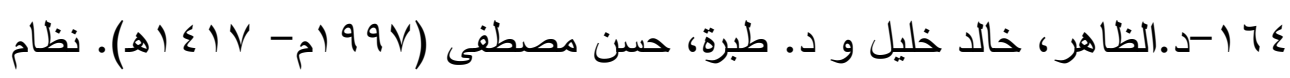
الحسبة - دراسة في الإدارة الاقتصادية للمجتمع العربي الإسلامي، الطبعة ألأولى، دار المسيرة للنشر والتوزيع والطباعة، عمان

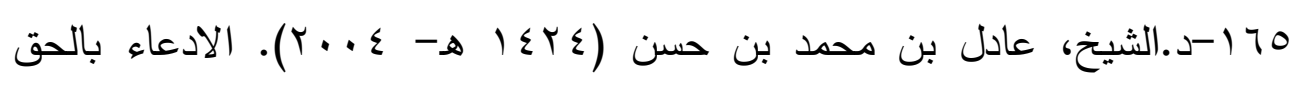
الخاص في الشريعة الإسلامية وفي نظام الإجراءات الجزائية السعودي وتطبيقاته في أحكام القضاء، رسالة ماجستير كلية الدراسات العليا جامعة نايف العربية للعلوم الأمنية، الرياض.

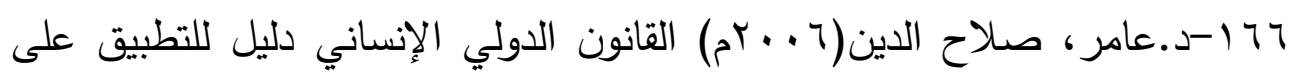
الصعيد الوطني تأليف مجموع من المتخصصين، اختصاص المحكمة الجنائية الدولية بمالحقة مجرمي الحرب، ط ب ،دار النهضة العربية، القاهرة VT ا ا-د.عبد البصير، عصام عفيفي (ع . . F م). قاضي تطبيق العقوبات، قضاء الإشراف على التنفيذ الجنائي نحو سياسة جنائية جديدة ، بلا ناشر ، القاهرة ،

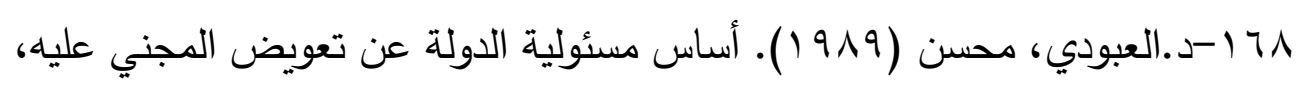
بحث منشور بأعمال المؤتمر الثالث للجمعية المصرية للقانون الجنائي، القاهرة: ا اع ا مارس ، دار النهضة العربية، القاهرة . 79 ا -د.العجمي، ثقل سعد(0 . . ץ).مجلس الأمن وعلاقته بالنظام الأساسي للمحكمة الجنائية الدولية , مجلة الحقوق الكويتية, جامعة الكويت, العدد(ع),السنة( و ب)

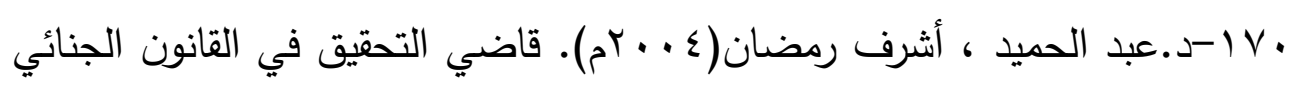
المقارن طا، دار النهضة العربية، القاهرة 


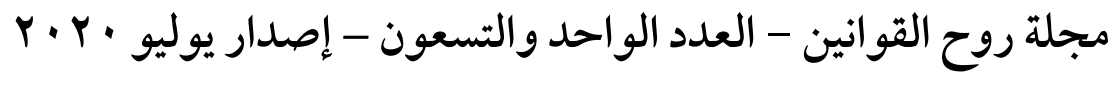

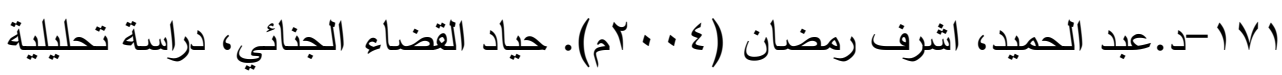

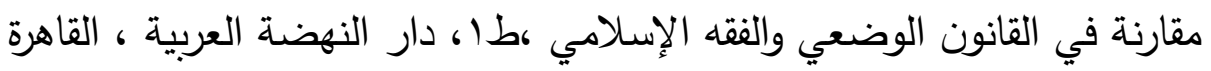

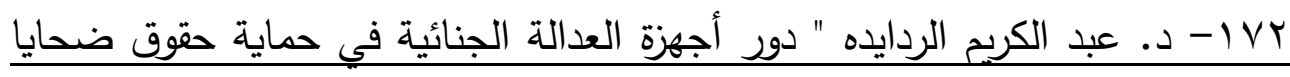
الجربمة " ندوة بعنوان "حقوق ضحايا الجربمة" في مركز الدراسات الاستراتيجية الأمنية، الموافق

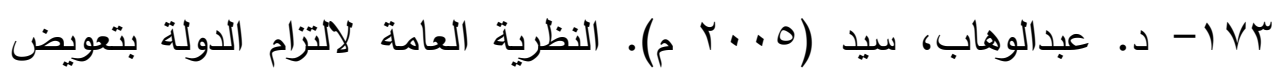

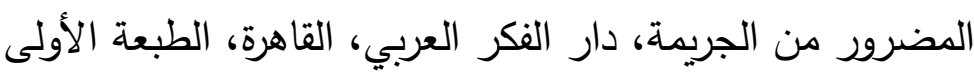

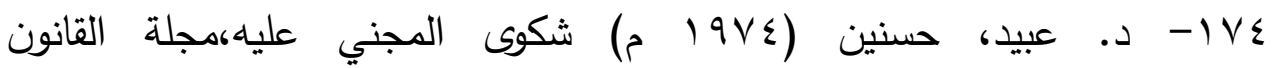
والاقتصاد،تصدرها كلية الحقوق جامعة القاهرة،العدد الثالث، القاهرة

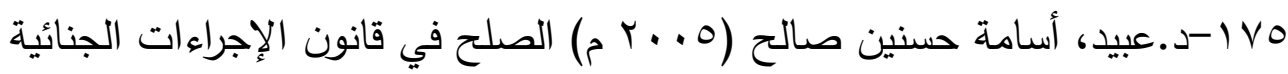
ماهيته والنظم المرتبطة به، دراسة مقارنة،دار النهضة ، القاهرة

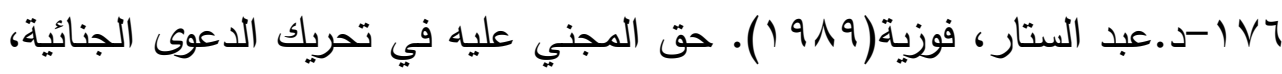

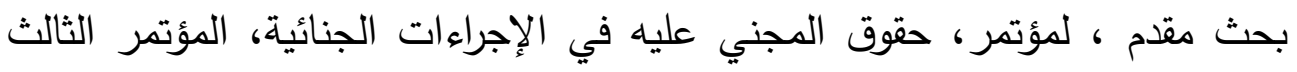

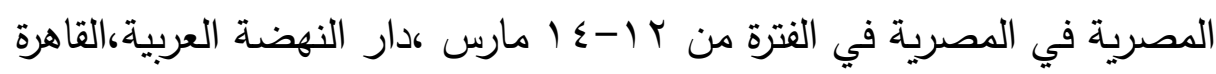

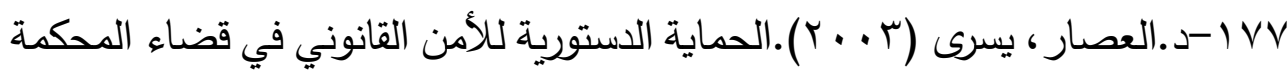

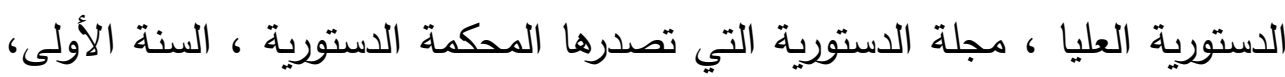

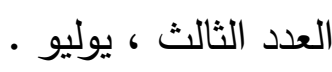

ا I VA الإجرامية،دار الجامعة الجديدة،الإسكندرية

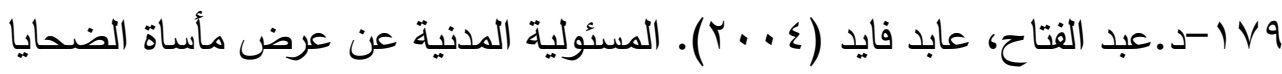

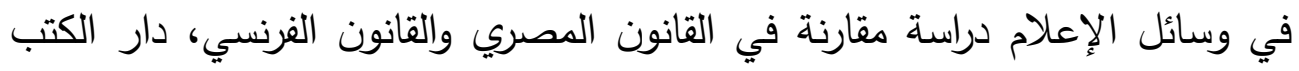

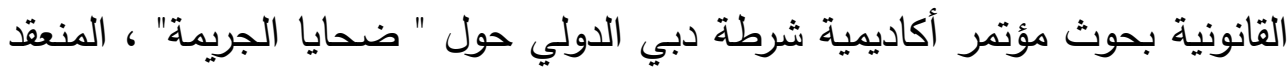

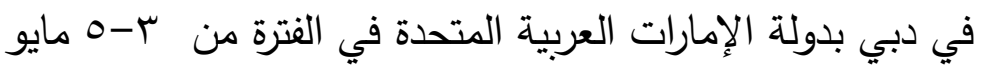




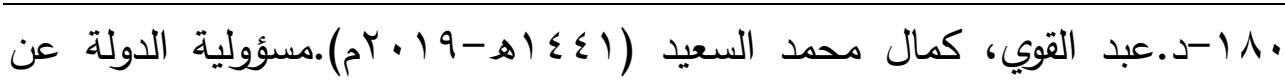
الجرائم مجهولة الفاعل دراسة مقارنة،العدد الرابع والثثلاثون،الجزء الثاني

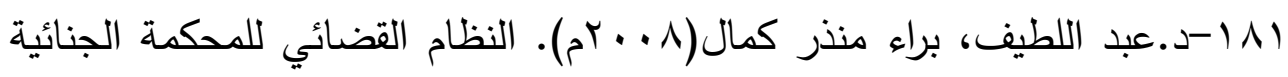
الدولية دار الحامد للنشر والتوزيع، الطبعة الاولي

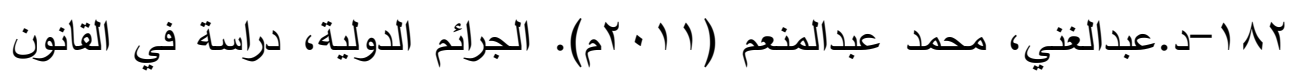
الجنائي الدولي، الإسكندريـة: دار الجامعة الجديدة

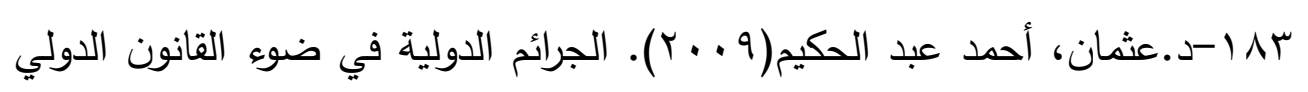
الجنائي والثريعة الإسلامية، دار الكتب القانونية، القاهرة، الطبعة الأولى. ع 1 ا-د.عثمان، آمال عبد الرحيم(9V1 (م). الإشراف القضائي على التحقيق ،مجلة الآفاق الحديثة في تتظيم العدالة الجنائية ، المركز القومي للبحوث الاجتماعية والجنائية ، مشروع قواعد الحد الأدنى لتنظيم العدالة الجنائية ،عهه، القاهرة ه 1 ا-د.علام، وائل أحمد( ( . . بم). مركز الفرد في النظام القانوني للمسؤولية الدولية، دار النهضة العربية، القاهرة ד1 ا-د.علوان، محمد يوسف (Y . .Yم). الجرائم ضد الإنسانية-المحكمة الجنائية

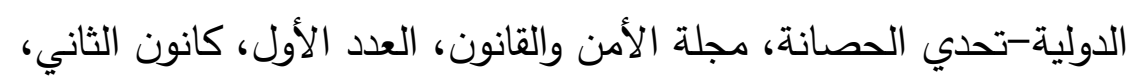

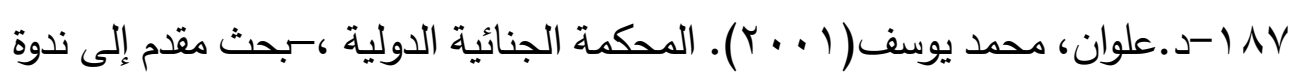
المحكمة الجنائية الدولية (تحدي الحصانة)التي أقيمت في دمشق للفترة من ب-ء تشرين الأول 1 1 ا-د.غنام، محمد غنام(ع · . rم). حقوق المجني عليه في الإجراءات الجنائية، بحث مقدم إلى مؤتمر أكاديمية شرطة دبي الدولي حول ضحايا الجريمة ، دبي ، الإمارات العربية المتحدة

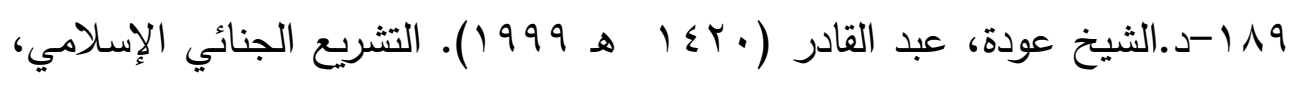
مقارنا بالقانون الوضعي، ج: ا، القاهرة: مكتبة دار التراث الإسلامي 
F. r. · مجلة روح القوانين - العدد الواحد والتسعون - إصدار يوليو • 9 ا-د.عوض محمد عوض،فكرة المحكمة الجنائية الدولية: نشأتها وتطورها، الموقع

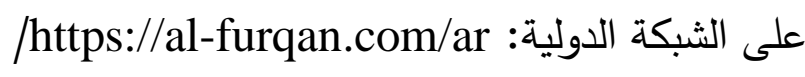

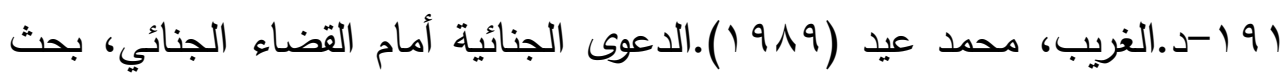

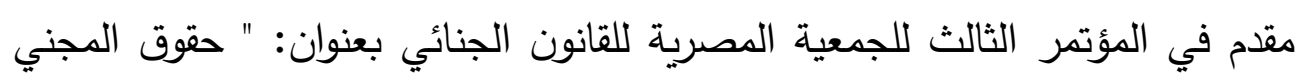

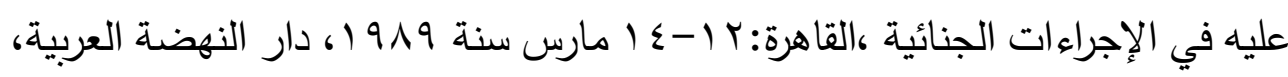
القاهرة.

بو 1-د.الغريب، محمد عيد ( . . ب).النظام العام الإجرائي ومدى الحماية التي يكفلها القانون الجنائي، دار النهضة العربية ، القاهرة.

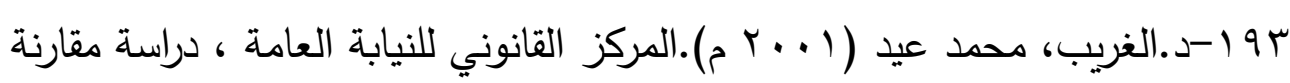
، دار الفكر العربي ، القاهرة . ـ 9 1-د.الغريب، محمد عيد، النظام الإجرائي في المملكة العربية السعودية، بدون مكان ولا تاريخ نشر 90 19-د.الفار ،عبد الواحد محمد (997 (19). الجرائم الدولية وسلطة العقاب عليها، دار النهضة العربية، القاهرة

49 9 -د.الفار ، عبد الواحد محمد (910 1) ). المصلحة الدولية المشتركة كأساس لتطوير النظام الاقتصادي الدولي، دار النهضة العربية،القاهرة Y 9 1 -د.فاليري أوسترفيلد-القواعد الإجرائية وقواعد الإثبات ندوة المحكمة الجنائية الدولية

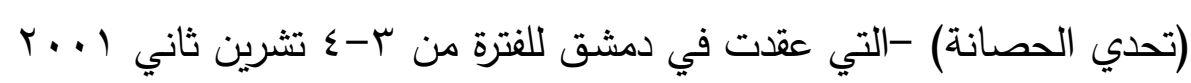

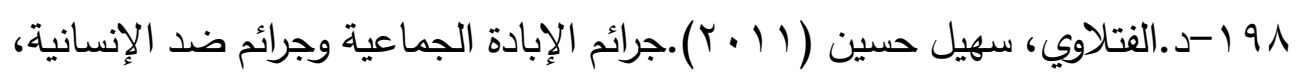
دار الثقافة، عمان، الطبعة الأولى.

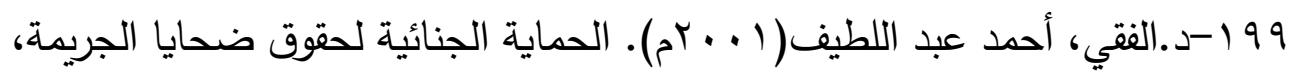
القاهرة، دار النهضة العربية.

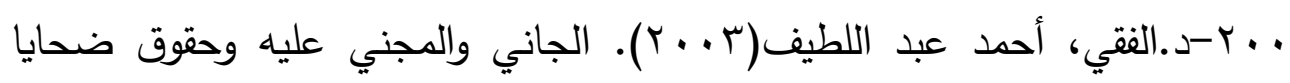

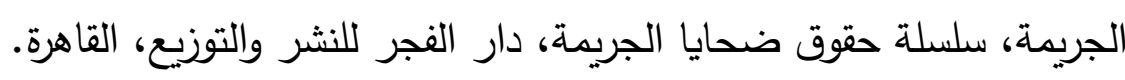
(or. 


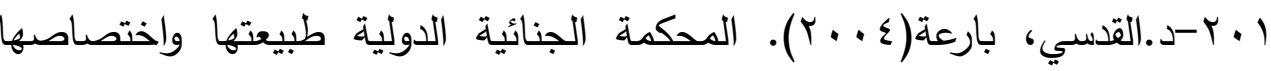
وموقف الولايات المتحدة الأمريكية وإسرائيل منها، مجلة جامعة دمشق للعلوم الاقتصادية والقانونية، المجلد • r r، العدد الثاني. r • r-د.القهوجي، على عبد القادر (1 ( . . م م). القانون الدولي الجنائي أهم الجرائُ، والمحاكم الدولية الجنائية، الطبعة الأولى، بيروت:لبنان،منشورات الحلبي الحقوقية

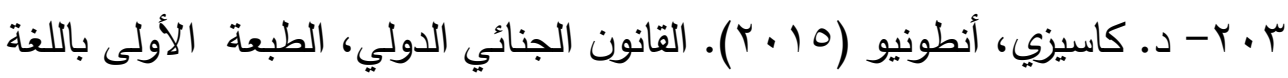
العربية، ترجمة مكتبة صادر ناشرون

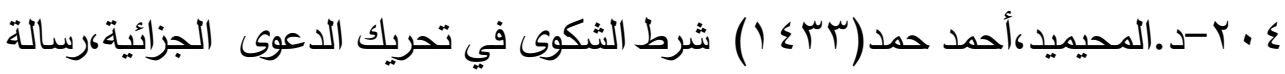
ماجستير ،جامعة نايف للعلوم الأمنية الرياض

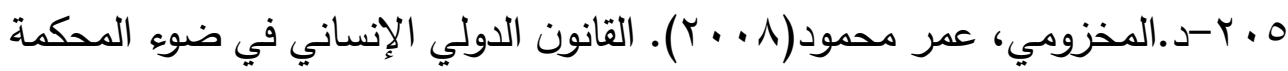
الجنائية الدولية، دار الثقافة للنشر والتوزيع، الطبعة الأولى، عمان ج • r-د.المرصفاوي، حسن صادق(99V 19 م). الدعوى المدنية أمام المحاكم الجنائية الإسكندرية: منشأة المعارف نفس المؤلف، دعوى التعويض أمام المحاكم الجنائية، حقوق المجني عليه في الدعوى العمومية،بحث مقدم في المؤتمر الثالث للجمعية المصرية للقانون الجنائي بعنوان: " حقوق المجني عليه في الإجراءات الجنائية "،القاهرة: Y اع ا مارس سنة 9 19، دار النهضة العربية القاهرة V • r-د .المطيري، فواز خلف اللويحق(1 ( • r م). التحقيق مع المتهم وإجراءات محاكمته أمام المحكمة الجنائية الدولية: دراسة مقارنة مجلة جامعة الشارقة للعلوم القانونية المجلد ro

A . r-د.محمد الأمين (Tr (1 هـ -0. . . م م).علم ضحايا الجريمة وتطبيقاته في الدول العربية الطبعة الأولى ،منشورات مركز الدراسات والبحوث جامعة نايف العربية للعلوم الأمنية الرياض

9. †-د.محمد عياط، حقوق المجني عليه في القانون المغربي في نطاق الدعوى المدنية،، بحث مقدم في المؤتمر الثالث للجمعية المصرية للقانون الجنائي بعنوان: " 


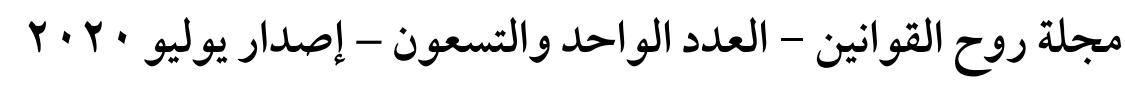

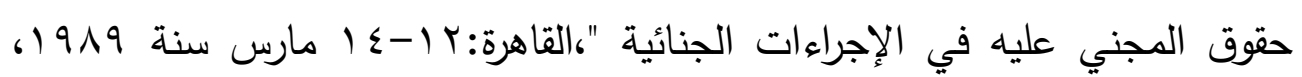
القاهرة: دار النهضة العربية

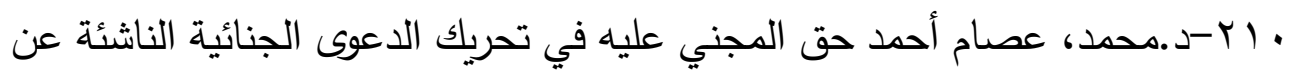

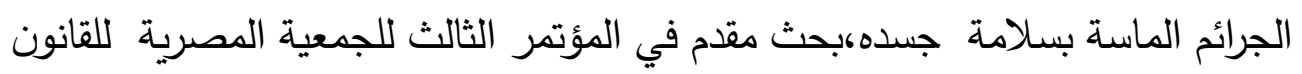

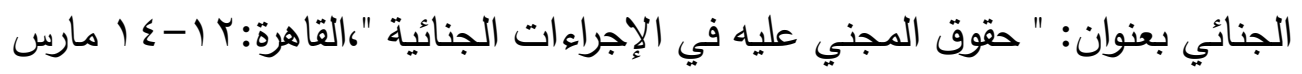
سنة 91919، القاهرة: دار النهضة العربية.

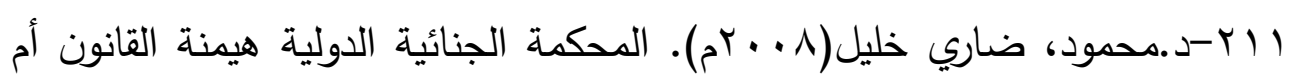
قانون الهيمنة، منشأة المعارف، الإسكندرية

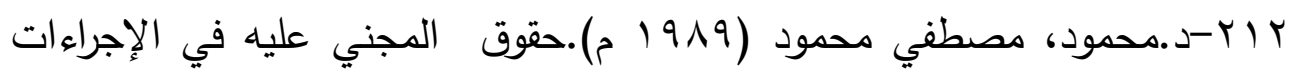

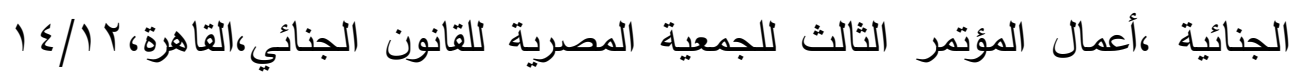
مارس ،دار النهضة العربية القاهرة

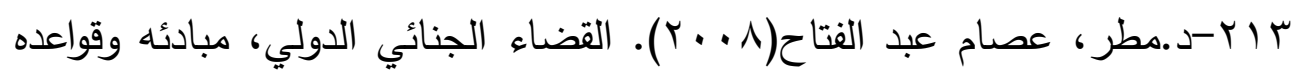

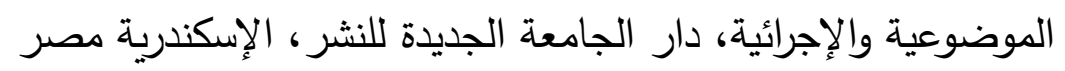

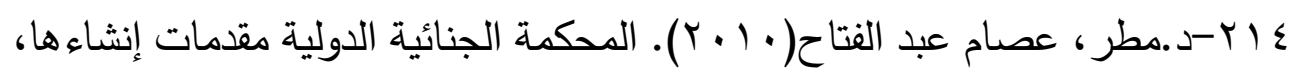

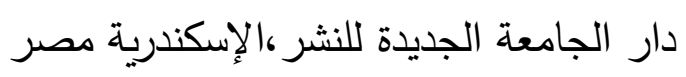

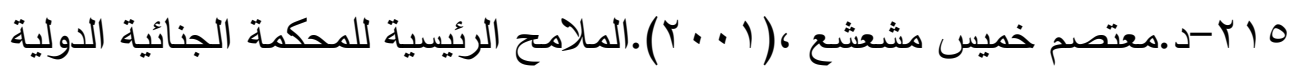

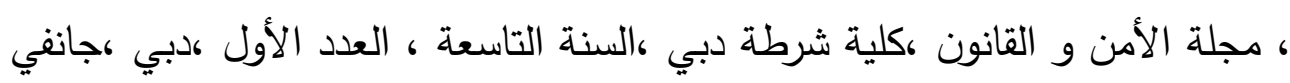

צا (Y-د.منصور ، الطاهر ، القانون الدولي الجنائي، الجزاءات الدولية، مركز الدراسات

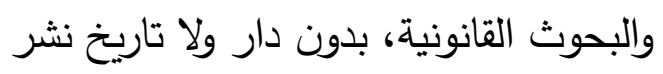

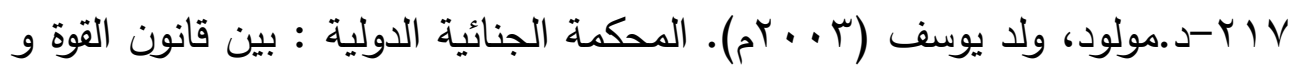

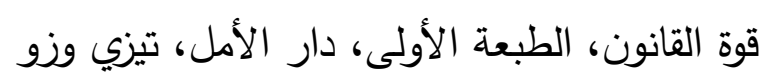

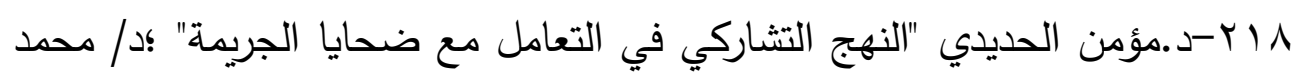

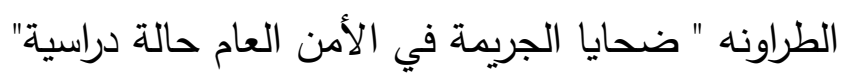




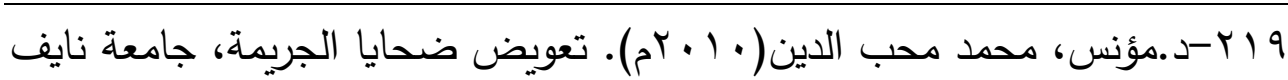
العربية، الرياض

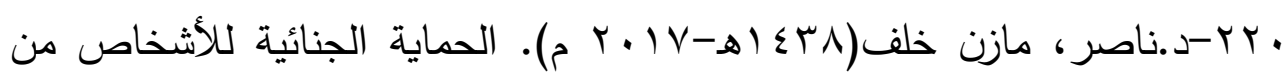

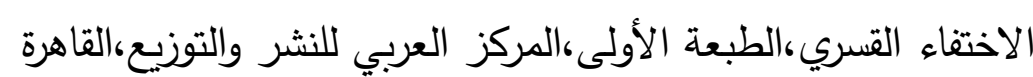

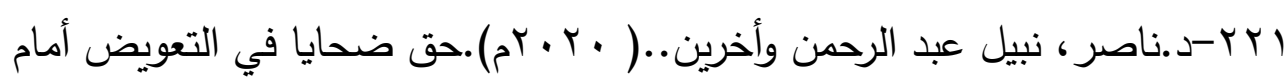
المحكمة الجنائية الدولية، كتاب العدالة الجنائية الدولية الصادر عن المركز الديمقراطي العربي برلين

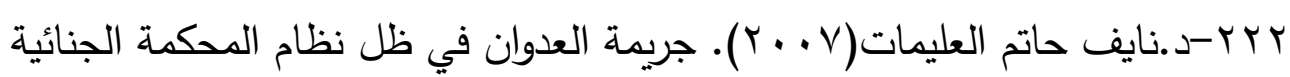
الدولية،دار الثقافة،عمان Tr Y-د.نجم، صبحي محمد (9/9 ().دعوى التعويض أمام المحكمة الجنائية، بحث مقدم في المؤتمر الثالث للجمعية المصرية للقانون الجنائي بعنوان: " حقوق المجني

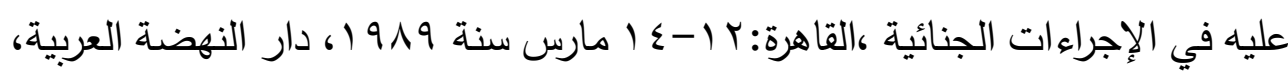
القاهرة צ צr-د.هادي السعيد،(919 ( ). "حقوق المجني عليه في الدعوى العدومية"، ، بحث مقدم في المؤتمر الثالث للجمعية المصرية للقانون الجنائي بعنوان: " حقوق المجني

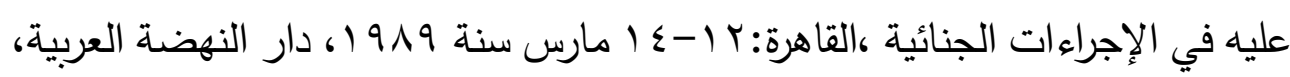
القاهرة

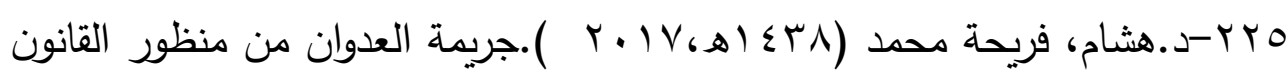
الدولي الجنائي،مجلة كلية القانون الكويتية العالمية،العدد (Y) س (0) رمضان

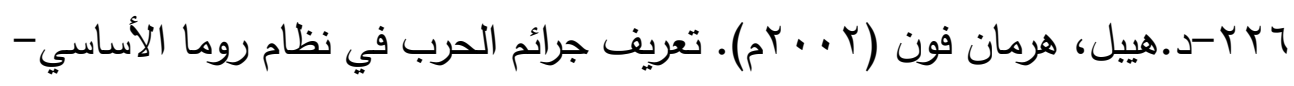
المحكمة الجنائية الدولية- تحدي الحصانة- مجلة الأمن والقانون

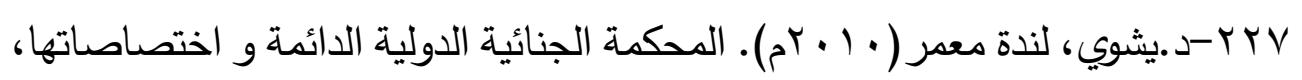
دار الثقافة للنشر والتوزيع، عمان الأردن، الطبعة الأولي 
F. r. · مجلة روح القوانين - العدد الواحد والتسعون - إصدار يوليو

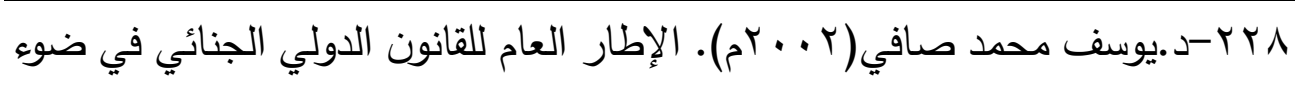

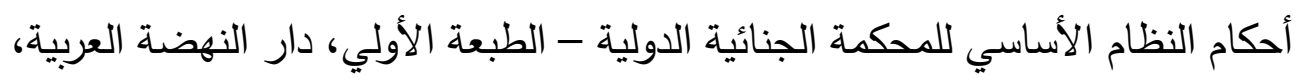

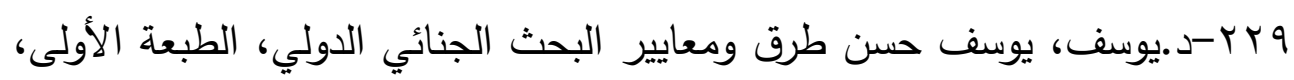

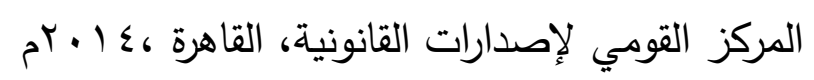

\section{الرسائل العلمية:}

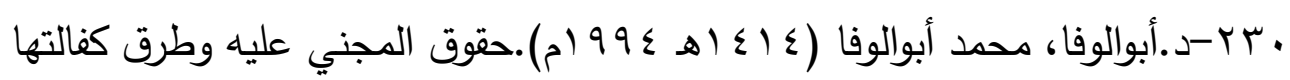
له، دراسة مقارنة في الفقه الإسلامي والقانون الوضعي، رسالة دكتوراه، من كلية الثريعة

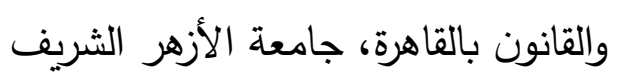

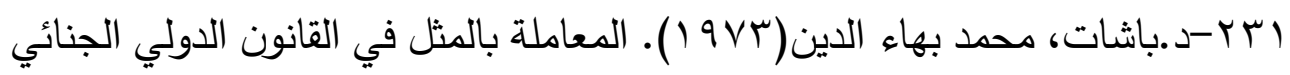

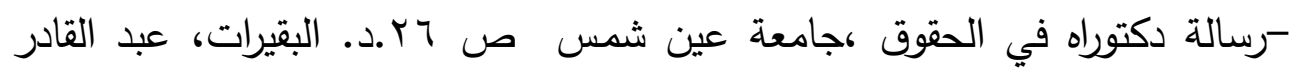

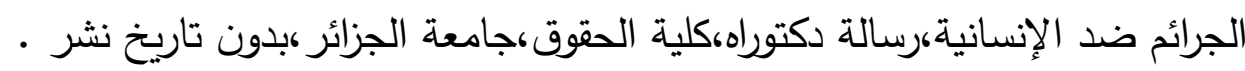
ץ ץ-د.البنا، يحيى أحمد الإرهاب والتعاون والمسئولية الدولية، رسالة دكتوراه، كلية

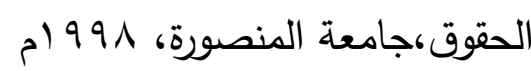

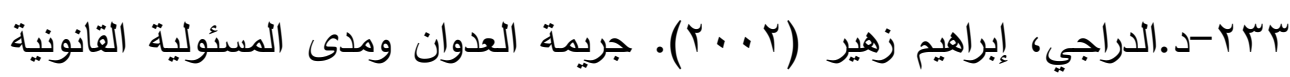

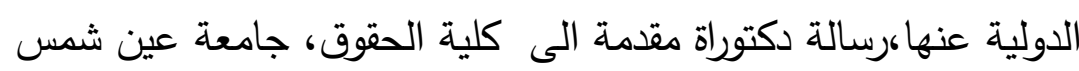

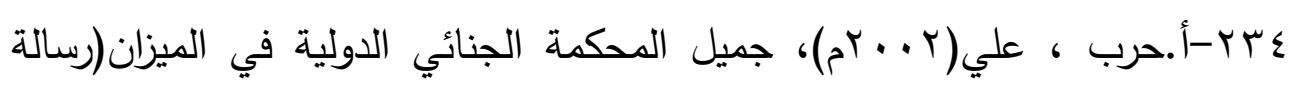
ماجستير)، جامعة بيروت العربية ، لبنان

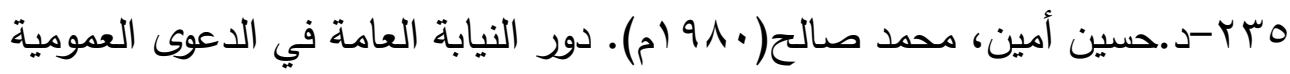

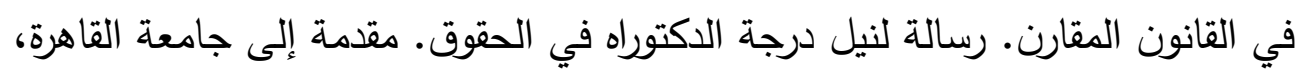
كلية الحقوق الفان العنا 
بسץ-د.حوة، سالم (10 • ( م).سير المحاكمات الجنائية في القانون الدولي الجنائي على ضوء تجربة المحاكم الجنائية الدولية،رسالة لنيل درجة الدكتوراه،كلية الحقوق والعلوم السياسية،جامعة الحاج لخضر باتنة،الجزائر • V V r -أ.حيدر ،عبد الرزاق حميد(0 . . rم).تطور القضاء الدولي الجنائي من المحاكم المؤقتة إلى المحكمة الدولية الجنائية الدائمة ،رسالة ماجستير الجامعة المستصرية -

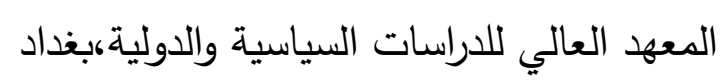

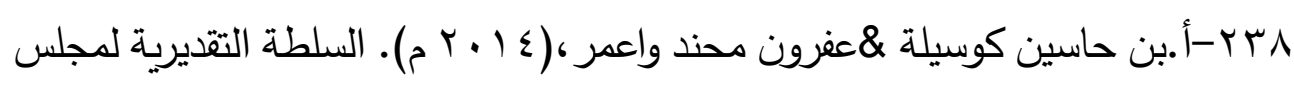
الأمن في تكييف جريمة العدوان مذكرة لنيل شهادة الماستر في الحقوق تخصص القانون الدولي الإنساني وحقوق الإنسان كلية الحقوق والعلوم السياسية جامعة عبد الرحمن ميرة

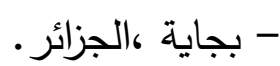
وسr-أ. بن خديم نبيل،استيفاء حقوق الضحايا في القانون الدولى الجنائي،رسالة

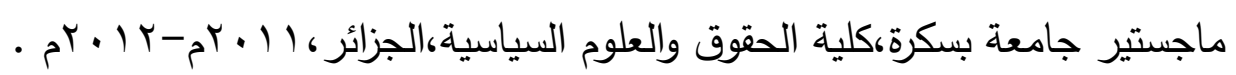

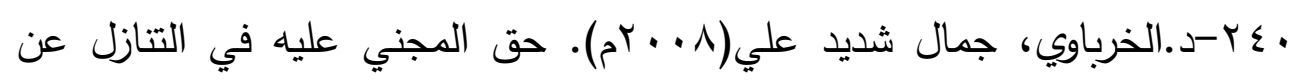
الدعوى الجنائية، أطروحة دكتوراه غير منشورة، كلية الحقوق، جامعة القاهرة اءץ-أ.درويش، مصطفى محمد محمود (Y (Y).المسؤولية الجنائية الفردية وفقا

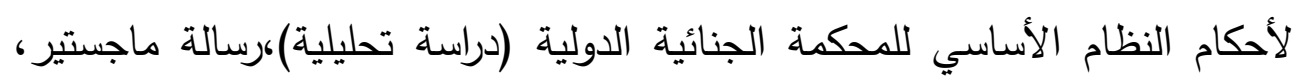
قانون عام،جامعة الأزهر بغزة، فلسطين . Y צ Y-د.الدسوقي، عزت مصطفى قيود الدعوى الجنائية بين النظرية والتطبيق، رسالة دكتوراه، كلية الحقوق - جامعة القاهرة

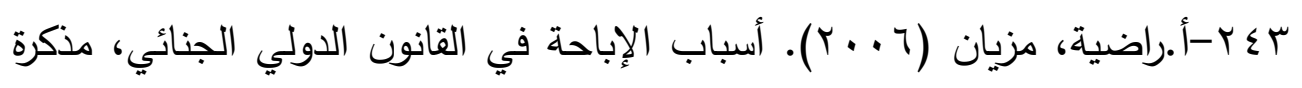
لنيل شهادة الماجستير في القانون العام، كلية الحقوق، جامعة قسنطينة،

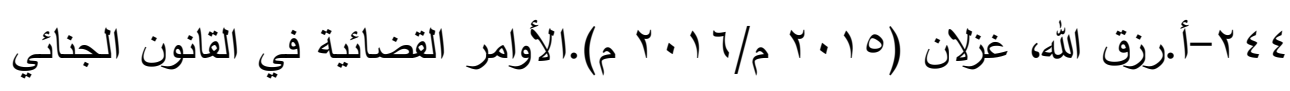
الدولي، رسالة ماجستير جامعة الشيخ العربي التبسي،تبسه،الجزائر 
r.r. · مجلة روح القوانين - العدد الواحد والتسعون - إصدار يوليو

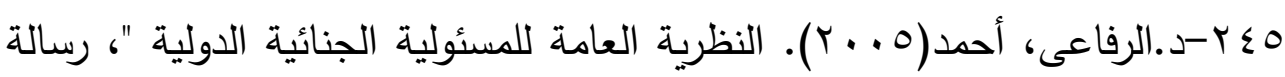
دكتوراه مقدمة لكلية الحقوق، جامعة القاهرة T؟Y-د.العشماوي،عبد الوهاب(190r م).الاتهام الفردي،حق الفرد في الخصومة الجنائية،رسالة دكتوراه،كلية الحقوق جامعة القاهرة، القاهرة

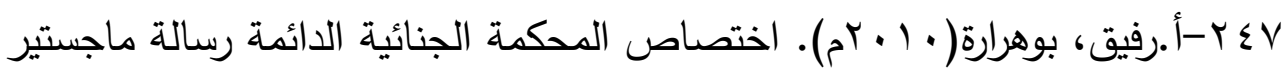
جامعة الإخوة متنوري، قسنطينة، الجزائر

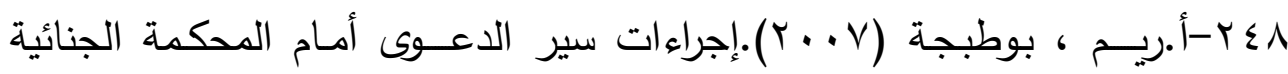

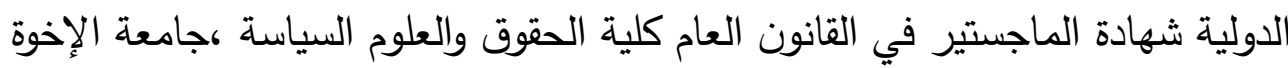
منتوري - قسنطينة-الجزائر

9 § צ-د.الزنداني، عبد الناصر محمد محمد،(99V (1). "القصد المتعدي" دراسة مقارنة، رسالة دكتوراة، جامعة القاهرة • مץ-د.سعود محمد موسي، شكوى المجني عليه دراسة مقارنة ، رسالة دكتوراه،القاهرة: أكاديمية الشرطة، .199

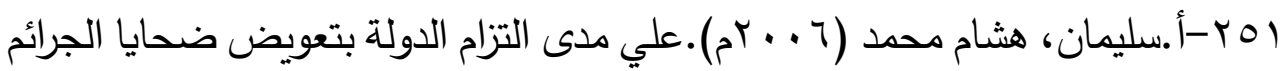
الإرهابية بين الشريعة الإسلامية والقانون الوضعي بحث مقدم للحصول على درجة

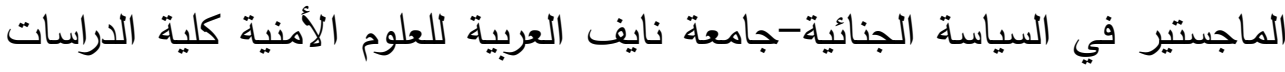

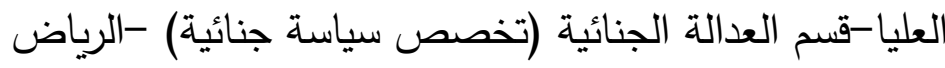
ror والتحقيق، دراسة مقارنة، رسالة دكتوراه، مقدمة إلى كلية الحقوق بجامعة عين شمس،

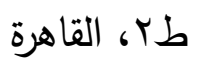

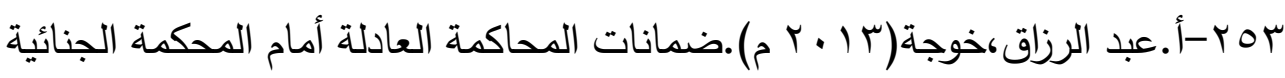

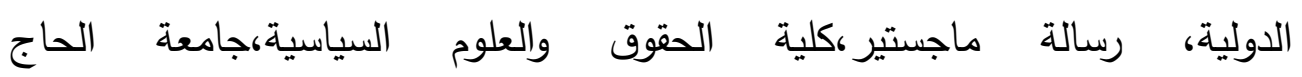
خضر ،باتتة، الجزائر 


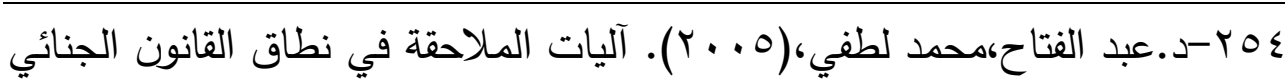

الدولي الإنساني، رسالة دكتوراهكلية الحقوق جامعة المنصورة.

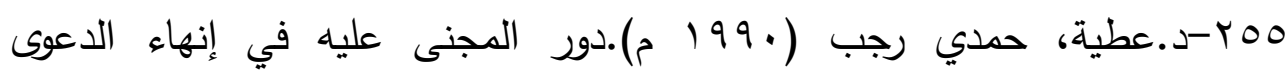
الجنائية،رسالة دكتوراه،كلية الحقوق جامعة القاهرة، القاهرة

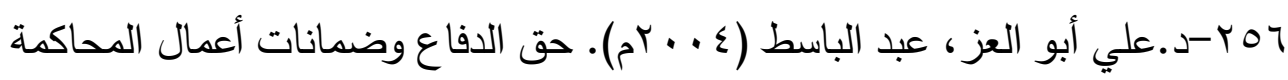
التأديبية في القانون الإداري وقانون المرافعات المصري، دراسة مقارنة ، رسالة دكتوراه ، كلية الحقوق ، جامعة القاهرة

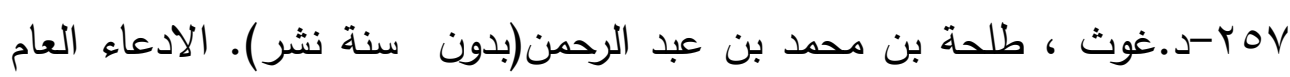
وأحكامه في الفقه والنظام، كنوز إثبيليا، رسالة دكتوراه، المعهد العالي للقضاء، بجامعة الإمام محمد بن سعود الإسلامية، بالمملكة العربية السعودية/ الرياض.

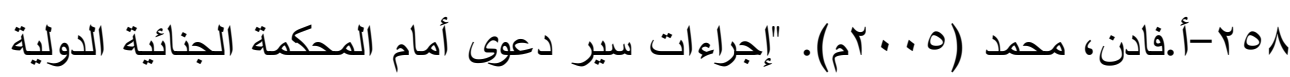
الدائمة"، مذكرة ماجستير، قسم القانون العام، كلية الحقوق، "جامعة البليدة" 9ه ץ-د.فرج، محمد عبد اللطيف (ץ . . م م).سلطة القضاء في تحريك الدعوى الجنائية دراسة مقارنة في النظامين المصري والفرنسي رسالة دكتوراه،جامعة القاهرة،القاهرة/مصر • ب -أ.فريزة، بن سعدي (Y ( • (Y). المسؤولية الجنائية الدولية عن جرائم الحرب في نظام المحكمة الجنائية الدولية، مذكرة لنيل شهادة الماجستير في القانون، فرع القانون الدولي العام، كلية الحقوق والعلوم السياسية،جامعة مولود معمري، تيزي وزو آب-د.الفقي، أحمد عبد اللطيف الحماية الجنائية لحقوق ضحايا الجريمة، رسالة

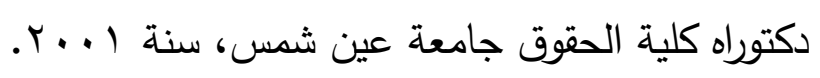

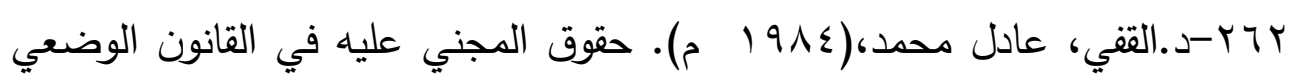
مقارنا بالشريعة الإسلامية، رسالة دكتوراة في الحقوق، مناقشة بجامعة عين شمس، كلية 
مجلة روح القوانين - العدد الواحد والتسعون - إصدار يوليو · r.

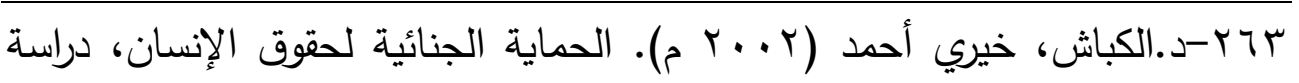
مقارنة، رسالة لنيل درجة الدكتوراه، كلية الحقوق، جامعة الإسكندرية. ع ب-د.الكردي، انتصار علي محمود،( (991 ام( .إشكالات إنشاء المحكمة الجنائية الدولية (رسالة ماجستير)، الجامعة الأردنية، عمان.

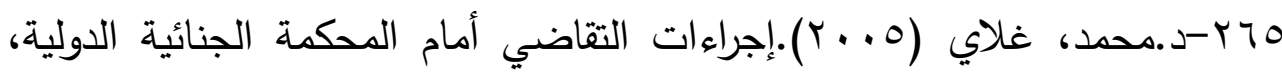

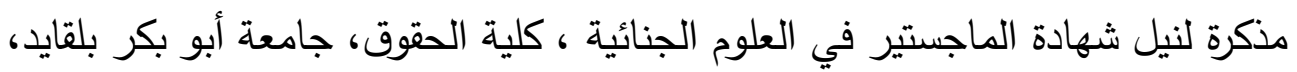
تلمسان، السنة الجامعية 74 Y-د.مصطفى مصباح- وضع ضحايا الإجرام في النظام الجنائي - دراسة نقدية

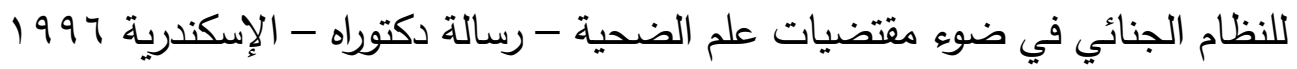

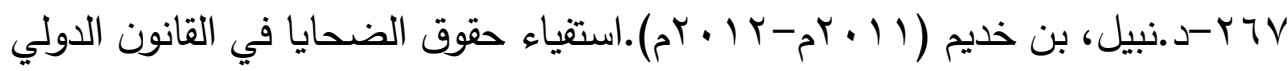
الجنائي،رسالة ماجستير جامعة بسكرة،كلية الحقوق والعلوم السياسية

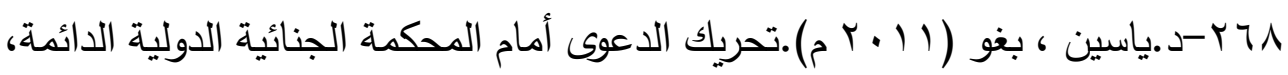

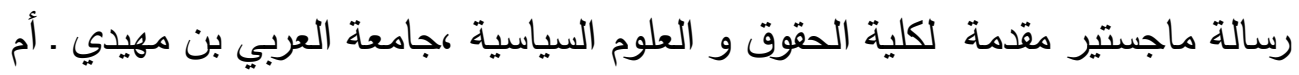
البواقي ـ الجزائر. 
Andrew Karmen, crime victims; An Introduction to victimology, rчq- Eighth Edition, Belmont, U S A

$r v$.-Antoine Garapon, $(r \ldots r)$ Des crimes qu'on ne peut ni punir ni pardoner Pour une justice internationale, $E^{\prime}$ ditions Odile Jacob, Paris,

rv)-Antonio Cassese et al(eds.), ( $r \ldots r$ ) The Rome Statute of the International Criminal Court: A Commentary, Vol. ${ }^{\curlyvee}$, Oxford ,University Press, Oxford,

Barriga (eds), $(Y \cdot \mid \vee)$ The Crime of Aggression: A Commentary YVY-,vols ${ }^{r}$, Cambridge University Press,.

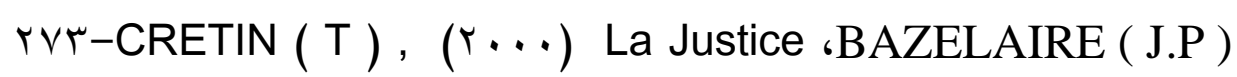

pénale internationale son évolution, Son avenir de Nuremberg a Paris , Imprimerie presse universitaire de France, ‘La Haye rV乏-BESSIOUNI $(\mathrm{CH}),(r \cdots)$, Note explicative sur le statut de la cour pénale internationale, La cour pénale internationale ratification et mise en œuvre dans les législations nationales .R.I.D.P Vol $\vee$ I

rvo-Bonnie.s.Fisher.Steven P.lab; (r.1•) Encyclopedia victimology and crime preventation.volume .', sage publications, ,California

Y Y -Brian Egan, Legal Adviser, US Department of State, $(Y \cdot 17)$ 'International Law, Legal Diplomacy, and the CounterISIL Campaign: Some Observations' International Law Studies, Vol 9 r 


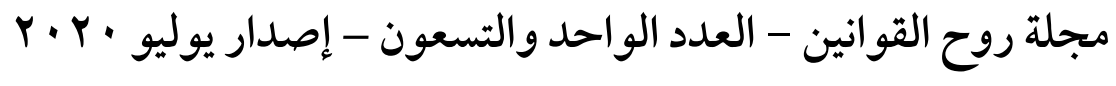

rv $r$-Caianiello. Michele, $(r \cdot 11)$ Law of evidence at the international criminal court: Blending accusatorial and inquisitorial models, North Carolina Journal of International Law , and Commercial Regulation, Vol ru

Cambridge University Press $r^{+} \mid r_{-} \mathrm{p} \leqslant \cdot$ https://doi.org/1•, 1.1 V/CBO $9 \vee \wedge .011 \wedge \cdot 1 \cdots 4$

Y $\wedge \wedge-C h e r i f$ Bassiouni, ( 1999 ) Crimes Against Humanity, Crimes Against Humanity, Kluwer International .Law, The Hague .Second Revised, Edition

rVq-CLAPOT, Y. (1990) Indemnisation des victimes: les infractions pénales, dommage, préjudice, réparation, Paris, Editions ESKA,

rA.-DAVID (ERIC) ( 199 \&): Le terrorisme, en droit international (déFinition, in crimination, répression) dansré Flexion sur la déFinition et la répression du Terrorisme Bruxelles, EdL .،'U.L.L.B.

ץ^)-DOROY, F." ) (ץ..r) Le réexamen d'une décision pénale consécutif au prononcé d'un arrêt de condamnation de la CEDH, mise en œuvre de la réforme du 10 juin $r \cdots$, questions juridiques et problèmes pratiques", Droit pénal, juin, chr. $\$ rAr-Esper (B.) (19Vr): La Separationdes Fonctions des Justice repressiv Travaux et recherches de L' universite de Paris P.U.F $\checkmark \wedge r$-Establishment of a fund for the benefit of victims of crimes within the jurisdiction of the Court, and of the families of such victims, Resolution ICC-ASP/ /Res. ${ }^{\top},{ }^{9}$ September $r \ldots r$ 


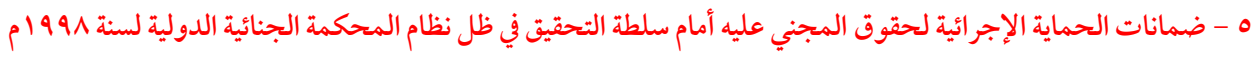

Francois Bughion ( $(\cdots r$ ) Juste War and War of Aggression and $Y \wedge \varepsilon-$ International Review of 'International Humanitarian Law ‘No. $\wedge \leqslant \vee$ ،Red Cross

Y^o-Garaud ,V.R, Traité théorique et pratique d'instruction criminelle et de procédure pénale .Tome $1, \mathrm{n}^{\circ} \mathrm{V} V$

rᄉ criminal Law :, more candour about criteria : The exercise of discretion of the prosecutor of the international criminal court , journal of international criminal justice, (JICJ), oxford , $r \cdot{ }^{\prime} \cdot$,

$\checkmark \wedge \vee$-GRANIER, J. la partie civile au procès pénal, in RSC 190^

r^^-Guatemala, February $r$,,$r \ldots r$, Series $\left.C n^{\circ} q\right)$ (reparations)

$\S 0$ \&, $\uparrow \leqslant-70$; Caracazo v. Venezuela, August $r q, r . r$, Series $C$ ,$n^{\circ 90}$

Y^१--Héctor Olásolo, Alejandro Kiss The role of victims in criminal proceedings before the International Criminal Court.Dans Revue internationale de droit pénal $r \cdot 1 \cdot / 1-r$ (Vol. 1),

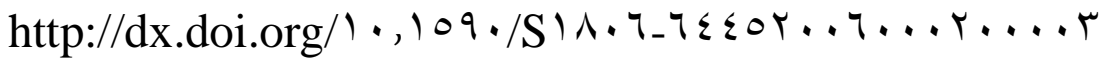
Hugo Grotius, The Rights of War and Peace: Book II, Chapter 1 rq.- (New York: M Walter Dunne, 19.1 rq)--Humanitarian Law, International Review of Red Cross, No. $\wedge \leqslant \vee, r \ldots r p \leqslant 9$ KAMTO Maurice, L'agression en droit .,international, Edition. A. Pedone, Paris , $r \uparrow$.

r9)--Janet Reno,- , 1999-Crime Scene Investigation, A

Guide for Law Enforcement, US Department of Justice, Office of Justice Programs, National Institute of Justice, copyright PhotoDisc, In 


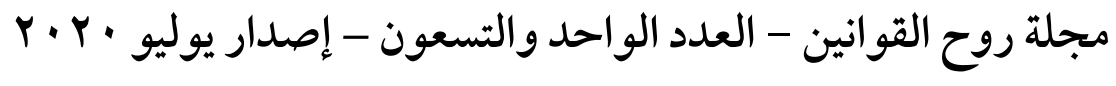

r 9 Y--Jean Pierre ALLINNE, les victimes des oubliées de

l'Histoire du Droit? In CEuvre de justice et Victimes (volume 1), .extrait des sessions de formation du site de l'ENM

rqr--Jonas KNETSCH, $(r+11)$.Le droit de la responsabilité et les fonds, d'indemnisation Thèse en vue de l'obtention du grade de Docteur en droit privé présentée UNIVERSITÉ PANTHEONASSAS le $\vee$ octobre

Jules Basdavant, (, $19 \leqslant 7)$ Le veto dans L'organisation des Nations Unies, Revue de politique étrangère, Année $11, \mathrm{~N} \cdot$. r 9 \&-Julien, $(r \cdot 1 \cdot)$ L'influence perturbatrice du dommage corporel en droit des obligations, th. Tours, Paris : LGDJ, coll. Bibliothèque de droit privé,

KAMTO Maurice, $\left(Y \cdot r^{\cdot}\right)$ L'agression en droit international, Y90_-Edition. A. Pedone, Paris, r 9 ฯ--Lewis, P. and Friman, H., $(r \ldots 1)$ "Reparations to victims," in The International Criminal Court: Elements of Crimes and Rules of Procedure and Evidence (Lee, R.S. (ed.)), .Transnational Publishers,

r १४--LOMBART, F. (191 victimes d'actes de violence, Centre de recherches sociologiques sur le droit et les institutions pénales, Paris,

r 9 A--LOMBART, F. ( $191 \mathrm{r})$ - Les systèmes d'indemnisation des victimes d'actes de violence, Centre de recherches sociologiques sur le droit et les institutions pénales, Paris, Y. CLAPOT, (1990) Indemnisation des victimes: les infractions pénales, dommage, préjudice, réparation, Paris, Editions ESKA, 
ه - ضمانات الحماية الإجرائية لحقوق المجني عليه أمام سلطة التحقيق في ظل نظام المحكمة الجنائية الدولية لسنة 1991م

r $99-$-Luke Moffett, $(r+10)$ Justice for Victims before the

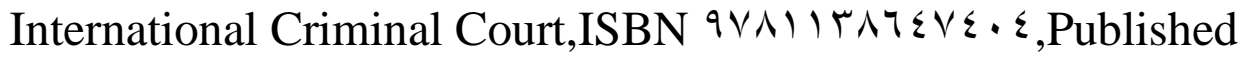
December $r, r, 10$ by Routledge

r..--Luke Moffett,Reparative complmentarity:ensuring an effective remedy for victims in the reparation regime the international criminal court,egime of the International Criminal Court: The International Journal of Human Rights: Vol I V, No

$r, r+1 r$

$r \cdot 1--$ Martson danner, enhancing the legitimacy of prosecutorial discretion at the international criminal court, American journal of $r \cdot r$--international law, (AJIL), New York, issue $9 \vee, r \ldots r$

r.r--MBARGA, A. (ץ...) L'indemnisation publique des victimes d'infractions, L'indemnisation par le Fonds de garantie, Paris, ÉditeurL'Harmattan

$r . \leqslant--$ Megret, F. $(r \ldots q)$ 'The International Criminal Court and the Failure to Mention Symbolic Reparations', $17(r)$ International Review of Victimology

Promoting the rights and interests of victims before the international criminal court, www.vrw.org r. o--Rajapakse, L. ( $9 \vee Y$ ) Is a presumption of gulit or of innocence of an accused in a criminal case necessary ? The ,Ceylon Law Society Journal, Vol. $1 \cdot, n^{\circ}{ }^{\text {, }}$

r. १--Rapport au Premier ministre, (1999) Pour une nouvelle politique publique d'aide aux victimes, préparé par Groupe interministériel d'aide aux victimes, M.-N. LIENEMANN (présidence), H. MAGLINO et J. CALMETTES (rapporteurs), .Paris, 


$$
\text { r.r. · مجلة روح القوانين - العدد الواحد والتسعون - إصدار يوليو }
$$

$\Gamma \cdot \vee--$ Robert Cryer,Hakan Friman,Darryl Robinson,Elizabeth

Wilmshurst, $(r \cdots \wedge)$ an introduction to international criminal law and procedure,cambridge,

$r \cdot \wedge--$ Sergey, Vassiliev, , $(r \cdot 11)$ The role and legal statue of the prosecutor in international criminal triale, in L.Reydans, C.Ryngaert, S.Parmentier, International prosecutions from Nuremberg to the Hague, oxford, oxford university press ,

The international criminal court :Ensuring an effective role for $r \cdot q--$ victims. www.amnesty.org $p^{19}$

T. ---The UN Handbook on Justice for Victims on the use and application of Basic Principles of Justice for Victims of Crime and Abuse of Power, U.N. Doc. E/CN. 10/CRP. ₹/Add. ' ( 1991 ), MIY-VITU, A. ( $90 \mathrm{~V})$ : procedure pénale. Press Universités De France. Paris 